634.9

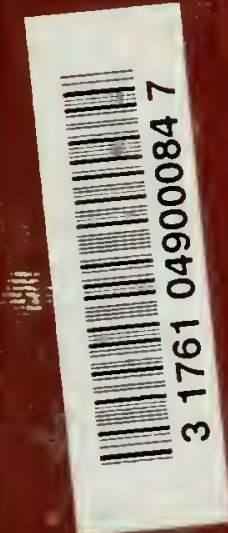




$$
\begin{array}{r}
6319 \\
176
\end{array}
$$








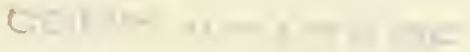

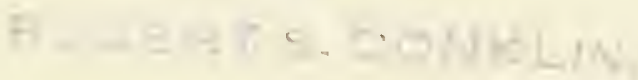




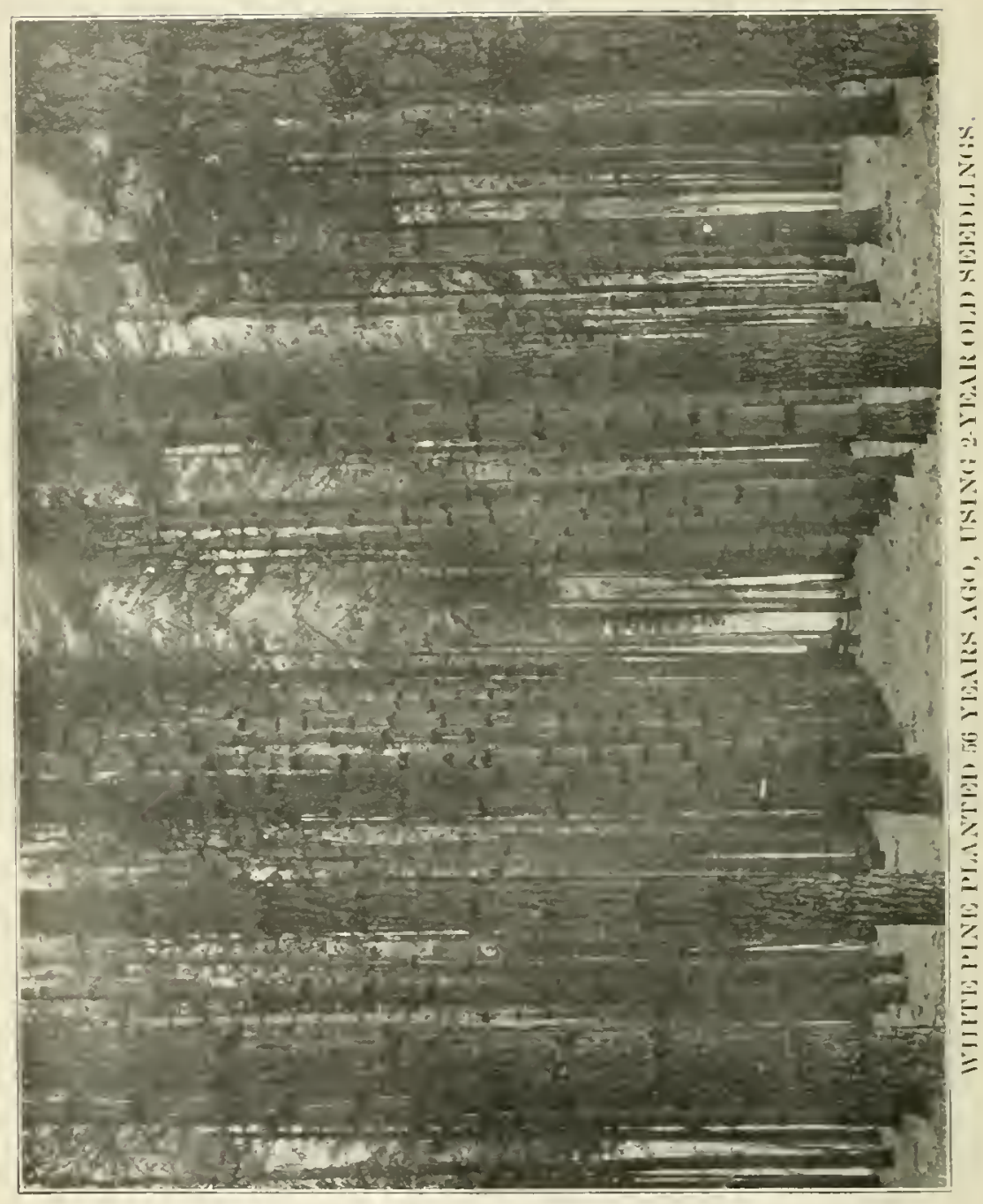




\title{
Commonwealth of Pennsylvania
}

\section{DEPARTIENT OF FORESTRY}

\author{
JILIETIX NO. II,...JU. IE, 1911.
}

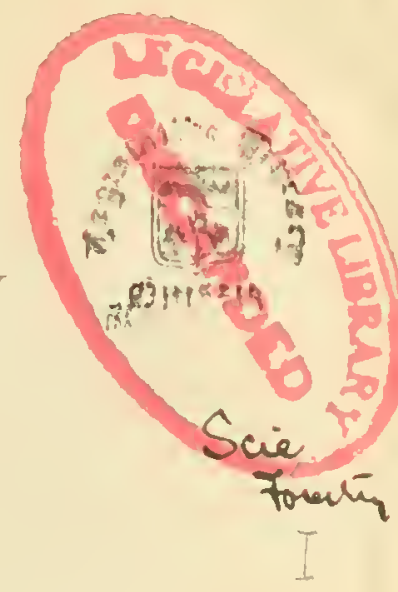

\section{PenNsylvania Trees}

BY

J. S. ILLICK, A. B.. F. E.,

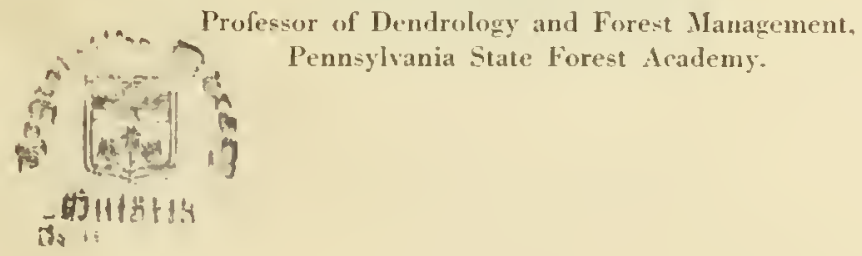

ISSUED IBY DIRECTION OF THE COMMISSIONER OF FORESTIY.

HARRISBURG, PA.:

NAI, STANLEY RAT, STATE PRINTER 



\title{
PENNSYLVANIA DEPARTMENT OF FORESTRY
}

\author{
ROBERT S. CONKLIN, \\ Commissioner of Forestry. \\ IIVIN C. WILLIAMS, \\ Deputy Commissioner of Forestry.
}

STATE FORFATRY IESERVATION COMUISSION.

\author{
ROBERT S. CONKLIN, \\ President. \\ SIMON B. ELLIOTT \\ J. LINN HARRIS \\ FRANK L. HARVEY \\ WM. P. STEVENSON.
}




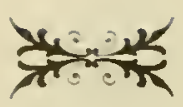




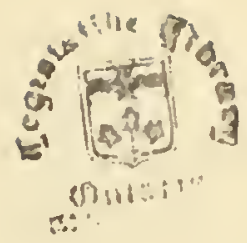

\section{LETTER OF TRANSWIT'TAL}

Hon. liobert S. Conklin,

Commissionel of Eorestry.

Deal Sir: In compliance with your lequest I lave the lonor to transmit holewith the mamuscoipt, plates, and ploblographs for a bulletin on "Penusylunia Trees." It is the lope of the writer that the bulletin may aid in developing a fullor aplopeciation of the in. portance and ralue of onr trees and forests.

Yours respect fully.

J. S. ILTICKE.

Inonl Alto, I'a..

.June, 1914. 


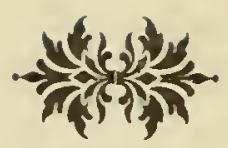

(6) 


\section{PREFACE}

Trees are among the commonest and most conspicuous objects of nature. The numerous products derived from them are very useful, often indispensable. In all ages trees and grasses have been the most important produets of the soil. A dense and valuable tree growth covered originally almost the entire area of Pennsylvania. Abont 27s speries of trees and shmus are native to this State, of which number 125 are trees. The number of native representatives in the present forests is the same as in the original forest. While the number of representatives remains lhe same, yet one finds a marked difference in the degree of their abundance, and in their age, size, form, density, quality, value, and productivity. The original forest of the State was large, dense, and extremely productive. The present forests are small, open, and very muloductive. Each gener. ation of mankind has seen a smaller, more open, and less productive generation of forests. It is not a proplery, but the statement of a fact, when we sis that the source of our timber suply is beconing an acnte and vital question. Fast-ranishing forests and ever. lising lumber prices are conriers of this fact. The Federal and some State Govermments lave already inaugurated policies to offset the present destructive tendency in our forests by starting constructive work. To date no state lus made a grealer alvance in forestry than Pennsylvania. She has, however, just started on this useful mission. The men who are directing her forest policies are endeavoring to lay a substantial foundation upon which a stable superstructure may be reared. In order to accomplish this it is necessary to have the co-operation of the citizens of the State, especially the woodland owners and managers. Forestry needs the support of public sentiment. No sulstantial and permanent advance is insured until our citizens understand the fundamentals of forestry and can distin. guish the important timber trees from the inferior weed trees. It is hoped that the sphere of usefulness of this bulletin will not be limited to woodland owners and managers, but will extend to laymen, students, and botanists.

Part $I$ is intended for the layman and the beginner of forestry. A careful perusal of this part will enable one to comprehend Part II more fully. The former comprises abstracts from the author's lec- 
tures on Flementary Forestry at the Pennsylvania State Forest Academy.

Part II is essentially a manual of Pennsslrania trees. It comprises a discussion on the identification of trees and a description of families, genera, and species, with accompanying kers. The descriptive material aud kers are the outgrowth of typewritten outline wotes lreprared lip the author and used for the past six rears in connection with a conse in deudrologr given at the Penusylvania State Forest Academy. Each species is descrilied under about 14 headings. Yo special originality is claimed for the characteristics giren under these leadings. It is natural to expect that the descriptive mater ial should colrespond with that found in other texts. The author is glad to acknomledge his iudelitedness to the may books of reference which were frequently consulted to rerify obserrations and to make the description clear and comllete. The range of the species and the reight per cubic foot of their rood (air dry) have been drawn chiefly from sargent's "The Silva of North America." The distribution in Peunsrlrania wis worlied ont in co-operation with the forester's connected with the Department of Forestre and a few other's interested in the distrilution of trees. Porter"s "Flora of Pennstrania" aided considerably in determining the distribution. Our present knowlerge of the distribution of the different species in the state is by no means complete. Special effolts are being put forth to ascertain it mole accurately. Futule pullications will contain the results of the present aud prospective survess covering the distribution of our trees. Auy alditions, suggestions, or corrections will be gladly received.

The scientific names found in this bulletin are those used by the Department of Forestry, which follows the usage of the serenth edition of Grars's New Manual of Botany. Shifting of iudividnal plates from their proper systematic position was necessaly in a few cases in orler to place two compranion plates on opposite sides of the same sheet.

The photographic illustrations, 103 in number, are all original by the authop, except Figs. 5\% and 6is supplied by W. Gardiner Conklin: Fig. 22 supplied ly Guy Carleton Hawkins: Figs. 21 and 35 supplied by B. J. Guthnecht, and Figs. 1, 3, 4, 10, and 12 supplied by the Penusrlvania Department of Forestry.

The drawings have been made by Miss Margaretta Washington, of Philarlelplia, eithel from specimens supplied by the author or redrawn and adapted from Sargent's "The Silva of North America" by special permission of the publisher. Houghton Mifflin Comprany. In making some of the dramings Schneider"s "Pendrologische Winterstudien" and some of the reports of the Mrissouri Botanical Garden were consulted. 
Grateful acknowledgment is temlerel to Hon. Robert S. Conklin, Commissioner of lorestry, at whose suggestion the bulletin was started and muler whose rareful and constant direction it mas de reloped. Especial acknomletgment is due to How. I. C. Williams, Deputy Commissioner of lorestry. who read the entire manuscript, for his inspiration, many valuable sngorstions and criticism. Thanks are due to frenge $\mathrm{H}$. Wirl. Forest Iusjector, and Prof. George A. Retan for their assistance and valuable sugesestions.

I take pleasure in expressing my gralification to all others who have in any way assisted in this publivation, especially the students of the I'enusylvania state Forext Academy for their co-operation, and the graduatox for their assistance in collecting data concerning the distribution of trees in this state.

J. S. ILLICKK. 
政 


\section{CONTENTS}

PART I.

INTRODUCTORY.

The North American Forest. ....................... Page.

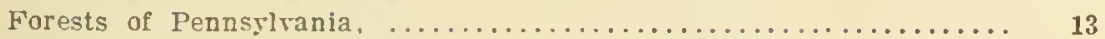

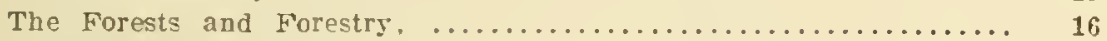

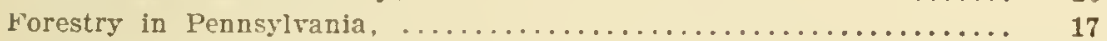

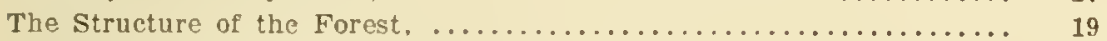

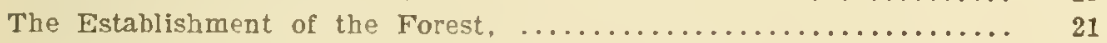

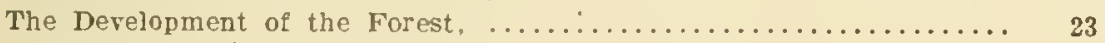

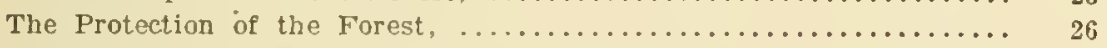

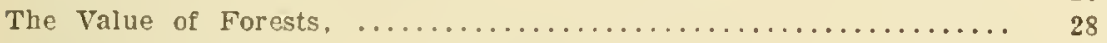

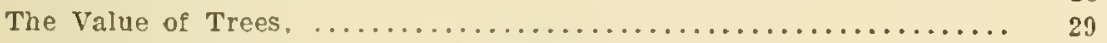

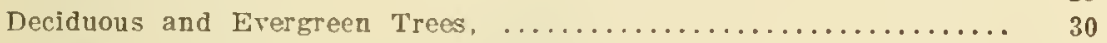

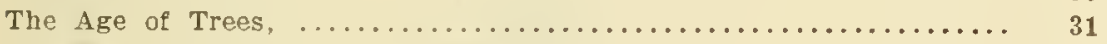

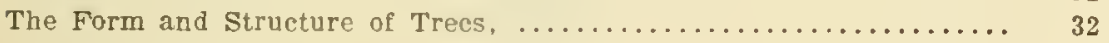

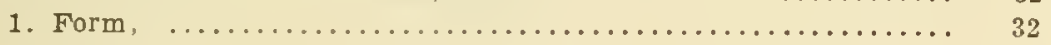

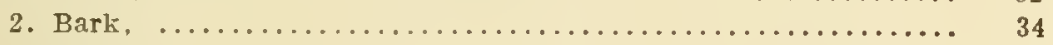

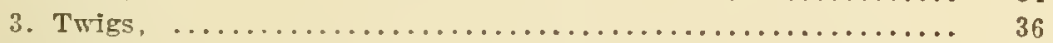

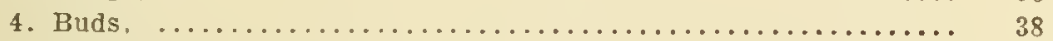

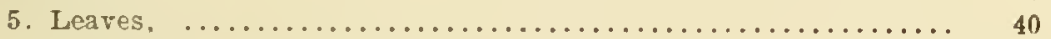

6. Leaf-scars and Bundle-scars. ........................ 43

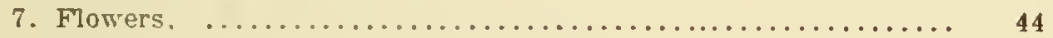

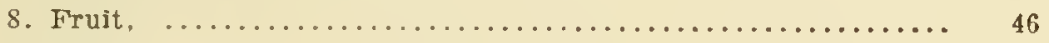

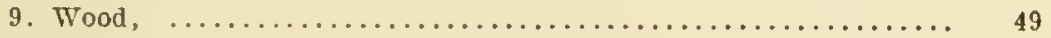

\section{PART II.}

MANUAL OF PENNSYLVANIA TREES.

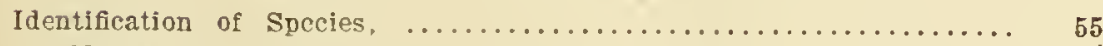

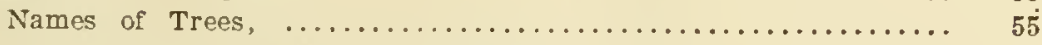

Explanation of Terms and Headings, $\ldots \ldots \ldots \ldots \ldots \ldots \ldots \ldots . \ldots \ldots$

How to Identify the Species and Use the Keys, ........... 58

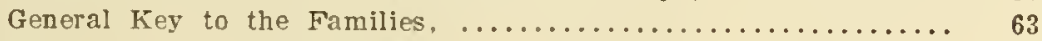

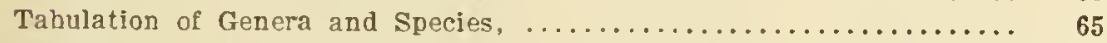

Description of the Families, Genera, and Species, .............. 67

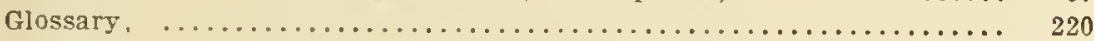

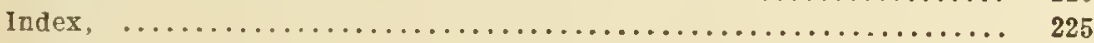


镱

(12) 


\section{PART I.}

\section{INTIOHETTORY.}

\section{THE NORTH AMERICAN FOREST.}

There is good reason to believe that the majol part of the habitable earth was originally woorlol. North America is no exception to this. The original forest extended from the Itlantic coast west to ahout the ninetieth meridan having only a tew small openings like mealows and the tops of mountains. It also covered a large portion of the Rocky Mountain region and the Pacilic slope. Estinates place the aggregate original ara of the forests of North Imerica at about $850,000,000$ acres. This original area lak been so reducer that not more than $550,000,000$ acres remain at the jresent time and a large protion of this acreage is in a very unproductive condition.

The original forest of this country was vast in extent and composed of many and raluable species. The richness and variety of onl tree growth may be in part attributed to the dillerent climatic zones and raliable physiographic features common to this country. So variable is our forest structure that at least tive general forest legions may he recognized while often a local area may have its own peculial forest type.

Many of the trees in the original forest attained a great age and euormous size. They vielded a vast amount of valuable products, a source of great wealth, which has been supplying the raw material for one of our most important industries. Natme working througl many centuries leveloped the original forest and gave it to us gratnitonsly. Man working through only a few centuries has established a great industry-the lumber industry; but on the other hand he has wastefully exploited onr forests and left many of them in an unproductive condition. Howerer, there was no alternative because the economic conditions then prevaling required, in part at least this wasteful procedure.

\section{FORESTS OF PENNSYLVANIA.}

The word Penusylvania neans Penn's woods. It derived its name from its ealy proprietor and the dense and extensive forest growth 
which corered the State. The original forest corered almost its entile area, which is usually given as 2\$,594.560 acres. Practically the entire State, with the crception of a few natural meadows and the tops of a few mountains, was corered with trees. The original forest was composed of mans and valuable species often occurring in dense stands. The richness of our forest flora is due to its farorable location with reference to climatic and plysiographic factors. Pennsylvania is the meeting ground of many northern and southern species. In the western lart of the state one fincls outposts of species common to the Mississippi valles, while in the southeastern part some of the species of the coast region are found. Some of the northern species have their southern limits here, or else follow the mountains torrard the south, while some of the southern species hare their northern limits here, usuall r migrating northrard through the ralleys. The forests in the southeastern and the restern parts of the State are composed almost entirely of hardmoods, while the central and the northern or mountainous parts are composed of a mixture of hardwoods aud conifers. One may find the hardwoods br themselves and the conifers by themselves, or ther may occur in mixture. A fer of our native specics are verr valuable. while others are less valuable and some mere forest weeds. The real value of a species changes with the change of the general economic, particularly market, conditions. Within the last decade market prices of wood have risen so much that they have brought about a more inteusive utilization of our forest products. Manr species formerly left standing in the forest are now utilized. A moment's reflection upon the present tendencr in the utilization of the products of the rarious trees causes is to comprehend fully the truth of the statement that the despised species of to-das will he prized tomorrow. The richness of the arborescent flora together with the great age and large size which some of the trees attained justifies the statement that Pennsylvania was at one time "one of the best timbered states of the Atlantic Coast."

Nature working through many centuries developed in this State a forest which was one of the most raluable of the many heritages with which its citizens have been blessed. If we could see maps showing the structure and distribution of the forests of Pennsylrania in the sears 1600 and 1900, we would be astonished by the ronderful change that has taken place in a period that represents only a few generations of trees. Many were the agents which brought about this change, hut it was left to man to play the leading role. Man working through a few centuries has remored the forest or abused it through fire and unregulated cutting. The establishment of pioneer homes, the opening of agricultural and grazing lands, the increase of population, the derelopment of industrial enterprises, the 


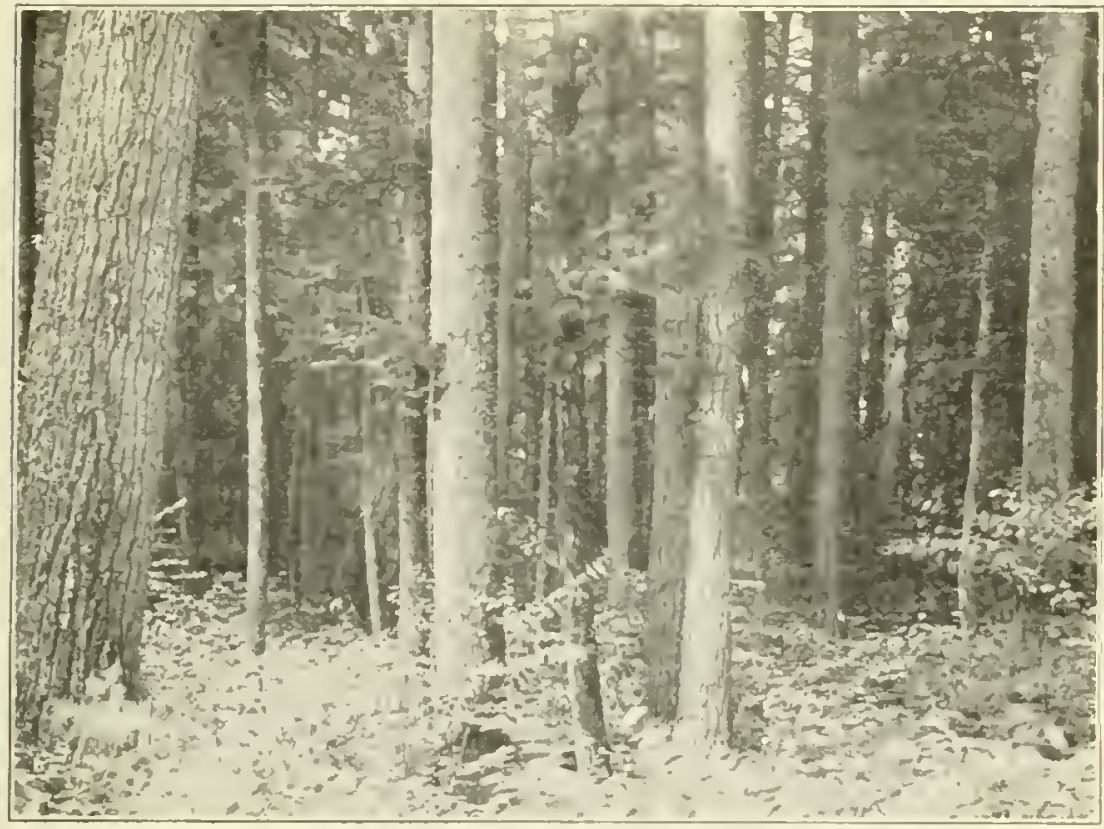

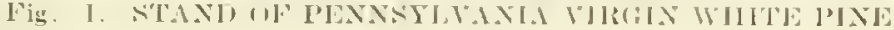

The lind of formst our forofathers foum]. I matgnilicut heritage. The real value wils unt ilyurecriated.

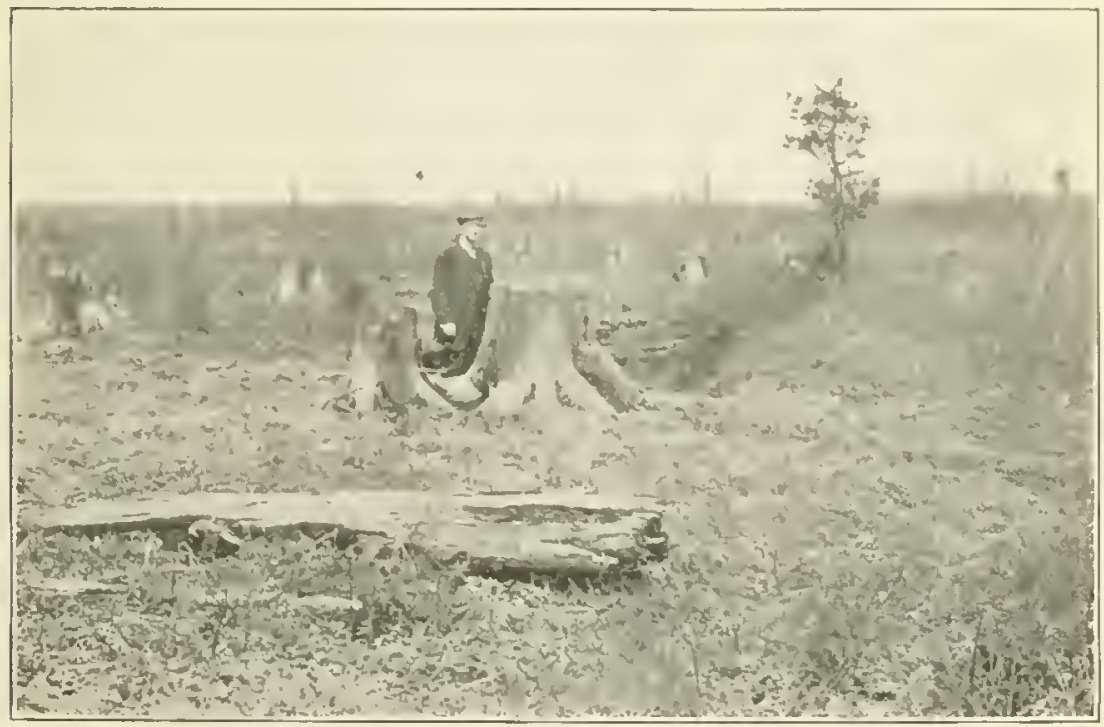

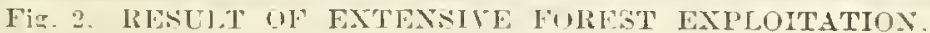

High stumps, and .. thin scattered grewth of inferior trees, is all that lemains. The stumps indicate the density and size of the original stand. 


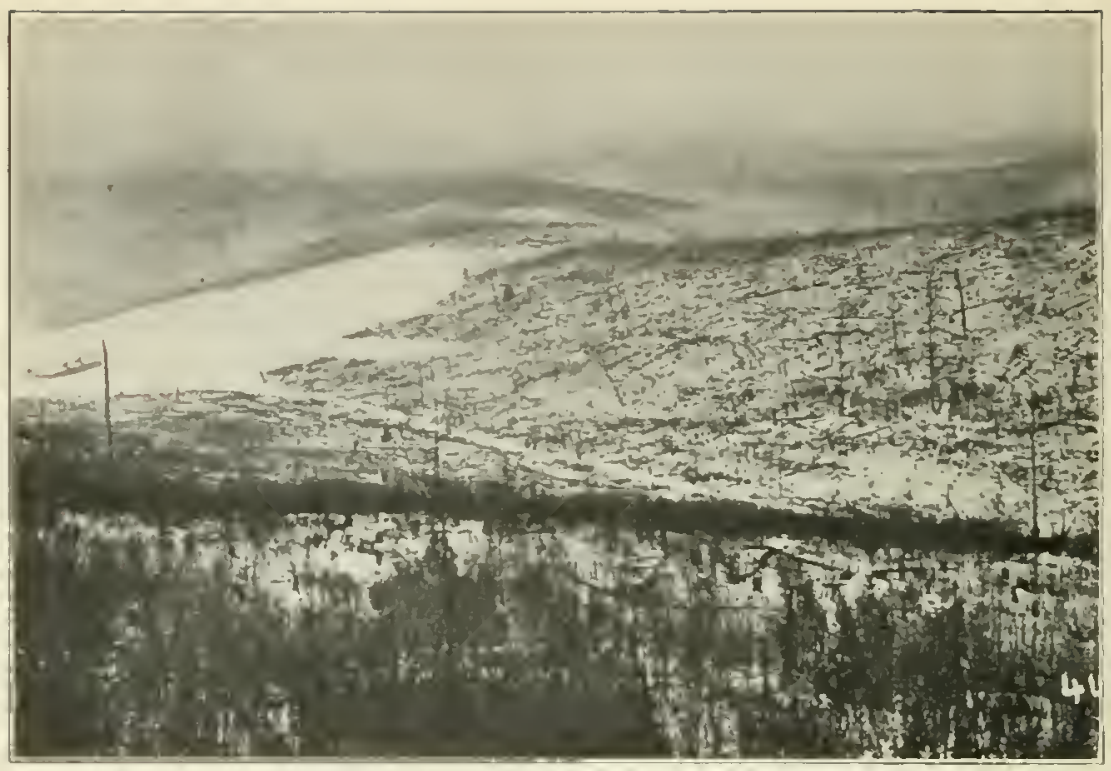

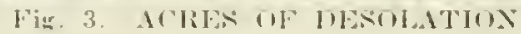

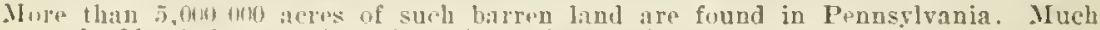
biluable timber wors lust thromgh rerkless "xploitation of the original forest.

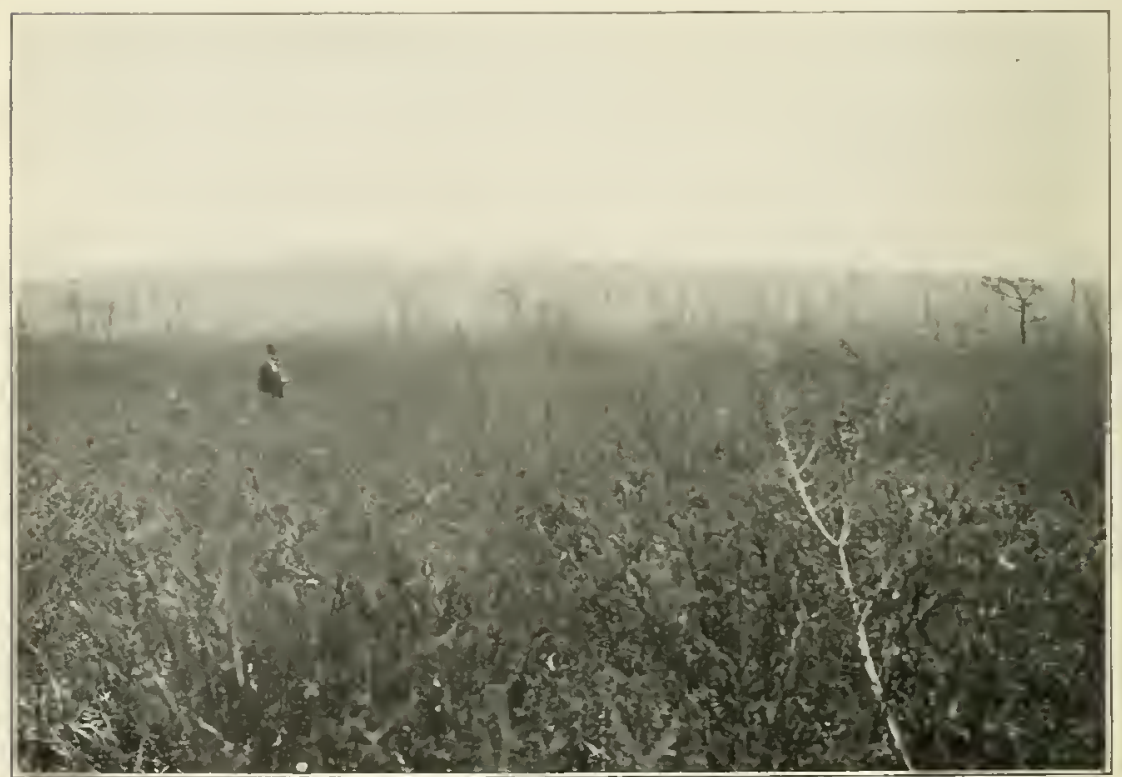

Fig. 4. ACRES OF SCRUB

Scrub Oak has uo timber value. large areas in our forests contain many weed species which uften prevent other valuable trees from establishing themselves. 
destructive work of lumbermen, and the adrent of forestry present a picture of change and progress, which enables us in part to comprehend the important role that man played in transforming the original forest into the present forest.

Pennsylrania originally contained large, dense, and extremely productive forests. The large have become small, the dense have become open, the productire hare become unproductive. Each generation of mankind has seen a smaller, more open, and less productive generation of forests. The march of forest destruction has been rapid and serere and yet ineritable on account of existing economic conditions. While originally almost the total area of the State was corered with tree-growth, to-day less than 50 per cent. is corered by woody growth and over 5,000,000 acres of this is barren or unproductire, while many more acres are poorly stocked with trees. Ilost of our woodland areas are at present in a very unproductive unsanitary, unattractive, and unregulated condition.

Economic conditions have changed and the old order of things need not continue. We must substitute conservative lumbering for the wasteful exploitation of the plast. We must do constructive work in our forests now to recompense for the destructive work carried on dnring the last few centuries. We should aim to show our social and ciric worth by handing down to future generations a heritage equiralent to that which we reccived from our forefathers. In order to do proper constructive work it is necessary to establish a goal or an ideal and derelop proper methods by which it can be reached or at least approximated. We need not be entirely original in this work since a few countries like Germany, Switzerland, and Fran e have already in more than a century of experience laid the foundation for conservative and constructive forestry. We can learn much from these countries. A risit to their carefully managed forests together with a general surrey of the methods which they use in managing then will be helpful in formulating plans for our Ideal or Normal Forest. We may not be able to adopt their methods but we can at least adapt them. The question at once presents itself: How can we improve our woodlands so that they will approach the well-managed forests of Germany, or the ideal or normal goal which we are setting up for them? The following answers suggest themselves:

1. By giving adequate protection. Fire is the chief agency against which our forests need protection.

2. By procuring wise taxation.

3. By prohibiting unregulated cutting.

4. By securing quick reproduction after the remoral of the timber. 
5. By extablishing a complete stock of valuable trees on all forest soils.

6. By removing nudesirable stock and replacing it with a better class of trees.

7. By estallishing a poper proportion and a suitable distribution of agre classes.

S. By making every part of the forest accessible by means of loads, lanes, trails, paths. compartment lines, ete.

?. Br making improvement cuttings.

10. By dividing the forcst into working mits (compartments) just as a farmer divides his farm into fields and the fields into patches.

\section{THE FORESTS AND FORESTRY.}

Thro oliginal forest was so modilied ly the activity of man, or man working ronjointly with natural acrencies, that the sonuce of our future rool supply lowanc a question of great importance. A gen-

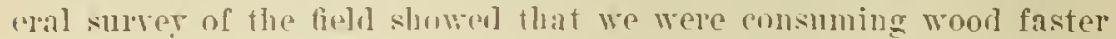
than we wele froduring it. This mulancer economic condition due to the unregrulatel condition of our forest gave birth to the subjeet of forestry. Man's altifule towards the forest showed that he was a distmbing ascut. Without lim the forest of Penuspryania would lave remaium practially undisturled, indefinitely. Hence it might follow that the forest thrives hest whele there are no people, and consequently no forestry. Further, one often hears the statement: Folmerly we harl no forestre and plenty of wood; now we bave forestry lut no mond. 'This statement does not jove that forestry is to be blamed for a deficiency in our wood supply, but it locs pore that forestry is the child of necesity. This chile of necessity. which is at presont just in its formative period, could never lave been born if wr had not been compelled to see that our timber lesources were l'apidly decreasing.

The word forestry to mant mạ be new. The most enlightened may have a rather rague enception of its exact scope. It is often identified with the plantiug of individual trees. landscape work, and tree sulger. Forestir should be regarded as the l'ational treatment of our woodlands for theil products. The kind of treatment derends largely upon the desire of the owner. The ownership may be private or there may be a jublic omner. as a municipality, a state. or a nation. The desire of the nmel may he to suplyly nood material. to retain or estahlish a protectire cover, to furnish recreation gromuls, ol to maintain a game cover. The forests which are managed for the purpose of producing a supply of wooly material are known as production forcsts or supply forests, while those which 


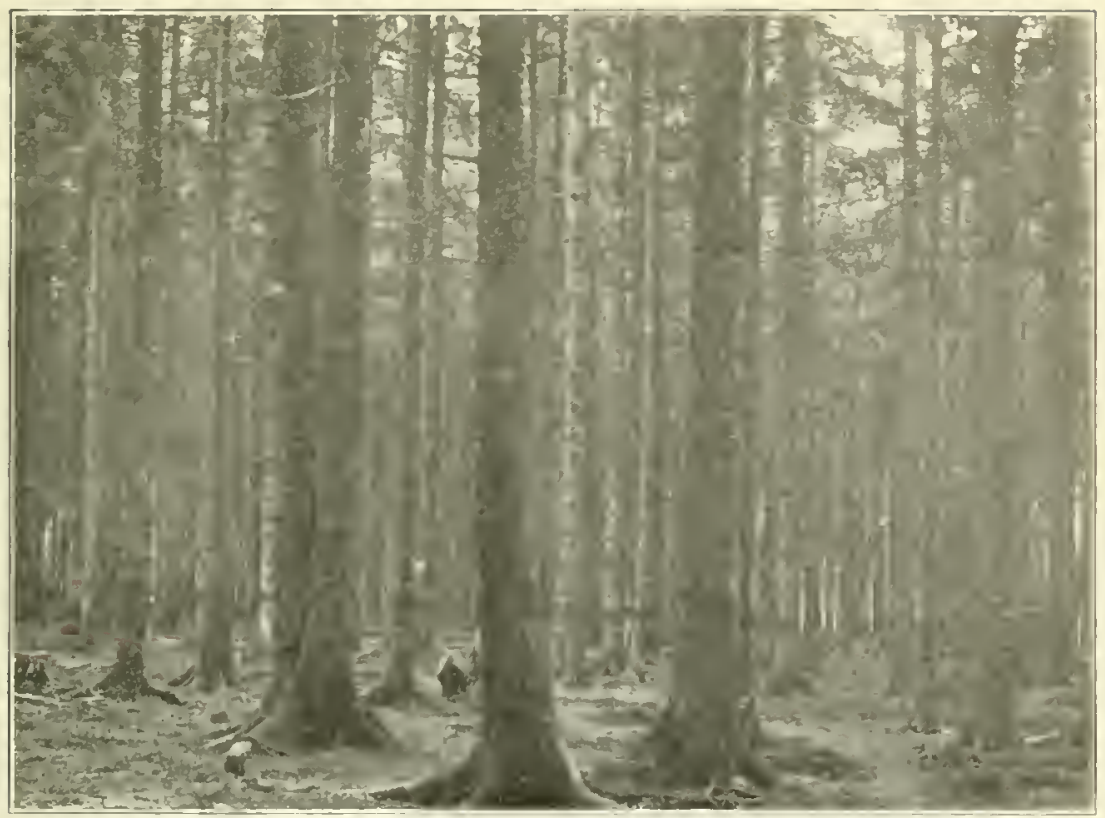

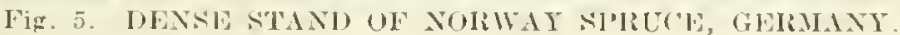

'The find of forests wh hope to develup. Norway sipuce is a valuable and a beatutiful tree.

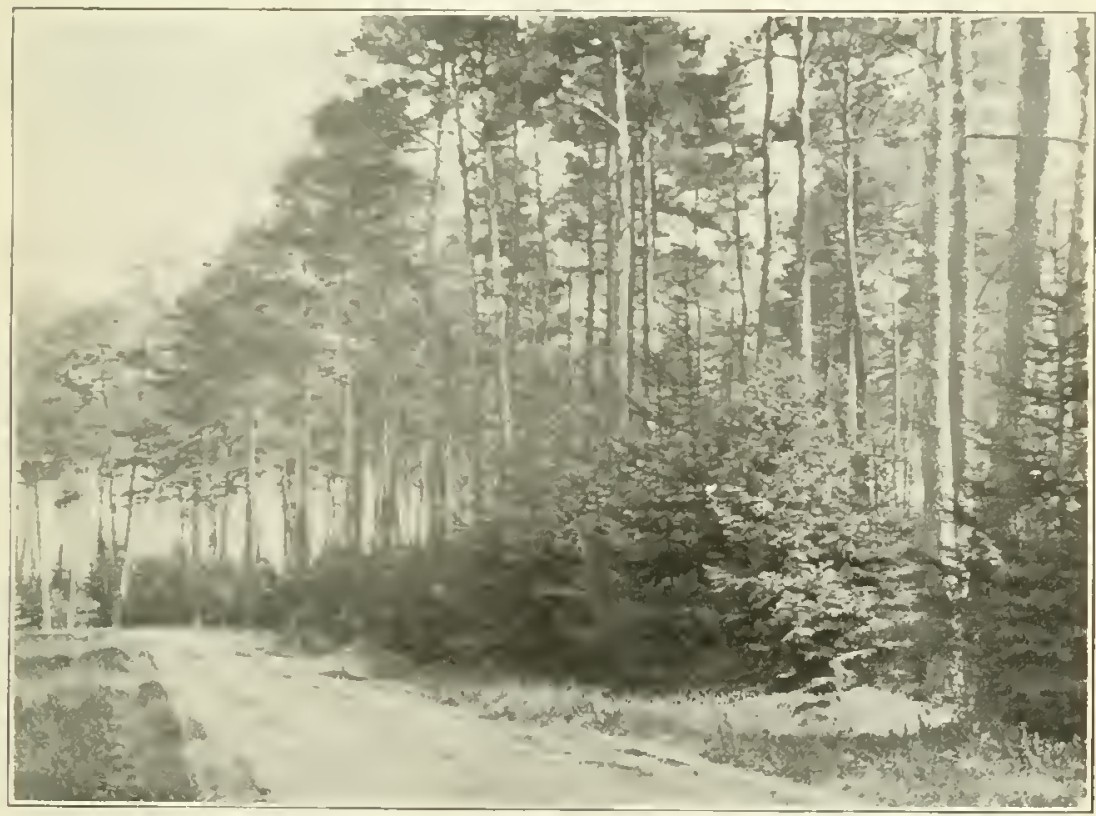

Fiz. 6. CAIEFULLY MANAGED FuREST.

Atractive, sinitary. nroductive, and organized. Good rouds ramify through all its parts. 


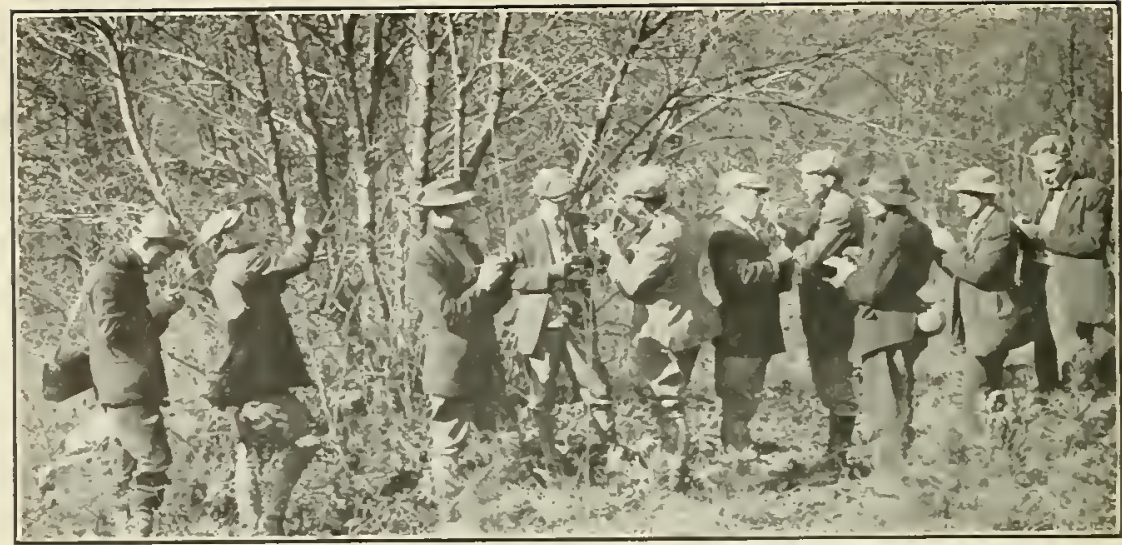

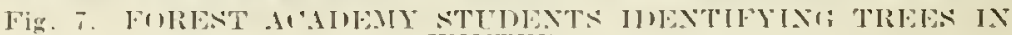
WINTER

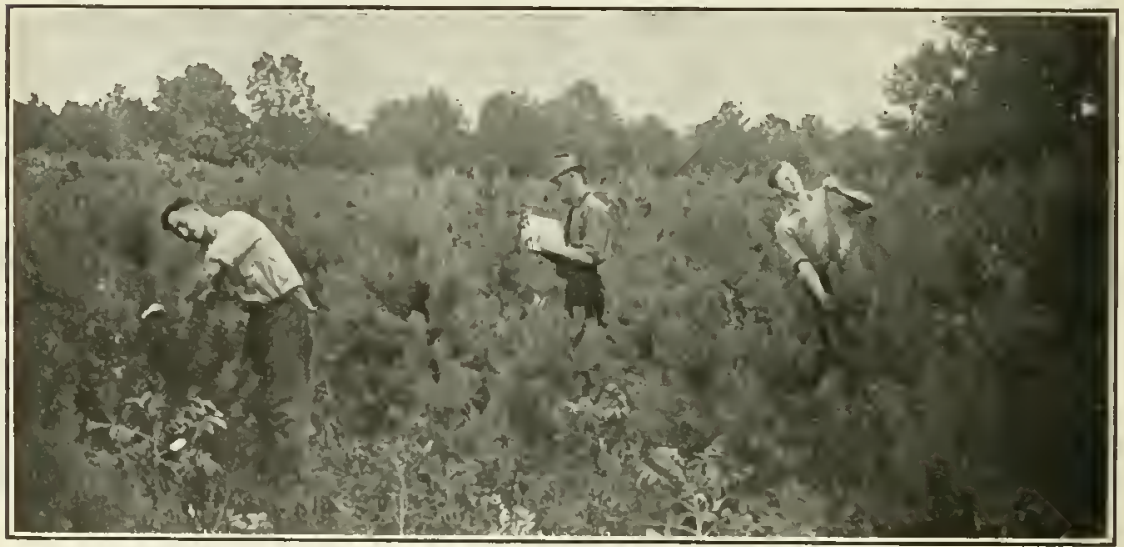

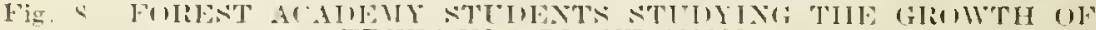
TREIES IN A PIANTATION

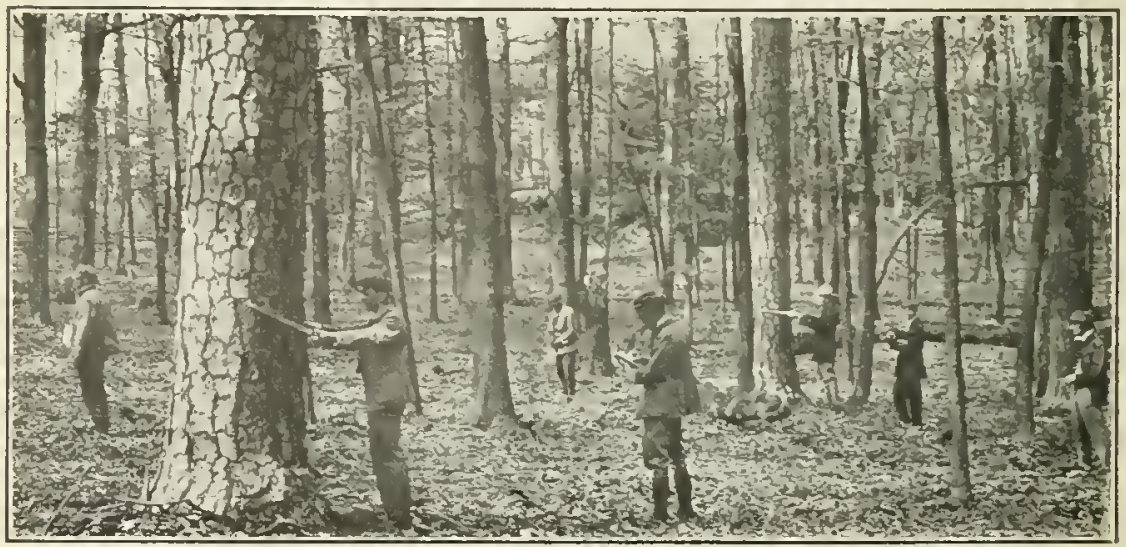

Fir. 9. FOREST ACAIHAY STUDENTS ESTHATING TIHBER. 
are retained or often established as a protective corer are known as protcction forests. I'rotection forests aim to prevent calamities like destructive floods, excessive erosion, sand shifts, and snow shifts. Forests mauaged primarily to enhance the beauty of the forests and to furnish recreation grounds for the public may be known as park forests. l'ark forests slunld always be accessible to the public. such outing grounds will not only be a means of preventing many of our diseases but also help to restore to health those who are already aftlicted. Forests managed by the owner primarily to enjoy sport are known as luxury forests.

Forestry aims to have man improve upon nature's ways of doing things. Yature grew forests upon areas regardless of the fitness of these areas to other more profitable pursuits. Both the thin, relatively sterile soils of the mountaius and the deep, fertile soils of the valleys were corered with forests. The latter are far more valuable for the production of food material than for the production of wood material. Forestry aims to develop forests on forest soil. It does Iot attempt to encroach on agricultural soil but aims first to classify the land into ploughland and woodland; and then to treat the woodland areas so that they will yield the largest quantity of high class wood material in the shortest time at the least expense of time and mones and 10 give to mankind as many other natural blessings as possible. The economic point of riew should always be kept paramount. The forester's forest should supply more fully the present and prospective human wants than they can be supplied by de pending upon nature's uncertain and unregulated performances.

\section{FORESTRY IN PENNSYLVANIA.}

Forestry had an enrly beginning in Pennyylvauia. As early as 1681 William I'enn in his Charter" of Rights stated that "In clearing the ground care should be taken to leare one acre of trees for erery five acres cleared; especially to preserve the oak and mulberries for silk and shipping." From this time on at irregular intervals acts were passed by the legislature protecting the woodlands from theft and firing; but no real, constructive work in forestry was done until the latter part of the 19th century.

In 1855 F. Andre Michaux left a legacy of $\$ 14,000$ to the American Philosophical Society in Philadelphia which became arailable in 1870 for forestry instruction. In 1877 Dr. J. T. Rothrock, Professor of Botany at the University of Pennsslvania, was appointed Michaux lecturer on Forestry, in which capacity he served until 1\$91. At this time it was dificult to interest the public in forestry and, as a consequence, at first, the lectures delivered by Dr. Rothrock were 
not well attended. The interest in forestry, bowever, grew gradually and cumulatively.

In June, 1886, the Pennsylrania Forestry Association was founded. It has always been and is still one of the best and most constructive organizations of its kind in America. In $18 s 8$ Gorernor Beaver appointed a Commission on Forestry, which was the first commission of its kind in this State. It presented a report to the legislature in 1859. The reports which this aud the subsequent commission presented to the legislature, together with the data obtained from the tenth census (18s0), helped to stimulate interest in forestry on the part of both legislators and the public. In 1895 the Division of Forestry was created in the Department of Agriculture and Dr. J. T. Rothrock was appointed Commissioner of Forestry. He serred in this capacity until Jnne 1, 1901, when he resigued. Hon. Robert S. Conklin, the present incumbent, succeeded him as Commissioner of Forestry. Under the direction of these able men the forestry work has progressed to such an extent in less than two decades, that Peunsylrania to-day stands in the frout rank with reference to the derelopment of its woodland arehs. Many constructive acts pertaining to forestry have been passed by the legislature, some of which have served as models for other states. In 1901 the Dirision of Forestry was raised to a Department of Forestry.

In 1903, by a special act of the legislature, the State Forest Academy, at Mont Alto, was established. Mont Alto is a small rillage in Frauklin connty, sixty miles southwest of Harrisburg on the Cumberland Valley Railroad. The ground occupied by the school buildings is a part of a state forest which affords an excellent oppórtunity for practical instruction and an accessible field for experimentation equalled by few if any forestry schools. Recently one of the leading forestry educators connected with an American Unicersity, a German by birth, in a public address said, "The Pennsylrania State Forest Academy has the best location and working field of any forestry school in the world." This school aims to train young men in practical forestry so that thes will be able to manage the State forests. Sixty-four meu have been gradnated, and most of whom are still in the service of the State. In addition to these foresters ninety-two ranger's are also emplored. A printed announcement of the school is arailable for free distribution and will be sent upon request.

The State authorized the purchase of woodland areas in 1897 for the purpose of establishing State forests. To date (July 1, 1914) 998,733 acres hare been acquired, located in 26 counties, at a total cost of $\$ 2,273,647.46$, or an arerage of $\$ 2.27$ per acre. This area is now being dereloped. Orer 5,000 miles of roads, lanes and trails hare been built, opened, or repaired. One hundred ninety-fire miles of telephone lines have been built and numerous fire observation 
towers have been constructed. The Department of Forestry aims to disseminate knowledge concerning folestry to the public, to protect carefully all State forests, to assist in the protection of private areas, and make accessible for management and utilization all State forests as rapidly as aluropriations ly the legislature will permit. Many large areas in various parts of the State are deroid of any raluable tree growth. Most of these areas are capable of developing useful forests. In orrer to have them developed it is necessary that such areas be stocked with valuable trees. It must he done by planting. About 6,000 acres have already been planted to trees in this State, which required a total of $11,970.500$ seedlings. In order to produce these seellings and to insure a future supply 4 large forest nurseries and 22 small ones have been established. Many other benefits are derived from the forests. Ther serve as recreation grounds to the jublic who seck their midst to regain or maintain health. Carefully managed forests regulate stream flow and are also the sources from which cities and towns olstain an excellent supply of unpolluted water. They furnish local labor, and, through permits, suitable camp sites to campers, hunters, and fishermen. The sale of material from the State forests lias alrealy yielded over $\$ 84,000$, eighty per cent. of which will be set aside for "The Siate School Fund of Pennsylvania."

\section{THE STRUCTURE OF THE FOREST.}

Every region and, often, even every small locality has its peenliar kind of forest. The composition of the folests along streams, on slopes, and upon mountain tops usually shows great difierences. The climatic factors and physiographic features of a region influcnce the iomposition of the forest very much. The more ralied the factors of the habitat are, the more varied the composition of the forest usually is. Ipon the same mountain slope one can often find three and sometimes more zones of trees. Each zone is composed of different species or gloups of species, which groups vary not only in composition, but also in form, density, and thriftiness.

The forester seldom considers trees raised in isolated positions, but rather concerns himself with trees raised in masses or stauds. Such masses of trees, irrecnective of their kind, size, density, form, number, ol value are known as woodlands. Woodlands may be composed of a single species or of two or more species. If one species composes ninety per cent. or more of the total stand it is known as a pure stand and if the stand is composed of two or more species uone of which forms ninety per cent. of the total stand it is known as a mixcel stand. Woodlands are rarely quite pure. A slight admixture of some species is usually present. The forests of Pennsyl- 
rania are decidedly mixed in their composition. The conifers are found oftener in pure stands than the broad-leared species. Since the forests of this state are composed largely of hardwood species it is rather unusual to find pure stands. Occasionally one mar find small pure stands of such species as I'itch Pine, White Pine, or Red Cedar and rather extensive ones of Chestnut.

About 125 species of trees are native to the State of Pennsylrania but not more than 25 species are of sufficient importance to deserve to be dereloped in our future forests. A large proportion of our native trees is found as undergrowth. They form dense and sometimes almost impenetrable thickets. This dense and complex structure of our underwood aids considerably in inereasing the number of rartieipants in our forests. Dense and tall undergrowth tends to Inotect the soil from erosion, to conserve the fertility of the soil, and to afford shelter to birds which prey upon the insect enemies of the forest; but it may also implede the utilization of forest pro. ducts and make the tending of the forest more difficult.

The tendener of forestry is to climinate the undesirable species. We shouId eliminate eautiously since the despised species of to-day may be prized to-morrow. If this process of elimination is dereloped on an intensire scale, it means a rerluction in the number of species aud. in extreme cases, leaves only one species, i. e. a pure stand. This is especially true where a forester aims to establish a stand by artificial seeding or planting. He is apt to choose a species, which he thinks will gire the highest returns. If he selects the proper species and it is not injured during its derelopment he may fossibly obtain satisfactory results. Before establishing stands one should consider the subjoined advantages of pure and mixed stands. The principal advantages of pure stands are:-

1. Pure stands are easier and cheaper to establish.

2. Pure stands are easier to tend and manage.

The principal advantages of mixed stands are:-

1. Mixed stands utilize the arailable plant food in the soil and air more fully. Close utilization of the factors of the habitat and keen competition by crery forest tree upon its neighbor are requisites for optimum quantity and quality production.

2. The forester can mect the demands of the market better with a few species than with one species.

3. A larger number of trees per unit of area is usually found in a mixed staud than in a pure stand.

4. Many species are Iess subject to damage by wind, frost, fire, fungi, and insects, in mixture than when grown pure.

5. Trees usually develop a better form if mixed properly than if grown pure.

6. Mixed stands are more attractire than pure stands. 

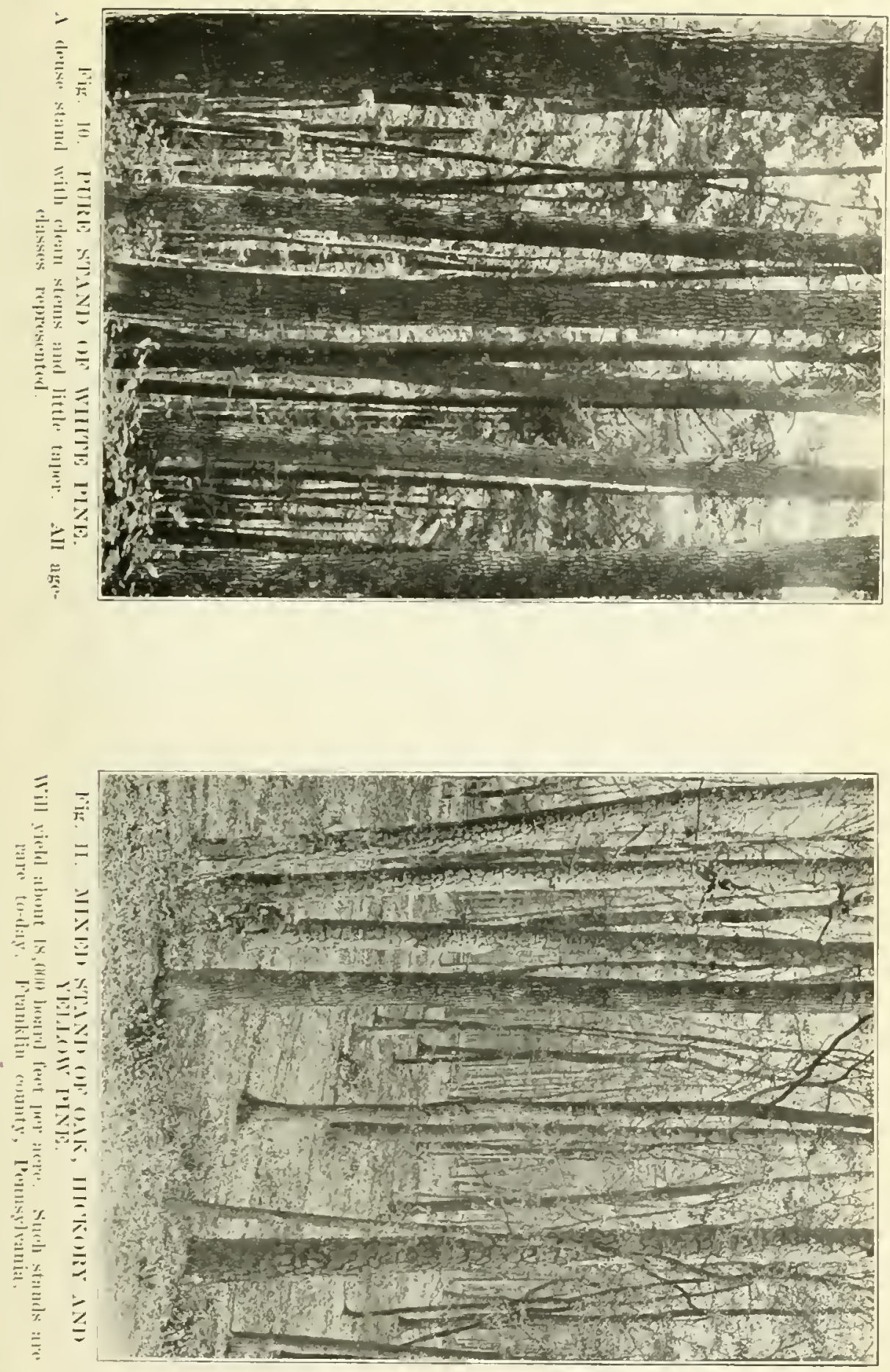


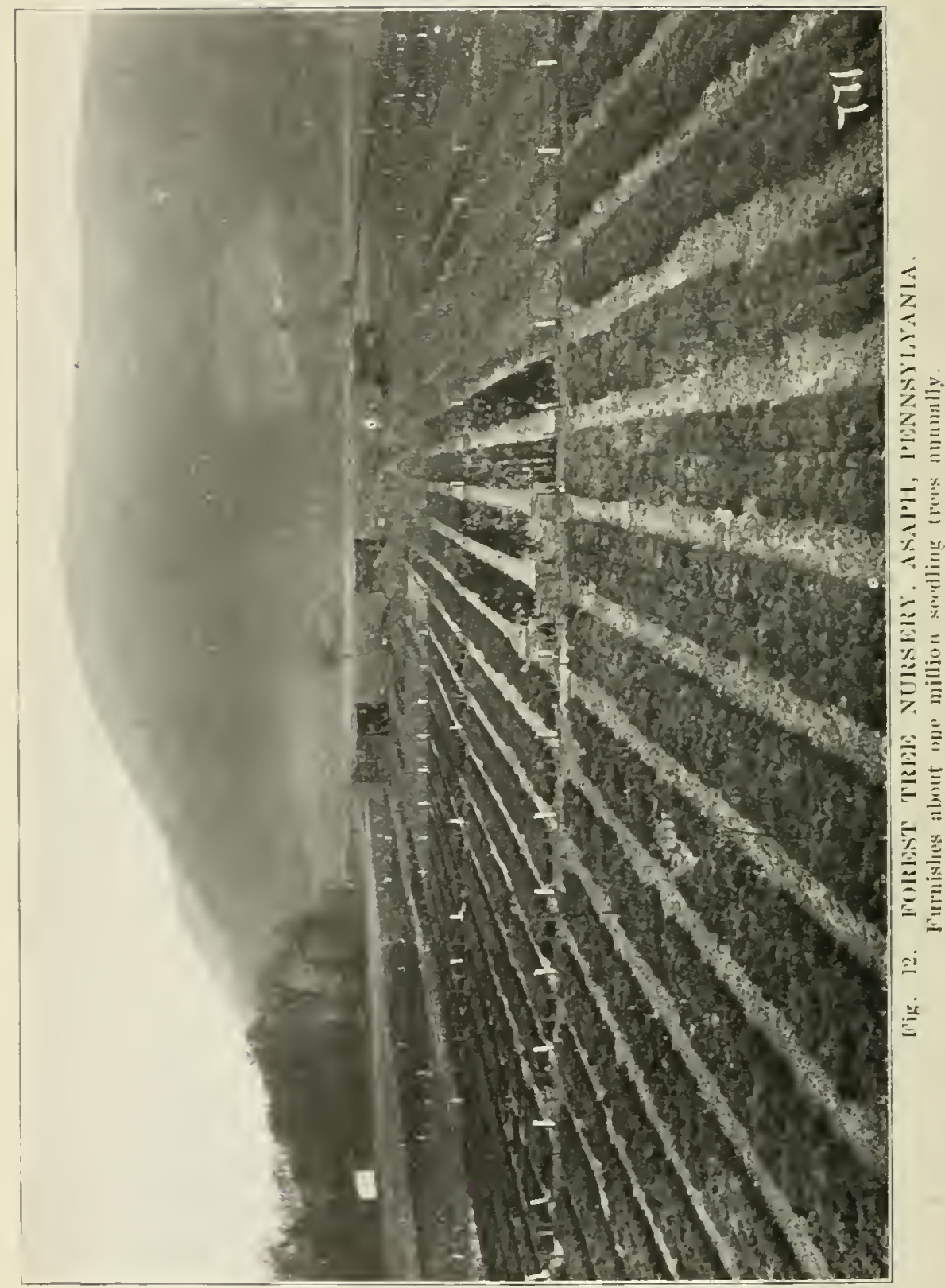


A great many pure stands may be seen in the forests of Germany. Some of them were established over 100 years ago and are now ready to be cut. After more than a century of experience in planting, the German foresters are abandoning the policy of establishing pure stauds and ale adrocating mixed forests. Mixed forests may consist of a mixture ly single trees or of a mixture by groups. The mixture may be temporary or jermanent, even-aged or uneven-aged.

We should aim to improve the composition of onr forests by reducing the percentage of inferior species and increasing that of the more valuable ones. The present cover types which consist of many despised, some neutral, and a few prized species, should be transformer into the future management types which will be characterized by a simpler but superiol comprosition.

\section{THE ESTABLISHMENT OF THE FOREST.}

As rapidly as the mature forests on absolute forest soil are removed they sould be succerded by young forests. 'These new forests which follow in the wake of those removed may he estahlished by one or by a combination of the following methods:-(1) Natural, whele uature, aided to a limited extent by man, sows seeds and produces sprouts. (2) Artificial, whele man sows the seeds or plants the seedlings. The former is usually spoken of as natural regeneration and the latter as artificial regeneration. In both methods nature loes most of the work; but man helps nature more in the artificial method than in the natural method. Nature working through many centuries produced the original forest. We cannot wait for nature to produce another original forest on our forest soils. It will take too long. We may assist nature and attempt even to improve upon its way of doing things; but we must be careful that we do not deviate too fal from its methods for fear of being punished.

In the case of artificial regeneration it is necessary to collect seeds from desirable trees. These collected seens may be sown immediately or stored. If stored, they must be protected from such animals as mice, squirrels, and birds, and from drought. The seeds may be placed between layers of sand to prevent drying ont. Those seeds which ale sown immediately may be sown directly npon the area where they are expecterl to germinate and establish themselves or they may be sown in beds in a nursery where they in time develop into seedlings. Direct sowing may be in the form of broadcasting, where the seeds are seattered lather uniformly orer the area or spot planting, and where only isolater or seattered spots, often regularly spaced, are sown with seerls.

The nurseries in which the seeds are sown may be permanent and loeated in the open, or temporary and located in the forest under the 
shelter of trees. The nursery is dirided into a great number of beds which are usually about twenty-five feet long and four feet wide. The seeds may be sown in these beds in spring or fall, either by sowing them broadcast or in rills. Here the seeds germinate and after an incubation period of usually less than a month, but occasionally exteuding over a year, they appear above the ground. The germination can sometimes be stimulated by soaking the seeds in watel before planting. These young teuder plants like children succumb rery readily to adverse conditions. Consequently they must receive careful treatment and adequate protection while they remain in the nursery. They must receive protection from the intense sun, excessive moisture, drought, weeds, fungi, and animals. The plants which develop from the sown seed may remain for one, two, or three years in the nursery. Those plants which remain for more than one year may be kept iu the same place where the seeds which produced them were sown. If too dense they must be lifted and planted in another place where they will hare more room. This process of lift. ing the seedlings and planting them again is known as transplanting, and the resulting plants are transplants. Transplanting usually produces better plants because they are stockier and better prepared for the shock they will receive when planted in the forest. Species like White Pine, Red Pine, and Norway Spruce are usually left in the nursery for two or three years and then transplanted while other species like Ash, Walnut, and Oak are left in the mursery only one year.

The seedlings planted in the forest are usually raised in nurseries but accasionally they may be taken from the forest floor where nature often produces them aloundantly. The cost of raising plants in the nurseries varies witl the species, cost and quality of the seeds. and the length of time left in the nursely, but is usually from about $\$ 2.50$ to $\$ 1.00$ jer thousand. The source, method of collection, prelaration, and storage of the seeds hare a marked influence on the quality of the resulting plants. The plants, taken from the nursery or lifted in the forest, are usually planted in the forest about $4 \times 4$ or $5 \times 5$ feet apart. This requires from about 1,700 to 2,725 trees per acre. The total cost of planting an acre of cleared land to forest trees, including cost of plants, is about $\$ 12$. In individual cases the cost may exceed this figure and again it may be lower. This artificial method of regeneration is generally used where forests have been clear-cut or where openings are to be reforested. It is also used for underplanting where a better humus corering is desirable. In Europe, especially in Germany, this method was used extensirely during the last century as may be seen in the many even-aged forests found there at the present time. During the last decade a reaction has been setting in, based on scientific investigations. Many of the 


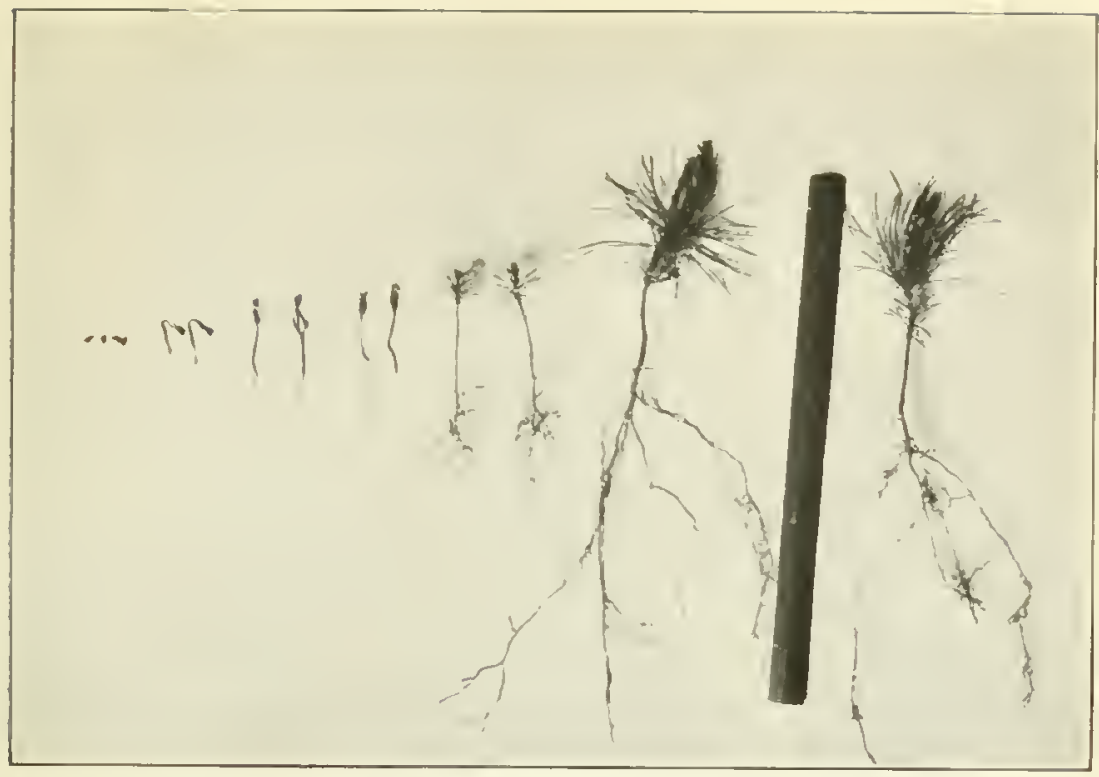

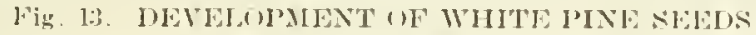

Seedling taken fr.m nursers May, 1914, after growth had stirted. From left to right: Four secels: six seedlings from fall-suwn seeds showing 3 stapes of derelupment directly after breaking through the uronte two l-year old seedlings : two 2-yent all serdlings.

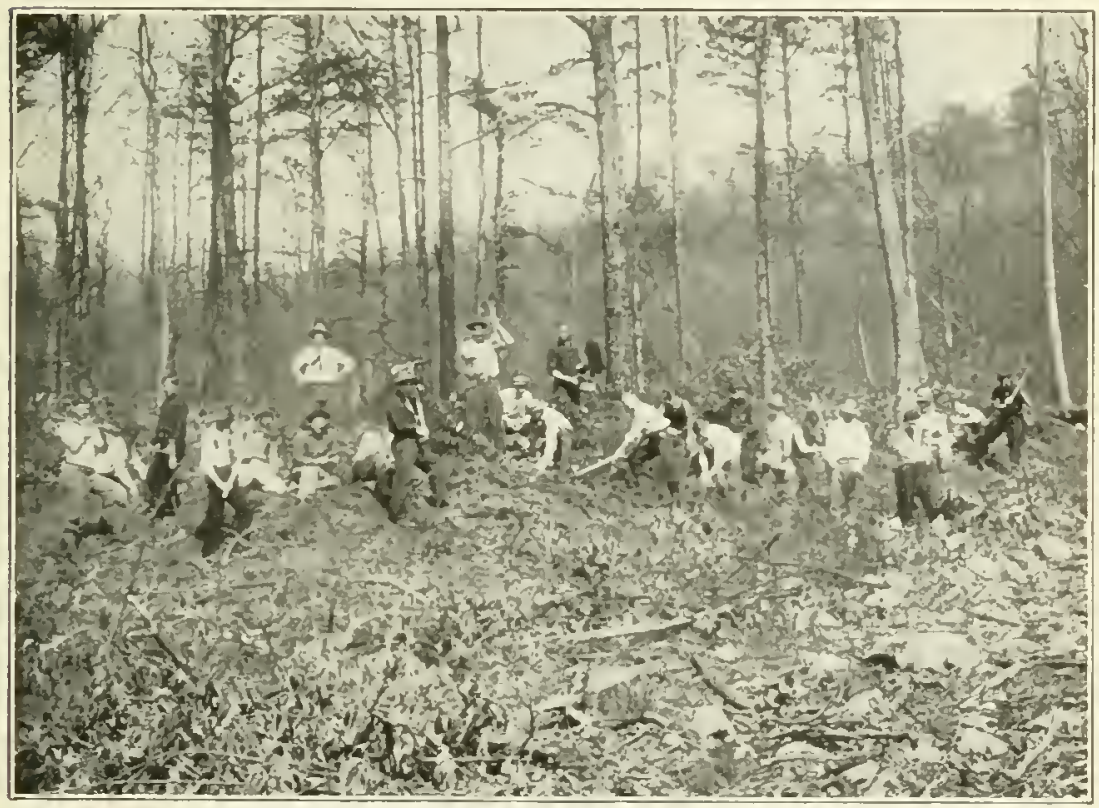

Fig 14. STUDFNTS PJANTING TIEES.

From 1,200 to 2,750 trees are planted per acre. A crew of 20 men ean plant 20,000 trees per day if conditions are favorable. 


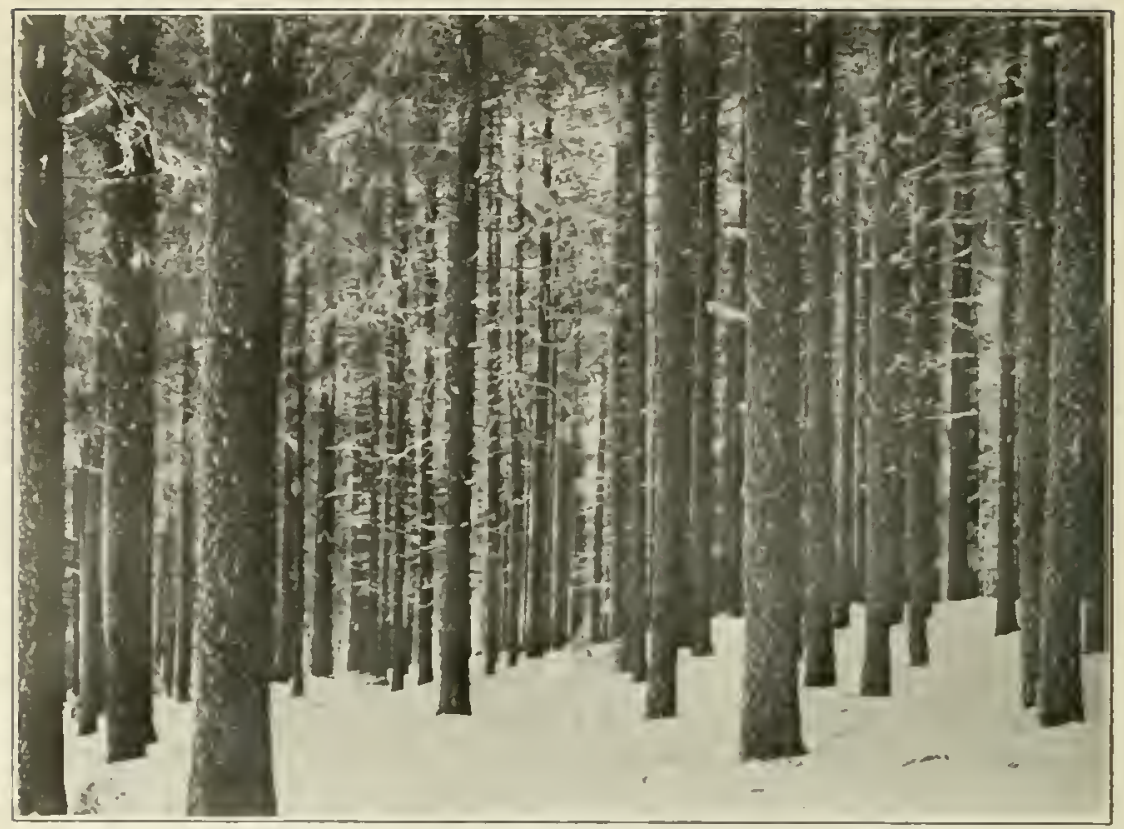

Fig. 15. NATURAL, REGLNERATION OF THE FUREST.

Norway Spruce before seeding eutting. Opening the leaf-canopy stimulates seed production .

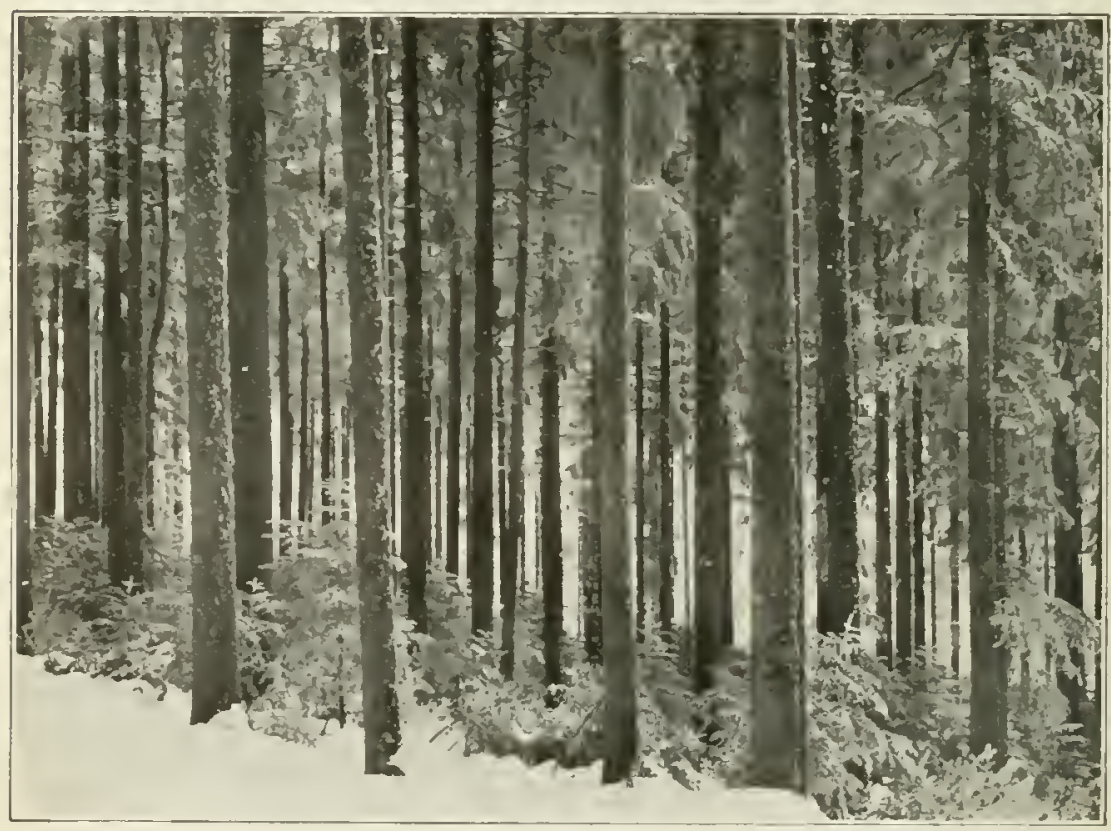

Fig. 16. NATURAL REGENERATION OF THE FOREST.

Norwa Spruce after seediug cutting. Regeneration following regulated seed production. 


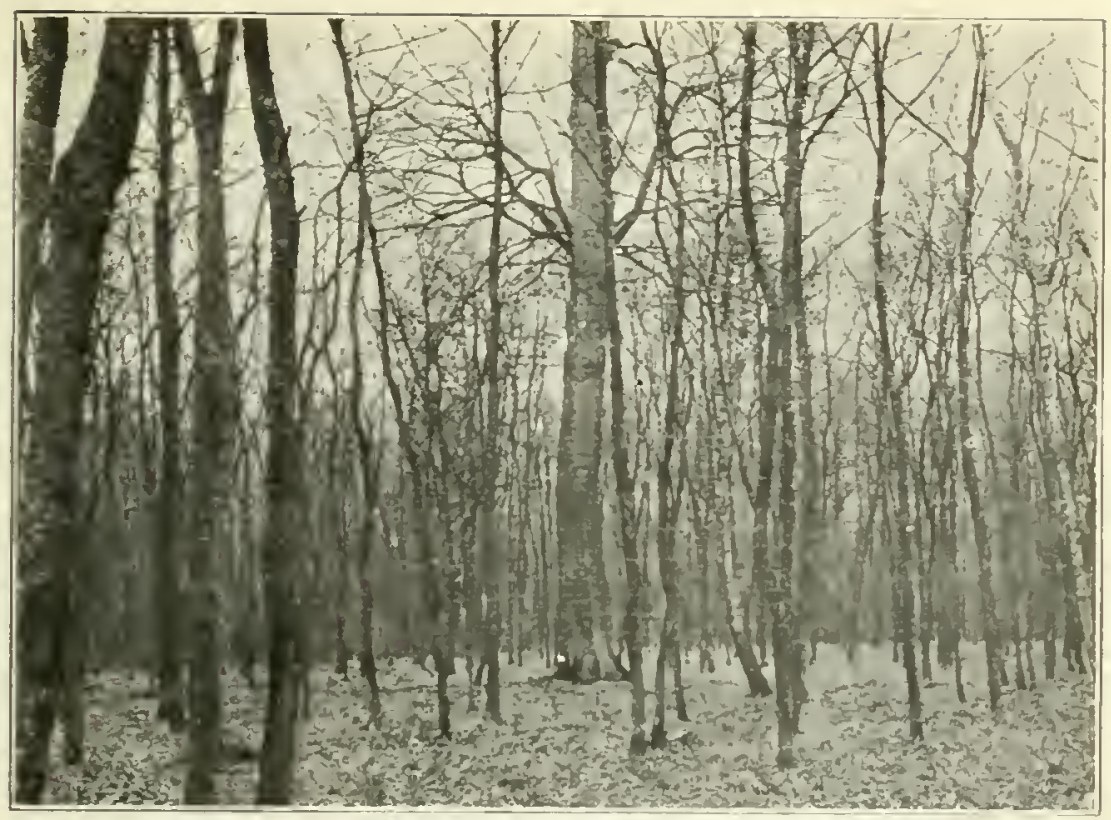

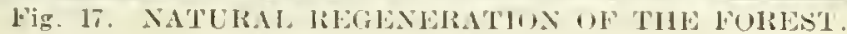

latrge Uak seed tree with its offspring.

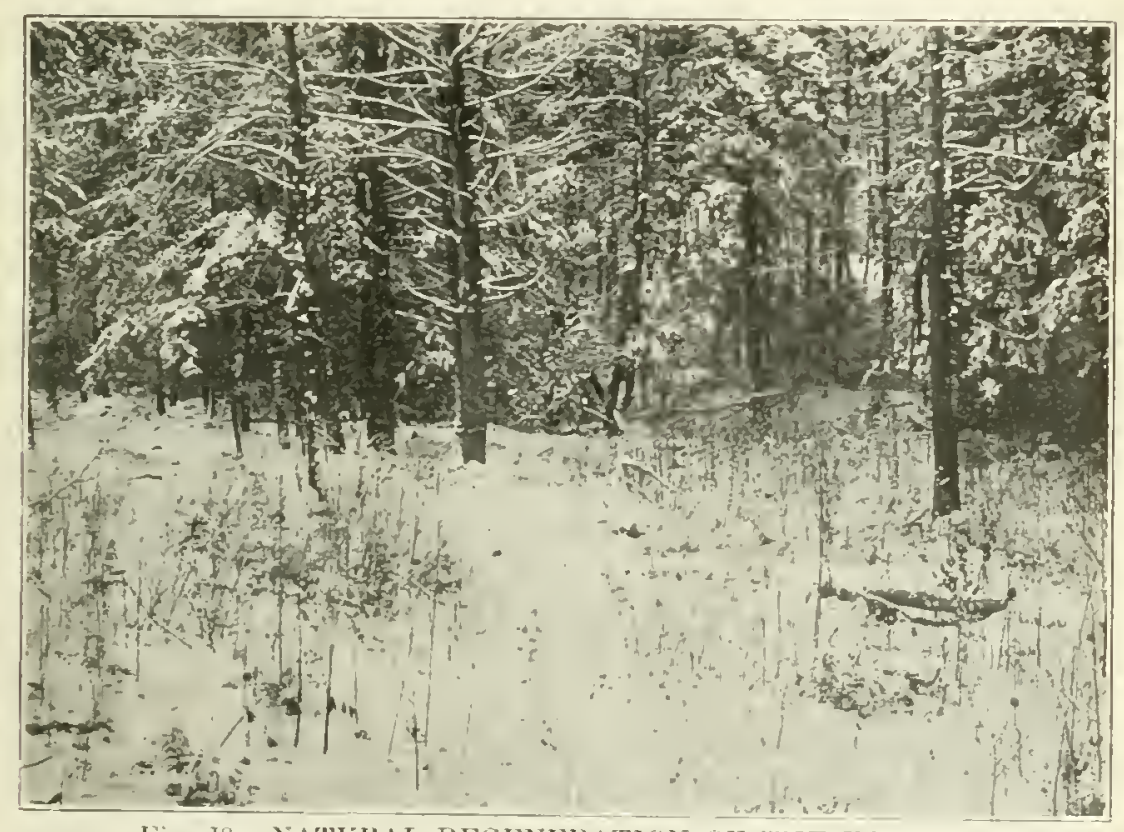

Fig. 18. XATLRAL REGEXER.ATION OF NITE FOREST

An opening being filled by a dense growth of White I'inr. Tulip, and IIemlock seed. lings, from seed scattered br bovdering lange trees 


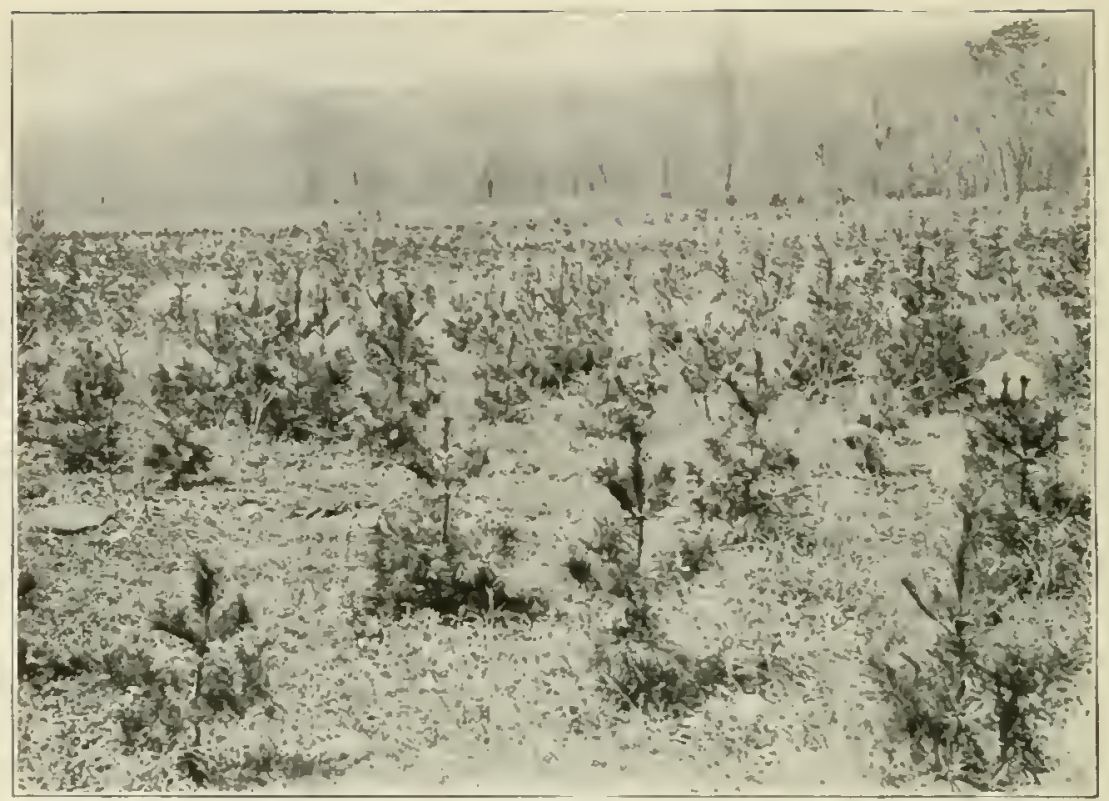

Fig. 19. PLANTATION WF WIITE PINE.

six sears oid from seed, about 2,000 trees, 2-3 feet high, per acre

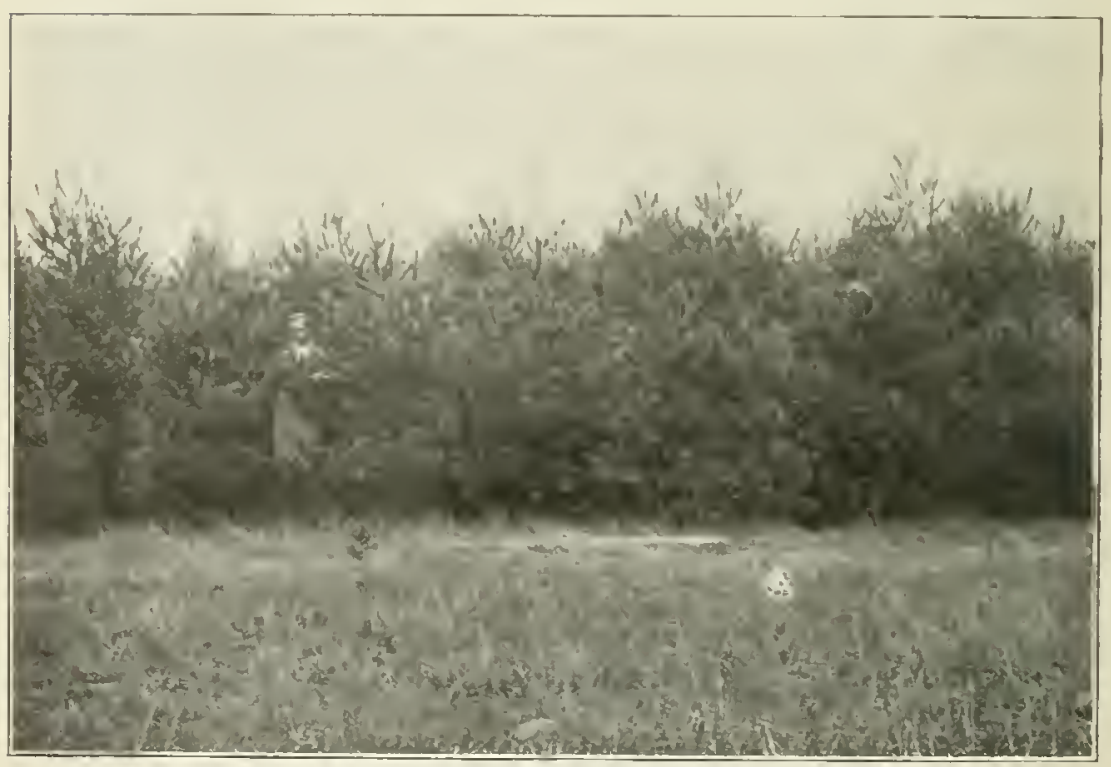

Fig 20. PLANTATION OF WHITE PINE.

lideren years old from seed, about 2.50il trees, $3-12$ fpet high, per acre. 
forests which were established artificially are now reaching maturity. Disadrantages of this method are becoming more evident and the foresters are gradually sulstituting the natural method for the artificial.

The natural regencration of forests may take place in two ways: (1) By coppice and (2) by seed. Br coppice is meaut the shoots which spring up from the stump when the tree is cut (Figs. 23, 24, 69, 79) and the suckers which spring up from the roots. Coppicing is a rather important method of reproduction in Penusylrania since some of our most valuable species, like Chestnut, Ash, and Oak reproduce readily by this method. Natural seed regeneration leaves most of the work to uature. Man attemits to hasten it somewhat by regulated cutting in the stand and by wounding the soil so that the seeds will find a farorable mineral soil upon which to germinate. The trees which produce the seeds may be scattered singly, or occur in groups, in strips, or in opened stands. These trees ale known as seed trees 01 mother trees. Some form of natural regeneration nust he used in protection forests, is arlvisalyle for game and park forests, and applicable to the forests which are managed for the production of wood. In some cases it is advisable to begin with natural regeneration and then fill in artificially all places which are not stroked with trees.

\section{THE DEVELOPMENT OF THE FOREST.}

The raising of some farm crops and the raising of a wood crop have many points in common. I farmer after planting his field to corn in spring does not leave it to mature to develop and mature, but he cultivates it and sometimes even cuts out undesirable sprouts called suckers, knowing that careful tending will result in a larger vicld. Likewise the forester is not satisfied in estahlishing a forest but he also aims to develop or tend it so that it will yield a large and valuable crop.

The method of developing a forest depends upon the nature of the forest and the desire of the owner. The forest may hare been established by nature and even partly developed by it or it may have been established by man. The forests established and dereloped by nature without the aid of man are usually in a rather unsanitary, unatractive, unproductive, and unregulated condition. Under such conditions it is necessary for man to transform these into forests which are clean, attractive, productire, and which show eridence of proper regulation on crery hand. The forests which man establishes usually start out with 2,000 to 20,000 or eren 50,000 seedlings to the acre, depending upon the method of establishment. If artificial methods of regeneration are used about 2,500 seedlings per acre are 
required but where natural regeneration is used one may find 20,000 or even 100,000 seedlings per acre. If we go into a mature forest stand and count the trees per acre we will find probably 150 , or sometimes 250 , and occasionally 400 ; hence, we must conclude that a large proportion of the trees which start out cannot survive. Two questions suggest themselves: What hapyens with the large number of trees which eannot mature? Why is it necessary to plant so many when only a small number can matnre? If one inspects a plantation of trees a fer years after it was established he will be able to note a difference among the trees. Some are thrifty, which is shown by their rajid growtb, others are arerage, while still others show no signs of growth whatever or may hare died. If one returns ten years later this condition is still more pronounced. By this time they will have grown to such dimensions that their branches are beginning to interlace. A struggle has started between them. There is no longer sufficient space for all of them. They must battle with each other for light and food. Some will conquer and be known as domin. ant trees, while others will jnst about hold their own and be known as intermediate trees, while still others will be conquered and be known as suppressed or deal trees. This struggle for existence is found in all places where trees grow in the form of a forest, and results in the elimination of the weaker specimens. At the same time it gives such drastic diseipline to the dominant ones that they will produce a much higher grade of wood. Trees grown in dense stands are usually free from lateral branches for a considerable distance from the ground and as a consequence the logs cut from them will be relatively free from knots; while trees grown in open stands or in open situations bear crowns which often reach almost to the ground and produce numerous knots. Such trees as the latter, consequently, yield an inferior grade of wood.

In dereloping forests the owner or forester in charge shonld aim to maintain a proper number of trees per acre and to treat them so that ther will not only rield a large quantity but also a good quality of wood. He should not aim to differ from nature's ways of doing things but improre on them. In ordel to inprove the forest it is necessary that the forester carry on certain operations in the immature stand which aim to improre the composition of the stand and the form of the individual trees. He should also aim to increase the rate of growth of the indiridual trees and as a result increase the rield in volume and value of the final prodnct. The principal operations which one must carry out in order to realize the abore obiects are: Cleanings, Liberation Cuttings, Thinnings, Damage Cuttings, Pruning, Weeding, and Underplanting.

Cleanings are cutting operations in young rather even-aged stands which remore undesirable trees with little prospectire ralue, and 

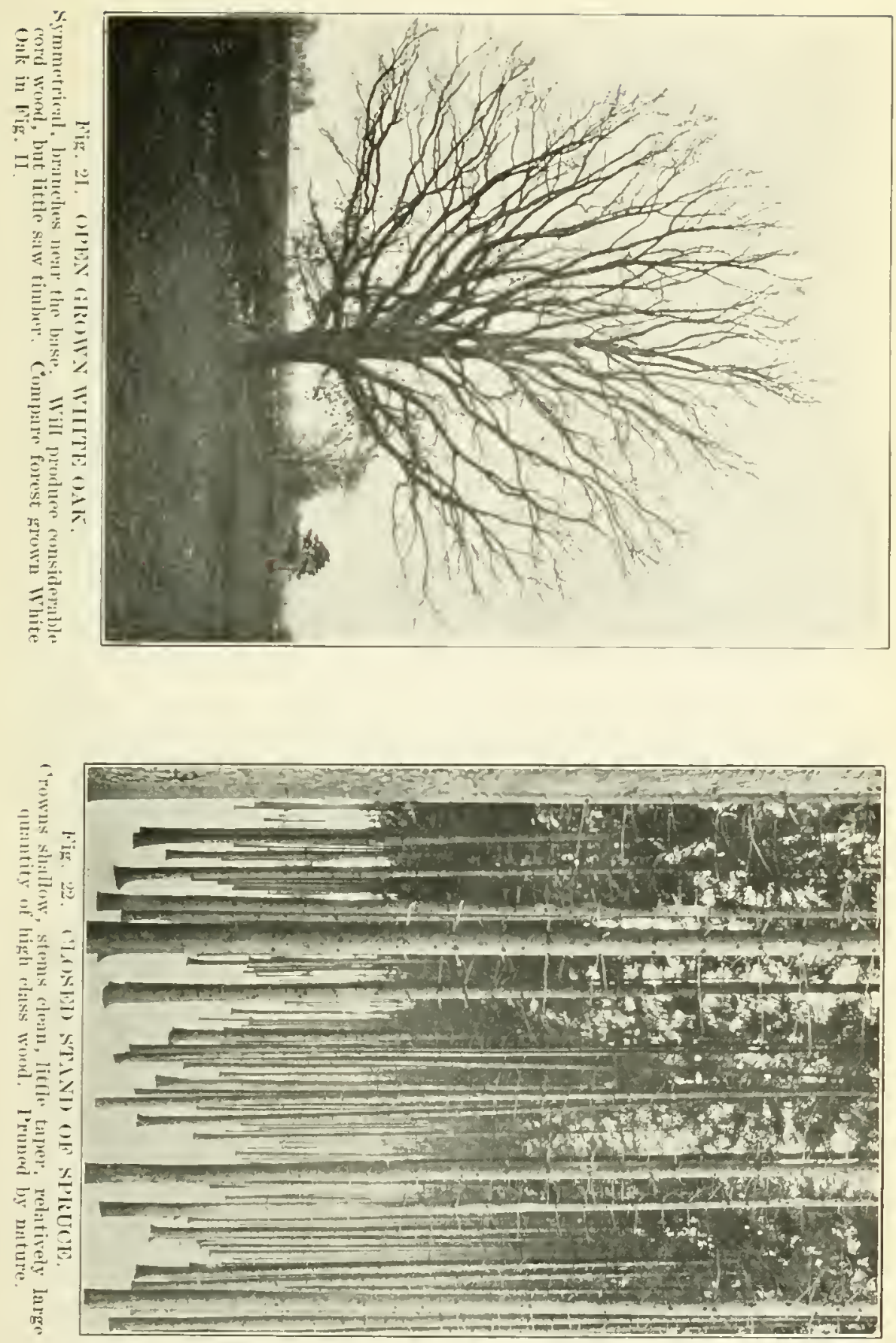


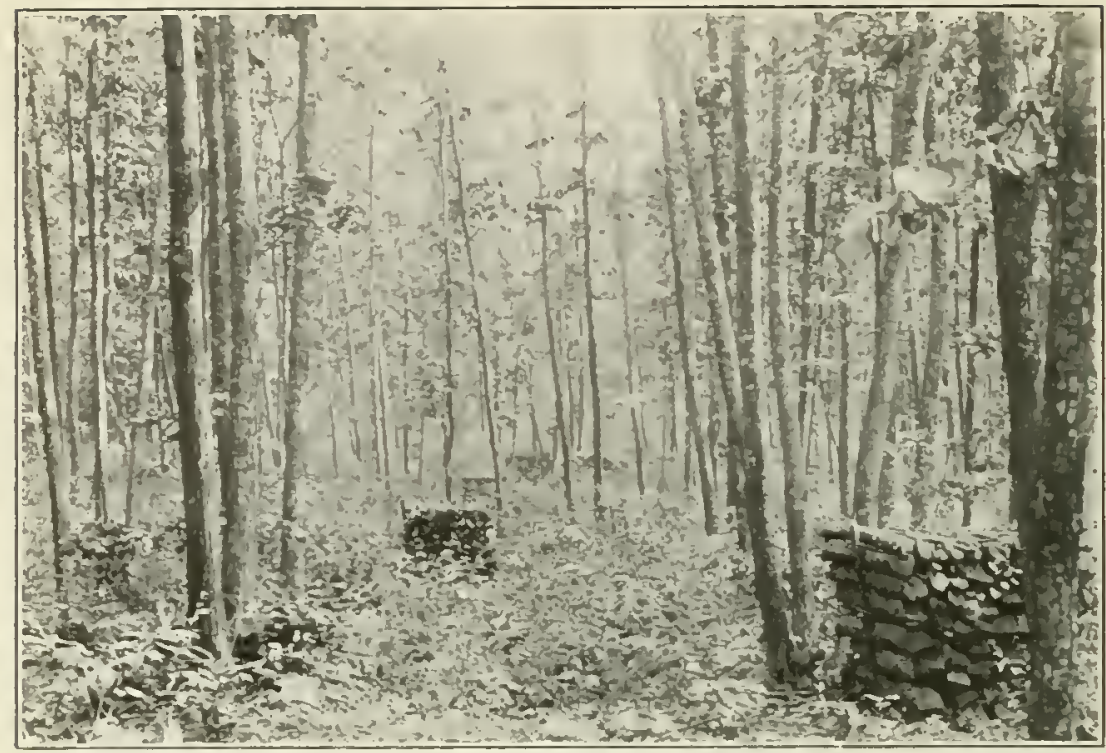

Fig 23. TIINNNED CHESTNUT STAND.

About 3.5 years old. Approximat 1 y 280 trees over 4 inches in diameter, breast high, still standing. Eight cords of wond per acre were removed.

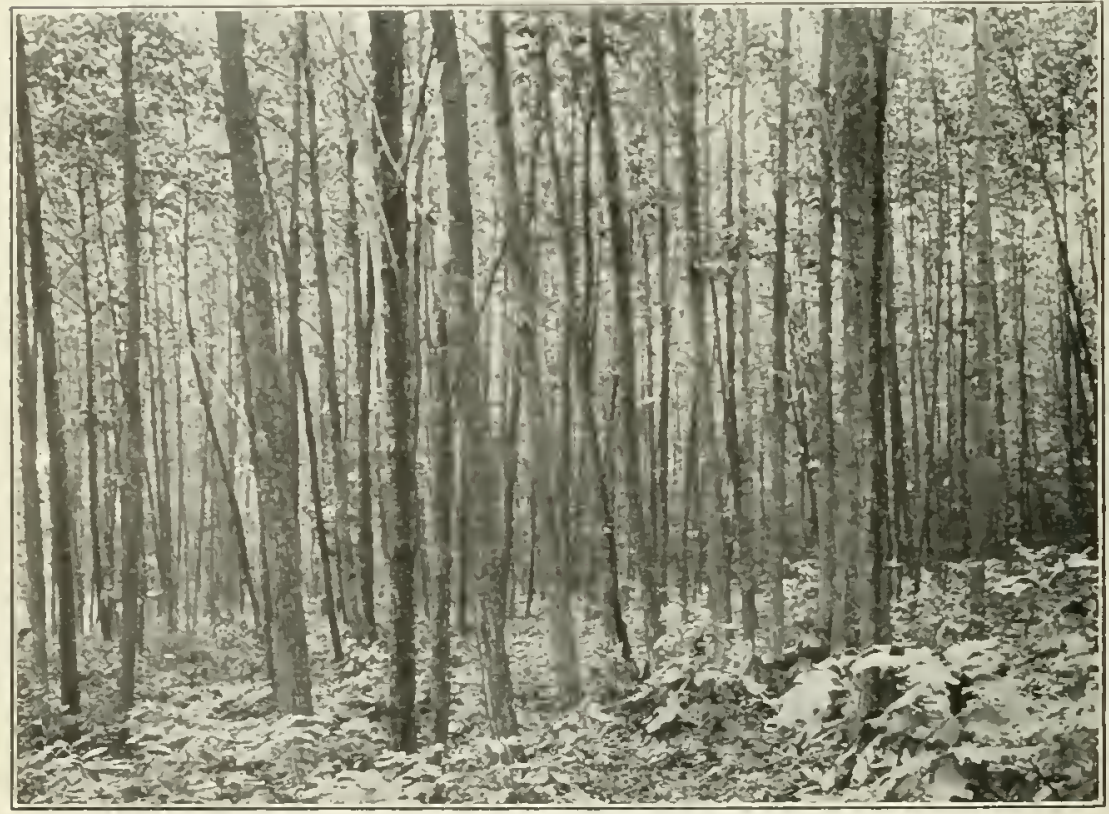

Fig 24. THINNED CHESTNUT STAND.

About 22 vears old. Average diameter of trees 5.5 inches. Approximately 650 trees per acre present. Over 90 per cent. Chestnut. 


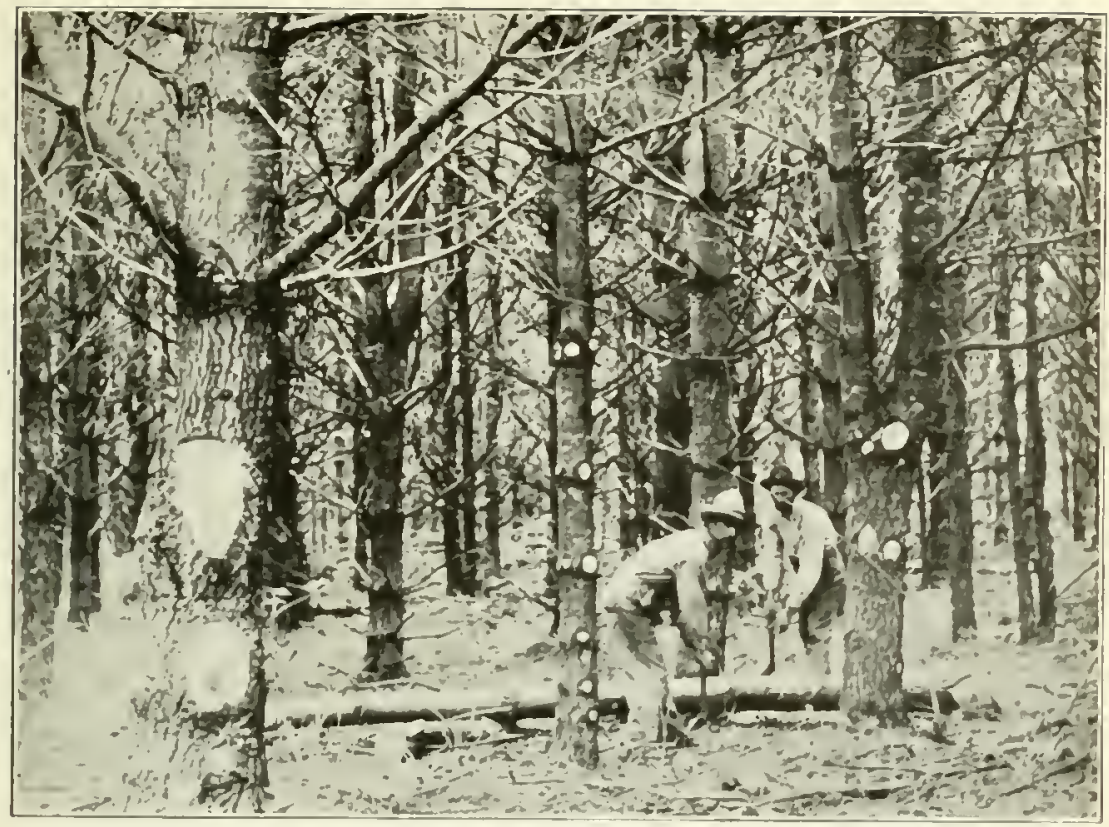

Fig. 25. WIITE PINE S'TANI IBERORE ANT DURING PRUNING

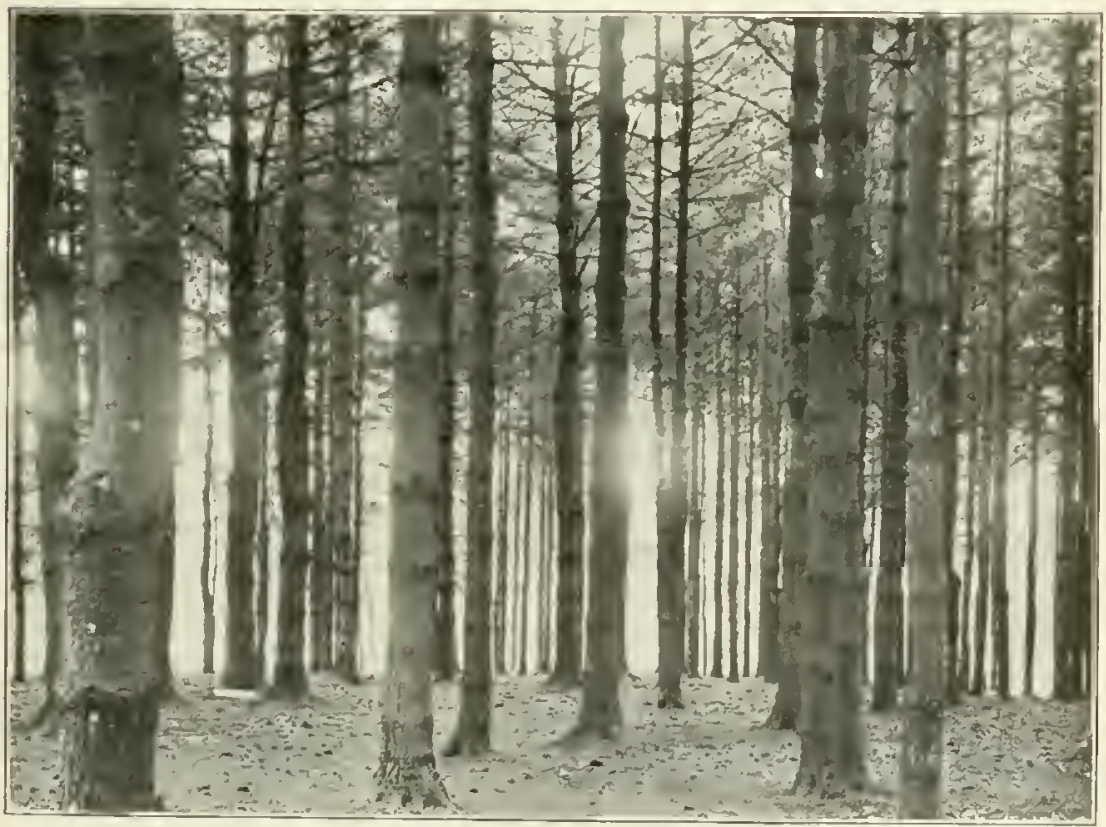

Fig. 26. SAME STAND AS FIG, 25, 10 Y EARS AFTER PIUNING 


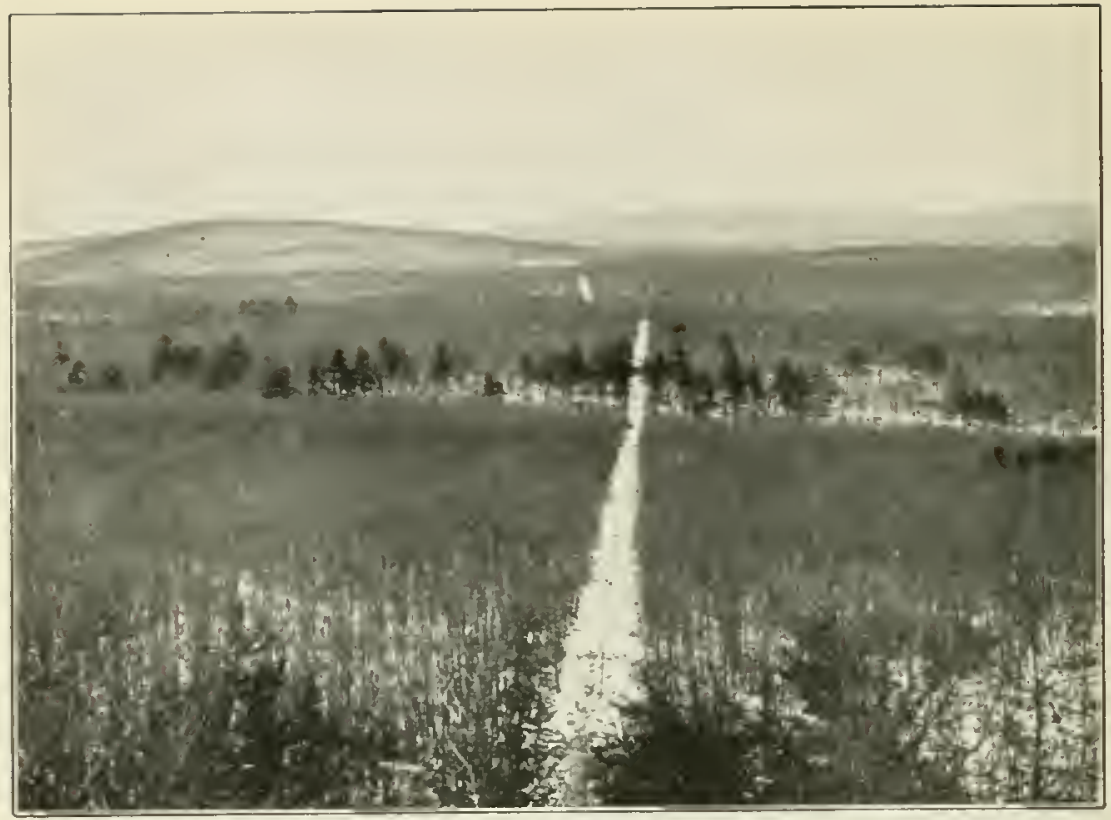

Fig. 27. OIL IPIP IANE AS A FIRE AND SUBDIVINION LIXE.

A base from whirln to fight fires. An excellent subrlivision line.

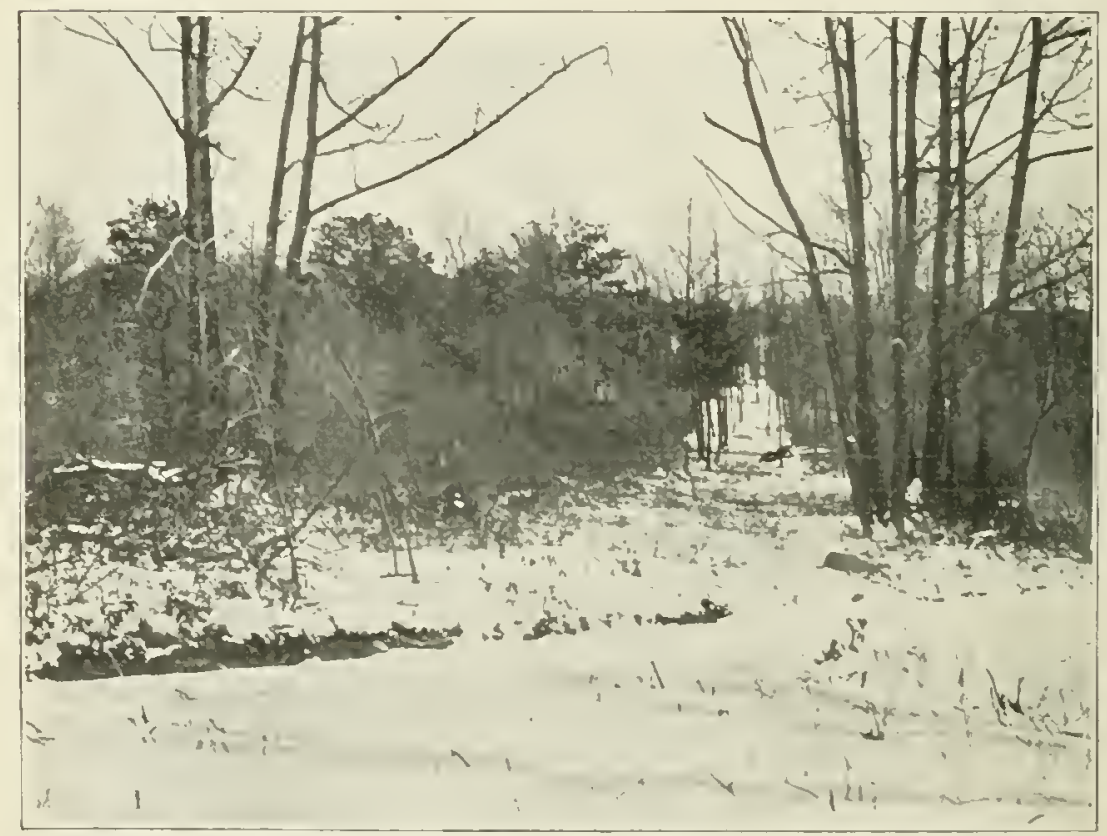

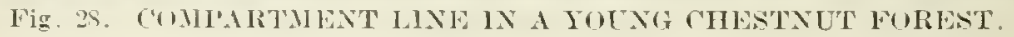

such lines afford a base for controlling fires, and make the forest accessible. 
favor other species with a good prospective ralue. These latter may have been overtopped by the undesirable ones.

Liberation Cuttings are operations in immatme stands in which the main crop of trees is orertopped by scattered older trees with very wide-spreading clowns. These older trees with present but little prospective value retard the development of a great number of younger trees with good prospective ralue. The removal of the larger trees is known as a Liberation Cutting.

Thinnings are cutting operations in immature stands for the purpose of accelerating the growth of individual trees and, as a consequence, increasing the total yield and improving the quality of the product. Thinnings result not only in a larger quantity and quality increment but aim to improve the appearance and health of the forest. They decrease the danger from fire since a large amount of inflamwable debris is removed. If thinnings are conducted properly the remaining trees are usually more windfrm. Thinnings also enable one to get returus upon a forest insestment without waiting until the crop is finally harresterl. 'Today, under on crucle method of regulating the returns from our forests, the thinnings or intermediate yield play a minor role, while the final yield comprises practically the total rield; but as onr niethods are developed and perfected, the intermediate yields will comprise as in the intensively managed forests of Germany, 25\%, and later, $50 \%$ of the total yield. All forest orners should aim to improve their forest stands by thinning them properly so that they will become more attractive, more sauitary, and more productive. This may be accomplished by thinning early, regularly, and with increasing intensity, but always cantiously, so that the fertility of the soil will be conserved and all arailable food properly utilized.

Damage Cuttings complise operations which remove all damaged material from the forest. The damage may be caused by wind, lightning, snow, insects, fungi, fire, or any of the many other agents which operate in the forest. Damage cuttings should be made as soon as possible after the damage is done not only in orler to utilize the material before it depreciates too much in value, but also to prevent the spread of such destructive agents as insects and fungi.

Pruning is an expensive operation and consists mainly in cutting off the lower blanches of trees where they were not pruned naturally, in order to produce stems with as few knols as possible and at the same time increase the beauty of the stand.

Underplanting is an intensive cultural operation which is practiced only under systems of intensire management of the forest. It may aim to conselve or eren improve the soil or to establish advance reproduction. The aesthetic value of underplanting is also a valuable asset in developing our forest. 
Environmental influences and inherent tendencies are factors which are constantly discussed in connection with the development of our youth into useful men and women. These same factors should be considered in dereloping the roung seedlings of the present forest into the reterans of the future.

\section{THE PROTECTION OF THE FOREST.}

The protection of the forest surpasses in importance all other forest activities during the early or formative period of forestry in any country. Forest protection is not only the oldest but also the most necessary branch of forestry. Many and raried are the destructive agents at work in the forest or upon the products derired from it. The destructive work of fire is very evident while that of fungi is often hidden. One cannot help but comprehend the destructive work of a forest fire which may sweep orer an entire mountain, kill every trace of tree growth, and, in addition, destroy buildings and occasionally human lires; but few eren apprehend the extent of damage by such agents as fungi which often cause the decay of the entire interior of a tree without giving any external evidence of their presence. In order to give adequate protection to our forests, it is necessary to know the dangers which threaten them. We must also know how to offset attack by employing preventive and remedial measures. The principal dangers which threaten the forest and against which man must protect it may be grouped as follows:-1.

Damage from human agencies. 2. Damage from organic agencies. 3. Damage from inorganic agencies.

Man's disturbing influence in the forest can be comprehended in part when one compares our present forests with those of the past. Primitive man had few wants, but as his cirilization progressed his wants multiplied and his destructire tendencies became more aprarent. The early settler found it necessary to destroy valuable forests for the purpose of establishing a home and for opening agricultural and grazing lands. He had no alternative then, but now conditions lave changed. He is just at the beginning of forest appreciation. He must introduce spstem and substitute conservative forestry for destructive lumbering, which latter has always been characterized by profligate exploitation and wanton waste.

Man is directly or indirectly responsible for most forest fires, since ther usually originate through lis carelessness or inaliciousness. Lightning is responsible for a rery small percentage. Of all the enemies of the forest none is so destructive as fire. A single fire may burn over a few acres only or it mar burn over thousands of acres in a single day. It not only destroys present but prospective value, since it consumes or lills mature trees and the young seed- 


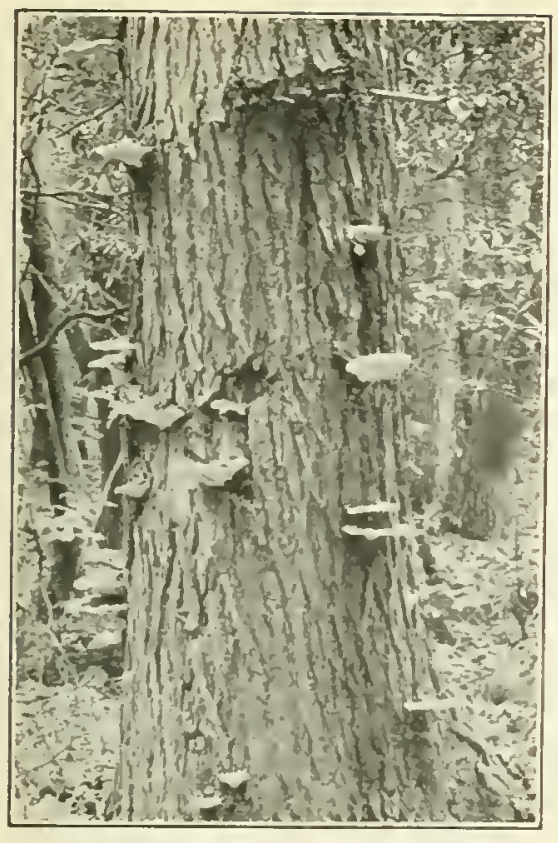

Fig. 29. HEMlloCl TRUNL WITH FliUITING BUDIES OF A FUNGUS.

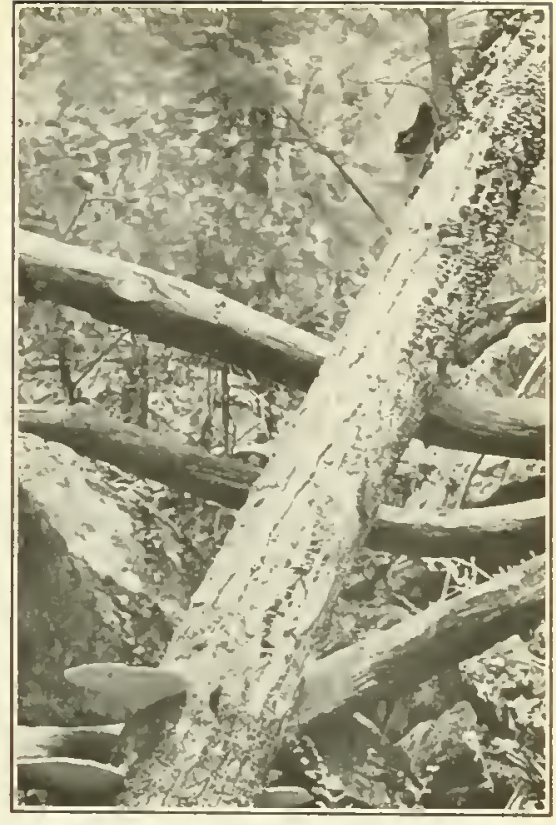

I’im. 30. BLAC'K IBRCH 'TRUNK IT' TACKED HY TWO DIFEIRINT SPECIES OH" FUNG

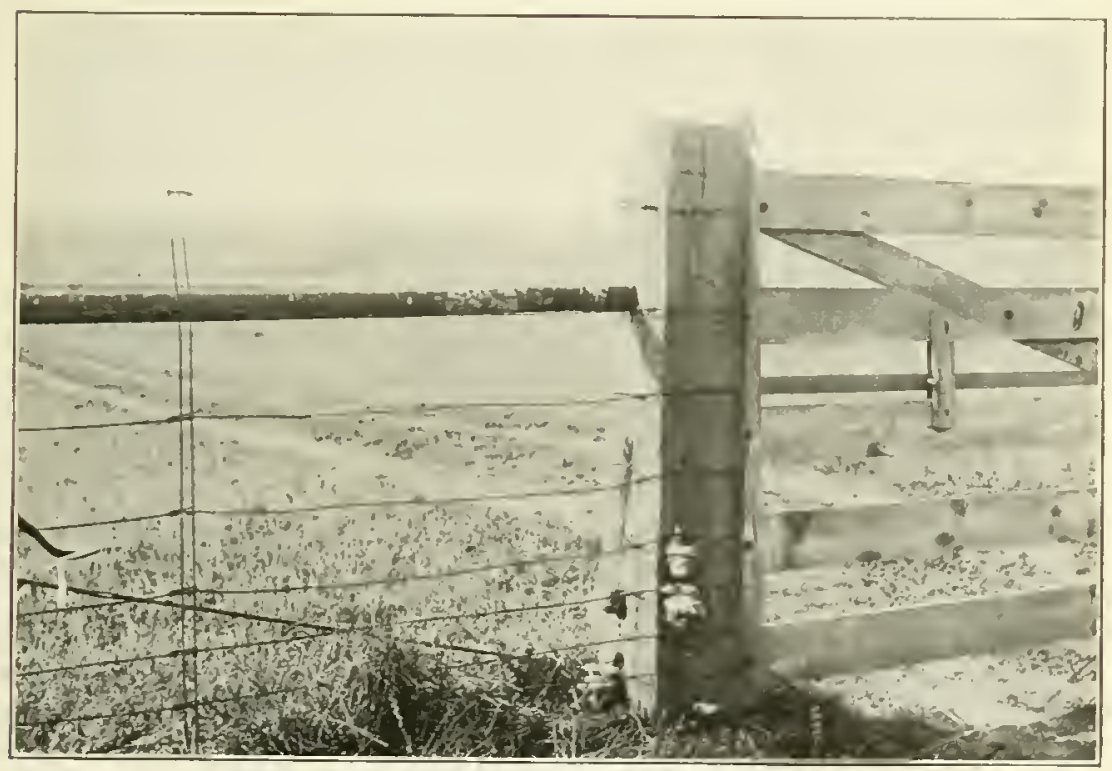

Fig. 31. CHESTNUT POST ATTACKED BY LRONN IROT (POLTPORUS SULPHURIUS).

Some fungi attack only living wood, cthers attack only dead wood. 


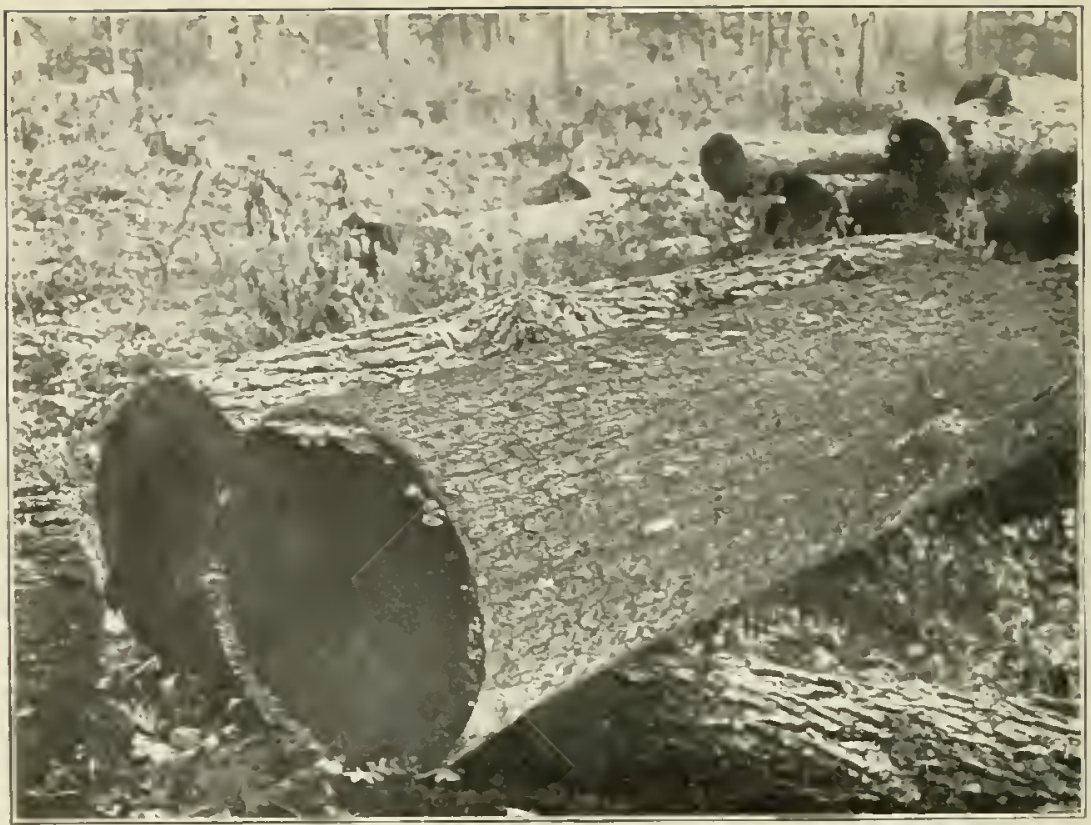

Fig. 32. WHITE 1 AK AND PINE LOGS ATTACKLD BY FUNGI

The White Oak logs in foreground attacked by 3 different species of fungi. Cut about 8 months befure photngraphing. The ralue has depreciated witb exposure and fungous attack.

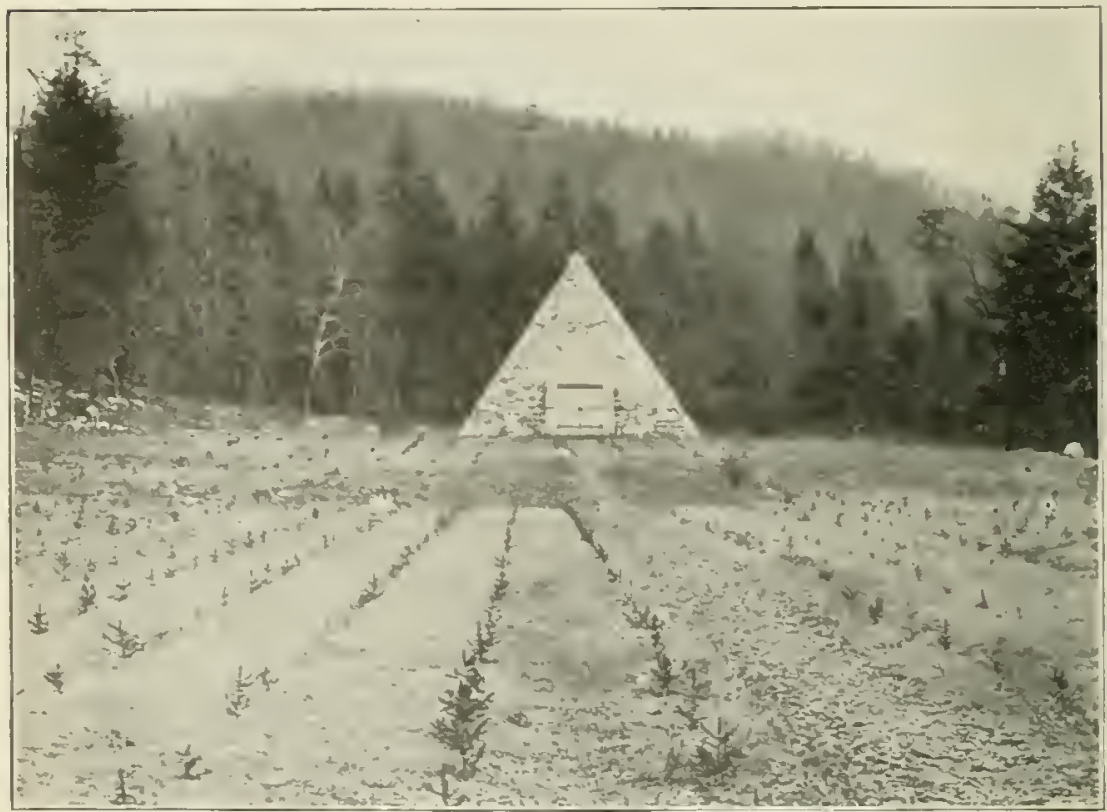

Fig. 33. PRESIDENT JAMES BUCHANAN'S BIRTHPLACE.

Luchanan State Forest, Stous liatter, near Mercersburg, Franklin County. Prramidal rough stone ninument. Norway spruce in the foreground 
lings and saplings which would have prodnced the forest of the future. In the years 1907,1908 and $1909,2,455$ fires occurred in the State of Pennsylrania, and burned over 184,987 acres. The estimated amount of damage was almost $\$ 1,000,000$. it is also estimated that the arerage annual direct loss from forest fires within Pennsylvania is $\$ 500,000$.

Three kinds of forest fires are nsually recognized: Surface fires, which burn the surface layer of leares, grass, twigs, and some trees; Ground fires, which buru through soils with abundant vegetable material; and Croun fircs, which burn throngh the crowns of trees.

Many fires can lse prevented by edncating the people concerning the real value and significance of the forests. Vigilant patrol during the danger seasoll, the construction of fire-towcrs, telephone lines, roads, fire-lanes, complartment lines, and the Iroper disposal of combustible material, help to mininize the fire danger.

The damage which man does in the forest is very noticeable to his fellowman, while that done by other agents often gocs unnoticed. Due to the derelopment of onr biological sciences in the recent past we are heginning to appreciate the extent of the damage done by such agents as insects and fungi.

The organic agencies which damage the forest are plants or animals. The principal types of plants which do damage to the forest or to the products of the forest are parasitic flowering plants, as the mistletoe, and fungi which cause the decay of mood. The extent of damage which fungi do to trees as well as construction timber is usnally underrated. They may be found upon living or dead trees, stumps, logs, railroad ties, and construction timber in bridges, louses and barns (Figs. 29-32). The Chestnut Bark Disease is an example of a parasitic fungous disease which attacks the Chestnut tree, doing enormous damage.

Many different kinds of animals do damage to the forest. Domestic animals, as cattle, sheep, goats, and hogs, and wild rertebrates, as deer, rabbits, squirrels, mice, and beavers, are among the most im.portant damaging agents.

Next to firc, insects are the most destructive enemies of the forest. They may infest young seedlings in the nursery, the fruit or seeds, the twigs, the cambial bark, and the wood. They also do considerable damage by attacking the leares. Complete defoliation is not uncommon.

The damage from inorganic agents may be in the form of windfall, wind-break, snow-break, excessive cold, excessive heat, shiftingsands, erosion, floods, and noxious gases.

Proper protective measines can sometimes be carried out success. fully by the individual, but in other cases the co-operation of the ration, state, or municipality may be required. Organizations or 
establishments for carrying out protective measures are also required where large areas are to be protected. On July 1, 1914, there were employed in Pennsyivania 56 Forester's and 91 Forest Rangers to look after the 998.773 acres of forest land which the State owns. Most of the foresters employed by the State received their training at the State Forest Academy. By developing the forest fire organization in Pennsylvania, forest fires will be rare erents, as in the managed forests of Europe, and if they do break out will cause relatively little damage.

\section{THE VALUE OF FORESTS.}

Prior to the time that the conquest of Constantinople closed the route to the Orient, the Atlantic was regarded the world's back door. Columbus, a mere sea captain, to his own surprise, discovered a land which, as the old royagers related, no one approached without appreciating the beauty of the forest. Those old royagers appreciated the beauty of the forests but not their prospective value. The forests at first had a negative ralue. They were something which must be conquered. Their remoral was necessary for the establishment of homes and the opening of agrieultural lands. Thousands of acres of the best forests were simply burned to get rid of them. They were obstacles in the way of development.

Gradually as our forest acreage decreased, as our population increased, and as the demand for wood goods multiplied, the forests became not only objects of interest and beanty, but also of value. After four centuries of rapid development we are just beginning to comprehend the real importance of our forests. They supply us with rood which is the most indispensable and universally used product of nature. Wood as a necessity or a luxury is used in our varions activities from the cradle to the coffin. Many of our houses are built, finished, and heated with wood. MLst of the paper upon which we write and mpon which our books are printed is made of mood.

The forests supply us not only with wood but with many minor liroducts like maple sngar, tanning materials, naval stores, charcoal, wood alcohol, ete. Artificial silk and even whole suits of clothing have been made from wood. In addition, the forests furnish leaves for stable litter, pasturage for cattle, pannage for swine, and great quantities of nuts which are used as food by man. Pasturage was formerly carried on more extensively than at present. It may be a legitimate industry if it pars and if it is so directed that the young seedlings in the forest, which will produce our future forests, are not eaten or injured. As a rule, grazing should not be permitted in 
young forests where the shoots ale still tender and readily eaten by animals, nor where the grazing animals may tramp ont the seedlings.

The original forest may be regarded a great reservoir of wealth filled by nature working through many centuries, and exploited by man either for its products or to establish in its place a more necessary industry. The present forest on the other hand may be represented by a much smaller reserroir only partly filled, and with material which is inferior not only to that found in the original forest but also far inferior to that which we hope to derelop in the future forest. The present forest if properly managed, which implies inprovement, is capable of producing continuously a large quantity of major and minor forest products representing an enormous value. In addition to the usual monetary ralue of forests we should also consiler their value as soil formers, soil fixers, soil improvers, preventers of floods, sanitary agents, suppliers of natural blessings, and beautifiers of the earth.

\section{THE VALUE OF TREES.}

Trees are among the commonest and most conspicuous objects of nature. They vary considerahly depending upon their kind, their enviromment, and the artificial treatment which they may have received during their development. The trees which surrounded the simple home of the early pioneer differed very much from those which adom the grounds of some of our wealthy citizens today, showing that nature, unaided by man produces trees in the forests which differ considerably from those wlich man has planted and cared for. Environment is a rely potent factor which not only influences the general appearance of a tree but also the structural parts which compose it. Trees as members of the forest stand have been considered in the preceding chapter. The subjoined material treats of trees used for purposes other than forestry.

Trees are not only valuable for their products, as wood, resin, fruit, and litter, but in addition have an aesthetic and a protective value. Although tree-planting for shade and ornament has been practiced assiduously in past generations, ret the value of such planting and the care which such trees require and should receive has not been fully appreciated until lately. Today individual trees or small groups of them are planted rather extensively about homes, along streets, in parks and public squares. for their shade and shelter. They are also used about the home to sereen objectionable objects, to direct and restrict the views along general lines, to frame the home picture and to give the surroundings the expression of comfort and homeliness. 
The establishment and care of shade and ornamental trees is entirely different from the care of forest trees. Knowledge concerning the life-history of trees in general is, howerer, a prerequisite for the proper treatment of both classes of trees, but the art by which this knowledge is applied is entirely different. The forester grows trees to harvest and at harrest time he aims to obtain from them as much and as high grade wood as possible. The tree warden grows trees to preserve. He aims to develop a tree with as desirable an appearance as possible and to retain it as long as the ritality of the tree will permit.

Thousands of dollars are spent annually by shade and park connuissions in dereloping the aesthetic side of our cities, towns, and many of our rural districts. The commissions or indiriduals who have this in charge, ain, by beautifying the environments, not only to improve the health and efticiency of the citizens, but also to raise their moral standard and hence increase their social worth.

\section{DECIDUOUS AND EVERGREEN TREES.}

All trees native to the State of Pennsylrania, when in a healthy condition, bear green foliage in summer. In autumu many of the green leaves change to brilliant color's, rellor, scarlet, deep red, or purple, and gradually fall to the ground. The species of trees whose leaves lose their green color and fall in antumn are known as deciduous trees. Most of the trees native to the State of Pennsylrania are deciduous. The deciduous trees are also known as hard. woods or broad-leaf trees. The Oaks. Maples, Birches, and Chestnut are common examples of this group. Many of the representatives in this group rield raluable products and furnish interesting objects of study on account of their variation in form. In winter the deciduous trees are far more conspicuous than in summer since the dense leaf canopy is absent. This atfords an opportunity to study the trees with special reference to their form, branching, and bark. These characters are among the most helpful in distinguishing our common trees, especially since they are at hand at all seasons of the rear. The leares of a few deciduous species like the Beech and some of the Oaks die in autumn but of ten persist through the winter.

Some species, howerer, do not shed all of their leaves in fall. Such trees are known as evergreen trees. The evergreen habit is char. acteristic for most trees commonly known as conifers. Most of the conifers have needle-shaped leaves which persist for two or more jears. The Larch, native to this State, and the introduced Bald $\mathrm{Cy}$. press are, howerer, two species which shed all their leares in fall and during the winter appear like dead conifers. The persistence of the 
foliage of most of the conifers euriches the winter scenery and affords shelter for birds and other animals. Many conifers are highly prized for ornamental purposes and some yield valuable commercial products. The Pines, Spruces, Firs, Cedars, and Hemlocks are the commonest examples of this group. In addition to the conifers a few broad-leaf species, such as Rhododendron, Hountain Laurel, and American Holly, are evergreen. A transition from the evergreen to the deciduous habit may be found in the Deciduous Holly and the Laurel Magnolia which are deciduous in the northern and evergreen in the southern states.

The deciduous trees are commonest in the eastern part of North America while the erergreen are commonest in the western part. The former are usually found in mixed stands, while the latter often occur in extensive pure stands. The hardwood species usually occur on rather fertile soils while the conifers may thrive on more sterile ones. Both the deeiduous and the evergreen habits have their advantages. The shedding of the leares in fall is a protective adaptation since it reduces transpriration, danger from snow-break, and damage from noxious gases. The evergreen trees have the advantage of lower summer transpiration and are ready at any season of the year for constructive activity. They are also less subject to damage by frost during the growing season. The advent of forestry may change the structure and distribution of our forests. The present tendency seems to be gradually and cumulatively in favor of the conifers.

\section{THE AGE OF TREES.}

Some trees reach great size and enormous age while others remain small and die young. The size and age which a tree attains depend upon the inherent tendency of the species and the factors of the environment. Some species which naturally grow tall and become old may remain small under unnatural and unfavorable growth conditions. Other species never become large and old even under the most favorable growth conditions since it is inborn in them to remain small. A definite age limit cannot be fixed for each species but for general convenience we may classify our common trees as short-lived or long-lived. Of the trees native to the State of Pennsylvania the Oaks, Chestnut, Buttonwood, Tulip Tree, White Pine, and Hemlock may le regarded as long-lived trees, and the Poplars, Willows, most Birehes, and some Cherries as short-lived. Some of the White Oaks found in the original forest of Pennsylvania showed an age of approximately 500 years. Some of the trees of this State reach a great age and enormous size, still none approach such 
trees as the Big Cypress Tree of Tule found in the state of Oaxaca, Mexico, or the Sequoia of Califormia.

It is not alwars easy to tell the age of a tree or that of an erenaged stand of trees. Planting reeords are often rery raluable in determining their exact age. The best means of finding out the exact age of a tree is to ask the owner who kept a record when the tree was planted. This method may be used for some ornamental trees and for forest stands which were artificially established. Detailed records should be kept of all forest stands whether established artificially or naturally. The determination of the age of trees in the original forest or in an unregulated forest is a more difficult task. The age of a roung tree like that of a child is more readily determined than that of an old tree. The best test for telling the age of a tree, if planting records are wanting, is to count the annual rings on a cross-section of the stem near to the ground and adding to this number, as many years as it took the tree to grow to that height. (Plate I, two lower series of drawings, and Plate XI, 1,3). Each ring usually represents the growth of one year. A second test will apply to such species as White Pine, which derelop their lateral branches in distinct and rather regular whorls. (Plate I, mpper right figure, and Fig. 19). Each whorl normally represents a year's growth. If the branches hare fallen off one can often find the scars of the branches on the stem. (See Frontispiece and Figs. 25 and 26 ). The age of young trees or small branches ean also be determiner by counting the rings of terminal bud-seale sears (Plate I, upper left figure). The portion of the branchlet from the end down to the first ring of lud-scale sears lepresents the last season's growth while that between the first and second rings represents the next to the last season's growth and so on. To tell the age of trees may sometimes be diffieult lut it is usually fascinating. After you hare been successful in determining the age of a few trees, you may find yourself questioning the age of others as you walk or drive by then. A careful study of their gromtl will often indicate the successes and failures which they met during their derelopment, since a relatively narrow ring often indicates a struggle, while a wide ring often indicates favorable growth conditions.

\section{THE FORM AND STRUCTURE OF TREES.}

\section{ForM :}

By form is meant the general appearance of a tree. One can study the form of deciduons or broad-leaved trees best in winter when they are devoid of their foliage. After one is familiar with the general form of different trees it is possible to distinguish the different species eren at a great distance. The form, together with 


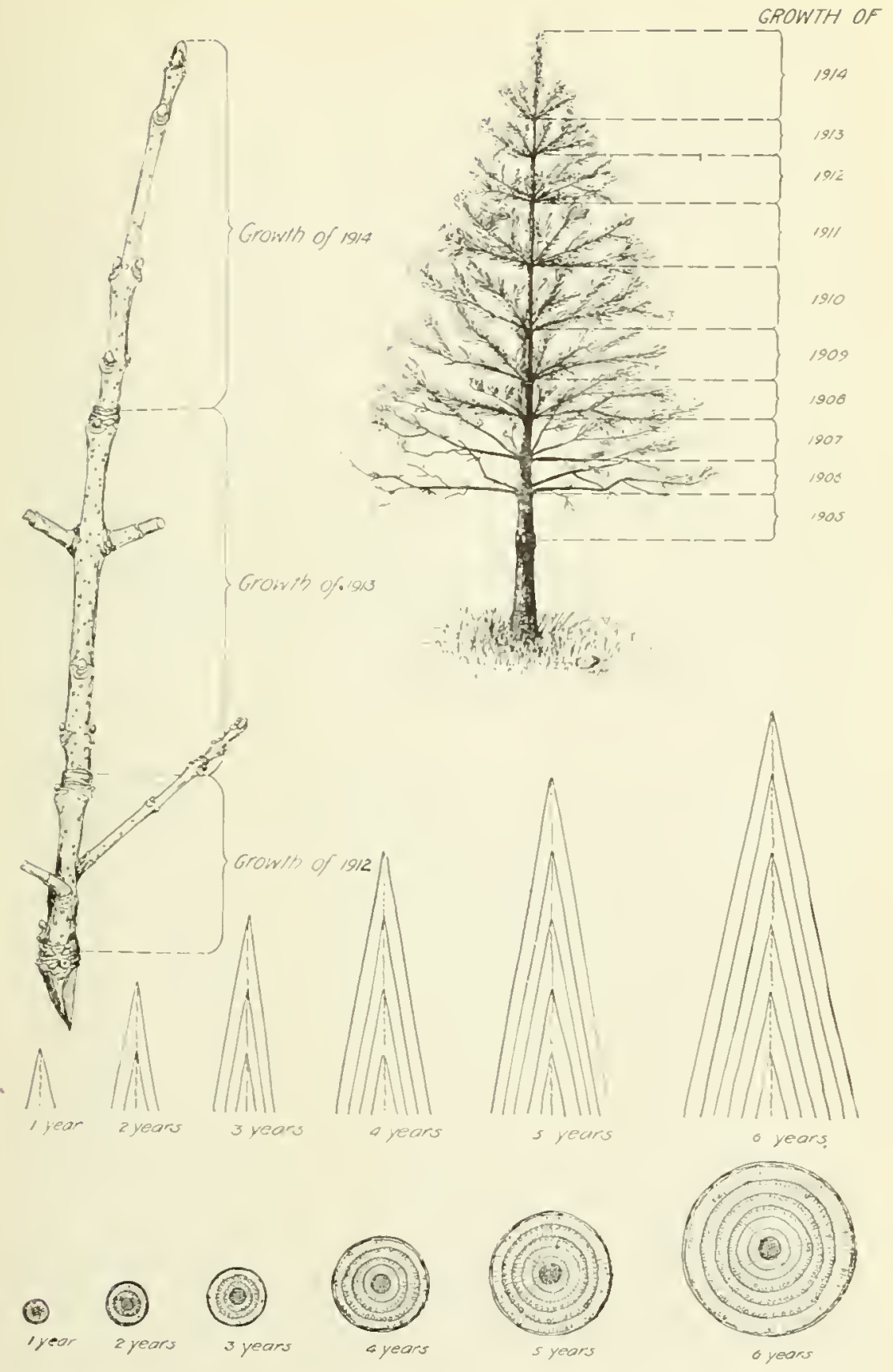

PLATE I. THE AGE OF TREES. 


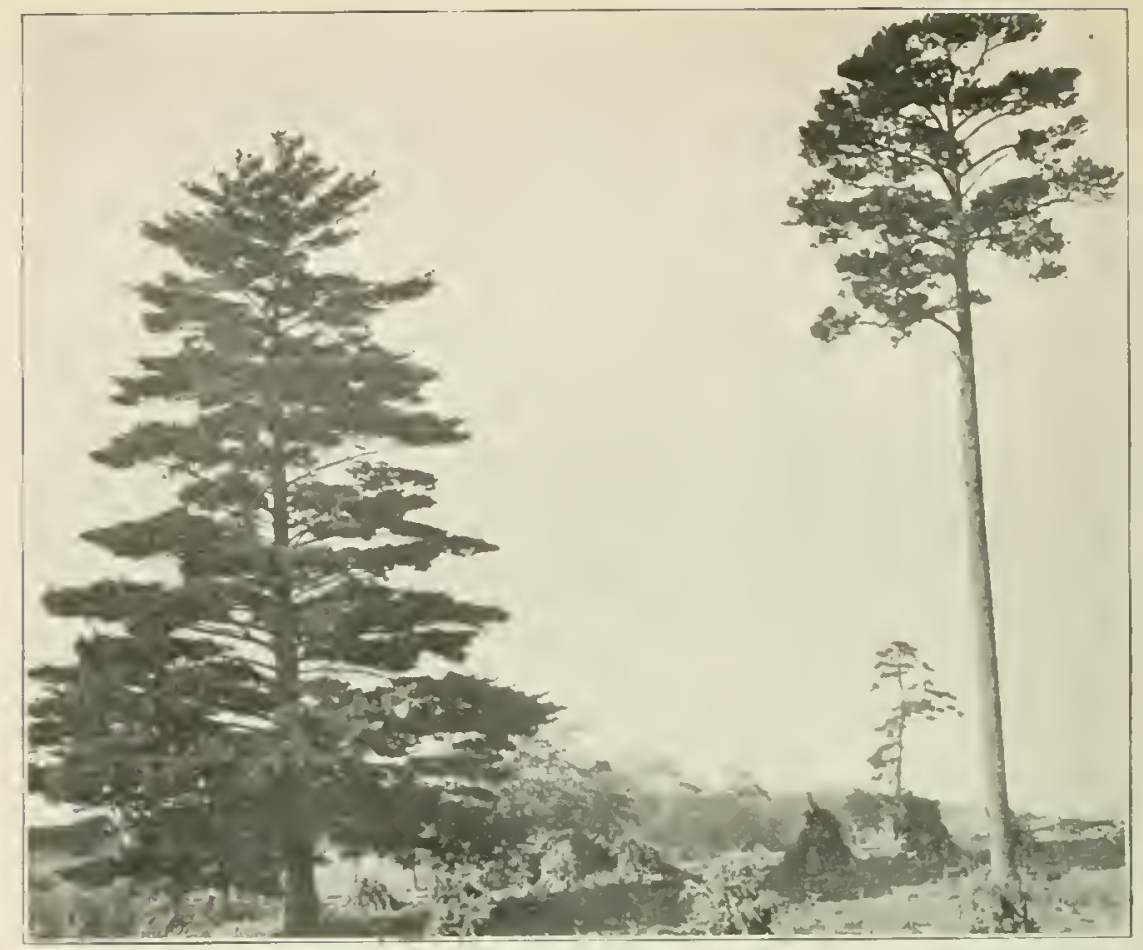

l'ig. 34. OPEX GROWN PINES.

White on left, Fellow on right. Botb trunks warrent and developed in same enviroument. Difference of form is due to inherent unalities. One tapers, with persistent lateral branches; the otber with little taper and few branches.

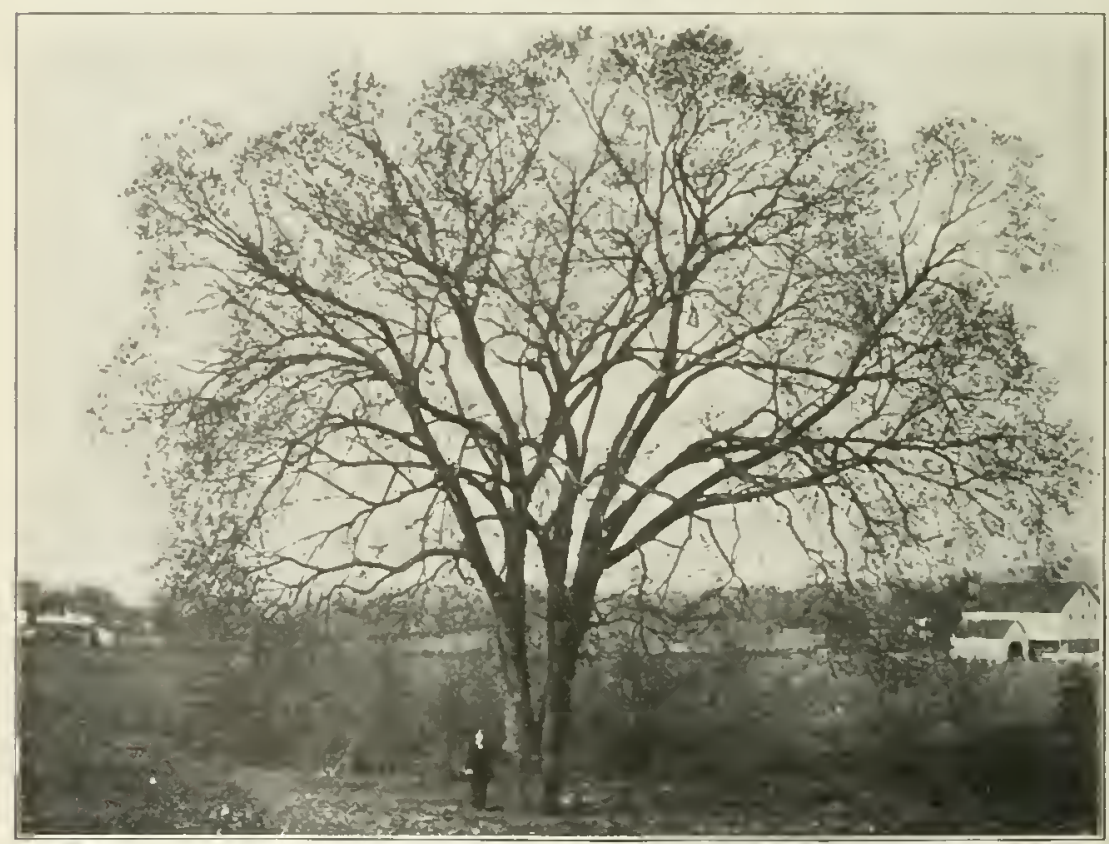

Fig 35. OPEN GROWN AMERICAN ELM.

Its trunk branches near the base and then repeatedly subdirides. Such a trunk is known as a deliquescent trunk. 


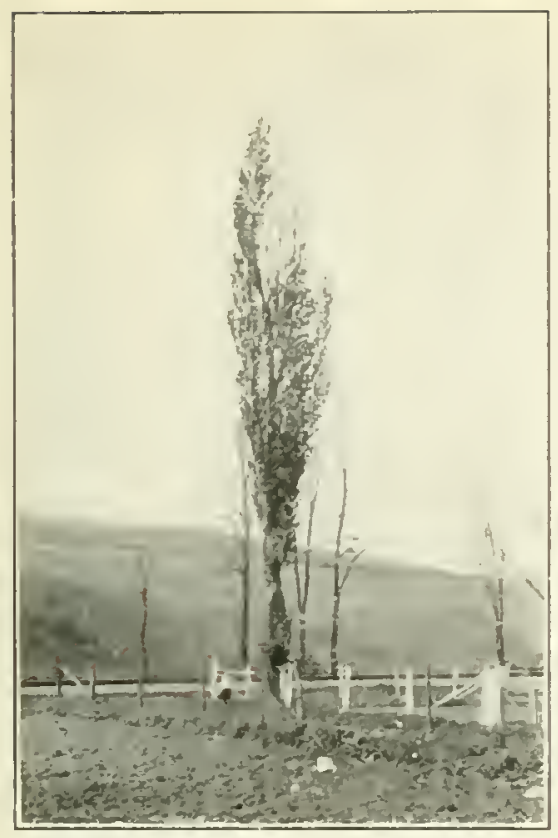

Iig. 36. FORM UF L.OMPARDY POPLAR.

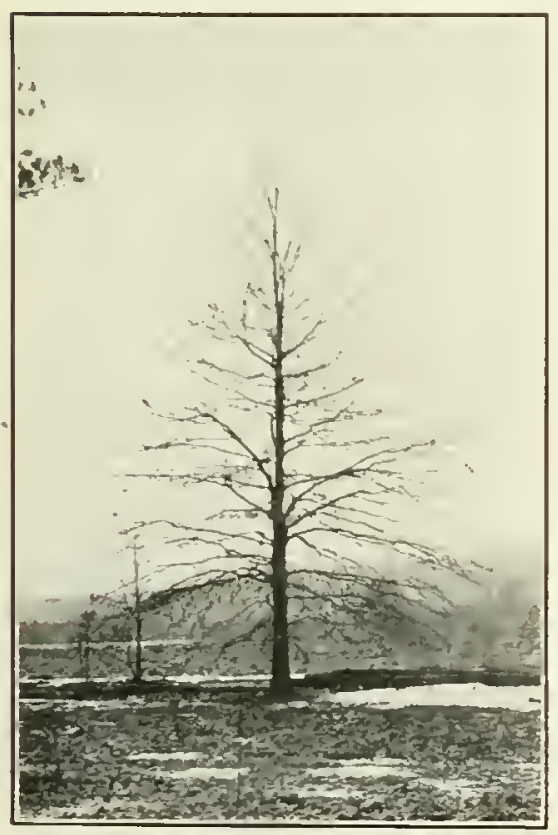

F'ig. 38. FURM OIF A POENG PIN OAK.

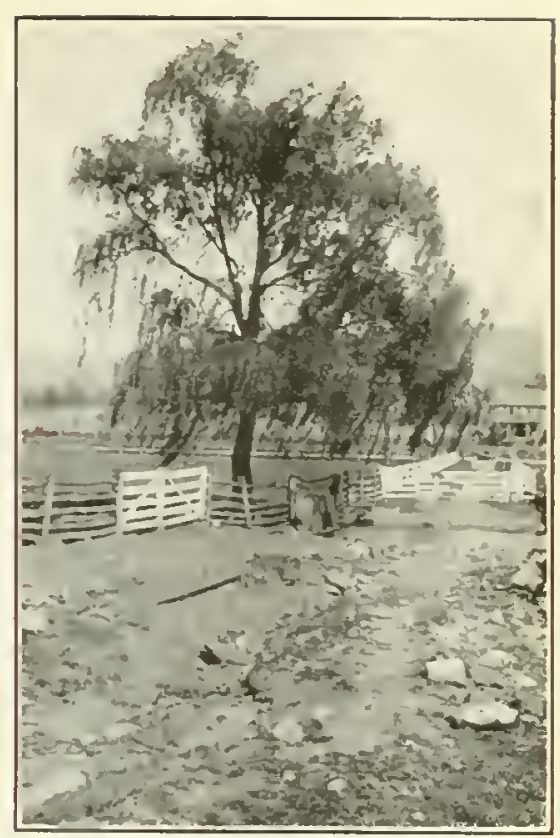

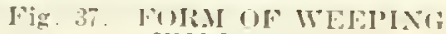
IIILLOW.

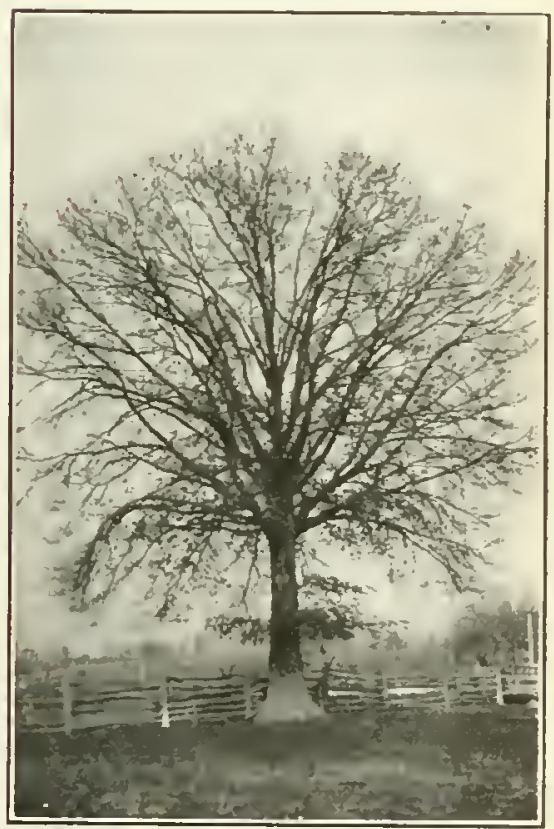

Fig. 39. FURM OF AN OI.N PIX OAK. 


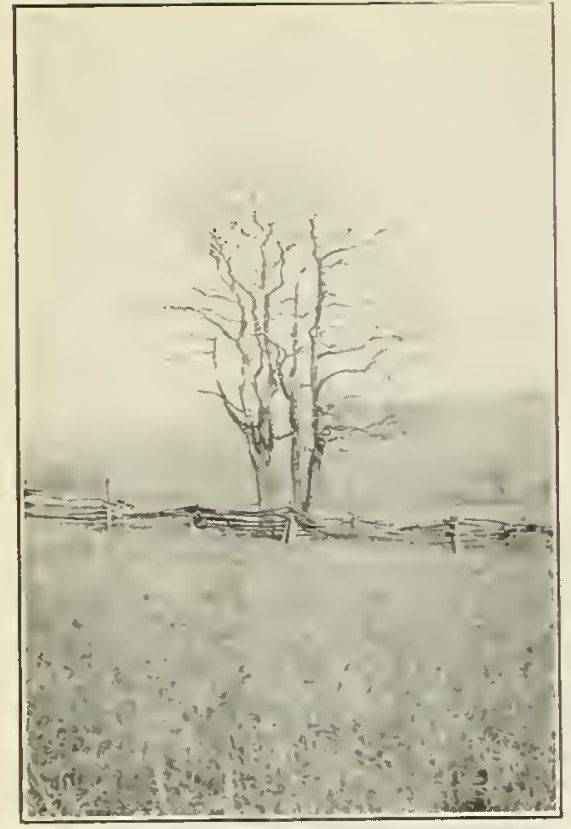

Fig. 40. FURII OF A SASX゙AFR.S.

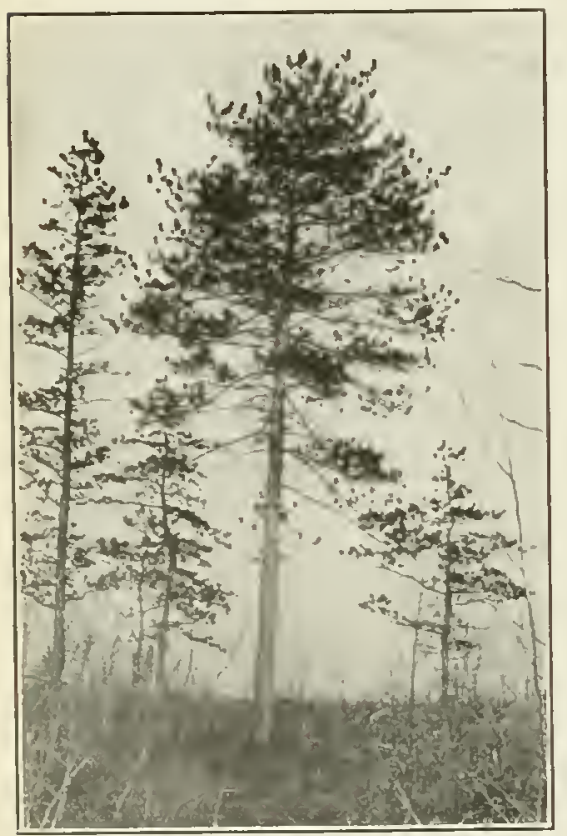

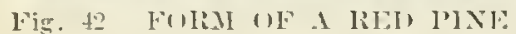

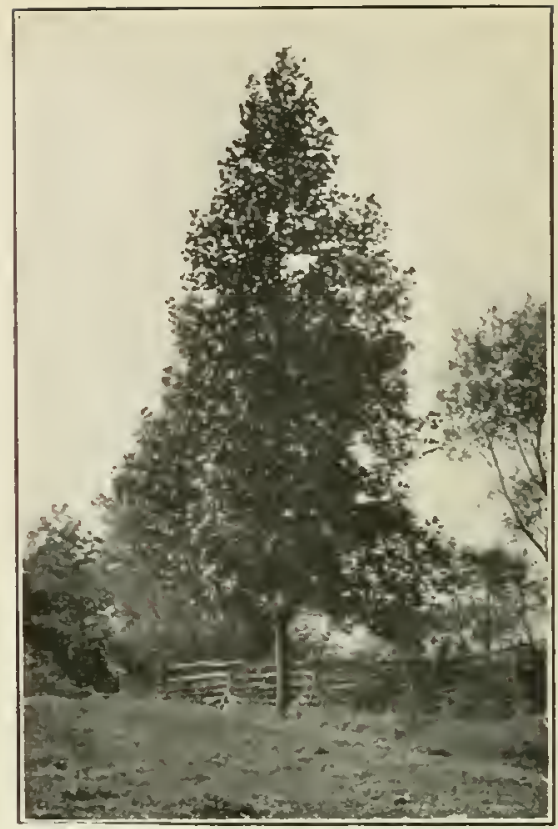

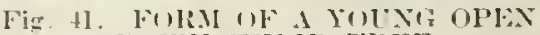
ARUIF: TLI.I" TREE.

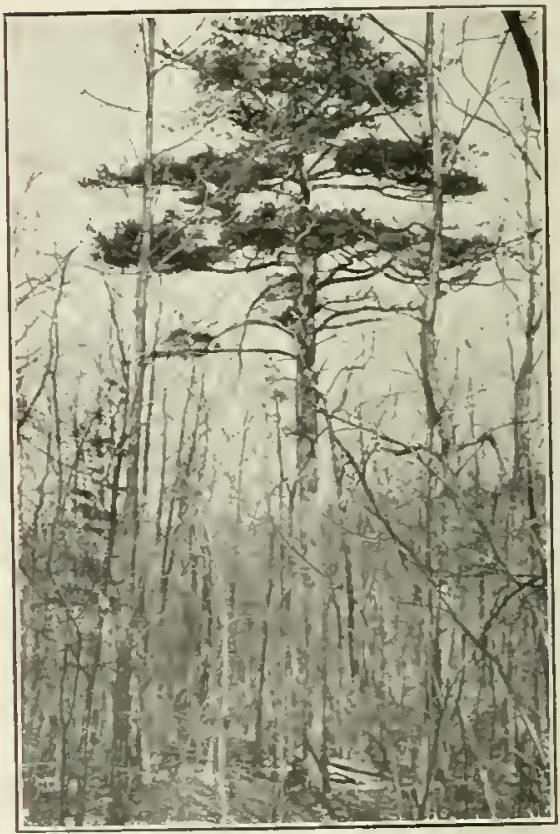

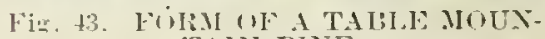
TAIN PINE.

It developer in at closed stand. Diameter 22 inches 
the color and figure of the bark, is a character by which many of our trees may be aceurately distinguished. The form of trees raries with the sjecies, the environment, and the sylvicultural treatment.

Some trees attain an enormous size and great age while other's never become large or olr. The Sequoias of Califolnia, also known as liednoods and Big Trees, and the Cyrress trees of Mexico liare representatives which are legarded the largest and oldest in existence. A sectiou of a Big Tree now in the Anerican Museum of Natural History in New Yolk ('ity slows that the tree when cut was 1,341 years old. It was 90 feet in eireumfelence at tle base, over 350 feet in height, and estimated by lumbermen to contain 400,000 board feet of Jumber. l'robably the largest Cyjress tree in the world stands in a churchyard alout five miles from the City of Oaxaea in Mexico. This tree has a circumference, according to recent measurements, of 154 feet 2 inclies, 6 feet above the ground. It is about 125 feet high and, accolding to various estimatols, can seareely be less than 4,000 Jears old, and may possibly be over 5,000 years. Specimens of this size and age have never been found in the state of l'ennsyliania. Some of our native trees, the Cliestnut, White Oak, lied Oak, Tuli], Tree, Hemlock, and White l'ine have, however, attained great size. A few large specinens which were cut in recent years, showed by count of theil annual rings that they had started life before Columbus discoreled America. In Forest Leaves, Tol. IX, No. 10, Dr. J. T. Rothrock describes a White Oak standing near Kutztown, Berks county. It was 31 feet in cireumference at the level of the ground and had a spread of blanches of 104 feet and an estimated height of almost 71 feet. This tree was probably the largest of this species in l'ennsylvania. Lalger specimens of Chestnut have been found in this State. The Jargest Chestnut tree on lecold had a diameter of 17 feet. It was found near Waynesville, North Carolina. Other species like the Scrub Oak (Fig. 4), Gray Birch (Figs. (6t and 69), and Scrub Pine never become large. Some species may remain small in one region and yet become large in anotler. The Chinquapin which reaches its northern limit in Penns.lvania seldom exceeds a height of 10 feet in this State while it reaches a height of 50 feet in southern Arkansas.

The character of the stem, to a large extent, determines the form of the tree. The main axis of a tree usually grows erect. The lateral branches valy according to the species and the position of neighboring branches. In some species like the Weeping Willow (Fig. 37) they are drooping, in others like the Black Gum and Pin Oak (Fig. 38) they are horizontal, while those of the Lombardy Poplar are ascending (Fig. 36). If the terminal shoot is remored or killed a lateral liranch in time may take its place. Sometimes two lateral 
branches strive for the leadership but they are such close competitors that neither can win out. The result is a "stag-headed" tree. Again a dormant bud may be stimulated into activity with the result that no lateral branch obtains the leadership. After studying these growth forms, one is inclined to think that the terminal shoot prevents the erect growth of the lateral branches.

Environment has a marked influence. The form of a tree growing on au exposed mountain top differs rery much from one growing on sheltered bottomland. An open crown tree has a form entirely different from one grown in dense forest stand. The form of open grown specimens varies with the spccies. Two different species of Pine shown in Fig. 34 grew side by side in the sane environment and still dercloped entirely different crowns. Open growu trees usually branch neal the ground and liare a broad, deep, symmetrical crown, while trees grown in deuse forest stand usually branch farther from the ground and have a long clean trunk with a shallow and often irregular and unspmnetical crown. Trees grown in a dense stand mas not be so attractive as those grown in the open but they yield a much higher grade of wood, since the lateral branches $w$ hich produce many of the knots in lumber are removed early in the life history of the tree. The density of the forest stand should be so regulated that on every acre of soil not only the greatest quantity but also the best quality of mood is produced.

Two kinds of branching arc usually recognized, the excurrent or upright and the deliquescent or spreading. When the main trunk is continuous and extends mprard to the tip without dividing it is known as excurrent, and when the main trunk is not continuous but divides and subdivides into more or less equal parts it is known as deliquescent. Most of our evergreen species have the excurrent type of branching. While most of our deciduous trees hare the deliques. cent type. A few of the latter, as the Pin Oak. Tulip Tree, and Buttonwood. often show an excurrent or upright tendencr in the form of their trunk, especially when soung.

\section{BARK:}

If we examine the growing point of a seedling we will find that there is rers little difference among the parts composing it. Soon, as a result of growth, various kinds of tissue will be formed. At the end of its first growing season we can differentiate roots, stem, and leares. The stem is still further distinguished into pith, wood, and bark (Plate XI, 1.) Nature seems to know that the rital elements in the stem need protection. This protection is given by the bark.

Bark is that portion of the stem which lies outside of the cam. bium larer. It consists of an outer and an inner part. The former is commonly known as the outer or dry bark and functions primarily 


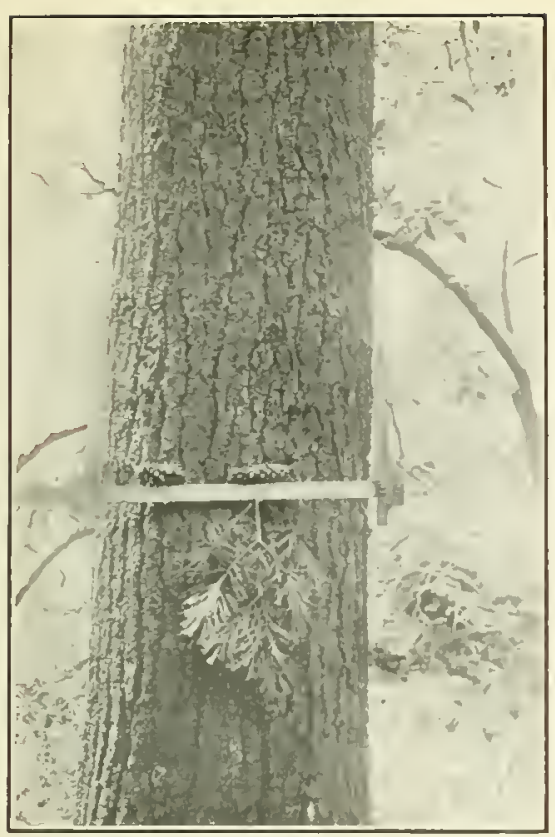

Fig. 44. WIIIT IPINF:

Trunk 25 inches in diamotor.

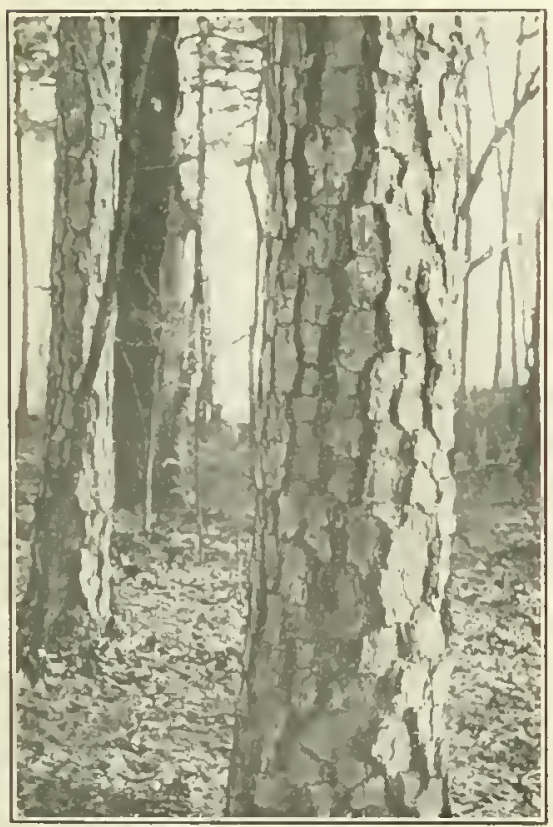

Fig. 1ti. IPT'II LIXE.

'Trunk ?2) inches in di:mueter.

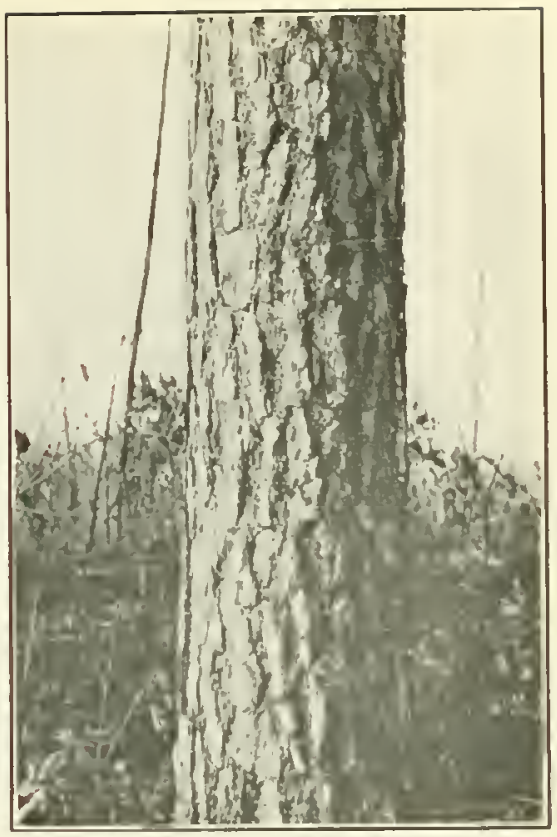

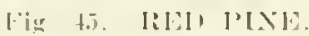

Trunk an inthes in thinterer.

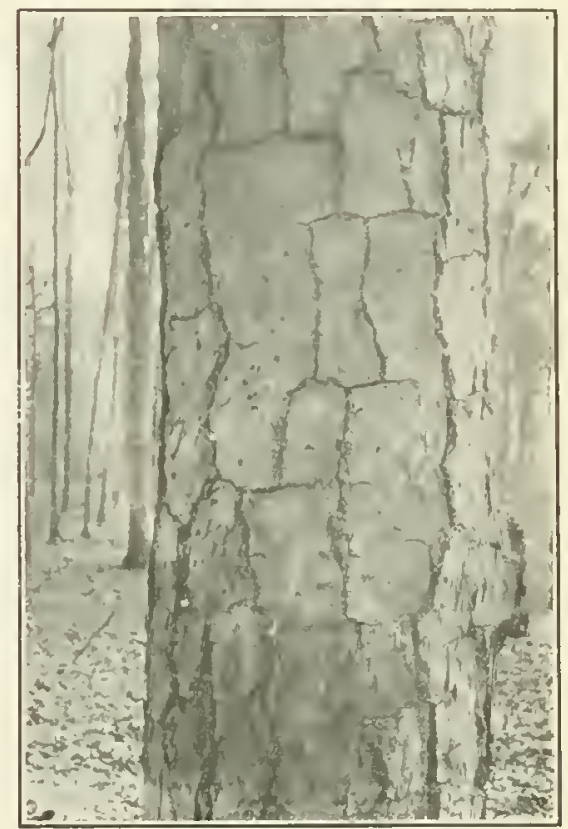

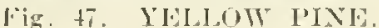

Trunk 39 inches in diumettr. 


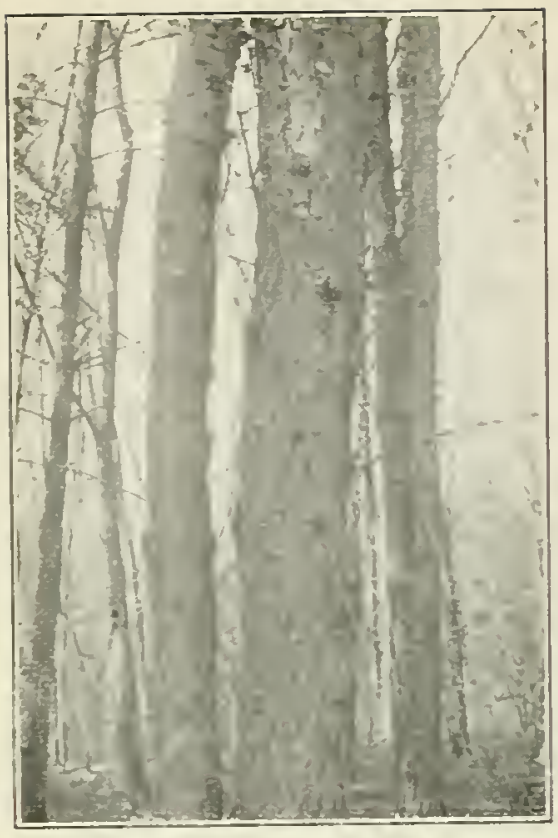

Fig. 48. JERSFY OR SCRUL PINE. Trunks 7 and If inches in diameter.

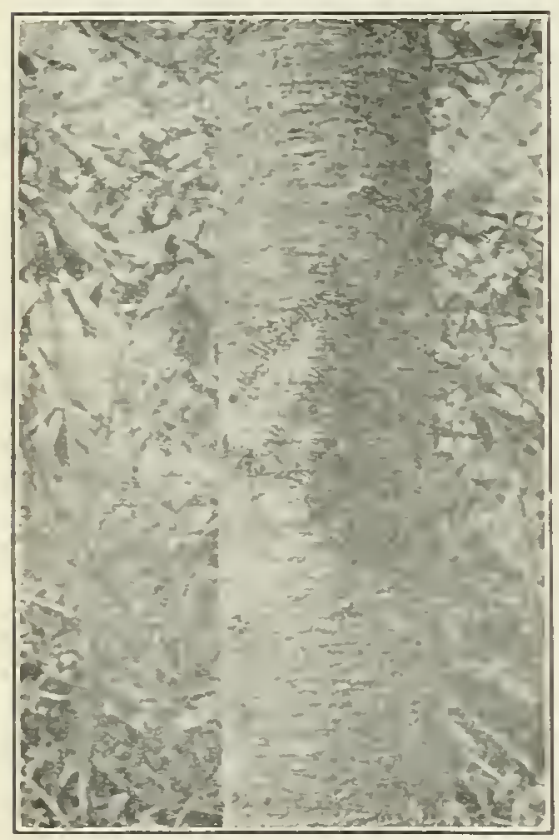

Fig. 50. BALSAM FIR.

Trunk 16 inches in diameter.

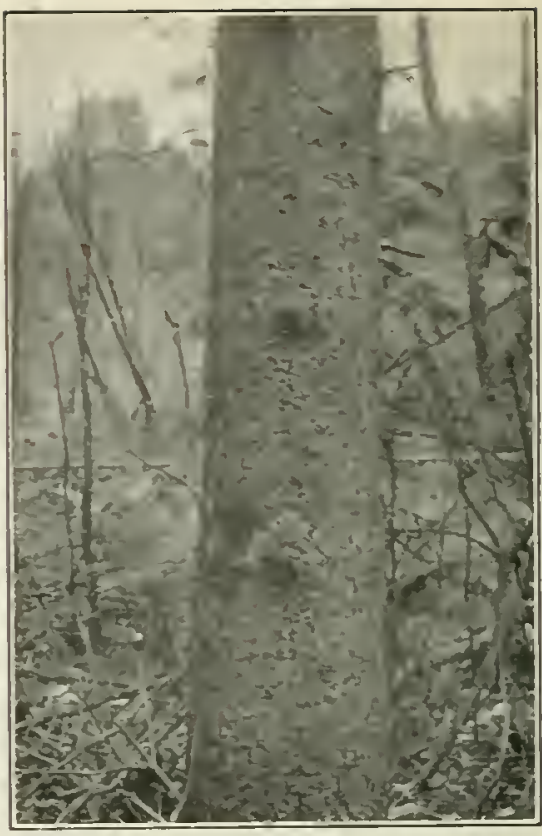

Fig. 49. AMERICAN IARCH Trunk is inches in diameter.

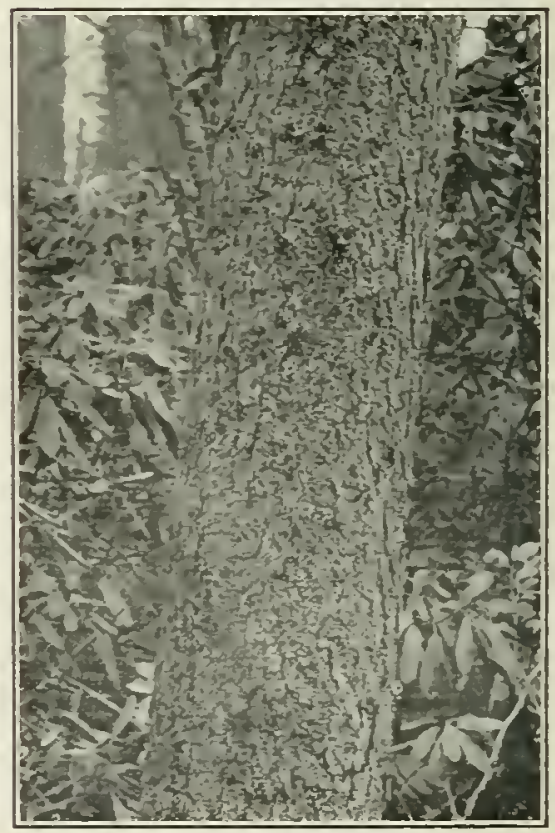

Fis. 51. BlatCK SPRLCE

Trunk 14 inches in diameter. 


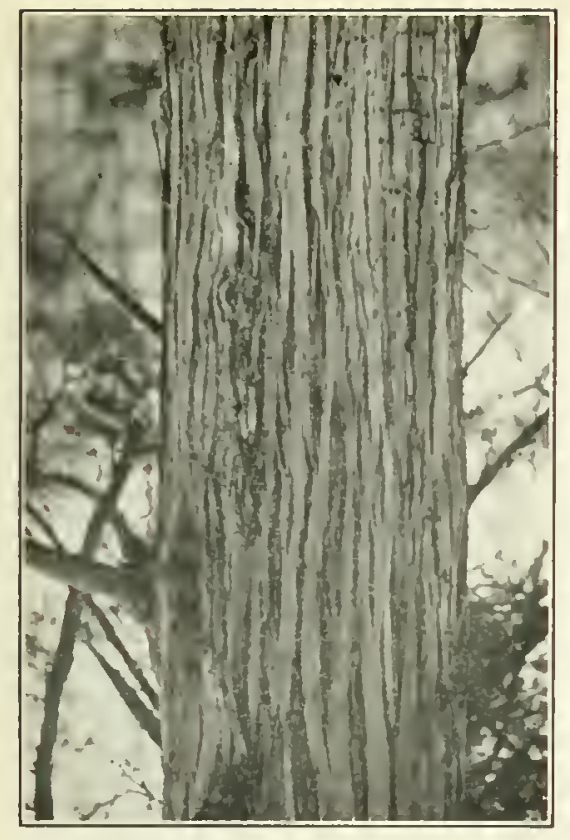

Fig. 52. RED rlendR.

Trunk 24 incless in dismetm.

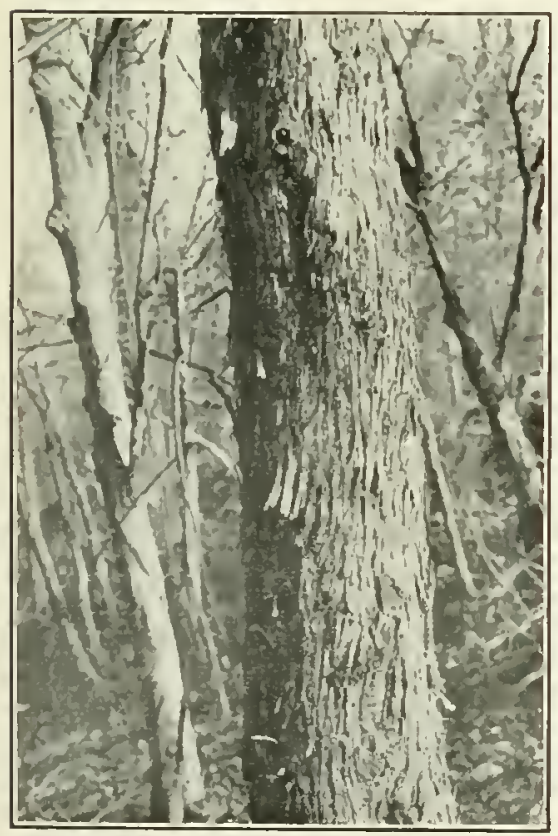

Fig. 54. AMERICAN IIOP HORNREAII.

Trunk 18 inches in diameter.

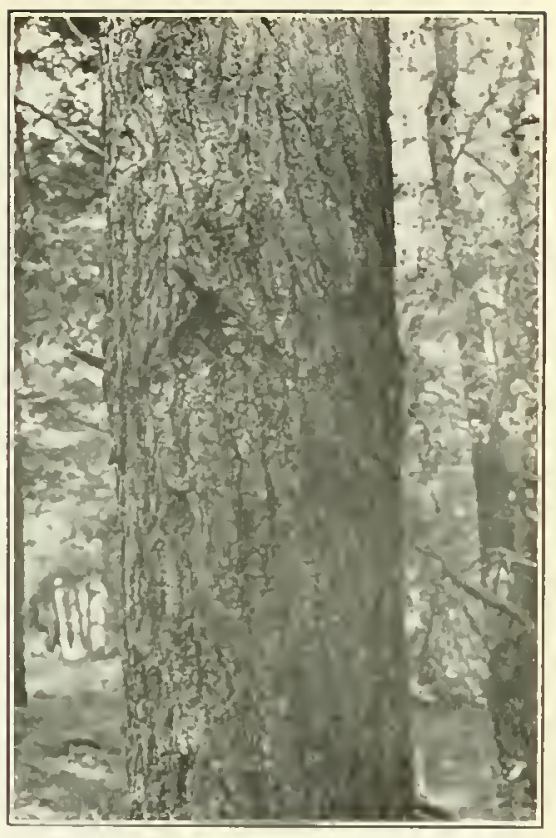

Fig. 53. IIJALLOCK

'Trunk 22 incliss in diameter.

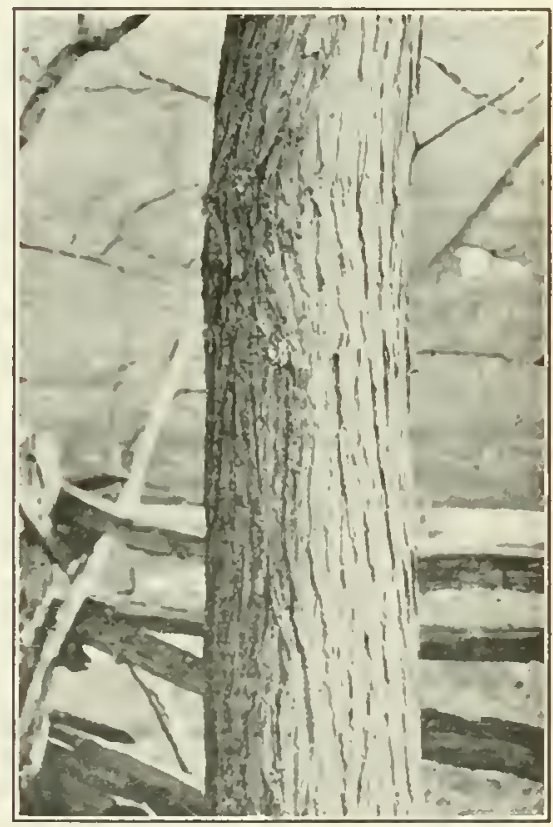

l'ig. 5.5 RED MULABERIY.

Trunk 17 inshes in diamoter. 


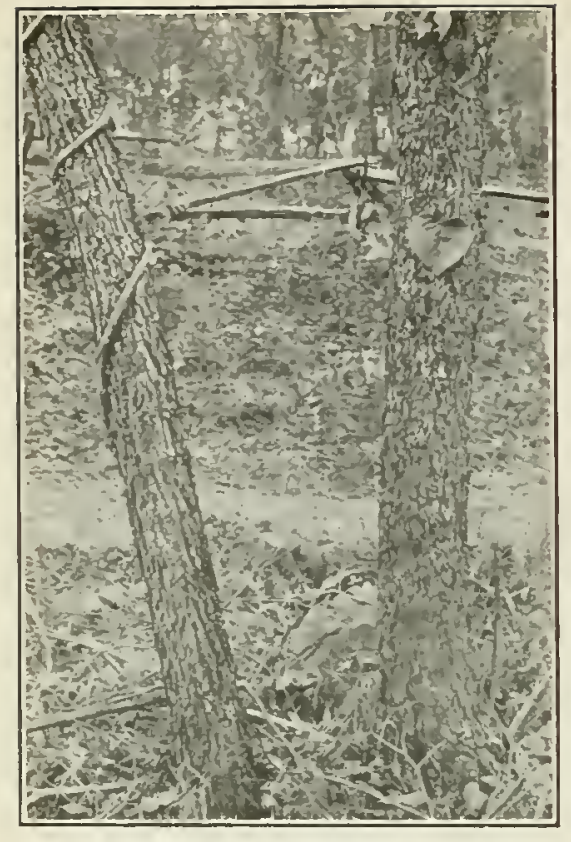

Fig. 56. IREDI;UD

Trunk s imcluss in cliameter.

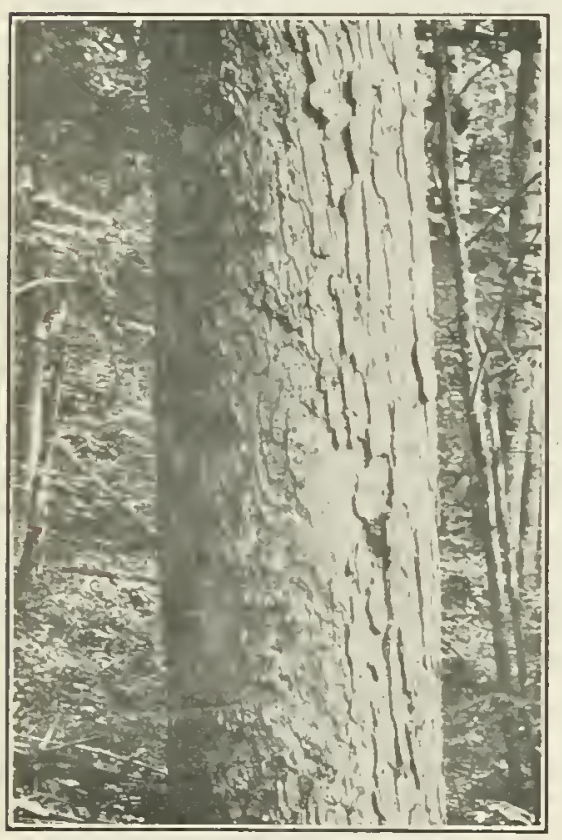

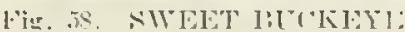

Trunk 32 inches in dianetur

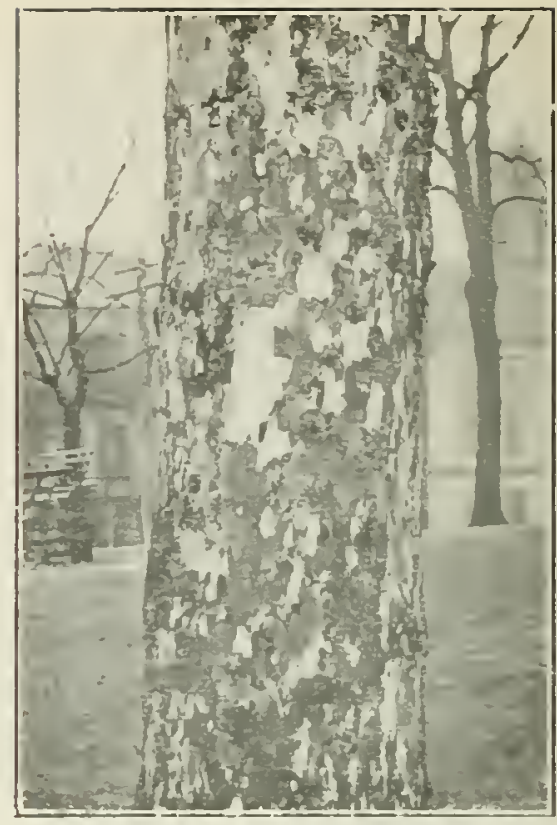

Fig. 57. BUTTONITOUl,

Trunk 18 inches in diameter.

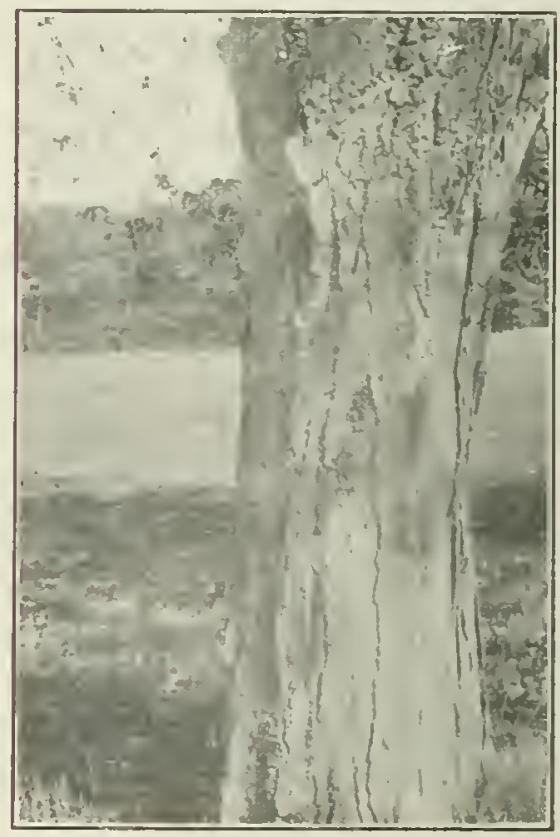

Fig. 59 HONEI I.OCUST

Trunk 30 inches in diameter. 


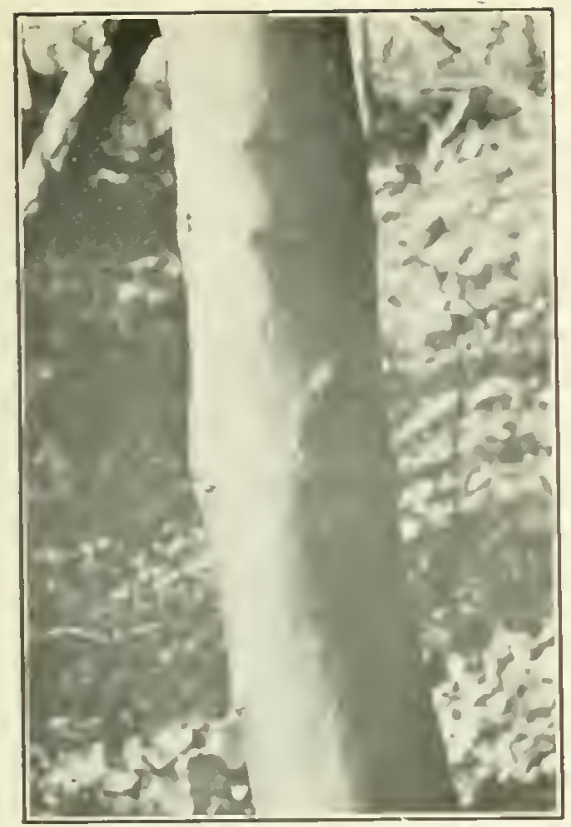

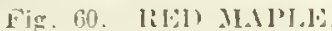

Trunli * inclues in dianeter

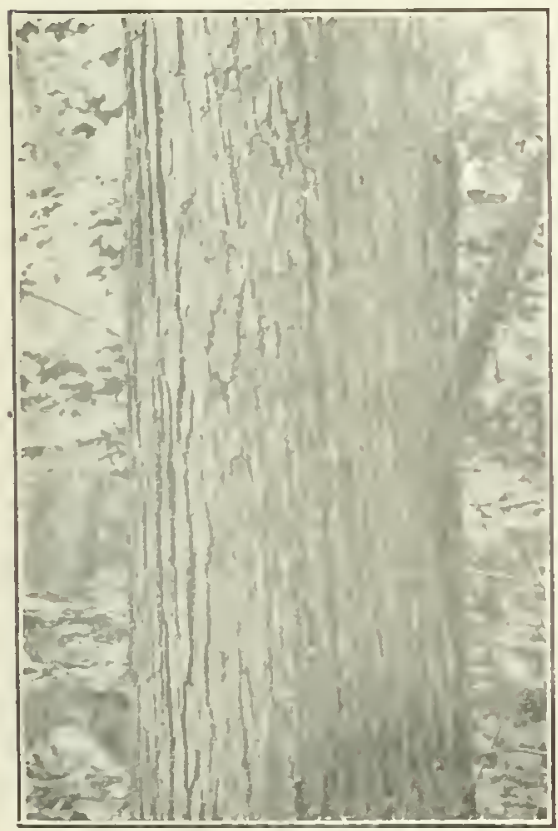

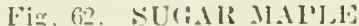

rrunk se inches in riameter.

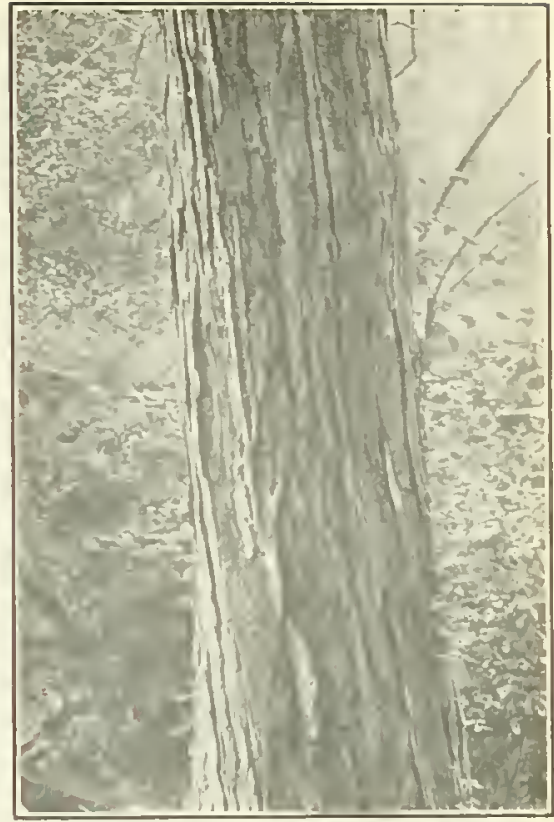

lijw 61 RED HAPl:

'l'umk 30 inches in dismetor

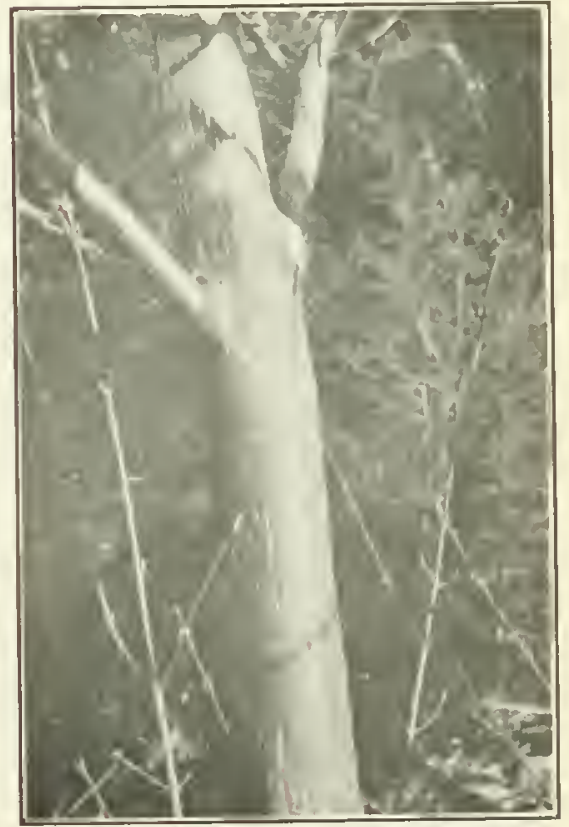

Fig. 63. STRIPLD MAPLE.

Trunk 4 inches in dimmeter. 


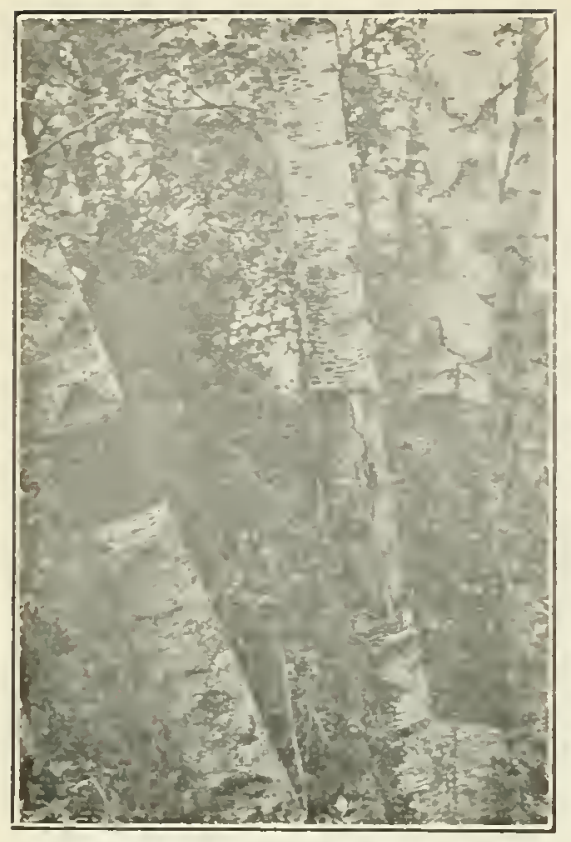

Fig. 64. GRAY BIRCH.

Trunls 4.9 inches in dianmeter.

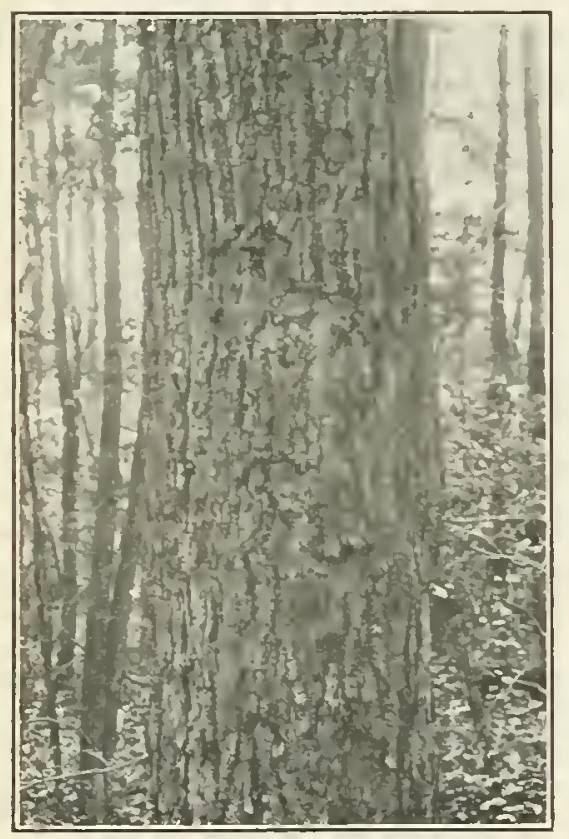

Fig. 66. SLIPPERT LLII

Trunk 26 inches in diameter.

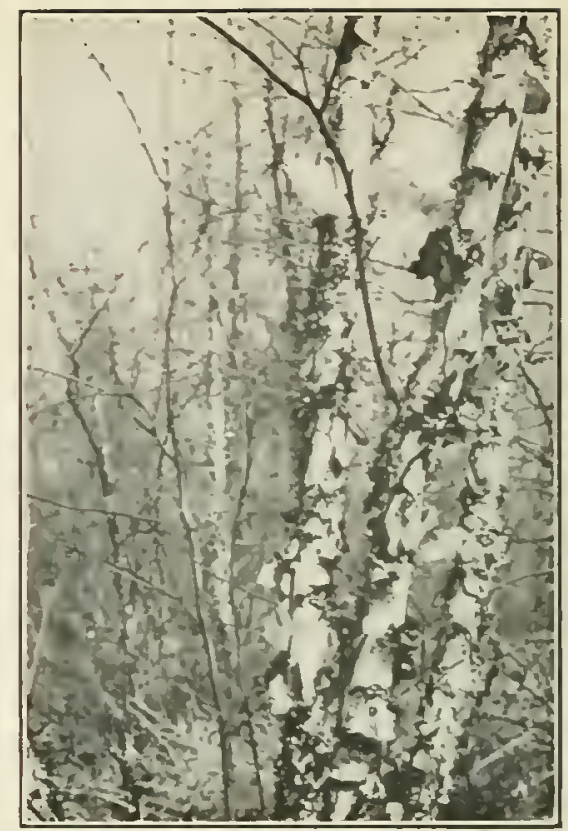

Fig. 65. RITEIR IIIRCII

Trunks 6 inches in diameter.

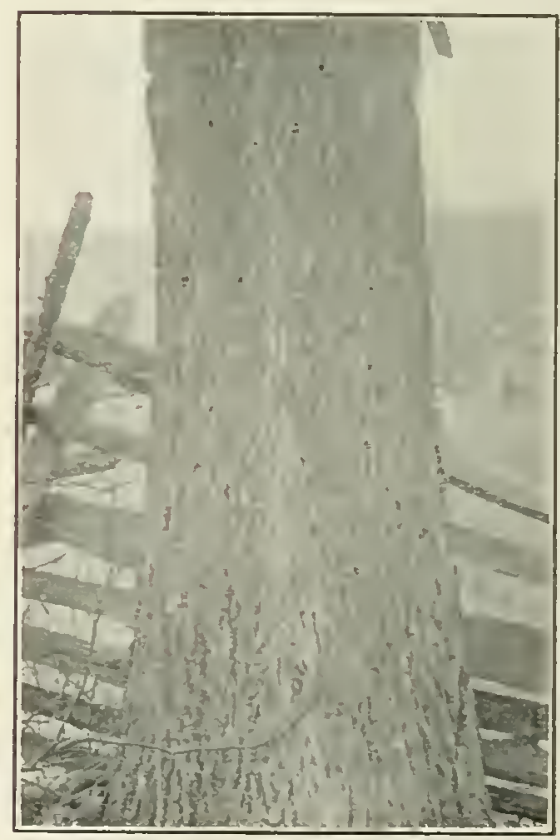

Fig. 6๐. SASSIIIIS.

'Trunk $26^{\circ}$ inches on dianetel' 


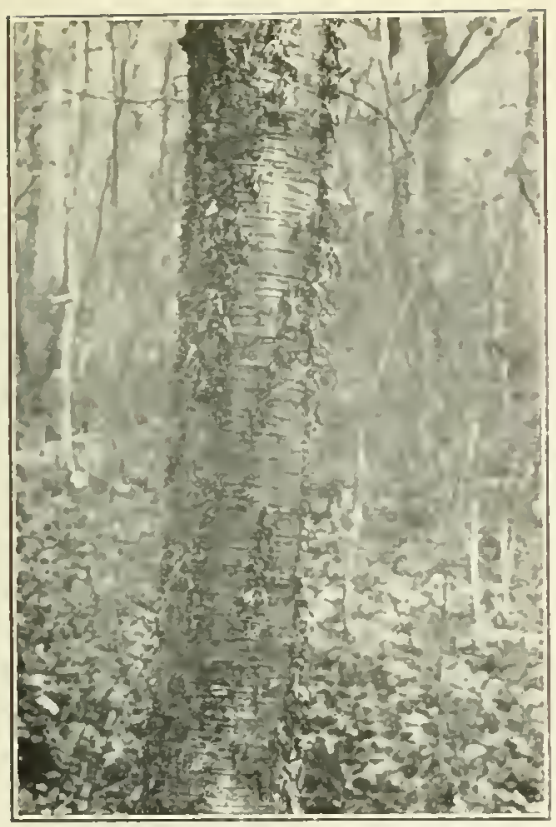

Fï. 6s. YELLoT" l:IRCH

'Trunk $\&$ inches in diameter.

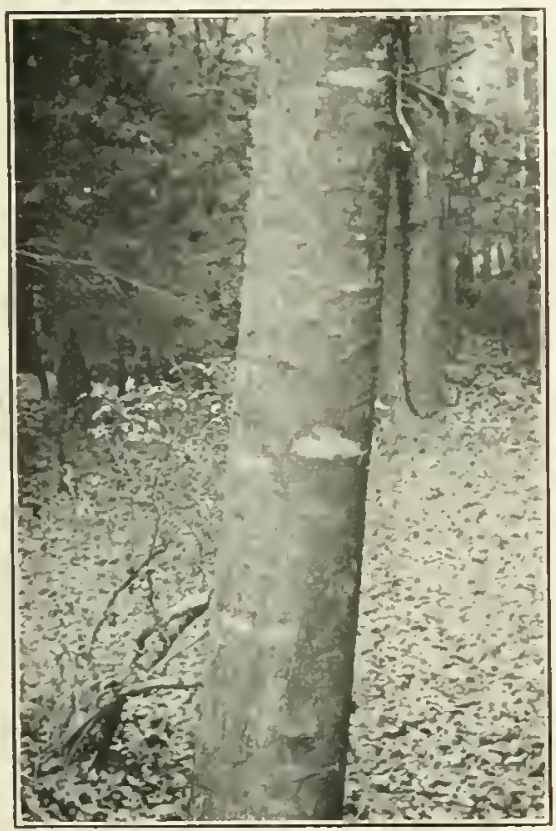

Irig. 70. IBIAC ('KIRCH (Koung.) Trumk 7 iuches in diameter.

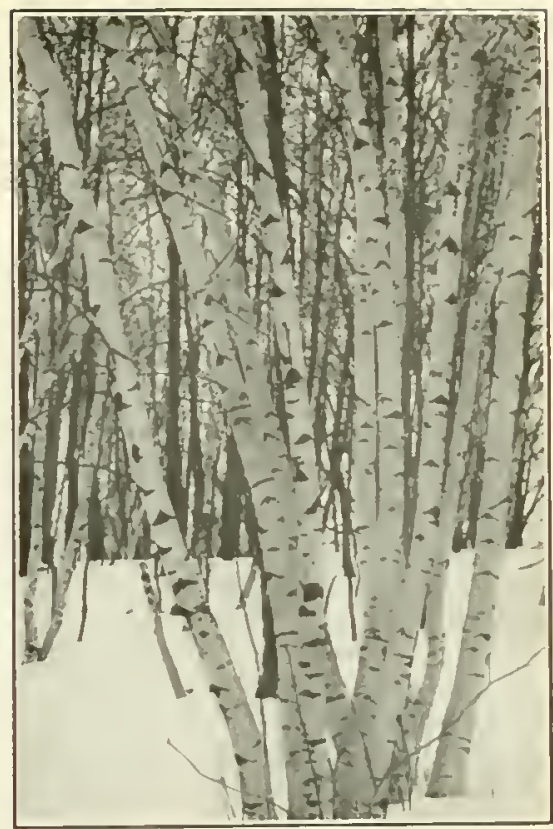

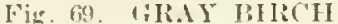

Trunk 4 inches in diameter.

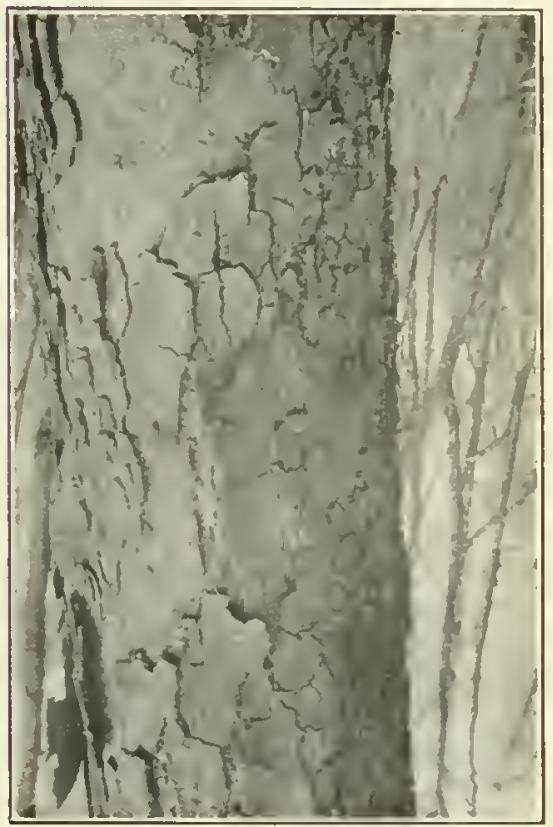

Fig. TI. IIIACK IBIRCH (OId.) 'Frunk 27 inclaes in diameter. 


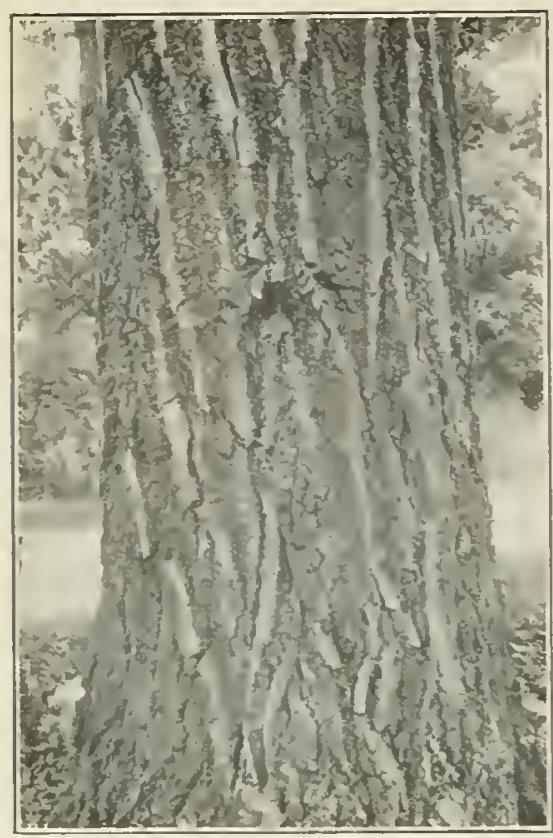

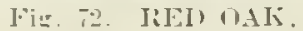

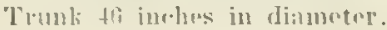

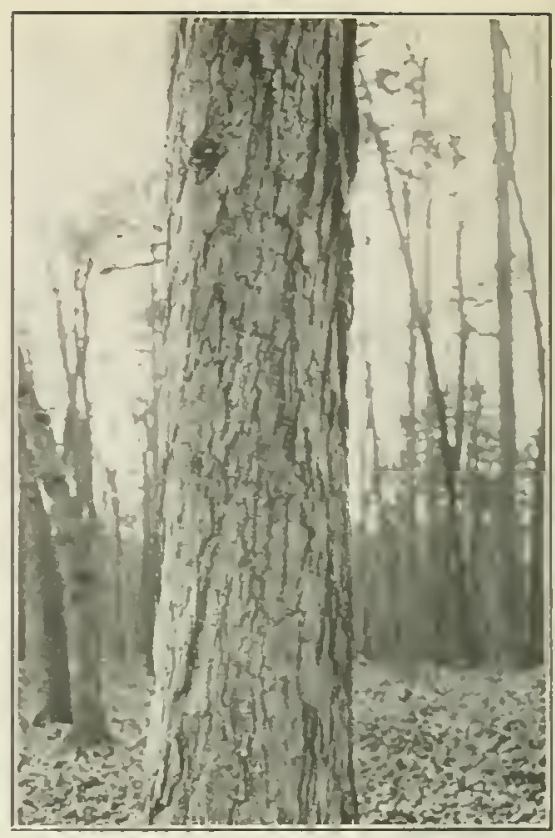

Fig. 73 , WHITE $0.1 \mathrm{~K}$

Trunk 3n inches in di-nunctor.

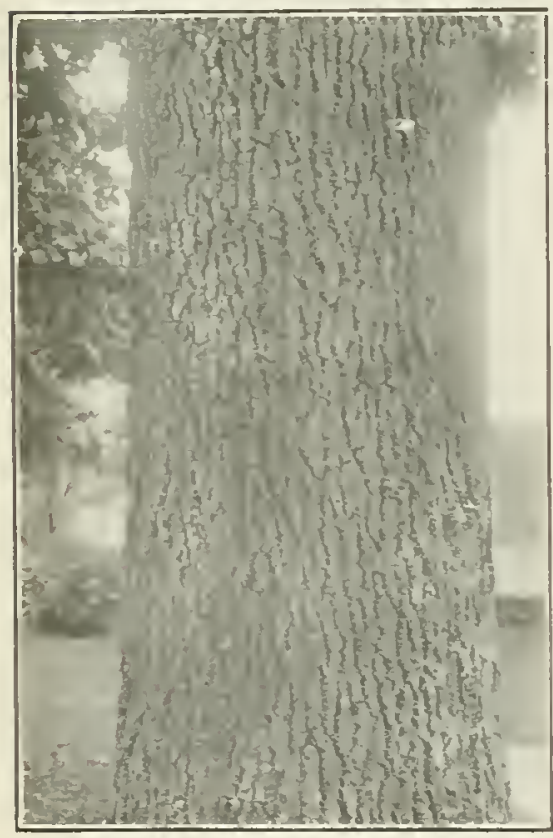

Fig. $7 \pm$ IBI.ACI $0.1 \mathrm{~K}$

Trunk t? inches in diameter.

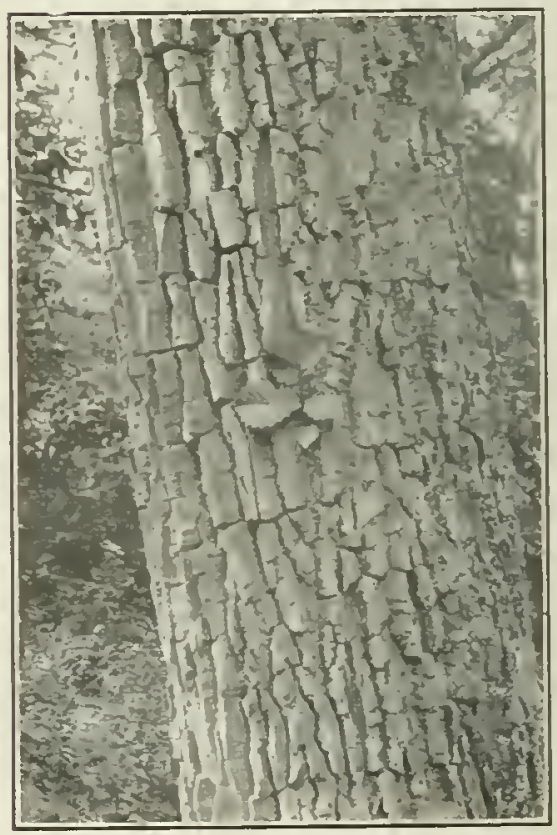

I.ig 5 ROCK OAK.

Trunk $3 t$ inches in diameter. 


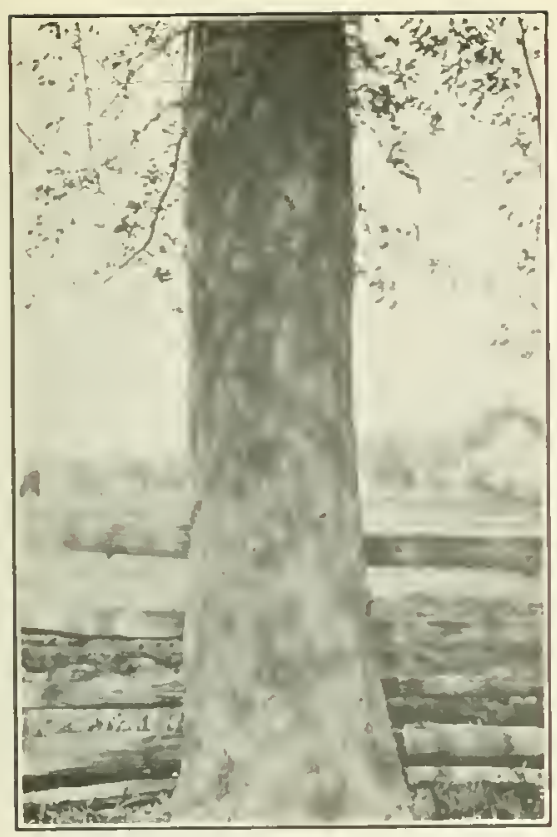

l*ig. To. PlX (1).

Trunk 1.5 incluse in diander.

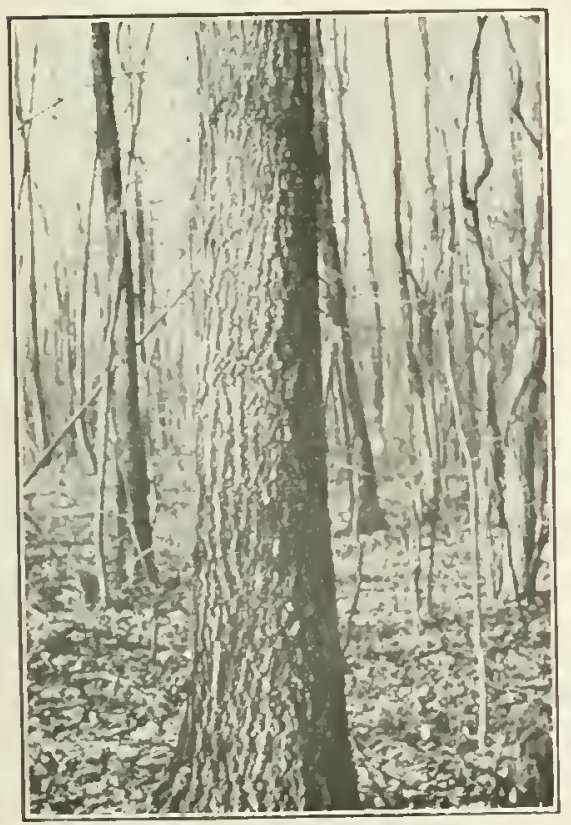

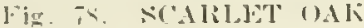

Trunk it inclues in dianeter

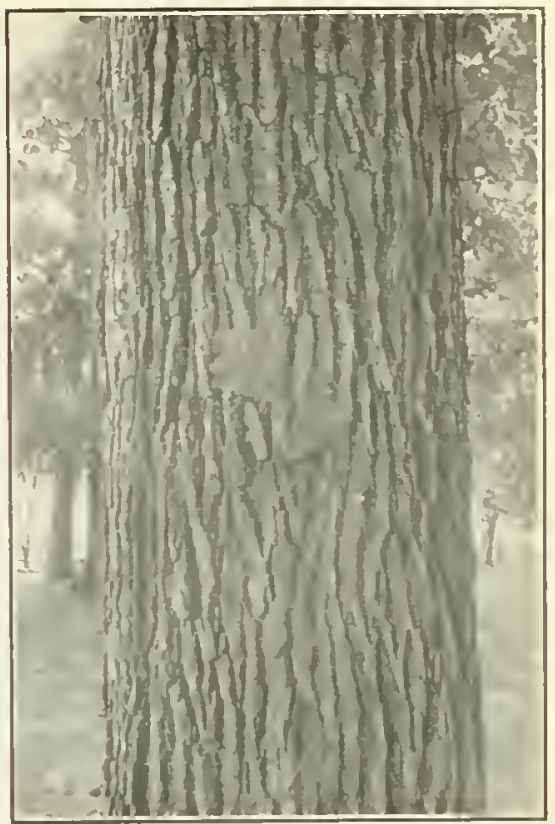

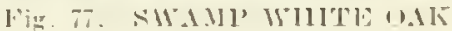

Trunk 32 inches in dianeter.

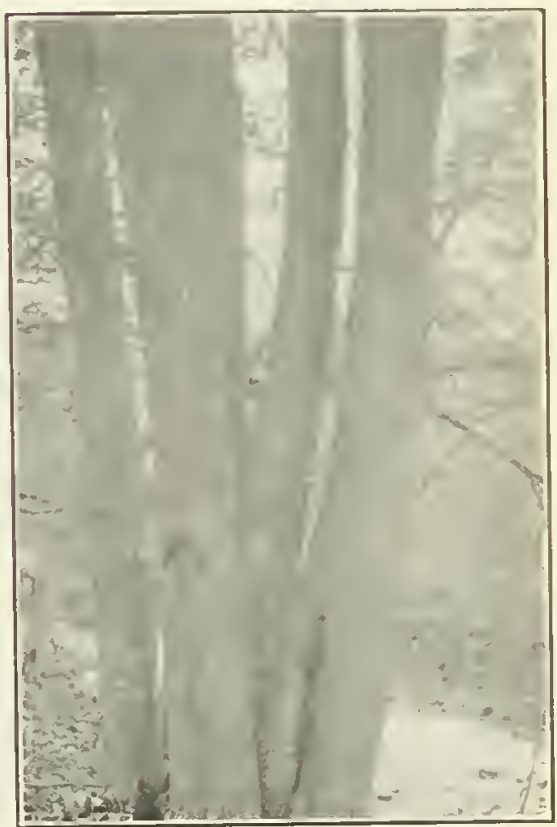

Fig. 79. I:ASSTTOOD

'Trumks 8-14 inches in dituneter. 


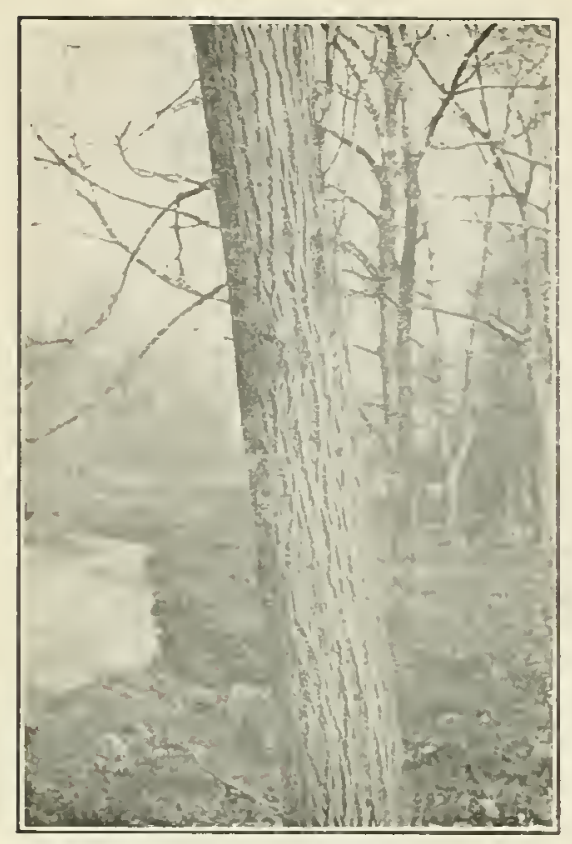

Fig. 80. BUTTERNUT.

Trunk 20 inches in diameter.

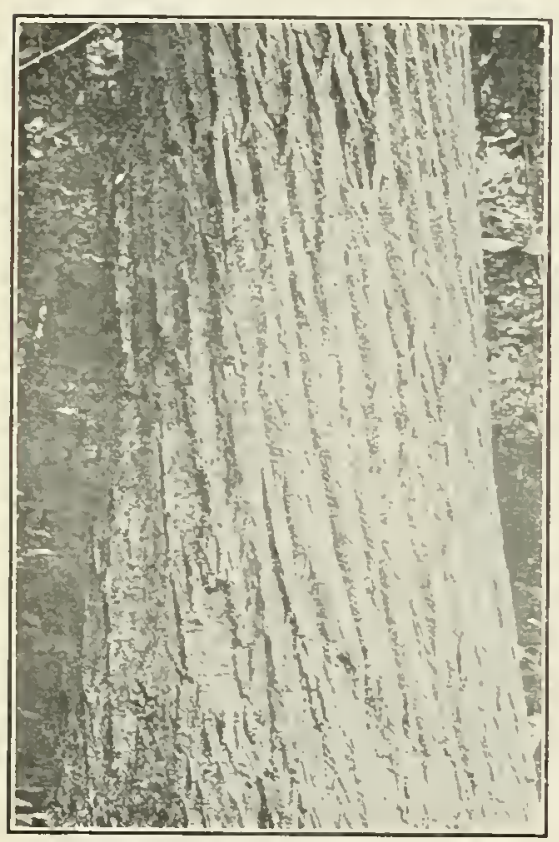

Fig. 82. CIISENTUT.

'runk 62 inthes in dianeter.

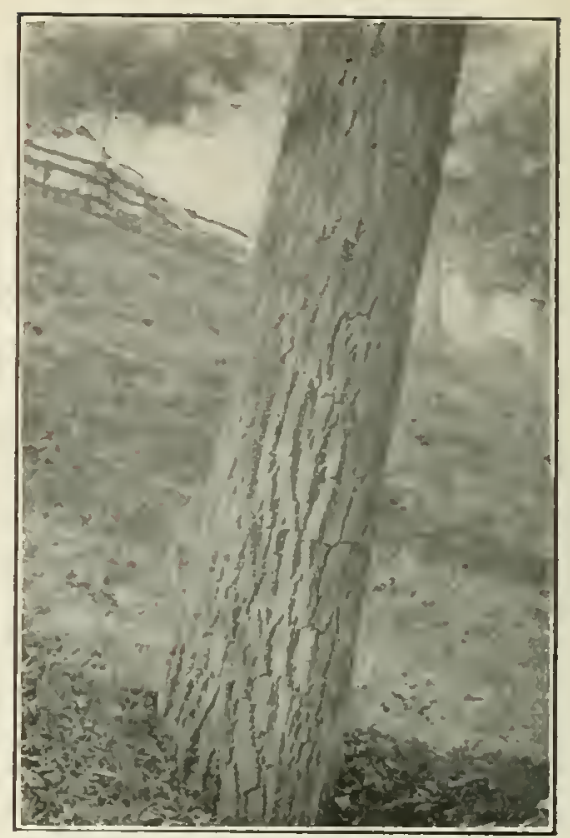

Fig. 81. BIACK WAINUT

Trunk $2 f$ incles in diametra.

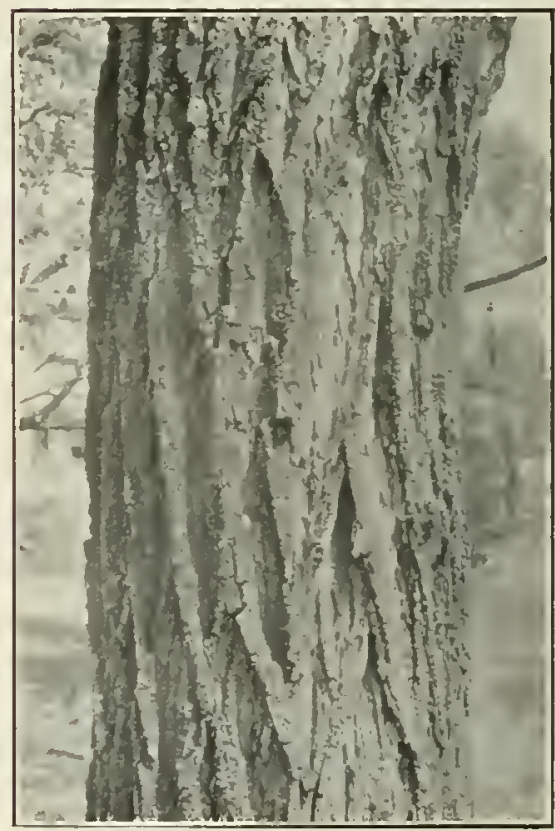

Fig 83. BIACK IOCUNT.

'Trunk 18 inches in diameter. 


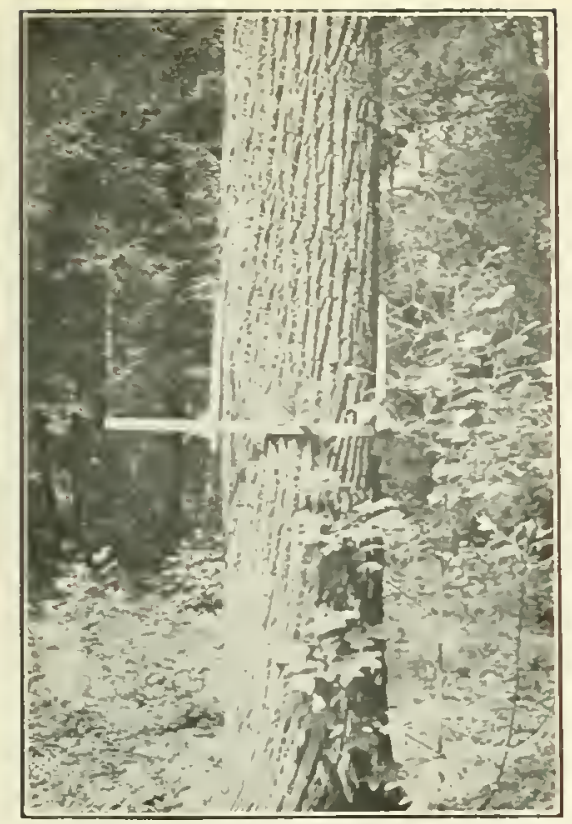

Fig. S4. TLIIT TIRE:

romk inders in dianeter

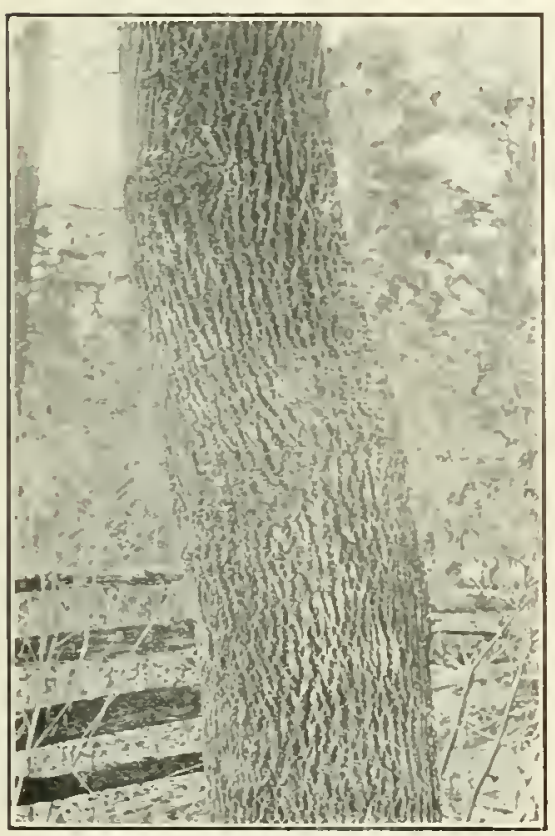

loig. 86. "11101\% .1:11

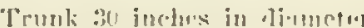

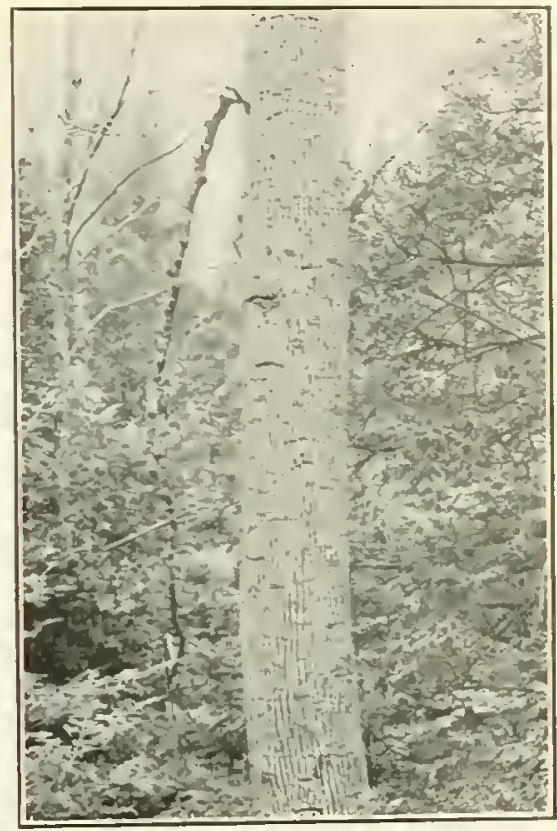

Frig. 4. C C 'UMI:BL

Trunk 26 inches in diameler

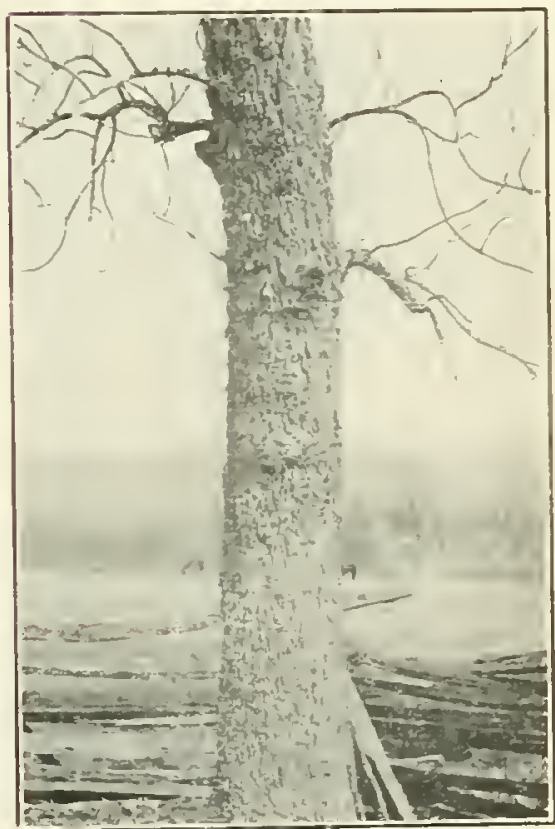

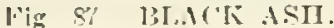

'Trumk 22 inches in diamotur. 


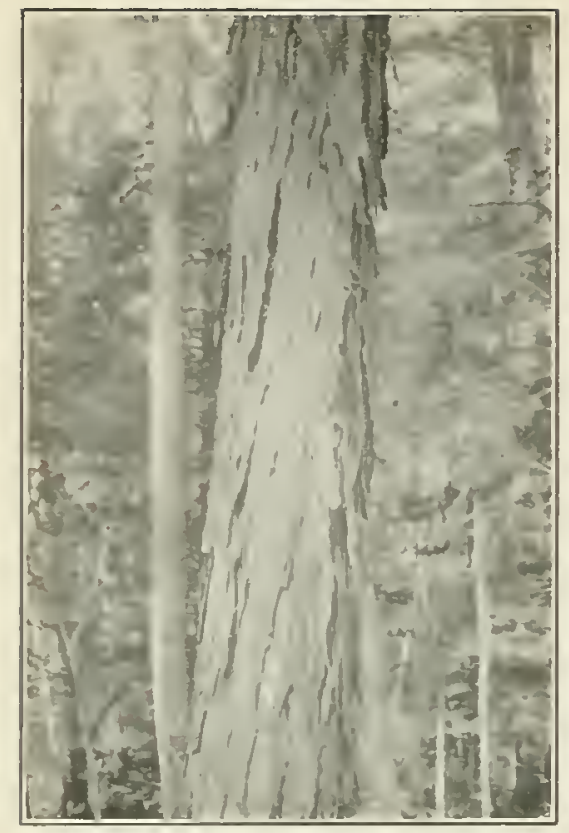

J"ï " NIIAG-IDAR HICKURT.

l'rumlis an iuches in diameter

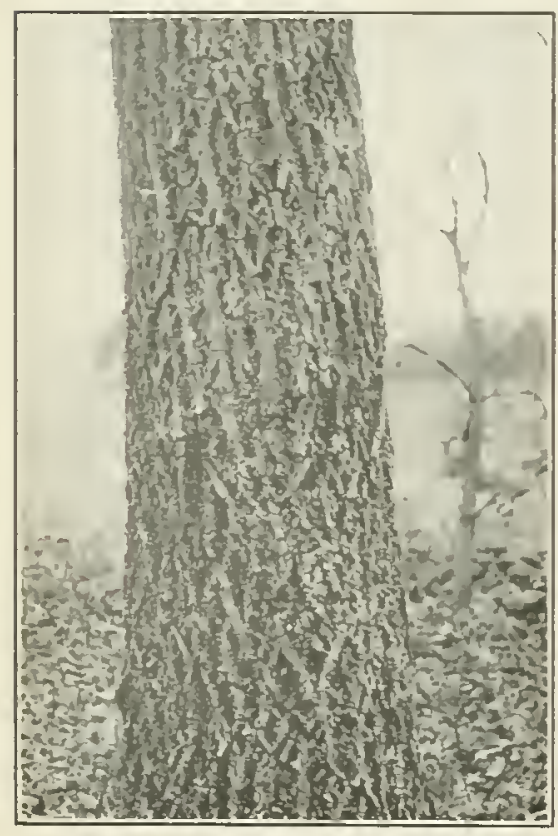

Fig. 90. MICKLR NLT HICKOHI. Trunk is inches in diameter

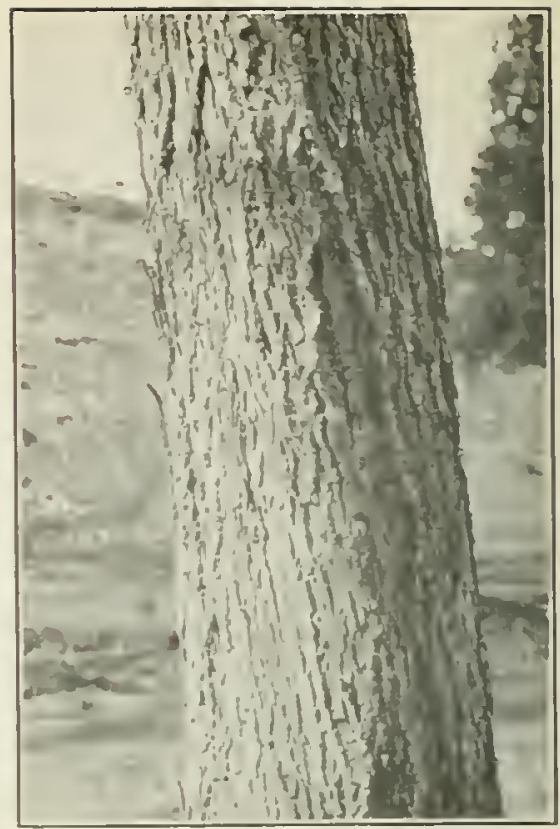

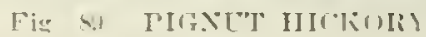

Tronk 22 inclins in di:m lor

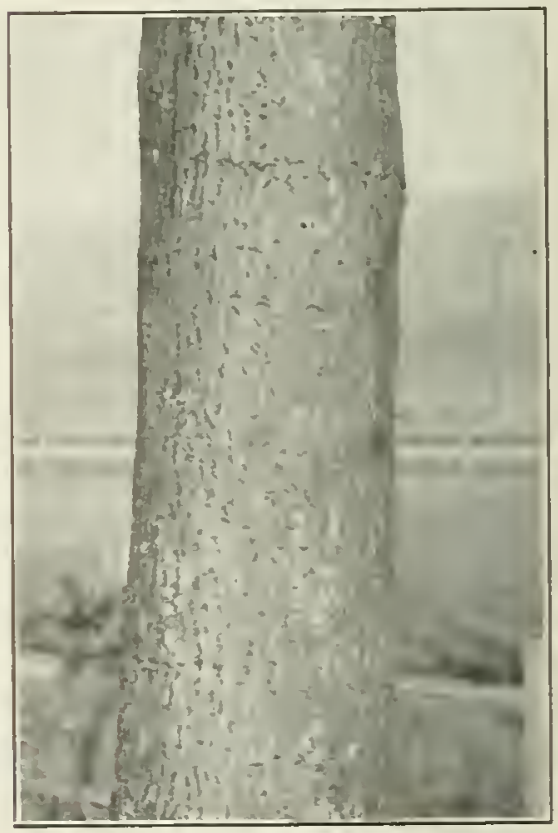

I'ig. 91. BITTER NIT JICKORY. Trunk 24 inches in diameter. 


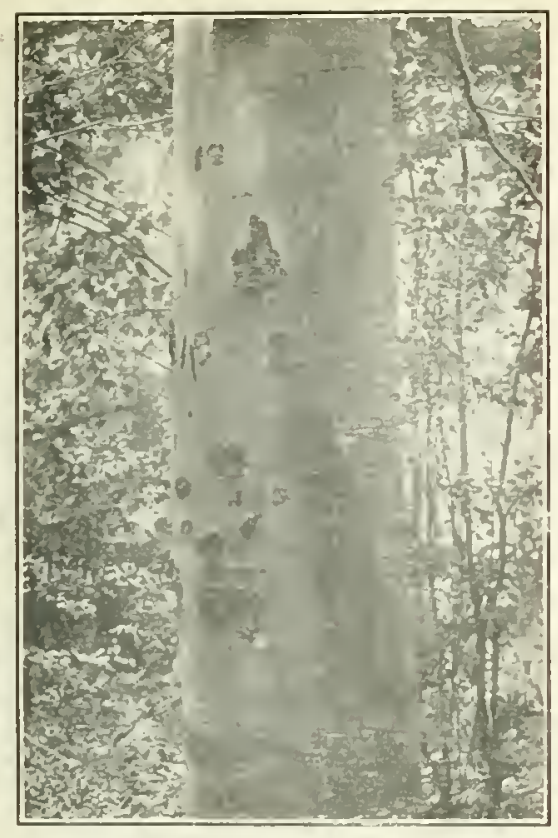

Fig. :12. LiF, II

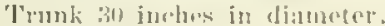

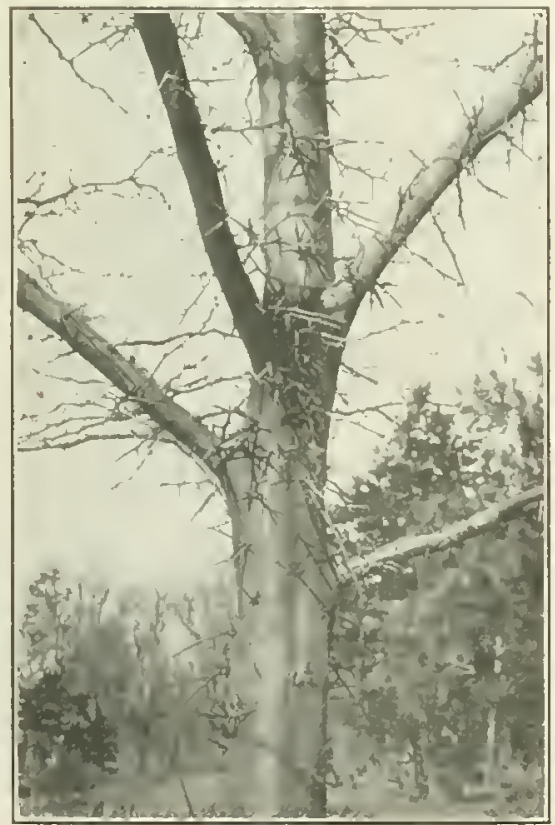

Jig. 94 IIMXEY I.MUST.

'Jlunk In inclese in diamutor

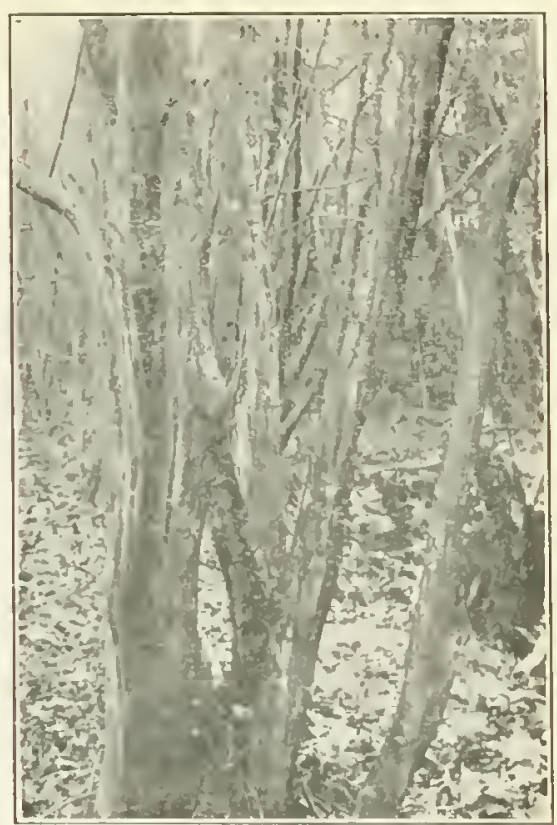

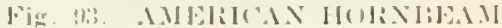
prunle of incluse in rliameter.

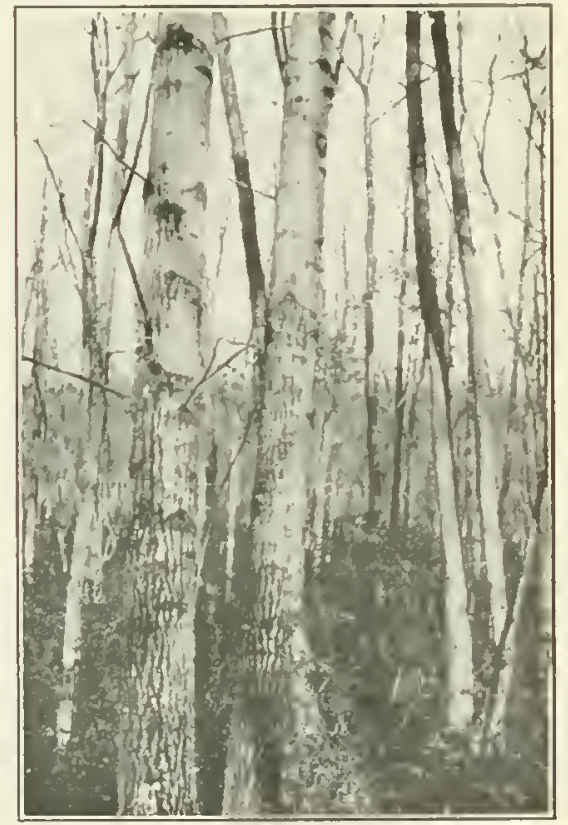

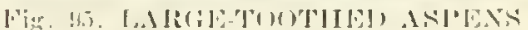

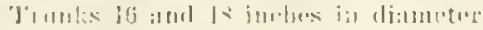




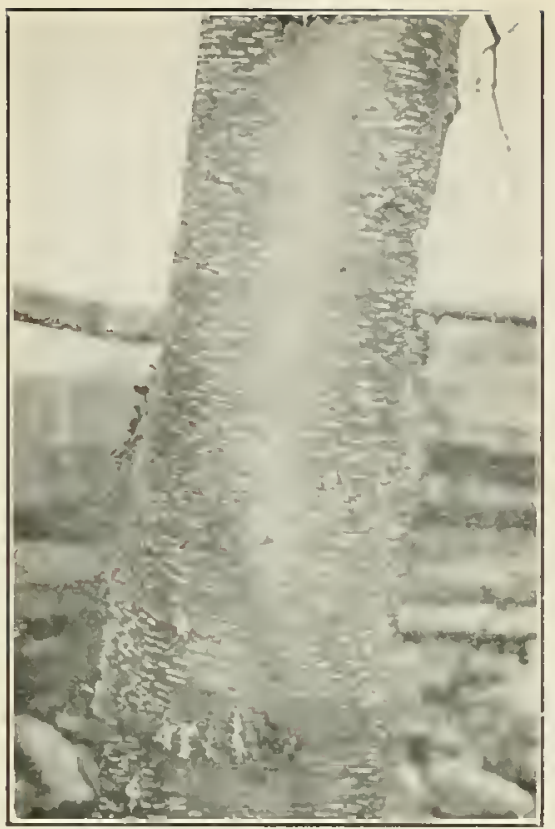

Fig. 96. WIID BI,ACK CHERRY. Trunk 6 inches in diameter.

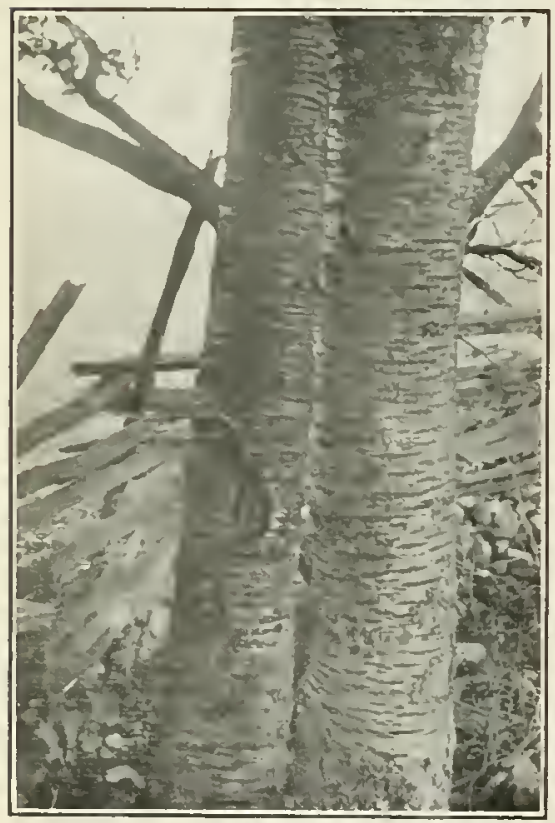

Fig. as IMOAFSTIC CHERRY.

Trunls. 12 and It ipches in diameter

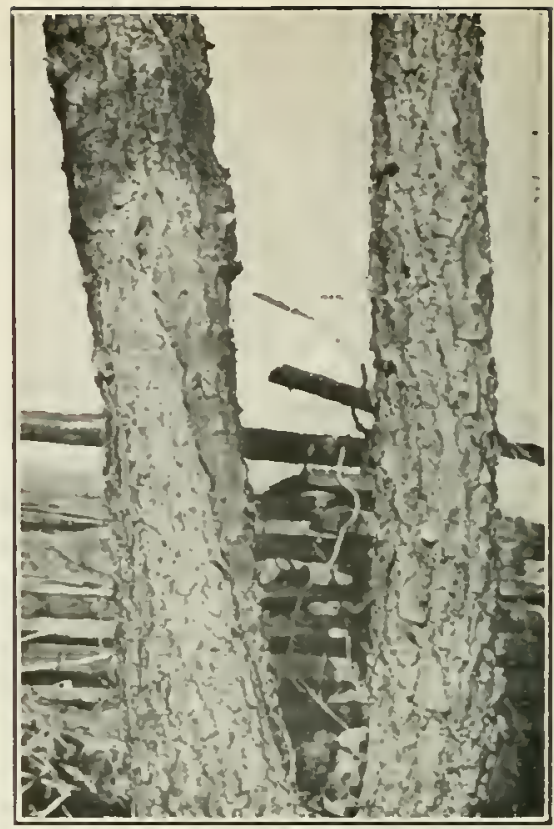

Fig. 47. WILD IOL.AT (OHEIRRY. rrunk ls inches in limeter

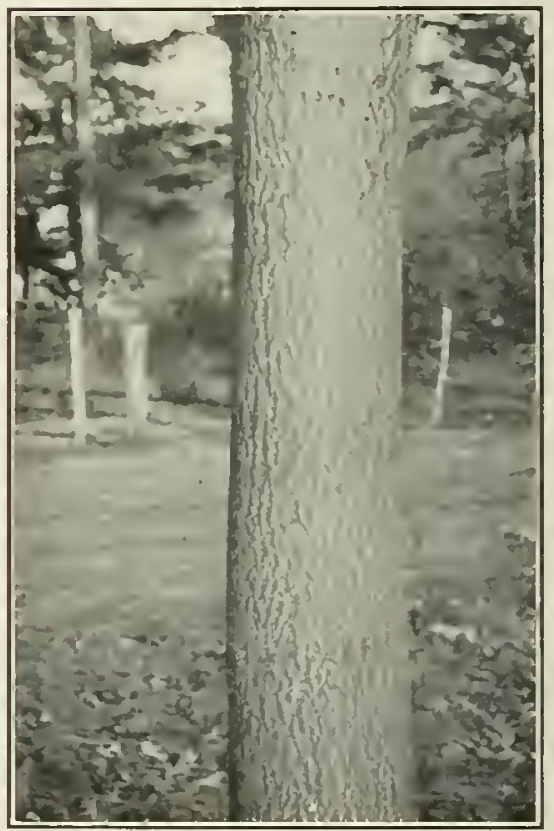

Fig. 99. TREE OF HEATEX Trunk 12 inches in diameter. 


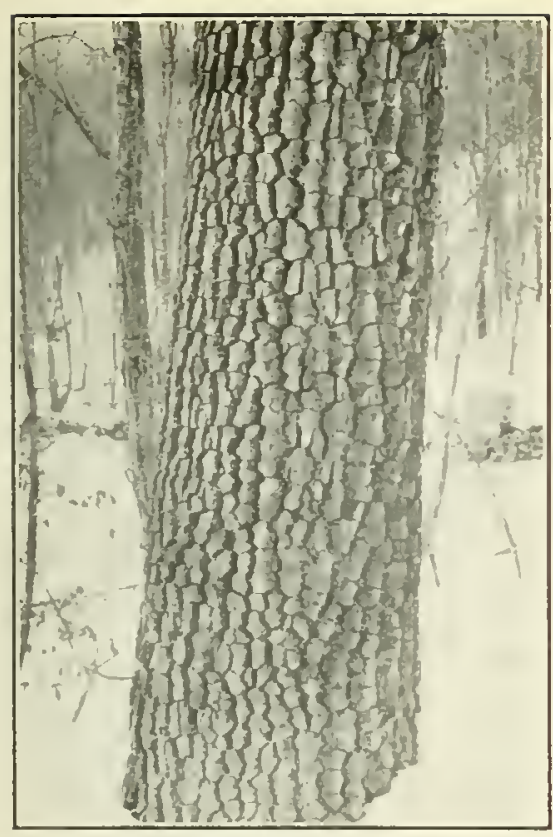

Fig. 100. BLACK GUM

Trunk 22 inches in diameter.

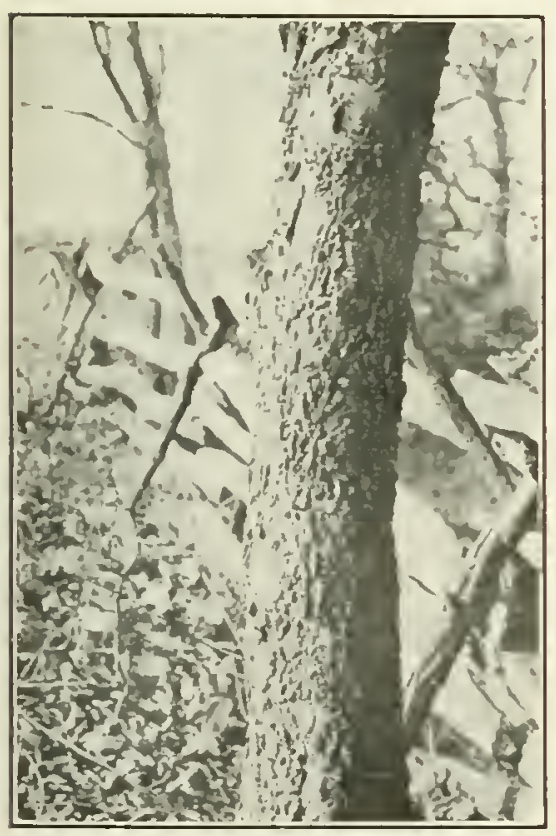

Fig. 1112. HARTIEIRT.

Trunk 8 inches in diameter.

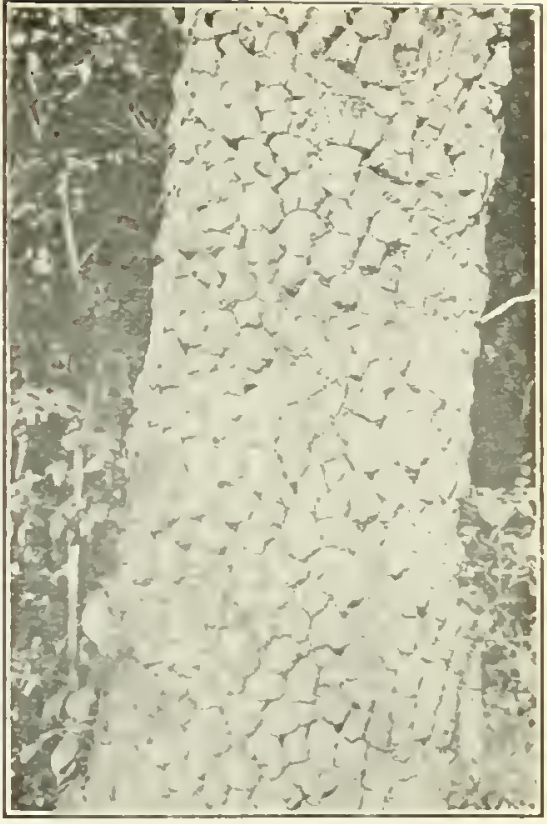

Fig. 101. PERSIMION.

Trunk 12 inches in dinneter.

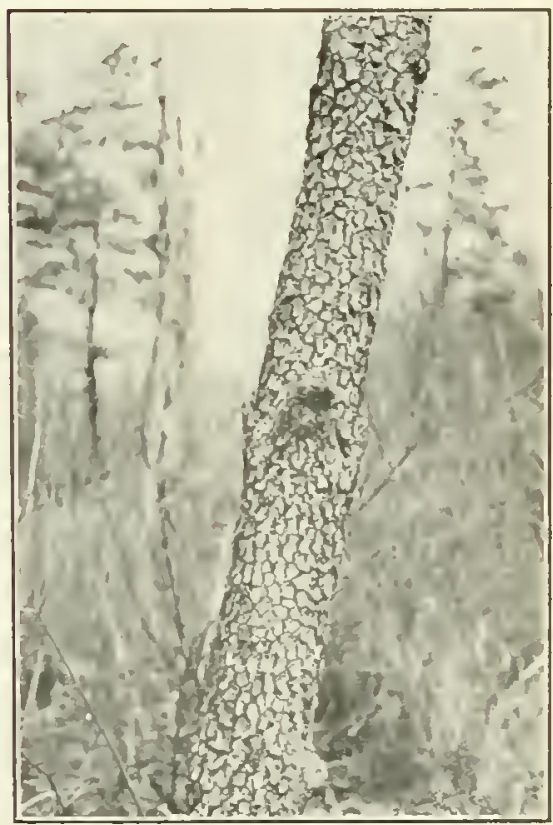

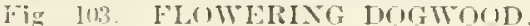
Trunk 6 inches in diameter 

as a protective covering while the latter is known as the inner or living bark and helps to convey the food which was manufactured in the leaves to varions parts of the stem. Thickness of the bark is often determined ly the rapidity with which it peels off. Its thickness, together with its larger number of dead, air-containiun cells, makes it a very ellective protective covering; but the chief protective feature of bark is the formation of corky layers. The chief function of the protective covering in plants is the prevention of excessive transpiration. The regular cork formations in the bar is help very much in controlling transpiration. Cork is one of the most valuable elements of the bark. Its structure is conplex and rariable. Cork is impermeable to air and water, a poor conductor of heat, and a preventel of fenetration by parasites. Local out-growths of cork like the wings of the swret Gum and Hackberry are probably of no value to the plants producing them. In some species the bark is not fully "lipenerl" at the end of the growing season, consequenty the subjacent tissues do not have the necessary plotection and frequently die back during the winter. The color of the bark varies in diflerent species, in dillerent situations, in diflerent prats of the same species, and with the age of the trees. Young lork is usually green, but it soon loses this enlol due to the formation of cork and other substances. A lew species like sassafras retain their green color for a lelatively long timo lne to deferred or late cork formation. Gray, brown, and black are the prevailing bark colols while red and white are also common. Color of the bark is very helpful in distinguishing mang of our common trees. All the species of Birch native to Penusylyaia may be distinguished from each other by the color of their bark together with a few other bark char. actelistics. The bark on some of the older trunks becones rough and then the characteristic color of the species may be present only on the branches and romng stems. The outer bark may be uniform, mottled, or variegated in color. The interior and exterior parts of the bark nay differ in color. Black Oak bark is yellow within and black without, while Hemlock is reddish within and brown to black without. The bark of the Buttomwood is peculiar since it is dark brown without and green, gellow, or white within. The inner bark often becomes very conspicuous due to the complete peeling off of the outer bark.

loung branches and stems are usually smooth since the bark ex[rands sufticiently to accommodate the increased diameter growth of the interior. Later, in most species, the bark begins to crack, since the growth of the interior is too rapid for the expausion of the bark. In a few species like Beech, Blue Beech, and Balsam Fir the bark lemains thin and smooth thronghout life. Other species like Basswood and Pin Oak remain smooth for a long time but be- 
come furrowed later, while many other species become rough early in life. The manner in which the bark cracks open or peels off affords a ready means of identification for many of our trees. The exfoliation of the bark is ratler constant for each species. In some species like the Yellow Birch and Paper Birch it peels off in thin film-like papery layers. In the shag-bark Hickory it is shaggy; in many species like the Pines and Spruces it is scaly; while in others like the White Cedar it is shredds. Mans species have furrowed bark. The furrows run usually in a longitudinal direction but may run transrersely. The furrows or fissures separate ridges. These vary with the species. The fissures may be short or long, close or distant, narrow or wide, longitudinal, transverse, or diagonal. The ridges may be pointed or broad, high or low, smooth or scaly. The bark may be broken up into sinall square or rectangular blocks as in the Black Gum. This form of bark is ofteu spoken of as "alligator bark." See Figures 44-103 for bark of most of our important native trees.

The bark may be of considerable technical ralue. Hemlock and some species of Oak and spritice have bark which is rich in tannin. The bark of these species is used extensirely in the leather industry. The bark of a European species of Oak is highly prized on account of the large quantity of cork which it produces. The inner bark of some species yields dyeing material while that of others is used in the manufacture of fibre cloth. Formerly the bark of the Paper Birch was used in the construction of canoes.

\section{Twigs:}

Twigs are the terminal parts of branches. The term twig usually refers to that portion of the terminal part of the branch which grew in the last season. Those portions of the branch which began their growth a few seasons ago are usually spoken of as older twigs or branchlets. The twigs have their origin in the regetative buds which may be located on the terminal end of the twig of the previous season's growth or along its side. If they emerge from terminal buds ther become leaders. and if from lateral buds they will develop into lateral branches. The lateral branches may be alternate, opposite, or whorled (Plate II). The method of branchiug is rery help. fnl in distinguishing our common trees. The lateral branches of most of them alternate with each other, while a fair number are opposite and a few whorled. The terminal twig elongates rapidly while the lateral ones nsually remain shorter and occasionally are compressed to a stub or spur.

When the regetative buds burst open in spring young twigs, which are often corered with dereloping leaves, emerge from them. These twigs are, at first, usually delicate, greenish in color, and 

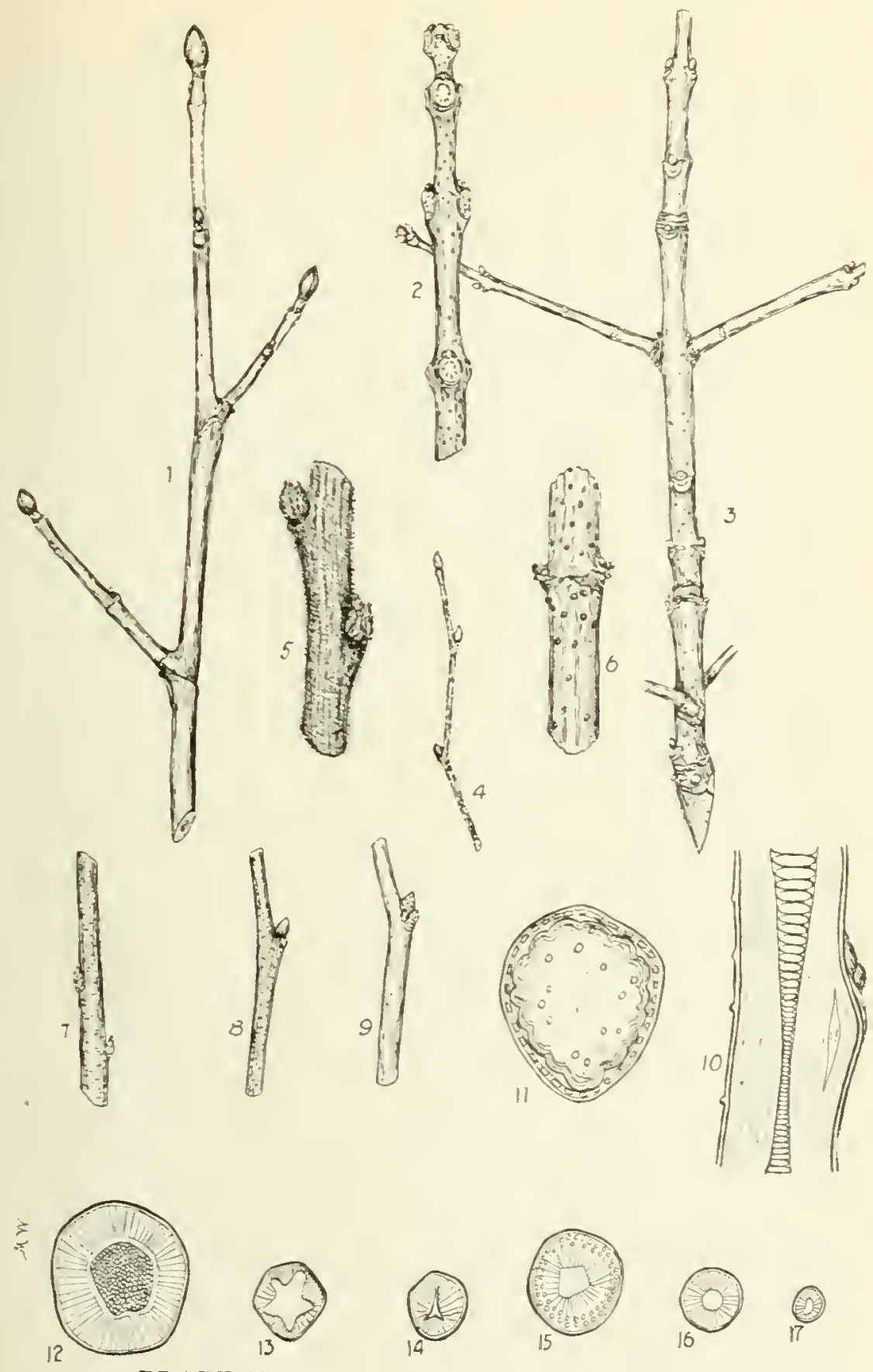

(2)

PLATE II. TYPES OF TWIGS AND PITH.

1. "ulip. Tren dalternate liranchingl. 3. White A t whorlerl branching).

3. Virge Ash (opposite branching).

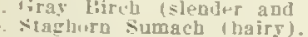

E. Elerberry llenticels promineat).

7. Blsuk riuers (lentivels trausverselg elonzatedi).

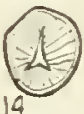

9. Blgek lium denticke resp and inconspicuons).

10. Filack Walnut (1.lambered pith)

11. Sumach llarge jith).

1.. Sassafras ( Damediun-sized pith).

13. Nak istar-sbaj wo! pitlul.

14. Hack Aliter itrianuzular pith).

C. Chestnut

1h. Elm (eircular yitb

Iraming are alout oue-half natural size. 


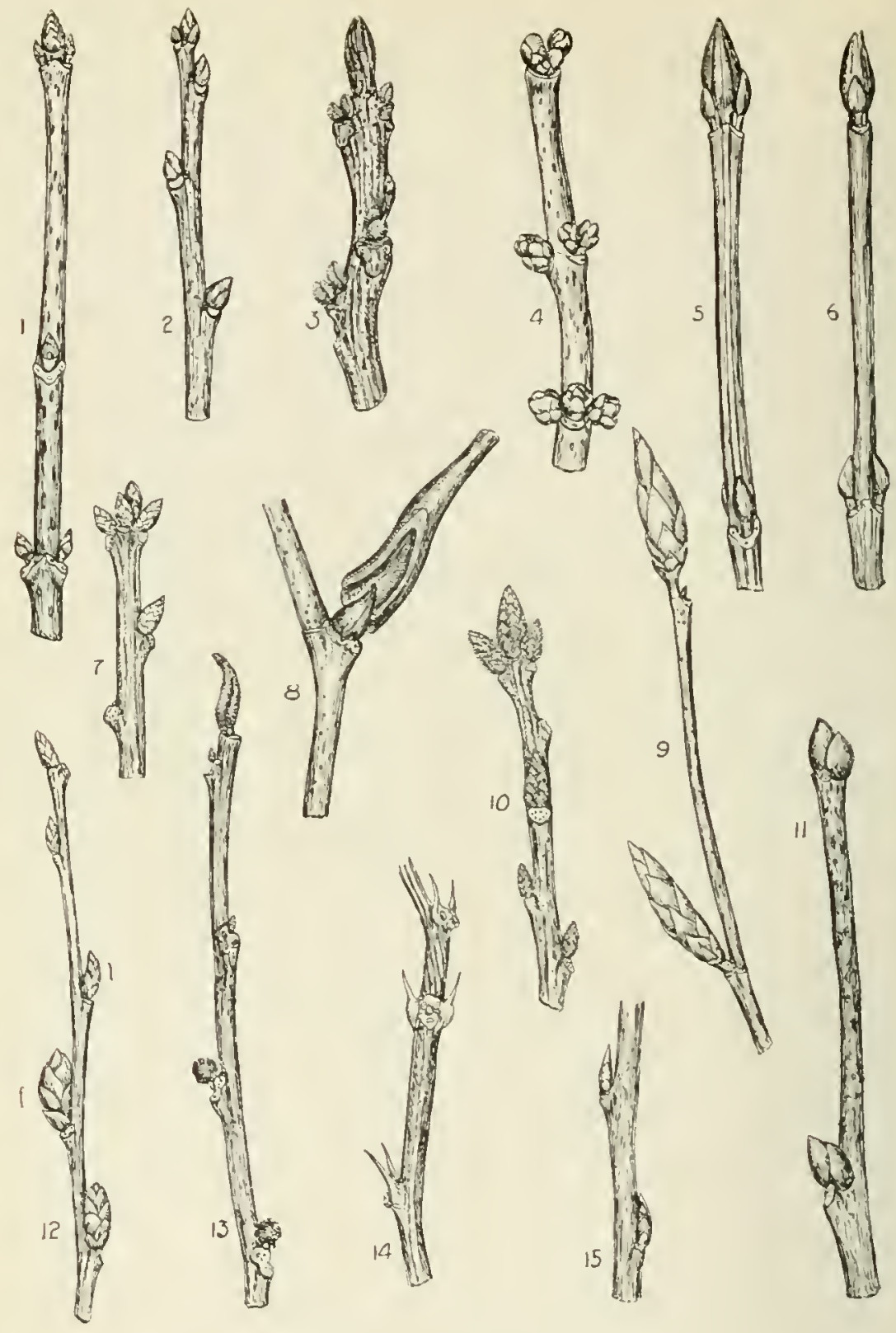

PLATE III. TYPES OF BUDS.

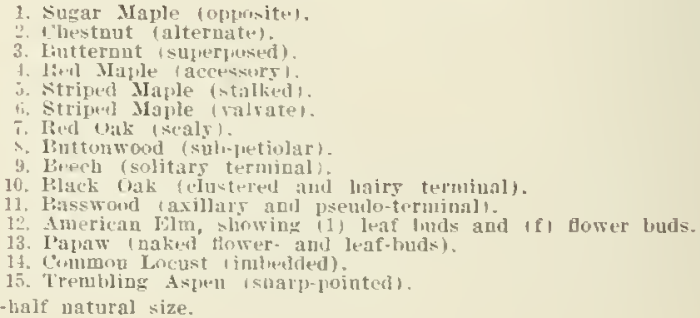


often hairy. As they develop during the season they become firmer and often lose their green color and their hairs. The direction of the new growth is rariable. In many species it takes at first a drooping direction and later, as its elements become firmer, it assumes a horizontal or ascending position. The nerr growth of the Pines is conspicuous in that it glows in an ereet direction at first and later becomes horizontal or drooping.

The taste, smell, and color of the twigs are helyful in distinguishing some of our common species. The twigs of some species as the Black Birch, Spice Busl, Sassafras, and Wild Cherry hare a characteristic taste and snell. The color of the twigs may be green as in the Sassafras, red as in the Basswood and Red Maple, or brown as in the Sngar Maple. Maur other different colors and combinations of color aid materially in distinguishing our trees.

Some twigs are rough while others are rather smooth. They may he roughened by hairs. lenticels, raised leaf-scars, bud-scale scars, warty or resinous exudations, corky projections, or decurrent projections of the hark. If we examine a young twig just after it has emerged from the bud we will find that it is usually green in color. At the end of the first season's growth a thick bark has usually dereloped which is un longer green on the surface, but, by cutting a cross section of a twig, one will often find that the inner bark is still green. This green tissue derelops chlorophyll and manufactures food just as does the green tissue of the leares. As the bark increases in thickness the chlorophyll decreases, erentually disappearing entirely from the stem. In order that this green tissue in the bark mas function it is necessary that gases be exchanged through the bark. Special structural modifications on the bark known as lenticels (Figs. 96 and 98 ) make jossible this exchange of gases just as the stomata on the leaf-surfaces allow and eren regulate the exchange of the gases of the leaf.

The lenticels are rery numerous and conspicuous on some species, while on others ther are rare and inconspicuous. They are raised on some species like the Elder, while on other's they are eren with the bark. Their color raries. They may be white, gray, pinkish, yellow, brown, or black. In outline they are usually circular or slightly elongated. In the Cherries and Birches they are confluent, a characteristic which results in the horizontally elongated lines of lenticels (Figs. 96 and 98 ) so common on their trunks.

The duration of the lenticels raries with the species and its environment. As a rule the more rapidly bark is formed the shorter is the duration of the lenticels. On some species it is difficult to find lenticels on any but the last season's growth while on others they mar persist for sone rears. The exfoliation of the bark causes their 
disappearance. On a few species like the Birches, Cherries, and Honey Locust they persist for many years.

The distribution of lenticels has not yet been systematized. They are distributed rather uniformly over the newer growth but are irlegularly spaced. In some species they seem to be somewhat clustered just below the nodes and in others like Honey Locust they are more numerous on the lower side of horizontal branches.

The pith usually occupies the central portion of twigs, branchlets, and roots. It is coniposed of thin-walled cells which are loosely aggregated. It seldom increases in size after the first year. The pith of a tree 100 jears old is usually not wider than that in a year old twig of the same species. It becomes functionless early in the life of a tree.

The pith of conifers is rather uniform in outline, structure, and color, but in the broad-leaved species it is rery variable. In most species it is suall in proportion to the size of the twigs, but in a tew species like Sumach, Elder, Sassafras, Ailanthus, and Kentucky Coffee-tree it is relatively large. The outline in cross section may be 5-angled or star-shaped as in the Oaks, Chestnut, and Aspens, 3-angled as in Alder and some Birclies, angular as in Common Locust, circular as in Elm, and oroid as in Basswood. As a rule the pith is continuous, but in a few species like Black Walnut, Butternut, and Hackberry it is chambered. A few species like Catalpa have continuous pith except at the nodes where it is sometimes chambered. A less distinct separation of the pith is found in Black Gum, Papaw, Tulip Tree, and the Magnolias where plates of stone cells occur. The color of the pith may be white as in the Sugar Maple, pinkish as in Red Maple, brown as in Striped Maple, Mountain Maple, Sumachs, and Walnuts, red as in Kentucky Coflee-tree, or greenish as in Shad Bush.

\section{Buvs :}

In temperate and colder climates the growing season extends orer a part of the year only. During the warmer part of the year vegetation is active, but as soon as the weather becomes cooler, many annual plants die while others make special preparation for the winter. One of the preparations is the formation of buds. They are formed in most trees and shrubs of cold and arid climates. If we examine a twig from one of our common trees in the month of Jnly we can usually find buds starting to develop in the axils of the leaves. They continue to derelop until they have reached a certain size, and then remain in an inactive condition for a few months in winter, only to become active again when favorable growth conditions return in spring. A year usually includes a period of rest alternating with a period of activity. Buds may be divided into 
two classes, active and resting. Active buds are growing or developing buds, such as one finds in late summer prior to the period of rest and early in spring when the resting buds have been awakened from their winter's slumbers. The resting buds are commonly known as winter buls (Plate III).

Buds are protected growing joints. The degree of protection given to the growing points raries with the species. A few of our trees and shrubs have buds which are nearly or quite destitute of a scaly covering. These are know as naked buds. The protection usually consists of scales which may he supplemented by hairy outgrowths, resin, gums, or air spaces. These are known as sealy buds. The buds may he covered hy numerous orerlapping seales, known as imbricated hud-scales, or they may he corered by simply one or two visible scales which do not overlap. The buds of the Willows and Buttonwool are covered ly a single visible bud-scale, while the buds of such species as the striped Traple and the Black Alder have only two visible hud-seales whose margius simply meet and do not overlap. The latter are known as valrate buds. The buds may also receive protection from the enlarged hases of the stalk of leaves which often persist far into winter. The buds covered by the enlarged base of the leaf-stalk are known as subpetiolar buds. The huds of some of our common trees are rery inconspicuons. It is often difficult to lowate them when sunken so leeply into the bark that only the tip is risille. The size of the huls is not indicative of the size of the tlowers or leaves which they will prodnce the following season. Many of the trees which bear small and inconspicuous buds produce lape and consprinous flowers and leares. The principal functions of the profective covering of huds are the prevention of the loss of water from the tender parts within and the protection of their delicate interior from mechanical injury. Some add that the protection also minimizes the damaging effect of sudden temperature changes.

The position of buds is of consideralle ralue in distinguishing many of our trees and shruls. They may occur at the end of the twigs or along their sides. The former are known as terminal buds and the latter as lateral buds. The terminal buds may be solitary as on the Beech or c]ustered as on the Oaks. On most of our trees and shubs the lateral huds appear just ahove the origins of leafstalks and are known as axillary buts. They may occur in pairs, one on one side of the twig and the other exactly opposite, or singly forming a spiral around the twig. The former are known as opposite buds and the latter as alternate buds. The axillary buds may occur solitary or in groups, either one above the other, or side by side. If they occur one above the other they are known as super. posed buds and if they occur side br side they are known as accessory 
buds. Sometimes axillary buds remain inactive for a long period of time without losing their vitality. Such are known as dormant buds. During their dormant period thes remain on the surface of the trunk by the elongation of their connection with their point of origin. A superabundance of food, excessive light, or the death of a great number of terminalls located buds, mas stimulate them into actirity again. A great number of these buds are often found along the stem of such species as Chestnut and Rock Oak. They derelop into short branches which are known as "water sprouts." Some buds are produced at rather unusual points, and in irregular positions along the stem, aud are called adventitious buds. They also form "water sprouts."

One finds a mide rariation in the size and form of the buds which our common trees produce. Some are long and slender; others are short and stout. Some of them are round in cross-section; others are augular. Some are sharp-pointed: others are blunt-pointed. The buds also vary in the manner of their insertion on the twigs. Some ale inserted directly on the twig; otliers are separated from the twig by a stalk, and still others may be almost entirely corered by the twig. The folmel are called scssile buds, the next stalked buds, and the latter imbedded buds.

The kind of buds which a tree prorluces is of considerable importance, especially where fruit trees are considered. Three principal kiuds of buds may be distinguished:-leaf buds, also known as vegetative buds, the contents of which will derelop into stem and leaves; mixed buds, the contents of which consist of leaves and flowers in their formative stage; and fower buds, also known as propagative buds, which contain the elements of flowers only. How can one find out what kind of buds are at hand? The buds mar be cut open by means of a sharp knife and their contents studied with the aid of a magnifying glass. One may also take a twig and place it in a jar of water in a warm room and in about a week the buds will have expanded fal enough to reveal the uature of their contents. The twig with its buds may also be left on the trees and its development obserred in spring when nature opens them. With all this variation in the position, insertion, form. structure, and kind of buds re still find here, as in all nature. law and order.

\section{LEAYES:}

The shoot of a seed plant consists of stem and leaves. The leave of our common trees are excellent distinguishing characters by which the species may be recognized. They are rariable in form. Tlis rariation, as well as the rork ther do, is little appleciated by the erowds which annually seek their shade and shelter. This chapter 


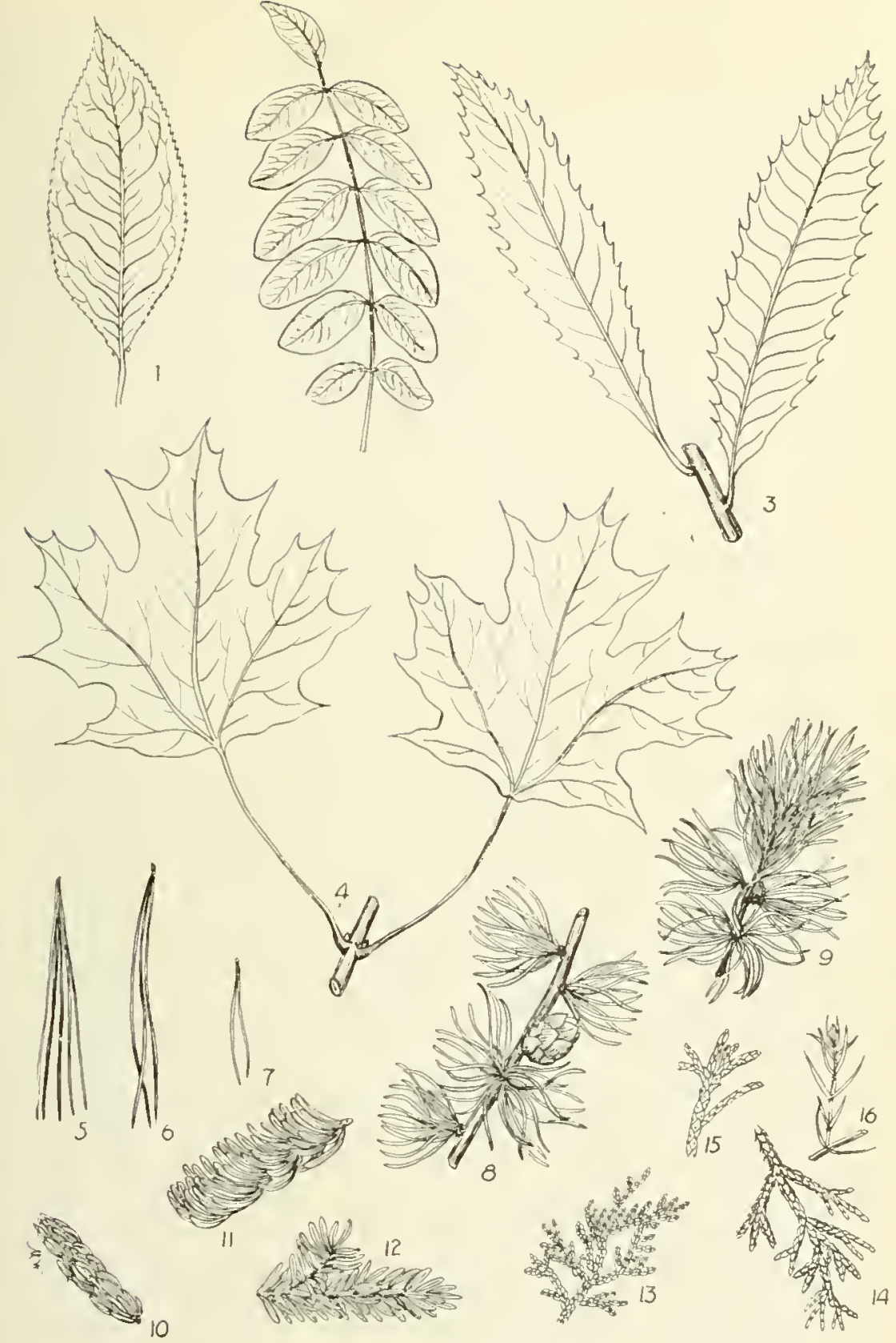

\section{PLATE IV. TYPES OF LEAVES.}

1. Black (berry (simple).

2. Common Locust (componna).

3. Chestnut (alternate arrangement).

4. Sugar Maple (opunite arrangemint)

5. White Pine (5-clustered).

6. Pitch Pine (3-clustered)

7. Jerses or Scrub Pine (2-clustured).

8. Larch (many clustered).

9. Larch (many clustered at base; solitary on loadigg shoots).

10. Red Snture (f-sider)

11. Balaan Fir iflat and sessile).

12. Hemlock (tlat and stalked).

13. Red Cerlar (scale-like needles).

14. Arbor Vitae (scale-like needles).

15. Artior Vitne

16. Red Cerlar (awl-slaped needles).

Dramings are ahout one-lalf natural size. 

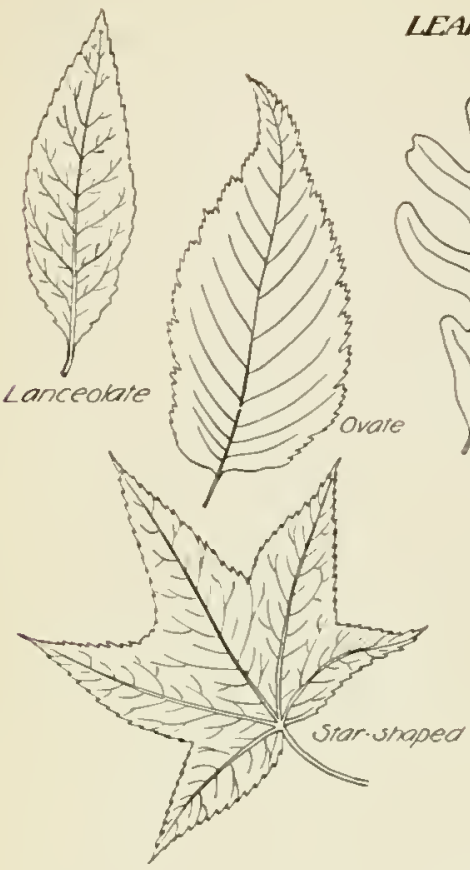

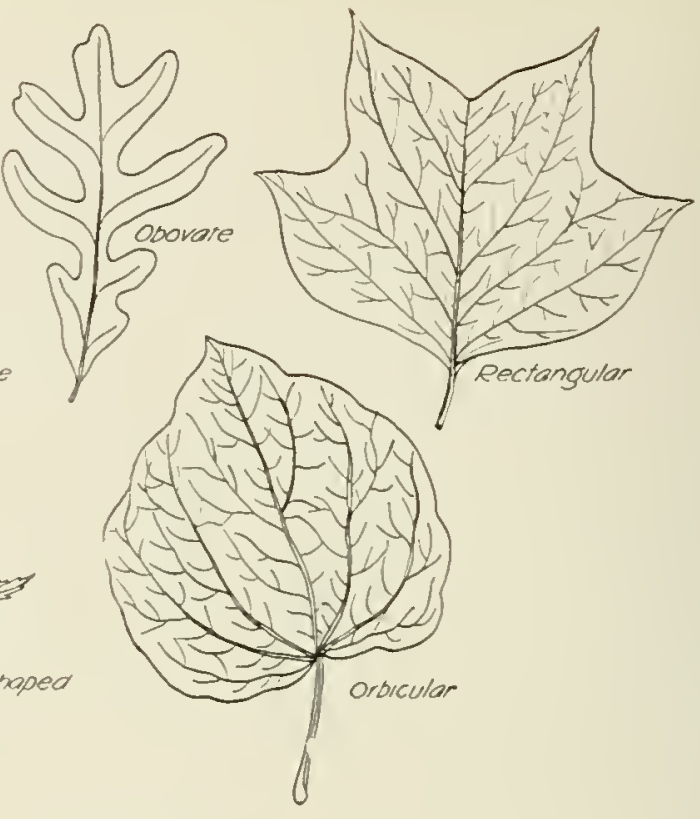

LEAN APEXES
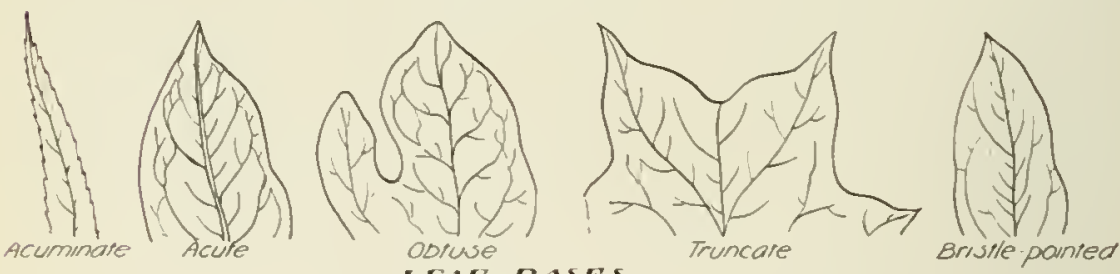

\section{ILEW BASE'S}
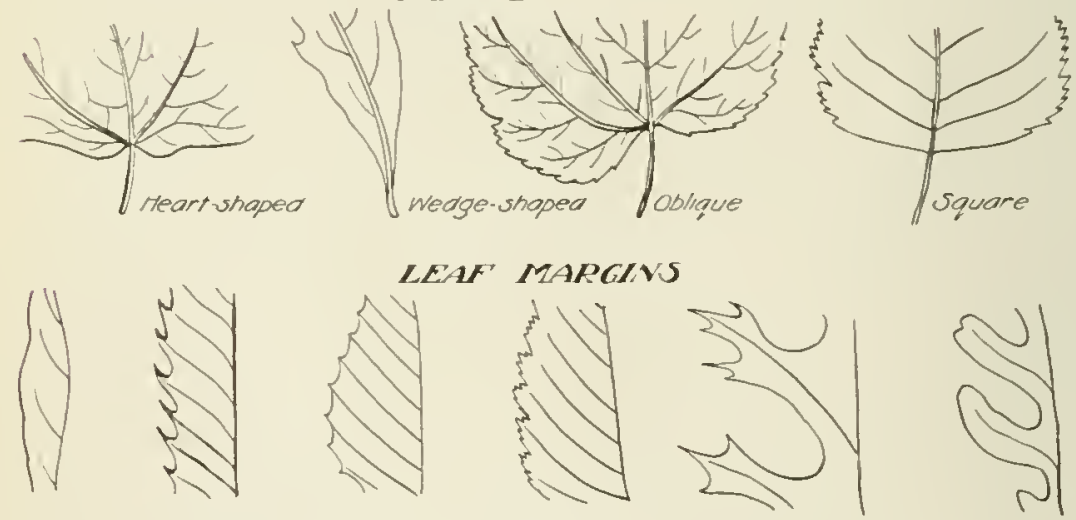

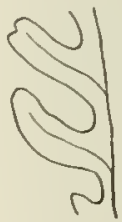

LODEC

PLATE V. TYPES OF LEAVES. 
aims to give a general description of leaves and a brief outline of their work.

A typical foliage leat consists of three parts: (1), the blade or flattened portion (lamiua): (2), the leaf-stalk (petiole); and (3), the leaf-appendages (stipules).

Tro kinds of leares are usually recognized:-simple and compound (I'late IT). Simple leaves have blades which are more or less united into one piece, while in componnd leaves each leaf is composed of a number of smaller leatlets. Compound leaves may have all the leaflets originate from one joint as in the Buckeyes (1)lates CXII, CXIII), or seatered along the man protiole as in the Common Loeust (Plate ICVII). Each primary division of a componnd leaf may again be componmed as in the Kentucky Coffee-tree (Plate XCIV). Such a leaf is linowil as a doubly compound leaf.

The arrangement of the leares on the twigs and buanches of our common trees may be alternate, opposite, or whorled (Plate IV). When the al'angement is alternate, the individual leaves are located singly at a node; when opposite, two leares occul opposite each other at a node; and when whorlerl. more than two leares oceur at a node and are distributed legularly around the twig. In a few syecies as the Birches, the leaves of the lateral spuls appear to be opposite, but npon closer exinination they are found to be alternate.

The leaves of the trees native to this state may be classified as follows: (1), Trees with needle-shapd leares, known as conifers or erergreens, and (2), trees with broad leaves linown as hardwoods or decidnous trees. The neerleshaped trees show a wide rariation in the form and distribution of lhoir needles. They may occur singly, in fascicles of $2,: 3$, or 5 , or in clusters on lateral spurs; they may also he stalked or sessile, scale-like or awl-shaped, and flat, semi-circular, triangular, or four-sicled in cross-section. The broadleavel trees liave an even wider variation in form. This may be in lart due to the greater number of representatives belonging to this order. A few of the commonest leaf forms are slown on Plate $V$. Other intermediate forms are commonly found among on trees. The size of the leares varies as much as their form. They may be small, scale-like, or awl-sliaped as in the Arbor Titae and Common Jnniper lespectively, or large and tropical-like as in the Magnolias and Рараж.

The point, or apex, of leares valies with the species and the general leaf-form. The commonest kiuds of points recognized are shown on Plate $V$.

The bases of leaves are also often charactelistic and of considerable ralue in distinguisling species, since different species may have the same general form but difierent bases. The commonest kinds of bases recognized are shown on Plate V. Intermediate forms nuy 
readily be found, since leares taken from the same tree or branch often slow a wide variation.

The margins of leaves are often mole rariable than their aperas and bases. The kinds most commonly recognized are shown on Plate $V$. The figures represent the margins of simple leares, but the margins of the leaflets of compound leaves follow the same terminology.

Most of the leares of our common folest trees contain a rather complicated system of fibro-iascular bundles. These fibro-rascular bundles, known as veins, form the famework of the leaves. Surroundiug and between these reins is found a green pulpy mass, the spongy parenchyma. The whole body of the leaf is covered by a protectire corering known as the epidermis, the thickness of which varies with the species of tree and the climate.

One can find rariations in the petiole and stipules of leaves as well as in the blade. The petiole may be alsent, short, or long. When the petiole is absent the lcaf-blade is sessile. It mas also be enlarged at the base, circular, heartshaped, flat, or triangular in outlinc. The enlalged base may be hollow or clasping. The stipules are usually not rert conspicuous. In many species they jersist for a short time only aud then fall oft. The main function of the stipules is protection, but a special modification of the stipules is seen in the Common Locust (Plate ICTII, where the thoms are modified stipules and function as mcchanicil protectors.

Leares are the most industrious organs of a plant. They work day and night from early spring until autumn. The four chief functions of leares ale: (1) Photosynthesis; (2) Respiration; (3) Transpiration. and (4) Assimilation. Photosynthesis is the process by which the leaf manufactures starch or sugar from carbon dioxide and water with the aid of the energy of light. That green plants requive light for their growth and development is shown by the manner in which the axis and their leaves adjust themsclves so as to receive the greatest amount of liglit. Br respiration in plants is meant the process by which oxpgen is consumed and carbon dioxide and water are given off. It is primarils a process of oxidation and resembles in general the process of respiration as found in man and ligher aninials. In order to facilitate this crchange of gases the plants are supplied mith openings on the leaf surfaces, especially on the lower sulface, and on the balk. The openings on the leaf surfaces are known as stomata and those on the bark as lenticels. Each slit-like opening on the leaf is surrounded hy two guard cells which are somewhat complicated in structure and very sensitive to changes in temperature and mater supply. Thes function primarily as breathing pores and as outlets for the water vapor given off during the process of transpiration. Their number varies, but it has been 

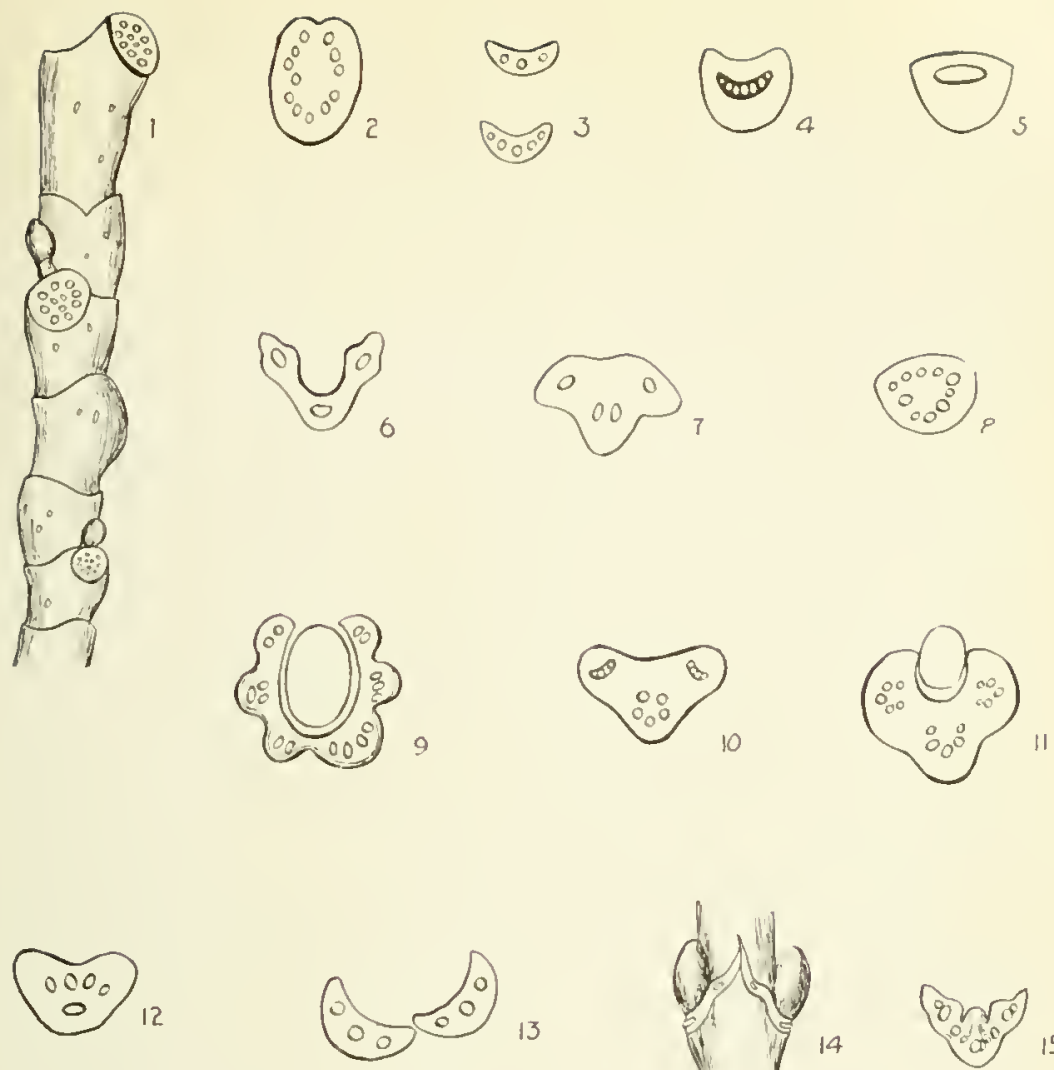

13
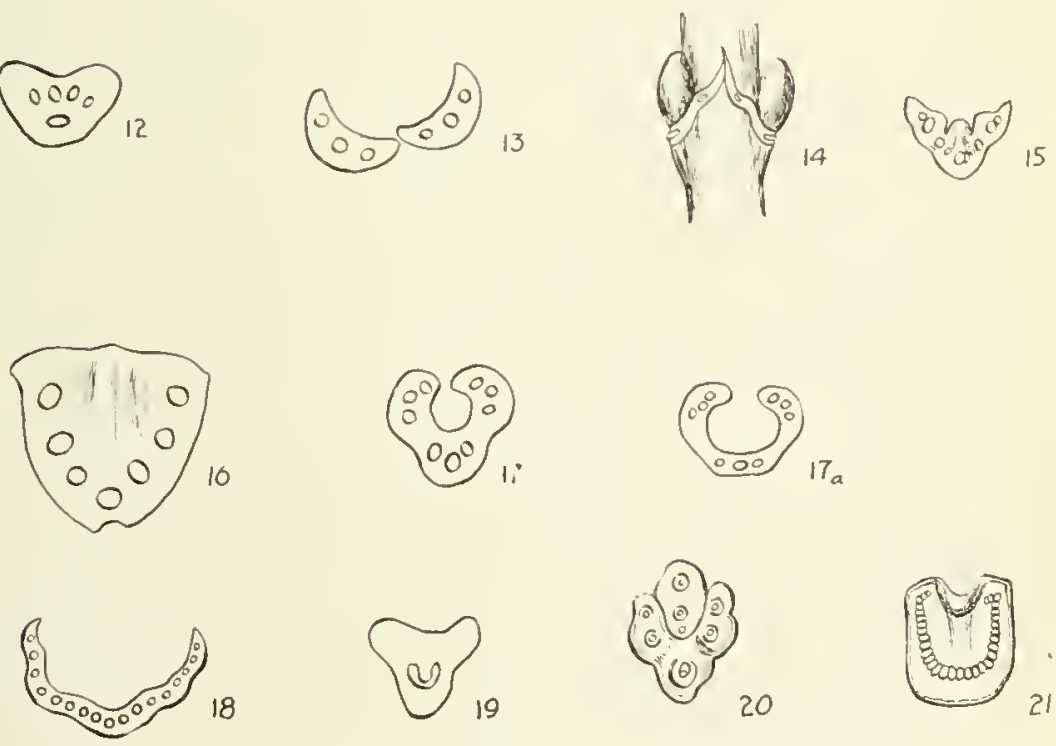

PLATE VI. TYPES OF LEAF-SCARS AND BUNDLE-SCARS.

1. Julip Trete.

2. Catalpa.

3. American Ifurnlean,

4. Sassafras.

5ersimuxin.

6. Mapile.

8. Kerl Mulberry.

9. Puttoumer d.

10. Chestnut.

11. Walnut.

All drawings are sighltls *ularged 

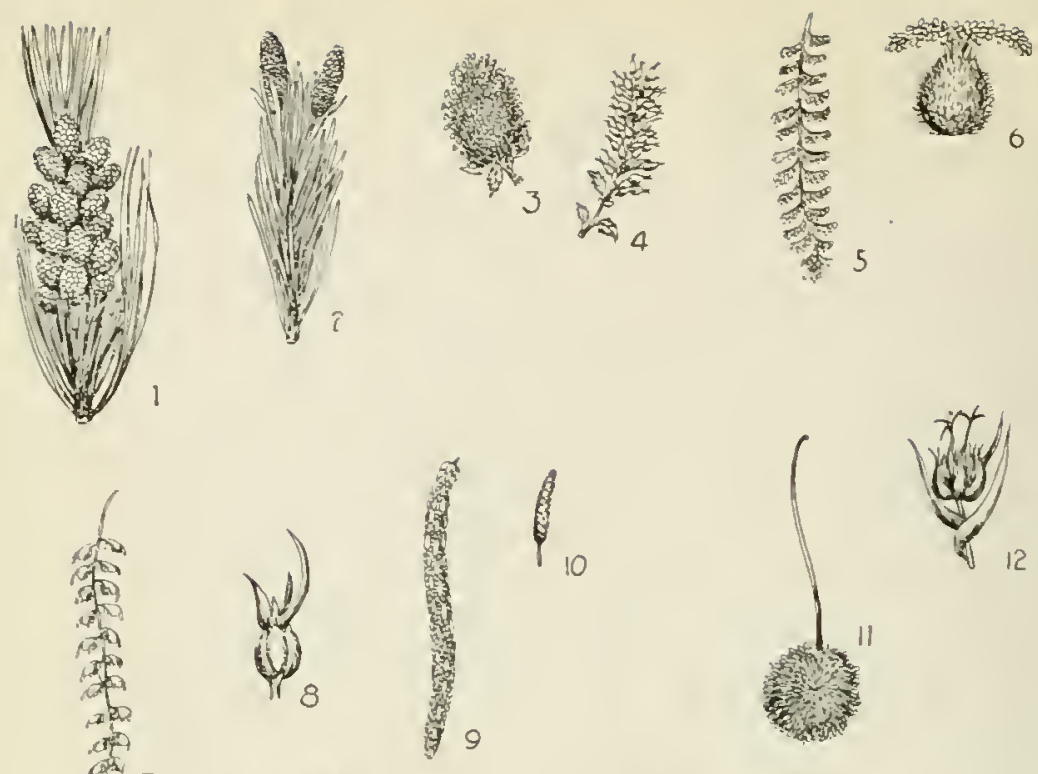

iv
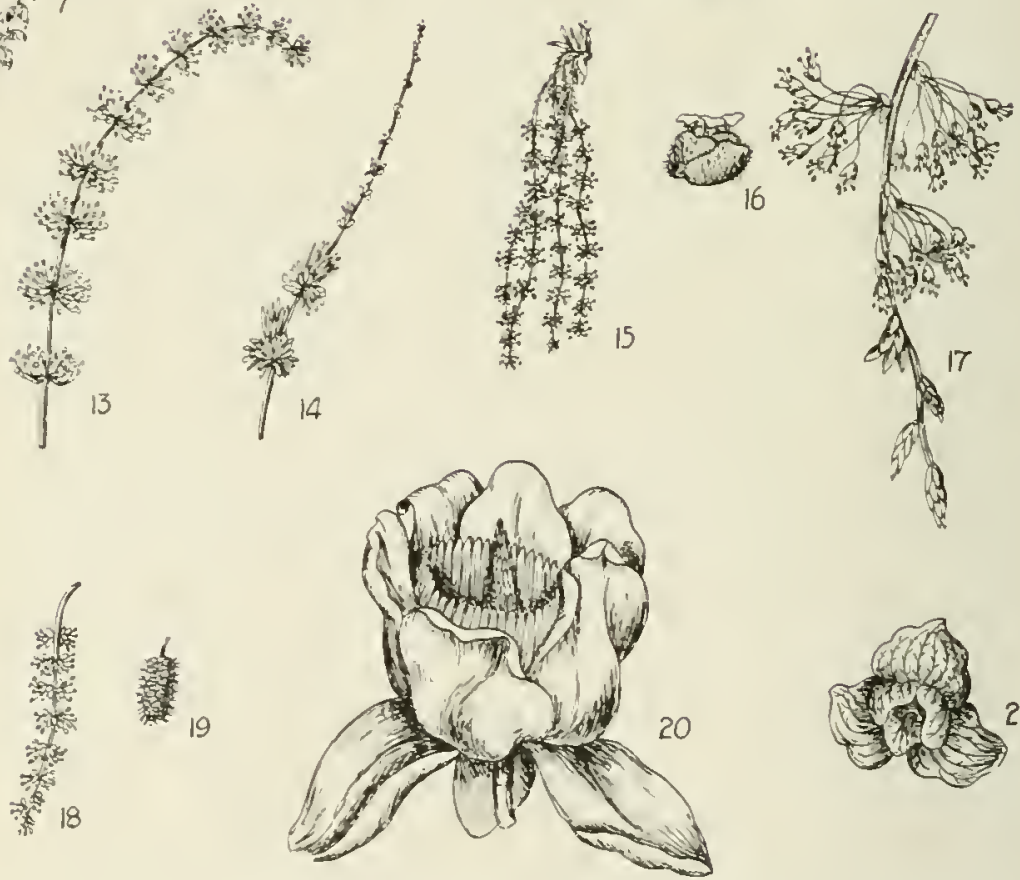

\section{PLATE VII. FLOWERS AND FLOWER ARRANGEMENT.}

1. White l'ine (staminate cluster), $\mathrm{x}$.

White Pine (2 pistillate), $x$,

. Willow (staminate ament), $x$ s.

4. Wilow (pistiliate ament). A

6. Walqut in vistillate flomer) enlarged.

7 . Hickors istaninate amen? $x$,

8. IIickors lil pistillate Aoweri. natural size.

Birch la staminate ament). $x$

10. Pirch la pistillate ament), $x$.

11. Fipese $l_{1}$ (a staminate lead) $x$ c.
12. Deecll (two pistillate flowers), aatural size.

13. Chestnut (a staminate ament), $\mathbf{I}$.

14. Clestuut (a pistillate ament), ${ }^{3}$

15. White Oak (t staminate aments),

16. White bak ia pistillate tower, enlarged.

14. Mnlberry (a staminate spike), $x \frac{1}{2}$.

19. Muluerry (a lease pistillate spike), $\mathbf{x}$

3). Tulip Tree (a complete flower), $x \geq$.

1. एapat (a minplete thwer), $x$ s. 
estimated that the lower leaf surface of Black Walnut contains about 300,000 per square inch. The leaf is not only peculiarly modified for the reception of light and the absorption of gases, but also for the loss of water. This process of losing water in the form of rapor through the stomata is known as transpiration. The large amount of water given off by trees is usually not appreciated. The Austrian Forest Experiment Station has published data which show that an open-grown birch tree with 200,000 leaves transpired on hot summer days from 700 to 900 pounds. Assimilation, the fourth of the functions named abore, comprises a series of changes which are necessary to transform the raw or newly manufactured food material into actual plant tissue.

\section{Leaf-scars and Bundle-scals:}

Most of our trees and shrubs, except the cone-bearers, shed practically all their leaves in antumn. Those which shed their leares in this manner are known as deciduous trees, while those which retain them for two or mole seasons are known as evergreen trees. When the leaf falls a scar is left at the point of its insertion. The leaf-scars rary in size, form, position, occurrence, and the number of vascular bundles which they contain (Plate VI). They may occur singly, in pairs, or in whorls. just ats the leaves which precede them. They appear at points on the twigs known as nodes. The portion of the twig between the nodes is called the internode. They may be large, medium, or small in size lepending upon the species. If they occur in pairs on opposite sides of the twig they may be so large that they completely encircle the stem, or only a portion of it. Their form mas be lound, oval, elliptical, beart-shaped, shieldshaped, crescent-shaped, lobed, or triangular. Thes may be raised, depressed, or even with the surface of the twig. Their surface may be flat, concave, smooth, or wary.

The leaf-scars contain bundle-scar's. The bumlle-scars mark the position of the rascular bundles which formed a connection between the leaves and the twigs. They carry liquid material to and from the leares. Two distinct portions may be distinguished in these vascular bundles; the woody protion which serres to carry water into the leaf, and the sieve-tube portion which serves to carry plant food from the leares where it was manufactured, down into the twigs, branches, and stem. These hundle-sears vary in size, form, and number in a leaf-scar, and the manner in which they are distributed. Some of our common forest trees have only one bundle-scar in a leafscar, while many have three, aud other's four, fire, to many. The number is constant in some species and rariable in others. The in dividual bundlescars usually are circular in outline but may be linear, crescent-shaped, or irregular. Where more than one is found 
in a leaf-scar they vary in their arrangement. They may form a closed ellipse, a lunate line, a double line, a $\mathrm{V}$-shaped or a U-shaped line, or ther mas be irregularly scattered orer the leaf-scar, or grouped in clusters. A number of bundle-scars may sometimes be grouped so close together so as to form a compound bundle-scar or a line of confluent bundle-scars. The leaf-scars together with their bundle-scars are excellent characters with which to distinguish many of our common forest trees during winter when most of the distinguishing characteristics which one can use in summer are absent. By carefulls studying these characteristics, together with others, it is as eas to distinguish the forest trees in winter as in summer when the foliage is present.

\section{Floters:}

Sometime in their life bistory plants usually give rise to others of their kind. The method which ther use to accomplish this raries with the species or the group. Most of our trees derelop flowers whose chief function is pollination, the initial step in the production of seeds. The existence of flowers is consequently for the good of the plant and not for the good of man, eren though their beautiful forms and colors do please his fance aud make his life happier.

The flowers of our common trees rary considerably in form, structure, and color (Plates VII, VIII). Most of them are rery modest in appearance while a few of them are conspicuous on account of their large size and brilliant color. In speaking of the flowers of our trees collectivels; one often bears the phrase "The uncommon flowers of our common trees." The truth of this phrase becomes clear when we think of the small and inconspicuous pistillate flowers which such trees as the Oaks, Birches, American Hop Hornbeam, Walnuts, Hickories, and others produce. A few species like the Magnolias, Cherries, Dogwoods. Tulip Tree, and Basswood produce rather conspicuous flowers.

The parts of a flower are of two general kinds - the essential organs which are concerned in the production of seeds and the floral en. velopes which act as protecting organs. The essential organs consist of two series,-the onter which is composed of stamens and bears the pollen, and the inner which is composed of pistils and bears the seeds. The floral enrelopes also usually consist of two series, - the outer which is composed of sepals. collectively known as the calsx, and the inner which is composed of petals, collectirely known as the corolla. The corolla is usually the showy part of a flower while the calyx is usually green in color. A flower which has calyx. corolla. stamens, and pistils is said to be complete. If any part is wanting it is incomplete. When both the floral enrelopes are ranting it is naked. A flower in which the pistils are lacking is known as a staminate flocer, while one in 


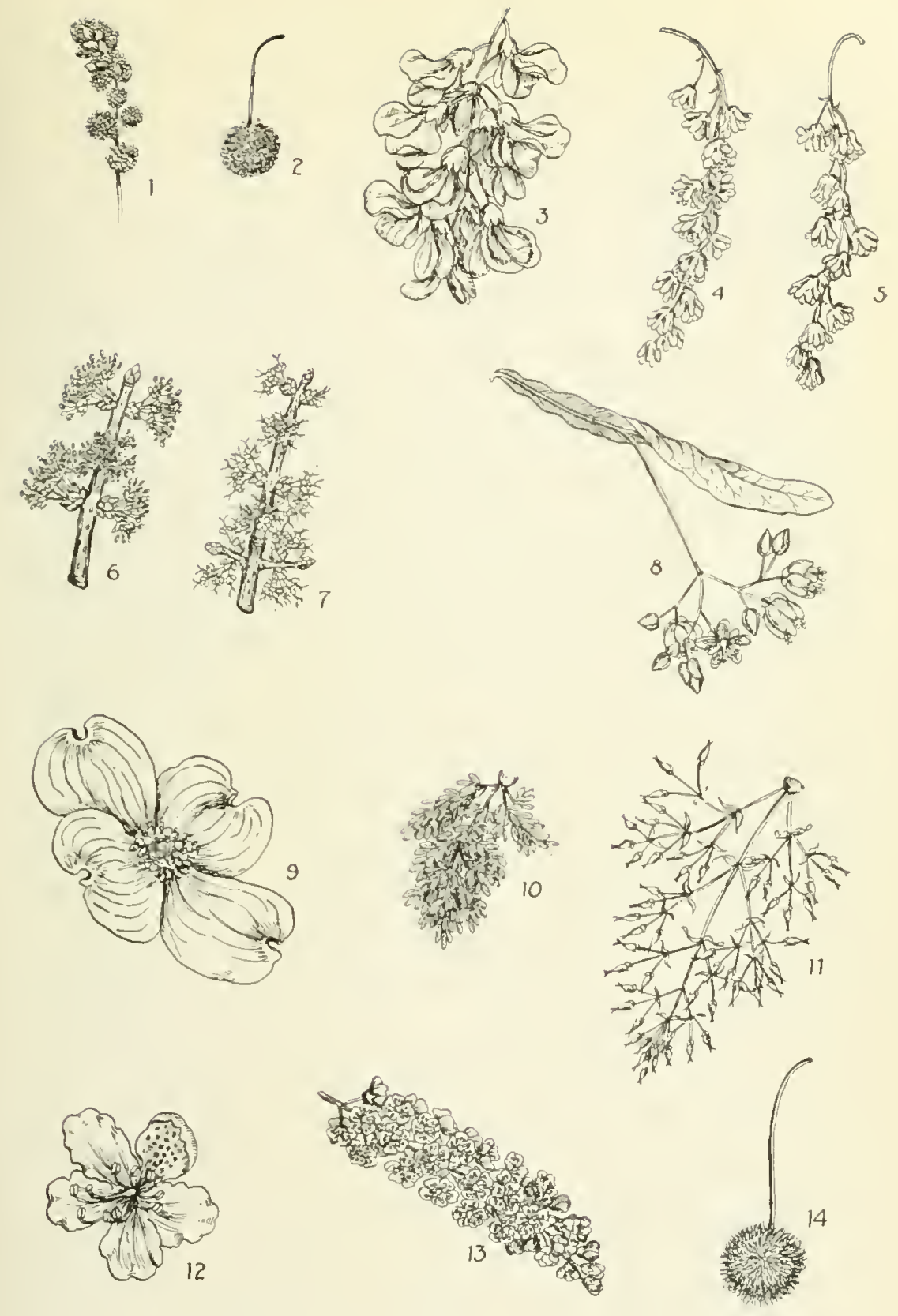

PLATE VIII. TYPES OF FLOWERS.

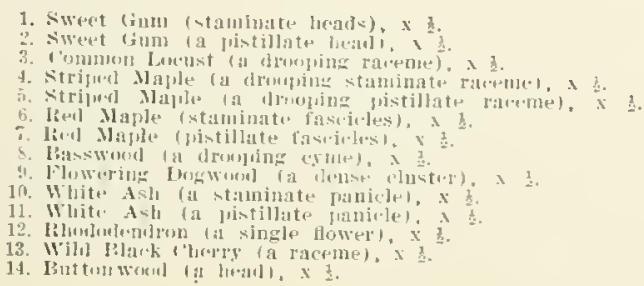



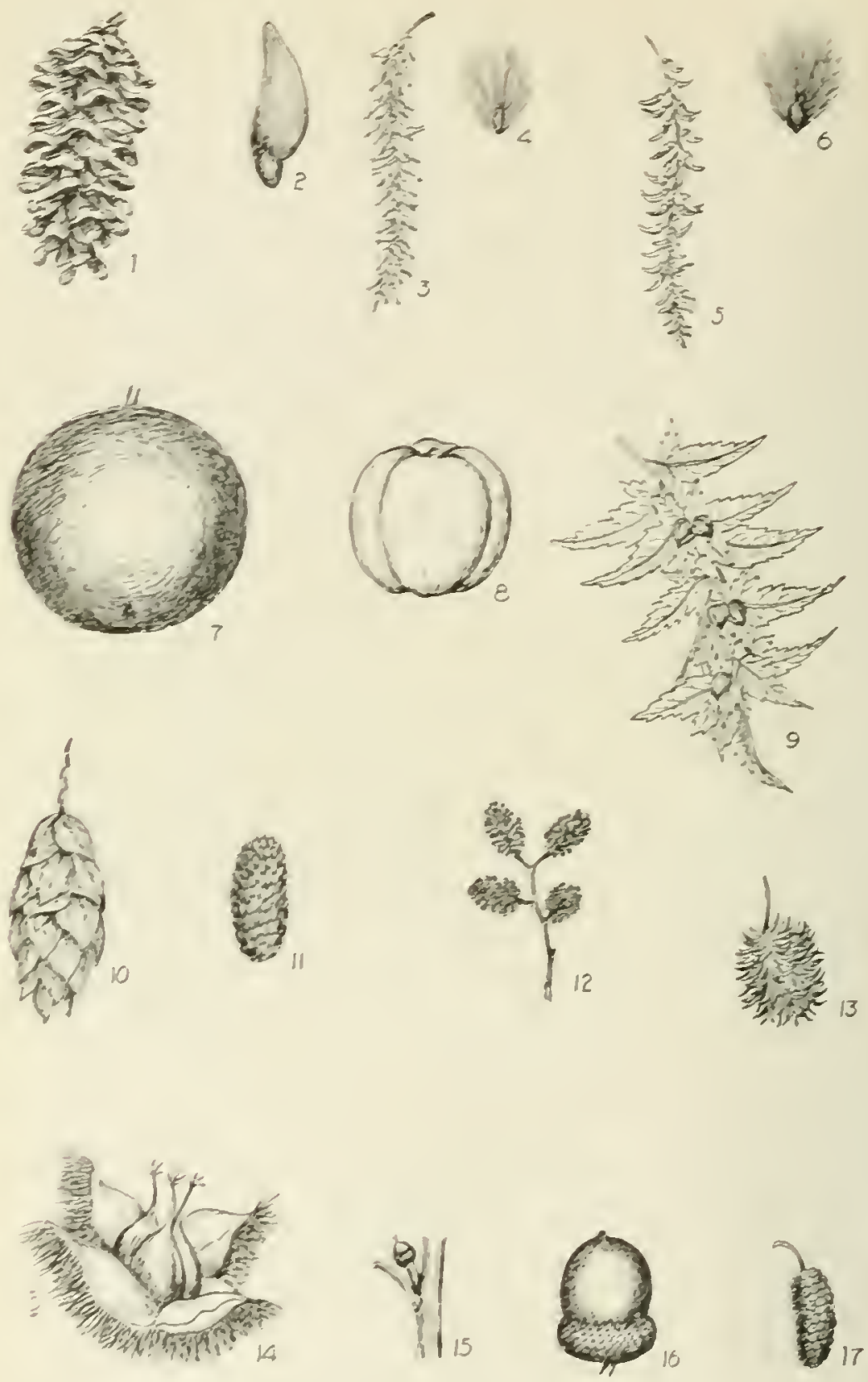

PLATE IX. IYPES OF FRUIT.

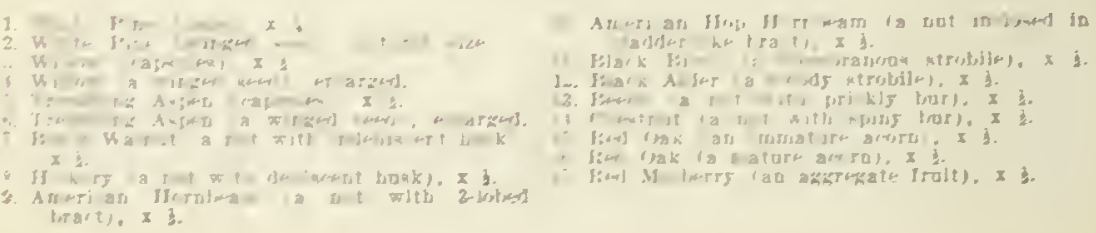


which the stamens are lacking is known as a pistillate flower. Sometimes the staminate and pistillate flowers are not only found on different parts of the same tree but on entirely ditferent trees.

The chief role of flowers is pollination. Pollination is the transfer of pollen from the anther of the stamen to the stigma of the pistil. When pollen is transferred from the anthers to the stigma of th" same flower it is known as closc-pollination, and when pollen is transferred from the anthers of a flower of one plant to the pistil of a flower of another it is kuown as cross-pollination. Wind and insects are the chief agents which carry the pollen in the case of crosspollination. The flowers of the Tulip Tree, Pallaw, and Cherries, are examples in which close polliuation can take place, while the flowers of the Willows and Poplars are good exauples in which cross-pollination takes place. When the staminate and pistillate flowers are on the same plants e. g. Oaks, Imerican Ilop Hurnbeam, Beech, Chestnut, Hickories, and Walnuts, the plants are known as monoccious and when they are on different plants as in the Wrillows, Poplars, and occasionally some Maples, they are known as dioccious.

Flowers rary not only in the size, form, shaje of their parts, and color, but also in their arrangenent. In a few cases the flowers of trees like the Tulip Tree and l'a yaw are borne singly and known as solitary flowers. The flowers ina also be arranged in clusters like that of the Lily of the Valley or the Wild Black Cherry (I'late VIII, 13). Such an inflorescence is known as a raceme. A raceme may be compact as in the Wild Plack Cherry; or loose as in the Common Locust (Plate VIII, 3) and the striped Maple (Plate VIII, 4-5). When the flower cluster is dense and the flowers sessile, or nearly so, it is known as a spilic. Spilies may he 2-ofowerer as in the pistillate flowers of the Hickory (Plate VII, S), or rensely flowered as in the staminate flowers of the Mullerry (1'late VII, 1S). A very short and dense spilie is linown as a hearl (I'late VIII, 14). A spike is sometimes short, flexible, and rather scaly as in the Willows, Poplars, and rather long as in the staminate flowers of the Oaks, Hickories, Birches, and Alrers (Plate VII, T, 9 and 15). Such a spike is known as an ament or callin. Other types of inflorescence are the umbels (Plate LXXXYII), panicles (Plate VII, 10.11), and corymbs.

The time at which the flowers appear and their duration raries with the species. The Allers. Hazlenut, and some Maples produce their flowers early in spring before the leaves are out. Others produce them with the leares, while still others produce them after the leares. The Witch-hazel prorluces its flowers late in fall. It is the last of our trees to blossom. 


\section{Fruit :}

Sometime after jollination the egrg cell or orule is fertilized, and as a result of fertilization. the orule, together with the surrounding ovary, enlarges. The enlarged orules, together with inclosing ovary, form what is termel the fruit. The fruit may in addition comprise modifations of other orgaus intimately connected with the ovaly.

Seeds are prodncts of the flower and are usually regarded as reproductive organs. but in leality they are the result of reproduction. Their chief work is the dissenination and the motection of the offspring of reproduction. They are usually corered by hard and impremeable coats which protect the young plant contained within 1lom the many dangers witl which it is beset. Nature tries to guard against these dangel's by developing suitalle protective corerings for each species. Nature, howerer, is not always satisfied by simply dereloping a thick and impermeable coat, but in addition it derelops an interual tissue which is compact and contains little water. If a seed possess these essentials it is well protected against most of the destructire agencies to which it is exposed. The chief dangers to which seels are subject are luemature germination, loss of vitaliț. and destruetion lyy animals. Fach seed usually has a suitable corering which regulates the germination in syring. This regulation is necessury so as not to allow the tender plant to emerge before the external growth comlitions are favolable for its development. In (mulyyo within a thin-coaterl seed would olten be stimulated by a few wam lays in spring with the consequence that the resulting tender plants would lie killed ly later frost. Nature acts as a guardian and places a thick coat around such embrJos, and as a result they are not stimulated until later when frost danger is past.

Food is stored in rarious julant organs such as roots, stem, and hranches, and is usually most abundant and conspicuous in the seeds. It occurs in rarious forms and may ofteu differ in composition. Food stored in the seen is rely raluable because it supplies nourishment to the small and tender plants before they bave dereloped the roots witl which they draw nourishnent from the soil and suplyy water to the leaves where starch and sugar are manufacturel. Primitive man olotainer considerable food from the seeds of trees, and present man derives rertain foods for himself and his animals from some of onr common trees. The food ralue of seeds raries with the species. Some species like the Willows contain very little food, while others like the Chestunt are riel in food.

The time at which the fruit matures raries with the species. Willows, Poplars, and Elms mature their fruits in spring; other's, like 

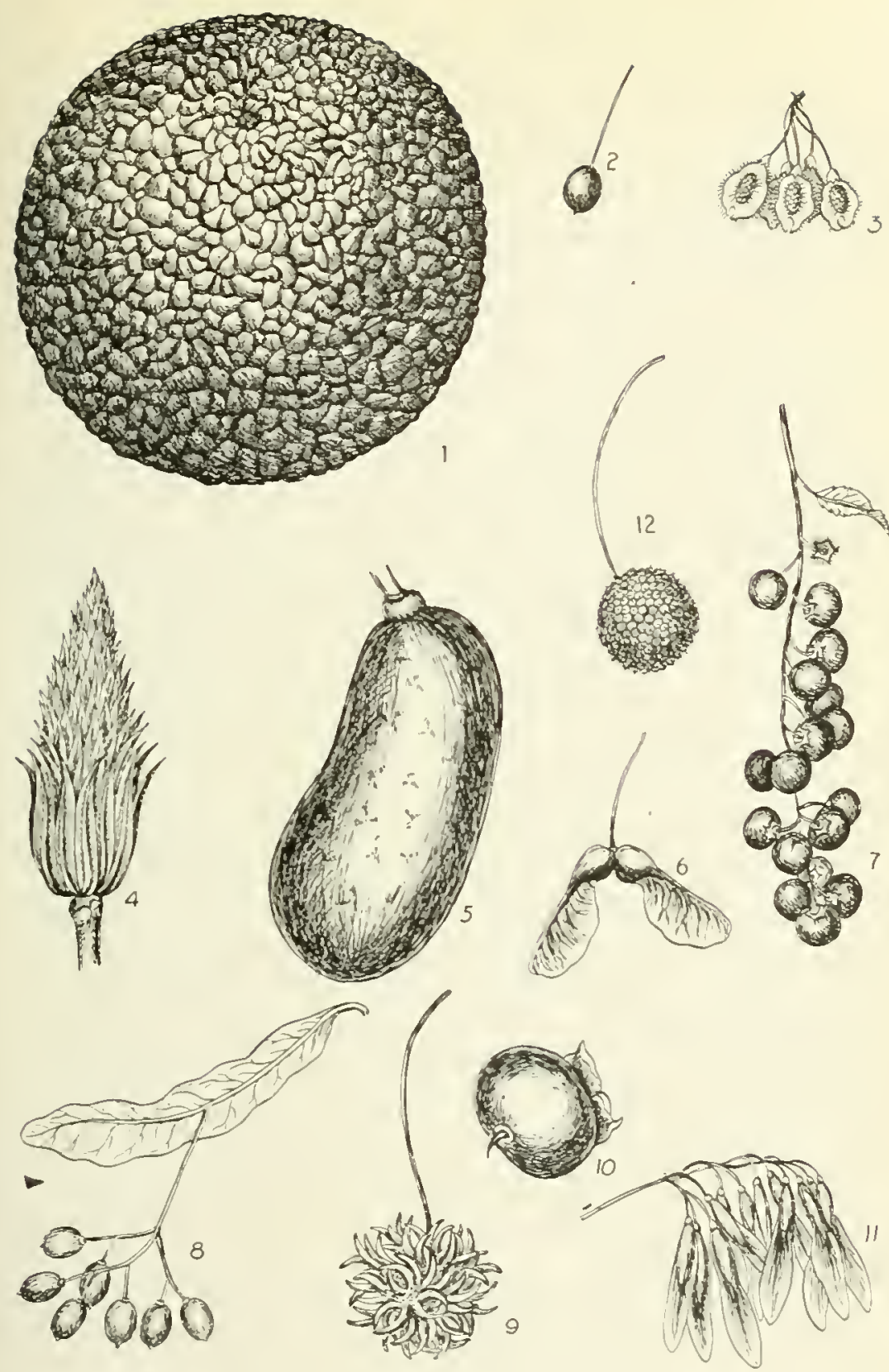

PLATE X. TYPES OF FRUIT.

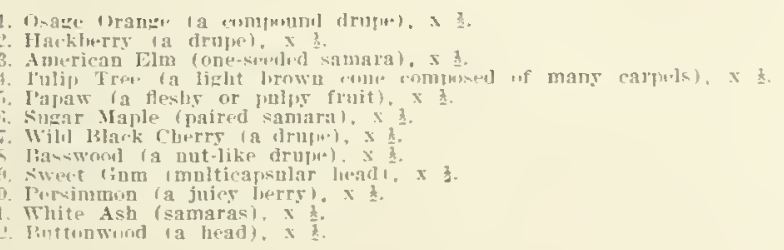




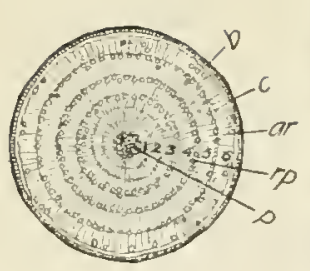

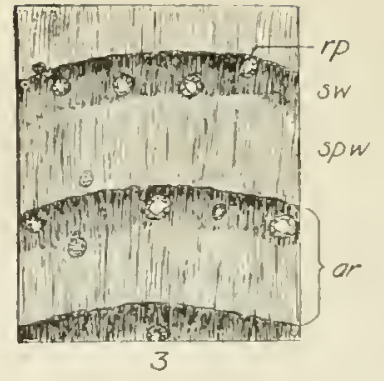

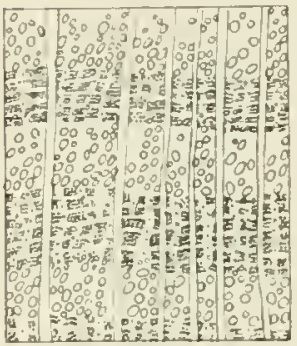

5

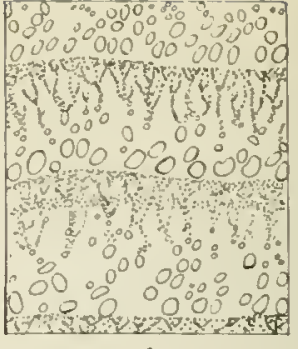

4

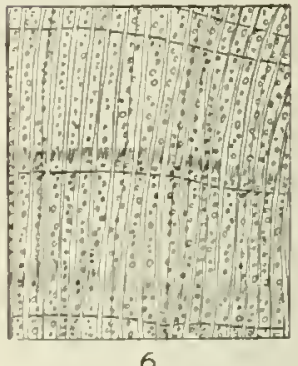

6

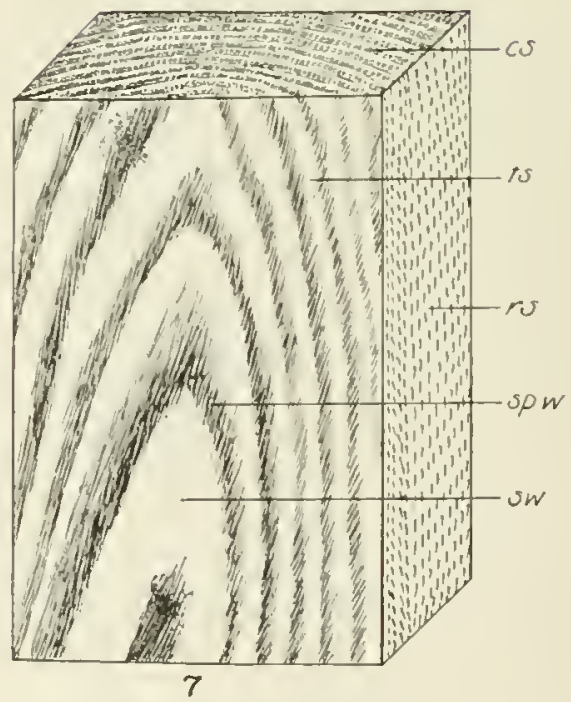

\section{PLATE XI. THE STRUCTURE OF WOOD.}

1. Cross sectioo of six-sear bld stem of Thite Fine showing (b) batk, (1') cambium, (ar) annual riog, (p) pith, and (rp) numetous small cireular r'siu passages, natural size.

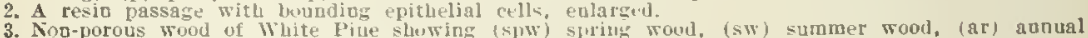
rigg, and (rp) renio prissage, 53

4. king-porous wood of chestant, is

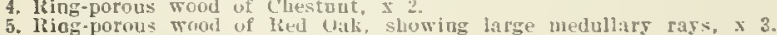

6. Difiuse-potous woor of bieel, 54.

7. Block of Chestont wood showing (es) cross section, (Is) ranial section, (ts) tangential suction, (spm) spriog wood, and (s $\left.\pi^{\circ}\right)$ summer wond, natural size. 
the Cherrirs, Mulberlies, and some Maples, in summer; but most of them, like the (Maks, Chestmut, l'ines, and others, in autumn. The sereds of some specios like the Willows die unless they germinate soon after they mature. Most species retain their capacity to gelmiuate for several months of several years, while a few members of the l'ulse family are reprortad to retain their vitality for more than 125 years.

The mature fruit and speds of our common trees show a wide rariation in thrile form and stucture. Fruits are usually classified on the hasis of theil texture, as fleshy fruits and dry fruits. Fleshy fruits are representrol by the fruits of such species as Cherries, I'ajall, Osage Orander. ote. (I'late X, 1, 2, 5, 7, 10). Dry fluits are those whirh flo not harr any flosh or julp, ancl are leplesented by the pruits of such species as the Majules, Ashes, and Oaks (Plate 1X, 1-16, aut l'late $\mathrm{X}, 3,4,6,5,9,11,12$. Flesly fluits including the stone louits, are indehisent. Indwiscent fruits (Plate X, 1, 2, $5, \tau, 10)$ are those which do not sjlit alyart regularly along certaiu lines for the liberation of the serds. while dehiscent fruts do split nien. Iry fruits may he indelsisent or dehiscent.

The followiug general tripes of frujts ale commonly reeoguized: the pome (1'late XCll), the drupe (I']ate X, 7. 10), the nut (Plate IX, $7,8,9,14,15)$, the smmarl (l'late $X,:, 6,11)$, the follicle (Plates LXXVI-IXXVII), the copsule t'late IX, :, 万) and (Plate $\mathbf{X}, 9)$, the legume ('lates ICIV-XCYII), the cone l'late IX, 1) and the

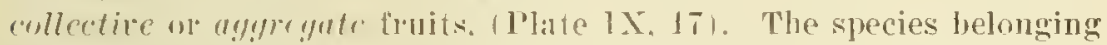
to a siugle genus usually prodnce a common type of fruit, but genera holonging to the sime family often have an entirely different kind of fruit. This dillerence of fruit of genera in the same family is shown very rarly in the Nettle family, to which belong the Elms, Hackbery, Osige Orange, aur Mulberry, whose fruit are shown on Ilate $\mathbf{X}, 3,2,1$, and I'late IX, 17. A wille variation may also oceur within the general types nentioned above. The nut is one of the commonest tyles of fruit found in the forest and will possibly show this wide variation best. Yuts may be small and light, as in the Buttouwood and Birches, or large and heavy as in the Oaks and Chestnut. Light unts often have appendages attached to them in the form of a nembranous wing or a tuft of hairs. The nuts may be producer singly $O l^{2}$ in strobiles as in the Birches and Alder. They may also be coreled or naked. If covered, the covering may be indehiscent and semi-fleslyy (Plate IX, 7), or dehiscent and dry (I'late II, 8). It may alsn comkist of a stalked prickly dehiseent lour (Ilate IX, 13), a large sping dehiscent bur (Plate IX, 11), a hadder-like bag (Plate $I X, 10$ ) or a leafy iuvolucle, as in the Commou Hazlenuts (Plate LI). In some speries the seeds are not covered entilely but simply subtended by a leafy bract (Plate IX, 9). 
In the Birches and Alder the small winged nuts are produced on 3 lobed bracts which are so arranged that they form a cone-like fruiting body known as a strobile. It is rather hard to classify the fruits of some species in terms of the trpes enumerated abore, e. g., the fruit of the Basswrood has the appearance of a nut, but is in reality a drupe; while the fruit of both the Mountain Ash and the Shad Bush has the appearance of a berry but is actually a pome. A superficial examination is often not sufficient to determine the type of fruit. The fruit of our common Sumachs is a drupe, but is usually covered with acid hairs. so that it is difficult to recognize the type of fruit to which it belongs.

After the fruits and seeds have been produced, it is necessart that ther be scattered on a mineral soil upon which they mag germinate. The distance orer which they are scattered may be short or long, depending upon the nature of the seeds and the agents by which they are dispersed. The fruit, as a whole, is usually scattered in the case of indeliscent fruits. while the seeds only are scattered in the case of dehiscent fruits. The drawings on Plates IX and $\mathbf{X}$ show varipus structural modifications of fruits and seeds which aid in their dispersal. The chief dispersal agents are propulsion, man, animals, water. wind, and gravity. The Witch-hazel (Plate LXXXII), is a good example of a species mhose seeds are scattered by mechanical propulsion. Man has been distributing seeds for forest trees intenfionally or unintentionally for many centmies, with the result that the forest structure and landseape in mans localities hare been entirely changed. Mans European and Asiatic species have been planted in America, and many of our native species like the Common Locust and White Pine have a wide distribution abroad. Wind is the most porrelful of the dispersal agents. Many seeds hare special structural modifications which adapt them to be scattered by the wind. The modifications may be a sac-like envelope (Plate IX, 10), a mat of straight capillary hairs (Plate IX, 4, 6) ol a membranous winged, or flattenel seed (Plate IX, 2 and Plate $X, 3,6,11$ ). Animals also seatter nany seeds. A great number are scattered inroluntarily by animals, especialle such seeds as will hang fast to their bodies. Other fruits are juiey and edible and are often eaten by birds and other animals. A large number of our common birds swallow seeds to get the juicr edible portion survounding them. These seeds are not injured in passing through the alimentary canal of birds. but in some cases it is thought that the seeds are eren benefited. The rohins, thrushes, and blue birds eat a large quantity of fleshy fruit and should he regarderl as raluable agents for dispersing seeds. The blne jar is also an agent that helps to scatter heart seeds like chestnuts and acorns. Other animals, especially rodents, are also raluable as seed dispersal agents. Water, while not so 
important as wind, must still be regarded as an agent of seed dislersal. It transports some seeds over great distances, especially those which will float $\mathrm{or}^{\circ}$ are inclosed in bladder-like inclosures like the American Hop Hornbcam (Plate IX, 10), or the Bladder Nut, a small shiub vers commonly found along our streams. Gravity on slopes, is a minor arent of seed dispersal, but sometimes does effectire work, especially with heary seeder species like Oal and Beech.

\section{Woon:}

Wood, next to food, and clothing. is frobalyly the most useful and inlispensable material which man uses. It is found in unany of the higher plants but becomes of commercial importance only in the spermatophytes or seed-Jearing plants. In the timber-producing trees it is found in the roots, branches, and stems. The rood derived from the roots is limited in quantity and inferior in quality. The branches froduce wood which, in some respects, very closely resembles that of the stem. but is inferior on al"omnt of its smitler size, irregular shape, and more knotty structure. T'he wood obtained from the stem is of the greatest utility and ralue on account of its desirable dimensions and satisfactory structure. The stem should not only yield a large quantity of woor but also a smperior quality. The quality of rood which a stem will rield depends largely upon its age, inherent ten. dencies of the species, and its environmeut during its derelopment. High grade material is nsually obtained from the stems of raluable species which bave attained a large size, are free from lateral branches, and josiess little stem taper. The form and cliaracter of the stem are dependent on the environment. A suitable environment may be cleated ly applying the fundamental principles of forestry which will not only increase the jroductivity of our forests but also the quality of the yield.

In order to identifs the different kinds of woods it is necessary to stud! them from the following three sections: cross, radial, and tangential (Plate II, T). In examination of a cross-section of a wooly stem will show that the major part of the structure consists of mood which is corered with barls on the outside and has a narrow cylimler of soft tissue kuown as pith runniug through the center (Plate XI, 1).

The mood $\dot{y}^{\prime}$ portion of most of our trees, especially the older ones, may be differentiated into two parts on the basis of colors. The central colored part is known as the heartuood, while the outer al. most colorless jurt is known as the sapuond. A narrow zone of cells locater between the saprood and the bark is known as the cambium (Plate XI, 1). All the mood elements have their origin in this zone. For sometime after their origin these elements are living, but later 
they become functionless and die. The sapwood comprises the feripheral zone of wood which lies next to the cambium and contains the only living elements of the wood. The heartrood comprises all the rood inside of this zone. The elements of the latter are dead and usually dark in color. The line of demarcation betreen the two regions is usually sharp. The width of the sapwood is variable. In some species like Sassafras it is rery narrow, while in other species like Hickory it is wide. The depth of color of the heartwood is also variable. In some species like Persimmon it is rery dark in color while in other species like Hemlock there is rery little difference in color between the heartwood and sapwood.

The cross-section also shows that the wood is dirided into numerous concentric zones or rings. These are known as annual rings since each one usually rejresents the growth of a season (Plate XI, 1,3). Certain disturbances like frost, drought, and insect damage may cause the formation of a second ring in the same season. These rings are known as false or fictitious growth rings. Growth rings hare a phrsiological origin. They represent alternating periods of rest and activity, and occur in practically all trees of the temperate region, characterized by an actire regetative period in summer and a resting period in winter. As one approaches the equator the growth rings disapyear, since the seasonal changes are not so sharp. Each growth ring may be dirided into two parts, the inner, called carly or spring wood, and the outer, called late or summer wood (Plate $\mathrm{X} I, 3)$.

The cross-section further shows radial lines crossing the growth rings at right angles. These are known as medullary or pith rays, or simply as rays. A few of them originate in the pith and extend through the wood into the bark. Such are known as primary rays. As the stem increases in size additional rays are necessary. These originate in the wood. extend into the bark and are known as seeondary rays. The rars are vers raluable in distinguishing the wood of many of our common trees since the different woods possess rays which rary in height, width, and structure. The very wide rays of the Oaks enable one to distinguish their mood from that of all other species. These large rays are a raluable asset to Oak wood since they give rise to the beautiful figure which one finds on some oak furniture and interior finishings. The best figure is"obtained by quarter-sawing i. e. cutting it radially.

The end of a freshly cut log of pine is often corered with small drops of resin. which were given forth from small openings in the wood. These openings are known as resin duets (Plate XI, 1, 2). They are long intercellular channels bounded by a layer of epithelial cells. Their presence in the wood of the Pines, Larches, and Spruces enables one to distinguish them from all other trees. Injury may 
sometimes stimulate the formation of abnormal resin ducts in woods in which they do not occur normally.

In some woods elements occur, known as ressels, which facilitate the transportation of rater in the stem. Their presence or absence and their structure and distribution are among the most valuable characteristies in classifying woods. On the basis of porosity one may divide the woods into three classes, viz: (1) Ring-porous or Unequal Pored, (2) Diffuse-porous or Equal Pored, and (3) Nonporous. Chestnut and Oak wood are excellent examples of the ringporous class (Plate XI, 4, 5). A zone of large pores is found in the early wood and smaller pores in the late wood. Naple and Beech are common examples of the diffuse-porous class (Plate XT, 6). The pores of this class are alproximately of the same size and distributed uniformly throughout the growth ring. Pine and Hemlock are common examples of the non-porous class in which pores are entirely absent. (Plate XI, 3). The wood of this class is also classified as Momogeneous, while that with pores is classified as Meterogeneous.

The rarious woods possess other eliaracteristics which are valuable in distinguishing them and in using them in the arts. The wood of the different species varies almost as widely as do their flowers, fruits, and leaves, especially with reference to grain, weight, hardness, color, gloss, smell, shrinkage, durability, penetrability, ete. These variable properties and the manifold uses to which the different woods are put are discussed under eaclu species. 


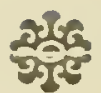




\section{PIRT II.}

\section{MANUAL OF PENNSYLVANIA TREES.}

The Identification, Tabulation, and Description of Species. 
类制 


\section{MANUAL OF PENASYLANIA TREES.}

IDENTIFICATION OF SPECIES.

\section{Nanies of Trees:}

Trees have two kinds of manes, common and scientific. Some species of trees have only one common wame while others may have as many as thirty. The same species of tree may have one common name in one locality and an entirely ditlerent one in another locality. The Piteh Pine deseriberl on jage $7 \mathrm{is} \mathrm{known} \mathrm{in} \mathrm{some} \mathrm{parts} \mathrm{of} \mathrm{this}$ State as . Jack l'ine and in otler parts as Nigger Pine. The common name giren at the fop of each descriptive page is the proper common name and the one nsed throughout this publication for that particular species. Under the healing "Distingnishing Characteristics," other common.names arce given.

Since Linnacus published his "fipecies Plantarmm" in 1753, plants have been known by scientific names. These names, as a rule, consist of two parts. The reneric and the sperific, as is shown by the following species of trees:- Pinus Strobus, Querens alba, Fraxinus americana, Acer lnbum. The first or generic part refers to the genus and corresponds to a suruame. The second or specific part refers not to a group of plants but to a particular kind aud corresponds to the Christian mame of a man. The White Pine, Red Pine, and Pileh Pine are dillerent kinds of pines. They belong to the same genus or groul and hence have the same generic name, Pinus. lach one, howerer, is designated by a diflerent suecific name. For example, the White Pine is known as Pinus Strobus, the Red Pine as I'inus resinosa, and the Pitch Pine as Pinus rigida. Closely related species are placed in the same genus and closely lelated genera folural of genus) in the same family. Such closely related trees as the Pines, Sprnces, Firs, and Larches, are placed in the Pinc lianily-l'inaceae.

At the time when plants first were studied serionsly the Latin language was the one used most commonly to preserve knowledge. The plants consegnently were given Latin names. The giving of Latin names to plants and animals has continued down to the present time and no doubt will contime. In the Latin language one finds that plant-names have gender, and that the termination differs 
in each gender. The specific part of the name must agree in gender with the generic part. The generic name Quercus is feminine, hence the Red Oak is known as Quercus rubra while the generic name Acer is neuter. hence the Red Maple is known as Acer rubrum.

The scientific names used in this publication are those found in the Serenth Edition of Gray's Manual of Botanr. and are in keeping with the rules of nomenclature laid down at a Congress in Tienna. On account of the present unsettlerl condition of onr nomenclature it is often possible to find a certain species designated by two or more different scientific names. c. g., the Scrub or Bear Oak is known as Quercus ilicifolia, Wang.: Quercus mana. Sarg.: or Quercus pumila, Sudw. The authorized scientific name is given at the top of each descriptive page, and where other scientific names are in common use. they are given as swnonrms just below the authorized one or in the description.

The mere knowledge of the names of trees is of little value or satisfaction. The name is simply a means by which to come nearer to the plant. Learning the nanes of trees serves about the same jurpose as learning the mames of persons. It is merely an introduction which allows us. in fact often stimulates us, to become more intimately acquainter with their life-processes. associations. enrironments. and commercial importance.

Explaxation of Teris and Heanngs:

Some readers no doubt will fint terms in this publication whose meaning ther lo not ruon. Some of the terms have been discussed at length in Part I while others will he defined in a glossary following the description of the species. The description of the species of trees contained in this publication is subdirided into a number of headings. Irost of these headings are discussed at length in Part I. The simificance and scope of those headings not discussed in Part 1 will follow at this point. Tuder the sereral headings is given such descriptive material which will be of ralue not only to the student of Dendrologr but also to the larman who may know little concerning the characters and habits of trees. The headings have been so selected and treated that one should be able to identify our common trees at all seasons of the rear.

Under the heading "Distingnishing Characteristics" are given both general and specific characteristics by mich the species can be recognized. The species are usually compared with other rather closely related ones with which ther might be confused. The distinguishing characteristics and comparisons are based upon the trees native to Pennsclrania, and consequently do not embrace other closely related species found outside of the State. 
The headings "Range" aud "Distribution in Pennsylvania" are often of special inportance on account of their identificational value. Many species of trees have a limit to their geographical distribution in this state, and by knowing this accurately one is often able to identify a species by the process of elimination. The swect Buckeye and Fetid Bucliege are found only in a tew counties in the western part of the statc. The Tied P'ine and Paper Birch are found only in the northern jart, while the White Cedar is found only in a few counties in the extreme southcastern prat of the state. If ouc finds a birch tree growing in the forest in the southern part of the State, he can feel certain that it is not l'aper Birch, because this is beyond the sonthern limit of this sprecies. A coniferous tree growing wild on the top of the Sonth Monntains in Franklin county, P'ennsylvania, must be a P'ine, Hemlock, or Red Cerlar, because un other coniferous trees grow there. Further we know that it cannot be the Red Pine, because this species does not extend so far south in the State, and on the basis of habitat we can also he reasonaly sure that it is not the Yellow Pine, the Jersey or surub Pinc, nor the Henlock, becausc they very seldon ascend to the tops of the mountains, but usually remain at lower clevations. Likewisc, if a maple tree is found at the same place we know that it is the Red Malple or Mountain Maple because they are the only Naples found in that particular locality. If Haguolia trees are foumd in Centre county one can be certain that the sprecies is not laxuel Magmolia. (Magnolia virginiana), because this species has its western linit of geogriplical distribution at Caledonia, near Chambershurg. Franklin county. The habitat also aids considerably in identifyng various species. A bireh tree found growing upon a mountain slope or monitain top is rarely the River Birch, becanse the latter usually frequents moist locations like banks of streams and lakes. Chemical composition of the soil also influences distribution. I soil rich in lime seldom has Chestnut growing upon it, at least in stands, while other species seem to thrive upon such soil. No doubt at least $99 \%$ of the Cumberland Valley in this State was originally timbered with a heary forest, but remy little of it was Chestnut, while on the adjoining mountain slopes of both the Sonth and North Momntains, Chestut is the prevailing species. Just as the Chestmut is essentially a tree of the slopes so the White Oak is essentially one of the bottom lands, and Table Mountain Pine of the mountain tops.

The heading "Importance of the Species" was introduced simply to give general information concerning the forestal significance of the sprecies and their adaptability for ormamental purposes. This heading is especially inportant when we realize that of the more than one hundred and twenty-five species of trees found in this State, 
fewer than twenty-fire are important for timber-producing purposes. Many inferior species which hare little present or prospective value hare been introduced into this publication, since it was thought just as important to know what not to plant as to know what to plant. Some species may not be valuable for the production of timber but they may hare a ralue as shelter to other species or as soil protectors and soil conservers. Many species which cannot be regarded as final members of a timber-producing forest may be of temporary value in helping to establish the more valuable permanent species. We should be cantions in eliminating the inferior species from our forest structure, because they may possess a ralue which is not erident at the present time. It should be remembered that the species despised by myself may he prized by my neighbor, and that the species despised today by my neighbor and myself may be prized by both of us tomorrow. Only general statements are made with reference to the importance of the species. A fuller discussion of this heading may be found in any standard tert on General Forestry or Silviculture.

How to Inentify the Species and Use tue Keys:

Since this publication is intended primarily for laymen and for students who are just beginning the study of trees, the omission of techuical terms was thought adrisable. We have many species of trees, some common, others uncommon, which the average layman may not know. He can learn them readily if their distiuguishing characteristics are presented to him in ordinary language accom. panied by simple and exact drawings. This publication is designed so that the average layman with even a limited knowledge concerning trees can use it and identifs the various species with little, if any, difficulty.

The procedure or method of ideutification varies with the individual. One may take material from a tree and compare it with the drawings until he fiuds one with which it corresponds or to which it fits, and then feel satisfied that he lias learned to know the tree. To check himself and to acquire additional information he may read over the descriptive material accompanying each plate. This method of comparison with plates, while the one commonls used by laymen who hare little or no working knowledge concerning trees, is laborious and entirely unscientific. A better and ret simple method is the use of an analytic ley for the identification of the species. Such kers according to their constmetion may be simple or complex, serviceable or unserricealule to the average larman. In constructing the subjoined analytic ker, an attempt was made to make it simple and yet exact, based upon permanent rather than transient, and constant 
rather than variable characteristics. This publication will no doubt come into the hands of different classes of people, some of whom will recognize at a glance the genus to which a certain tree belongs, while others will not have the slightest idea as to what it is. An attempt has been made to satisfy both types of persons. The former can go at once to that portion of the publication where the genus under consideration is treated and by the use of the "Key to the Species" determine the exact suceis which they have at hand, while the latter should begin at the "Key to the Families" found on page 63, and use the key until the family to which it belongs is found, then go to the family and use the "Key to the Genera" and the "Ker to the Species" until the species is determined. With a little practice one will find it easy to use such simple keys.

Before attempting to use a ker, it is necessary that good material be available. Parts of trees vary considerably, depending upon the environments in which they were developed. An abnormal environment will produce abnormal organs, and if these slould he the parts with which you are attempting to identify the species through the use of the keys, it is natural that it would he a difficult task. Structural variations are commonly found in leaves, flowers, fruit, bark, as well as other plant organs. Upon the same tree or even the same branch one may find three or more distinct varieties of leaves. On account of this variation, which often makes identifuation difficult, abundant material should almays be at hand, and especially that which is normal in aprearance. The keys are based upon normal material and may not fit rariable forms. Only by rears of constant and careful stndy of trees will one be able to distinguish accurately between normal and abnormal material; but by carefully observing and constantly studying the trees one will unconsciously absorb many details concerning them which can be appreciated but not described. This unconscious alsorption of appreciable lut indescribable detail in trees lias a greater significance than we attribute to it at first. The writer, in conducting field work (Fig. 7) for five years in connection with a course in Dendrology given at the Pennsylvania State Forest Academy, finds that the students learn to notice many differences between species, which differences they cannot describe.

The keys are subdivided into three classes, viz: "Key to the Families," "Key to the Genera" and "Key to the Species." The "Kev to the Families" is found on page 6r, preceding the description of any of the splecies. The "Tey to the Cencra" is found under the description of each family which contains more than one genus; and the "Key to the Species" is found under such genera which contain more than one species. The reason for subdividing the keys into throe classes instead of combining all three into a general key to genera 
and species. Was the fact that a combined kes is often difficult to use on acconnt of its great length, ancl tedious to operate for those who can recognize the family or genus at a glance but do not know the species. Besides, kers to the genera and keys to the species are more selviceable when placed close to the written description and its accompancings plate than if they precede the descriptive material of all the species.

The three classes of kers are constructed on the same plan; consequentls, they ean he nser in the same manner. To use them it is necessars to make a choice for the most part between tro alternatires stated in two paragraplus preceded by the same number. The choice leads to another number or to a famils, a genus or a species followed hy the page upon which a further lescription is found. The Sugar Maple mat he taken as an example to show how to use the ker. Under "Ker to the Fanilies." page 6r. ire start with 1 . We hare the (hoice hetween trees with "Leares narlow, needle-like, awl-like, or scale-like. usually persistent exent in the genus Larix" and trees with "Leaves broak. flat. rarely five times as long as wide, usually leciduons:" Tre select the lattel, which is followed by 2 . Under 2 we have the choice between "Leaves opposite or whorled, i. e. 2 or 3 necur at a nodp" and "Leaves altermate, i. e. only one occurs at a node." We clonose the folmer. which is followed br 3 . Here we hare the choice between "Leares or at least most of them three at-a node" and "Leaves almays two at a node." We select the latter. which is followed hr t. Here we hare the choice "Leares simple" and "Leares componnd." We select the former. which is followed by 5 . Here we have the choice between "Leaves palmately lobed" and "Leares not lober." Tre select the former, which is followed by Aceraceac, which is the family name for the Maples. This is followed br a number which indicates the page upon which a further description of the fomils mat be fonml. At this point it is advisable to check one's self. This can he done br carefully studying the descriptire matter of the famils indicated in order to find out if the description colresponds to the species under consideration. If the description does not correspond it is advisable to go back to the "Tiey to the Families" and attempt to find the mistake. If the description does colrespond it is reasonable to think that the "Key to the Families" was msed correctly. If rou feel certain that this is the corlect family roul should go to the "Ker to the Genera," or to the "Kẹ to the species." No "Key to the Genera" is giren under this family hecause it contains onl ̦ one genus. Cnder the "Key to the Genela" and the "Ker to the Species" the same method of procedure shonld he used that was used under the "Ker to the Families." On account of the wide rariation between the distinguishing characteris. 


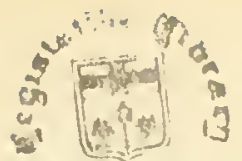

tics which are present in summer from those whiclfhte present in winter, it has sometimes been found necessary to make two keys to the species, one a sunmer liey and the other a winter key. Two such keys are found under the Maple family. If the material at hand happens to be a spray of leares of the Sugar Maple, the summer key should be used, and if it happens to be a branchlet with buds, the winter liey should be used.

Since the family key which was used to this point was based primarils upou summer characteristics, the winter key will now be used in order to familiarize you with the slight variations which are found between the two kejs. [ndur. "Winter Key to the Sipecies," page 191, we start with 1. Turler 1 we lave the dioice betreen "Buds stalked with few exposed scales" and "Burls sessile or" nearly" so, with 6 or more exposer scales." We solert the latter, which is followed by 4 . Under 4 we have the choice lotween "Burls with 8.16 exposed scales, brown, acute, non-collatelal: leaf-scars neally encircle stem" and "Buds with 6-S exposed scales, l"ed ol green, olstuse." We select the former which is followed ly. Sugar Majle ( A ('er saccharum) page 194. On this page a full description of the species is found accompanied by a sketch on the opposite pire of the principal characteristics. If the descriptive material and the slietcles show that this is the species moler consideration. one may feel satisfled that the key has been used properly. If the description does not correspond it is advisable to go back to the lieginniug of the lies, follow the same procedure indicated ahove but elininating the mistake which must have been made. The same method of identification or procedure should be used for erery other species. In a short time one will be familiar enough with the use of the key to identify the species and will do so with considerable accuracy.

If you cannot identify the specimen at hand with the aid of the keys, description, and plates. there are still other means which you may use. It may be possible that an institution or a private person in your part of the state possesses an herbarium in which may be found a similar specimen properly labeled. If you cau get access to such an herbarium and find that rour specinen and the one in the herbarium are alike, and that the herbalium specimen was labeled by a reliable person, it is reasonable to assume that jou have identified your specimen correctly. It may also be possible that some one connected with some local edurational institution will be able to assist you in identifying the naterial. All material sent to the Dendrolngical Department of the Penusylrania State Forest Acadeny, Mont Alto, Pa.. will be identified free of charge. Persons sending material should always ain to send an abundauce of it. If flowcrs, leares, fruits, and bark are obtainable they should all be sent. 
The wider the range of material the easier and the more accurate the identification will be.

Those who desire to collect and preserve material should proceed in the same manner as one would in making general botanical collections. The dried material may be secured on strong mounting paper. The writer has found the "Riker Specimen Mounts" very satisfactory for preserving and displaying the different parts of trees. Different sizes are obtainable, which allows one to select them in proportion to the size of the material to be preserved. 


\section{GENERAL KEY TO THE FAMILIES.}

1. Leares narrow, needle-like, awl-like, or scale-like, usually persistent except in the

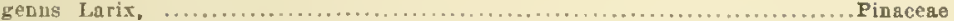

1. Leaves broad, fat, rarely fre times as loug ns wide, usually deciduous, .........2

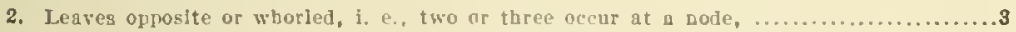

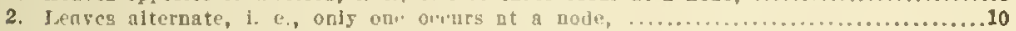

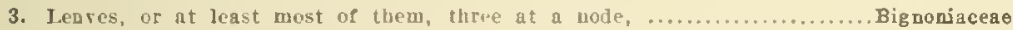

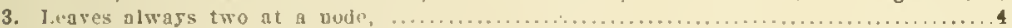

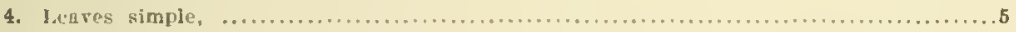

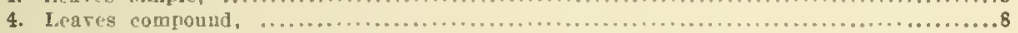

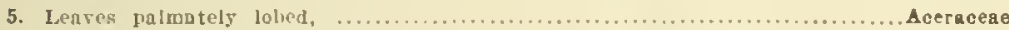

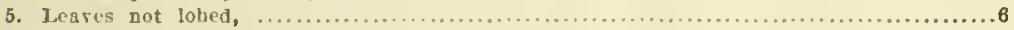

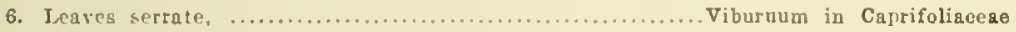

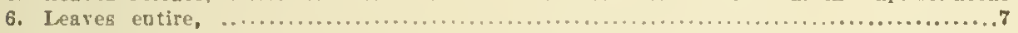

Page.

67

211

7. Ieares 3-6 inches loug with curving larallu-1 vins: basus of leaf stalks eniarged,

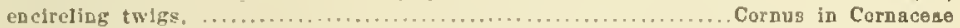

7. Leares 1.8 Inches long witbout eurving luatallel vrins; bases of leaf stalks do not en-

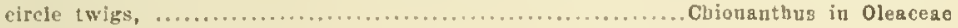

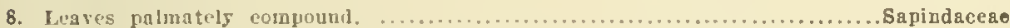

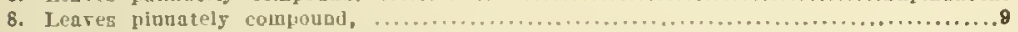

9. Leaflets usually $5-11$; fincly lootber or eutire marglued, ......... Fraxinus in oleaceae

9. Leaflets nsually 3, sometimos 5 .lohed or confscly serrate, .. Acer Negundo in Aceracea

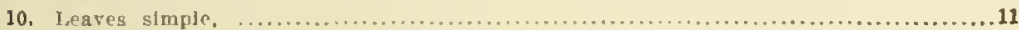

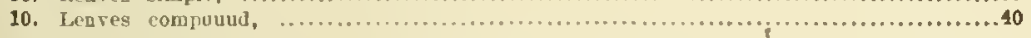

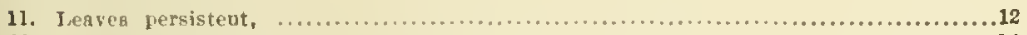

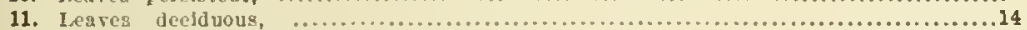

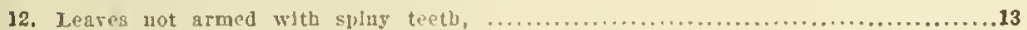

12. Leaves urued with splng tecth, ........................ llex opaca in Aquifoliacea

13. Sinall trees; learrs stout, whlte sluky benenth, not taner pointed; flowers soli-

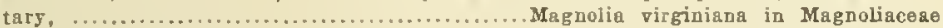

13. Shrubs; leaves leatbery, yullowlsh-gran to seurfy benesth, often taper pointed; flowers in elusters, ......................... Rbododendron and Kalmia in Ericapea

190

213

197

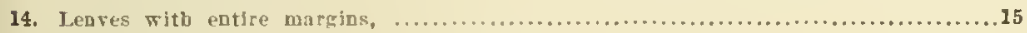

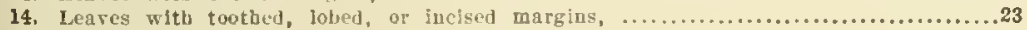

15. Leaves brondly bent-sbajed; flowers reddisb-purple, sboped life pea blossoms; Iruit

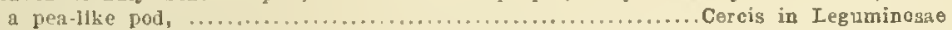

15. Learea not broady heart-sumper; flowers dot gloped like pea blossoms; fruit not.

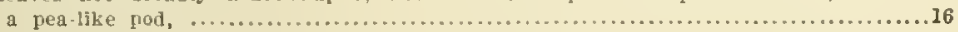

16. Stout axillary spines present; fruit $3-5$ incbes in dinmeter,......Maclura in Urticacea

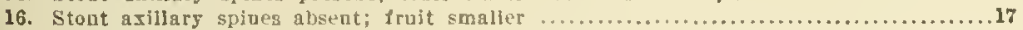

17. Leares decidediy arountic, often somewhat lobed; twigs spieg-aromatic, mucilagln-

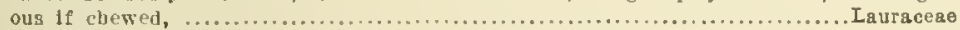

17. Leares not aromatic or lobed; twigs not spiey-arumatlc, nor mucilaginous, ........18

18. Leares 2-6 inches long; lowers small except pistillate of Diospyros, not soll-

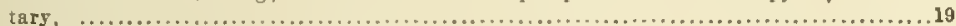

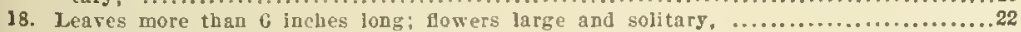

19. Leaves bristle-tipped, linear-1anceolnte to oblong; pith star-sbaped; fruit an acorn.... Qvercus imbricaria and $Q$. phellos in Fagacea

19. Leares oral-orate or ohornte, not bristle-tipped; pitb not star-shaped; 1ruit a drupe or a berry, 
20. Leares thin, clastered at tip of trigs, with prominent curred parallel reins; small trees; twigs greenish streaked with white. .......... Cornus altarnifolia in Cornaceae

20. Leaves thick, not clnstered at the tip of twigs; reins not parallel; medjum sized

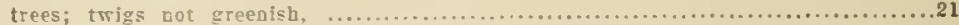

21. Legres +6 inches Iong: leaf netioles with on. fibro-rascular bundle; fruit a globular

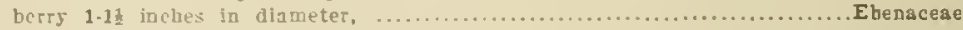

21. Leares $5-5$ inches long: leaf petioles with 3 bbro.rascnlar bandles: fruit a purple

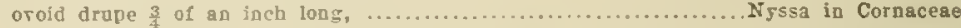

22. Stipoles and stipule-scars encircle twigs: flowers greenisb-mbite or 5ellomish: fruit

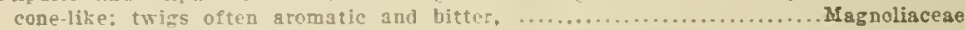

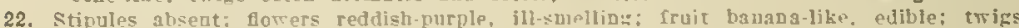

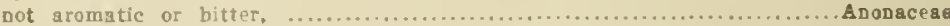

Page.

205

210

206

23. Leaf marcins usunlly lobed or incisen, 24

23. Leaf margins usually roothed. .29

24. Leares star-shaped, ............................. Liquidambar in Hamamelidacea

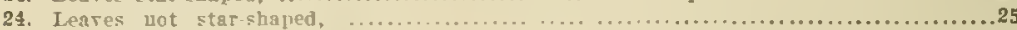

25. Leares silrery begpath, ............................. Populus alba in Salicaceae

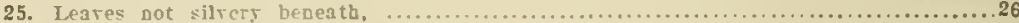

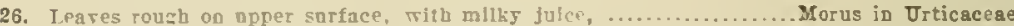

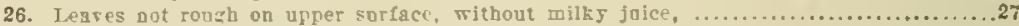

27. Leares decidedir aromatic, lobed or entire; twigs spicy-arnmatic, mucliginoos,.......

Lauraceae

27. Leares not aromntic: twigs not spics-8romntic nor mucilaginous, .................28

28. Leares ralmately reioed; I ase of leat petioles bollow: leas lobes irregularly toothcd. Platanacea

23. Legres pianats veined; base of lat fretioles not hollow: leaf lohes roundal or bristle-pointed, interrening spaces deep or shallow, ...........Most specles in Fagacea

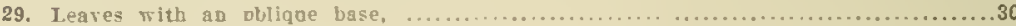

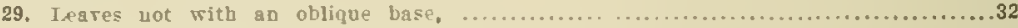

30. Leares orate or orate-obleng: rough on uyper surface, Ulmas and Celtis in Drticaceae

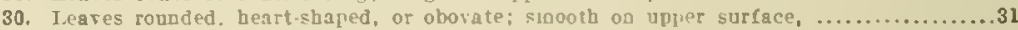

31. Leqres strajght-reined with wary margins; finwrrs is lnte autumn: froit withont hract. Hamamelig in Hamamelidaceas

31. Leares not straiglt reined, deeply and surply toothed; fowers appear in summer:

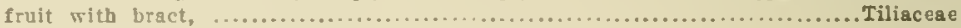

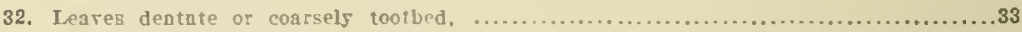

32. Leares not dentate gor coarsely toothed. . . . . . . . . . . . . . . . . . . . . . . . . . . . . . 34

33. I.eares with laterally fiattened petioles, ........... Populus grandidentata in Salicaceae

33. Lenres not with lateraliy fattened petioles. .................... species in Fagaceze

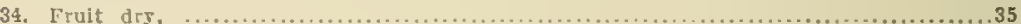

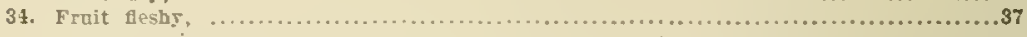

35. Leares decidedy sour; fowers nad fruit produced in racemes resembling the lily of

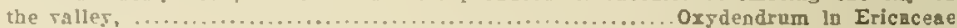

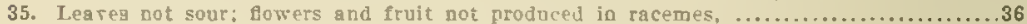

36. Fruit 1-seeded, Dnt or samsia, sobtended bs bracts: seeds withont tuft of hairs at

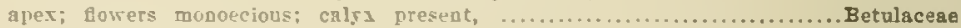

36. Fruit a small capsule inclosing oumerous seculs; seeds with toft of hairs at apex; flowers diopcions: calyx absent, ............... Salicacere

37. Thorns or spige.like spurs present,

Prunus americana. Pyrus coronaria, and Crataegus sp. in Rosaceae

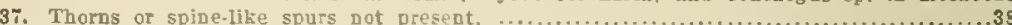

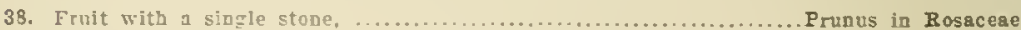

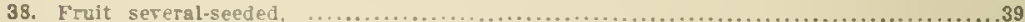

39. Lenres heart-shaped or rounded at base, 3-4 inches long; fowers in loose racemes, Amelanchier in Rosaceae

39. Leares Tedge-shnped or rounded at the base, $4-5$ inches long: forers solitary or in one to few fowered axilary clusters. ................ Ilex monticola In Aquifoliacese 
40. Leares with entire margias,

Page.

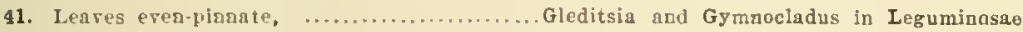

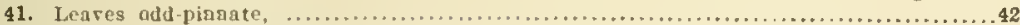

42. Leaflets small, elliptic: twigs thoruy.

Rabiaia in Leguminosae

42. Leaflets Iarge, ovnte; twigs aot thorgy,

43. Leaflets $\mathbf{7} \cdot 21$, not toothed at hase, without tagd:

Rhus Veraix and R, copallias in Anacardiacea

43. Lenflets 11-41, sometimes with $2-4$ bIut tutl at base which bave glaads on Iawer side at the point of eacb tonth, ................................ Simarubaceae

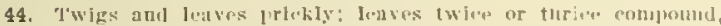

Araliacege

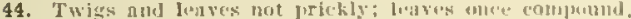

199

45. Large trips; staminatu flowers ill umetuts: fruit i unt, ..............Juglandacege

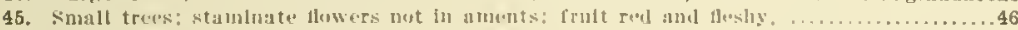

46. Leaflets 12-15; saj, mot nilky: branches leavy tipued.

46. Leafluts 11-31; sa! milky; hranches henvy-timperk ,

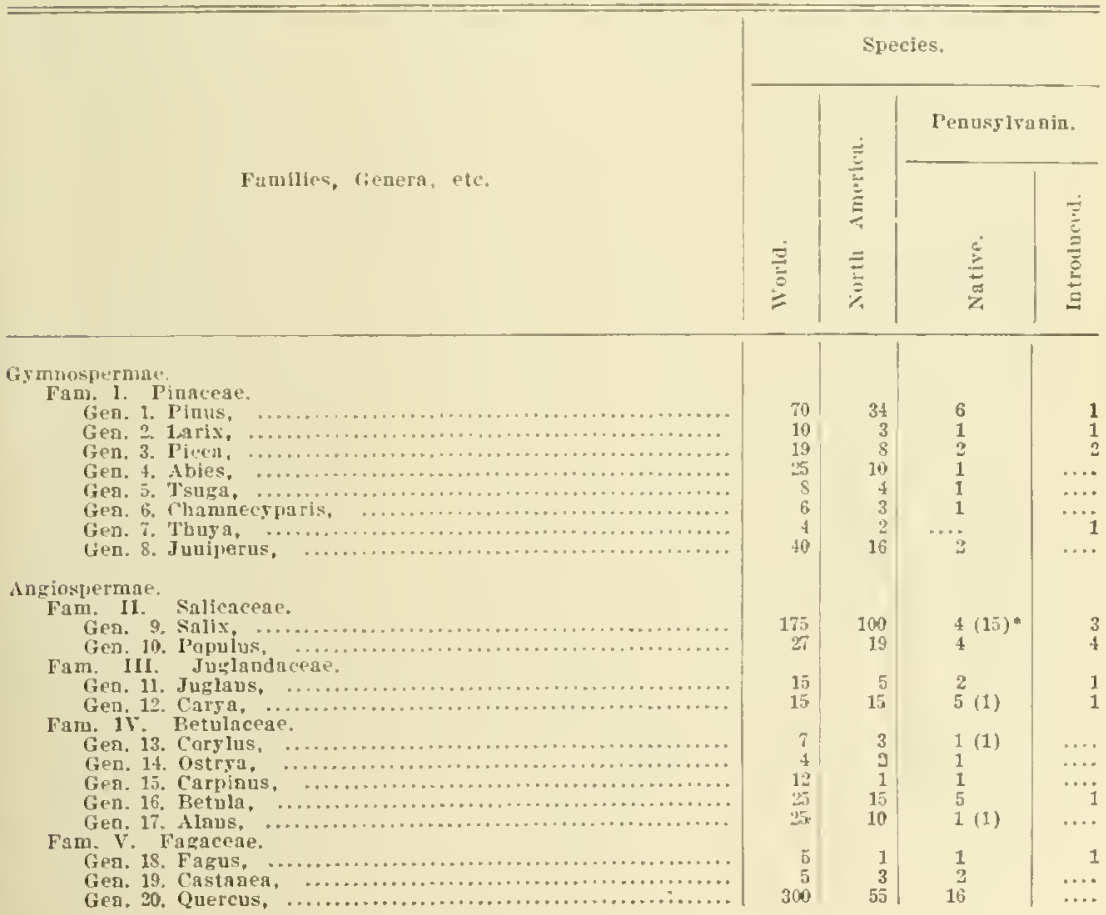




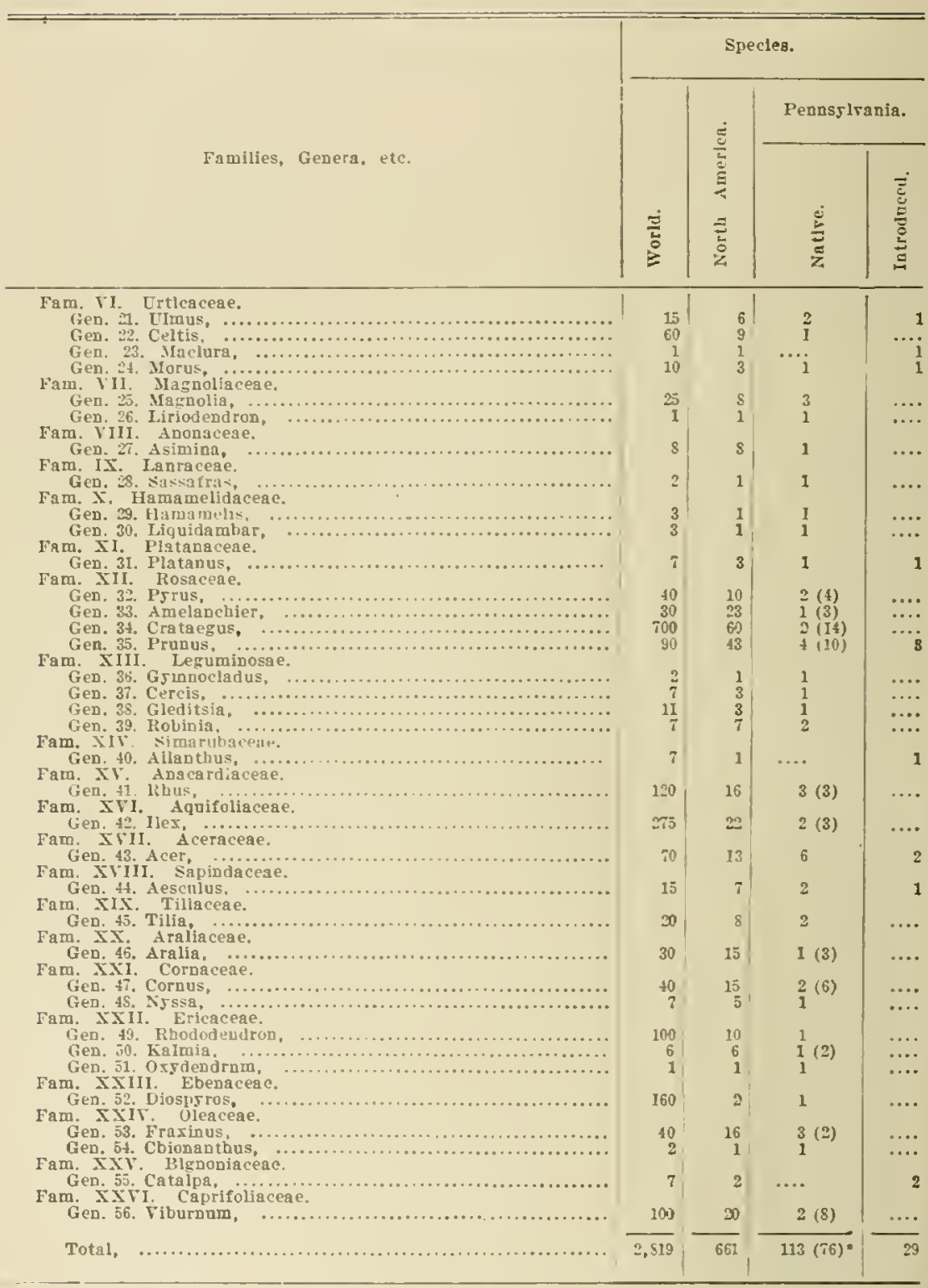

*The numbers giveu in parenthesis refer to species native to Peunslrania but not described and rarels mentioned in this pnblication. 


\section{THE PINE FAMILY-PINACEAE.}

There is general agreement that the Pine and Yew families comprise the two dirergent branches of the conifers which differ from each other in morphological characters and geographical distribution. The conifers comprise 34 genera and about 300 species, of which number 8 genera with 71 species belong to the Yew family (Taxaceae) and of genera with 206 species to the Pine family (Pinaceae). The representatives of these two families are found mainly in temperate regions, hoth northern where the genus Pinus predominates, and southern where the genus Podocarpus predominates. The geographical distribution of these two families is peculiar since the genera of the northern temperate region are not found in the southern and those of the southern are not found in the northern, excepting the two genera (Heyderia and Podocarpus) which cross the tropies. Geological records together with the simplicity of floral structure show us that the members of this family are amongst the oldest living rejresentatives of the ancient arbores. cent type of regetation. IInrphological eridence seems to point to the belief that the Yew family contains representatives of the most primitive form of conifers and that the genus Pinus in the Pine family contains the most highly specialized forms. The sole representative in I'enusclvania of the family Taxaceac is the American Yew or Ground Hemlock (Taxus canadensis, Marsh.) It is a small erergreen shrub seldom exceeding 5 fect in height.

The Pine family is of especial econonie value on account of the many commercial products which are obtained from it and the wide range of silvicultural characteristics whieh its members possess. The annual wood production of the members of this family in the Uniter states far surpasses that of the members of any other family. The wood differs markedly from that of the broad-leaved trees in its greater uniformity. smaller porosity, and less conspicuous medullary rays. Some members of this family yield large quantities of resin, tar, turpentine, and pitch. The fruit of some species is often of considerable importance as food, and the bark of many species is used in the process of tanning.

The members of the Pine family have awl-shaped, scale-shaped, or neclle-shaped entire leaves, which are usually persistent. The American Larch is the only coniferous species natire to Pennsylva- 
nia which is without foliage in winter. The subjoined liey gives the claracteristies of the genema commonly found in Pennsrlyania:

KEY TO THE GENERA.

1. Fruit a drs cone with wioged seeds,

$\ldots \ldots .2$

1. Fruit a deshy, round, dark-colored lierry with bouy sects, .................. Junperus

Page.

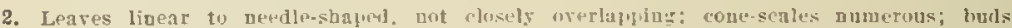

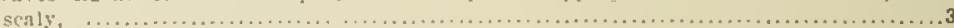

2. I.eaves scale-1ike, closuls orerluphing; cone-seales few; huds not scals, ...........

3. Leares in hnodles of two or more exient on soung sepdings and na termiaal twigs

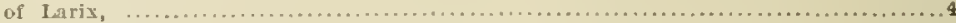

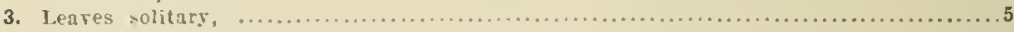

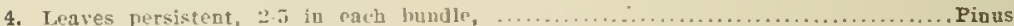

4. Leares deciduous, more than 5 in tarle cluter, $\ldots \ldots \ldots \ldots \ldots \ldots \ldots \ldots \ldots \ldots$. Larix

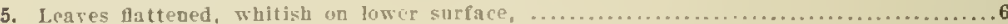

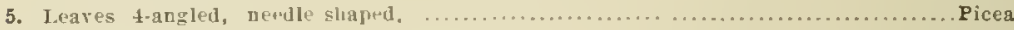

6. Leares with leaflike stalks, about 2/5 of an inch long: twigs rough: cones small

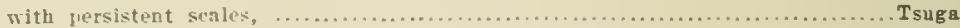

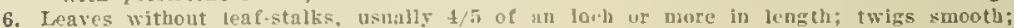

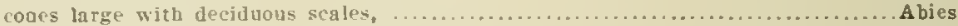

7. Leares less than 5 of an inch lnng: twigs rather slind:r. not proninently flattened: cones clohular with shield-shaped seales whith in not orerlap, ....... Chamaecyparis

7 Leares $\frac{1}{6}$ of an inch or bort in lomgth: tu gs: rathegr provanently flattencil; coaes

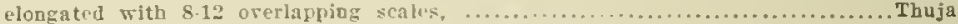

THE PINES-PIXUS (Tourn.) L.

This gemus complises mote species than any other belonging to the Pine fimily. Alout 70 suecies ale kumber in the world, $3 t$ of which are fomm in Nomth America and fi in Prmsylyania. Of the st species in North America. 1:: are found in the eastern part and 21 in the western part. Bexides the native Pines a number of exotic species have leen planferl extensively for ornamental, and locally for forestry jurposes. The commonest exotic species are Scotch

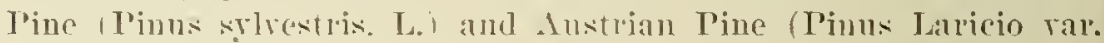
austriaca. Enell.).

The l'ines arr arlapted to a wide lange of climate and soil. Certain species may be fonnl borlering streams and lakes $m$ close to the ocean front while others are confined to monntain tops where they aseme to the limbel line. This adaptaliblity makes some of the sprecies of considemalble ecomonic vinlue eren though they may purntuce no wond of commertial importance. They can be used for afforesting momutain slopus where protection forests are to be formed and maintained. and to reclaim sand barpens.

The Pines ale generally trees, rarely shluls, and of considerable rommerial importance on aroount of the excellent quality and large quantity of najor and miuor forest products which they vield. Sereral species of Pine lare alwars been foremost in the estimation of 
lumbermen and the jublic since the American Forests began to be exploited. [nti] recently more pine lumber has been produced annually in the [nited states than all other kinds of lumber combined. The lumber-probluring pine trees have played a very important role in onv ecomomic and industrial develojment. The Pines are distinguisluel commerebally into two classes, Soft Pines and Hard lines. In the rniter stales there are 12 species of Soft Pine. and 2.2 suecies of Hart I'iur. The White l'ine is the sole eastern representative of the suft l'ins. whilo the Hard Pines lave 12 representatives in the eastm ams suthern rniter States.

The ['ines have three kimls of lagks: seed, jumary, and secondary

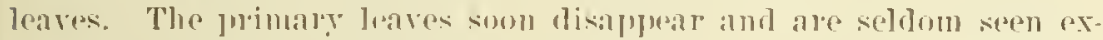

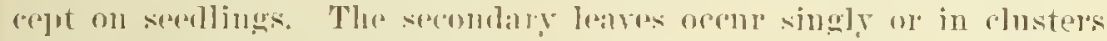

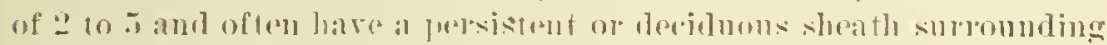
them at the base. They me sumi-cimula of triangular in eross-

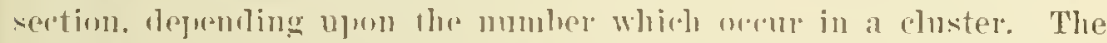

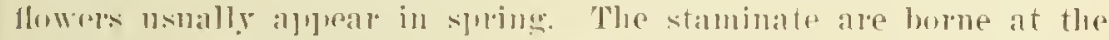

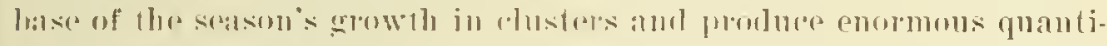

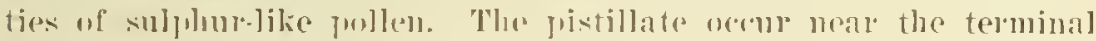

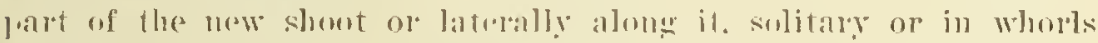

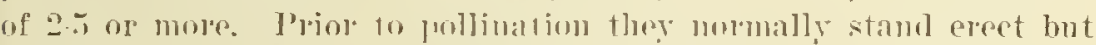
after this process has luen rompleted thry legin ta droop. The wiml is the ehiof agent of pollumtion. Fortilization takes place about $1: 3$ momlls after pullination. The result of these procosses is usmally a cone which matures at the amb of the secomd or sometimes

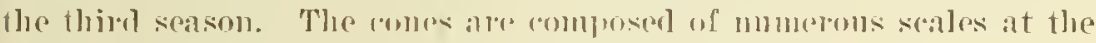
hase of which the seeds are jundured in frairs.

\section{KEY TO THE SPECIES.}

1. leares in in slieath, slender. with 1 fibro-vasmular lundlo

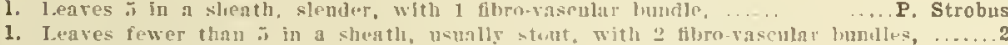

2. Inares 3 in a sheath,

P. rigida

2. I.eares 2 in a sheath,

3. Leares $\mathbf{7 0}$ inches long; mux subterminal, sculeg wuarmed.

P. resinosa

3. Leaves less than $\overline{3}$ inches lub; cones latmal, scalps armed with spinps or prinkles. 4

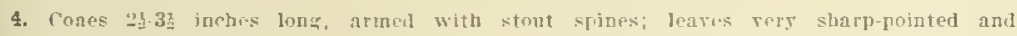

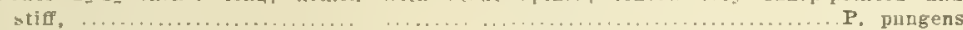

4. Cones 3 inches or less in length. armed with jrikkles: lenves sleuder to slightly stiff, .5

5. Ieares slender, straisht, orasiounly 3 in a sheath, 4 inches lous or legs, P. echinata

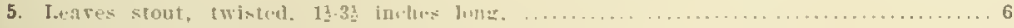

6. Twigs smooth, greegish-Imrje to gragish-browi, cones at right angles to branch

P. virginiana

6. Twigs rougb, dull grarish-Jellow; cones pointing hackward; bark of npper third of trunk reddish; European species.

P. sylvestris 


\section{WHITE PINE.}

\section{Pinus Strobus, Linnaeus.}

FORM-At present seldom exceeding $3 \mathrm{ft}$, in diameter and $125 \mathrm{ft}$, in height, usually $50-90 \mathrm{ft}$ high and $1 \frac{1}{2}$ to $3 \mathrm{ft}$. in dinmeter. Then grown in dense stands (Figs. 1 and 10) the trees are tall, stralght, free from lateral branches for a coasiderable dlstance from the groaad, have little stem-taner and shallow crowas. When grown in the oped (Fis. 34. speclmen on left). It has much stem-taper. Is relatirley low, ofteo forked, corered with persistent lateral bracches almost to the groud which make it attractire oramentally bat of low commerclal ralue.

BARK-0n young branches, thlo, smootb, greenlsh-brown; latet scaly and darker. OD old trees thlck, dark gras, and dirided by loog and shallow fossures lato broad longitudinal ridges (See Fig. 44.)

TWIGS-Slender, fiexible, at first hairs, slightls ronghened by ralsed leaf-scars. New growth at first light green aod erect. Duriog first winter llght brown in color, lesg erect in positlon, very resinous if punctured.

BUDS-ln terminal claster, crate-oblong, sharp-polated, with aumerous browa, long-pointed aud orerlappiog scales. Apical hud f-l of an inch loug. Lateral bods ahout $\frac{1}{6}$ of as iach long.

IEAVES-Ligbt green when jousg and bluish-green, soft, flexible, 21.5 locbes long when mature: persist usually uotil eod of second senson, occne io clusters of fire, are trlangular in cross-section, contaio one fibro-vnsculnr bandle, have finely serrate edges and are surrounded at the base by a deciduons sheath.

FLOWERS-Appear ubout May. Stamlonte flowers clustered at base of new growth of season, sellow, oral, abut $f$ of an inch long. Pistlliate flowers solitary or lo small groups, lateral along Dew growth, plaklsh-purple, cylindrlcal, about $\frac{1}{8}$ of an lach loog.

FRUIT-A cone maturlag in two seasons, 5-10 inches long, drooping, stalked, sllghtly curred, and corered with thin unarmed scales without thickened apex. Seeds are winged, of an fach long, dark browa io color on both sldes aod mottled with black spots.

WOOD-VoD-norons; resloous, coft, straight-grained, egsily worked, llght browo except sapwood which may be almost white. Weighs 24.0 lhs. per cubic foot. Formerly used for a wider range of purposes than any other aative species and adapted for practicnlly all oses except where strength, hardness, flexibility and dorability in contact with soll are required.

DISTINGUISHING CHARACTERISTICS-The White Pive is the ody species of Pine native to eastern North America which has soft, flexible, bluish-green beedles id clusters of five. The lateral branches, wsually 3-7 in a whorl, are arranged in distinct borizontal lajers. The cones are 5-10 inches long, lovg-stalked, and their cone-scales nre thin, fiat, and auarmed.

RANGE-Newfondlad to Manitoba on the vorth, sooth through nortbera states to Pean. sylrania and along the Allegheny Jountains to Georgia, and southwest to Iowa.

DISTRIBUTION IN PENNSYIVANIA-Common in the mountainous portloo of the State. Originall formed hears stads especlally to the central and northern parts of the State. Some time pure bot usually mixed with other specles. Fond sparingly in the southwestera and south eastern parts. Rarely found at present io ralleya like the Cumberland, Lancaster, Chester, lower Lehlgh, and lower Delaware.

HABITAT-Prefers a fertlle, moist, well-drafned soil, bat will grow well ou dry sady, soils and grarelly slopes. Common on baoks of stregm, rirer fats, in bollows and rarloes, but rarely foud in swamps. Anj habitat in its astural rage will be farorable to its dereloproent except swamps and ridges exposed to serere riads.

IMPORTANCE OF THE SPECIES- White PiDe is one of the most important timber trees of the Caited States. It is indigeoous to Amerlca bot was introdnced Into England by Iord Wey. movth in 1705 and shortly afterwards into Germany where it is no longer regarded an exotic specles but a naturnlized member of the German forest. This specles cau be recommended for forestry purposes, because it may be regenerated successfully both naturally and artificially as showa by the aumerous aud exteoded German experimeots. It adapts itself to great variety of soll conditions, is a rapid grower, is rets attractire ornameotalls, and will thrire 10 pure or mixed stands; bot the latter are best on account of less danger from disease, better natural prouing, and earler financial returas from thioniogs. 


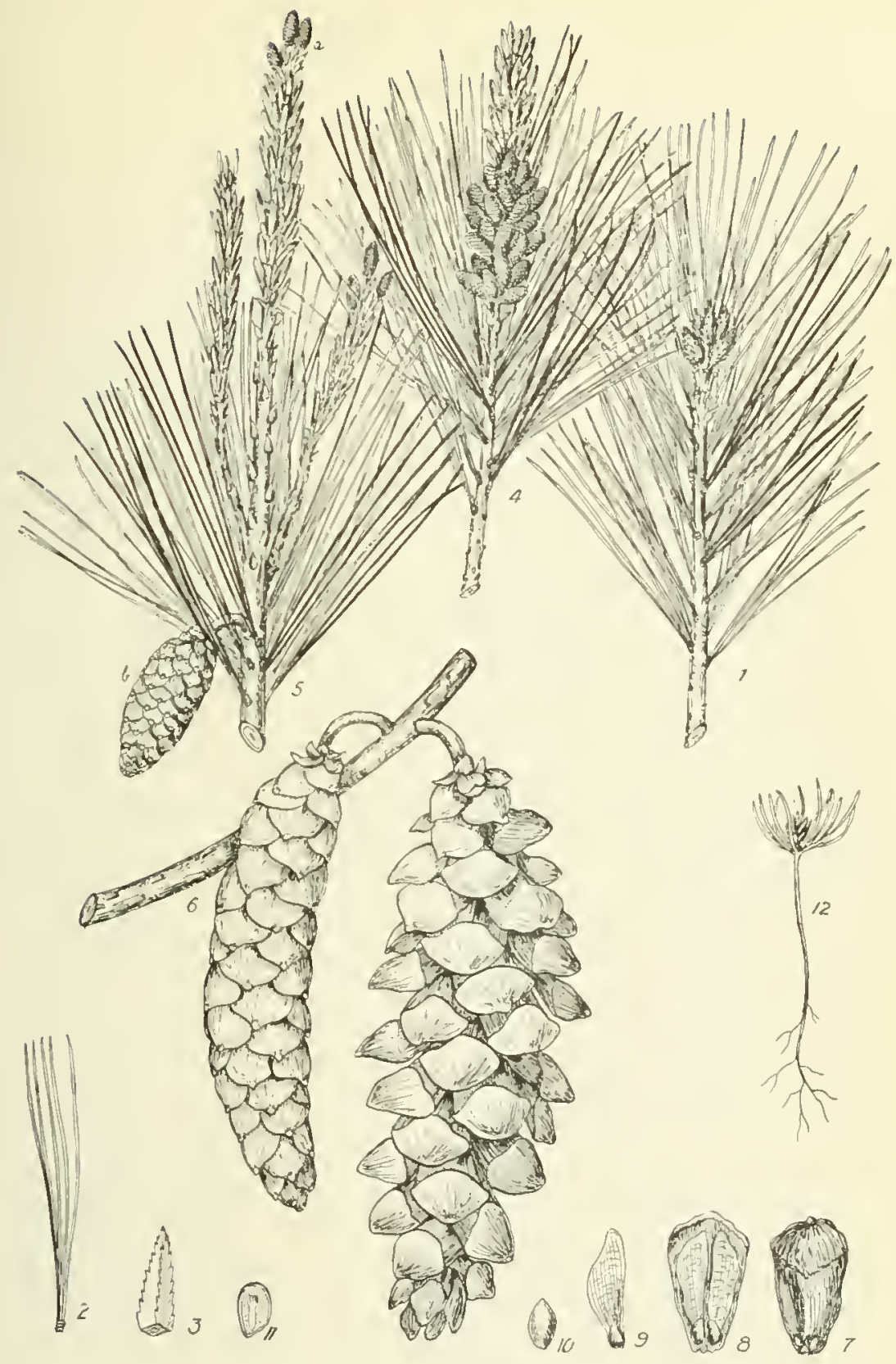

PLATE XII. WHITE PINE.

1. Hranch wath umdles and torminal cluster of buds, $x, \lambda$.

3. A cluster of bive neerlles, i 3 .

4. Itramin neelle wit

5. Bramel with stiminate lowers, $x$ ?

growth.

6. Iranch with an open and a closed cone, $x^{3}$

8. Cpier sirle of a cone scale with two wingul seeds. I

10. A winged searl. $x \frac{1}{2}$.

11. Section of swal with entury, natural sizn. 

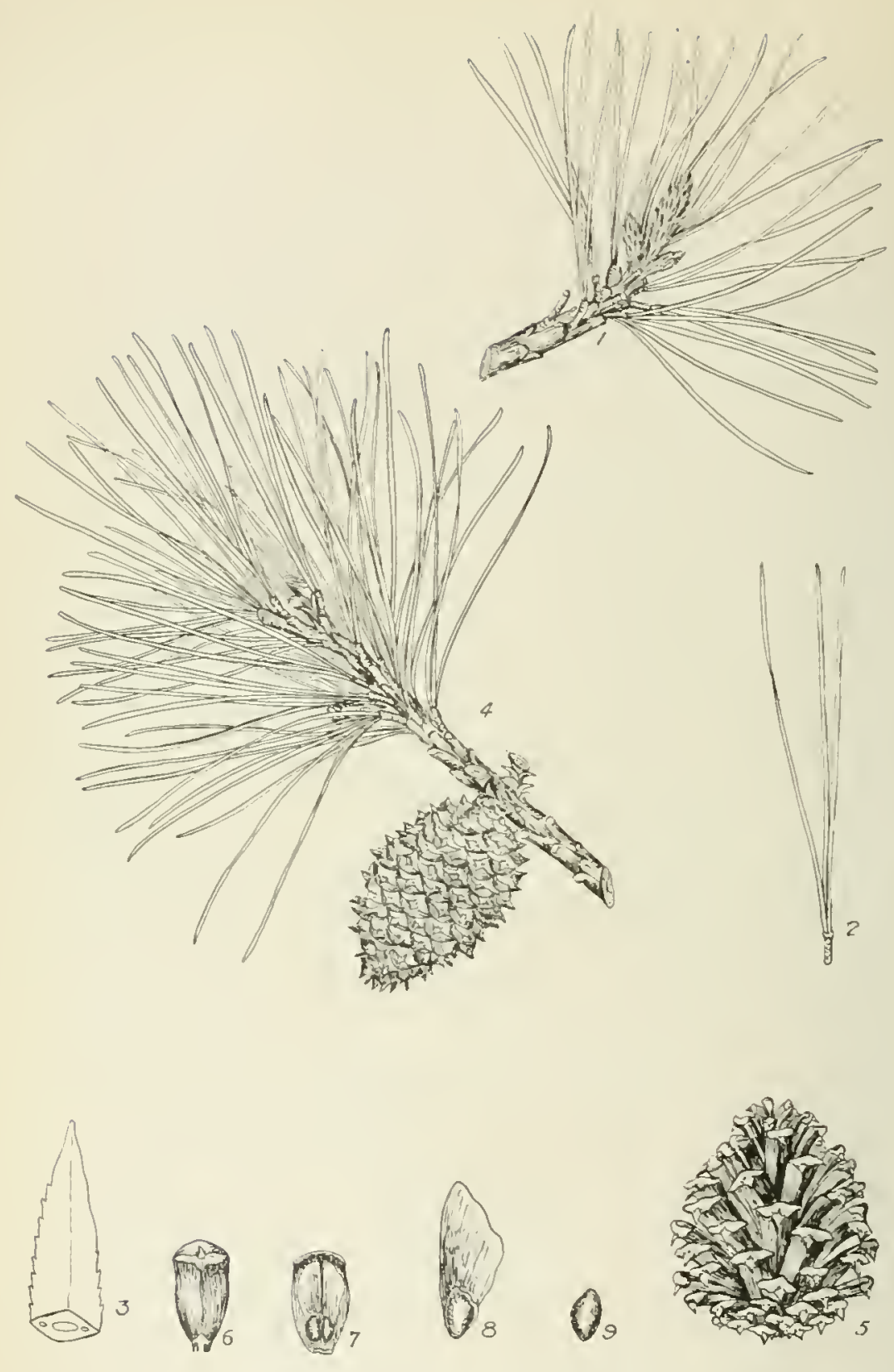

PLATE XIII. PITCH PINE.

1. Branch with needles and terminal clustor of huds, $x$ t.

2. A cluster of three needles, $x \underline{k}$.

4. Franch with needles and a elosed cone $x$.

5. An open cone, $x \notin$.

6. Lomer side of a cone scale, $x$.

7. Upper side of a cone scale witb two winged seeds, $x$

8. A ringed seed, natural size.

3. A seed, natural size. 


\section{PITCH PINE.}

\section{Pinus rigida, Miller.}

FORX-Lsually attains a helght of 40.50 $\mathrm{ft}$. and a diameter of $1.2 \mathrm{ft}$. abd seldom exceeds 70 $80 \mathrm{ft}$. is height and $3 \mathbf{f t}$. ju dianeter. Trunk rather taperiog excent in occasional pure and closed stands. Opea grown trees bave an Irregular wide prramidal cromn. Braches pamerous, Irregular, gDarled, often drooping, and covered by small plate-like scales and oumerous persistedt cones. Crown is often so trreguiar and scraggs in appearance that it becomes picturesque.

BARK-On young branches greun aud snooth soon becoming yellowish, later grajish-brown and roughened by persisteat bases of the bud-scnles. On joung trunbs roughened with reddisb-brown scales, with age lecomlug rougler through deep fursows and flat ridges which Eefrarate into thin redlish-brown scules. The scnles sometimes apnear black, whence the name Nigger Pine. See Fig. 46.

TWIGS-Stout, Lrittle, smootb, brown and very rough on accout of persistent elerated and decurreot lises upon whlch the leap-ciustars rested.

BUDS-Orate, sharp-pointed, often resfuons, 3.7 of an incb long, corered with imbricated, loose, brown, and stining scales.

LEAVES-In sheathed clustera of 3, slont, rigid, dull-fointed, closely and sharnly toothed, at first light green, later jellowlsh-grecn, $21-5$ incbeg long, with stomnta on all sides, and contait 2 fibro-vasenlar bubiles and $3-\bar{t}$ resin-ducts.

FLOWERS- Imwar in April or May, stabluate flowers clustured at basp of new growth of season, are cylindrical. Seliow, $z$ of an inch long, and produce a enormous amount of polled. Pistlllate Howera solitary or clustered, latcral on dew growth, at first green, later tinged with red.

FRUIT-A cone maturing in 2 seasons. It 3 Inches long, sessile or stort stalked, orate, occnrs solitary or whorled, ofted stands at right angle's to the brancb, and persists for 10 or more yenrs. Cone scales thickeoed at apex, arwed with short rigid recurved prickles. Seeds winged, dull or glossy black, sometimes nottled with gray or red dots.

WOOD-Non-porons: resinous, light, hritte, coarso grained, rather durable, hrownish-red with abundant lighter sapwood. Weighs 32.10 lbs, per cubic loot. Lsed for rallroad tles, charcoal, mide props, Inel, sometimes for construction timber and lnmber.

DISTINGUISHING CHARACTERISTICS-The T'itch Pine, also know as Jack Pjne and Nigger Pine, is the only natire Pide of l'ennsylvania with leaves in sheathed clusters of 3 . The Iellow Plne may occasionally bave the deedies in clusters of 3 , bat usually 2. Pitch Pine has a rery Irregular and scragss anpearance dut to the dead and gonrled brapches which are often corered with clusters of persistent cooes. The bark is thick and irregularly dssured with ID. tervening dat ridges which separato into thu reddisb-brown suntetines black scales. Truaks are often are scarred. Such truaks are frequedty corered with dedse mats or clusters of leaves and short branches.

RANGE-Xers Brapswick to I.gke Ontario on the north, sonth to Firginia and alomg mountains to Georgin, and west to western New Fork, Kentucky and Tepuessee.

DISTRIBUTION IN PENNSYLVANIA-Fond in practlcally all parts of the State. Occurs in excellent pure stands at the base of the Sionth Mountains in Franklin county, and in Pike connty. In many regions it occurs only as a scattered tree mixed with hardwoods.

HABITAT-Commón on dry burned-over areas, sterile plains, grarelly slones, rocky clifts, and sometlmes found in swamp. In the glnclated area it is common on rocky glacial soil.

IMPORTANCE OF THE SPECIES-From a commercial poipt of riew this species is not so Important as the White Pine or the Red Pine, but it is gradully growing in Importasce since new uses are found for the wood and prices of other woods are rising. Silsiculturally it is valuable on account of its adapataullity 20 poor soil and its fire resisting qualities. These qualities recommend it for reforesting neglected or fire endangered lands on monntain blopes a well as low sandy areas. It may not be the species nltimately desired upon the area, but may act as a sbelter during the establisbment ef a stand of a more raluable species. 


\section{RED PINE. \\ Pinus resinosa, Aiton.}

FORM-Csually from $50-75 \mathrm{ft}$, in height with a diameter of $2-3 \mathrm{ft}$, but reaching a maximum height of $140 \mathrm{ft}$. with a diameter of $41 \mathrm{ft}$. In closed stands trunk is straight, toll, slightlytapering, and free from lateral branches for a considerable distance from the base while in apen stands the lateral branches extend nenrly to the base and the trunk is often branched and strongly-tapered. Crown usually broad, irregular, pyramidal, with darb green foliage tufted at the ends of the bravches. See Fig. 42.

BARK-Reddish-brown, 31$\}$ inches thick, dirided bJ sballow farrows into broad at ridges whicb peel off in thin scales. See Fig. 45.

TWIGS-Stout, slightls roughened by persistent bases of bud-scales; at first yellowish-brown, later reddisb-brown.

BUDS-orad, polnted. $*$ ? of an inch long. Lud-scalcs brown, thin, laose, and frioged on the margín.

LEAVES-In sheathed clusters of $2,4.6$ Inches long, dark green, rather slender and flexible, sbarp, persisting for 3-5 sears.

FLOWERS-Appear in May. Stamingte flowers about of an inch long, occur in dense clusters at base of growth of season, bave dark purple aothers. Pistillate flowers subterminal, 2 to 3 in a whorl, short-stalked, scarlet.

FRUIT-A cone about ? inches long, nearls sessile, light browo, orate-conical when closed and somewhat spherical when open, perslsting until the following jear. Cone-scales chestnotbrown with ends slightly thickened and transsersely ridged but not armed with spines or prickles.

WOOD-Non-porous; resinous, hard, pale red, with thin light sawwood, and very conspicuous medullary rays. Weighs 30.25 hs per cubic foot. Green wood is rery beary and will sink. Used for hears construction, piles, masts, in general for nearls all other purposes for wbich White Pine is used.

DISTINGUISHING CHARACTERISTICS-The Tied Pine, also known as Norway Pine, is es. sentially $\mathrm{n}$ northein trce and is the only native Pine of Pennsylrania with needles $4-6$ inches long, sheathed in clusters of 2. Its cones are ahout 2 lucbes long, subterminal, and bear scales which are not armed with splpes or prickles. The peedles are borne in tufts at the ends af branches.

RANGE-Distinctly a northern tree occurring from Nova Scatia and Quebec on the north to Pennsylrania on the soutb, and rest to Minnesota.

DISTRIBUTION IN PENNSYLVANIA-Found only in the porthern part of the State. Its sonthern limit in the central part of the State is about at Willamsport. In the eastern and western parts it does not come so far sourh as in the central part.

HABITAT-Lsually foumd on dry gravelly ridges, mountain-tops, and dry saudj plains. Rare on flat lands with wet clay soil.

IMPORTANCE OF THE SPECIES-The Red Fine is a raluable timber tree usualls mired with other species of trecs but occassionally fonnd in dense pure stands in Minnesota. Thls tree is remarkably well adapted to natural seed regeneration since it produces a great quantity of light, large-winged seeds which are readily disseminated by the wind and does not shed an its secls at the same time. It leadily adapts itself to variable conditions, is attractive ornamentally, and should be regenerated naturally where seed trees are at band and artificially upon such areas where othe: more valuable trees will not grow. 


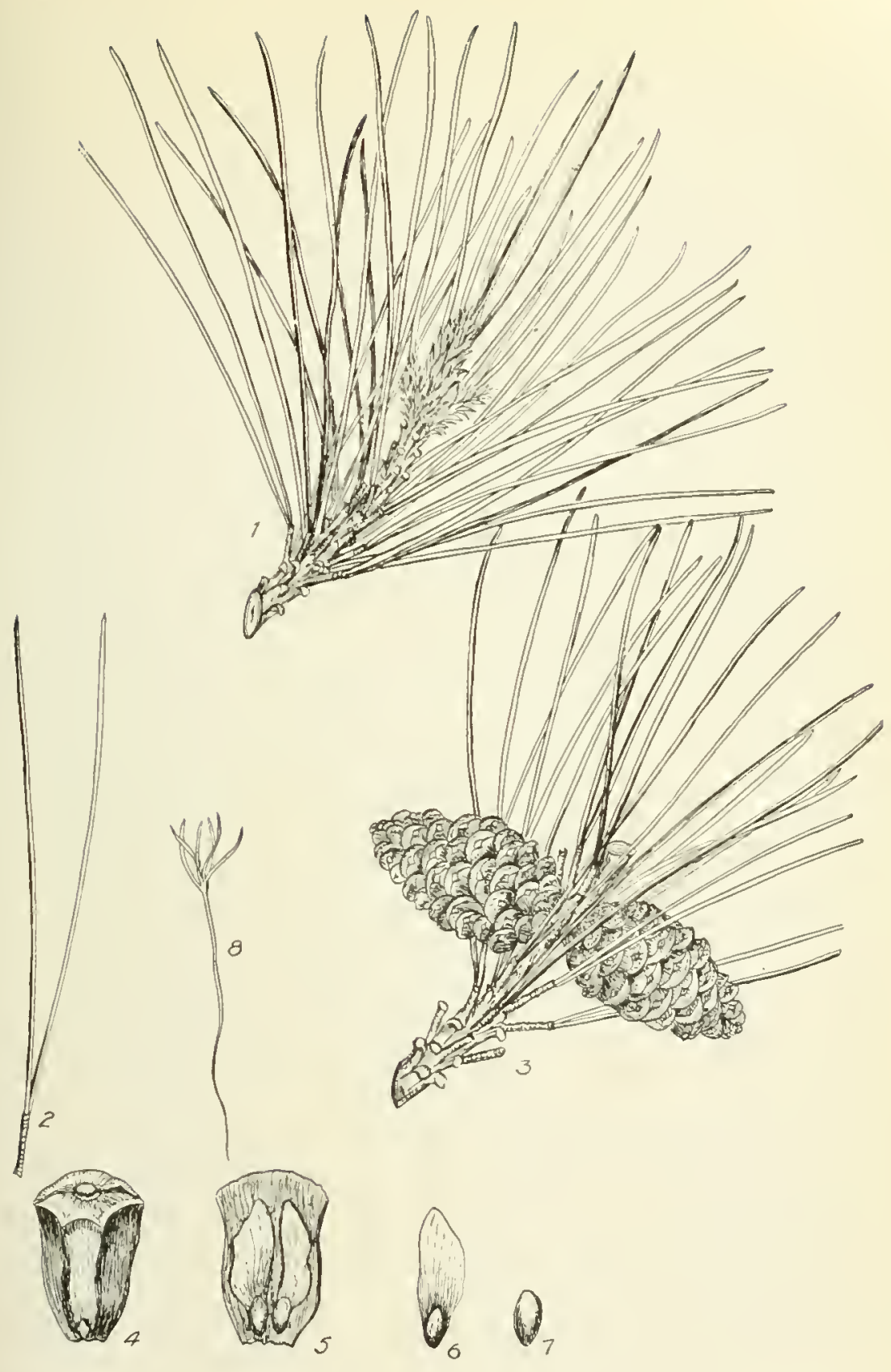

PLATE XIV. RED PINE.

1. Eranch with newdles and terminal cluster of buds, $\leq$ b.

. A cluster of two needles, $x \quad 1$.

3. Branch with needles and cones, $x$

4. Lower side of an unarmed cone scale, natural size.

5. Upper side of a cone seale with two winged seels, natural slze.

6. A winged seed, natural size.

7. A seed, natural slze.

8. A seedling, $x$ t 


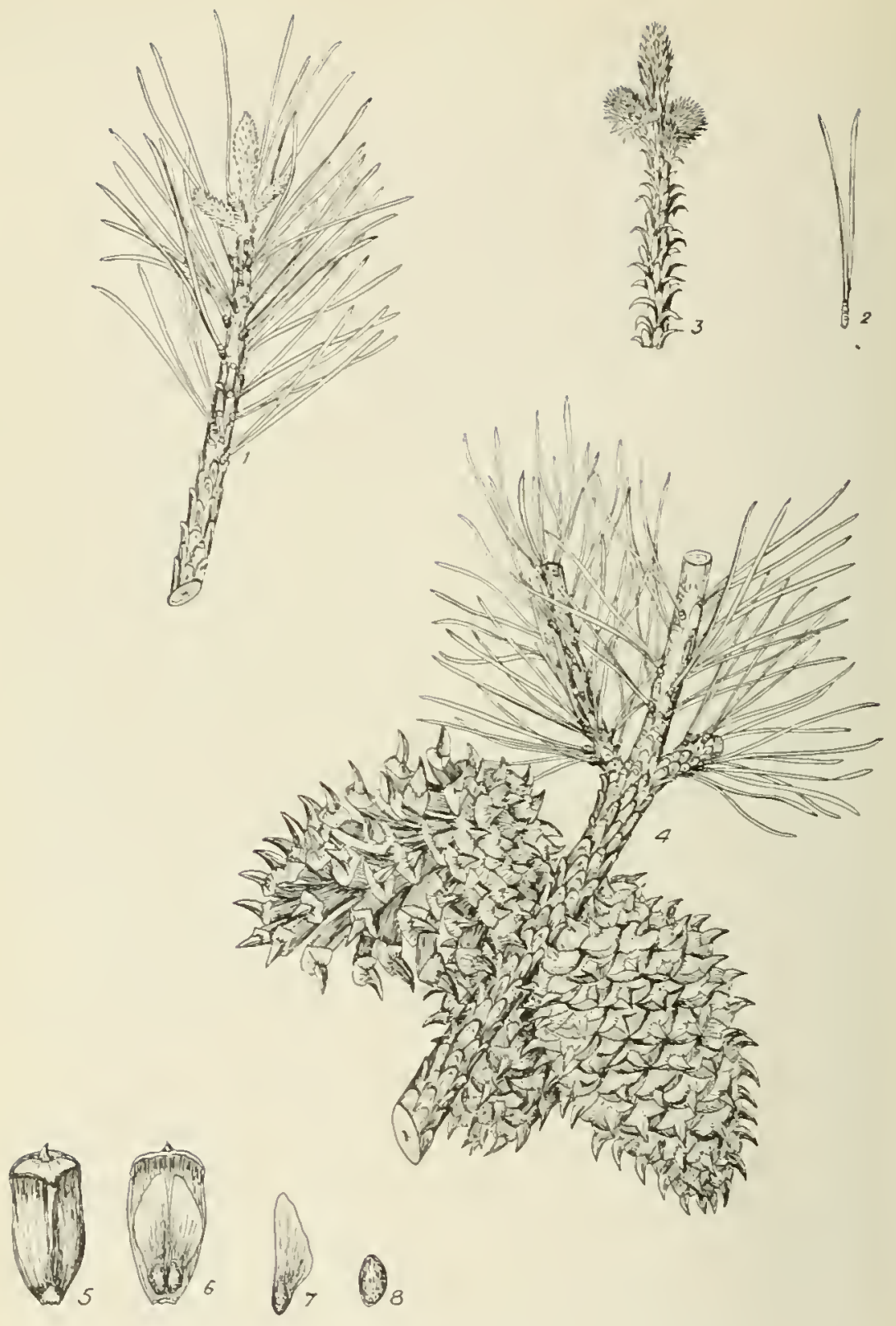

PLATE XV. TABLE MOUNTAIN PINE.

1. Branch with needles and terminal cluster of luds, $\mathbf{x}$.
2. A cluster of two stiff, twisted and sharp-pointwd needes, $\mathbf{x}$,

3. New growth with two pistillate fluwers. $x$ is.

4. Brancb with needies and a whorl of tliree cones, \& 1 .

5. Lower view of a cone scale with a spine. $x$.

6. Lpper view of a cone scale witl two ningerl seeds, s

7 A wincel seed, $x z$

s. a secu. natural size. 


\section{TABLE MOUNTAIN PINE. \\ Pinus pungens, Lambert.}

FORM-Csually attains a height of $30-40 \mathrm{ft}$. with a diameter of 1 - $2 \mathrm{ft}$., but when crowded ju a closed forest stand it may attain n height of $60 \mathrm{ft}$, with a dinmeter of $2 \mathrm{z}-3 \mathrm{ft}$. Crowo ia closed stands shallow, irregulur, uarrow, and round-topiled. In the open the trunk is short, bearing short lateral branches, the upuer ones ascending and the lower ones drooping. often the tree is covered with branches to the base of the truak so that the lower branches lje prostrate on the ground. See lig. 43 .

BARK-Dark reddish-browo, 1 -s of an inch thick, roughened by stallow fissures into irregular plates which peel on in thin films.

TWIGS-Stout, rather brittle, at fisst smooth aud light orange to purplish, later rather rough and dark brown.

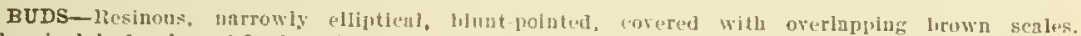
Terminal buds about $1-3$ of an inch long, the luteral silorter.

LEAVES-1n clusters of 2 surrounder] by a persistent shesth, 2-4 idoches long, light bluishgreen, stont, very stiff, nore or less twisted, very sharp-pointed, tufted at the ead of the brauches, liersisting for 2.3 gears,

FLoWERS-Apjear In April or May, Staminnte fowers ocenr in long, loose clusters at the base of the growtl of the season; have jollow anthers. Pistillate dowers appenr liaternlly along new growth in whorls of $2-5$ or 7 , and nre very short and stont-stalked.

FRUIT-A cone 3.4 inches long, sessile, oblique at the base, jo whorls of 25 or 7 or eyen more, ligbt brown, sluort ovoid, [rersisting for 15 or more sears but shedding seeds soow after maturity. Code-scales, especinlly those near base, much thickened and provided with a strong

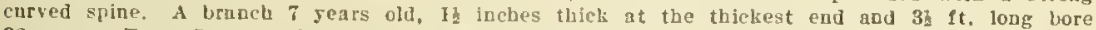
30 cones. Trees 5 years old nnd $2.3 \mathrm{ft}$. thll pu be found whleh benr dereloping cones.

WOOD-.Ton porons; resinons, brittle, cnatse grained, pale ceddish-brown with liglut sapwnod. Welgh 30.75 lbs. per cubic foot. Used primarily for fuel and clarcoal, and oceasionally snwed into lumber.

DISTINGUISHING CHARACTERISTICS-The Inhlo Mountain Pine, nlso known as Poperky Pine, can readils be distinguished by 1 ts coarse and massire cones aromed with very stout curved spines. The colies uppear usually in whorls of $3,5,7$ or more and persist for inany jenrs. The stout, twisted, and rery sharp-polnted oeedles are also eluaracteristic.

RANGE-From Penasylvnia and New Jersey along the mountains to North Carolioa and north erd Georyia.

DISTRIBUTION IN PENNSYLVANIA-Sparse tn nbundant unon the monntnins in the south. central part of the state and extends northeast on the mountains to Schuglkill county. It is primarily a southern species whict occurs io jure stands on the pountains in Franklin county. Common on some nountajns in Fulton, Blair, lluntingdon, Mlalio. Perry, and Voion counties. Small outposts of it are also reported Prom Iaucaster and York counties,

HABITAT-Commonly found on dry, rocky, and gravelly slopes, Occasionally found at the base of the mountains on somerhat moist clayey soll.

IMPORTANCE OF THE SPECIES-The lumber outnined from this tree is of little commercigl importance on acconat of its small size and the mumerons knots which it contains. It is a very ngressive species and is adapted for the regeneratioo of worn-ont felds as well as to protect rocky slopes and promidences from erosion. It occasionally reaches a size which will yleld luwber. Trees 20 inches in diameter and with a clear length of 25 feet are not uncommon locally fa the southern part of the state. 


\section{YELLOW PINE.}

\section{Pinus echinata, Miller.}

FORM-Attains beight of $80-100 \mathrm{ft}$, occasionally $120 \mathrm{ft}$, and dismeter of $2-3 \mathrm{ft}$, occaslonallf 4 ft. Crown shgllow, wide, pjramldal or rounded. Trunk clean, tall, and slightly tapering. Iateral branches relatively ligbt, very brittle, intolerant of shade, and consegnently drop off Fery early producing the clean, tall, and stately trunk. See Figs. 11 and 34.

BARK-On joung branches at first pale green and smooth, later reddish-brown and acaly. On old trees dark brown tinged with cinnamoo-red, often 1 inch thick, broken by distinct tssures into 1rregular, often rectangular plates which peel of rery readily into nnmerour thin film scales. See Fig. 4i.

TWIGS-Staut, brittle, slightlj rough, at first aften corered with glaucous bloom, later be. coming reddlsh.brown.

BUDS-0roid, dull-pointed, corered with sharp-polnted dark brown scales.

LEAVES-Lsually in clusters of 2 sometimes 3 or eren 4, slender, fexible, faintls toothed, abruptly pointed, dark blulsh-grcen, 3-5 inches long, surrounded by persistent sheatb, and perBisting for $2-5$ years.

FLOWERS-Alpenr in April or May. Sinminate towers clustered at base of new growth uf season, nearly sessile, pale purple. Pistillate fowers rarely solitarJ, but usually 2.4 in a $\mathbf{w b o r l}$ just below end of new growth, borne on stout erect stems, and pale rose colored.

FRUIT-A cone maturing in 2 sessons. One sear old cones short-3talked, oral, abont 1/6of an inch long. Mnture cones short-stalked or sesslle, conle when closed and oroid when open, 14-2 Inches long, often persisting for 2 or more years. Cnne-scnleg hare slightlj enlnrged enda terminated bJ went or decldnous prickles. Seeds small, tringgular, $3 / 16$ of an inch long, of an inch wide, yale brown mottled with black spots.

WOOD-Niou-porous: reslnous, hard, strong, with distinct spring and summer wood, yellowish or dark brown. Weighs 39.04 lbs, per cubic foot. it inruishes the most desirable of the ycllow pline lumber of commerce and is largely manufactured into lomber used for general construction and earpentry.

DISTINGUISHING CHARACTERISTICS-The Yellow Pine, nlso known as Sbort-leat Pine, is rarely found In the northern part of Penssyania which will preveat confusing it with the Red Pine natire only to the oortbern part of the state. It cao be distiogulshed from the other specles af Pine fouod growing with it in this State bJ its rather slender texible leares in sheathed clusters of 2, sometimes 3 or 4 , its conic cones with scales terminated by weak or deciduous prickles, its brittle branchlets, and its cleaa, stately, slightly.taperlng trunk, the bark of which is marked of by deep furrows into irregular or rectadgular plateg which peel nfl very readliy into numerous thin $61 \mathrm{~m}$-like scales.

RANGE-Southeastern New Fork and northern Penosylvania to Floridn. Westward to Illnois. Kansys and southeastern Texas.

DISTRIBUTION IN PENNSYLVANIA-Thls is essentlally a southern specjes but extends into Pennsylvauia. It is nsually mixed with hardwoods. Large specimens of it are fond in the Benjamin George tract (Fig. 11) near Mont Alto, Franklin coonty. It Is also reported on the Cook irgct in Jefferson and Forest counties, nnd in Fulton, Lancaster, Perry, Lycoming, and Union connties.

HABITAT-Cummon on poor, sandy, or clayey soll. It is a tree of the plains and foothills. Reaches Its cotimnm derelopment on the uplands and undulating plalas west of the Misslsslppi. In the east it is usually mised with hardwoods.

IMPORTANCE OF THE SPECIES-Next to the Iong-leaf Pine this species is the most important of the Sonthern Pines. It is destined to plas a very important role in intore forest management in the regions where the conditions of growth are farorable, on account of ita economic and commercial ralne. This species, on account of the ease with which it regenerates naturally, requires little assistance from the bands of the forester. It can be planted apon farorable situations anjwhere la Pennsylrania. 


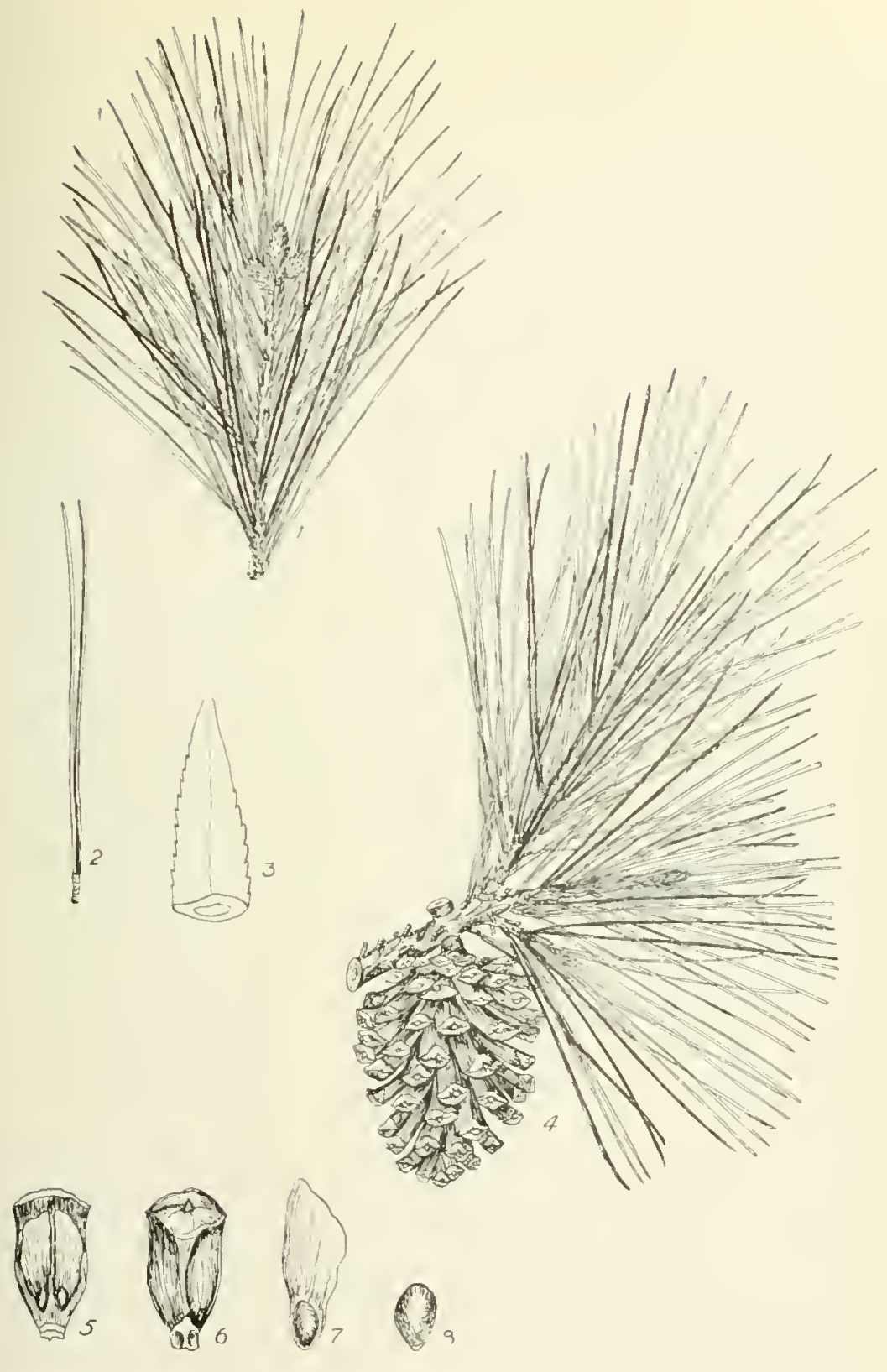

PLATE XVI. YELLOW PINE.

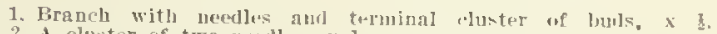

2. A cluster of two uecdles, $x$

3. Tip of needle with sorrate margin, enlarged.

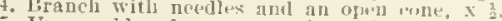

5. Upper side of a cone sulfe witli two winged seeds. $x_{2}$

6. Lower side of a (o) sente, $y$

7. A winged sued, natural sire. 


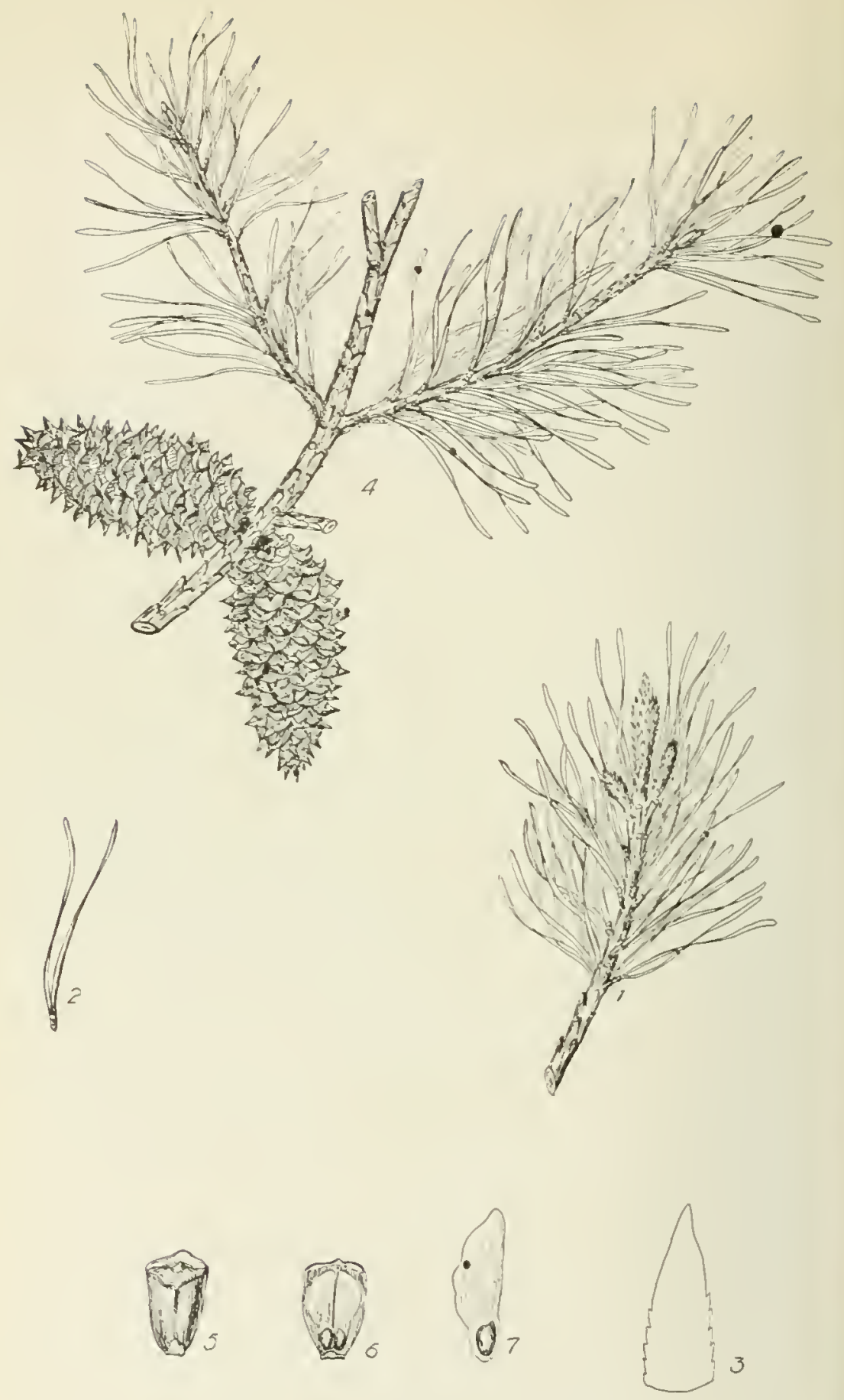

PLATE XVII. JERSEY OR SCRUB PINE.

1. Brageh with netules and terminal cluster of 5 . T.ower side of a cone srale. I 3 .

2. A cluster of two needles, $x$

3. Tip of a needle with serrate margin, en- 7. A winged seed, nutural size.

4. Brancli with nevedle and closent cones, $\mathbf{s}$. 


\section{JERSEY OR SCRUB PINE. \\ Pinus virginiana, Miller.}

FORY-Lsually nttalns a helght of $30.40 \mathrm{ft}$. wh a diameter of 18 faches, but reacheg larger dimenslons, especially in Tndjana. Trunk usually short slnce the long horizontal or penđuloos bramches corer it almost to the base. Young trees have a pyrnmidal form whlle older treeg develop a ruther fat-topped conic corm.

BARK-On the truak \& 1 of an lacb thick, dark reddisb-brown, shallowly fissurcd into amall Dat plates separating Into thin flm-3jke scales. smoother than that of our other natlre Plneg. Sce Flg. 48

TWIGS-Slender, tough, fexlble, rather smooth, nt first grecnlsh-purpte and corered with n glacous bloom, later light graylsh-urowa.

BUDS-Orate, shnry-pointed, i-1 of an inch long, covered with orcrlapping, sharp-polnted, brown acales.

LEAVES-In clusters of 2 with peralstunt slenth, 113 lacbes long, twlsted, brlght grcen, ratber stout, fragrant, sharply thick lojoted, fincly toothed, divergent abore the shenth, and closely dispersed on iwigs.

FLOWERS-Apuear In April or May. Stnmlnnte tlowers crowded at base of growth of season, b of an loch long, ollong, with yellowisb-brown authers. Pistillnte flowers apnear near the mlddle of the season'g growth and are long-stalked, sub-globose, solltary, or few in a whorl.

FRUIT-1 cone, 2-3 \{nches Jong, usunlly sussllo, sometimes slightly curred, conical when closed nnd orofl when opcn, seldom persisting for more than 3 or 4 yearg. Cone-scales thin, nearly fat, thickened at apex, and termanated with a prickle. Seeds rounded, $\frac{1}{3}$ of no incb long, fs of an fach wide, and pale brown.

WOOD-Xion-porous; slightly resinous, light, solt, brittle, pale orange, with rery ught sapwood. Welgbs 33.09 lbs. ner euble foot. [sed for fuel, and to some extent for railroad ties and lumber.

DISTINGUISHING CHARACTERISTICS-The Jersey or Scrub Pine ean be distlaguished by Its short, twisted, and divergent necdleg distributed in pairs along the smooth, purple, and tough brancblets. The cones are smnll, with thln rather fat scales and prorlded with slender urlckles. The divergent fnd twisted needles closcly dispersed on the twigg gire ratber a dishercled aprearance to them, and permits one to disthgulsb thls tree at a distance alnce the light of the background is diffusel through it so evenly. The bark is smoother than in the other native specles of Pine.

RANGE-Southenstern New York and Pennsrlvmala, soutb to Georgia and Alabama, west to Indlana and Kentucky.

DISTRIBUTION IN PENNSYLVANIA-Found localiy throughout the southerd part of the Strte, It is peimarlyy a southern specieg and extends as far nortb a Allegheng conty in the restern part, Clinton and Lycoming counties in the central part, and Northampton county in the egstern part. In Franklin county it is ususlly foond at the base of the mountalos, seldom ascending the mountalns or cxtending into the ralley.

HABITAT-Common on ligbt sandy or noor rocky soil. It is common on the sund barreas of Sew Jersey, and on exhuusted farm land aod cut-orer areas.

IMPORTANCE OF THE SPECIES-It is not of much importance as a timber tree on accoont of its small aize. While it is of litte commercial 1mportance still it is of considerable economic ralae as a relorester of worn-out and neglected lands. For ornamental purposes it bas been ased rery little, other species heing preferrcd. 


\section{SCOTCH PINE.}

\section{Pinus sylvestris, Linnaeus.}

FORM- Csually $70 \mathrm{ft}$. high with a dianeter of $13.3 \mathrm{ft}$. lut nag attain a beight of $120 \mathrm{ft}$. with

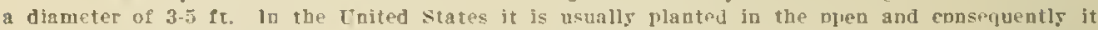
bas a short. cloan, often hrapebed trunk hearing pumerous, more or less drpoping lateral branches. Trees in closed stands prounce strajobt and clean trunks with little taper and a short complact crown. At a distance it resembles the ['jtcb Fine.

BARK-00 the trunk sculs and peels off in flakes from the rillues whlch nre sepnrated ly long slallow fissures. Lower part of the trunk is rough while the opper is rather smooth and distinctly reddish in color. Outside bark on the lower trunli is gragtsb-brown while the lnner is reddish brown.

TWIGS-Fairly stout, brittle, dark ywluwish-gray, smootb, not glokss.

BUDS-0rate, blunt-roinlexl, browu, oftus sommbat seslupus.

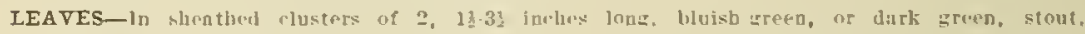
twisted, semi-circular in cross-section nud contaluing 2 fbro-vascular bundles.

FLoWERS-ippear in April or Mng. Sinninate howers elustured on the lower balf of this

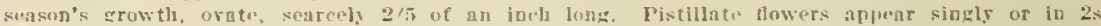
just below the termingl luds of thls senson's growth, are ovoirl and short-stalked.

FRUIT-A cone 11-2h inches long. short.stalked, conic.ublong, solitary or in 2v usually pointing backward and grayisb or reddish in colpr.

WooD-Yon-porous: resincus, light, redlisb-brown with thick linbt jellnwish or reddish sep. wood. Lsed for genernl construction, lumber. ralinan tir.s. hop-poles. grape vine frolos nnd fuel

DISTINGUISHING CHARACTERISTICS-The Swoteh Pine, a nntive of Europe, mas he distinguished from lise other Fines of Fennsrlynin by the redish nppearance of the upper part of the trunk and adjoining branches, the buish-green luaves 11-31 inclies long, snd the barkwardnointing cones. It Las rougber twigs than the Jerses or Scrub Plne, shorter needles than the Red Pine, stouter neelles thau the Frllow r'ine, and blunter-poiated needles than the Table Mountaiu Pine.

RANGE-Not native to Americu. Ahrond it extends nrer the grenter lunt of Eurne and part of western Asfu. In the Cnited sitates it cun he planted over a large area in the northeastern stintes, the lake states, fud some of the prairie states. Planted for ornmental purposes in many parts of this state anil hy the Pennsylvania Department of Forestry in numerous plantations.

HABITAT-This species is judifferent to soil requirements, water, bint of snmmer, nnd colil of winter. It will grow on all classes of soil, even dry. sterile saru. The rate of growth deriends more on the phssical structure than the chemical composition of the soil. It prefers deep well druined sandy loam. it is very intolerant of shade.

IMPORTANCE OF THE SPECIES-The Scotch Pine is a rers importnot tree in its natire and ndopted Eurupena home. It plass n prominent role in the forst structure of parts of Germany, such as the sandr plnins nlnag the Rhine and the large sandy areas of northern and enstern Frussia. Fxcellent forests of this species ean he seen in Germung, but it is not necessary to introduce it juto the Cuited states exteusirely for forestry puryoses since me bare superior antire species It grows rers rapidls in south, but later more slowly. 

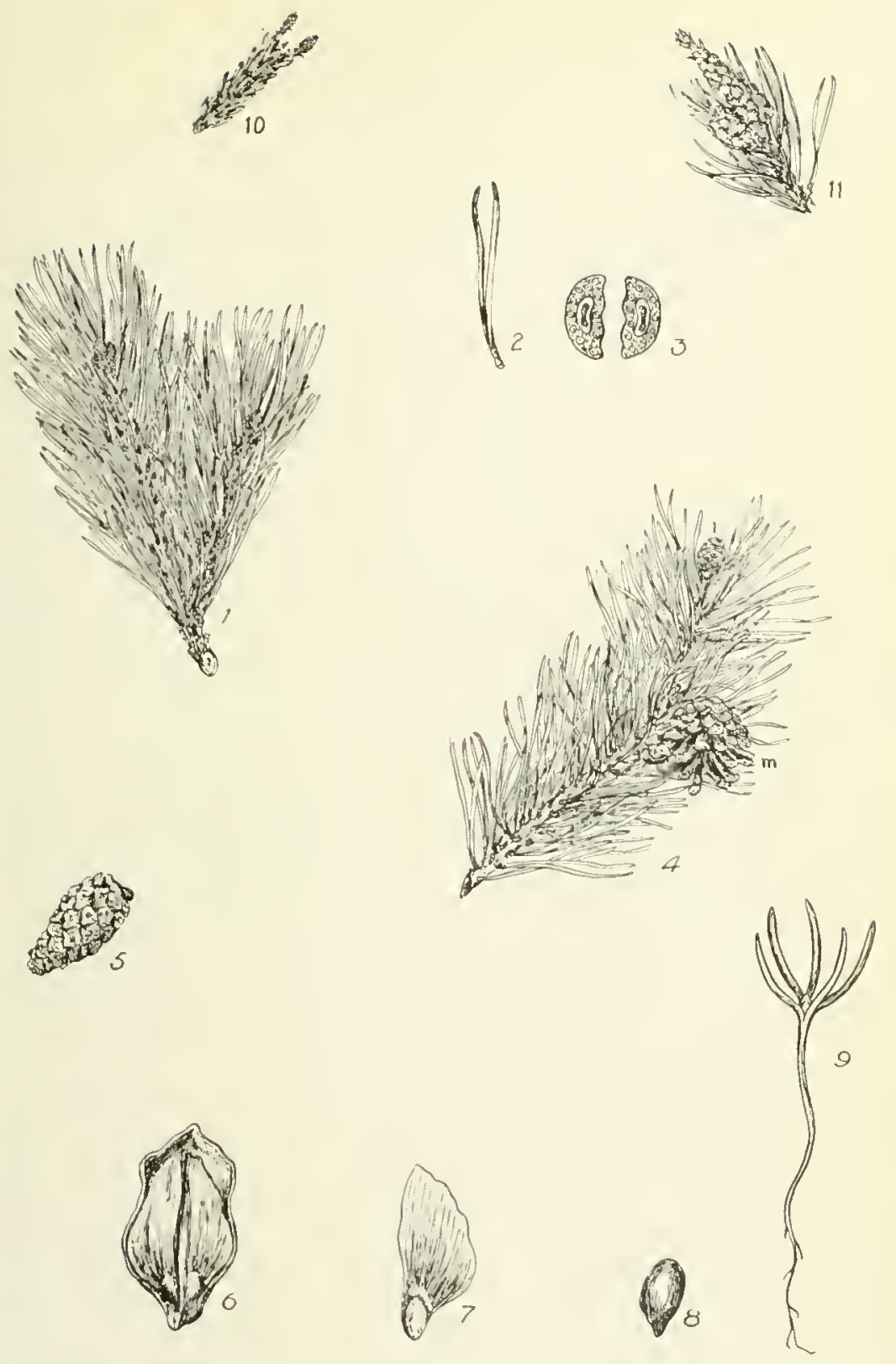

PLATE XVIII. SCOTCH PINE.

I. A brancl, with needles and buds, $x$ t.

2. A cluster uf two needles, $x \notin$.

o. Cross-section of two needles, enlarged.

4. Branch with neerles; $i$, imbiature cone; m, mature cone,

5. A closed cone, $x$ z

6. A cone scale witl two winged seeds, enlarged.

7. A winged secil, enlarged.

8. A sped. entarged.

9. A seeding, natural size.

10. A small portion of a brauch with two pistillate flowers, $\mathbf{x}$.

11. A branch with a cluster of staminate flowers at the bise of the new growtb, $x$. 


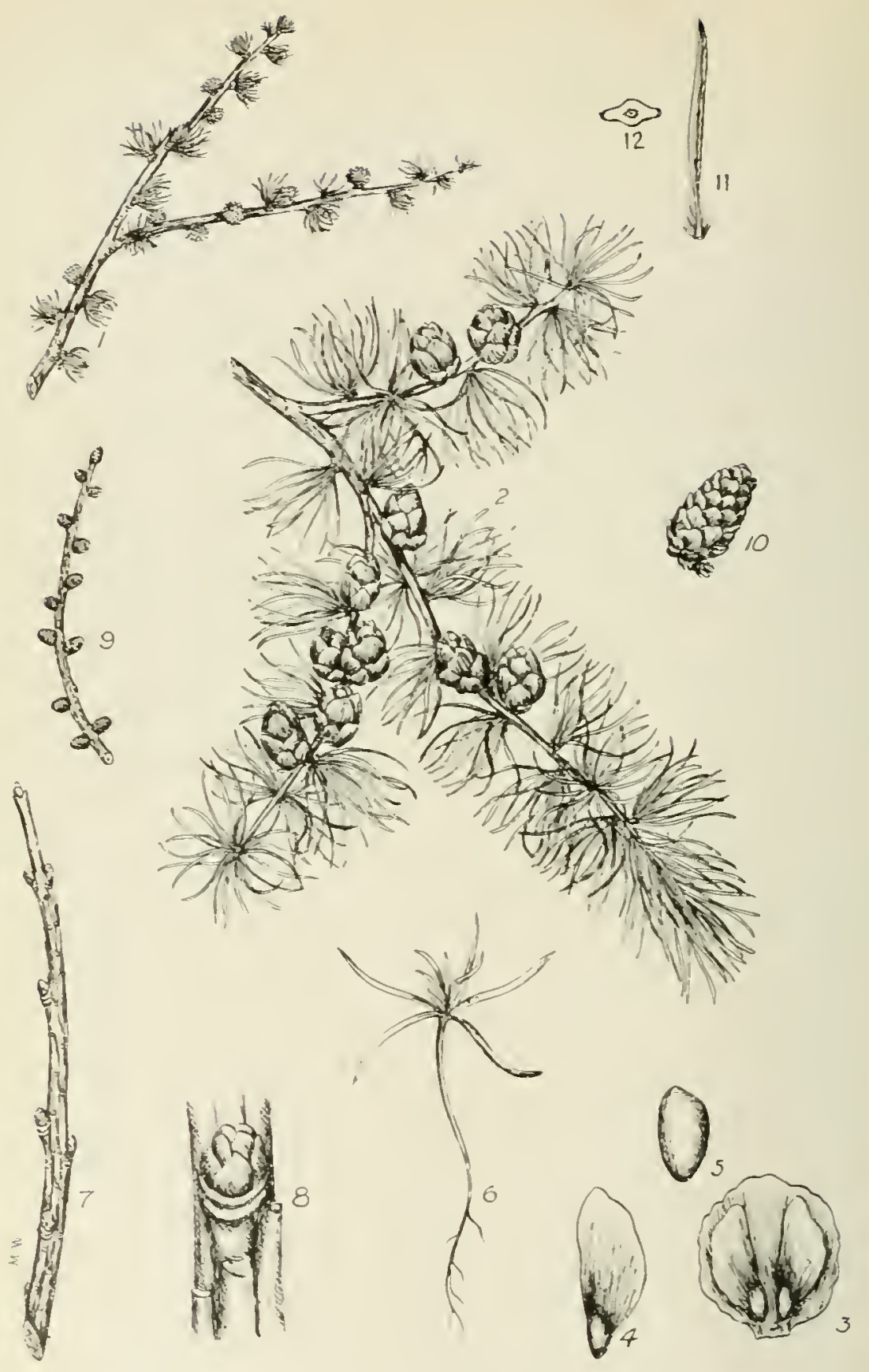

PLATE XIX. AMERICAN LARCH.

1. Branch with dereloping leares and fowers. [ . Terminal portion of a ninter branch, natura) 2. Brach with neelles (clustered and solitary) 3. A cone scale with two wingel seeds, enlarged. 4. A ringed seed, eularged.

5. A seed. enlarged.

6. A seediug, enlarged.

s. Section of a minter branch. ealarged.

9. A winter brancb with lateral spars. I 3 . 10. A cone of Enroptan Larch (Larix decidua). 11. Legf , te Europear Larch, 5 A

11. Cross-section of leaf of Enrojiean Larch, enlarger. 
AMERICAN LARCH.

\section{Larix laricina, (Du Roi) Kioch.}

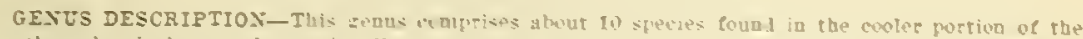

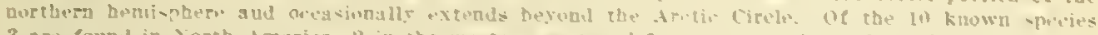

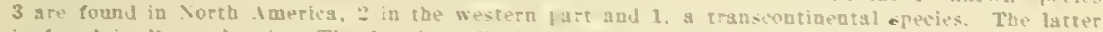

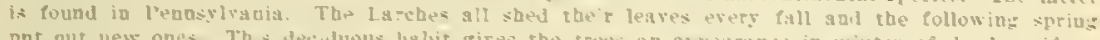

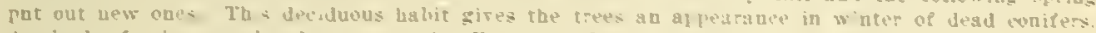

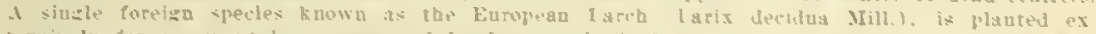

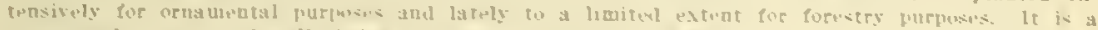

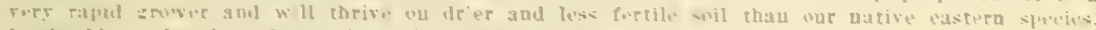

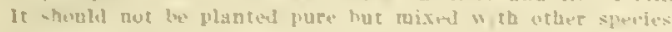

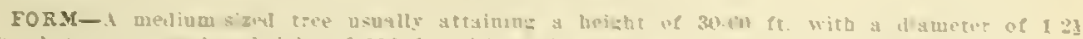

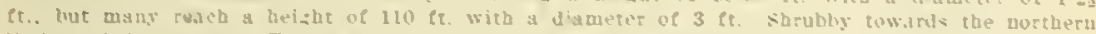

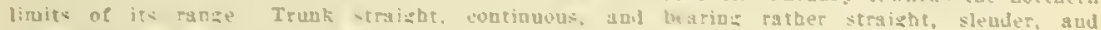

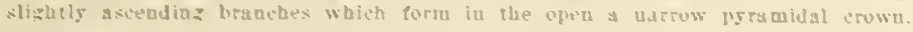

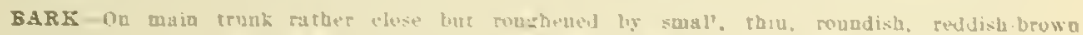

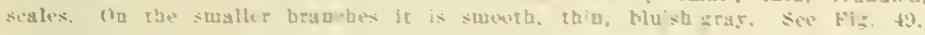

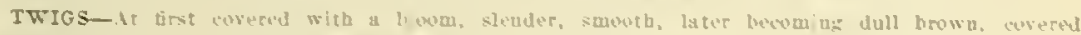
with numerous, short, stuur, sulur like latersi branclas.

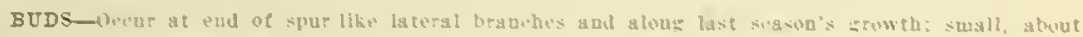

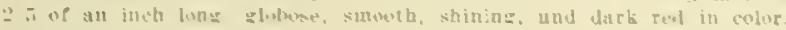

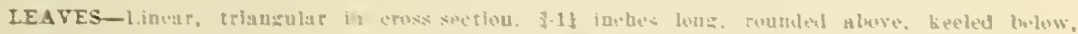

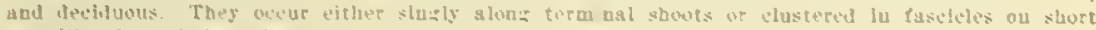
sput like lateral Drakibes.

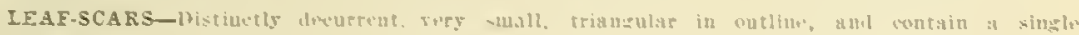
bundle star.

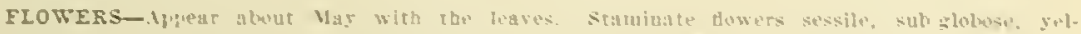

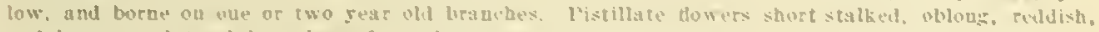
and boruc on lateral braukhas of frevlous yeas.

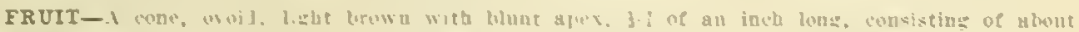

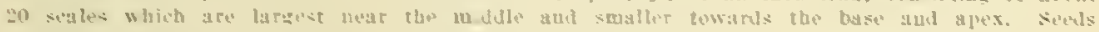

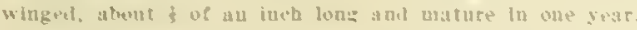

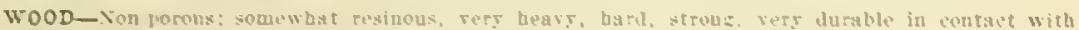

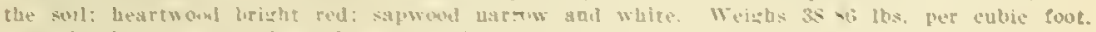

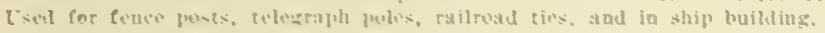

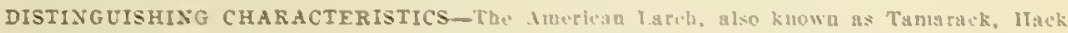

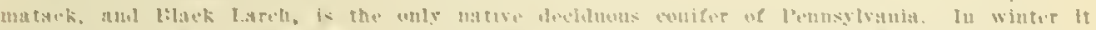

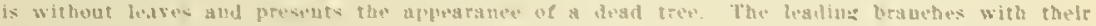

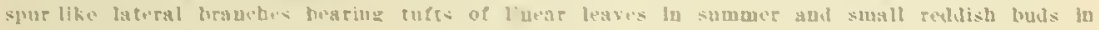
winter. afe ehafgetertistle. It hears ligtle resemblance to ang of ant hative coulfers hut does

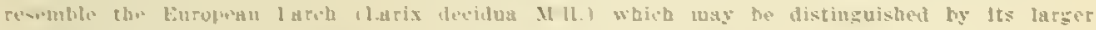

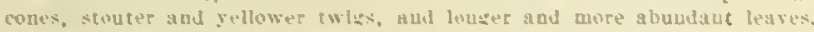

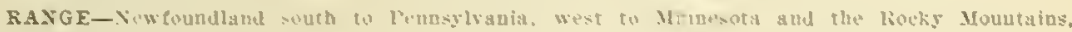
tbrougb Rritisb Colubibia to Alaks. It is aue of our tew trauscoufiueutal species.

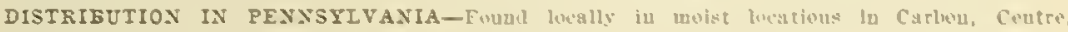

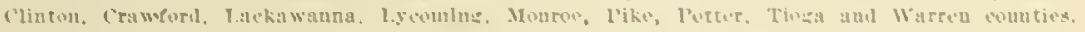

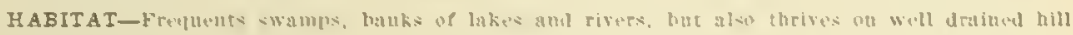

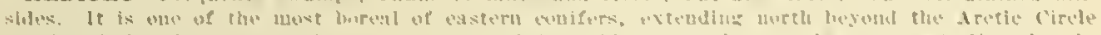

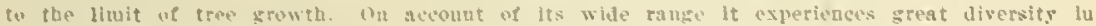

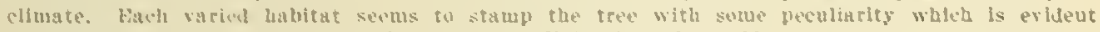
In its form and structure. It regules abudant light throughout life.

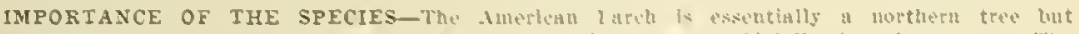

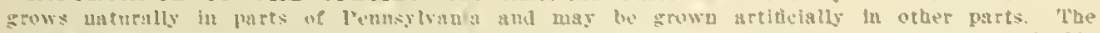

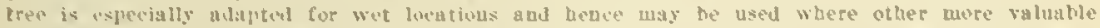

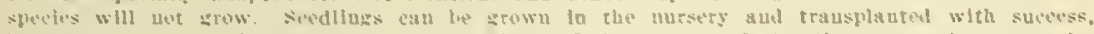

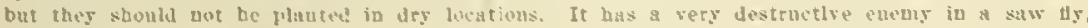

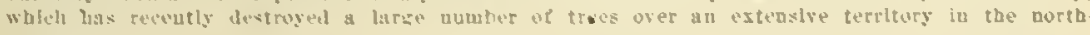
easc. 


\section{THE SPRUCES-PICEA, Link.}

The Spruces are evergreen trees with stiff, often sharp-pointed needles which persist for $7-10$ years. All the species of Spruce found in eastern North America and all bit two species found in western North America hare four-sided needles. The two exceptions have flattened ncedles and bear stomata, commonly knorn as breathing pores, only on the upper surface, while the species with four-sided needles have stomata on all sides. The needles are spirally arranged on the branches and are not stalked but horne on decurrent projections of the bark known as sterigmata. The staminate and pistillate flowers are separate on the same tree, usually on the same branch. The staminate, which hear the pollen, are yellow to red in color, cylindrical in outline, and open lengthwise. The pistillate, which develop into cones, are erect, cylindrical, short-stalked, and pale sellow to scarlet in color. The cones mature at the end of one season and are always drooping and usually cylindrical to orate in outline. The cones usually fall entire during the first winter or sometimes persist for a few years. Ther consist of numerous persistent conc-scales which are thin and unarmed, and consequently stand in strong contrast with the thick, usually armed, cone-scales of the Pines. The cone-scales are largest near the center and decrease in size towards the apex and the base. The fertile scales bear two winged seeds on each cone-scale. The seeds are usually light and bear a rather large wing, by means of which they are disseminated over great distances by the wind.

The trunks of the Spruces are straight, continuous, and taper sradually to the top. The lumbermeu for a long time looked unfarorably upon the Spruces but owing to changed economic conditions and a more thorough knowledge of their technical value, these same species are now' considered among our most important commercial species. The wood of these same species is now considered amongst the most important of the northern hemisphere and especially adapted for the manufacture of paper pulp. The spruce forests of North America for a long time remained practically untouched, but are now heing exploited on a gigantic scale. The march of forest destruction is very rapid since an enormous supply is required for the paper pulp industry. In order to supply this growing demand and not diminish the arailable supply of spruce wood it is necessary that proper and systematic treatment be given to the existing spruce areas, since we cannot hope to import a supply sufficient to satisfy our demand. 
This genus comprises about 18 to 20 known species, of which numwer $S$ are found in North America, 3 in the eastern part and 5 in the western part. Two of the eastern species are native to Pennsylvania. In addition to the native species 2 species, exotic to the State, are commonly planted for ornamental purposes, viz., the Norway Spruce (Picea Abies (L.) Karst.), and Colorado Blue Spruce (Picea pungens Engelm.). The subjoined key will distinguish the spruces commonly found in Pennsylvania.

\section{KEY TO THE SPECIES.}

1. Cones cylindrical, over 3 juches long; termlnal part of lateral branchlets pendulous: leaves slender, dark green, glossy, sharp.pointed, .................. P. Abies

1. Cones orate to ollong. less than 3 inclios lowg; torminal part of interul hrauchlets Page.

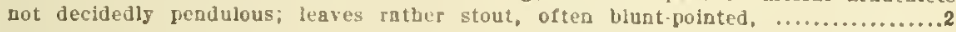

2. Leares dark Jellowish-green; cont's elongated-ovoid with clear browa, eutirt-margined scales, ................................................. rubra

2. Leaves bluish-zreet; cones short ovo.d; often persistiub beyund arst seuson; cone-scales dull, graglsh.brown with jagged marglu, ........................... mariana 


\section{RED SPRUCE.}

\section{Picea rubra, (Du Roi) Dietrich.}

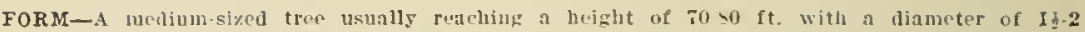
$\mathrm{ft}$., but niay attain a leight of $110 \mathrm{ft}$. with a lismeter of $3 \mathrm{ft}$. Truak straglit, continuous, sligbtly taperag̈, hearing long persisting lateral branchis which are borizantal in the midale, ascemting nbeve and dropplng bolow. Crnwn narrow, conjeal in forw.

BARK- Cn to brown scales.

TWIGS-Rougb, sleuder, light brown to dark browa, coreren with pale to back balrs.

BUDS-0void, shrp-pointed, i-1 of an ink long, corered by ormplaping shurp-pointed reddisli-lurown senles.

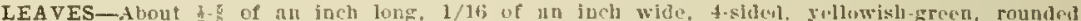
at apex, crowded, aud pointing outward lo all directions on twig. without real leaf-stalkg Lut raised on decurrent projections of lark, kaown as sterigmata.

LEAF-SCARS-Suall, with a single budle-sear, borbe on decurrent projections of bark.

FLOWERS-Appenr in April or May, Staminate and pistillate flowers separate, but appear on the same tree. Staminate oral. alnoost sessile, reddsh lo color. Pistillate ejhodrical, of of an inch long, and cousist of rounder thlu seajes.

FRUIT-A cone abont $1 \frac{1}{2}-2$ inclues long, chusatwl oroid, short-stalked, Iaturing at the end of first season: cone-scales rougded, reddisl-Lrowa, with entire margin.

WOOD-Xon-porous: light, soft, not stronk, pale in color. timgul with reil, with resin pas. sages present, Weighs :S 13 lhs. per euble foot. Used in the manufacture of paper pulp, sounding bonrols for musical instruments; aud constructlon.

DISTINGUISHING CHARACTERISTICS-The I? Spl Spruce, somptimes known as thr spruce Pine, ean the distioguished from the llack spruce ly its largot cones, which usually fall during the first winter. While those of the latter usually persist for a longer time. The conesiales of the lied sipru are a clear trown and entirc-narginel. while those of the Black Spruce tare grilyish-lirown and uore jazapent. The unedles of the lied siruce are dark green to

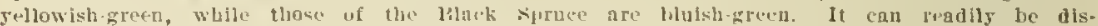
tinguished from the Irbite spruce and the Colorado Mlue spruep by its bniry twigs, and from the Norway spruce hy its much smnller cones and absence of long pegdulous branchlets.

RANGE-Xew fondhand to Peunsylranin and south alogg the Alleghnoles to Georgla, west to Minnesota. Heavs stands oecur ujoo the high mouotaios of western North Carolina.

DISTRIBUTION IN PENNSYLVANIA-Frequents the swampis of Monroe, Pike nad a few other counties.

HABITAT - Cummon upon mountnio slopes nnd well drained upland, but also fonod on mountain tols and on the margin of swamps and streams.

IMPORTANCE OF THE SPECIES-The Red Spruce is one of the most important species which supply the wood uset in the manufneture of piner pulp. Where nutural regeneration is possible this species deserves to be cleveloper, especially in places too wet for otber species to grow, In this state, the Benr Meadow's in Centre county nad the lake regions of Pike and, Monroe counties, with their adjoining swamps, gire excellent conditions for the natural development of this species. 

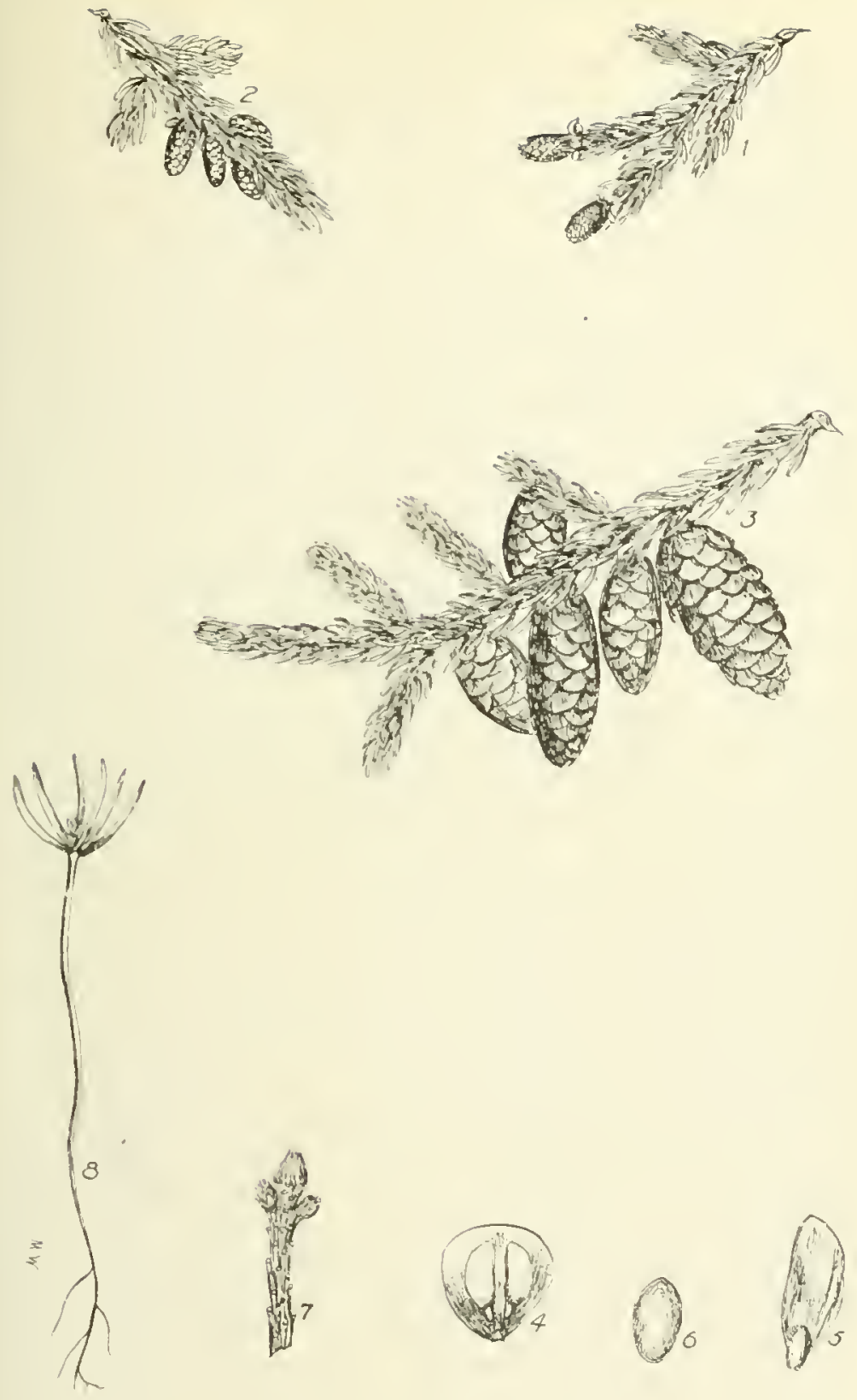

PLATE XX. RED SPRUCE.

1. Pranch with pistillate flowers, $x_{3}$.

2. Pranch with staminate fowers, is $x^{2}$.

3. Branch witb needles and cones, $x$ s.

5. I winged seed, natural slze.

c. I seed, enlarged.

7. Terminal portion of a twiz with buds and withut noedles, natural stze.

S. A reedling, natural size. 

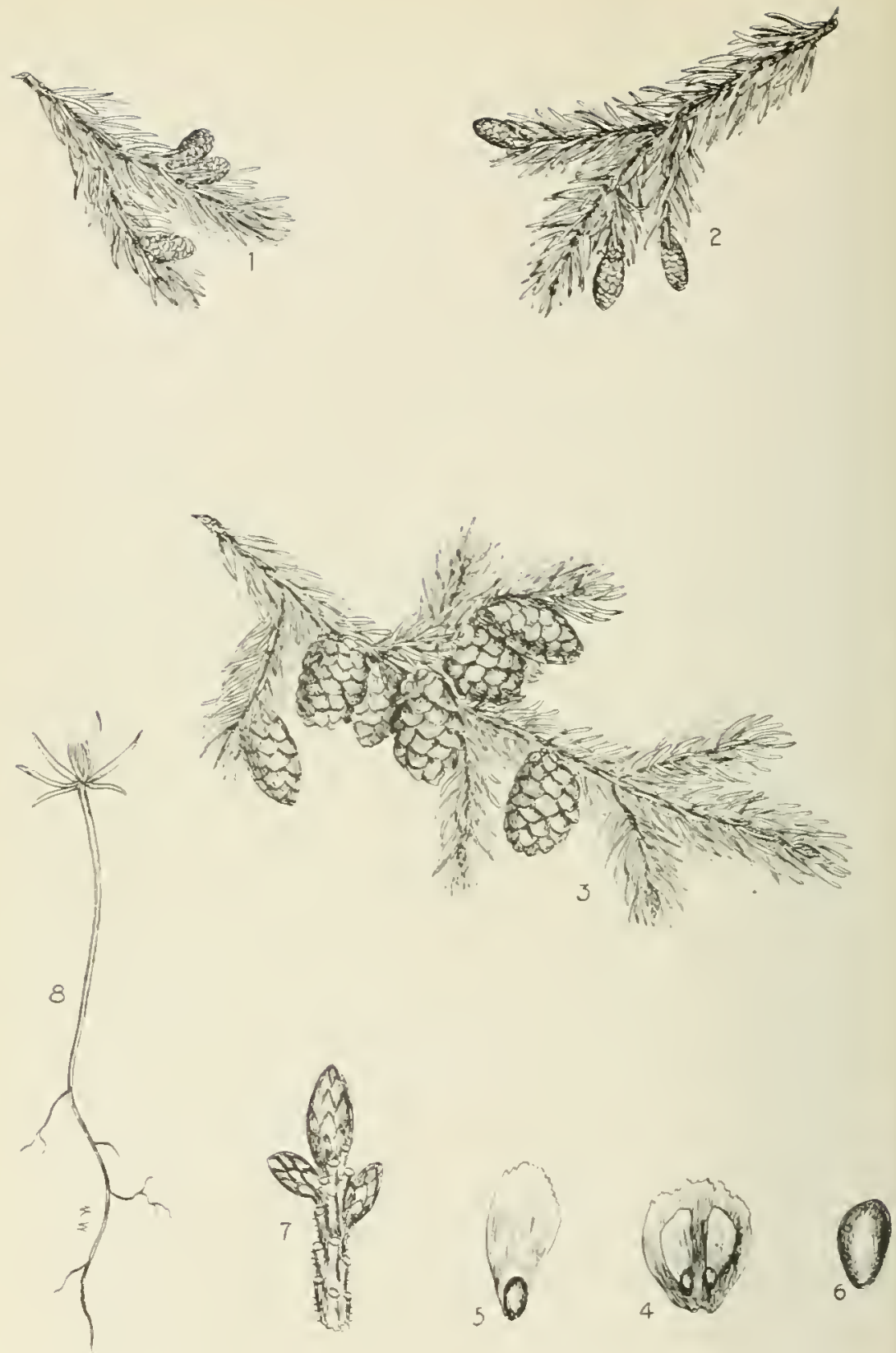

PLATE XXI. BLACK SPRUCE.

1 Iiranch with pistillate fotrers, $\mathbf{z}$.

Iranch with staminate fowers, $x 1$.

3. Branch with needles and cones, $x, z$

A cone-senle with two wingerl seeds, $x$ z

6. A seed, enlarged.

7. Terminal portion of a twig with buns and witbont neelles, enlarged.

8. A seedling, natural size. 


\section{BLACK SPRUCE.}

\section{Picea mariana, (Miller) BSP.}

FORM-A strall tree usually attaining i belght of $20-30 \mathrm{ft}$. with a diameter of 1 ft., but mas reach a beight of $100 \mathrm{ft}$. with a diaroter of $3 \mathrm{ft}$. Trunk straight, continuous, very taperIng, bearing irregular, rather short, horizontal branches, often with ascending tips which give the tree a rers narrow, irregular, conic inem.

EARK- C 1, to ! of an inch in thickness and roughened by irregular, this, close, grayish brown scales. See Fig. 5 I.

TWIGS-lkough, stout, brown to yellowish-brown, covered with pale to black hairs.

BUDS-Oroid, sharp-pointed, $\}$ t of an lach loag, corered with overlapping, sharp-pointed, reddish.brown scales.

LEAVES-I bout 3.3 of an Juch long, 4-slded, blulsh-grcen, rounded at apex, straight or slightly curred, whthout real leaf bases, but resting on decurreut profectious of bark bnown as sterigmata.

\section{LEAF-SCARS-See "Ienl-Scars" uader hed Spruce.}

FLOWERS-Appear about Mas. Staminate and plstillate flowers occur on same plant but often on different parts of it. Stuminnte sub-globose, alniost sessile, $\frac{1}{b}$ of an inch long, reddisb in color. Pistillate oblong. eylindrical, if a a inch long.

FRUIT-A cone ahout 1 th laches long. short-ovoid, shart-stalked, unaturing at the end of the tirst sesson; core-seales rouuded, dull grasish-hrown with jagged margin.

wOOD-.iva-forous; wlth resin passages present; light, soft, not strong, pale yellowishwhite In color. Weighs 32.86 ibs. per cublc foot. Csed in the manolacture of paper pulp and occaslonally in lumber.

DISTINGUISHUNG CHARACTERISTICS-See "Distingulsbing Characteristics" under Red Spruce jage 80.

RANGE-1t is a trauscontinental species extending from Labrador to Alaska and south to Penusylvanfa and Tisconsin.

DISTRIBUTION IN PENNSYLVANIA-Frequents swamps, rather common along lakes and in swams of Joaroe and Pike counties and in Bear Meadows, Certre and Huntingdon coanties. Also reported in Cambria, Clinton, Lackawnua, Iycoming and Mifin counties.

HABITAT-The Black Spruce, also known as Swawp Spruce, usualls frequents cold, poorly drained swamps throughout its rangc. It sometimes ascends well drained billsides, bat is usually stunted in such situations. It makes its best growth on moist allavla! soils and is very tolerant of shade.

IMPORTANCE OF THE SPECIES-The Black Spruce is of little commercial importance in Pennsylrania and should be considered for forestry purposes in extremely swampy locations only. Where other more raluable species will not grow. it canaot be recommended for oraamental planting since other species of Spruce far surpass it for thls purpose. 


\section{NORWAY SPRUCE.}

\section{Picea Abies, (Linnaeus) Karsten.}

ForX-A large trep usnally attainiog a height or $50.50 \mathrm{ft}$. With a diameter of 2 it.. but may reach a height of $225 \mathrm{ft}$. With a diameter of $3 \mathrm{ft}$. Truni straight, continuous, slightly tapering, and sometimes free from lateral branches for a considerable distance from the base. Crom less acutely prramidal than that of on natire species.

BARK-On old tranks roughencd wlth large, rather thick reddish-brown scales; on $y o u n g e r$ trunks the seales are thinner and closer. Used in tanneries in Europe, bnt only slightly charged with tanoin.

TWIGS-Slender, rather pequlous, dight reddisb-bromn and roughened by projecting leatbases.

BUDS-Orate to conical, smcoth, rointed, corered ly orcrlapping, sharp-pointed, light brown scales.

LEAVES-About $3-1$ inch long, gharp-pointed, 4-sided, dack green, withoat real leaf-stalks, but resting on decurient projections of bark known as steriguata.

LEAF-SCARS-See "Leaf-Sents" under Red Spruce.

FLOWERS-Appear about Mas when pollioatlon takes place. Fertilization takes place io June.

FRUIT-A cone glout f-T inches long, cylindricalohlong, jendant, almost sessile, maturing nt the end of the first senson: cone-scales thin, stif, rather brond reddish-brown wlth finely toothed margin.

WOOD-Xion-porous: resin passages fresent: straight-grained. strong, not durable in eontret with the soil, medium in hardness, works easils, heartwood jellowish-white with thin white sapwood. Weighs 30 lhs. per culie foot. I"sed in the manufacture of paper pulp, general construction, interior finish, basket making and for masts and oars on small resgels.

DISTINGUISHING CHARACTERISTICS-The Norwng Sprnce, also known as the European Spruce, ean readilg be distingushed by its large cones, which are from $4-\vec{t}$ incbes long. and by the long, peadulous branchlets terminating the lateral branches. The sharp-pointed, blnishsrecn, 4-sided needlez will also gld in distinguishing it from some of the other closely related species.

RANGE-1ts native home is in middle and northern Europe. It forms a rery jmportant part of the forest structure of Germany. Switzerland, Austria and Russia. Planted extensirely ia the United States for ornamental purposes from Majnc south to Wasuington aad west to Kansas.

DISTRIBUTION IN PENNSYLVANIA-It is Iound throughout the State as an ornamental tree, and planted rather extensirely for forcstry porposes by the Stnte Department of Forestry.

HABITAT-In Europe it groms in valleys and upon the mountain slopes. It prefers rather lich moist soils, in this respect somcwhat resembling the White Pine. It cannot endure rery drs, vers sterile, or extremely rich regetable soil. It ig rather tolerant of shade and soraewhat susceptible to late frosts.

IMPORTANOE OF THE SPECIES-The Norway Surnce is a foreicuer lo oar forest flora, but before long it will be regarded a nuturalized member of cur forest structure. It will be an extremely valuable addition to the Iist of species of forestal significance. To the present time it has been planted mostly for ornamental purposes and for wind breaks but in the future it will also be planted extensively as a forcst tree. It groms rapidly and is rather hards and free from organic enemies and produces valuable wood. A noted Encopean authority on forestry has said: "Spruce is the best paying forest species in the world." It should be planted as a scedling and preferably mixed with such species as White Pine. Earopean Larch, Douglas Fir, Red Oek, White $A s h$, and Tulip Tree. It is also possible that it coald be grown at a profit for Christmas tree parposes. 

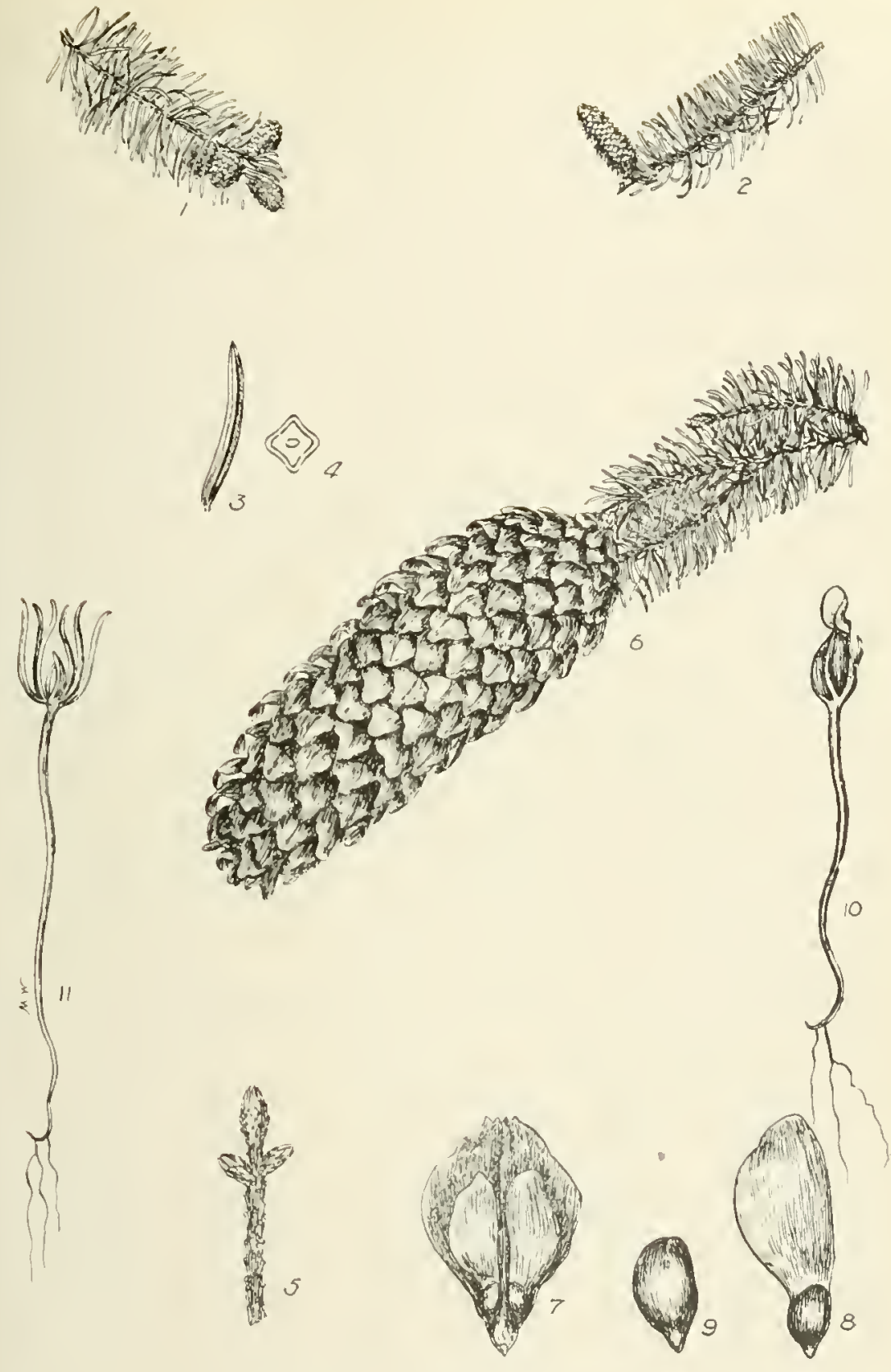

PLATE XXII. NORWAY SPRUCE.

\footnotetext{
1. Branch with staminate flowers, $x$ z.

2. Branch with pistillate flowers, $x$,

3. A needle, natural size.

4. Crross suction of a nerede, enlarged.

3. Branch with needles removed bowing winter

6. Brancli with Deedles and a cone, $x$

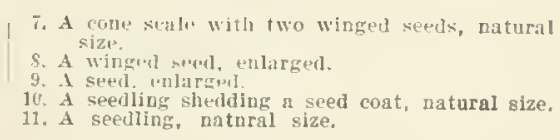



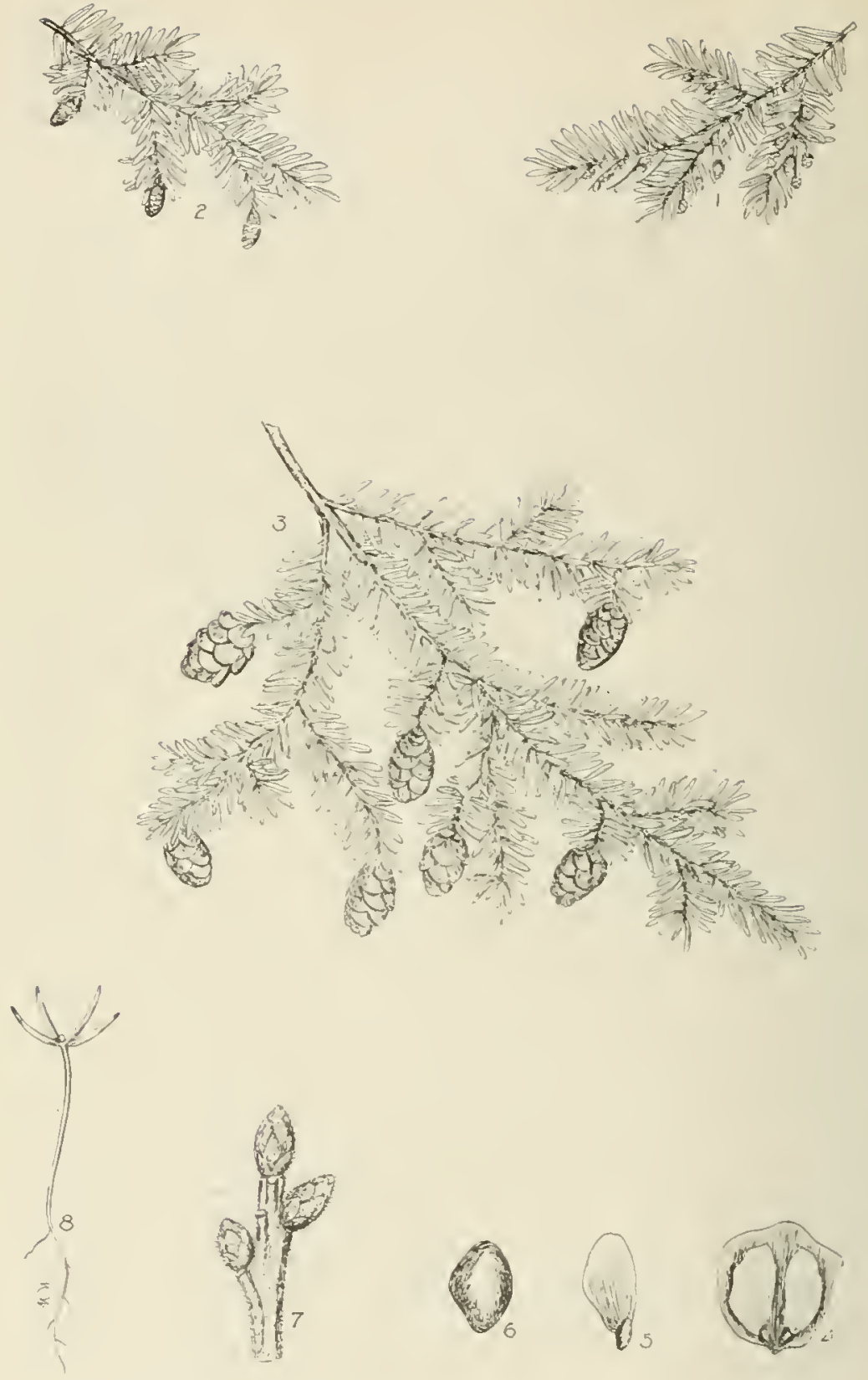

PLATE XXIII. HEMLOCK.

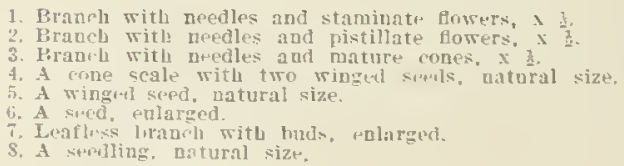




\section{HEMLOCK.}

\section{Tsuga canadensis, (Linnaeus) Carriere.}

GENUS DESCRIPTION-Thls geaus comprises 8 specles In the world, 4 of which are pative to North Ameriea and 1 to Pensylranla. Of the 4 species natire to North Amerlca, 2 are lound in the eastern and 2 in the western part. The 2 eastern specles are the Carolina Hemlock (Tauga carollnlana Engelm.) found only in the mountains from Virginia to Georgia, and the specles described below. The Hemlocks are trees of the northern hemisphere, found in North America and Asla, but absent in Europe. The eastern species in particular are slow growers and difficolt to transpladt. A well known student of forestry bas said, "Hemlock treeg are like the Indians, they will not stand eivilization."

FORM-A large tree usually attaining a helght of $60-80 \mathrm{ft}$. with a diameter of $2.3 \mathrm{ft}$, but may reach a helght of $100 \mathrm{ft}$. with a dlametur of $4 \mathrm{ft}$. In the open its crown is dense, conic, and high with llmbs extending almost to the ground. In dense stands it has a bole, clean from laternl branches for a considerable distance from the ground and with little taper.

BARK-Grarlsh-brown to reddish-hrown, rich in taunin, beconing $4 / 5$ of an inch thick on old trunka and rougbencd by long tssurcs separating rather broad rldgea whlch are covered with close scales. Innoer bark la cinoamou-red. See Hig. 53.

TWIGS-Slender, rough on account of decurrent projectlons of bark upon whlch the leaves rest, at first soinewhat hairy and gellowlsh-brown, later smooth grayish-brown tinged wlth puiple.

BUDS-Alternate, ovate, I/I6 of an inch loag, blunt-pointed, reddish-browp not glossy.

IEAVES-Linear, tat, about of a lach long, rounded or notehed at npex, dark green and shlnlug above, pale green aud aull below with a white line on ench slde of midrib. The leaves peraist for about 3 sears and are jqlnted to short, perslstent, woody stalka. They are somewhat aplrally arranged around the cwig but appear two-ranked.

IEAF-SCARS-Small, round, ralsed on decurrent projections of bark.

FLOWERS-Appear ahout April nr Mas. Staminate and pistillate dowera separate, but usually borne on the satac hralich. Stauinate sinall, globose, gellow, ahout $\$$ of an inch long. Pistlllate obloog and pale green.

FRUTT-A smoll, short-stalied cone maturing at the end of the first seabon, about 3 of an inch long, usually yersisting durlag fral wlater.

WOOD-Nion-porous: without resin pasages; light, bard, not strong, brlttle, coarae-grained not durable, llable to splinter, diffcult to work, lisht brown with lighter sapwood. Weighs 36.42 lbs. Iler cuble foot. Used for construction, coarse lumber, and especlally for frame work and weather-hoarding of bulldings, paper pulp, and latha.

DISTINGUISHING CHARACTERISTICS-The Hemlock, also know口 ag Hemlock Spruce ad Spruce Pine, cas be distingulshed by itg flat lineaz needles with two longitudinal whlte streaks or. the lower surface; the needles are jointed to short rersistent woody gtalks known as aterigmata nod a pundr two-rabked, but in addition to the two conspicuous lateral rows there is a ratler luconspicious row of small needles on top of the twig extending in the same direction as the twig. The lateral twlgs occur rather irregularls aloug the main branchea and diverge from the latter at an agle of usually less than $75^{\circ}$. The cones are about of an inch long, aud often persist thrugh one winter. The inner bark is cinnamon-red.

RANGE-Nova Scotia south to Pendsylvanin and along the mountains to Alabama, and weat to Minnesota.

DISTRIBUTION IN PENNSYIVANIA-Rather commonly distributed in molst altuations throughout the mountainous regions of the State. Most common in the central and northern parts. Scattered in local 5 roups in the southeastern and southwesteru parts.

HABITAT-Usually found in molst locations like northera slopes of rocky ridges, banks of streams, ponds and lakes, swamps, rlver gorges, and mountaid slopes. Jt prefera a dense forest atructure sioce it is shade loving and not very wind-firm.

IMPORTANCE OF THE SPECIES-This tree sieids not only lumber hut also bark rich fo tannic acid nad a vulatile oil to which a medicinal value was attached. The Inferior wood which it produces coupled with Its slow grewth and the dificulty with which lt la estahlished by plantlur will tend to decrense its prevalence in on forest structure, especially since more valuable aod more rapid growing specles like Pine and Spruce will thrive on the same area. Wherever it can be regenerated naturally wlthout snerlficlng more raluable speciea it should be retained in the forest structure. It in one of the wost attractive if not the most attractive of our coniferona evergreens. 


\section{BALSAM FIR.}

\section{Abies balsamea, (Linnaeus) Miller.}

GENUS DESCRIPTION--The Firs comprise about 25 species, of which umber 10 species are native to North America and 1 to Peansrlvauia. Theg are usually foud in cold and temperate regions. Eight species are found ju westeru North America, while onls a species are native east of the foot hills of the Rocky Mountains, 1 of which is a atire to Penusylravia. The other eastern species aot a atire to Pennsrlraia, Abies Fraseri (Pursh.) Poir, is found ouls ja the Appalachiau Mountaius from Tirginia to North Carolias and Tendessee.

FORM-A Inedium-sized tree attaining a height of $30-50 \mathrm{ft}$., bnt way reach a height of 100 ft. with a diameter of $3 \mathrm{ft}$. Tsualls a low spreadiug sbrub in high altitudes and bigh latitudes. Crowa slender, symmetrical when soung, and sharp-poluted, deeper aud often broader io older specimens.

BARK-On old trees reddish-browa aud somewhat roosheved by irregular scales. On yoang trees smooth, thin, close, grajish-broma, and marked by projectivg resia blisters. See Fig. 50.

TWIGS-Slender, at first hairy and zellowish-greea, later smooth, and gragish-brown, usually arrauged opposite ode auother.

BUDS-Clustered at ead of terminal twiss, orate to spherical, about $1 / 6$ of an iach long, covered with very glossy, raraisbed, orange-greeu scales.

LEAVES-Apucrently 2-ranked as in the Hemlock, liaear, fatteaed, of an inch loug, usuglly blnot at apex, stalkless, dark green aud shiaing above, pale with light dots below, very fragraut ugou dryiug.

FLOWERS-Ippear about Mas or Juoe. Staminate and fistillate flowers senarate but asually foud ou differeat parts of szace lragch. Staminate cylindrical, yullow, $\frac{1}{f}$ of an inch long. Pistillate obloug-cyliadrlcal, purple, I luch long.

FRUIT-A erect, oblong-crliudrical, dark purple cone, 2.4 inches long, with broad roud deciduous scales which fall of and leare the bare ceatral axis. Cones mature at the end of first seasou. Seeds about $\frac{1}{3}$ of go inch toug, winged, and borue on cone-scales.

WoOD-Yoa-porous; without resin liassages; with no distioct hentwood, light, soft, pale browv, not stroag no: durable. Weighs 23.80 lus. per cubic foot. Used with Spruce for paper pulp, crates, packing bores, aad occassionally for lumber.

DISTINGUISHING CHARACTERISTICS-The Balsam Fir, also kgown as lir, Balsam, aud Blister Pine, is distinguished from the other uatire conifers of Peuaszlrania by its smooth gras. ish-browa bark covered with projectiog blisters, its oblong-cylindrical erect cooes with deciduous seales, and by its rather flattened, afrareutly 2-ranked leares which are stalkiess and leare a circular flat scar upou falling. The leares of the Balsam Fir somewhat resemble those of the Hemlock, but thes are not jointed to a moods stalk while those of the latter species are joluted to short nersistedt stalks knowu as sterigmata.

RANGE-Labrador west to Alberta, south to Penasslvania aud Minnesota and along the mountaius to virginia

DISTRIBUTION IN PENNSYIVANIA-Confiued almost entirely to the swamps and lake regions of Ceotre, Pike, Mouroe, Lrcomiug. Tioga, and Sulliran counties. It is glso reported from a few wher local outposts.

HABITAT-Usunlls inhabits swamps or their borders. In the north found commonls in low swampy bogs but in the south usually foud ou the moutain tops ad slopes. Generalls occurs ia mixture hut may occur locally iu almost pure stands. Snruce aod Hemlock are its common associates.

IMPORTANCE OF THE SPECIES-TLls tree is of little commercial importance in this State on account of its limited distribution and the small size which it attains. It is difficult to re. generate artifially siace the seeds have a low germinating perceatage, aud the subsequeat establishmeat is also difficult. This species sheuld be regeverated uaturally unon such areas where other more ralaable species will not grow. The Balsam Fir is commouly used as a Christmas tree and it is possible that in the future it may pay to raise it for this purpose. 

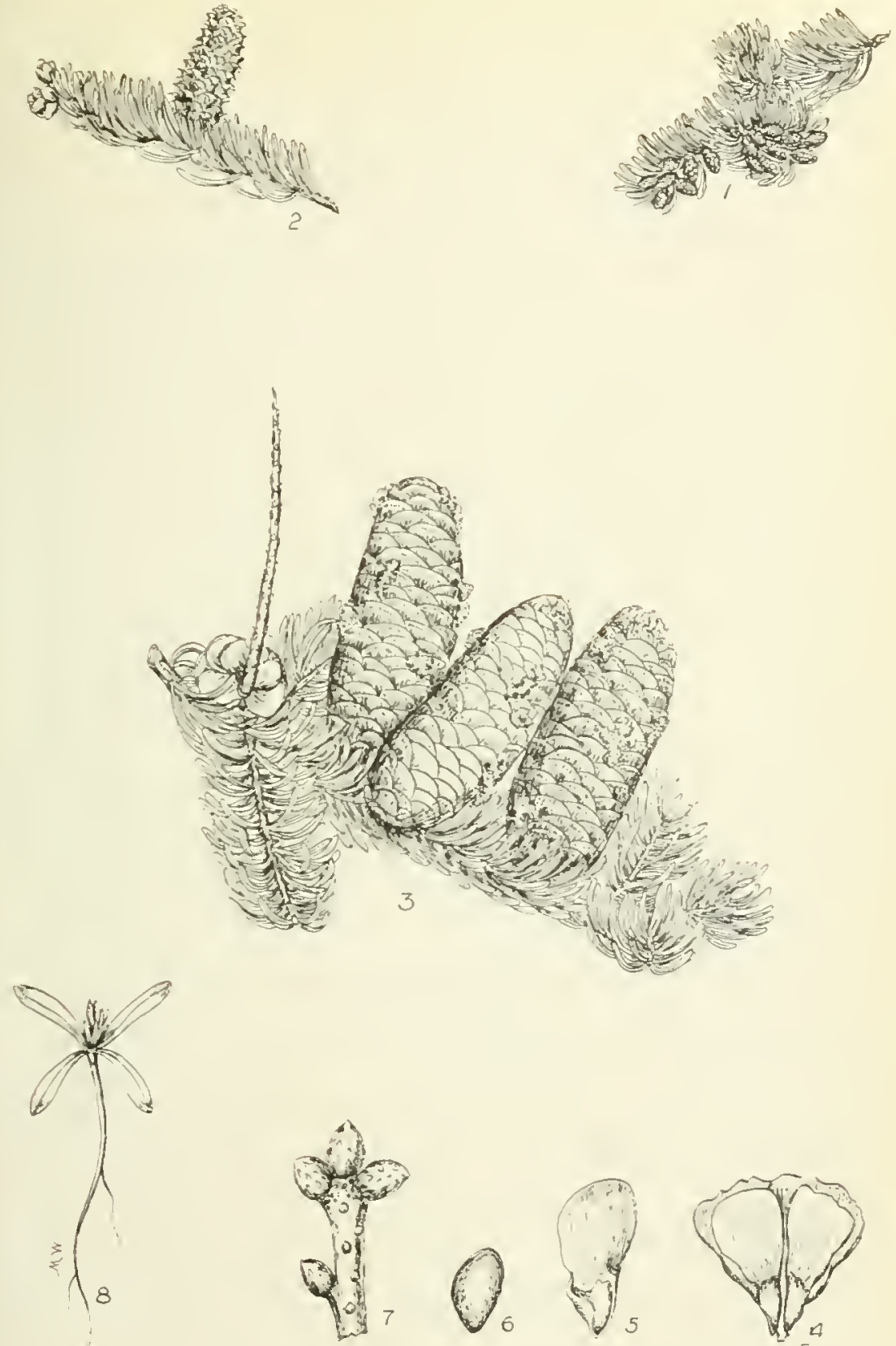

PLATE XXIV. BALSAM FIR.

1. Branch witi neetler and staminate fowers, $x$ a

. Branch wit! ceedlos and pistillate fowers. i z.

3. Brabeh witl needles, three cones and one cone axis from whinh the scales bave fallen, $x$,

5. A cone scale witl two winged seeds, batural size,

5. A winged sceet, sizhtly enjarged

6. A sued, enlarged

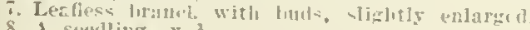

8. A smedling. $x$, 

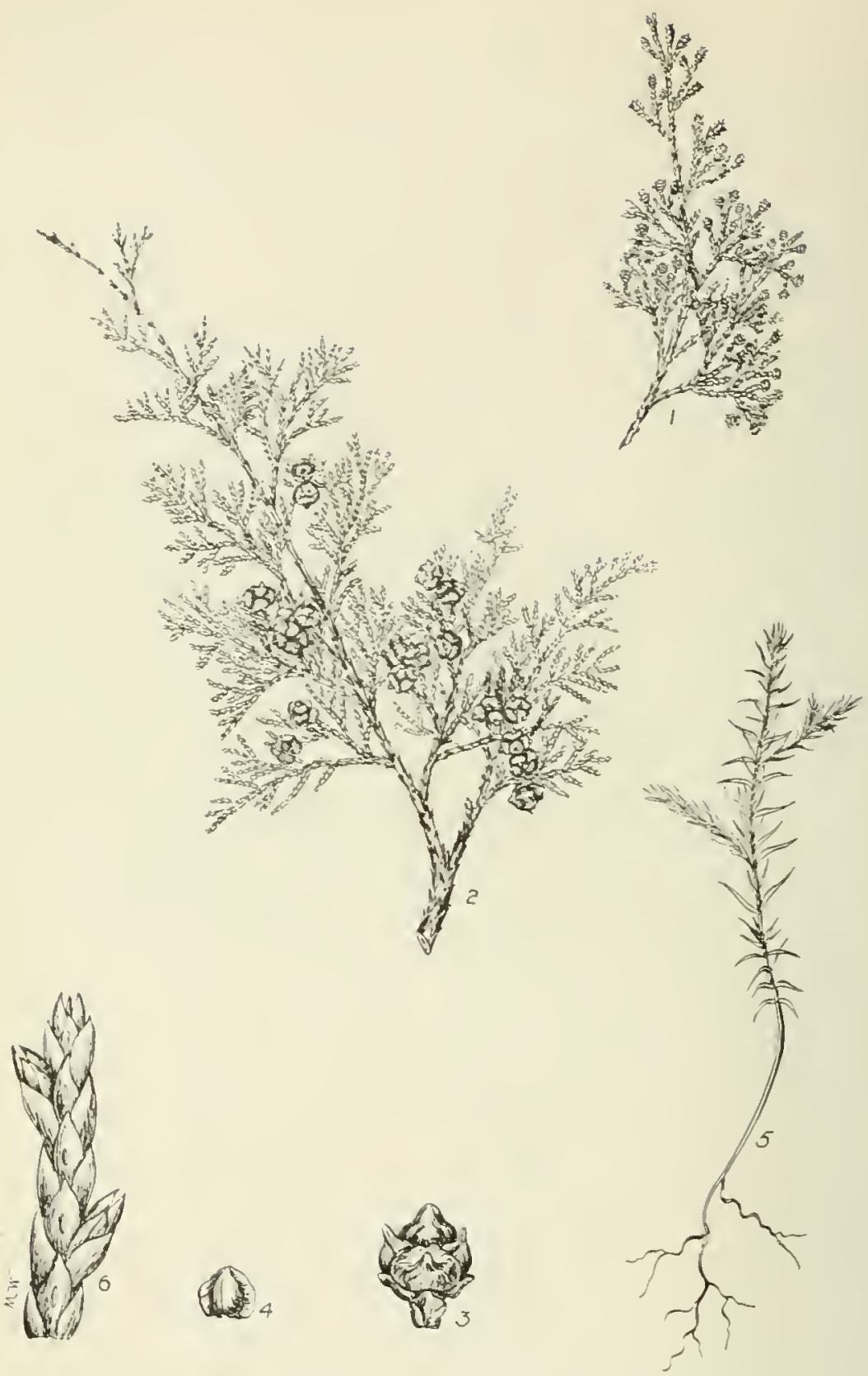

PLATE XXV. WHITE CEDAR.

1. A flowering branch, $x$.

2. A branch with neerles abd froit,

4. A ringed seed slinhty enlarger.

5. A seedlios, natural size.

6. A'urtiou uf toratch, enlarged. 
WHITE CEDAR.

Chamaecyparis thyoides, (Linnaeus) BSP.

GENUS DESCRIPTION-This genus eomprises about 6 specles in the world, of which number $\mathbf{3}$ are antive to Vorth imerle. of the 3 sluecies native to Corth smerien 2 are fond in the western part, wbile only 1 is found in the eastern part. The latter is native to a small portion of Pennsyiraula. The Cedars are not very well known as forest trees, but are planted extensively in this country and abroad for ornamintal purjoses. The lumberman is just beginning to appreciate the value of the wood which is ohtained fron the western specics,

FORM-A small tres usut!ly attaining a height of $20-\bar{n}$ ft with a diameter of $1-2 \mathrm{ft}$, but may regch a height of $90 \mathrm{ft}$. with a diameter of $4 \mathrm{ft}$ Truak straight, continuous, tapering, aod bears slender horizodtally spreadin branches wbich form a narrow, potnted, confeal crown.

BARK-Father thin, reddisb-browa, somewhat furrowel, peels off into long, fbrous, film-like seales.

TWIGS-Father slcuder, somewhat fattened, at first hlulsh-green. later after the leares bare fallen ther become rmunlish and reddish-hrown. The termillal twigs are often arranged in fan. like elnsturs.

BUDS-Very small and faconspicuous, usually ecered by the elosely overlapplag scale-líke leares,

LEAVES-small, orgte, sharp-fointed, hlulsh.yreen, elosely orerlapping, scale-ljke, 4.ranked but presenting a compressul aprearance. Often spreading and awl-shaped on rigorous shoots. I mnspicuons lut ratbre suall glandular dot is nftra found nn the hark.

LEAF-SCARS- Not present beanse leawe pusist for 4 or more gears; then die and dry up npon the branches.

FLOWERS-I I war in Marcli or April. Struninate flowers olylong, ahout $\frac{1}{\text { of }}$ an inch long,

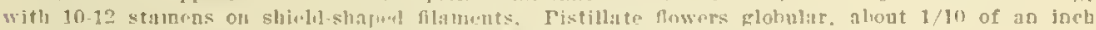
in diameter, witl about six sbirld-shaped scales each usually bearigg 2 orules.

FRUIT-A small glohose cone whlch is rather conmon but inconspicnous, ahont of an juch in diameter nod maturing at the enl of the first senson. Scales of cone shleld-shaped and foined to axis of cone by stalk. Outer fnce of scale is marked by a slight projection. Each fertile scale hears 1 ur 2 fertile wlaged seed.s.

WOOD-Non-porous; light, soft, not strong, vers durable, slightly fragrant, light brown thoged with red; saywood pale. Weighs 20.70 lhs. per eubic foot. Csed in cooperage and bont building, for fence posts, railroad ties, shingles, and woodenware.

DISTINGUISHING CHARACTERISTICS-The Whitn Cedar, alsn known as Fedar and Coast White Cedar, can ve distinznisbed br its charactarlstic globose froit with shield-shaped scales whleh are fastened to the main nxis br means of sbort stalks. It somewhat resembles the Arbor Vitae but the fo:mer has less fattener? and less distinctls fan-shaped twigs. The twigs of the White Cedar are no: so stout as thoso of the Arhor Vitae. The former also bas biuish-green leares whlle the lattcr has yellowish-green. It can he distinguished from the Red Cedar and the Conmon Juniper hy its more promlaent glandular dots on the leares and its round twigs; the turigs of the inter species aro 3 tn 1-ided. It also lacks the aml-shaprid leares foud on the Common Junlper and nsually found on the Red Cedar.

RANGE-Cape Breton 1xland southward aloag coast region to Florida and Mrississippi.

DISTRIBUTION IN PENNSYLVANIA-Yativ only to a few comties in the sontheastern part of the state, lmt found as an ornamental tree in practically evers part of the State.

HABITAT-Prefers swamp and marsbes but will grow in dry loeations. Occupies many swamps to the exclusion of other tree species. In the soutb it js ofted found in the swamps with the Bald Cypress and in the oorth with Arhor Vitge, Fir, and Spruce.

IMPORTANCE OF THE SPECIES-This species is so linited in its distribution in Pennsylranin sul the weod of so littlis commercial importance that it cannot he recommended for forestry pur proses. It may le recomm-nded for very swampy locations where other more raluable species will not grow, and deserres to he planted extensively for oruamental purposes since it is one of the most beautifal conlferous trees of eastern North Ameriea on aceount of $j$ ts attractire form and beautiful foliage. More than a dozen rarieties of it are known. 


\section{ARBOR VITAE.}

\section{Thuja occidentalis, Linnaeus.}

GENUS DESCEIPTION-This genus comprises 4 known specteg in the world, of which number 2 are found in North America. One of the 2 specles natire to North America is found in the enstern part, and the other in the western part. The species found in the mestern part attalns a large size, while the one lound in the eastern part usully remains a small tree. They are hest known ag orununctal trees but furnish some lumber, which is pery valuable on account of its grent durability. The hark also ylelds tanning material and the twigs and leares contain a rolatile oll which possesses stimulating properties.

FORM-A medium-sized tree usually attaining a height of $20-50 \mathrm{ft}$. with a dameter of $1-2 \mathrm{ft}$. hut my rench height of $75 \mathrm{ft}$. with a diameter of $3-4 \mathrm{ft}$.

TRUNK-Tapering, furrowed, huttressed and often divided. Crown dense, conicnl, very hlgh, and often covered with follage almost to the base.

BARK-Grayish to reddish-brown, thln, furrowed, separating into long rather thln, Dhrous and often perslstent strips.

TWIGS- Fellowish-green, evidently flattened, somewhat 4-alded, completely corered by elosely adhering leares, zig-zag or arranged iu fan-shaped elusters.

BUDS-Lenf-buds not scaly, corered by closely adhering scale-like leares.

LEAVES-Opposite, scale-like, closely orfripping, aromatic when crushed, with very conspicuous glandular gpots on the thrifty shoots, \& of an lnch long, of two kinds in alternating pairs. Those on the side of the twigs keeled; those on the lace of the twiga flat.

FLOWERS-Appen about April or May. Staminate and plstillate cumera usually occur on äifferent twigs. Stamlnate roundish, Inconsplcuous nnd gellowish. Pistillate small, ovoid, purplish, with $4-6$ polis of thln oral scules.

FRUIT-An oblong cone with 6-12 obtuse acales, $\frac{1}{3-\frac{1}{3}}$ of an foch long, reddish-hrown, matures In one season. Seeds oblong, tringed, thout of an inch long

WOOD-Non-porous; resin passages ahsent: light, soft, lurahle, fragrant; sapwood almost white, heartwood yellowlsh-brown. Weighs $19.72 \mathrm{lbs}$. per cubic loot. Used for fence posts, ralls, shingles, spools, and railroad ties.

DISTINGUISHING CHARACTERISTICS-The Arhor Vitae, also koown as White Cedar and Cedar, may be distinguished nt any season of the jear by its scale-like nad closels overlapping leareg from all the other trees native to the State of Pennsslvania except the White Cedar. It can be distinguished from the latter, which also hns scale-like leaves, by ita more flattened and Inrger twigs, which are also more fan-shaped. The fruit of the Arbor Vitae is oblong with thin oblong scales, while thnt of the White Cedar is spherical with thick shield-shaped scales.

RANGE-Southeris Iabrador west to Mnnitoha nnd Minnesota, and south along the mountains to North Carolina and enstern Tennessee.

DISTRIBUTION IN PENNSXLVANIA-The Arbor vitae is found to the porth and sonth of Penusglvanla, but so far no nuthentle records are arailable which show that it is natlve to this Stnte. It 1s, hcwerer, lound rery commonly throughout the entire State as an ornamental tree and sometimes as a bedge.

HABITAT-Usually found in low swampy situntions on the horders of ponds, streams, and lakes, but occrssinally ascends to drier ground. In the north it is often found in the sphagnum bogs with Spruce and $1 \%$ r, whlle in the south it is usunlly found on the mountain slopes and topa with the Spruce and orlier coniferous apecies.

IMPORTANCE OF THE SPECIES-The Arbor Vitae is one of our most valuahle bpecies for ornamental purposes. It is common throughout the State ns an ornamental tree and occasionally planted for hedges. As a timber tree, Lowever, it is strpissed hy many other native species and should be plauted for forestry purposes only in such habltats where other more ralnable specles will not grow. 

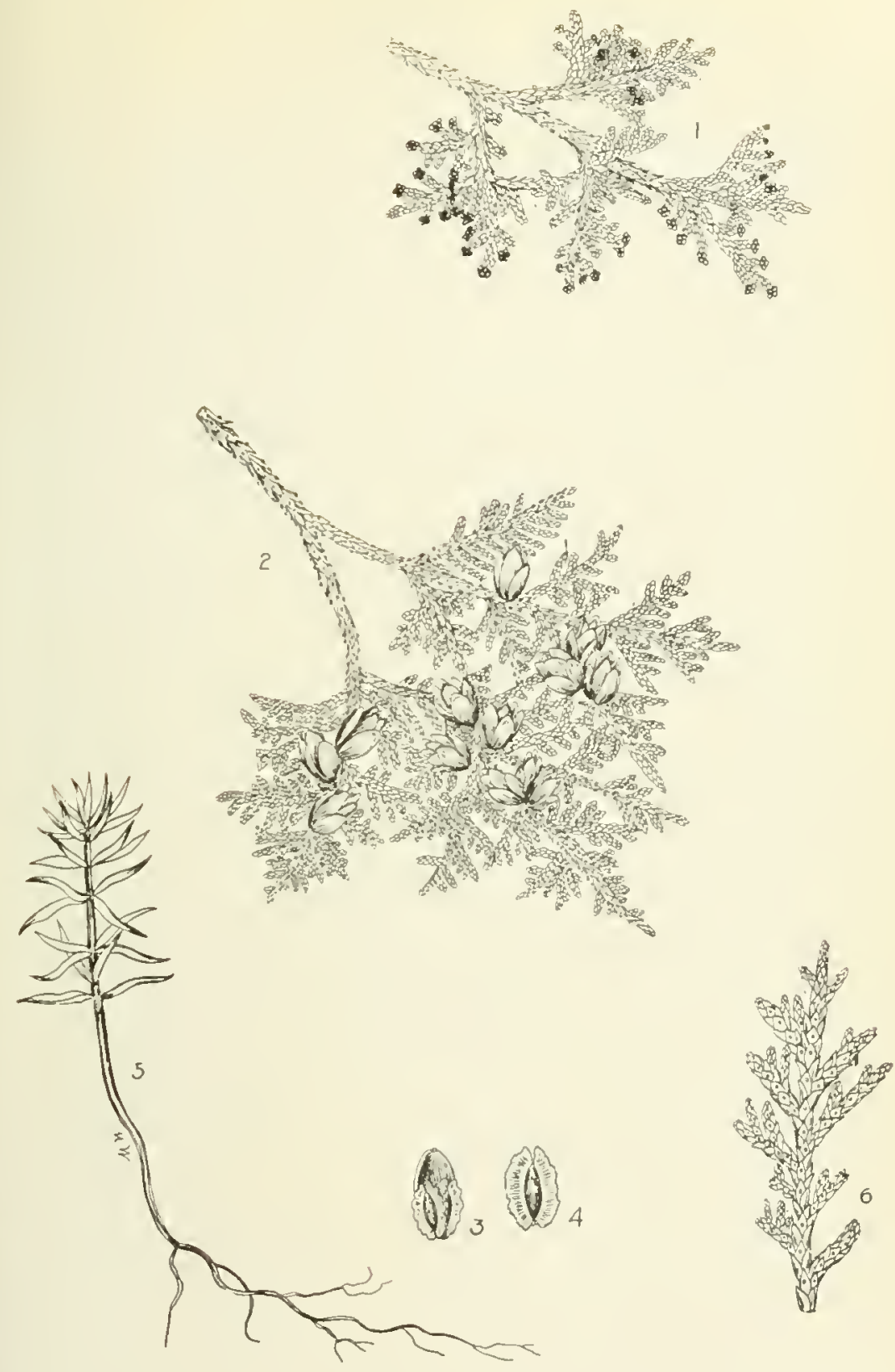

PLATE XXVI. ARBOR VITAE.

1. A flowering lranch, I ?

2. A branch with neerles an? frnit, $x$,

3. A cone-scale with wingw? seerls, natural size.

4. A winged seed, enlargid.

5. A soplliog, natural size.

6. Portion of branch, natural size. 


\section{THE WILLOW FAMILY-SALICACEAE.}

The Willow family comprises about 200 species belonging to two genera, the well-known Willows and the Aspens or Poplars. The members of this family comprise hoth trees and shrubs found chiefly in the north temperate and aretic zones. A few shrubby species extend far into the arctic regions. They usually prefer moist habilats but may also be found on drier locations. One is rely apt to associate the Willows with wet habitats.

The flowers appear in early spring, usually before the leaves. The staminate (male) and pistillate (female) flowers are produced on different trees. A tree hearing staminate flowers does not hear the pistillate. As a consequence one will find fruit only upon pistillate trees. . The pistillate flowers are fertilized by insects, usually bees, which carry the pollen from the staminate flowers. The fruit consists of capsules which split into 2.4 parts and are arranged in drooping tassel-like clusters. The fruit matures in late spring at about the same time that the leares reach their full size. The seeds are small and surrounded by a dense covering of long white hairs which aid considerably in their dispersal. The seeds must germinate soon after they mature or they will lose the power of germination. The bark is usually rather bitter.

The replesentatives of loth genera are noted for their remarkable ability to grow both flom root and shoot cuttings. One can cut a small twig from a tree, put it into moist ground, and feel assured that it will grow. They also sprout very freely from stumps irreslectire of the age of the stump. The following ker will distinguish the two genera lolonging to this family.

\section{KEY TO THE GENERA.}

1. Buds witb one bud-scale; bracts of the catkins entire; stamens fewer than 10 , usually

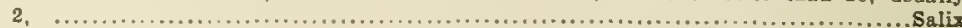
1. Buds with more than one bud-scale; bracts of the catkins fringed or lobed; stamens

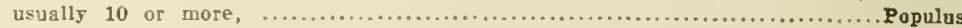

Page. 88 99

THE WILLOWS-SALIX (Tourn.) L.

This genus comprises about 175 species of which number about 100 species are native to North America and about 15 species to Pennsylvania. The members of this family are met as trees and shrubs. Most of our native species are small trees or shrubs. Those which 
attain treesize are usually found near buildings and have been introduced.

The Willows produce wood which is light, soft, not durable, and weak. It is of little commereial imprortance. The value of the Willows lies in the shoots or rods which are used in the manufacture of baskets and furniture. Some reach a large enongh size to be used 101 saw Inmber lut the trunlis are usually of a poor shape and also legin early to decay in the center. They are valuable to bind the borler of streans by means of their interlacing roots and thus prerent erosion. They may also be used to prevent the movement of shifting sands.

Few frees possess such a tenacious vitality as the Willows. They live a long time after they alperar to lie dying and repair broken parts rery readily and often replace them with new growth. They reproduce freely ly means of sprouts, enttings, and seeds. On very wet situations, like islands or the borders of streams, they often form dense thicliets to the exclusion of almost all other growtlus.

The Willows as a group are easily recognized even by a layman. They hive a characteristic exterual appearance which one can soon learn to appreciate. It is, however, dificult to distinguish the different Willows lion each other. They sport and hybridize freely. Very often one leaves a Willow in clespar because of the fact that it was impossible to identify it. Only 4 of the 15 or 20 Willows found in l'ennsylyania ale described below becalse many of them are mere shrubs and others have been introduced from the castern hemis phere. The Weeping Willow (salix babyloniea L.) (Fig. 37) is very common in coltivation and in some localities it las eseaped cultivation. It can readily be distinguisher by its drooping branches. The Crack Willow (salix fragilis L.) is a native of Europe. It is common along our streans where it reaches a large treesize. The lateral branches are very brittle and after a windstorm the ground around the tree is usually covered with branchlets which have cracked off, whence the name Crack Willow.

\section{KEY TO THE SPECIES.*}

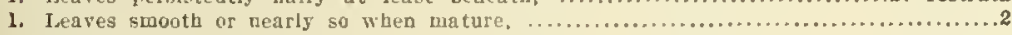

2. Large tree; leaves garrowly lanceolate, ............................. nigra. 90

2. Shrub or small tree rarely 20 leet tall; leaves broady lagceolate, $\ldots \ldots \ldots \ldots \ldots . . . . .$.

3. Capsules pubesceat; petioles aud stipules got glagdular; buds large, ........ S. discolor 92

3. Capsules glabrous; petioles and stipules glandular; buds small, .......... S. lucida 91

It is not inteaded that this key will eaable one to distiaguisb all the species of Willow found in Peansylvagla. It simply aims to foint out the distiaguishing characteristics of the four species which are described bere. Other species may be distiaguished by the use of Porter's Flora of Peassylvanla. 


\section{BLACK WILLOW. \\ Salix nigra, Marshall.}

FORM-Largest of our native tree-willows, usually $25-30 \mathrm{ft}$, high with a diameter of 10-20 inches, hut may reach a height of $60-50 \mathrm{ft}$., with a diameter of $2-3$ feet. I'runks usualls crooked, of ten lacllaed and occurring in small groups. Crown wide, open and round-topped.

BARK-Thick, rough, deeply furrowed, blackish-brown, witb wide ridges covered with thick scales. Ridges of bark often connected by narrow, transterse or diagonal ridges.

TWIGS-Slender, smooth, brittle, drooping, bright reddish-brown to orange colored.

BUDS-Alteratc, small, about $\frac{1}{5}$ of an juch long, sbarp.pointed, reddish-brosn, corcred by a slogle scale.

LEAVES-Aiternate, simple, narrowlÿ-lanceolate, very long-poluted, tapering or sligbtly ronnded at base, fonely serrnte on margin, usually smooth and dark green above, pale green below.

LEAF.SCARS-Alternate, narrow, with 3 bundle-scars in a lunate line. 'Terminal scar often larger than lateral ones. Stipule-scars large and prominent.

FLOWERS-Appear to Marcb or April hefore the leares. Staminate and pistillate fowers oc. cur on senarate trees, and hoth are borne in drooping aments or estkins from I- 3 inches long.

FRUIT-A redilsb-brown, smooth, arate capsule which splits open and liberates many small secds. Seeds corcred with a dease tuft of fine long bairs.

wOOD-niruse-porous; with rery inconsplcuous medullary rays; reddlst-brown, soft, weak, arm, close-zrained, not dorable. Weigbs about $2 S$ lbs. per cuble 1oot. Used mainly for fuel and charcoal.

DISTINGUISHING CHARACTERISTICS-The Black Willow is the largest of ont native Willows. The rough thick-scaled, blackish-brown bark is characterlstic. The aarrowly-lanccolate and short-petioled leares which are always smooth or nearly so are also distinctire. The trunks often occur in small groups. The slender drooping branches are easily broken off at their eads.

RANGE-New Brunswick to Florids, west to Dakota, Kansas, soutbern Arizona and central Californla.

DISTRIBUTION IN PENNSYLVANIA-Throughout the State, Most common in eastern and southern parts.

HABITAT-Prefers moist or wet situations like banks of streams and lakes. Reqnires plenty of light. Occasionally lound on molst, gravelly and sandy soil.

IMPORTANCE OF THE SPECIES-The Black Wjllow is the largest tree-willow natire to our fora and is very conspicuous in its appearance, it is of no present or prosnectire value except as a soil coaseirer and to a limited extent as a prodacer of fuel wood and charcoal. other more valuable nad more attractive trees sbould be grown in place of it. 


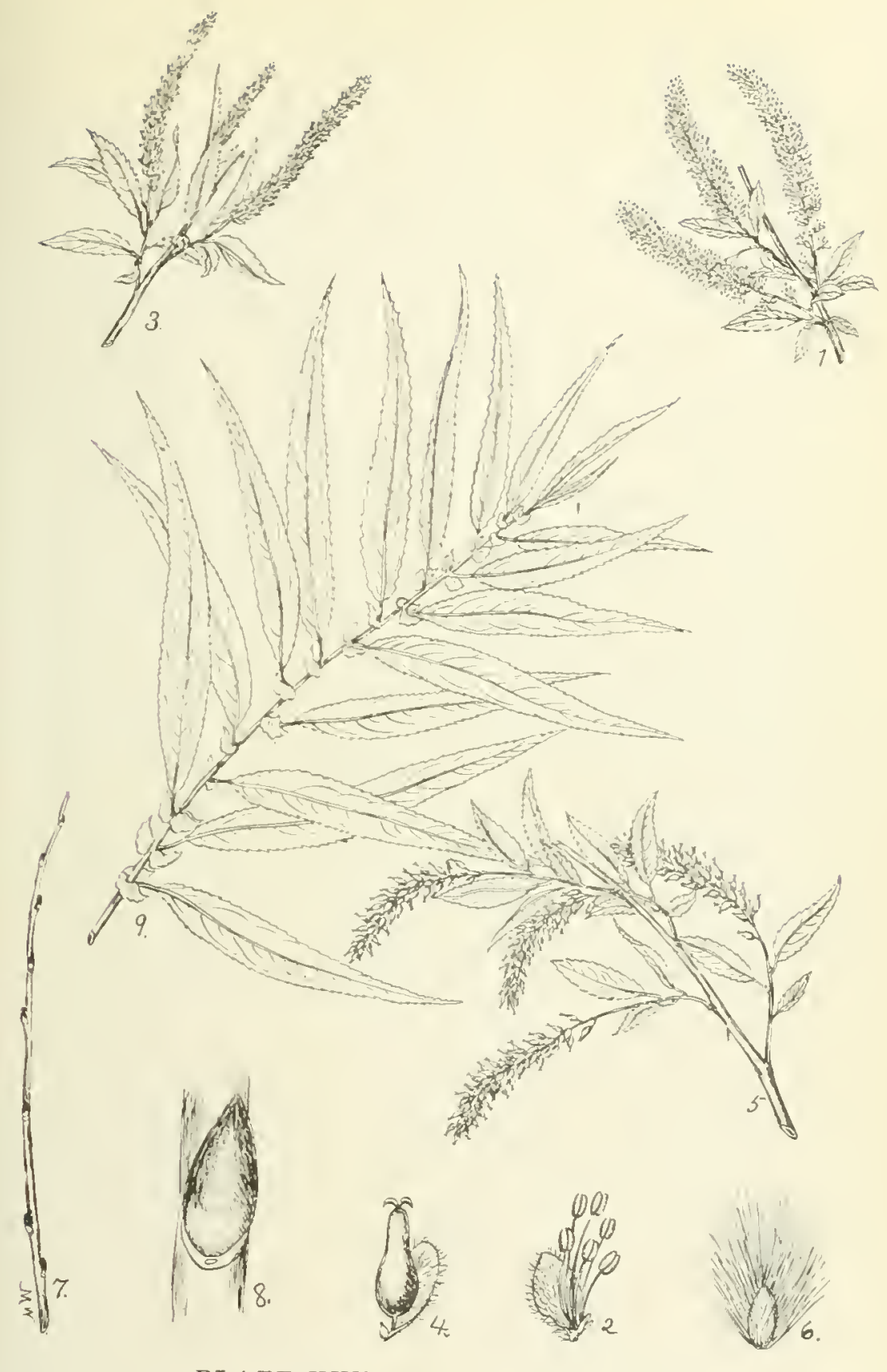

PLATE XXVIII. BLACK WILLOW.

1. A staminate Prowming b,ranch, $x$ ?

- A staminate Hower, enlarged.

it wistillate Mowtring lironch, $x$

1. A pistillate forer. enlarged.

$\because$ A fruiting branch, 5 .

b. A seud witl luirs. ellarged.

7. A Winter twiz. $x \frac{3}{2}$.

Section of $\mathbf{n}$ winter twig with bud and leaf-sigr enlarged.

9. A leafy bram-h, $x$. 

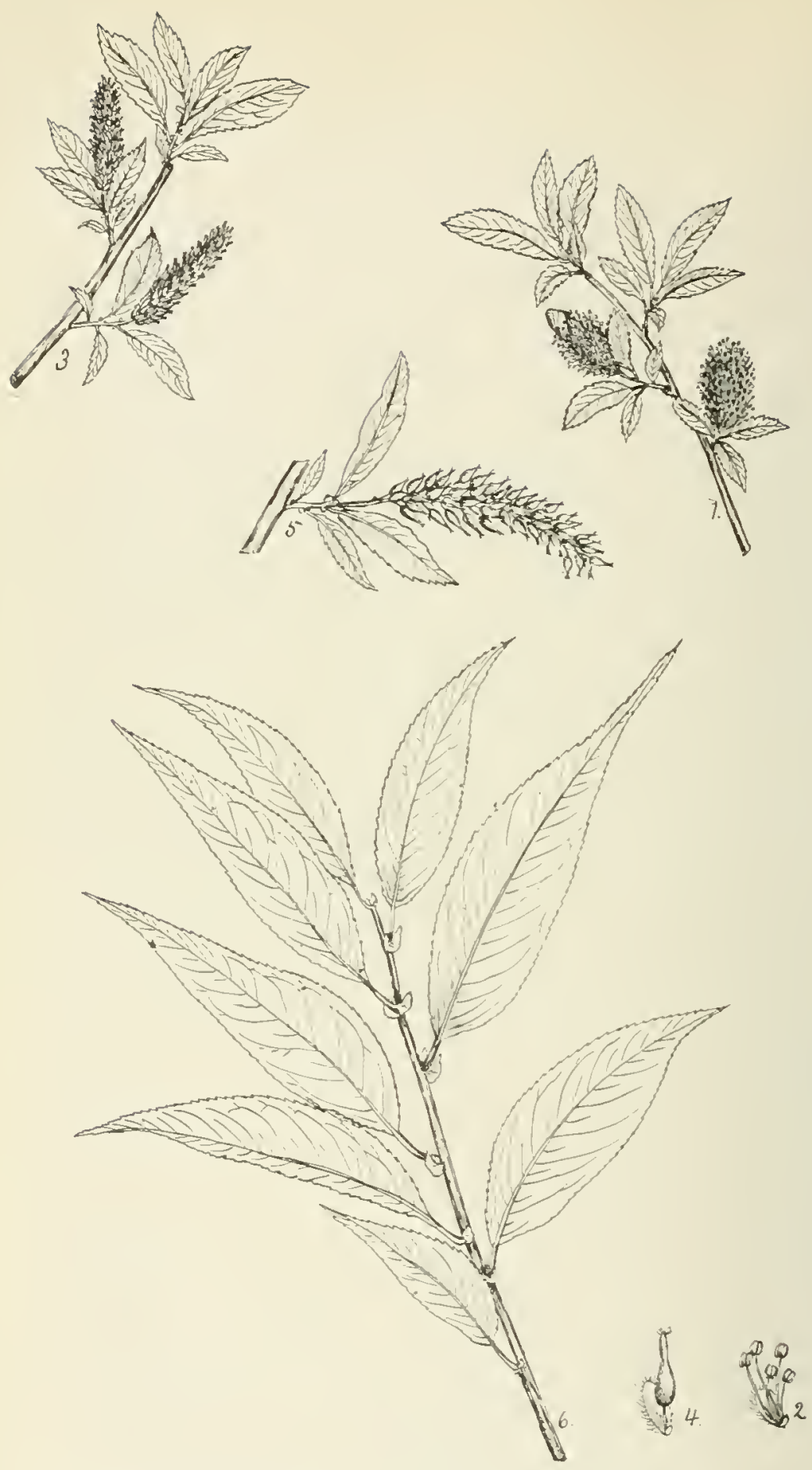

PLATE XXIX. SHINING WILLOW.

1. A staminate flowering branch, $\ \stackrel{1}{2}$.
3. A staminate flower, slightly enlarged.

3. A pistillate fowering branch, $x$ a.

1. A pistillate forrer, slightly enlarged.

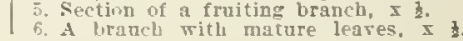




\section{SHINING WILLOW.}

\section{Salix lucida, Muhlenberg.}

FORM-A kbrub or suall tree sometiues reachiag a helght of 25 ft. with a dameter of 8 laches. Trubk shor, bearing tather ascendiag branches whlch form a rather gywrotrlcal and luroad crowa.

BARK-Smootin, thln, bitter, brown to redilsh-brown.

TWIGS-Shlaing, yellowlsb-brown, later dark brown.

BUDS-Aleraate, smooth, ovate, polated, about is of an lach loag, covered by a siagle yellowish-brawa scale.

LEAVES-Nteruate, simple, broadly lanceolate to ovate, loag-polated at apex, taperlag or ronaded at base, finely toothed on margia, smooth and shlalng above, paler below.

LEAF-SCARS-Alternate, somewhat rafsed, lonate, with 3 corsplenoga buadie-acara.

FLOWERS-Ajprar la catklng about Aprll before the leaves have uafolded, Stamiante and pistillate fowers oceur on separate trees. The staminate have fow stamens, and are arrangea Iu dease flowered catklns about 1 to li lnches long. The plstillato are arraged la slender catkln from 1-2 lachea loag.

FRUIT-A narrowly-ovold, smooth, dull, evldeatly-Btalled, atraw.colored to pale browa or greenish capsule which is crldeatly-rounded at the base.

W0OD_Same as that of other WHlows, S* description under Black willow, page 90.

DISTINGUISHING CHARACTERISTICS-THe Shlalng WHllow, also known as Glossy IVlllow, nay be dlstingulshed by Its ahiaiag leares whlch are laaceolate ta ovate in ontliae, aad by Its glandular jetioles aad stliules. The shining hrownlsb or yellowlsh twlgs are alao characterlatic. The capsules are sropotl. and the stamiate fowers usually have 5 stameas.

RANGE-Finwfoubdland to Magtolu, south to Peansylvanla, west to Keatucky and Nebraska.

DISTRIBUTION IN PENNSILVANIA-Localy throughout the State except la the soutbera part.

HABITAT-Prefers wet habltats. Commoa aloag atreams, on lslaads, and la wet aeml-boggy Bituations.

IMPORTANCE OF THE SPECIES-The Shinlog WHllow is a very commog ahrub or small tree in wet situations throughout this State. The wood is of no commerclal lmportance. The tree often acts as 1 soll hinder upon areas whore erosion is to be feared. It is also oae of the most attractlve of our small Willows, hoth in Its batural bauats and artifial eavlronmeats. 


\section{GLAUCOUS WILLOW.}

\section{Salix discolor, Mulhlenberg.}

FORM-A shrut or small tree usjally from ti.15 feet ligh but mng rench a height of $25 \mathrm{lt}$. with a diameter of $S$ inches. Truak stort and bearing stont ascending branches which form a reusd.topped crowa.

BARK-Thin, smooth, oceasionally sculy, reddish.hrown.

TWIGS-At first hatry, later smooth, stout, reddist-purple to dark green, rather flexible.

BUDS-Alternate, closely appressed, flattened, nointed, ghout $\$+1$ of an inch long, corered hy a solitars stinng reddish.purple scale, Flower-buds much larger than leaf-buds.

IEAVES-Alternate, simple, elliptic to oblong-lanceolate, sharp-pointed at apex, rounded at base, coarsaly tcothed on margiv, glaucous or white beneath, green and smooth ubore. Petioles and stipules rot glandular.

IEAF-SCARS-Alternate, somew hat rajsed, lunate, contain 3 bundle-scars.

FLOWERS-Appear in Mareh on iwigs of prerious season's growth hefore the leares unfold. Staminate and pistillate fowers occur on separate trees; catkins densely fowered, with browntipped bracts.

FRUIT-A large, hairy, long-beaked, light brown capsule.

WOOD-Same as that of otter Wlllows, Spe description under Black Willow, page an,

DISTINGUISHING CHARACTERISTICS-The GlanCnUS Willow, also known as Eussy Willow, may he distinsuished by its lascenlnte to elliptic leares which are smonth nud bright green above and glaucous beneath. The blussoms are thick, about bulf as wide as long. Capsules are pubescent. The scales of the blossoms are clnthed with long shining hairs.

RANGE-Nora Scotia and Manitaba, south to Delaware aod Missouri.

DISTRIBUTION IN PENNSYIVANIA-I.aeally throughout the State. Father common along the main streams nad their tribntaries.

HABITAT-Prefers wet habitats such as one tinds along streams, on the border of Iakes, in swamps and semi-boggy situatiozs. Occasionally on moist billsiles. Planted specimens oftea grow on rather diry situations.

IMPORTANCE OF THE SPECIES - The Glaucous Willow prodaces wood which is of no special comruercial jmportance. The main value of the tree lies in its attractire blossnms which appear early in spring before the leaves tare unfolded. It also possesses a rather bandsome form and attractire barl. 


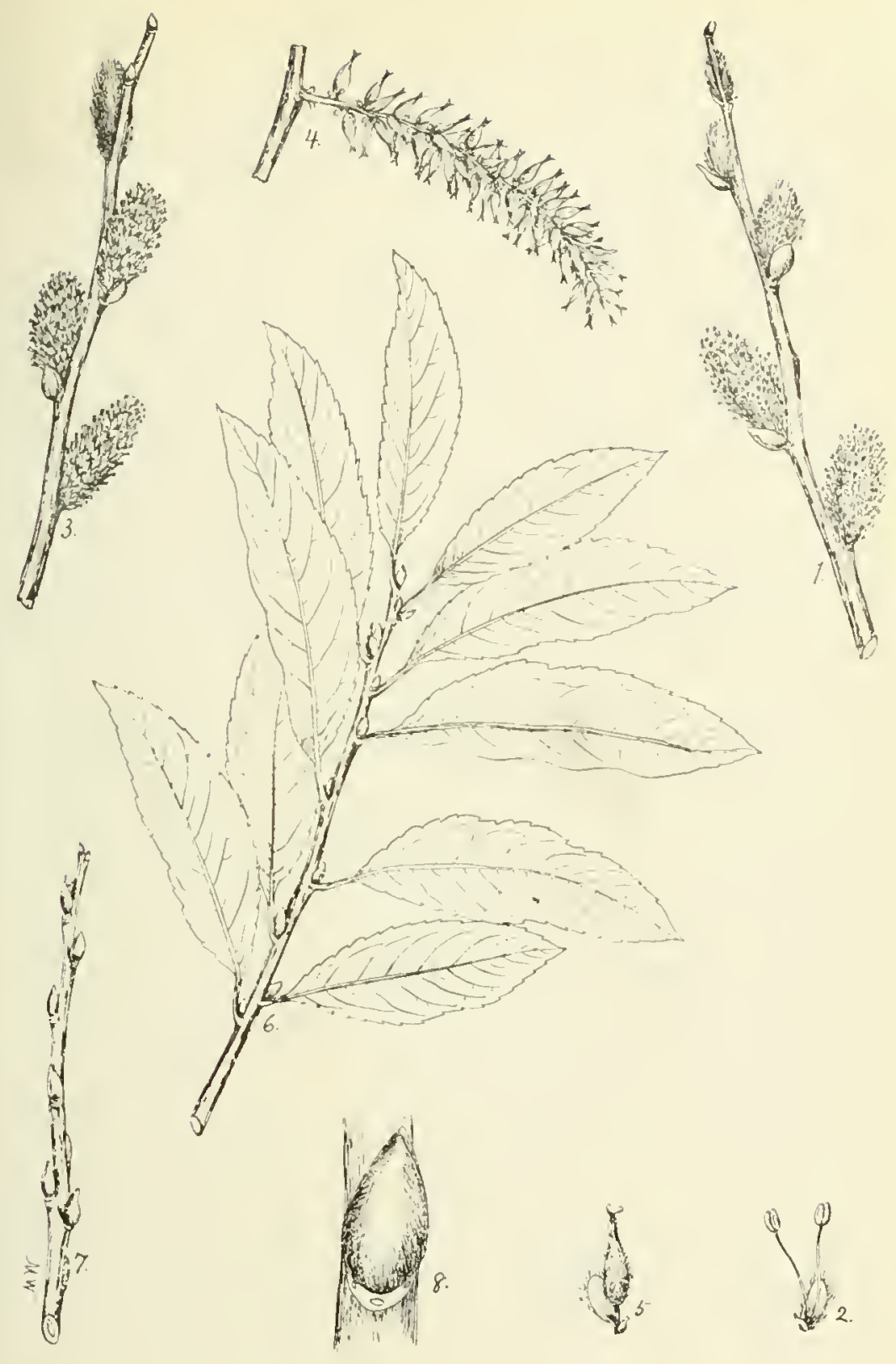

PLATE XXX. GLAUCOUS WILLOW.

1. A staminate lluwring branch, $x$ z.

3. A [istil]ate Huwering liranch, $x$ t.

4. Siretion of a fruiting liranels, $x$ s.

5. A fistillate llower, slightly inlatger.

1. A branil with mature leates, $x$

o. A winter twige $x$.

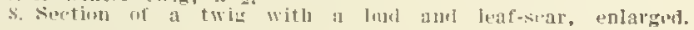



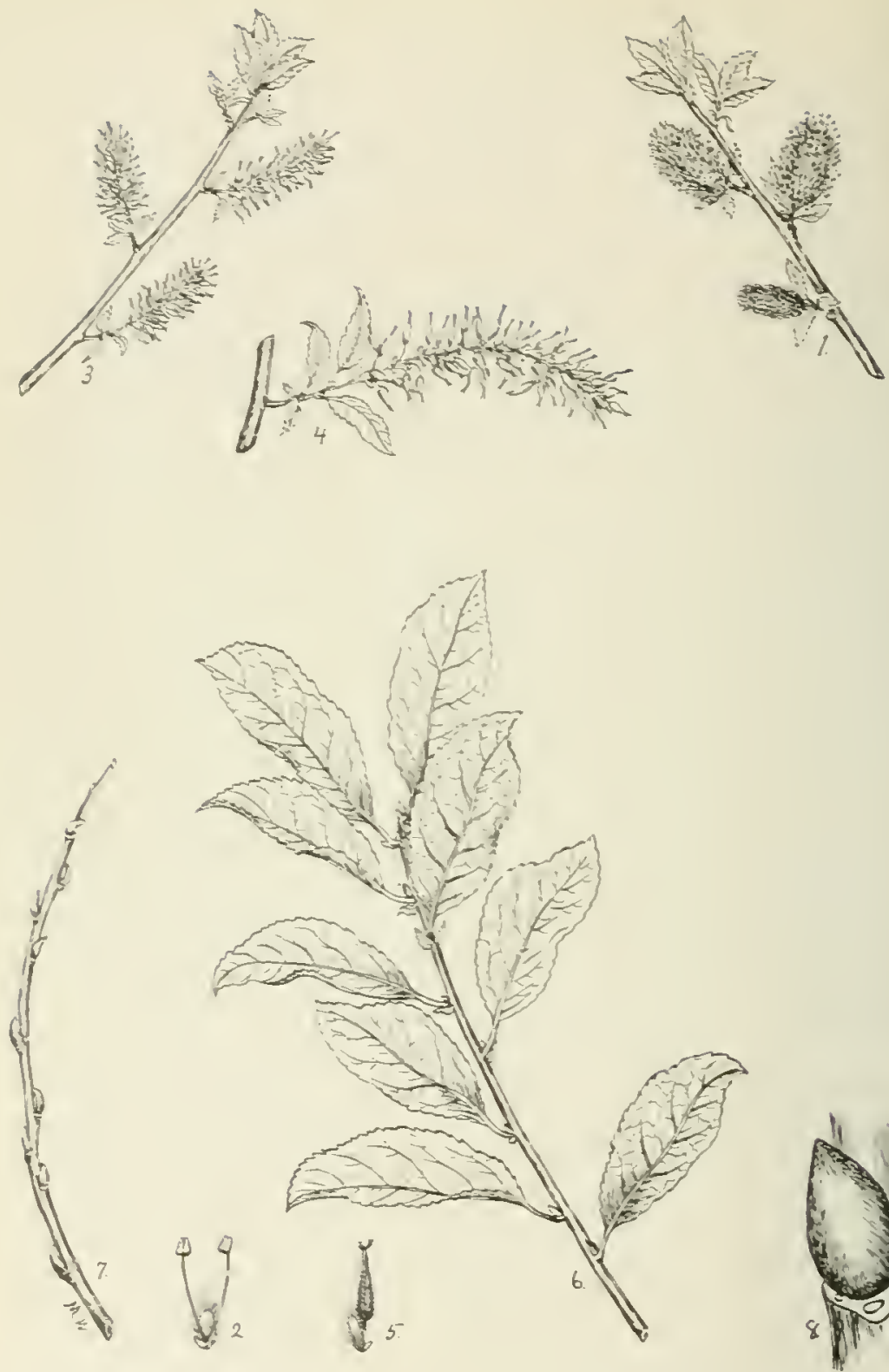

PLATE XXXI. BEAKED WILLOW.

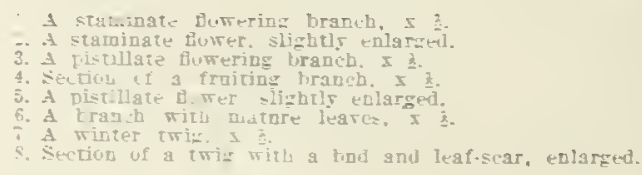




\section{BEAKED WILLOW.}

\section{Salix rostrata, Richarr:}

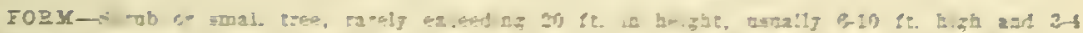

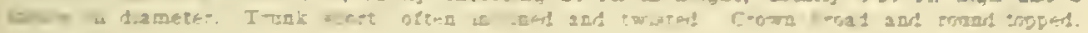

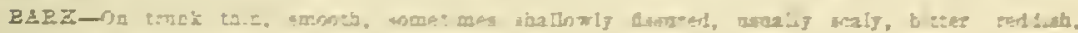

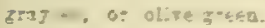

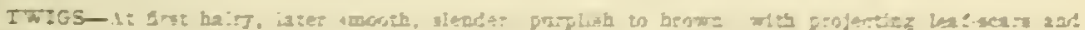
: W Inederts.

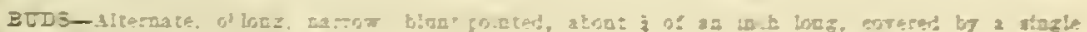

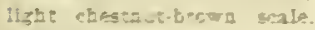

IIATE3-Mltsan

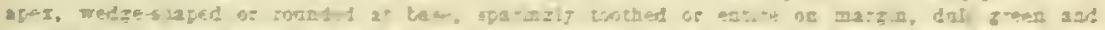

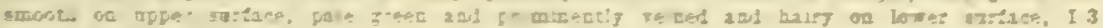

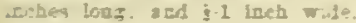

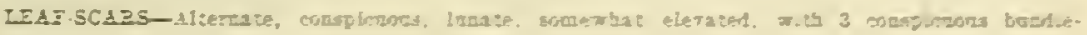
mas.

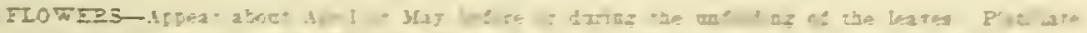

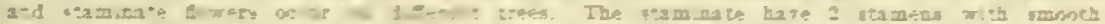

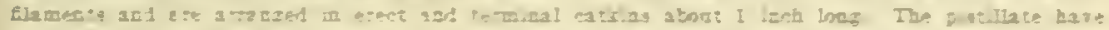

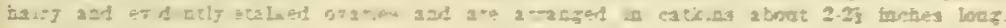

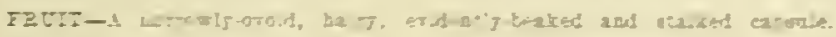

W00J-

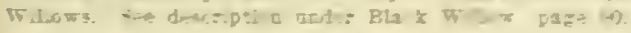

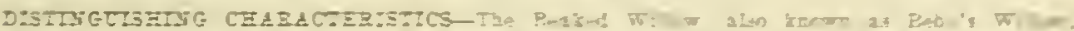

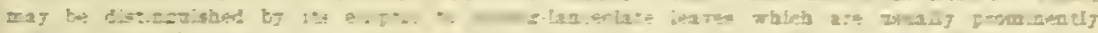

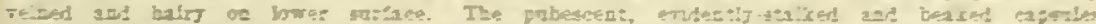

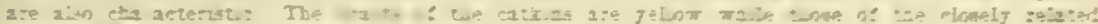

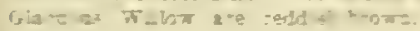

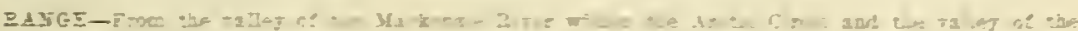

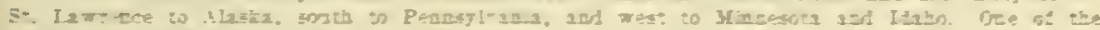

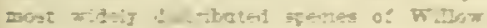

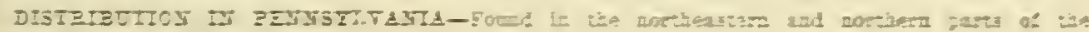
Sirs:

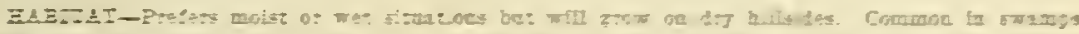

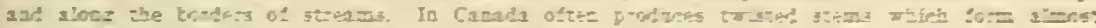

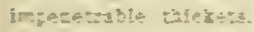

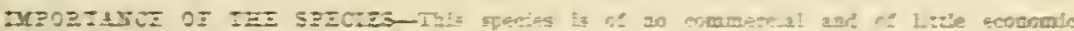

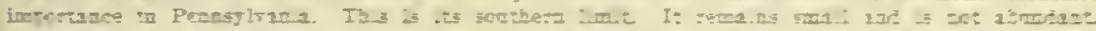

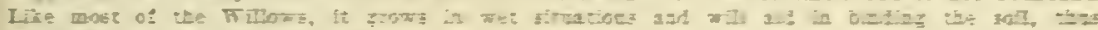

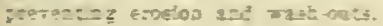


THE ASPENS AND COTTONWOODS-POPULUS (Tourn.) L.

This genus comprises about $2 \pi$ species native to the north temperate and arctic zones, of which number 19 are native to North America and 4 to Pennsylvania.

The trees belonging to this genus hare many common names, as Aspens, Cottonwoods, Poplars, or Popples. Although some of them are called Poplar, still they are in no way related to the well-known Yellow Poplar or Tulip Tree which belongs to the Magnolia family.

The leares of some of the representatives become very conspicuous on account of their trembling or quaking habit. This fluttering of the leaves, even when only a slight breeze is at hand, is due to their laterally compressed leaf-stalks. The buds of a fen species are eridently resinous and of ten pungent. Possibls no group of trees, except the Willows, is so well equipped to disseminate its seeds. The seeds are rery light. produced in great abundance, and furnished with a dense covering of long white hairs which aid in their dispersal.

The wood of the members of this genus is just beginning to be of commercial importance. It was formerly despised but is now used for various purposes, especially for paper pulp. These trees hare some raluable merits in that thes grow rery fast, often on situations where other species refuse to grow, especially in wet places, and may easily be reproduced by cuttings, sprouts, or seeds.

In addition to the $t$ species described and contained in the subjoined key, a few other species are rather common throughout the State especially as ornamental trees. The White or Silver.leaf Poplar (Populus alba L.) is a natire of Europe and Asia but very common as an ornamental tree. It can be distinguished by its lobed leaves, covered by a dense white persistent wool on the lower surface, and by its twigs, usually covered with white cottony felt which rubs off easily. The Lombardy Poplar (Populus nigra rar. italica Du Roi) is frequently cultirated in this State. It can best be distinguished by its form (Fig. 36). The lateral branches are almost erect forming a high but narrow crown, The leares hare flattened petioles, arc finely toothed, smooth, and sharp-pointed. The Balm of Gilead (Populus candicans Ait.), sometimes regarded a rariety of the Balsam Poplar, is occasionally found as a cultivated tree and frequently escapes cultivation. It can be recognized by large resinous buds, reddish-bromn twigs, and its orate leaves with round or channeled petioles and heart-shaped base. The leares of the closely related Balsam Poplar (Populus balsamifera L.) do not have a cordate base. 


\section{SUMMER KEY TO THE SPECIES.}

1. Learea with round or chanueled petloles; twigs with orange colored pith,

Page.

1. Leares whth fiattened petioles; twlgs with white pitb.

2. Leares brcadly deltold, ahruptly acuminate; stigma-lohes expanded in all drec-

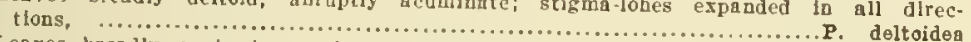

2. Leares brondy orate to nearly round, uaually acute at apex; stigma.lohea thread-

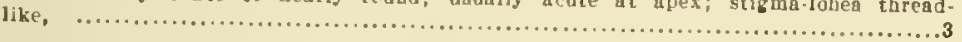

3. Leaves tinely serrate on morgin; bark greenish.wblte,

................ tremuloides P. Frandidenteta

\section{WINTER KEY TO THE SPECIES.}

1. Terminal buds to of an inch long, decidedly restuous; lateral brapchea with a tend-

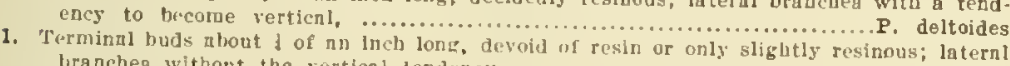

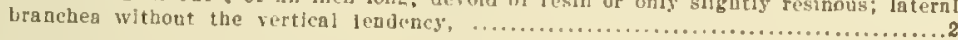

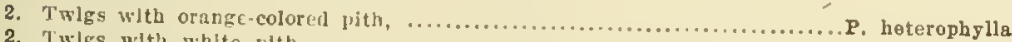

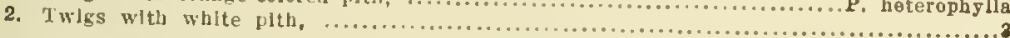

3. Buds smootb, slossy, conicnl, sharmpolnterl: aften lncurved and closily appressed,

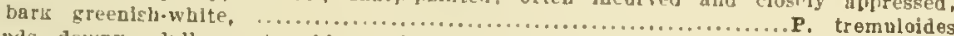

3. Buds downy, dull, ovite, blunt-polnted, siralght, dlvergent; bark yellowlsh-gray

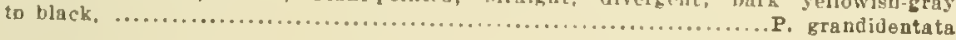




\section{AMERICAN ASPEN. Populus tremuloides, Michaux.}

FORM-A swall tree usually $30.40 \mathrm{ft}$. high but may reach a beight of $\mathrm{s} 0 \mathrm{ft}$. with a diameter of 20 ioches. In Penosylrania usually very small. Trubl continuous, tagering, hearing slender, brittle, and rather ascendiag lateral branches. Crom high, narrow, rather round-topped.

BARK-On ald trunks thick, deeply fissured ad black; oo upper portion of trunk and joung stems yellowish-green to white, with dark blotehes below the branches. Usanlls whiter at bigh altitude.

TWIGS-Rather slcoder, reddish-brown, clossy, smooth, round, sometines covered with a scaly bloow; marked pr reddisb-yellow lenticels; rougheoed by leaf-scars; pith white aod 5-aogled.

BUDS-Alteraate, Darrowly cooical, sharp-pointed, smooth, shing, usually appressed, ofted incurved; covered by 6-7 reddish-browo, smonth, shing, bnd-seales; hasal scale of lateral buds eutside.

LEAVES-Alteroate, simple, ovate to gearly rouad, cordate to truacate at base, acute at apex, foely serrate or margia, $1 \frac{1}{2}-2$ inches loos, thin, dark green aod shioy abore, pale green below. Leaf-staliss laterally flattened.

LEAF-SCARS-Alternate, large, coospicuous, luate, with a cork-like surface; buodle-seara 3 , simple or compounded. Stipule-sears ligear, blackish, rather distinct.

FLOWERS-Appear about April. Staminate and pistillate fowers occur on different trees. Staminate ameots droopiog, 13-23 ioches long, bearing mang closely packed indisidual forrers with 6.12 stamins. Pistillate ameots drooping, $1 \frac{1}{2}-2 \frac{1}{2}$ inches $100 \mathrm{~g}$; whe mature 4 inches long. beariog relatirely few indiridual flowers with thick stigmas dividel into thread-like lobes.

FRUIT-AD oblong-conical culsule, 2-ralved, light green, borne ou a drooping stalk ahout 4 inches long. Seeds light brown, surrounded by a mat of loog, soft, white hairs.

WooD-Difuse-porons; medullars rass very fioe and indistinet; pres rery minute. invisible rithout a leis. Fine in texture. light brown to white io color, neither strong nor durable. Welghs 25 lbs. per cubic foot. Ised for paper pulp, boxes, jells turckets, lard pails, spice kegs, wooden dishes.

DISTINGUISFING CHARACTERISTICS-The AmericsD Aspen, also known as Quaking Aspen, Trembliag Aspen, Small-toothed Aspcn, Popple. Poplar, ad Asren, may he distioguished by the round or orate leares which hare a fuely serrate margio aod are short-pointed. The petioles of the leaves are decidedls flattened which causes them to tremble or flotter in response to eren a light breeze, wheoce the aame Trembling Aspeo. The alternate, sharp-pointed, cooical, often jocurred, closely appressed, shiog buds are also characteristic. The buds of the closely related Largo-toothed Aspeu are stouter, not so sharp-nointed, ususlly dirergent, and corered with a flour-like, crusty, pale, woolly substancr. The twies are reddish and usually smoth whilo those of the Large-toothed Aspen are sellowish-brown often pale-down or pale-scals. The lateral branches arz more asceodiog aud the bark is lighter in color than that of the Large-toothed Aspen. The bark is jellowish-green to white often marked with dark blotebes.

RANGE-A trabseotinental species extmaling from Nowfoundland to the Hudson Pay region and Alaskn, south to Penasylradia ad along the mountains fo Keatucks, west to the Rocky Mourains, Mexico, aud Califordia. The widest range of aus species of tree in North America.

DISTRIBUTION IN PENASYLVANIA-Fond locally throughout the state, IIost common in the mouataicus part.

HABITAT-Found upon practically all soil coaditions except swamps. Prefers dry situations. commoo io abondoned fields, on cut-over areas and borns. Frequevtly mixed with Scrub Oak which shades ont in time.

IMPORTANCE OF THE SPECIES-The American Asped is of no commercial importance in Pentsylrania. It remains too small a ad is too local in its distribution. Next to Spruce and Hemlock it is the pribcipal pulpwood of the country. It is nlso beginning to he used for lumber. The wood is white ad torns well. Ordinarily it is a poor competitor io the forest bot it does avercome the Scrub oak upon burnt-over areas bj shading it ont. It Is also raluable as a temponis shelter species for other raluable trees. 

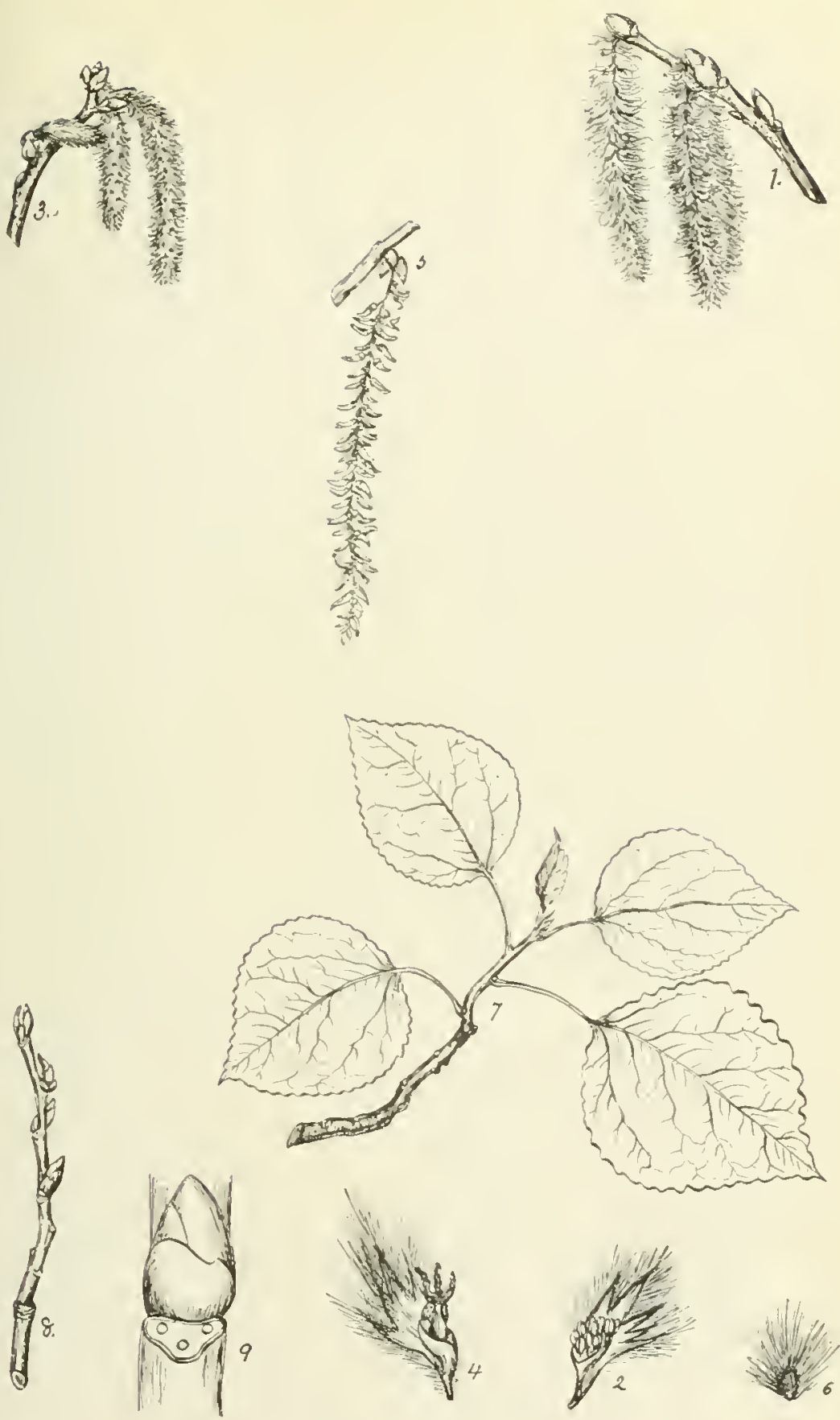

PLATE XXXII. AMERICAN ASPEN.

1. A staminate tlowering branch, $\mathbf{x}$.

2. A staminate Hower, enlarged,

3. A pistillate fortering urabch, $\mathbf{x}$ k.

4. A ristillate thwer, enlarged

$\therefore$. Section of a fruiting hranch, $x$.
6. A seed with hairs, enlarau.

8. A winter twis.

9. Seetion of a imig witb a bud and a leatection of a twig witb a bud and a leat-
scar. eularged. 

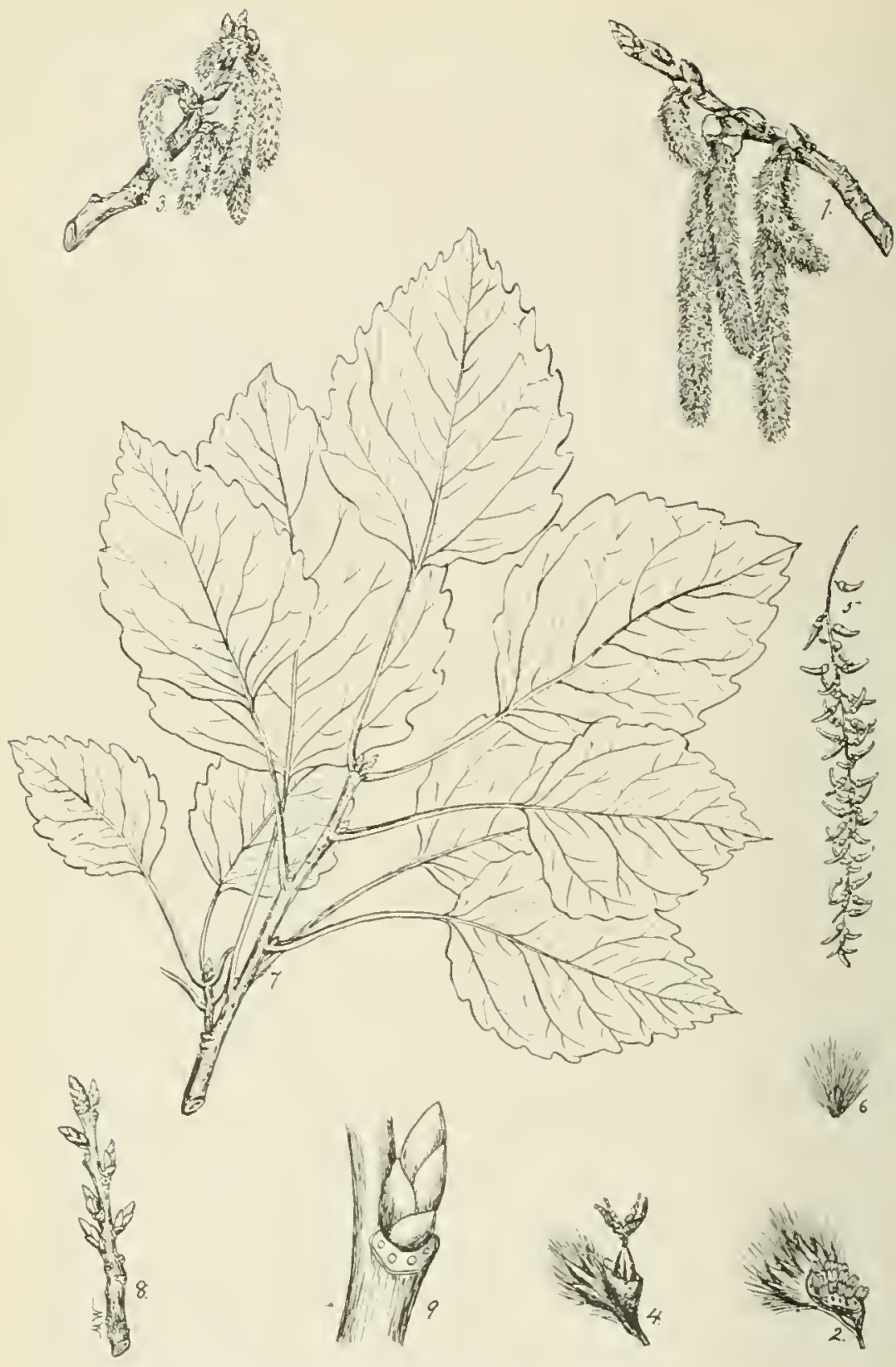

PLATE XXXIII. LARGE-TOOTHED ASPEN.

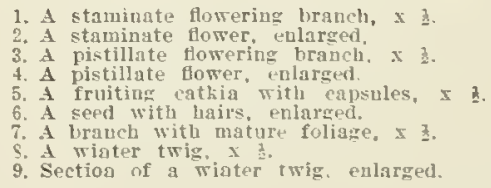




\section{LARGE-TOOTHED ASPEN. Populus grandidentata, Michaux.}

FORM-L'sanlly a small tree 30-40 $\mathrm{ft}$. high but mas reach a belght of $70 \mathrm{ft}$. with a dameter of 2 feet. More frequent and larger in this state than the American Aspea. Trunk contlnuous and tnpering. Crown often Irregulnr, due to the absence of branches whlch bare been broken of on nccount of theis brittleness. Hranches usunlly less ascending than those of the American Aspren.

BARI-Xizar the base of old trunks black, very pough, thick, hard, does not heal over branch wounds tupidly. Large smooth surfuces found on flnt ridges between Assures. Smaller branches simal!n: to those of the American Asnen but with a more prouounced $y$ ellow color. See F'lg. 95.

IWIGS-liather staut, reddish to ycllowish-brown, round, aften covered with a coating of pale, woolly, crastz cown which occusJonally peels of in sumil dakes.

BUDS-Alturnate, uvate to conleal, polnted, dusty, dull, usually divergent, covered by $6 \cdot 7$ Hight ches:uut-biown scnles which are nften contid with a dusty flour-like mat of a pale, woolly substance, Rasa' scuje of lateral buds on outslue.

LEAVES-Alternnte, simple, broady-ovate, wedge-shaped to cordate at base, ncute to acumlnate at apes, coarsely dentate on margin, 3-4 inchea long, dark green nbove, pale green below, Len r-stalks Internliy flattered.

LEAE-SCARS-Same us leat-schrs of American Asprn, page 96. Stipule-sears are less distinct.

FLOWERS-Siec "lowers" vnder Auerican Aspen, page 96.

FRUIT-1a nment benring scattered, light, green, 2-ralved capsnles whlch contaln minute dark browa seeds surrounded by a mat of loug white bairs.

WOOD-Same as American depen, Jage go.

DISTINGUISHING CHARACTERISTICS-The Iarge-toathed Aspen, also known as Popnle and Poplar, muy be distivgushed by its coarsely wayy-toothed leaves, larger than those of the American Aspen whicb it closely resembles. Sec "INstiaguishing Chntacterlstics" under the Intter. It does not bare the resinoug buds, nor the ridged bark on the twigs, nor the deltold lenres so cbarneteristic of the Cottonwool. The bark is often corered with orster-sbell-like bodies whicn are the armored portion of the ogster-ghell scale, Many small trecs are killed bs this senle.

RANGE-Vara Scotla and Ontarlo anuth to Pennsyjauia, along mountains to North Carolina and west to Minjesotn

DISTRIBUTION IN PENNSYLVANIA-Rnther common throughout the State especially on limbered and turnt-orer areas, in abnadoned ficlds, and on charcoal benrths. Unually 1ound in mixture, but occasionally iu smanll fure stinds.

HABITAT-Prefers rather. rlch moist soll, but is also fonad on dry grarelly soil. Usually Jnrge on moist situations and smaller, often scrubby, on rery dry sltuations. Frequent associntes are Birch, Bird Cherry, Shad Bush, and Scrub Oak.

IMPORTANCE OF THE SPECIES-The Lnrge-toothed Aspen is of no coramerclal Importance In thls State. It is of ralue in ou: Jumbered areas because it corers the soll rapldiy, acts as a soil-conserver, and often ns a soll-improver. It may also act as a temporary shelter for more raluable snecies while they are young and establishing themselres. It also aids in shading out our most aggresslre rorest weqd-Scrub Oak. 


\section{DOWNY POPLAR.}

\section{Populus heterophylla, Linnaeus.}

FORM-In the uorth usually a small tree from $30-50 \mathrm{ft}$. bigh; in the south mas reach a beight of $100 \mathrm{ft}$. with a diameter of $3 \mathrm{ft}$. Crown high; rather prond and roond-topped. Trunk short, continuous, nid taperiug.

BARK-On olo trunks thick, light reddish.brown, rough, broken by long fissures fnto long nartow plates. Cn jounger tuluks nul large branches thinner, not so rough; fissures shallower and ridges smoother than on old trutis.

TWIGS-Stout, light yellowish, marked ug a few scattered pale lentlcels, rooghened by tevated leaf-scurs; pith orange-colosed.

BUDS-Alternate, broadly orate, slightly resinous, bright redulsh-brown, corered with 4-7 scules whicb ar sliritly pubescent towards the base. Leaf-buds abont $f$ of an incb iong. Flower-buds sbout of an inch long.

IEAVES-Alternate, simple, bronjly orate, cordate, rounded or truncate at base, rounded or acute at apex, ccarsely serrate cn margin, $4-7$ inches long, dark green above, pale green below; leaf-stalks ronnd.

IEAF-SCARS-Alteruate, large, clerated, aften 3-lobed, Indented on upper margin; witb 3 conspicuous bundle-scars.

FLOWERS-Aprear in March or April. In general simllar to the Cottonwood only both staminate anj listillate aments are shorter.

FRUIT-A drooping ament, when mature about $4-6$ incheg long, bearing a few, scattered, dark green, 3-4-ralred capsules containing small seeds surrounded by a mat of white hairs.

WOOD-Same as that of the Cottonwood only slightly hearier. See descrlption page. 99.

DISTINGUISHING CHARACTERISTICS-The Downg Poplar, also known as Swamp Cotton." wood, Blnck cctlontwood, River Cottonwod, and swamp Poplar, may be distinguished from all the Aspens. Poplars, an 1 Cottonwoods natire to this State by its round leaf-stalks. The leaf-stalbs of all the others are laternlly fintened. The leares are large and more bluntly pointed than these of the other spccies. The leaf-margins are not so finely toothed as those of the American Aspen but finer than the otber two natle species. The bark on old trunks is light reddish brows. The twigs are stouter than those of the Aspena and contain orange colored pith. The Aspens bare white pith. The buds are brlght reddish-brown, slightly reginous, corered with scales which are often pubescent near the base.

RANGE-Connecticut along coast to Georgia, mest to Louisiana, and northurard to Kentucky and Missouri. lts range suggests a somewbat contorted borseshoe.

DISTRIBUTION IN PENNSYIVANIA-Found only in the extreme southeastern aud aouthern parts of the State. Reported from Chester, Delasare, and Fraulin counties. Very rare and local.

HABITAT-Found only in low wet situations, and always mixed with other speciea In thia State.

IMPORTANCE. OF THE SPECIES-This species is too rare and local to be of any commercial importance. It is not attractive ornamentally on account of its beary limba and sparse, rounded crow?. The wood is not listed separately on tbe market but bougbt and aold as Cottonwood. 


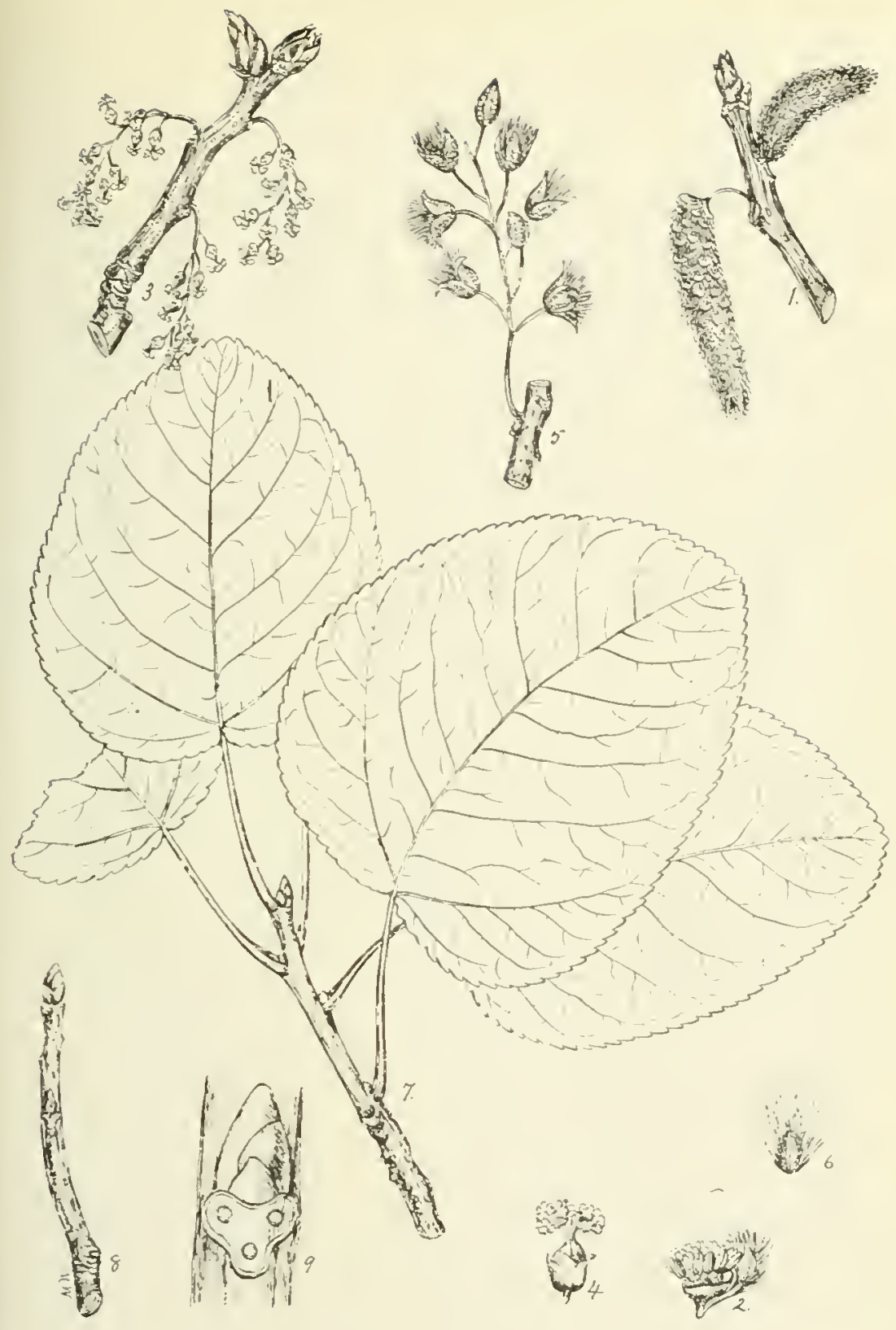

PLATE XXXIV. DOWNY POPLAR.

1. A staminate flowring branch, $\leq 3$.

3. I staninate flower, eflarged.

4. A listillate flower e

5. Sution of a lrumeb witi a fruiting catkin and capsules, $x$.

6. A sped with hairs, enlarged.

7. A liranch with mature folisge. $\frac{1}{2}$.

S. A winter twig, $x$ k.

9. vection of a winter twig, eularged. 

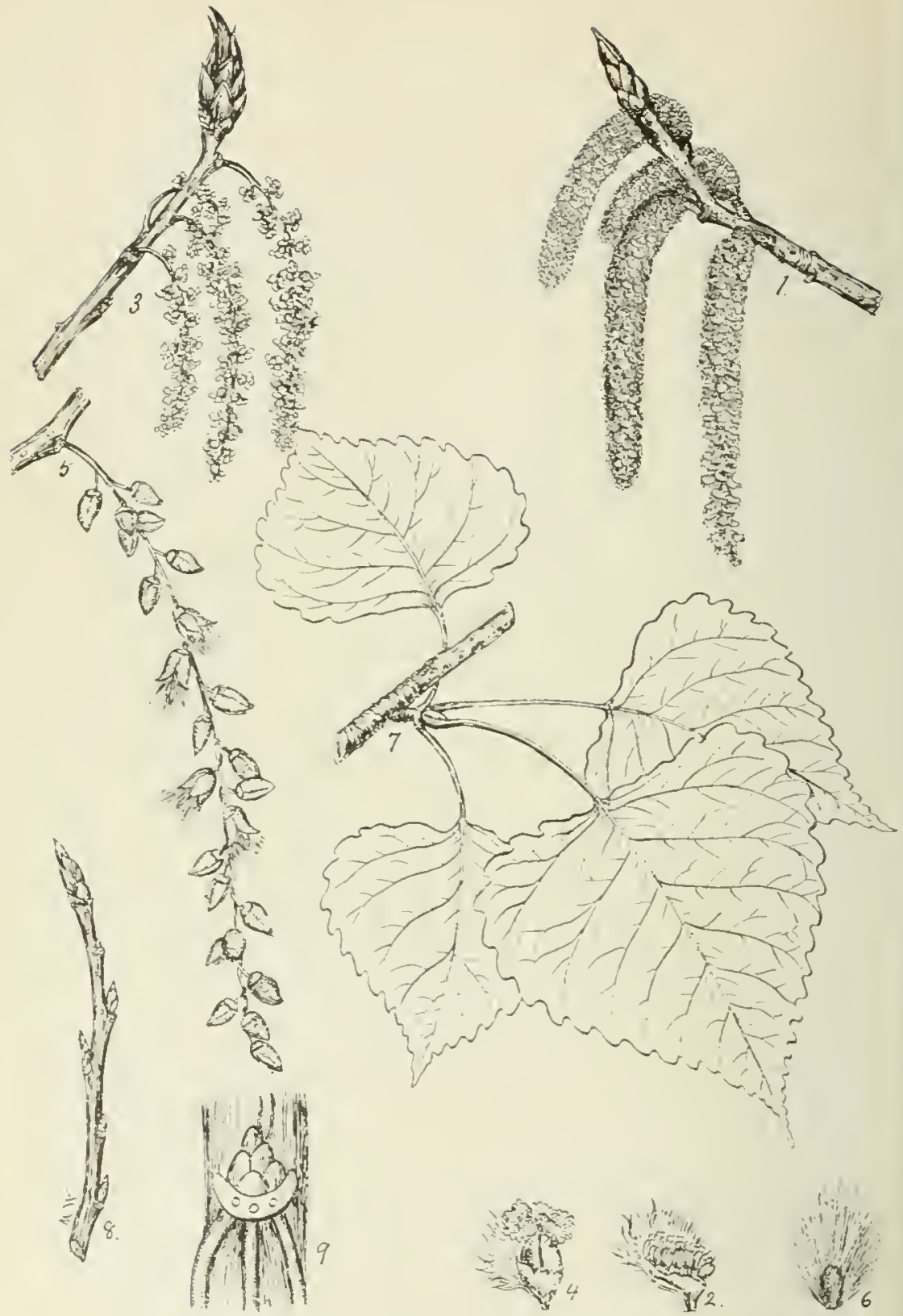

PLATE XXXV. COTTONWOOD.

1. A staminate fumering branch, I 3.

3. A staminate fower, enlarged.

4. A pistillate flower, enlarged.

Section ur a branch with a fruitiou catbin and capsules, $x$

6. A sted with hairs, eniarged.

9. Section of a wister twig. enlarged. 


\section{COTTONWOOD.}

\section{Populus deltoides, Marshall.}

FORM-1 large tres usually 50.75 ft, bigh but may reacb a beight of more thas $100 \mathrm{ft}$. with a diameter of f. fiet. 'Irunk taynelng, contiunous, sometimes clean for a coasiderable distude from the gruaud. Crown umaly high and jyramidal. Lower lateral braches herizontal, while most of th. viper branches are deciludly ascendiog.

BARK-On old trutsks thick, asby-grny, tuu-buned by long deep furrows which are usually lonoitudinally inrallel, and often conter with onc agother. liatber thia, smooth, and greenish. sellow on yauger trunks.

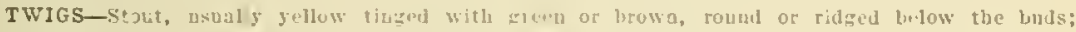
covered with large, longitudinally elongated lenthols; frich white agd angular.

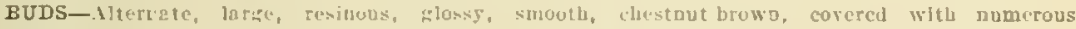
but scales which are sticky, resinous un the interior and smooth on the exterior. Terminal huds ofteo 5-agled and larker than lateral olles; lateral bud usilly dirergegt and often recorred.

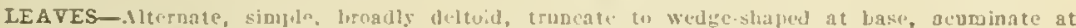
apes, coarsely serpate on tuarioia, 3.5 Inches long, thick, deep sbinlng green alove, pale green bilow. I ear-stulks litterally linterged.

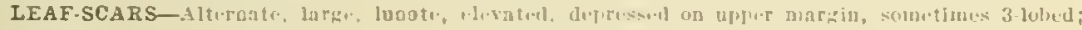
with 3 bundle-zears. Stipule-bcars ourli and consjlicuous.

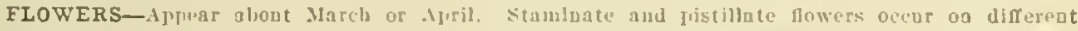

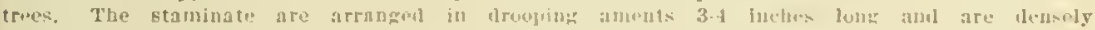
Howered; the pistillate, In droopiag anuts $2 \frac{13}{3}$ inches lung aud sparsely dlowered.

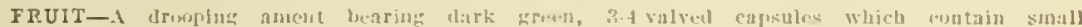
seeds surrounded with a mat of long white hairs. l'ruiting aments longur than in the other antive species, $5-1 \%$ inches.

WOOD-Difuse-jorms; witb very indistiat cays; jores in early wool visible to unalded eyes; beartwood dark brown; sapwoul wide ant whitu: woml is soft. warps "asily, aol is difficult to split. Wrighs about $23 \mathrm{Hs}$. Irer cubic foot. Lised for paler lubly, boxes, erates, berrs toses, pails, and tubs.

DISTINGUISHING CHARACTERISTICS-The Cottomool, also knowz as Carolina Poplar, Cottas 'Iree, and Whitewood may readily be dintinguished at agy senson of the juar by its lateral branches wbich has a tendency to ascenul like the Lombarly poplar (Fig. 36), aad by its rellowish twigs which afte bare jrominent ridges running awn from the leafsenrs. The linds are larger, mor cesinuos, and often wore flattened than those of ang other memtur of this genus: asually diverent nol offen incurved. Thu leaves are viry elaracter-

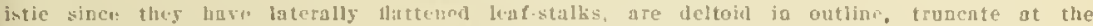
base and long fuintud at the njex. The pores in the early wood are risible to the unaided eye whlle thos: wi the imerican and large twothed Aspeas are oot risible.

RANGE-quebec a ad Untario south to Florida, west to the Rocks Mountains.

DISTRIBUTION IN PENNSYLVANIA-Natural distrihution is very limited. Reported from

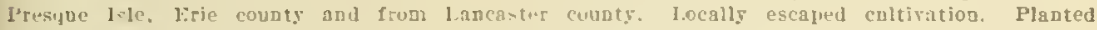
extensively for ormamental purjoses and in a few platatioes for forestry porjoses.

HABITAT-Puftrs rich moist soif, like halss of streams, borders of lakes, and semiawamps.

IMPORTANCE OF IHE SIECIES-Th. Cottoowood is rilanted extensirely as a oramental tree but as sucb it has few merits escept its rapjd growtb, rather attractive form in winter, nnd the pieasat balkamic odor fram its conted, soua:, developiog leaves, It is well adapted to wet locaticns and mas be planted where other more valuahle trees will not grow. It grows rapldly, and froluces an excelleat pulp-wood. This tree is known to grow $\vec{b}$ feet in a siagle rear and 40 fect in 10 sears. Cuttigg taliea from trees aod placed is the grouad grow very readils. When blanted ia the streets its roots oftea lift porements, and clog drajos aod sewers. Not adanted for street plaating. 


\section{THE WALXLT FAMILY-JCGLANDACEAE.}

This family comprises about 6 genera with 35 species of trees and shrubs found chiefly in the warmer portion of the north temperate zone. Tro genera witl about 19 species are native to North America. Both of these genera. Juglans and Carra, hare representatives in Pennsrlvania. The former genus has 2 species and the latter 5 species native to the State. In addition to the existing species a great number of fossil species have been referred to this family. Thirty fossil species belonging to the genus Juglans and 10 species belonging to the genus Carya hare been described.

This is one of the most important families of trees native to Pennsclvania. Both the Hickories and the Walnuts rield rery raluable rood. The mood of the Walnuts is esteemed especially for cabinet work and that of the Hickories on account of its strength and flexibilitr. The bark and husks of the Waluuts are used sometimes as a dyestuff. The fruit of both genera is edible.

The staminate and pistillate flowers are separate but borne on the same tree and usually in the same branch. The staminate flowers are in long drooping anients while the pistillate appear as buds and occur in small few-flowered clusters. The leares of both genera are compound and alternate. The fruit is a mut. The nut of the Walnuts is sculptured and corered with a fleshy, indehiscent, pulpy husk while the nut of the Hickories is not sculptured but corered with a dehiscent husk.

KEY TO THE GENERA.

1. Pith of twigs chamberd: Duts sculptured of rugose with indehiscent husk; staminate catkins thick, compact, usually sessile and solitary : wood difuse-forous, ......Juglans 1. Pith of twigs continuous; nuts smooth of ridged with dehiscent husk; staminate eatkios slender, loose, long-stalked, in 3 ; ; wood ring-porous, .........................

Page. 101 101 


\section{THE WALNUTS-JUGLANS, L.}

This genus comprises about 15 species which are found chiefly in the north temperate zone. Five species are native to North America, two of which are native to l'ennsylvania. In addition to the native species a buropean species known as the English Walnut (.Juglans regia $T_{\text {. }}$ ) is widely distributed in the United States as an olmamental tree. It is this European species which yields the ralualle Circassian Walnut wood nser so extensively in the manufacture of furmiture and it also froduces the English walnuts so common on our markets.

Our native speeies produce materials which are of considerable commercial importance. The wood is highly prized. The nuts are delicious and raluable as a food. The hark and husks are used as dyes and tans. The woor of our speries is diffuse-porous and brown to black in color. The leaves are alternate and compound. The pith is chambered. The fruit ripens in one season and consists of a sculptured or rugose uut covererl by a pulpy husk which does not split open into regular segments. The kernel of the nut is $2-4$ lobed, large and oily. The nuts are seattered mainly by rodents, which bury them for lood, and by tloods which earry them along their courses.

\section{SUMMER KEY TO THE SPECIES.}

1. I.caflets 11-17, often viscid-lialry, the terminal leadet usually preseat; pith dark brown: lark gray; fruit slleky litirs; nut clongated-oratr. ............... cinerea

1. I.eaflets 13-23. not biscid-liairs, the terndus leathet oftea absent; plth ligbt browa; bark dark brown; frult not stlekghalrs; nut glohose, ................. aigra.

Page.

103 103

WINTER KEY TO THE SPECIES.

1. Bark gray; pita dark lrowa; nut eloggated-ovate; upper surface of leap-scar not notchid; hairs transterse fringe abore leaf-scar preseat; terminal buds erldeatly flattened, got luss than $z$ of an inch long, ........................... cinerea

1. liark dar's brow: pilth light hrown; ut globose; upper surface of leaf-scar notched; lairy fringe above leaf-acar absent: terminal buls slightly flatteaed, of of an lnch or less la lengtb. 


\section{BUTTERNUT.}

\section{Juglans cinerea. I.mmaeus.}

FORM-A small to medium-sized tree usualy attainlng a leight of $30-50 \mathrm{ft}$. with a diameter of $1-2 \mathrm{ft}$, but mis reach a height of $80.100 \mathrm{ft}$. with a diumes.r of 3.4 foet. Trunk usualy sbort. Jike that of the apple tree. Crown usually uroad, deep, ronnd-toyged, rather orea, oftea unsmmetrical.

BARK-On lisanches and rond: trurks tather smootl, light gray: on older truoks roughened by black fissuris which separate wide, smooth, liwht \& ray rilges. Inner bark bitter, light in color, bccoming jellow an exposure. see Fig. so.

TWIGs-Ajterrate, stont, ronud; nt first bairy and sticky, later smooth; rougheaed bs leaf-scars, bitter to taste, grecnish-gray to buff io color, covered with a few pale leaticels; pith chambered, dark browa. If chewed, twigs aud yougg bark color salira rellow.

BUDS-Altetnate, covered with dense pale down. Terminal bui $\mathrm{d}-\mathrm{g}$ of an ioch long, flattened, bluntrointed with its outer scales lobed. Lateral lusls smaller tlau terminal, orate, very blunt-riointed cfton superposed. Scals cone-like lateral buds often present. These are in reality partially dereloped catkins.

LEAVES-Alternate, componnd, 15-30 inches long. with 11-17 Jeaffets. Leaflets $\mathbf{3}-\mathbf{a}$ inches long, serrate on marein, acute at apex, unequally rombers at linse and usually sessile or nearly so. Petioles uniry and sticky.

LEAF-SCARS-Htermate, large, 3 lobed, concare, with raisul pargins, with 3 clusters of bundle-scars arrauged in a ['shaje日 line. ["prer wargiu of lenf-scar usually convex, rarejs notclied.

FLOWERS-10neat ahout Ins when leares are half dereloned. Staminate and nistillate fowers separate, hat recor on tue sable tree and nsully on the sanu branches. Staminate

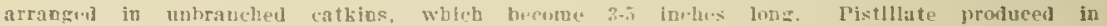
6-S.flowered spikes.

FRUIT-An dengated-orgte sculptured aut corerel with a fleshy indehlscent busk. Husk rery hairy and sticky. Nut four-ribued, pobted at one rad; contains a sweet edible and rery oily kernel.

WoOD-Difuse-pnous with ring-porcus tendencr; with inconspicuous medullary rars; soft

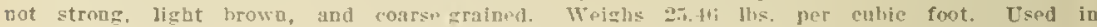
furbiture, interor finishings, and orcasivnally in cburcb altars, ceiling, ado fooriag.

DISTINGUISHING CHARACTERISTJCS-The Butternut, alio known as White Walout and Oilout, lesemlles the Black Walnut, but is distinguisied from it hy its shorter nad light.

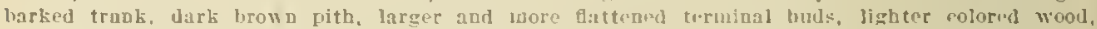
elongated-arate fruit, ungotched ujper margin of the leaf scar with a hairy fringe above it.

RANGE-New Eruswick and Qnebec, Trest to Mindesota, and south to Delaware and Arkansas, and along the mountaius to Georgia.

DISTRIBUIION IN PENNSYLVANIA-Local throughout the State in rich bottomlands and on fertile hillsidus. Vory common locally in the swutheastern and southern larts.

HABITAT-Prefors rich moist coll. Commou along fences, streams, and roads, occasionalls found on high meuntains.

IMPORTANCE OF THE SPECIES-Tht Butternut can hardly be classitied as a ralnable timber tree. It Irruluces a beautiful wood and delicious nuts bnt the trees seldom reach a large size. The old trees are very susceptible to the attack of rood-destrosing fungi. The tree is attractive oranucntalls. It braucbes freely often forming may crooks and crotches which yield the ligbly fisured rood. 

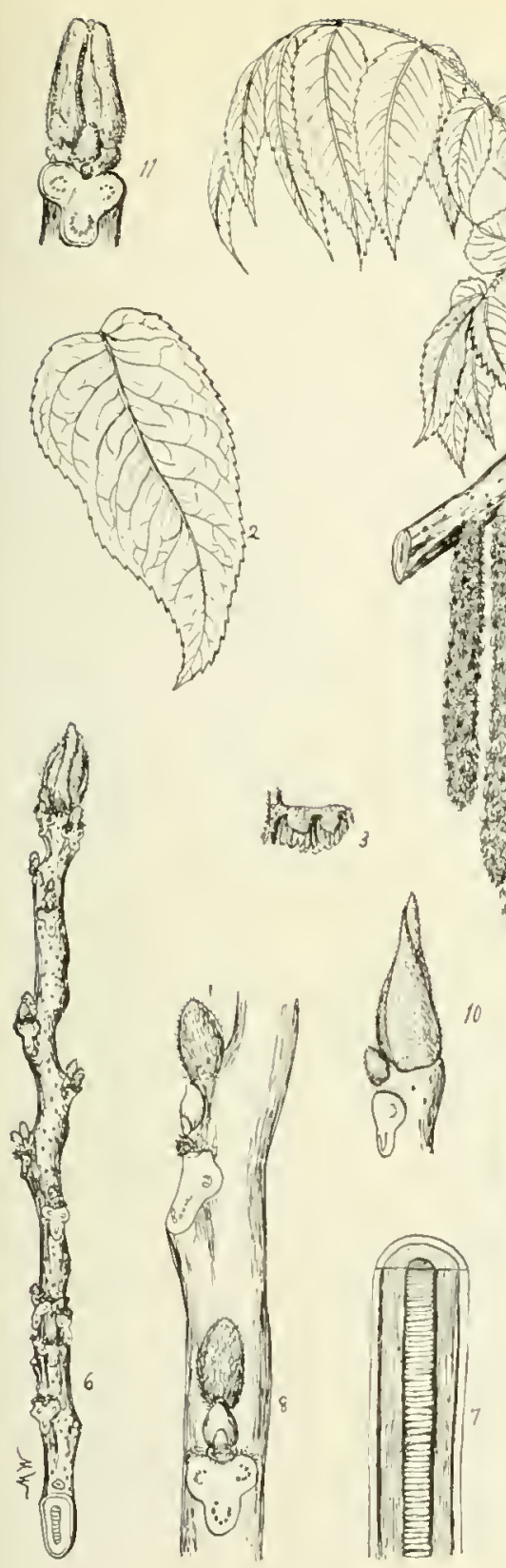

PLATE XXXVI. BUTTERNUT.

1. Branch with one-half dereloped leaves, (s) $\tau$. Longitulinal wortion of twig shwiag cham3 voliranclied catkins of stamiate towers. and (p) a chuster of pistillate flower's. $x$. 3.

2. A mature legtlet, $x$ b

3. A stamiagte Hower, slightly enlarged.

4. A pintillate buwer, slightly ealargenl.

5. A cluster of mature fruit, $x$ i

6. A winter twig showing buds, "ienticels, leafscars, and pith, $x$ is.

7. Longitulinal wortion of twig showigg clamSectinn of wiater bralur-b sbowiug leaf-scars, hairy friuge above leaf-scars and suprposed buts, stiglitly eolarged.

9. A nut ryith hick removes $x 3$

10. A terminal bur. vatural size.

11. A termiual bud (broad-sinte view), aatural size.

12. Section of a lranth showing superposed lateral fluwar buds, eularged. 


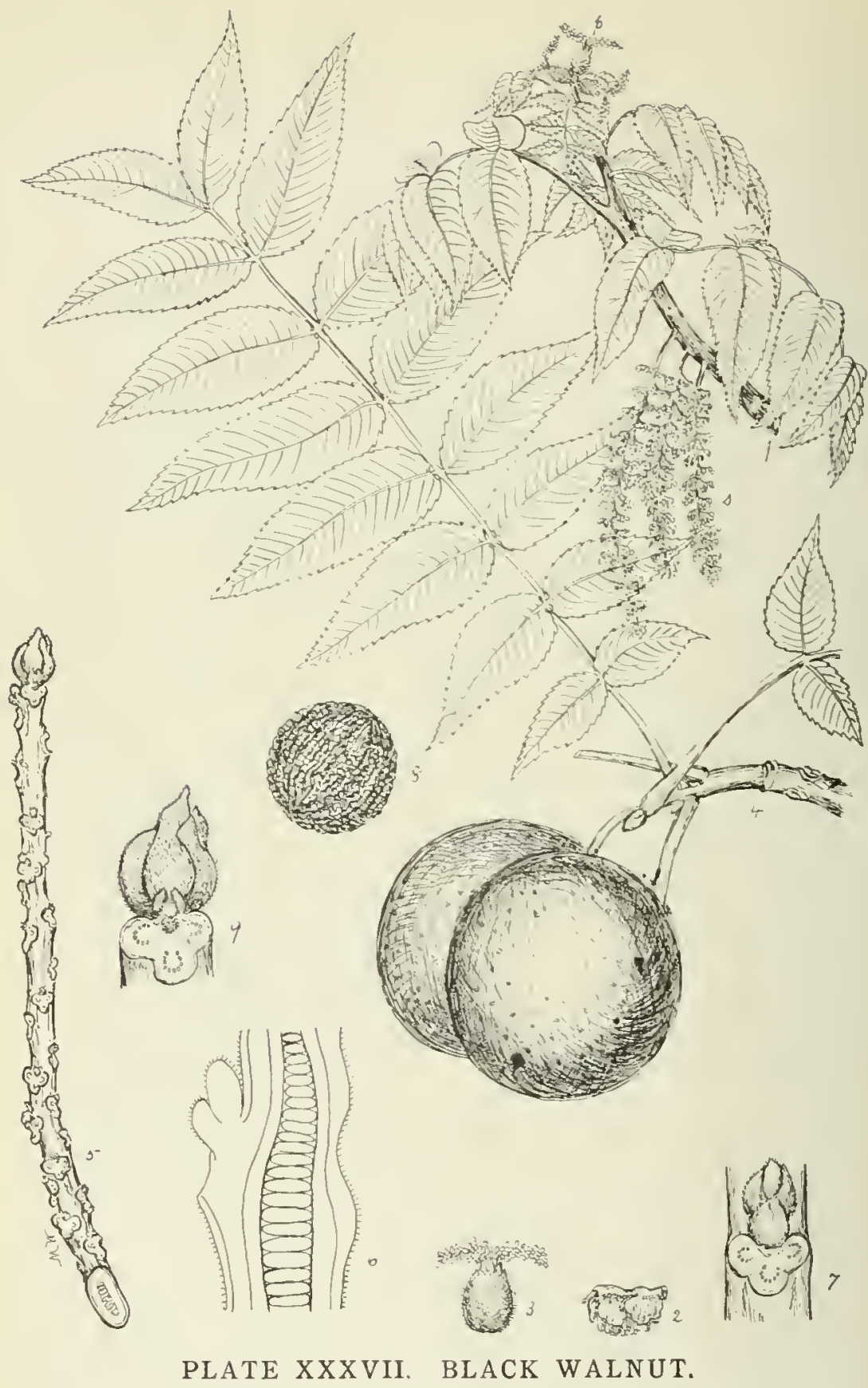

1. Prancil with dereloping leaves and (s) three s litary entlink uf staminate flowers and (p)

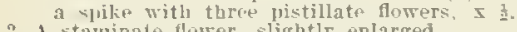

3. A pistillate flower, slightis enlarged

4. $A$ brapch with a mature leaf and fruit. a s

D. A winter trig, $x$,

6. Loluritudinal sintion of twig showing chambersl jith, enlaraed.

7. Section of twig showing superuosed and caping lumls, nnil leaf-scars with 3 clusturs of lunnde-

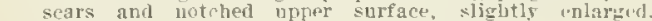

8. A nut rsit! husk remored, $x$ is

9. Terminal certion of winter twig showing leaf-siar and twrminal loul with bad-keales, slightly tolarged. 


\section{BLACK WALNUT.}

\section{Juglans nigra, Linnaeus.}

FORM-A large tree, usunlly attrioing a helght of $80.100 \mathrm{ft}$. with a diameter of $2.3 \mathrm{ft}$, but mny reach a beight of $150 \mathrm{ft}$. with a dlameter of fis feet. Trunk usually straight, cIeau, sllghtly taperiog, beariog a round.topped crowa.

BARK-Semi-fibrons, thick, rough, loggitudioally and necnsionnlly dingonally fissured. Outer bark dark brown to grayish-black. Inner bark light, but turas gellow unoo exposure. See Fig. 81 .

TWIGS-At first balry, later amooth, orange-brown to dark browa, stout, covered with rather laconspicuous, soluewbate rnised lentlecls; plth light browo, clambered.

BUDs-Aiternate, corered with thlek, pubesceot scales. Terminal buds usually lesg than 4 of an Inch long. fattened, ornte, blunt-poiuted. I.ntural luds usunily less than $1 / 6$ of an Incb loag, obluse at apex, oftea nuprosnod.

LEAVES-Alternate, couplound with $13-23$ lentlets. I.maflets 34 luehes long, ollique at bnse. acute nt apex, azrnte on margio, almost aessile and arrniged opposite or alternate to ench other.

LEAF-SCARS-Alternate, large, 3lobed, often leart-shaped, ralsed; upper margin noteheal In whtch an axlln:y bud is ofteo located. Hundlescars grouned in thrce clusters, nrrnaged io $\mathrm{n}$ U-shaped line.

FLowERS-Apjen in Mny when the leares are nhout half developed. Stnminnte and pistillate flowers spparate, but occir on snme tree and usunliy on same bracb. Staminate arraged fn uabrauched eatkins. Pistillnte produced in 2-5-flowered apikes.

FRUIT-A sculptured nut with a fleshy indehisent covering. Nut round, very rough, 12 laches in diameter, oerurs solitary, fo pnirs, sonetimes io 3 s: contains an edihle bomerhat olig kernel.

WOOD-Diffuse-prous whth a ring porms tendency; medullary rays lomspleuons; rleh dark brown, rery durable, hard, strong, spllts ensily, tnles glue well. Weighs 38.11 lbs. yer cublc foot. Used in furniture, intcrior flaishlngs, musical lastrumeats, automobiles, sewlag machlnes, fire-arms.

DISTINGUISHING CHARACTERISTICS-The [B]ack Walnut, also koowa as Walout, somewhat resembles the Rutternut or White Wnlout but benrs little rescmblsoce to other trees. It mas be distinguished from the Eutternut by its light browa ebambered pith, fhorter nad less ontteoed terminal buds, darker bark, larger slze, more globose out, notched upper marglos of leaf-gears, and the ahsence of a hairy fringe above the leat-senr.

RANGE-New Englaud aod New York to Minaesota, and south to Florida.

DISTRIBUTION IN PENNSYLVANIA-Local throughout the State io rich bottomlsods and od iertlle hillsidea.

HABITAT-Prefers rich molst soll. lequires pleoty of light aod deep soil sioce it is evidently trip-routed.

IMPORTANCE OF THE SPECIES-The Black Walout is ooe of the most valuable timber treeg native to this state. It reaches a lnrge slze, Is attractive ornmmeotally, sod produces wood vaiunble fur its color, figure, aud the fige nolish which it takeg. The Duts are blghly prized. lorest grown trees rarely produce wucls fruit. Onen growu trees produce abuadact fruit aod ofteu highls figared wood. 


\section{THE HICKORIES-CARIA, Nuttall.}

The Hickories and the Walnuts belong to the same family. All species of Hickory, so far as known, are native to the part of North America lying east of the Rocky Mountains. Geological records inform us that the ancient forests of hickory extended into Greenland and Europe. Tone of the fossil species shows evidence of living after the ice age. This suggests the presumption that the hickory forests were completely destroyed by sheets of ice adrancing from the North towards the Sonth. These sheets covered a large part of Europe and North America. To-day no native species of Hickory are found in Eurole, showing that they were completely exterminated during the ice age. In North America the ice corered only a portion of the range of hickory. Hickory is found todar not only in the nonglaciated region of North America bnt in addition it has regained some of the lost territory. The northern limit of Hickory is, however, still about 1,000 miles south of its nor ther'n limit in the ancient flora of Greenland. The range of some of the more important species of llickory has been extended by man.

The Hickories have alternate, compound and odrl-pinnate leares. The leaf-scars are large and conspicnons. The flowers are unisexnal. The stamiuate or male (pollen-bearing) flowers are prodnced in long slender, drooping aruents. The aments are nsnally in $3 \mathrm{~s}$, united near the base of twig into a common stalk which is attached to the twig at the base of the new growth. The pistillate or female flowers which develop into the fruit occur at the end of the season's twigs in spike-like clusters of 2-6. The finit resulting from the derelopment of the pistillate flowers matures in one season. The ruts are oroid to eylindrical and covered with a husk which is 4-valred. In most species the husk splits open at least to the middle when it becomes dry but in a few species it separates very little.

The Hickories are amongst our most injortant timber trees. They are not important becanse they produce a large quantity of wood but because they produce a special quality of rood used for special jurposes for which no substitutes have been found. The wood is unsurpassed for such uses where strength combined with lightness is desired. It is largely used for handles and in the manufacture of our best carriages, especially in the construction of the wheels. Not all of the species, hotrever, prodnce raluable wood. The wood of the Bitter Nut Hickory is relatively of little value. The nuts of a few species are edible. These nuts were used for food and for oil by the Indians and at the present time ther are used extensively 
for food. The most raluable and edible nuts are obtained from the Shag-bark Hickory (Carya orata).

This genus comprises about 10 species found in eastern North America and 1 species in Mexico. Six species are native to this State. One species, the small-fruited Hickory (Carra microcarpa, Nutt.), sometimes considered a rariety of the Pignut Hickory, is found locally in the State but not described in this publication. In addition to our native species the Pecan Hickory (Carra illinoensis) is llanterl extensively for ornamental purposes and for the sweet nuts which it produces.

\section{SUMMER KEY TO THE SPECIES.}

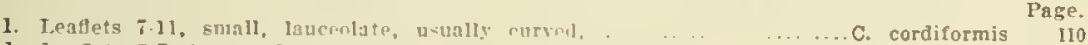

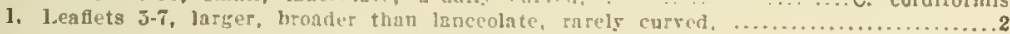

2. Husk of fullt sfilits tardily Into + ralres: ralves of frult thin and rather friable at matur!ty: twigs smooth, relatively sleader, cherry-colored to gray, ......... glabra

2. Hosk of eruit splits promitly iuto a valies; valves of frult thick and bard at maturity; twigs often lairy tomaris tip, ratbur stout, bur, gray, ur lirownish......3

3. Bark eloss, rough but not slaggy on old trunks: iwigs relatively stout; folinge scurfy

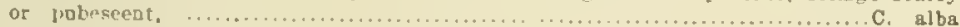

3. Bark slinggy separatlng lito lod filates on old trunks; twigs oot so stout; folinge

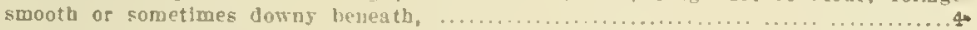

4. Ieaflets asually $\boldsymbol{i}$; nuts dull wbite or jellowish aud poloted at both ends, $c$. laciniosa

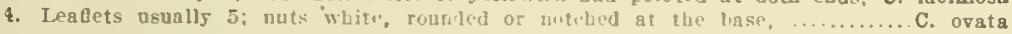

\section{WINTER KEY TO THE SPECIES.}

1. Bods rellew with 4.fi bud-senses ralvate jn pairs: lateral bads often evldently. stalked; terminal huds eloneater gnd fattrned. .................. C. cordiformis

1. Buds not ycllow. troly scaly; bud-scales in or more usually orerlapping, excent outer oars ou lateral buds which ingy form a chood sac liut in tiale split from the

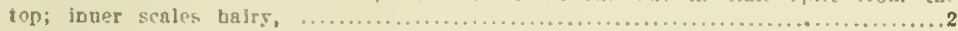

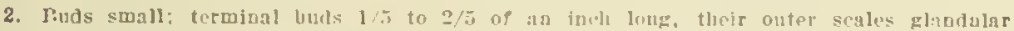
dotted; twigs smooth, relativels slender. cuerry-colored to gray; busk of fruit thin, not freely splitting to base, with thlu-shelled but. .................. glabra

2. Buds large: terminal wods $2 / 5$ to $3 \%$ of an incli loos, their outer senles almost glandless; twigs often lairy tomards tip, ratber stoot, und, gray, or brownish;

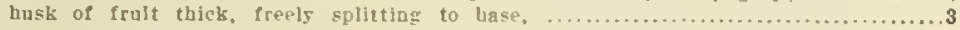

3. Twigs relatirely stout; bark rough anu close, uot shaggy; nut brownish, thicksbelled, with small kerbel; terminal buds broady-ovate with their outer scales

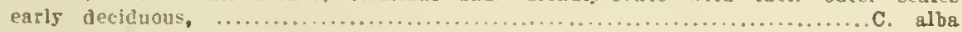

3. Twigs not so stont; bark shaggr: aut whito dull whitw or yellowisb with large kernel; terminal buds elongate-orate with their outer scales tardily deeiduous,....4

4. Nuts dull white or rellowish and pointer at botb ends.

C. laciniosa

4. Nuts white. rounded of notched at the base. 


\section{SHELL-BARK HICKORY.}

\section{Carya ovata, (Miller) K. Koch.}

FORM-1 Ialge tree usaalls reaching a beight of 50-75 $\mathrm{ft}$. With a diometer of $2 \mathrm{it}$, but mag reach a bcight of $120 \mathrm{ft}$. With a diameter af $3-4$ feet. Truak straight, sleader, in dease stands free irom branches for the greater part of its length; ia opea growa trees short, with ar oblong-erlindrienl high crown.

BARI-On old trunks shaggr, light grar, 2/5-1 ineh thick, peeliag off ia tough strips or plates which are usnally loose at both ends and fastened in the middle. 0 o joang tranks 6mooth ad light gras. See Fig. 88.

TWIGS-latecmediate in thickness hetweea the Mocker Nut and the Pignut Hlckors, nsually slightly dawus, sametimes smooth anl glossg: reddish-brown to grasylsh, corered wlth nomeroos coasplcuoug ani longitudinally-eloogated Ientjcels; plth angular.

BUDS-Alternate, more then 2-ragked. Terminal bad Lroadly orate, blust-pointed, $2 / 5-4 / 5$ of nu iach loaz, ustally cavered br aboat 10 bud-scales. The $3-4$ oater scales dark brown. broadly triaugular, sbari-1rointed. often hairy esparislly along margia, sometimes smooth. nad aften with the apex termianting in 3 long rigid point. Janer scales increase in size la spring, are tardily decidnous, rellowish-green or reddisb. deasely downy on outer surface and smooth withid.

IEAVES-Alterante, compound, with 5-7 Ieaflets, 8-If inches loag. Lenfets differ in slze; basal rair small, relativels short and widest aear the hase; upper pair oborate and larger tha basal pair; terminal large and ohofate. Liaflets strate ou margin, acute nt apex, taperiag or rounded at base, usaally smooth but sometimes hairy on lawer surface.

LEAF-SCARS-Altraate, more tha 2-raaked, Iarge, coaspicuous, somewhat raised, beartshaped or 3-lobed or incersely-triangular of sometimes elliptical, coataining pumerous conEpicuous buadle-scars which are distributed irregularly or gronped in 3 clusters or arranged in a curred line.

FIOWERS-Anuear about Mar when leareg are almost fully develoned. Staminate and pistillate flawers occur scparately. Staminate hairs end arraged ia aments wbich are elustered Ia 3 a a $4-5$ iocheg long. Pistillate rusty-woolly arragged la $2-5$ large gpikes.

FRUIT-Globular or depressed at apex, I-2 laches lang, with n thick hask which splitg into fonr pieces completely to the base. Nut white, abloag, somerhat fatteaed, ridged, barely tipped with a point. with thic shell and large sweat kerael.

WOOD-Riag-joroas; rores of summer wood rather large, Isolated, rather erenif distrlbnted, not ja grouns or lines; mednllary rays rather abandant bat iscoaspicnons; conspleaons llnes of wood nareacisma prescot. Wood rery heary, hard, strong. tough, elastic, close-grained, asaaliy straight-erained, not durghle in contact with coil. IIfartwool light brown or reddish with white sapwood. Wwighs from 50 to $52 \mathrm{lhs}$, ner cubie foot. Csed cbiefly for baadles a ad light rebieles. Valuable for rucl and smokiag meat.

DISTINGUISHING CHARACTERISTICS-The Shell-bark Hickory, also knowa as Shag-bark Hickory, ean be distinguished from the Eitter Nu\& Ilickors bs means of its larger mans-scaled bnds which are not fattened nor rellow, and b5 jts bark which is shaggs. while that of the latter is clase and rough. The bark of the Pingut Hickory, is also close and rough. The Pigaut Hickory has scaly buds but ther are much smaller thea those of the Shell-bark Hickory. The fralt of both the Pigaut Hickors and Bitter sut Hickory is smaller and has a thin tardily or non-splitting bosk and a small hitter kerapl, and their leares ane smoother a ad thelr feaflets aarrower than those of the Shell-batk Hickorjes. The Jtocker Nut Hickory has stouter twigs, seurfler pubescent foliage, closer aad rougher bark, and bromper nuts with a small kergel. For distinguishing characteristica hetween Caryn orata and Carya laciniosa, see page 107.

RANGE-Quebee west to Mlinaesotz a ad south to Flocida and Texas.

DISTRIBUTION IN PENNSYIVANIA-Most commoa ia the soatheastera and southwestera parts of the State. Rare in the mountainous parts, except lacally in the rallers. Rather abandas 10eally east of the Allechens moutains especially in the fertile rallers and aloag the rich foothllis, Reported rather abundant locally is the aorthera part.

HABITAT-Prefers rich moist soil and plenty of llght. Common in the ralley and in molst hillside woods. Also common along streams, åd oa the border of swamps.

IMPORTANCE OF THE SPECIES-This is a rers important specles or acconat of the ralaable wood and auts which it produres. It is aot rers common ia the State as a whole, bot where it does occar it should be protected nad regenerated as much as possible. Seeds shonld bo planted rather than seediags beesase the Iattcr are sensitive to trasplantiag oa accoat of thelr long taproot. 

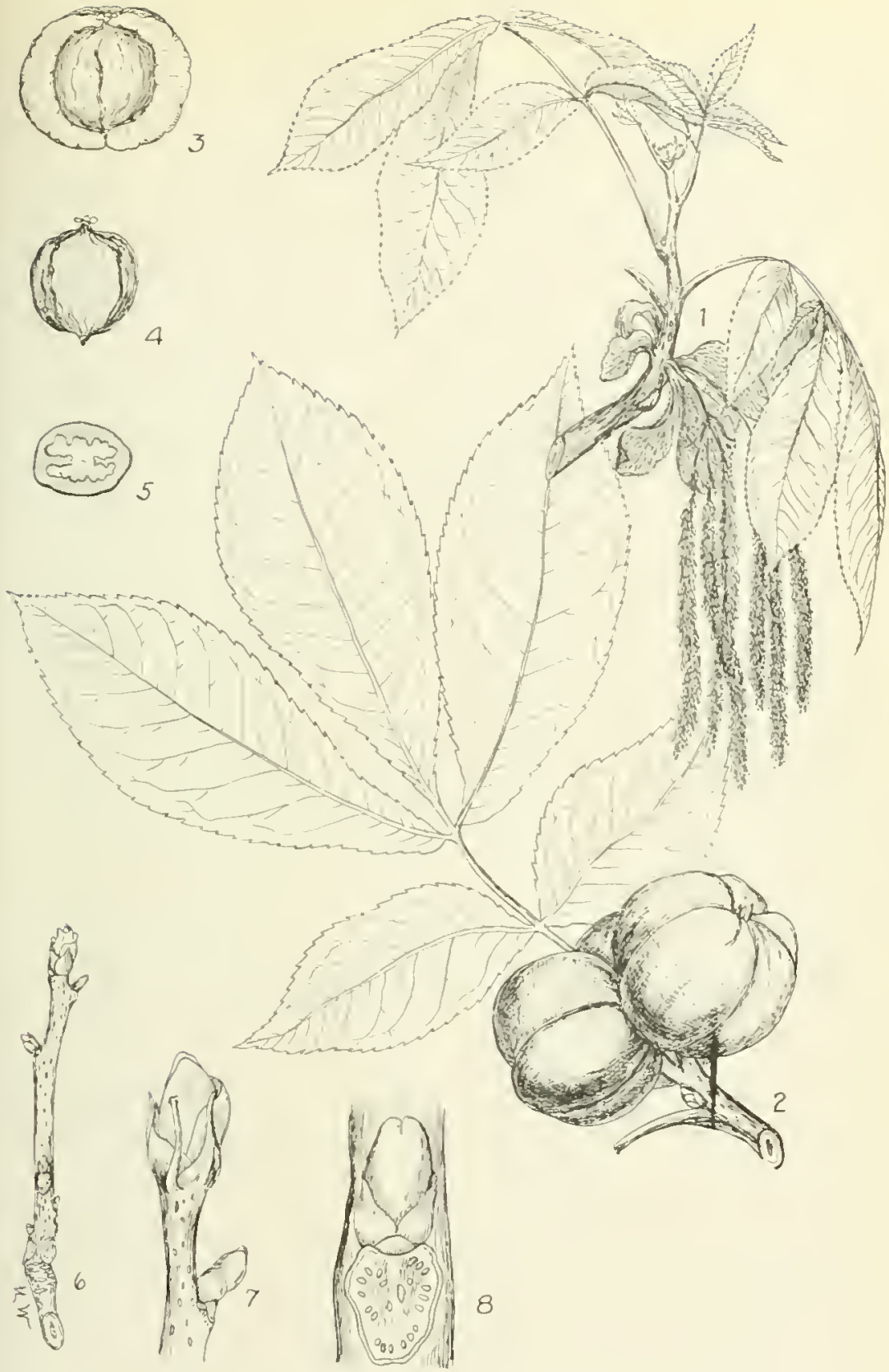

\section{PLATE XXXVIII. SHELL-BARK HICKORY.}

1. A fortering branch 51 .

2. I lranch with fruit and a matur. leaf, a

2. I nut with liart of husk remored, y $\frac{1}{3}$.

4. A nut, x 13 .

5. Crus-spetion of a nut showing licruel. x is

$t_{1}$. A wiuter twig, a ${ }^{2}$.

4. Torminal nart of a wintur twig notural tige

8. Section of a winter twig sbowing a Iateral bul and leaf-senr, eniargenl, 


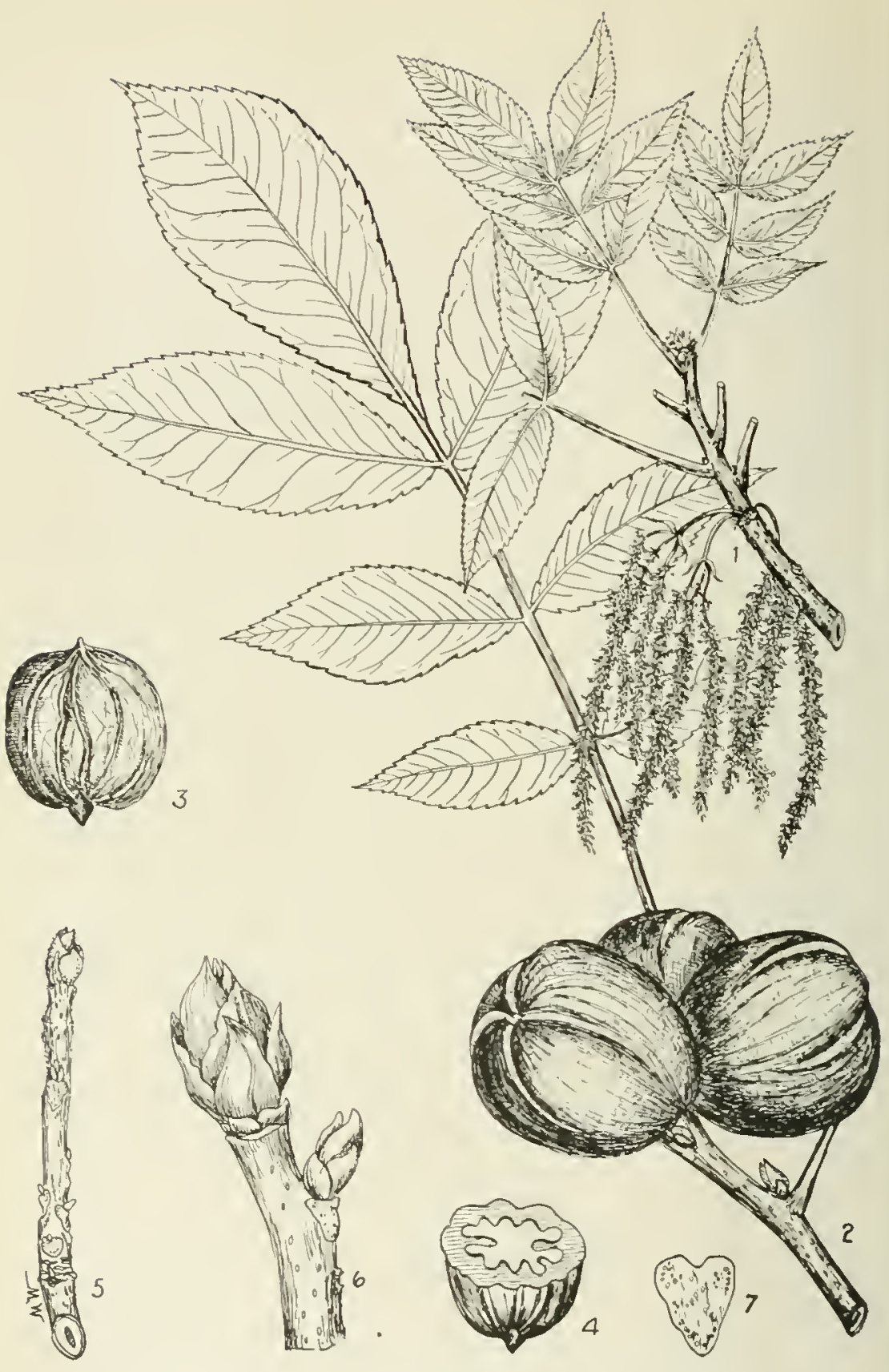

PLATE XXXIX. BIG SHELL-BARK HICKORY.

1. A flomering branch, $x$ s.

2. A branch with fruit and a

4. Cross-section of a nut, I $\mathbf{z}$.

5. A winter twig, $x$ t.

7. A leaf-sear with bundle-scars, slightly enlarged. 


\section{BIG SHELL-BARK HICKORY. \\ Carya laciniosa, (Michaux f.) Loudon.}

FORM-la general it is the same as (he shell-turk (Carya ovnta) except that ft does not attain so large a dinmeter. When growa iu a dense forest its truak is verg lun:, cleau, and slightly tapering.

BARK-Same as shell-hark lllckory (Carya ovntr) or probubly somewbat less shaggy.

TWIGS-Stout, usually a dittle velvety or tomentose, lut to aearly orange in color, corered with

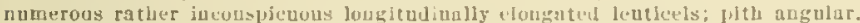

BUDS-Similar to those of the slicll hark (firyu vrata) except that they are a little larger and have less kecled and inore halry outer scales.

LEAVES-Altirnata, compound, with 79 lunllots, $10-22$ Inches long. l.ealets differ ia slze; lasal

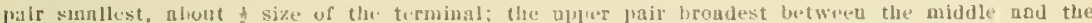

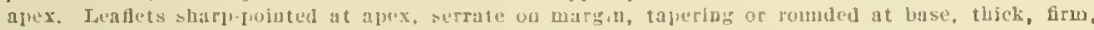
dark green and smovth avove, pale green to lnownish aml hairy helow. 1, f-stalks grooven, stout, surooth or hairy. thiclictad at base, often jetsint for a luag time.

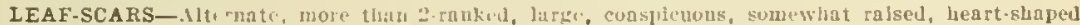

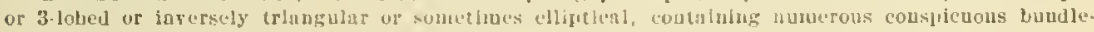
scurs which are d.stributcd irregularly, groujed in 3 lusters or arranged ln a curved liat.

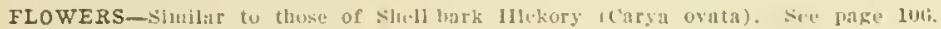

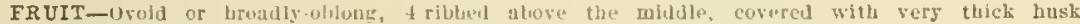
which splits rendily to th. like, Sut dull white or grhowish, thick-walled, usually strougls

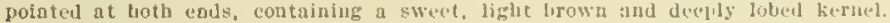

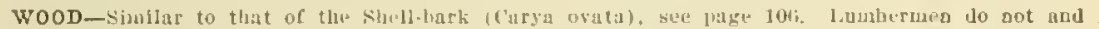
maufacturers camot distingu!sh hetweed the wrod of the two slecies.

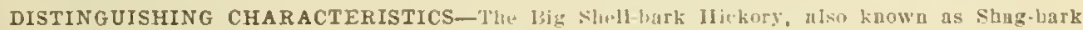

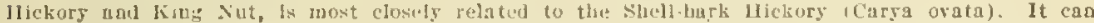
bust be distinguished by its dull white or yelluwish ants which nre usunlly strongly pointed at both

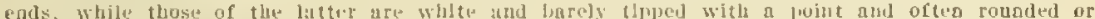

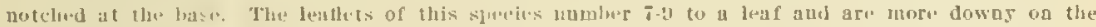

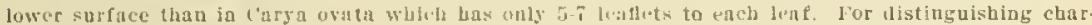

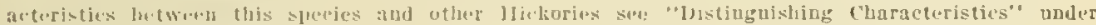

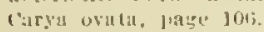

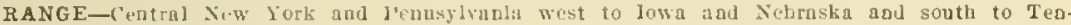
nessece and Arkaasas.

DISTRIBUTION IN PENNSYLVANIA-Cumanoa in the southeastera lint of the State. Most cominon enst of the sllegleny mountafns. Iiaje in the mountaigous region except locally la the fertile valles between the numbins, locally wresent iu the westera jart. l'robably most common In Nurthawiton, Bucks un.1 Montgomery counties.

HABITAT-Prefers wet, rich soil. Ofteu foud on situatioas which are temporarily flooded in spring. Frequent in rich buttomluads and on fertile billsides.

IMPORTANCE OF THE SPECIES-ThIs is a verF imjortant species on account af the valuable wood and ants wijch it produces. It is uot verg common in the stats as a whole, but where it does occur it should he protected and regenerated as muel as possible. veeds should he planted rather thas seedlings becanse the latter are sensitive to trunsplanting co accoun of their long taproot. 


\section{MOCKER NUT HICKORY.}

\section{Carya alba, (Linnaeus) K. Koch.}

FORM-A large tree usually 50-75 ft, high with a diameter of about $2 \mathrm{ft}$. but mag reach a beight of $90 \mathrm{ft}$. With a diameter of $3 \mathrm{ft}$. Crowu nartow oblong to brad round-toned. Trunk ofted swollen at base, in dease stands strairht, cleau, with little taper and frce from branches for onebulf of its beight.

BARK-Dark or light gray, A-7 of an inch thick, close, not shaggy por smooth, roughened by irregular furrows which segarate brond, that, close, more or less sealy and rouded ridyes. See Fig. 90.

TWIGS-Compared with the other Hickories rery stout, usually dectdedly downg, reddigu-brown, covered with numerous pale and longitudinally-elongated lenticels: plti angular.

BUDS-Altirnate, pore than 2-ranked. Terminal bud very latge, orate, 2/5-4/5 of an inch long. densely hairs, usunlly blunt-10inted, covered with overlaplug senles, the outer pair of which drons off in autumb aud exploses the inner gellowish-gras silky scales. Lateral buds reddishbrown and do not split opea rely eнrly.

LEAVES-Alterante, compound with $7-9$ lenflets, 8.12 inches long. Lenflets Inaceolate-oborate, sharp-yointed at apex, tootbed on margiu, ruuaded or taperiug at base, very fragtant, often downy on lower surface. leaf-stalls balry, flattused, grooved, nod eularged at hase. Upher pair of leaffets largest with grentest width betweed the mildle and the apex; iower palr often ohlong. lanceolste.

LEAF-SCARS-Similar to those of Shell-bark Hickory (Carya orata).

FLOWERS-Apner nhout May when the leares are half develoned. Stamiagte and pistilate

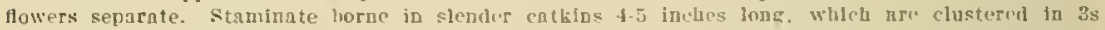
cn a common stalk. Pistillate borne in $2-5$ tlowered fale hairy splkes.

FRUIT-Globular ar ovaid. 1h-2 inches long, with a rery thick or hard busk which splits to 'the middle or base. Nut glohular, brownish, not evideotly-Hattened bat ifridged towards aqex, with a very thlek shell and comparatirely small aod sweet kernel.

WOOD-similar to that of the shell-hnrk llickory (Carrn orata). Sur deseription page 10 . Has a somewhat wider sapwood which is very white in color whence its speciffe name-alba. Heartwood dark hrowa.

DISTINGUISHING CHARACTERISTICS-The Mocker Nut lickory, also known as the Big Jud Hlckory and the White-beart Fickory, ean be distinguished from the two species of Shellbark llickory by its bark, whlch is rough and close and does unt shag off, its stouter twigs, its scurfy pubescent loliage and its glohular fruit which contains a glohular browalsb thick. slelled Dut with a relatirely small kernel. The buds are somewlint linger than those of the Shellbark Hickories and thicker than the pignut and Bitter fut. The kernel of the latter two species is bitcerer and their leaflets are narrower and suoother.

RANGE-Massachusetts nnd Ontario, west to Nebraska, and sauth to Florlda and Texas.

DISTRIBUTION IN PENNSYLVANIA-Found most commonly in the rich ralleys in the eastern and sonthern parts of the State with local outposts in the central part. Also found la the hardwood forest region in the western part.

HABITAT-Prefers rich, moist woods. Requires considerable moisture and sunlight. Does not thrire in shaded situatlons. Found mainly in ralleys and in fertile situations at the battom of slopes.

IMPORTANCE OF THE SPECIES-This speeles produees as raluable a wood as any of the Hickories. Some think that the wood is better than that produced by our other native Hickories because of the large amount of white sapwood. It is difficult to trapsplant on account of its long taproot, beace it is adrisable to plant the seeds rather than seedlings. Erery effort which one puts forth in dereloping and perpetunting this species in our forests, especially la the farmer's woodlot, is Justifled. The pruit is large but the kernel is small and as a consequence it bas no speclal market ralue. 


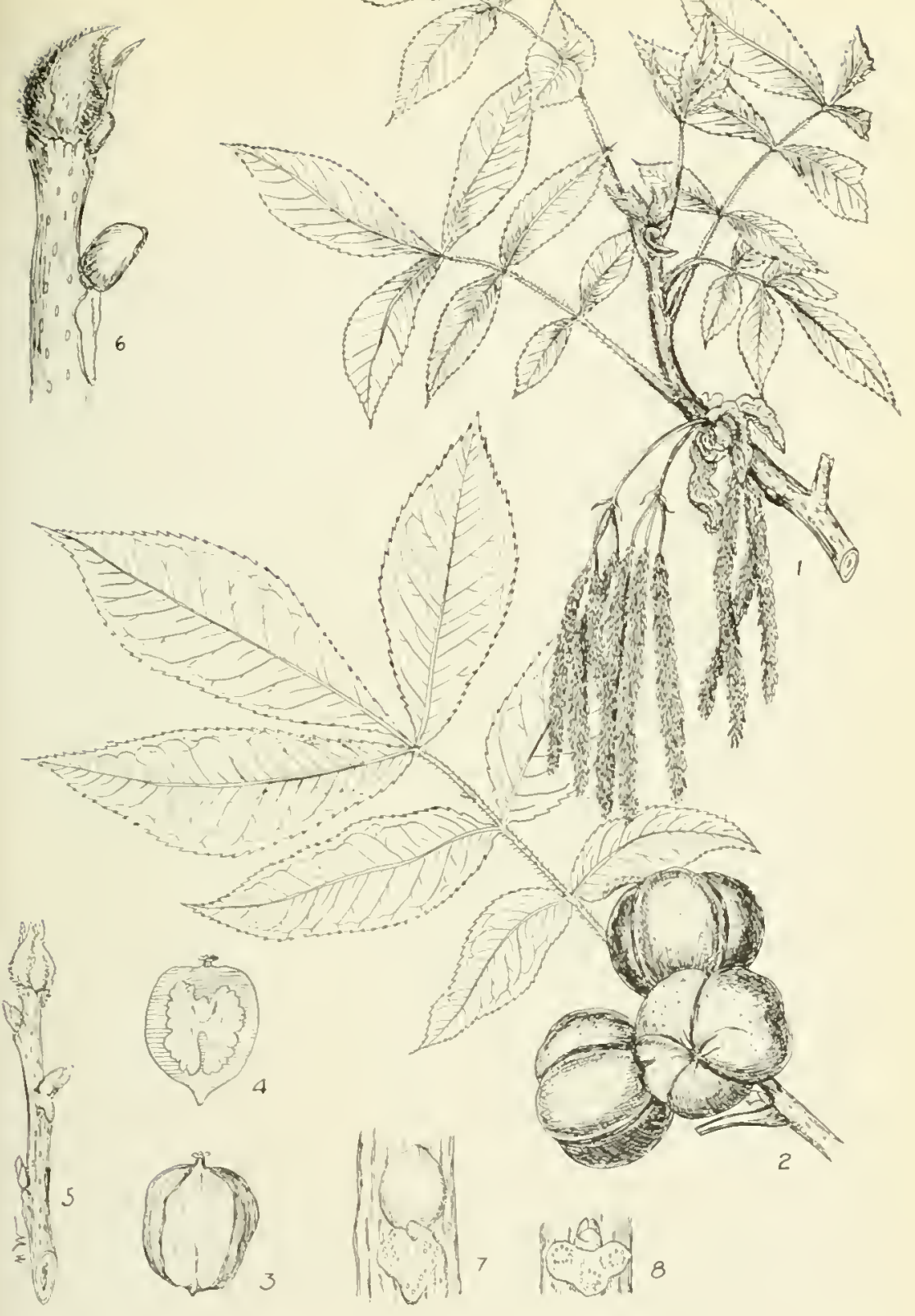

PLATE XL. MOCKER NUT HICKORY.

\footnotetext{
1. Branch with immature learts and flowers, $x$ 3.

2. liraucb witb a mature leaf aud fruit, $x$.

3. 1 nut with lusk remored. I 3

4. Louritudinal siection of a not, $\mathrm{x}$,

6. A winter branchlet, slimbits ealarged.

7. Aection of rinter branch enlarated.

. Sertion of minter branch, ealarged.
} 


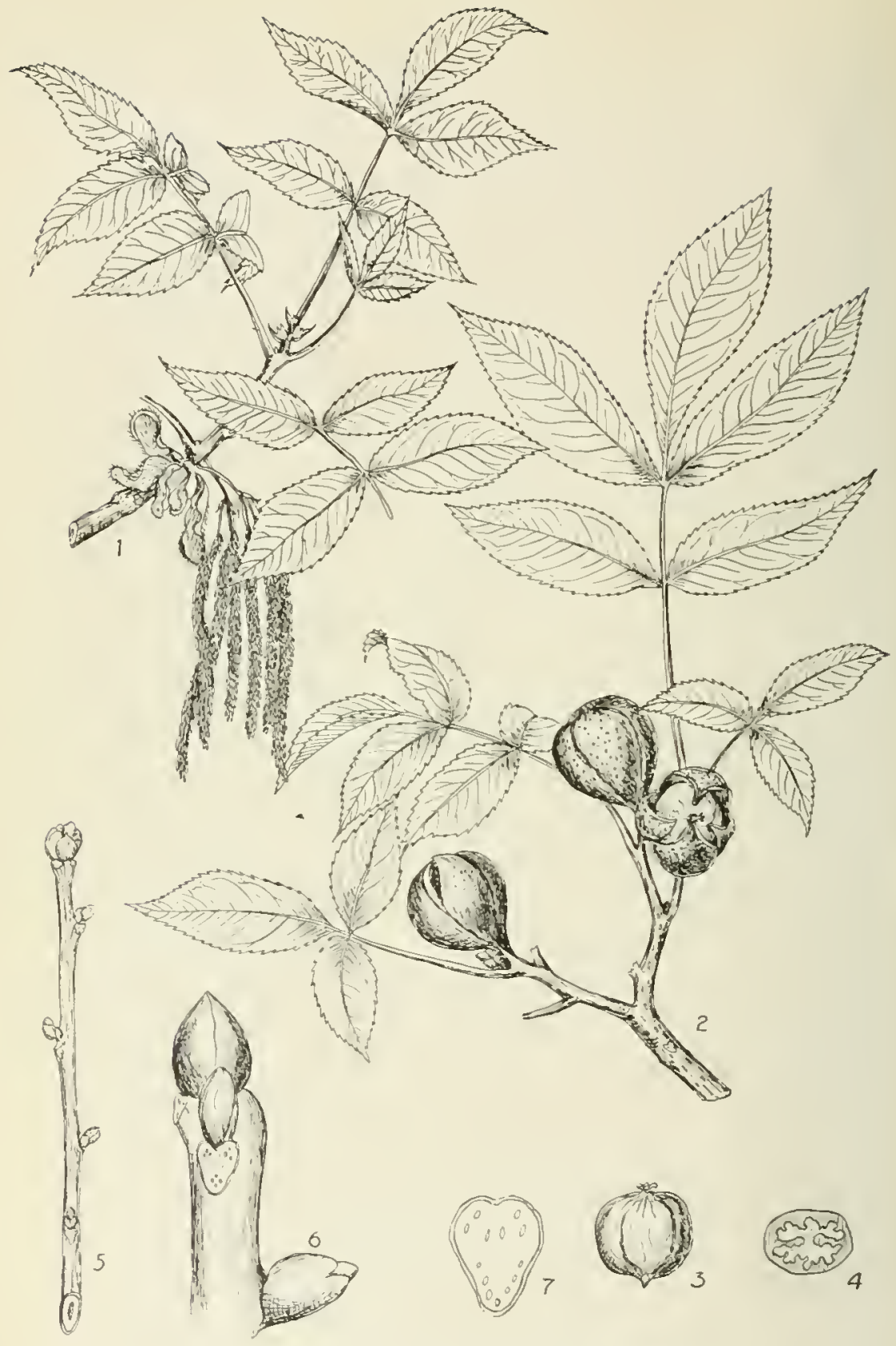

PLATE XLI. PIGNUT HICKORY.

1. Brauch with immature leases and forrers $\frac{1}{2}$.

3 A nut with husk removed. I 3 .

4. Cross-section of a nut, 8 is.

5. A winter branch, $x$.

6. Terminal section of a winter branch, enlarced.

i. A leaf-scar with bundle-sears, eniarged. 


\section{PIGNUT HICKORY.}

\section{Carya glabra, (Miller) Spach.}

FORM-A falr.sized tree usually 50).60 ft. in belght with n diameter of $2.3 \mathrm{ft}$, but may reach

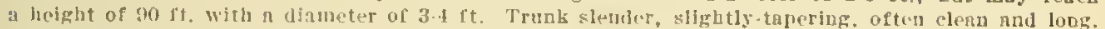
Crown ablosg in shilw, rather narrow, sometimeg high, formed by sholt, spreadigg braaches, the lower ones of tin drooping.

BARK-linrely peels off or exfolintes, is elose, dark gray, slallowly-bssured, narrowly ridged, tough, 13 of an inch thick. Reseubles the bark of the White Ash. Sce Fig.

TWIGS-Iinther slender, usunjly smooth, at first yellowish-green, later reddish-brown, covered with numerons jale longitndinalls-elongated leuticels, rouglened by leaf-sents nnd bud.scale scars: Iilth angular.

BUDS-Alternte, more than 2-radiea, redash brown to gras, oval, blunt pointed. Termloal bud 3 of an lnch long. Jarger thau the luturals. All buds covered with redulsh-brown, smooth, sharplointed, somewhat leeled outer scules and pale-silky Inder scales. Outer senles oftea drol of during winter.

LEAVES-Alternate, compound, with 5.7 leaflets, S-In iowes long. Leaflets oblong to obovatclanceolnte, shrip-jolntad nt njex, Bncly twothed on margln, tnpering or oblinuely rounded at bnse, thick, suboth, dark green nbove, jaler below.

IEAF.SCARS-Altwate, hrart-shaped ar oblong or laversily triaugular or 3-jobed, cootalnIng numeroug prominent bundle-sears irregularly scatterod ar arrooged in $n$ curved line or in 3 clusters.

FLOWERS-Appear nhont Ma: whep leares are nbout hilf developed. Strminate and pistllnte llowers uecur separately. Ktamlnnt. in : common stnlk. Pistllitte in "2-5-1lowered asikes on the new growth.

FRUIT-Matuies about October, variuble in slupe nud slze, pear-shaped or spherical to obovold, I. inchus long, tinluing at the base, reddish-brown, nonutines pubesceat, Husk may remaln closed or split onen from apex towards the midde or occastonally along the entre length. Nut otslong to oval, with thick buny shell contairang a liernel which is at first sweet, later bitter.

WOOD-Similar to thint of the other Ilfkories of the State, except the Ibitter Nut Hickory. Sire descriptiou of wood page 106 .

DISIINGUISHING CH\&RACTERISTICS-The Pignut or Broom Hickory, also known as the Bitter Siut llicliory, call be distinguished by its smooth and rather sleoder twigs which bear smnll ovgl reddish-browu buds covered with scales, the outer hair of whlch is smooth or glandular dotted nud often fall: utr before spriog, thus exposing the joner velrety seales. Its buda are oot yellow like those of the bitter Nut Hekvis nad smuller than those of the other specieg of our

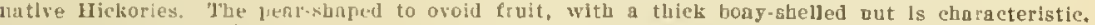
'1'he liark Is close and does not exfollate like that of the shag-bark lickorg. The leaves, with 5.7 usually smooth aud ablong to obovate-linceolinte leastets, are distinctive.

RANGE-Maiue and Outario west to Minnesota and Nebraska, ad south ta Florida and Texas.

DISTRIBUTION IN PENNSTLVANIA-COnmon in the sonthenstero ad southwestero parts. Also fcuad locally clsewhere. More commou in the mountalnous portion of the State thab aag other Hickory.

HABITAT-Most common OD bry rldges and billsides. Iarer in swampy aituations. Commonly scattered amidst our viks and Chestuut, I'ref(rs plenty of suolight.

IMPORTANCE OF THE SPECIES-The Pignut Hickory produces a rery rolunble wood, especially for the farmer. The fruit is aot idible. It should be grown in the farmer's woodlot and In our lnrger furests in mixture with otler specles. The secllings are difficult to traosplaot on account of their long talroots, which are rather sedsitive. In attemptiog to grow this speeies, oue should plant the nuts nnd aot the secdlogs. The grent value of its wood justifea every effort that one cas put forth in growing it. 


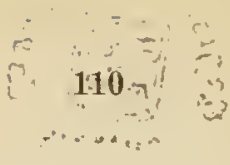

\section{BITTER NUT HICKORY.}

\section{Carya cordiformis, (Wangenheim) K. Koch.}

FORM-A lather large tree psually 50-7j it high with a diameter of 1-2 $\mathrm{ft}$. hat mas reach a height of $100 \mathrm{ft}$. with a diameter of $21-3$ feet. Trunli lous, clean, with little taper. Crown roual-tonned, broadest urar top, rather shallow in forest growa specimens. lateral branches stout and ascending, oftun with semi-pendulous branculnts.

BARK-Light gras. mther thin, rovghenel by shallow fissures and narrow ridges: tigbtfitting and does not neel off or shag of in loos seales like the Shag barb Hickory. See Fig. 91.

TWIGS-Slender, swooth, glossy, often yclicw-glandular and bairy towards apex, grayish or orange-hrown or reddish, roagheapd with uumerons fale and longitudinally-elougated linticels: pith browa, angular.

BUDS-Alternate, covered by i yellowish, glandulardotted scales mintring in ralvate pairs. Turmical bus eridentlselongared, flattenad, ulnot-polnted. lateral luls usually superposed; the lowest ur axillary one asually small and sharp-pointed; the upper ont larger, evidentlystalked and angular.

LEAVES-Alternate, compound, with $7-11$ leadetc, $6-10$ inches loig. 1.,3fots lanemlate to orate-lanceolate, lateral ones sessile, sharn-pointed at apex, finely toothed on margio, obliquely tapering or heart-shaped at base; when mature dar jellowish-green above, paler below.

LEAF-SCARS-Alternate, large, consnicurous, raised, heart-shaped, triaugular to elliptical, lighter than twigs, coutaining numerois burdle-scars arrangel in 3 grougs or in a single curred line or oceasiocalls scattered irregulaly over whole scar.

FLOWERS-Appear ahout Mas when leswe are balf-dereloped. Staminste and pistillate fowers separate. Staminate greerl and arrated in triple-clustered aments about $3 \cdot 1$ inches long. Pistillate, and small elasters on the new growth about s of au inel long. somewhat angled and scurfy hairy.

ERUIT-Matures aboat October; spherical to obovate about 911 inches long. II ask thin, rellowish glandular.dotted, splits open to alout the middle into four valves: hefore splitting appears 4-winged from apex to ahont the unflde. Nut thin-shelled, at least as broad as long. smooth, short-pointed, with reddish-brown are? rery bitter kernel.

WOOD-Wood of this sleches resembles the worl of the other nickories. deserihed on page 106, only it is somewhat lighter, not quite so strong, of somewhat less fuel ralue, wore brittle, less stiff, and yields wore asb whew burach.

DISTINGUISHING CHARACTERISTICS-The Bitter Not lliekory, also knomn ns swamp Hickory and Bitter llickory, can be distinguished ly jts lanecolate leatets which are pubescent beneath, and smaller than those of any other natire llickors. It is the onls natire

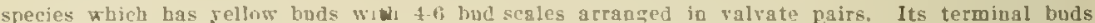
are flatcened and eloncated while the laternl bods are evilently-stalked and superposed. The not is glohular, short pointed, thin-walled, containing a litter kernel, and is corered by a thin misk which in time splits open from the anes to about the middle. The bark is rougb, but does not seale off, which characteristic it has in coumon with the Pignut and the Mocker Nist.

RANGE-Quebee to Minnesota and Neliraski and sonth to Florida and Teras.

DISTRIBUTION IN PENNSYLVANIA-Local throughout the southenstern and southern parts. Also renorted from the central and northern parts. Nowhere common. ['sually solitary and seattered.

HABITAT-Prefers low. Wet, and fartile situatiuns such as lorder of streatus and farmers' woodlots located In rich agricaltaral regious. Often found, bowerer, far ap the slopes of mountains. It ascends to the top of the South Mountains in Pennsrirania. Not rery tolerant of shade,

IMPORTANCE OF THE SPECIES-This species prodaces raluable wood bat its fruit is not edible. It grows bus or, rich noist woil sueb as one nsualls finds in a farmer's woodlot. It eadures transplanting hetter and grows more rapidy than any other of our Hickories. This raluable wood is becoming rare. A future supply should be insured by dereloping this tree ln mixture with others in the farmer's woodlot and in fertile portions of larger forests. It ls not gregarious but prefers to grow as a single specimen in mixture with other species. 

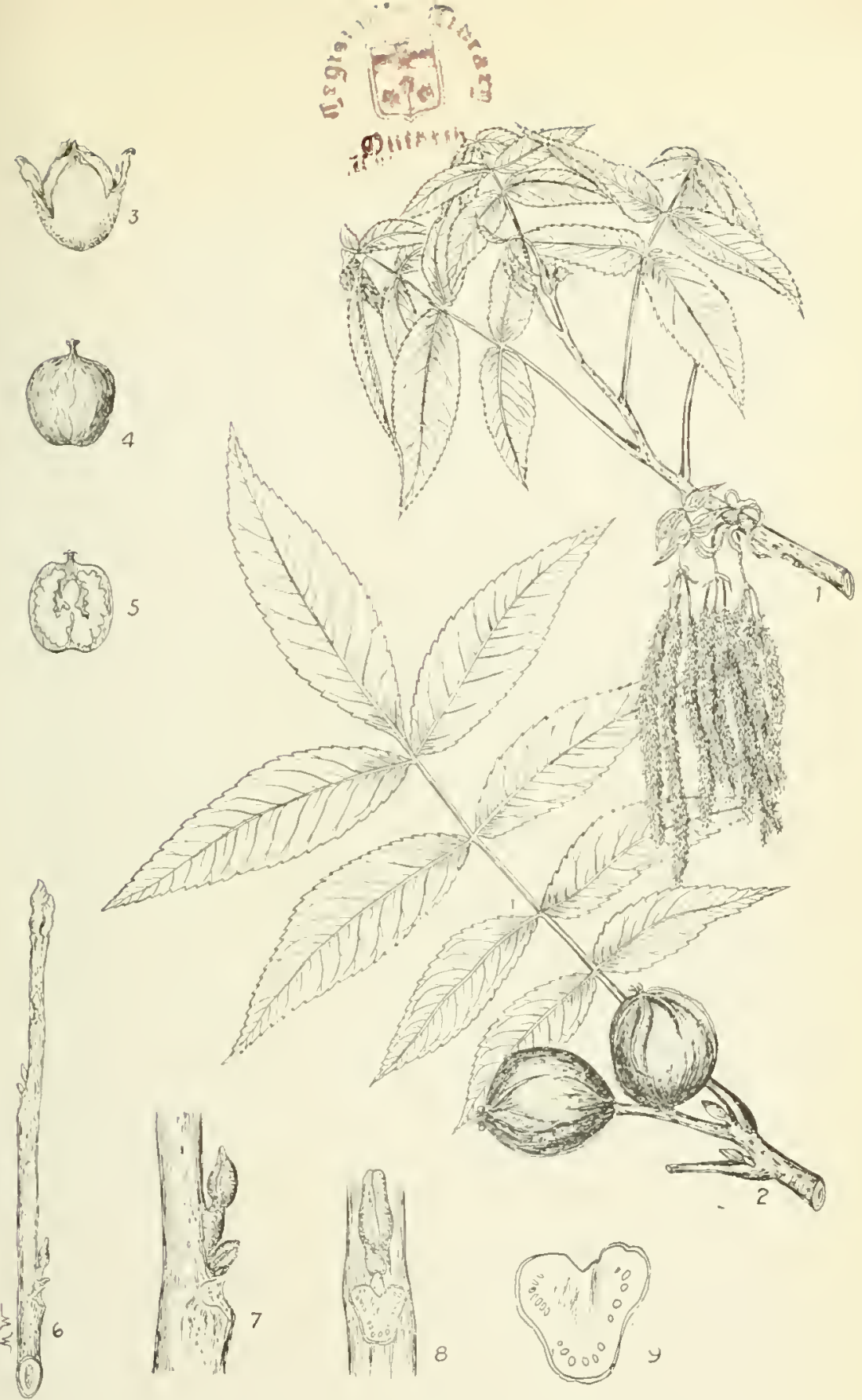

\section{PLATE XLII. BITTER NUT HICKORY.}

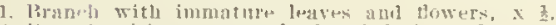

. Brancil with a miture leif ind fruit, $x$.

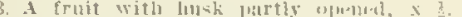

1. A nut witle busk riemessive, $\mathrm{x} z$

5. Loneiturinal soctien of nut, $x$

6. A winter loranch, a 1

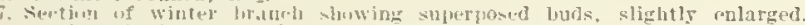

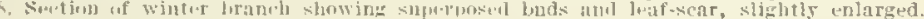

9. A loaf-scar with humlle-sears, eularged. 



\section{THE BIRCH FAIIIT-BETULACEAE.}

The Birch family comprises 6 genera with about 75 species of trees and shrubs which are confined to the colder part of the northern hemisphere. Of this number $\Sigma$ genera with abont 30 species are native to North America and 5 genera with 11 sjecies to Pennsylvania.

All the members of this famils, even though they may belong to diflerent genera, have many morphological features in common. The leaves are simple, alternate, borne singly or in pairs on the branches but nerer opposite each other. The staminate and pistillate flowers are separate, but are borne on different parts of the same tree and usually on difierent parts of the same branch. The staminate flowers are lomg, usually in drooping aments, or in spike-like or knoblike aments and may be with or without a periantls. The fruits are small, one-celled, usually subtended by a large braet which in the most inportant genera derelops into a cone-like stricture called a strobile.

Varions prorlucts of high commercial importance are produced by this family. The wood of the Birches is used extensively for furniture, flooring, interior finishing and has a rery high fucl value. The fruit of the Hazelnnts is prized as food. The roorl of some of the Alders is especially adapted to the manufacture of gunpowder and chareoal. The bark of the lBlack Birch yielts a rolatile oil of considerable importance. The technical value of the products from the members of this fanily are hecoming more important every year. The nood of some of the species which was despised formerly, is now cousidered of high value in some particulap industries, on account of the new uses to which it is being put. The science of Xylology, which is merely in its formative periorl, will do much in advancing the position of the wood of species at present despised or at least not fully known. The subjoined key will aid in distinguishing the genera of this family.

\section{KEY TO THE GENERA.}

1. Staminate flowers solitary on each bract; pistillate flowers with a prianth; frut

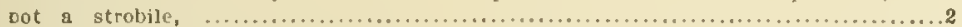

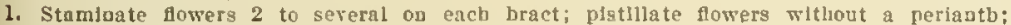

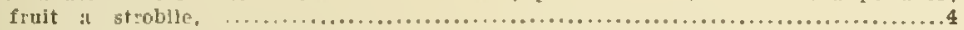

2. Sbrubs: twigs coverei with stuff rred hurs staudib out at right augles; uuts large

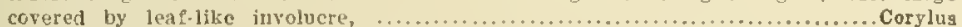

2. Trees: Twigs not corted with stif red huirs; auts small and subtended by a large

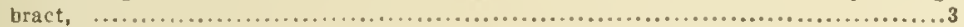

3. Bark close, suronth and tured; nut subtended by a tat 3-lohed bract, terminal

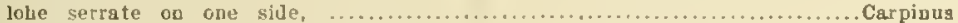

3. Park thin covered by loose rihbon-like narow brown seales; nut subtended by $\mathrm{n}$ closed bract arranged in hop-like clusters, .......................................

4. Shrub with close, soniewhat flutel bark: wood sellowish upon exposure; buds stalked, obtuse at apex, covered with wo exposed ralrate scales; fcuit woody and

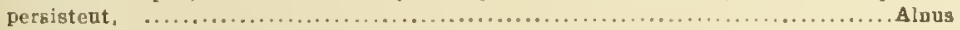

4. Small to large trees with loose burk usually peeliog off into thia fim-like layers; buds not stalked, acute at ajex, covered with 3 or more overlapping scales; fruit membranous and declduous, 
THE BIRCHES-BETULA, Tournefort (L.)

This genus comprises about 35 known species of which number 25 are trees and the other's shrubs. Of the known species about 15 are uative to North America and כ̌ to Pennsylvania.

The members of this genus are without exception called Birches. In most of them the bark of the trees when young is smooth and peels ofl into film-like papery larers which rars in color according to the species from chalky white to reddish-brown. A few species have, howerer, a close and smonth balrk which does not peel off into thin film-like papery layers. The mood is dense and hard, does not show the annual rings very clearly, is of high fuel ralue and usually reddish-browu in color, sometimes possessing a highly prized curly or wary figure. The twigs of the season produce only one leaf at a point, while the twigs of the prerious season produce two leares from the lateral buds situate on the short spur-like brauches. The leares are simple, alwars alternate, occur singly or in pairs but nerer opposite. The flower's appear before or with the dereloping leaves. The staminate flowers aprear clustered in long tassel-like bodies hanging down from the end of the twigs and are known as aments. The pis. tillate flowers appen below the staminate and are nearly erect, lather small and slender. The fruit is a cone-like structure known as a strobile consisting of a centrial axis to which numerous scales are attached. The scales are thin, 3-loberl, and bear the small flat nuts with their wings. The nuts are verr light and easily scattered by the wind for considerable distances from the mother or seed trees.

The commercial products derired from some of the members of this genus are rather important and raluable. The species found in the eastern part of North America sield products of more value than those found in the restern part. IIost of the species found in the western part of North America are tno small, or infrequent in the form of stands, to be commercially importaut for general or even domestic use. Some of the species found in the eastern part of North America are also small shrubs but others reach the size of large timber trees which rield not only excellent wood but also raluable oils, flarol's, and bark.

The subjoined key will aid in distiuguishing the species of Birch found in I'ennscrlvania. Separate summer and winter keys were not dereloped since the following key is based primarily upon bark characteristics which are preseut at all seasons of the year. 


\section{3}

KEY TO THE SPECIES.

1. Bark usualls separating into thin flm-iske paperg lagers, ....................

1. Bark close, not serarating into thin film-likf payerg layers, ......................

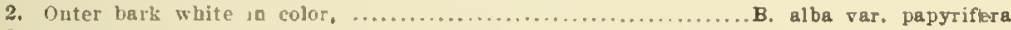

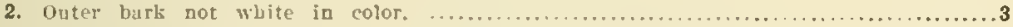

3. Uuter bark yellow in color: strobiles usually sessila*; leaves nsually rounded at

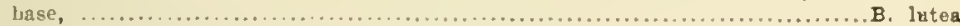

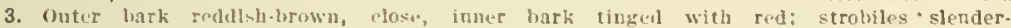
stallied: lonves usually wedge.shaped at base, $\ldots \ldots \ldots \ldots \ldots \ldots \ldots \ldots \ldots \ldots \ldots$. nigra

Page.

Bari chalky white cosered with black triangular spots below busertion of latera] brancbrs; stunll tree, often in cluntus; leavag loug-acuminatu. ........ B. populifolia

4. Bark dark reddish.brcwn; large tree, usullly accurs singly; leaves ovate with acute apex; twigs and inuer bark with wiatergreen like taste, .............. lenta 


\section{PAPER BIRCH.}

\section{Betula alba var. papyrifera, (Marshall) Spach.}

FORM-A large trec usually attaining a height of $50-\overline{6} 5 \mathrm{ft}$. with a diameter of $1.2 \mathrm{lt}$., bot mas reach a height of $\mathrm{si}$ f. with a diameter of 3 feet. Trunk in open grown trees short and corered nearly to the base with lateral, often ascending branches; in close standa branchless below and bearing a narrow open bead.

BARK-On trank anl older branches chalky to creamg white and peeling of in thin filmlike layers which are tinged with jellow and corered with horizontally-elongated lenticels. On older tranks routh and often bssured into irregular thich scales.

TWIGS-Rather stout, somewhat riscid, decidedly hairy, at first greenish, later becoming smooth. reddsh-hrown, ani after several jears, bright white, like the trunk, corered with pale, horizontally-elongated, orage-colozed lentlcels.

BUDS-Alcernate, orate, sharp-pointed, divergent, abont $\frac{1}{3}$ of an inch long, dari chestrutbrown in color, corered by a fem orerlapping bud-scales with downy margins.

LEAVES-11ternate, sinjple, orate, $*-3$ inchrs ton:, $1 \frac{1}{2}-2$ inches wide, rather firm la textare; upper surface dark grcen, under surface light grefn; narrowed or rounded at the base, sharpls toothed on the margin and sharp-pointed at the apex.

LEAF-SCARS-See "Lenf-Sears" under Black Birch, page IIS.

FLOFiERS-Appear in April or Mar before the leares. The staminate are arranged in nments, which occur in grools of $2-3$ sud are about 3 to $1 \frac{1}{1}$ inches long, heconiug $33 \cdot 4$ inches long in spring. The pistillate dave light green lanceolate scales and bright red styles, and are arranged in clusters about $1-13$ inches long.

FRUIT-A crlindrical, short-stalked strohile about 13 inches long. Seales long. with thick lateral lobes and a rathar long terminnl lobe. Seeds small and winged. Wings wider than the nut.

WOOD-Dimuse-porous; rays small and incouspicuous; light, strong, hard. light brown tlnged with red, with rather thick, light sapwood. Weighs 37.11 lbs, per cubic foot. [sed extensirely for spools, shoe lasts, pes, fuel, and in the manfacture of paper nolp.

DISTINGUISHING CHARACTERISTICS-The Pafer Ritch, also known as Canoe Blrch and White Birch, may readily be distinguisled from all the nther specles of Birch In Pennsglranja except the Gay Kirch, hy jts characterintic white bark. which is nerer renewed when once remored. The European White Pirch. Which is introdnced extensirely for ornamental purposes, also has a white bark. To distinguish it from the Gray Birch see "Distingulshing Characteristics" ander Grag Birch.

RAXGE-From Newfondland to Alaska, scutb to Pennsylrania, Michigan, Colorado, and Washington. 'This is one of the fer transcontunental species.

DISTEIBUTION IN PENNSYLVANTA-Enund only in the porthern part of the State. Common bot scattered in Tioga and adjoining ceunties.

HABITAT-Csually fond on rich wooded slepes and on the borders of lakes. swamps, and streams; also scattered throngh the forests of other hardwoods and occasionally throogh coniferous forests.

IMPORTANCE OF THE SPECIES-This species is commercially of little importance in Pennsfriaria on acconn: of its limited distribution. It is not of suffecient importance to justify its artificial propagntion, but whererer it occurs naturalls it should be protected so as to instre an abondant future growth. The wood is saficiently prized to justify its conserrative utilization, and also its protection, where natare prodnces it gratuitously. 


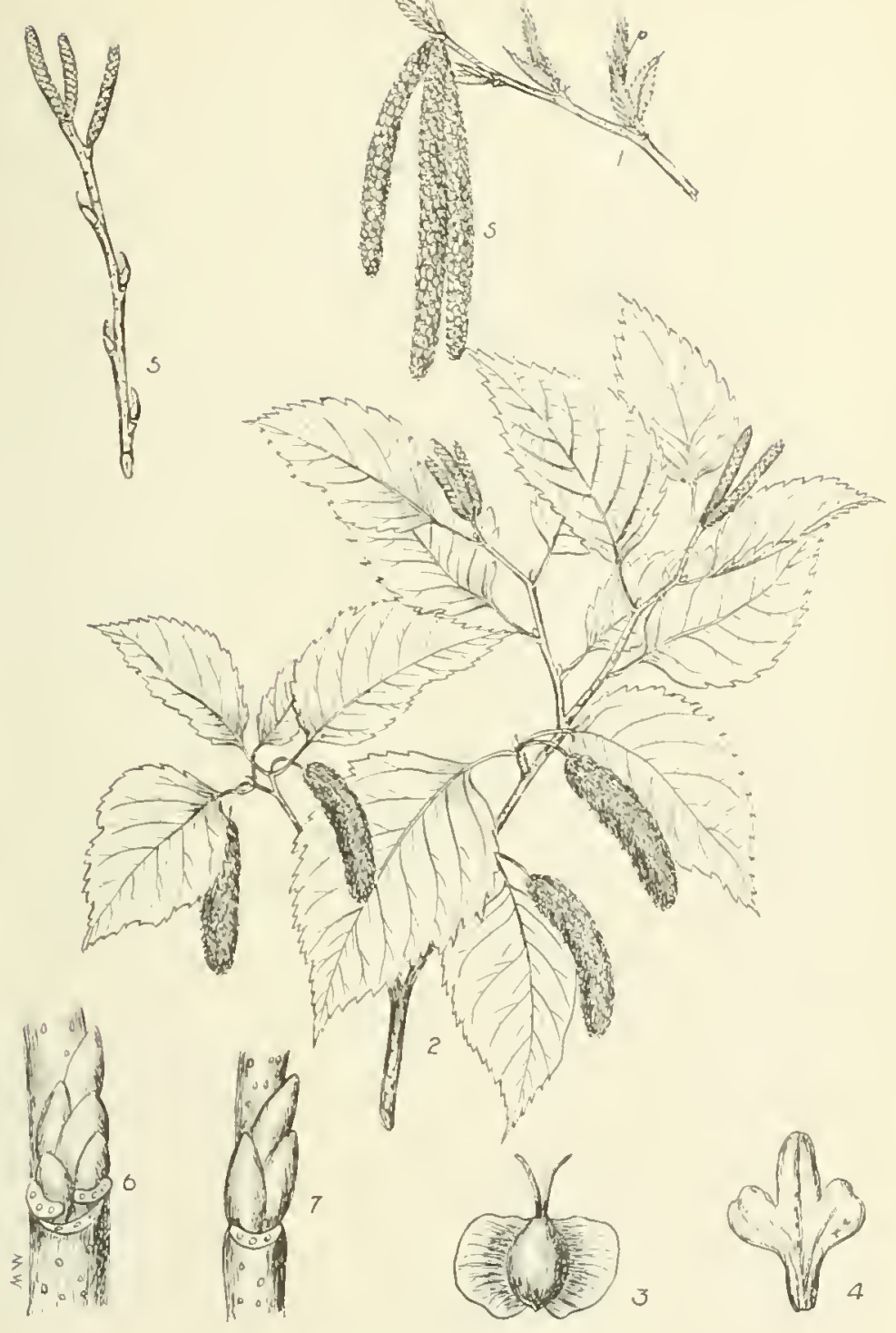

PLATE XLIII. PAPER BIRCH.

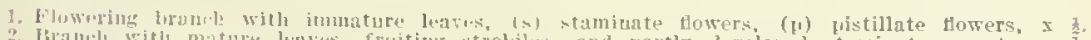

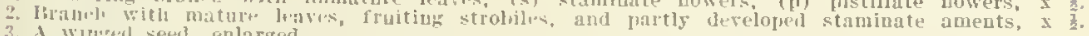

3. A wivized seed, enlararil.

5. A winter branch witl 3 jartly dovelopud torminal staminatu aments, $x$ z.

6. sectiun of a lateral wint-r spur-luacb, enlarged.

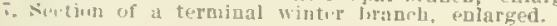




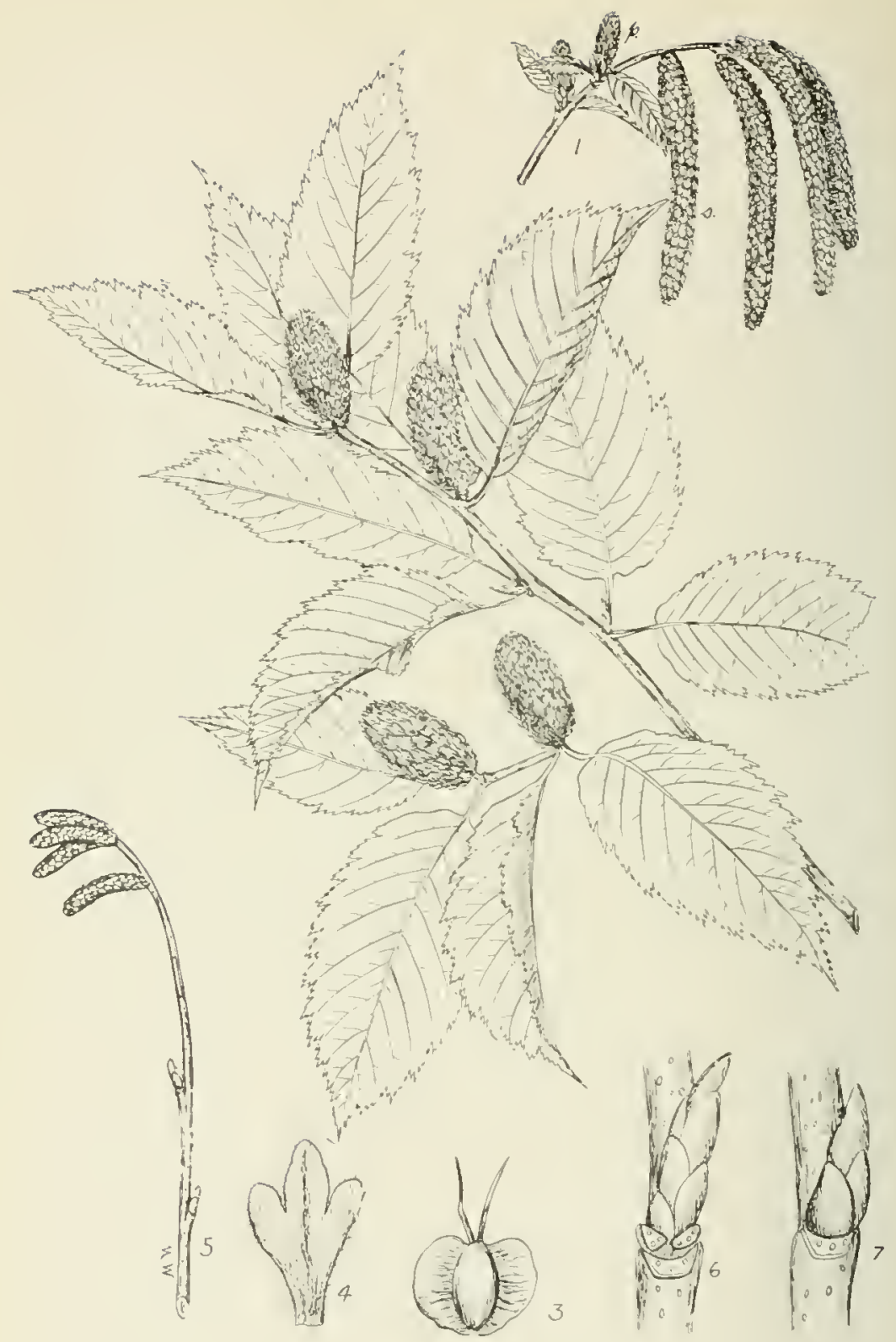

\section{PLATE XLIV. YELLOW BIRCH.}

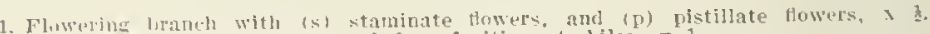
2. Frouch with matur. leavits and four fruiting strobiles, $x$

3. A winured seed, enlariged.

4. A strulite swale, enlarged.

6. Nution wf a lateral winter twig, enlarged.

i. Sertion of a terminal winter twig, enlarged. 


\section{YELLOW BIRCH.}

\section{Betula lutea, Michaux.}

FORM-A large tree usually attaining a height of $60.50 \mathrm{ft}$. with a dinmeter of $\mathbf{2 . 3} \mathrm{ft}$. hut was reach a maximum height of $100 \mathrm{f}$. With a diameter of $3-4$ feet. Trunk in the open usually short, brunching near the base; its long slender branches formiag a wide open ratber bemispherical crown, in elose stauls ofturather free from lateral tranches.

BARK-Close and furrowed or peeling of in thin sellow film-like papers scales. Varies with the nge and location of the tree. On yong trunks and branches rather close, shining. sellaw but soon forbing a ragged fringe, ls ler weeliag of into thin, yellow, film-like, papery lagers. On old trunks it tinalls becomes redtist.brown and roughened with fissures. The ragged bark is rftea nulled of and used by camrets to start fores in wet weather. See Fig. 68.

TWIGS-. I first grean and bairy, latu blorn and smootb, foally dull silverg-gras. Terminal twigs loug and slendir: laperal short and stout: usually corered with elongated horizontal lenticels wbleb in time nnite to form a long horizontal line.

BUDS-Simlar to those of the Black Birch, but sometimes alightly more domas. See rnge 11s.

LEAVES-Alternate, slmple, occur singly or in pirs but nerer opnosite, 34 inches long, ovate, wedge-shalud or henrt-sbaped at base, doubly serrate oo margin, acute at apex, doll green alove, gellowish green below.

LEAF.SCARS-Simllar to those of the I:lack Birch In particular, and all of the other Birches in general.

FLOWERS-Apear about Apll before the leaves. stam nate and pistillate separate, but ustrally w the same litanch. Stamuate ar. formed in the fall, remaluing orer winter as anents about $\hat{\text { g }}$ of an Inch las which elouznte to about 3 Inebes in spring. Pistillate about i of an inch loig. With acule seales which are light red and hairs above, and green below.

FRUIT-Au erect, usunlly very stort-calkel strobile, alout 1.I linches long, ovate in out. liac, consisting of nomerons 3 lohed scales fostened to a central axis and bearing small winged nuts with rather aarrow wings.

WOOD-Diffuse-joron.; rays indistinct: lawy, bard, strong, compact, not durable wben in coutact with the son. lleart-wonl liath brown, tluged with red; sap-wood pale in color. Weighs 40,36 pounds per cubic foot. Used fo furaiture, fooring, interior finisb, boses, certaln veneers and fuel.

DISTINGUISHING CZARACTERISTICS-The Yellow Birch, also known as Silver and Gray

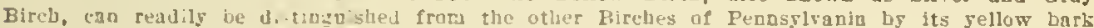
which peels off into thin, litm-like, papery sules. Its uethod of peeling the bark resembles that of the Paler Birch and the Red Eirch, lut it does not bare the white color of the former nor the reddish to greenish-lirown color of the latter. The loose, filfi-like, pavery seales of the lied Birch are stinller than those of the Yellow hirch and the strobiles of the former are sleuder-stallied white those of the latte? are asually sessile or rery sbort-stalked.

RANCE-Iewfonudland, south to Pennsylvania, and along the mountains to North Carolina and Tennessee, rest to Manuesota.

DISTRIBUTION IN PENNSYLVANIA-Foud localls thraugbout the state but most common in the Allestuenies.

HARITAT-Common on moist ricti vulands, borders of streans, and in swamps.

IMPOKTANCE OF ThE SPECIES-The Yellow Birel is ane of the largest decidunus trees of nartbeastern America. ['ntil recently the value of its wood was not fully appreciated, bnt today it holds a fair position on the lumber market and in the future it will no doubt attain a still better position. It bas been classed as one of the most artistic, reliable, and versatule of the hardwoods of this coustry. With all ats good qualities, it has saperior assaciates and consequently cannot be recummended for forestry purposes except on the farmer's woodlot wbeic fuel is especially desired and in such other places where it comes up naturally and othe: unore desired specirs will not grow to adrantage. 


\section{RED BIRCH.}

\section{Betula nigra, Linnaeus.}

FORM-A medium-sicel tree usually attuiniag a heiçht of $30-50 \mathrm{ft}$. with a diameter of $1-2$ $\mathrm{ft}$., but mas reach a height of $100 \mathrm{ft}$. witi a diaweter of 5 feet. Trunk usually short and divided near the base isto a few slightly dirergiog limbs, Crowa rather narrow, oblong, and irregolar.

BARK-Varies with the age of the tree aod its location on the trunk. Oo lower part of old trunks dark reddisil-bun and rongheneu by hsoures which separate irregular scales. On younger trunks nad npper portion of older ones neels off into thin, film-like, panery seales which are reddish-brown to ereenish-bromn in color aod persist for a few years during which time they form a ragged fringe nad 'xinose the lfeht red ad close bark underneath. See Fig. 65.

TwIGS-Sleader, at fist hairy and greealsb, Iater smooth. reddish-brown, covered by pale Lorizontally-elongated lenticels.

BUDS-1lternate, ovate, sharppoioted, shiniog, smootl or slightly hairs, corered urith osualls 3-T chestaut-b:Jwa arerlapping scules.

LEAVES-Alternate, simnle, bruadly swate, $13-3$ inches long, wedge-shaped at bnse, acute at apex, doubly serrate ou margin, deep green above, pair yellowish-greeo below.

LEAF-SCARS-Similar to those of the riack Pirch. Ste page 118.

FLOWERS-Alnear ahout April hefore the leaves. Staminate and pistllnte separate, but usually on the same biach. staminate formcl in the fall, remaniog over water as amenta ahont ar an inch lorg, usually in clusters of three, which elongate to ahout $2-3$ iaches the following spring. Pistillate about $\$$ of $n$ incts long. developing in suring from buds situate lhelow the starbinate flowers.

FRUIT-An erect, sleder-stalked, pulusceat, crlindrical strobile, 1.13 loches long, coosisting of aumcrous 3.lobed juLwsent scales fastened to central axis and bearing small, hairy, whinged auts. Terminal loke cif the seales is larger than the laterals.

WOOD-Diffus-forons; rays indistinct; light, scft, strong. with light-hrowe henrtwond and

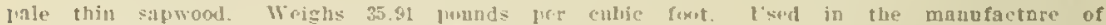
furniture, slack-coojerags, frult and vegrable baskcts, wooden wire, and turaery.

DISTINGUTSHING CHERACTERISTICS-lihe Red Rirch, al:o bnown as the River Blrch, cao be recognizel by its rudeish-brown tn .iunamun.reil hark which feels off into fim-llke panery scales. The lagers are smaller anu less ragred than those of the Fellow Bireh which has a decidady rellow tr silvery-yellow polored lark. The Black Bireh has a closer bark which does vot puel off aad the other species of lenssylrania have a white bnrk. The Rirer Birch is usually fonad along streams or io other wet locatious which may also aid in distioguishing it.

RANGE-Mrssachusetts south ta loridn, west to Minnesota, Kabsas abd Texas.

DISTRIBUTION IN PENNSYLVANIA-Found throughout the Siate along the baoks of the procinal rivers aod their chief tributaries.

HABITAT-Prefers the bnaks of strea.as, lakes, pools, and swamns. Occasionally found upon dritr locations. It is called rivar Firch hecause it is usually found along the baoks of rivers or other locations laring similar moisture coaditions.

IMPORTANCE OF THE SPECIES-The Red Birch is of little commercial importance ia Penasylranin as a limber species on accont of the relatirely small size which it attains, the softress of its wood, and the abseoce of bigure and attractive color io the wood as well as its limited distriburion. It is essputially a zouthern snecies reaching its optimum development in North Caroliun and adjoining states. While it is of litte commercinl importance it may be of economic importunce in such situations where moistuloloriag troes are required to bind soil, as along streams, or where it is desirable to establisb stads ia extremely swampy locations. It is attractire as an oranueatal tree. 

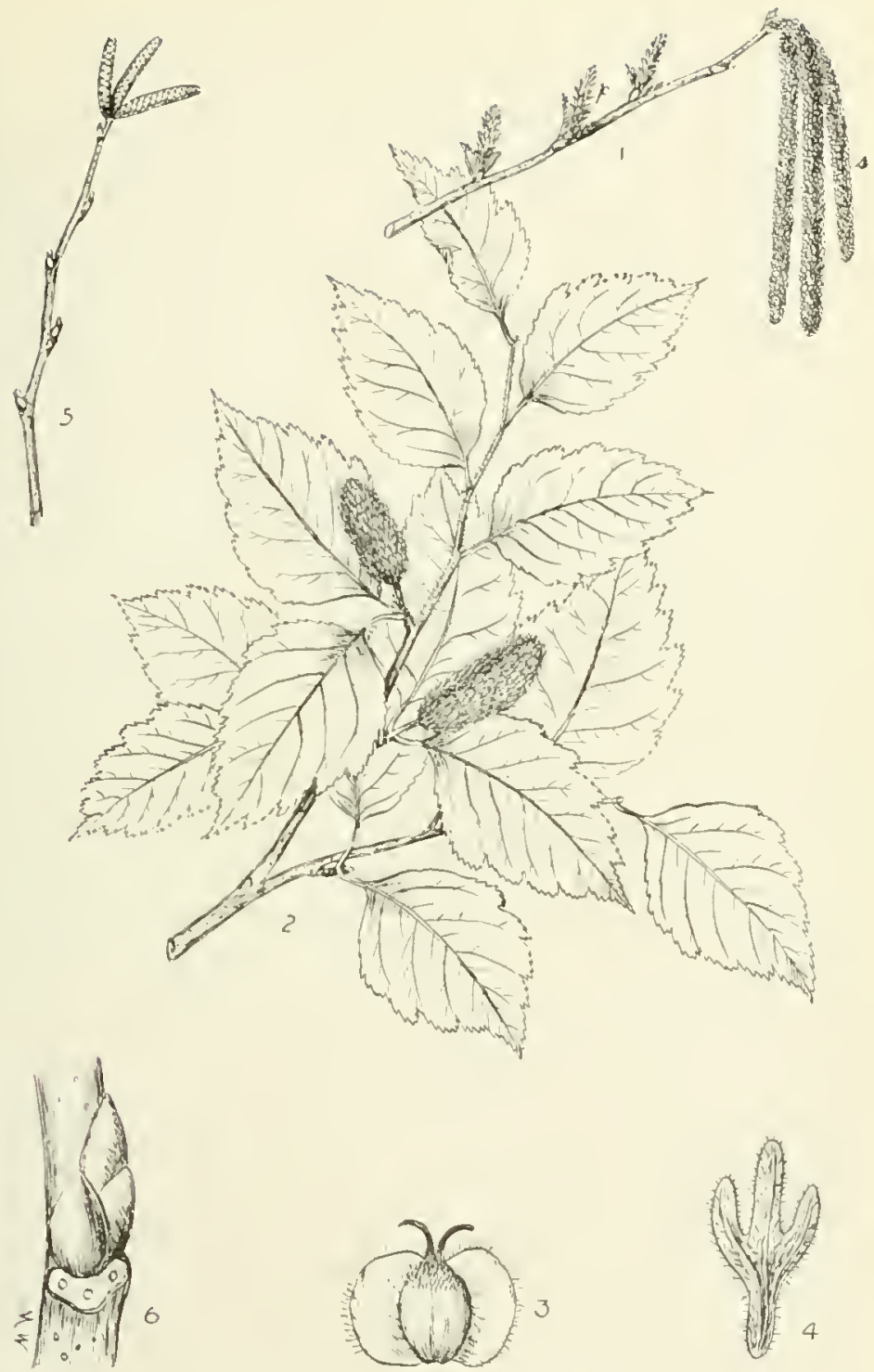

\section{PLATE XLV. RED BIRCH.}

1. Flowering branch with (s) stnminate flowers, (p) pistillate flowers, $\mathbf{1}$, . Branch witl matnre leaves and two fruiting strobiles, 5 .

3. A winged seed, enlnrgeal.

4. A strobile scule, eplnrged.

5. A winter branch with three lartly developed terminal staminate aments, $\mathbf{x}$ 6. Section of a winter branch. enlarged. 


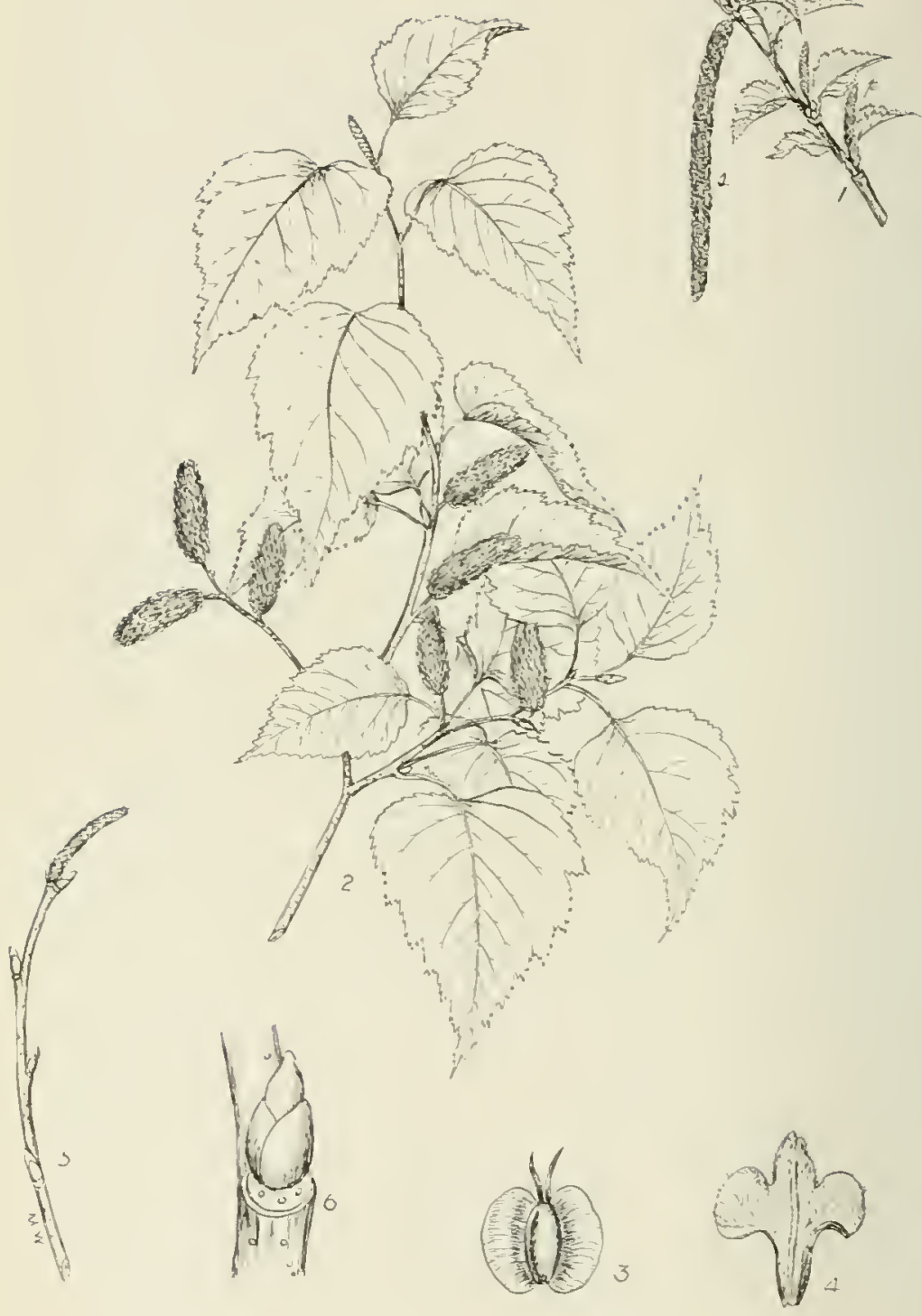

PLATE XLVI. GRAY BIRCH.

1. Flowering branch with immature leares (s) staminate fowers. (p) pistillate flowers, $\mathbf{x}$.

2. Brauch "Iith mature leaves and fruiting strobiles, $>$.

3. A ringed seed, enlarged.

5. A strobile scale, enlarged.

5. A winter branch with a partly deret
6. Section of a winter twig. enlarged. 


\section{GRAY BIRCH.}

\section{Betula populifolia, Marshall.}

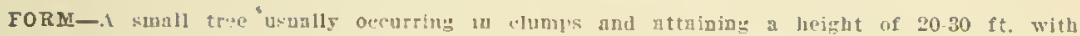
a dameter of 9 inches, but mas reach a beight of $45 \mathrm{ft}$ a ad a diameter of 18 inches.

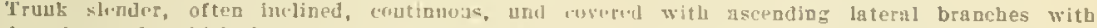

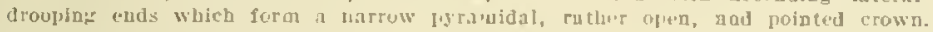

BARK-Dull white, close, smooth, not peeling of into thin film-Jike layers but corered with triaugular black spots bclow the instrtiva of the lateral brnaches. in old trunks black and

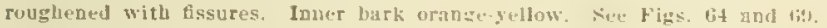

TWIGS-Slender, greftish to brown, :ougholud ly warty exudations nnd by raised, prle, and horizontally.clongates! leaticels: later suouth anul dull white.

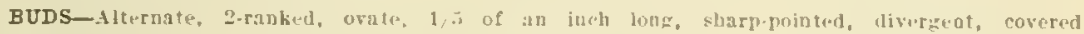

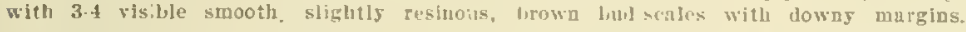

LEAVES-Alteraate, simple, trinuzular, ontu, 21-3 inclues long, Iz-2 inches. wide, wedgesbaped at base, deoidedis strmte on margin, whth longtonthed apex aud Joog. slender

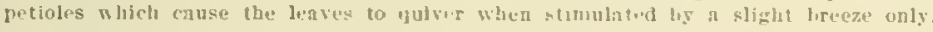

LEAF-SCARS-Sep "Leaf.Scarg" undeT Blnck litrch, page 118.

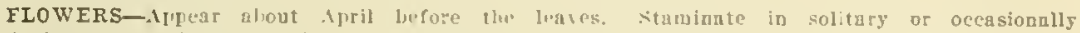

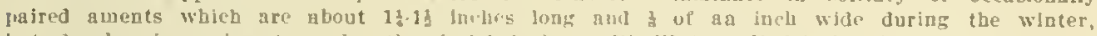

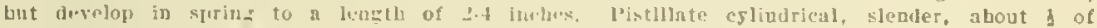
an inch lon: and staiked.

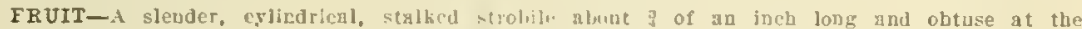

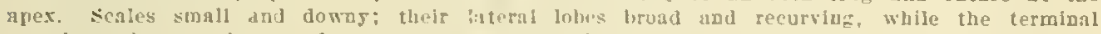
one is ratber straignt and narrow. Serds sunll, oval, and winged, Wings broader tuan the seed.

WOOD-Ijfuse-porus; rays inconspicuous; Jight, soft, uot strong, not durnlü: heartwoud

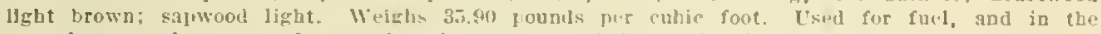
maufacture of paper pulp, spools, slioe pegs, and hoops for barrels.

DISTINGUISHING CHARACTERISTICS-The Gray Pirch, also kuown as Olufield, Wibite, Poserty, or Poplar Birch, ea be distioguislud from all the other Rirches of Pennsylvania, except the native Papel Birch. nall tbe commonly introduced Europeno White Bireh, by its white bark which is nerer rebewed when onen ronosed. The bark is elose, dull white, and warked with black trlangular blotchek just below the finsertion of the lateral branches, and does not peel of in thin 1 1 pperlike lajers libe that of the Birch. The Gray Birch is usually a small trce with a rather continuous trunk and trequently occurs in clumps. Ibe twigs of the Grag Birch are also rougher than tlie luper Iirch and its leaves are longacuminate. While those of the Paler birch are winte.

RANGE-Nova Scotia south to Deluwure and southera Fennsylrania, west to the soothern shores of Iake Ontario.

DISTRIBUTION IN PFNNSYLVANIA-Lecalls in the mountainous portion. Common in Montoe, Schuslkill and like counties. Ibundant along streams in porthero jart of the State. A few specimens founl on top of South Mcuntains in Franklin conoty near Mason and Dixon line.

HABITAT-Usually occurs on molst soil aloag streams, ponds, and lakes; also grows on hillsides and oceasionally on rocky mountain tops.

IMPORTANCE OF THF SPECIES-This species is of little commercial value on account of the strall size which it attajus due to jts short life. The existlog stands should, howerer, be conservatively utllized. It cannot be recommended for forest planting, but is a extremely attractive tive for ornameat purposes. 


\section{BLACK BIRCH.}

\section{Betula lenta, Linnaeus.}

FORM-This tree usually atiains a height of 50 -f: $\mathrm{ft}$. with a diameter of $1-3 \mathrm{ft}$, but mas reach a height of $50 \mathrm{ft}$. With a diameter of 5 fect. Trunk rather continuous, sometimes subdirided, bearing long, slepder, lateral brapches which are ascendiog on roung trees forming a narrow comical crown, or often pendulous on old specimens forming a wide spreading crown.

BARK-On old trunks (Fis. T1) distioctls black, brokeu into large, thick, irregular plates which are smooth on the surface; on younger parts of the trees (Fig. T0) smooth, shining. rers close fitting, reddish-brown, with sweet wintergreen taste and covered witb borizontally. elongated lenticels.

TWIGS-During the first summer light green and hairy, later becomiog reddisb-brown, smooth, shining, with propounced wintergreen-like faror. Terminal twigs slender and elongated, mbile lateral spurs are numerous, stout, and short.

BUDS-Alternate, nboot of an inch long, conleal, sharp pointed, shloing, corered with reddish-brown overlapping scales with domn margins. Three bud-scalcs osually risible on buds of terminal shoot and fiom $5 \cdot 8$ on lateral spur shoots.

IEAVES-Aiternate, simple, orate, usunlly healt-shaped at base, serrate on magrin, loogpointed at apex, dark green abore, pale green below, 21-5 ibches long, $11-3$ ioches wide.

LEAE-SCARS-Alteroate, small, semi-oral in outline, containin; 3 rather small, equidistant bundle-scars.

FLOWERS-Appear abuut April before the leaves. Staminate formed in fall, remalning over winter as aments about of an lnch long, in clusters of usually three, which elongate to about 3 or 4 inches the following spring. Pistillate about 1 - of an inet long, slender, and pale green.

FRUIT-A strobile alout 18.2 inches long, sessile, smooth, erect, with smooth 3-lobed scales and small winged nutlets. Lobes of the scales are about equal in length bot the terminal is narrower and sharper-pointed.

WOOD-Diffose-porous: rass indistinct; heary. strong, hard, dark brown. with thin jellowish sapwood. Weighs $\mathbf{4 7 . 4 7}$ lbs, per cubic foot. ['sed for furniture, often in Imitation of Mahogany, and for interior finisb; also substituted for Cherry and occasionally for Hickory. Trees cut in suring at about the time the buds open, bleed more than auy other species. but the sap contains less saccharine material than that of the Maples.

DISTINGUISHING CHARACIERISTICS-The Filack kireb, also known as sweet Rirch, and Cherrs Birch, can be distinguished from all the other specles of Birch in Pennsylrania by its close, blackish. cherrj-like bark which does not neel off Into film-like layers. It closely resembles the Fellow rirch lut the latter bas yellow bark which peels of inte thin filmlike larers. The twigs have a distinctly wintergreen-like flavor which is absent in the other species. The scales of the fruit of the Black Birch are smooth about equally lobed while those of the Fellow Birch are hairy and irregularly lobed.

RANGE-Newfoundlan 1 to Florida, rest to Ontario, Illinols and Tenuessee.

DISTRIEUTION IN PENNSYLVAN1A-Common tbroughout the State, and locally frequent.

HABITAT-Csunlly found in sich soil and on dry slopes but also common on reck monatain slopes and tops. Commun on the rocky ridzos of the South Mountains in Penusjlrataia.

IMPORTANCE OF THE SPECIES-The Bitches, next to the Hickories, furnish the best fuel rood of all the native species of Pennsylrania. The rood of Black Birch ranks bigb as a fuel wood and is becouning more importast in the manufacture of furniture, especially as a snbstitute for Mahogauj and Cherrs. This tree also rields an oll sold as a snbstitnte for wintergreen. While this species has may good qualities still it is a slow grower aod when quite soung is subject to the attack of fungi, wbich materially decrease the technical valne of the rrood. It is not of sufficient importance to be regenerated astificially bnt should be dereloped where it appears naturally. This species occurs naturally apon extremely rocky ridges and may be a rery desirable species in establishing protection forests ppoo steep moontain slopes and rocky mountain togs. 


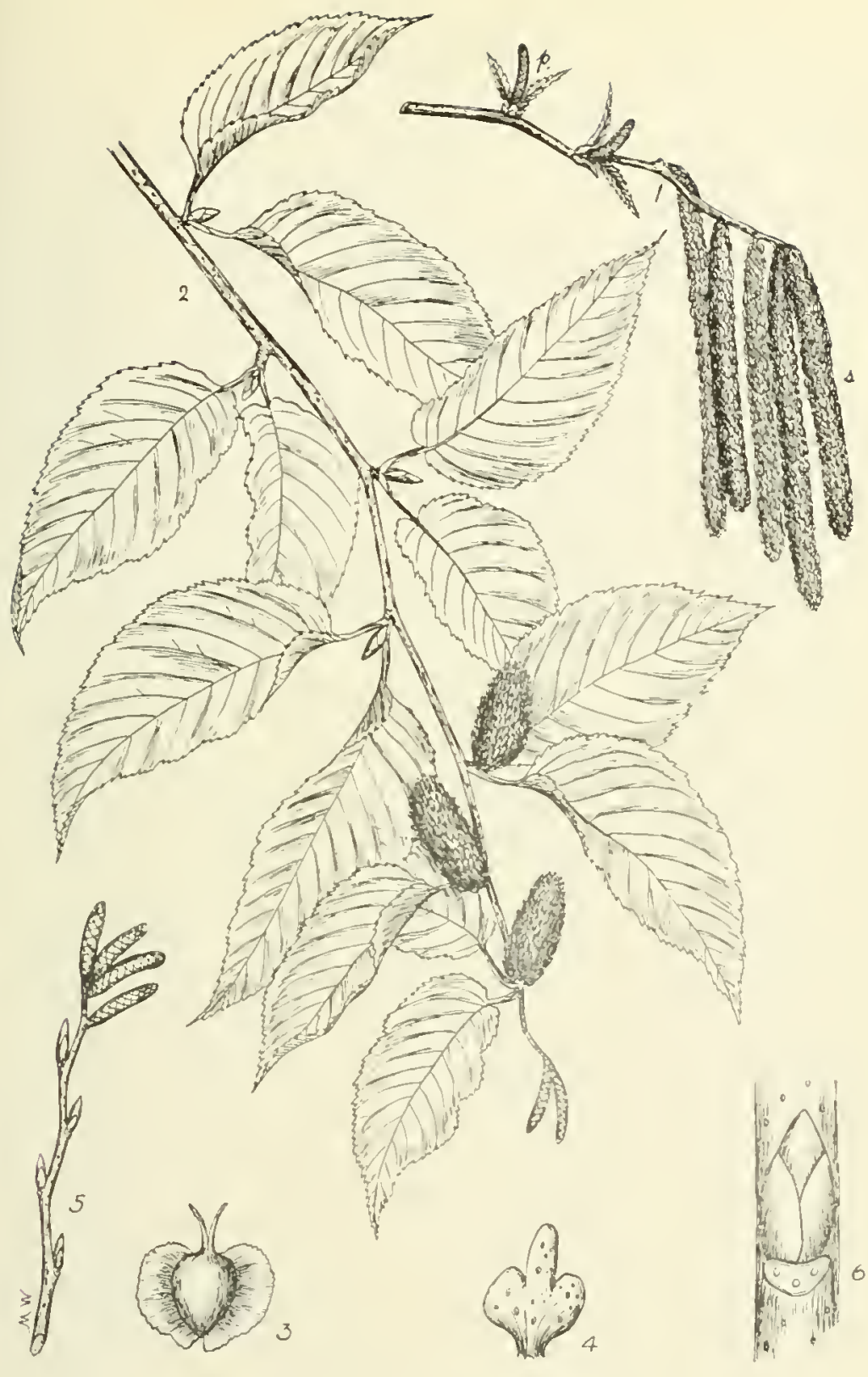

PLATE XLVII. BLACK BIRCH.

1. Flowering branch with (s) staminate flowers, (n) pistillatu Huwn, a

2. Iranull with natur. ligres and throe fruiting strobiles, $x$.

3. A winged seed, enlarais.

4. A strobile scale, enlarini.

5. Winter loranch with fartly dereloped terminal staminate mments, $x$

6. Secticn of a winter twig, finlargel. 

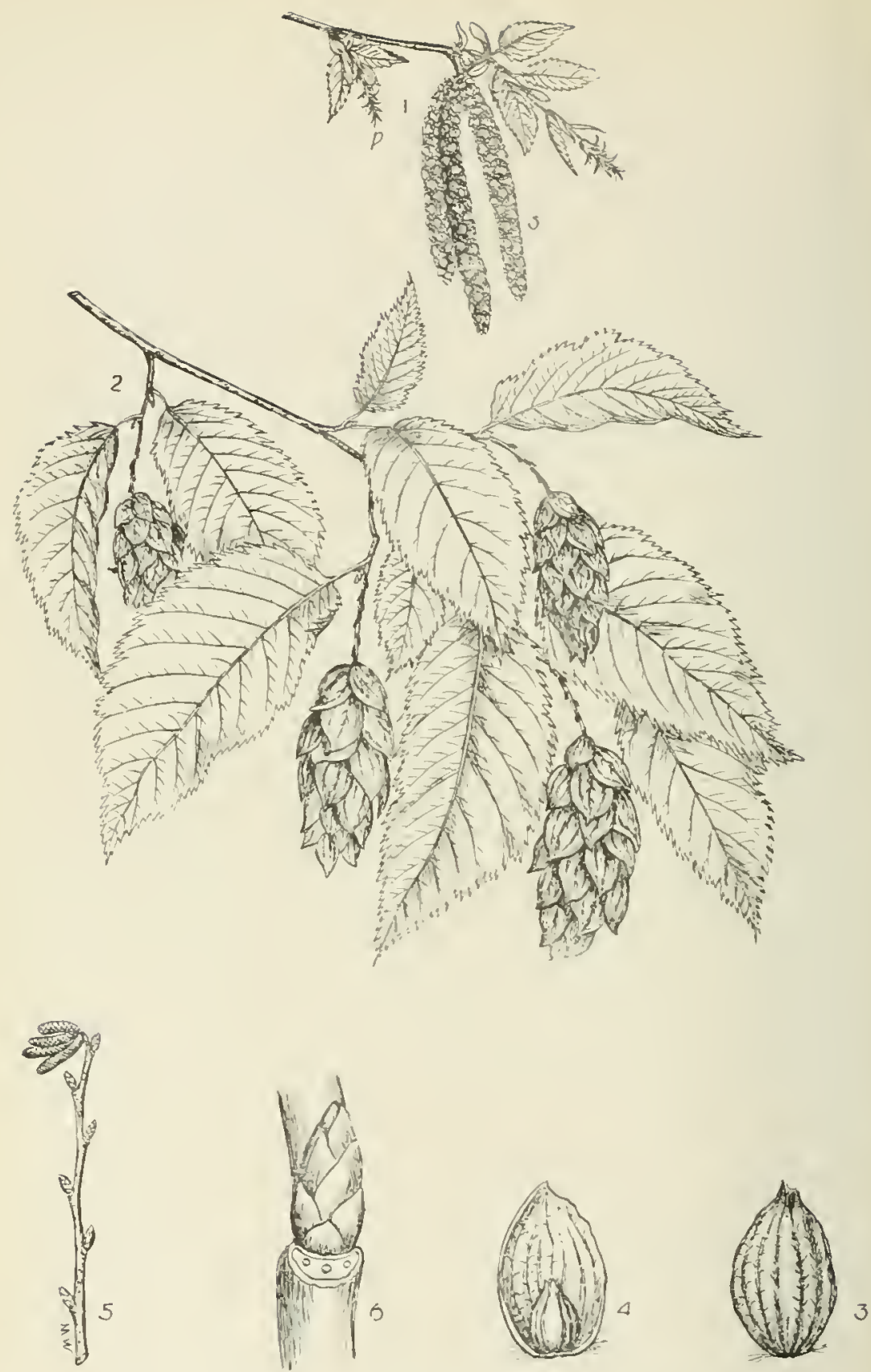

PLATE XLVIII. AMERICAN HOP HORNBEAM.

1. Hluweriug branch with jmmature leates, (s) staminate flowers, (p) pistillate fowers, $\mathbf{x}$. 2. Fianch with mature leaves and hop-like fruit clusters. $\bar{x} \frac{1}{2}$.

3. I seel with inclosing membrame. slightly enlarged.

4. A seed witl part of inclosing membrame remesed, slightlr enlarged.

5. A winter brancle with partly develogal teruinal stamingte aments, $\mathbf{x}$

6. Section of water twig, enlarged. 


\section{AMERICAN HOP HORNBEAM. \\ Ostrya virginiana, (Miller) K. Koch.}

GENUS DESCRIPTION-Ihis genus comprlses about 4 species which are widely distributed in the northero heuisplere. T'wo species are native to America aod 2 to the eastern bemisphere. Ooe of the Amcricno srcies is more $1 /$ mited in its distribution than ang other known tree, being found only in the Graud Cunon of the Colorado iliser in Arlzona while the other Anerlan species is ratber widely distributad over the enstern part of the country.,

FORM-Usually nttuios a beight of $20.30 \mathrm{ft}$. with a dlaweter of $11 \mathrm{ft}$, but mag rench a belght of $60 \mathrm{rt}$. With a dinmetwr of 2 reet. Crown hlgh, open, and rers broad, formed hy whlely spreading often drouning branches with ascending branculets.

BARK-Gragish-urown, thia, roughened by loose nnttah senles which are loose at the ends. See Flg. 54.

TWIGS-Sleader, tough, dark reddiab brown, zigzag, nt brst ladry and green, later smootb, lustrous, dark browis

BUDS-Alternte, axilnty; terminal bud absent; orate, z of an lach long, sharp-poiuted distinctly divergeut, slyghtlg putescent, snwoth, gumng, covered by nbout s visibje, lougl. tudioally-striated, 4-rnoked scale: whlch Increase in size Irom the bose towards the apex.

LEAVES-Alteroate, Blmple, ovate-oblong, acute at apex, doubly-serrate on margin, rounded or henrt-shaped or wedge-shaped at base, 3-5 incbes logg; dull gellowish-green above, naler green below.

LEAF-SCARS-Altetunte, suall, Anttried, 2-rankel, wlth nsunlly 3 small bundle-acars.

FLOWERS-Afrenr about April with the lenves. Stumlnate aments appear about nidsummer usually in ahout $3 \mathrm{~s}$ at the cnd of the twigs ans persist during the winter; they are sitiff. bairs, nhout 3 or an irch long, Lecoming about " Inches Ionis in spring nad covered with reddisb-trown seales. Pistintnte dowers ajuear lu eruct aments, each ooe inclosed in a bairy lladder-like braet.

FRUIT-A small that autlet. Inclosed in in fuflnted bladder-like bract which is corered at the base with long halra Irritating to the slin. Bracts arranged in Lop-llke, nendant cluatera whlch fall during winter and leave the pershting anked stalls.

WoOD-Difuse-porms; rass lodistioct; strong, hard, durable, light brown to white. Welghs about 51 ils, per cuble foot. [sed for teure josts, tool haniles, and wallets.

DISTINGUISHING CHARACTERISTICS-The Americun IIop Iornbeam, also known as Irouwoos. Laverwood, and Therwool, ran rendily he recognized iy its thin grayish-brown bark which pecls of Into Darrow fint seales often loose at both ends and only nttnched in the middle. The bon-lilse clusters of sac like fruit are also reculiar. which usunlly fall hefore winter but the stalks to which they are attached often jurstst. I:I winter the very slender interlaciag branches, the stnmlnnte catkius usually occurring in $3 \mathrm{~s}$ at the ead of the twigs, the small 2-ranked leap. scars with 3 bundesesr, and th: small wddish-brown buds with 4 -rnnked seales are eharactiristic. The autumnal color of thu leaves is yellow while that of the elosely related American Hornheam is brillinut oragge to deep scarlet. The bardness of the wood is also distinctive. The wood is about in per cent. stronger than White onk.

RANGE-Cape Rreton IsIands to Florida, west to Minbesota aud Texas.

DISTRIBUTION TN PENNSTLVANIA-Found loenlly throughout the Strte lut aowhere abnndant. Usually mlxed with other species. Rarely conspicuous in the composition of the forest.

HABITAT-l'refers dry gravelly slopes and ridges, necnsionally molst situations, Usually sereks cool and shaded situations, and is uever found is pure stands or groups, but occurs slogly in mixture, oftea as a undergrowth of 0ak, Maple, Chestnut, nad other forest specles common to its range.

IMPORTANCE OF THE SPECIES-The American Hop Horaheam produces a valuable wood and growa rapidy, but its solitary babits as well as its silvicultural charicteristlcs and the relatively small slze which it attalos, do not recommend it for forestry purposes. It is well adapted for plasting in lawns and parks. 


\section{AMERICAN HORNBEAM. \\ Carpinus caroliniana, Walter.}

GENUS DESCRIPTION-This genus comprises about 12 species wbich are confined to the uorthern benispber:. Only 1 species is foud in Americs. A fen of the other specles are natire to Europe, Whils most are found in northera snd ceotral Asia.

FORM-A small tree or sbrub usnallr attaining a beigbt of $10-30 \mathrm{ft}$. with a diameter of S-12 inches, but may reach a beight of to 4 . With a diameter of 2 leet. Trunt asually short. iuted, and bearing a wide-spregding usualls ruvad-topped crow with tough ascending branchea often pendulons towsids the end.

BARK-Fertically corrugated, smootb, thin, close-fitting, bluish-gray tinged with brown. See Fig. 93.

TWIGS-Slender, :t first silky, hbirs, and green, later smooth, shining, reddish to orange; corered with scatteres pale lenticels.

BUDS-Alternate, axillary; terminal bud ahsent: ovate, pointed, s of an lnch lang, reddishbrown, coresed with $8-12$ risible 4 -ranis bad-scales. Bud-scales increase in size from the base towards the aper, are longitudinaliy-striate and ofteu ciliate on margins.

LEAVES-Alternat?, simple, avate-oblong, acute at B pex, douhly-sprrate on margin, ronnded or wedge-shaped at base, 2-4 Inches long, ceep green above, paler below.

IEAF-SCARS-Altercate, small, elevated, elliptical, wlth generally 3 inconspicuons bnndlescris.

FLOWERS-Appear about April with the Jeares. Staminate start to derelop in fall and remain orer winter in the form of bods ribicb resemble the leaf buds, onls are larger. When fully dereloped thes are drooping aments abcut $] 1$ inches long. Pistillate appear as aments, about 3 of an inch long, with bright searlet stylos.

FRUIT-A small corrugated not abont 3 of an inch long loclosed by a leaf-like, 3.lohed Lract which is asoally serrute only on ane margin of middle lobe.

WOOD-Diffnse-porons: rars conspicnous and broad nlong short radii; hezrs, hard, strnng, light brown with broad sapwood. Weighs abnnt 45 lbs. per cubic font. Csed for fnel, tool bendles, and levers.

DISTINGUISHING CHARACTERISTICS-The American Hornberm, also knomn as the Blne Beech, Irouwood, and Wgter Deech, may be distinguishod hy its rertical, corrogated, bluish-gray, smooth bark. The leaf-like 3 lobed bract with its corrugated aut is also characteristlc. The staminate catkins remain in the bud daring the winter, while those of the American Hon Hornbeam are dereloped in cotumn. It resembles the Americna Beech, but can readils be distinguished from it ly, its corrusated bark and the absence of the long, slender, conical, and sharp. pointed bads so characteristic of the Peech. The hads are nsually duwny at the aprix while those of the American Dop Horabeam are smooth and slightls gumms within. The antumnal color of the leares is brilliant orsnge to deep scarlet.

RANGE-Xara Scotia to Flarida, west to Minnesota and Tezas.

DISTRIBUTION IN PENNSYLVANIA-Found locally throughnt the State. Sometimes rather abundant and conspicuans in wet habitats. Common in Franklin, Adams, Northampton, Fulton, Centre, Huntingdon, Tioga, and Cnion counties.

HABITAT-Usually found in swamps and on the border of streams, whence its name Water Bcech. In Pennsylraniz it is found in the ralleys, along stregms, in swamps, and in similar habitats on the mondtain iats and on moist fertile mountain slopes.

IMPORTANCE OF IHE SPECIES-This species on acconnt of its small size, slow growth, and preference for wet locatinns is of little commercial importance. It cannot be recommended for forestry purposes but is attractive as an nraguetel tree on account of its finted bark, peculiar branching, aad the beatiful orange and scarlet antumal coloration of its foliage. 


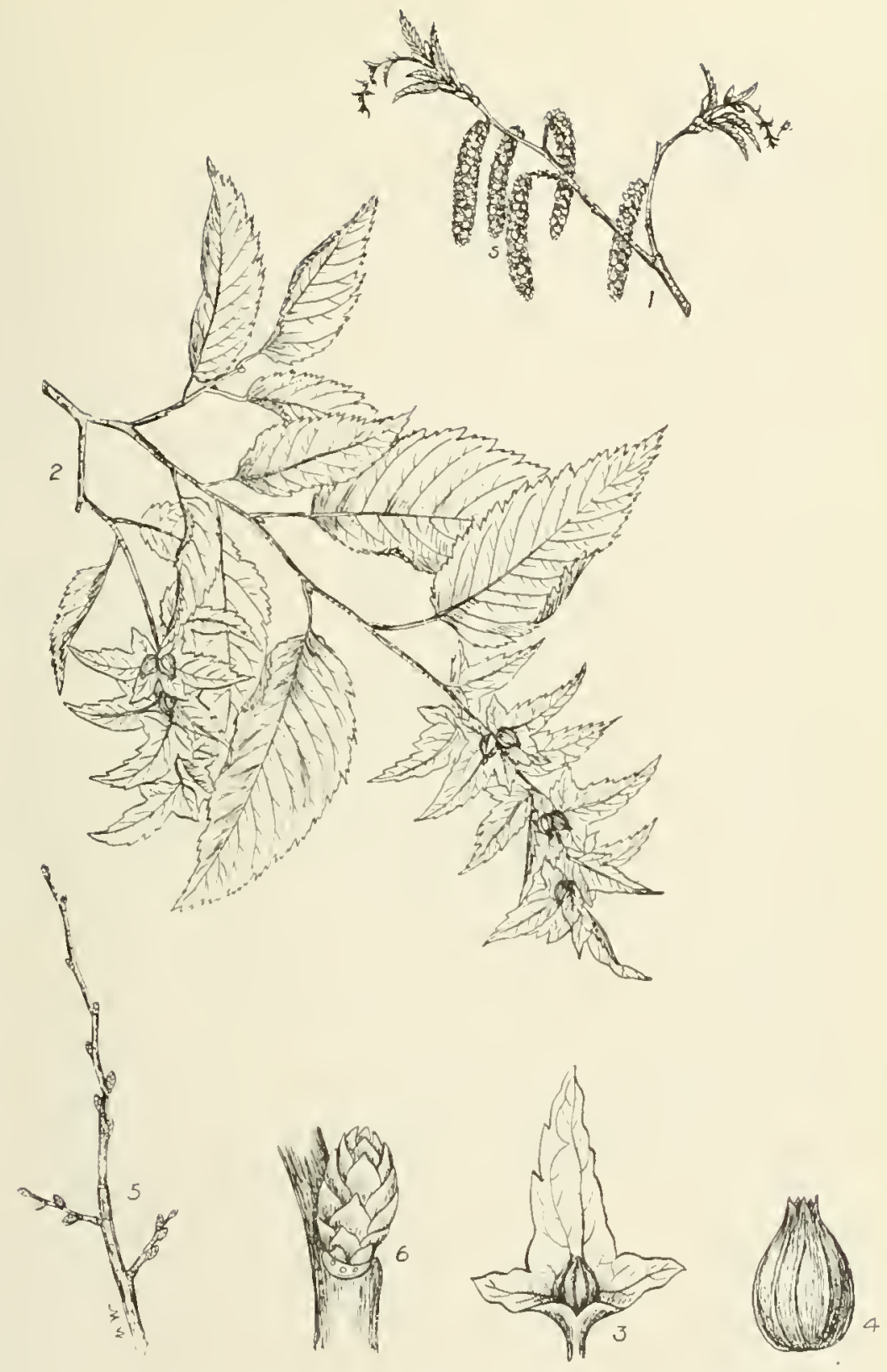

PLATE XLIX. AMERICAN HORNBEAM.

1. Flowering brunch witl immature leaves, (s) staminate flowers, (p) pistilate Howers, $\mathbf{x}$. 2. Branch with Disture leaves aud fruit

3. A nut svith subtending bract, slightly enlarged.

4. Nut witl bract removed. eplarged.

5. A winter branclulet. $x$.

6. Section of winter tivig, enlargin. 

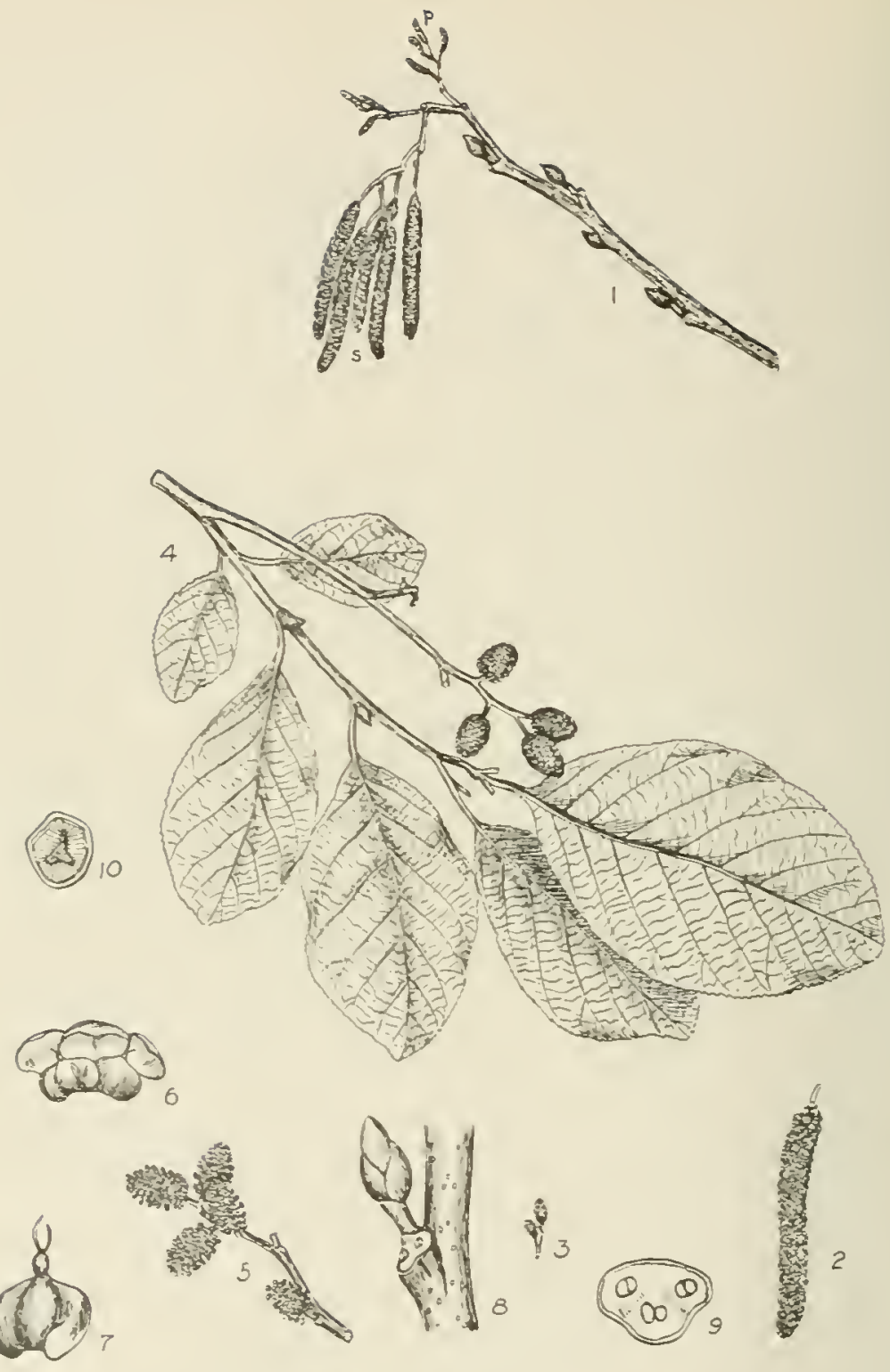

PLATE L. SMOOTH ALDER.

1. Winter branch showing bods, (s) staminate catkins, (p) pistillate catkins, I

2. I mature eteminate catkiv, $\leq \geq$.

3. Jature pistillate catkins, $\leq \mathbf{z}$.

4. Branch mith leares and truit, $x$.

5. Branch with mature fruit strobiles, s

6 A strobile suale with seeds, slightls enlarged.

7. A winger seed, eolarged.

\$. Section of

9. A leaf-scar, enlarged.

10. Cross section of branch showing triangular pith, enlarged. 


\section{SMOOTH ALDER.}

\section{Alnus rugosa, (Du Roi) Sprengel.}

GENUS DESCRIPTION-The Alows comprise ubut 25 kuown species, of whicb aumber about 10 species ary artive to North America ad 2 species to Peassirania. The members of this genus are distributed widely u the uartheru hemisphere agd extend south through Ceutral America a aul alchi the Audes mountaias to Bulivia, Most af them are suruis or small trees, wblle a few attaib a fair true size.

FORM-A smull shrub asually from 4 - I0 ft. iu beight. Sometimes solitaly, usually in clumps, aften forming thicketz which alte almost inipetrable, especially is wet lucatioas.

BARK-Thio, snuwh, fluted, astringeat, at first browaish-green, inter grasish-greed, asd oftea covered with witte blotches.

TWIGS-Ratber sleuöer, at lirst gremaish, later greeaish-browa and finally grasish-browa. ofteg grasish-nhite towards end of fruiting twigs. Lenticels aumerous, scattered, browaish, rouadish or longitudinaly-elouginted. l'ath gicwumh agd irregular or trigugular.

BUDS-Alterante, erideatly-stalked, about 1 ar a iach loag; greeaisb-red, laterally compressed, blunt-pointed, appareaty covered with two ralrate seales which ia reality are stipules. Stupular buj-ecales are ofteo whltish towards apex a ad usually slightly aticks.

LEAVES-Alterate, simple, whorate, bluut-pointed or rounded at apex, usually wedgeshay'd at base, nlmokt regularly serrate on margia at first slightly gummy, later smonth, ruther thick, 3h-4t inclies loog; greea ou both surfaces, but darker on upper surface, browalsh puturesut below especially in the axils of the veins. Velus depressed above aud rldged Lelow.

LEAF-SCARS-Alteriste, ralsed, usually 2 ar 3-ranked, somewbat triangular, contaialog aliuut 3 bundle-stuls which are uften complounded. Stipule sears anrrow, trlangular, browalab and very close to leaf sears.

FLOWERS-Appear in March or April hore'the leares. Stamiate and pistillate accur separatcly but on salue twig. Stauituate un aments which develop partly lu previous autuma aad remain durman: over wiutes. Ju witter they are stiff, pendnot, greenish, aad about one inch long: in clusters of "-5 at the ead uf bare stallis. Pistillate also develop ia the [revious autuma and ronaiu dormant over wirter, are about $1-3$ of as inch long, usually clustered iu 2s or 3s und greenish to purjlish la color. The tirst wurm days of spring brlog forth the scarlet styles of the plstillate Howers.

FRUIT-A coae-like woody structure, nbout of an joch loug, orblicular, peraisteat, composed of thick and wouly senles va which the little, practically wiagless, round and Hatceacd autlets are produced.

WOOD-Difruse-porous: growth riags distinct; rays rariable io width. Sapwood turas yellowisld-browz ироп exposure.

DISTINGUISHING CHARACTERISTICS-The Smooth Alder, ulso knowa as Black Alder, car be distiuguisted by the woody couc-like frult which ls usually present at all seasons of the Jear, The wet habitats which it freuceats mas also aid la recogaiziag $1 \mathrm{t}$. In spring it ia one of the tirst of oul small trues to blossom. In summer the stiff leares with tbeir rauaded ajexes art also characteristic. In water the wature fruit, developing stamiuate aad pistillate flowers, stalked buds. and triubular greeu pith, are distiactire. The oals other Alder native ta Peansylvanis is the sleckled or Hoary Alder (Alaus iacana (L.) Moench.) Thls species caa be distingulshed from the smooth Alder by its leaf-blades which are usually glaucous or baely pubeseent aud rovaded at the base.

RANGE-Lsseutially a soutbera specles, extendiag from Iaine to Florida aad Texaa and westward to Mignesota.

DISTRIBUTION IN PENNSYLVANIA-Very cammon la the eastera and southera parts of the state. Syarse a ad iocally abuadant ia aorthera aad westera parts.

HABITAT-Commoa along streans ad ia swamps, Rarels asceads the hillsides. In wet situations it often forms dense thickets.

IMPORTANCE OF THE SPECIES-T'ae twu species of Alder aative to Pennsylvaaia do not attais a size which wurld make them important commercially. Tbey was be af ralue as sail-bunders and soll-ccuservers along the baaks of streams or ia vers wet situations siace they derelop large and strong roots which throw of many suckera. 


\section{HAZELNUT. Corylus ämericana, Walter.}

GENUS DFSCRIPTION-Tbe Hazlenuts coanrise about 7 kamo species, of which aumber about 3 species are artire to North Amarica aad 2 to Peasslraoia. The members of this geaus are usually sbrubs, rarely trees, foud in the northera hemisphere. They do not produce wood of any commereial jmportace, but their fruit, which is a nut, is very common ia our markets. The wuts are sold voder the name Hazelauts or Filherts.

FORM-A shrub or small tree teachlog a helght of $3 \cdot 5$ feet. Occurs in clumps and often forms thickets.

BARK-Rather smooti. thin, durk browa, sometimes rougheoed with shallow loogitudinal Essures.

IWIES-Smooth hu: marked with a few scattered leaticels, and covered with aumerous piokish balrs which usuelly stad at right angles to the twigs; gras to russet-brown in color.

BUDS-1iternate, orale to globular, redish-browo, somewhat bairy, corered with about 3-6 scales with baily and slightly gladular margias.

LEAVES-Alteraate, simrle, ovate, obtuse or beyrt-staped at basc, aente at apex, serrate oa margia, smootb oa un[ surface and sligbily hairy on lower surface.

LESF-SCARS-Alterantc, seni-ciscular to glohular, roised, with scattered buadle-scars asually 5-10 in aumber.

FIOWERS-Appear in Aprll or Mar before the leares. Stamiaate occur in catkins which asually appear before tlic loares at the and of the twigs of the rrevious seasoa's growtb and are from $3-4$ incbes loog. Pistillate small, derelop from short scaly buds, with loag, sleoder, projecting, crimson stigmas.

FRUIT-A pale browa oroid uut ahout $\$$ of yn irch lone, slightls thatteaf, somewhat roughened at bosc where the intnlucre is attuched. Involnere consists of two leafy bractlets whlch are distinct in the Common Hazelont and noited inte a tabular beak In the Beaked Hazelaut. Ripeas ia Juls a ad Aurwst. Kerael swret a ad edible.

DISTINGUISHING CEARACTERISTICS-The Hazclnut, also kuown as America Hazel a fill Filert, caa be recogaized bo its rbaracteristic fruit, whicb consists of a aot with a lenfy involucre of 2 distinet bracts. The closely related Rerked Hazelaut (rorslus rostrata, Ait.) has its bracts untwd and much prolonged into a carrow tubular beak. The joung twigs are covered with ouarecus somewhat fladular piokish hairs. The staminate fowers, occurriog in catkins whlch develot somewhot in autuma a ad thea remain dormant over wlater, are charaeteristic. The partiolly derelojed stamiante aments are oftea abnormal and twisted due to the attack of some organic agent.

RANCE-Yaje min Ontario, south to Flmridy nad Kansas. The Beaked Hazelaut raoges from Quebee to British Columbln, south to Grorgia and Missoari.

DISTRIBUTION IN PENNSYLVANIA-30ti species are foud locally throoghont the state. HABITAT-Both specirs frequeut the border of woodlands, hillsides, thickets, and loose stonc feaces.

IMPORTANCE OF THE SPECIES-These strubs do not produce aay wood of commerclal importance, but sield raluable and treatir prized nats. The auts are commoa oo oar morkcts. Eotb speeics are rery attractire aud placted extedsirely for oraamental purposes. 


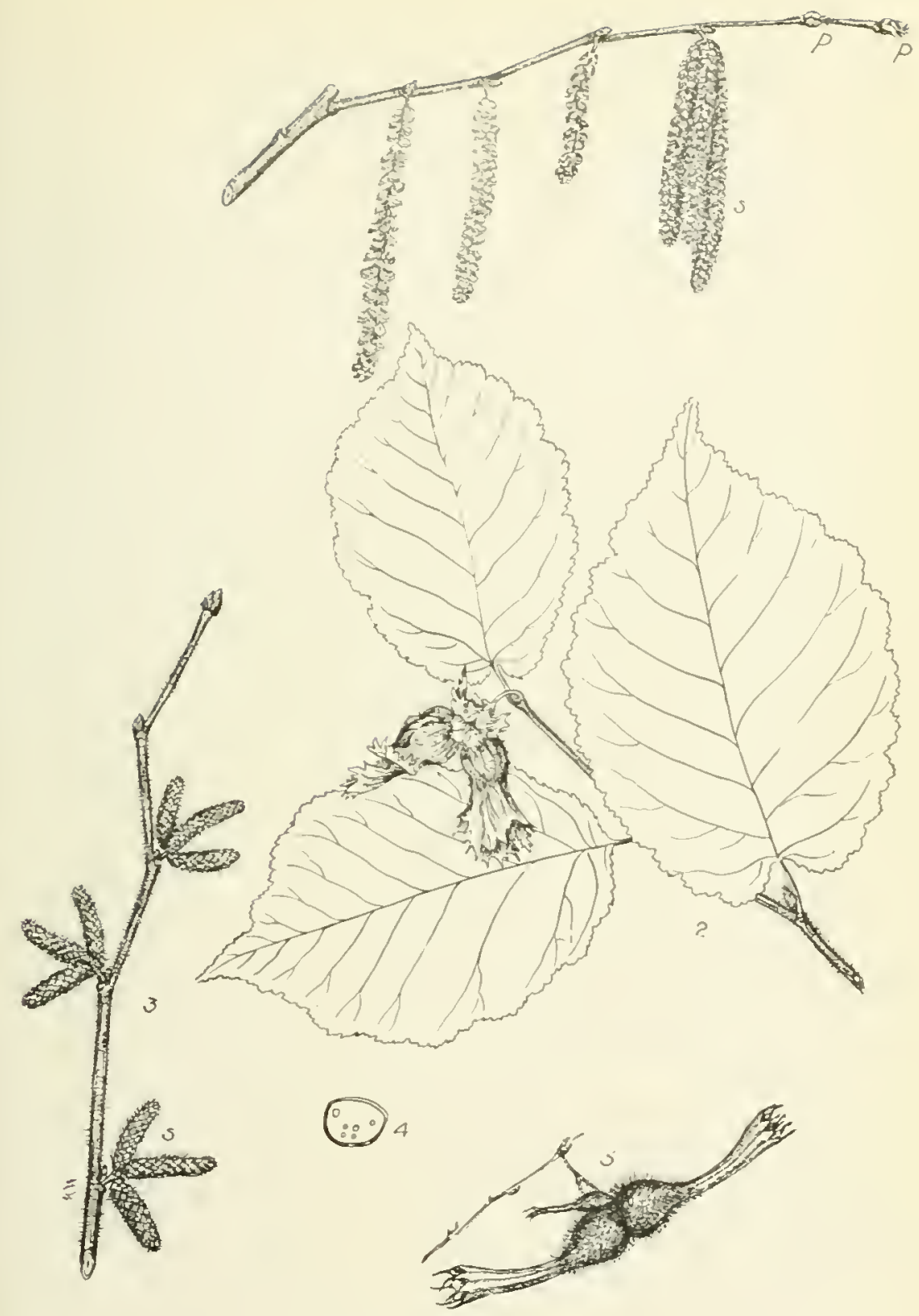

PLATE LI. HAZELNUT.

1. Branch with (s) staminate towers, and $(p)$ pistillate Howers, $x$.

3. liranct with leaves and fruit, $x$ k.

1. Le'zf sear with hindle scars, fanlarged.

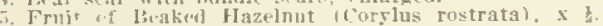




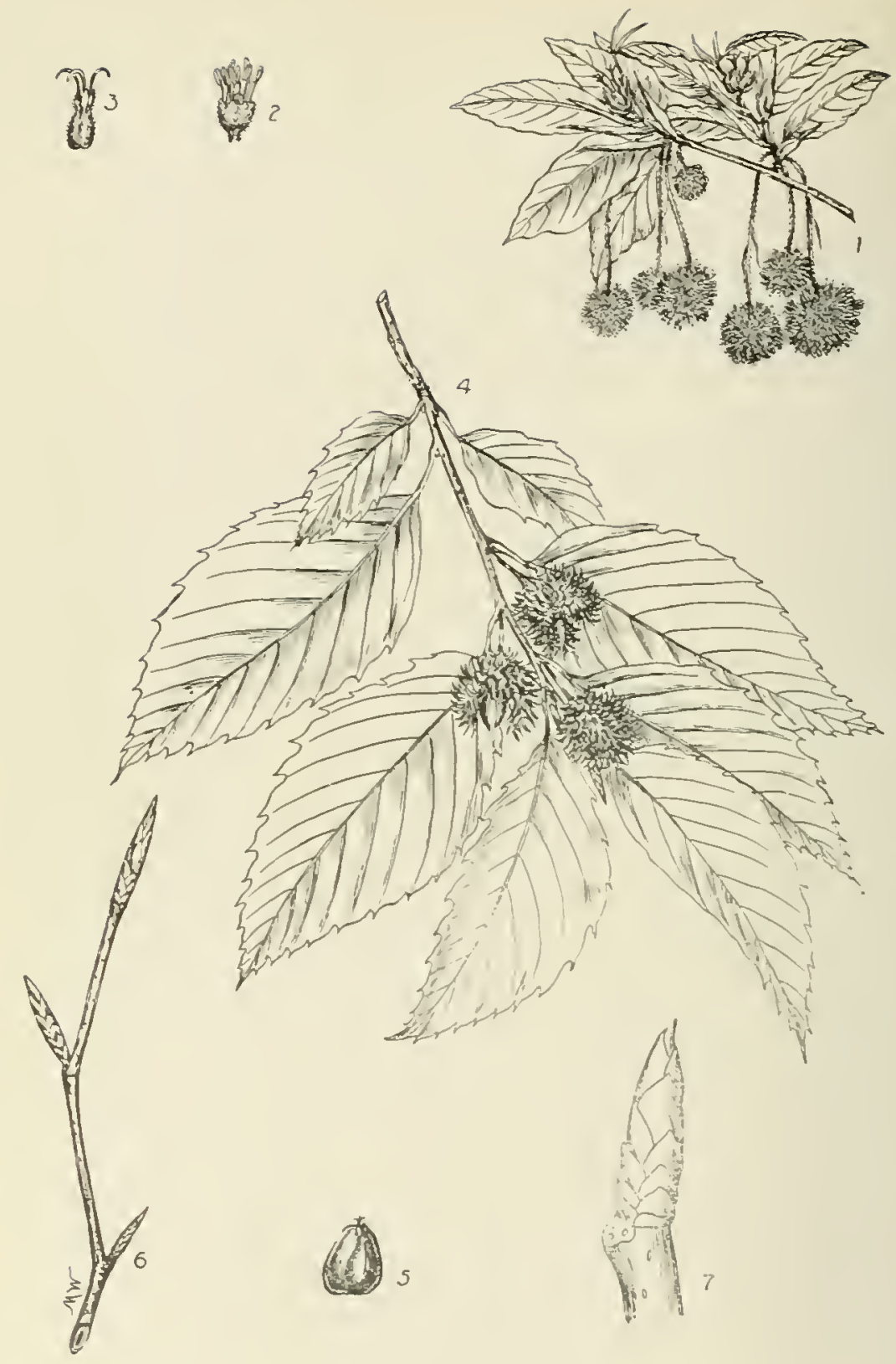

PLATE LII. BEECH.

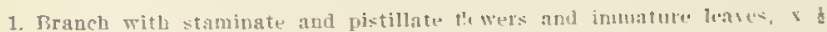

3. A staminate thwer, enlarged.

3. A pistillate fle wer. enlarged.

4. A branch witl mature leaves and three fruits, a

5. A seed, natural size.

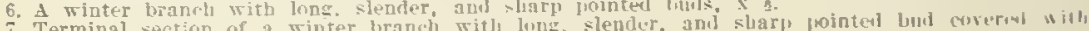
many orerlapuing seales. Eliglitls enlatged. 


\section{BEECH. \\ Fagus grandifolia, Ehrhart.}

FORM-Large tree nsnally attaning a helgbt of $50.00 \mathrm{ft}$. With a diameter 012.3 It. but mas reach a beight of $125 \mathrm{ft}$. with a illaweler of 4 li feet. Forest grown trees tall, slender, ifee ficm lateral bradiles for a considerable distadce from the hase, wich a rather compact shallow crown. Oficu grown trews short-truaked, covered with man lateral branchea which art often droofing below and erect above, sorming a dense, deer, symmetrieal crown.

EhRK-Vers close, smaoth, light gray, mottlel with dark spota. It invites the eattiog of initials and other outline carringa. See lilg. 92.

TWIGS-Slender, da-li sellow to gray, at frst balry, later smooth, zigzag, covered with gellowisi lenticels, and marked by jud-scale sears.

BUDS-Alternate: termlnal lual prosent: fire times as long as wide. slender. sbarp-pointed. conleal, usually scioctl. cosered bs 10.20 redd:slu brown bud-scalea with hairs margins.

IEAVIS-11ternate, Einule, avate, 3.4 inches long. stili leathery, wh tapering apes ad sharp-toctued marga: light green above, jellowist.greet below.

IEAF.SCARS-Raisel. creacent-abrod to cllytical with a lew fcattered bundle-scars. Stipule scars narrow, almost enclicling twig; one end of each st!pole-gear la raibed abore the wher end.

ELowERS-Aprea: abeut Arrll when lenres aro onethird developed. Staminate flowers in a stalked rond wead abont one lnch in dlameter; pistillate fowers in 2 -flowered clustera from the axil of the upper leaves.

IRUIT-A stalkel, prlekis, 4-valved liur containing trlangular pale brown, shining nuta with sweet edihle hernel.

WOOT-Diffuse-jorous with minnce hores: broad medullarg rage present with narrow ones Interreulng; hard, strong, tough, out Jurabic, diffiealt to season, light red is color. Weigha

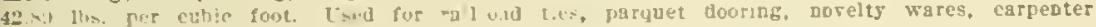
tools, fuel, and charcoal.

DISTINGUISHJNG CHARACTERJSTICS-The American Beech can readily be distlnguished by Its close, smooth, light gray bark, its simile, leathery, often persistent leares. its prickly and stalked fruit witl trabgular setdr. and its lona, slender, conical, sharp-pointed reddisbb:own buds.

RANGE-Nora Scotla to Ontario and Winconsin, south to Florlda and Texas.

DISTRIBUTION 1: PENNSTLVANIA-Found in esery part of the State, but most abundant ic the northern pa:t. Lucal in the southeastern and southwestern parts.

HABITAT-Commonly found on rich moint bettom lands, bot is also abundant on gravelly slopes and rich pplands. It enuires dense shade and rariations of temperature.

IMPORTANCE OF THE SPECIES-This speeies was formerly not of rery mach commercial Importance, bot it is now becomius more important since the process of timber impregation

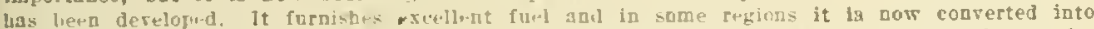
railreac ties and also manofactured into rarlous by-producta on a rather exteasive acale. It cannot, howera:, be recommended for extensire planting for forestry purposes but should l.e retained and dereloped in the farmer"s woodlot where the pradnction of 1 in 1 is lmportant. In the future when more intensive systems of forest management hare been dereloped it can be used for underplanting and as a soil conserver. 


\section{THE BEECH FAMILY-FAGACEAE.}

The Becelı family confains some of the most important timber species and has its representatives distrihuted in nearly all regions of the world. The Pine family alone surpasses this one in economic importance. It yields not ouly high arade wood but also food in the form of nuts, tamning and dyeiner materials, and cork. The wood is of a high grate and used extensiveiy.

The members of the Beech family lave alternate, simple, pinnatelyreinol. mostly deciduoms leaves. I livision of the family known as the Live Oaks retains its leaves during the winter. The floners, staminate and pistillate, which are rather inconspicuous, are usually vellowish to mreenish in color and found on different parts of the same tree and usually on diflerent parts of the same branch. The inconspricuons thwors of this fanily stand in strong contrast with the conspicunns flowers of such species as the Mannolias, Cherries, Apples, I'ajaw, and other broarl-linverl trees. The fruit consists of rne or more one.secled nuts covered by an outer cartilaginous and an imer membranous rovering. It is usually heary and in some speries matures in one season while in ofluers it requiles two seasons. On accomt of the heary weight of the seels they usually fall immeliately below the tree and remain there unless disseminated by animals, birds, water, or gravity un slopes. The seed fills the entire cavity of the mut.

This family consists of $f$ grmera and about 400 species of trees and slubs of which number ") genela with about 60 species occur in North America and : genera with 19spreies in l'enustrania. The 3 genera not found in Pennsylynia are Castanopsis, Pasania, and Nothofagus. Representatives of the first $\_$general are found in the western part of the Conited States. While the genus Sothofagus is confined to the southen lemisphere. The sulojoined key will distinguish the 3 genera found in Penusrlrania.

\section{KEY TO THE GENERA.}

1. Slaminate atments in globnse hends: Juts: triangulur; bnds long, glender, sharp-

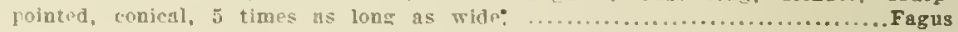

1. Staminate anekes elonsated, slender: puts not triaurular: buds slorter, stout.

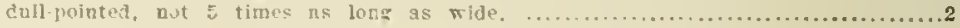

2. staminate nment< eroct or ascending; nuts enclosed in a prickly bur: buds covered

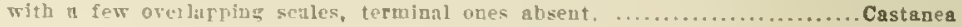

2. Strminte a rueuts d:coping: nuts sented in m open scaly cup; buds corered with manj overlaping scabs and cluitered at the termingl end of twis............enercus

Page.

125 125 
BEECH-FAGUS, (Tourn.) L.

This genus comprisis trees with a close, smooth and grayish bark: a light horizontal spray, simple straight-reined leares, hard and diffuse-porons wood and long, slender, conical, sharl-pointed buds. The members of this genus are limited to the northern hemisphere with only 1 native representative in America and $t$ in the eastern henisphere. One of the latter is widey distributed in lisrope and southwestern Isia. It is the bech which ligmes in ancicnt literature and is now known as the European Beech (Fagus sylvatica L.). 'This species is now flanted extensively for ornamental purposes in America, especially : valieties of it, with purple leares, cut leaves, and pendant branches resuectively. The wood of the Luropean Beech is used extensively in France and Germany for lumber and fuel and the nuts are nsed to foed swine. The nuts also yicld a valuable oil. The other species or the eastern hemisphere are found in eastcru Asia. The description of the sole native American representative, found on page 12:?, will suflice for the genus.

\section{CHESTNUT-CASTANEA, (Tourn.) IIIll.}

This gemus comprises aspecies of trees and shrubs with furrowed bark, round branchlets without terminal buds, ring-porous wood which is rich in tamnin and durable in contact with the soil. The leares are simple, alternate, stint, sharp-toothed, and straight-reined. The members of this genus blossom in summer ant mature their fruit the same autumu at about the time when the first flost appeal's. 'l'he fruit consists of a large spiny bur in which 1.5 nuts are bornc. The muts are highly prized as tood. 'Three species of Chestmints are cultivated in this comtry for their fruit, the American, the European, and the Japrusese. The Chestnuts are confined to the northern hemisphere, both castern and restern. No representatives of this genus are at $y^{n}$ esent found in the restern part of North America, but records show that the Chestmut was at one time indigenons to this region. 'Three species are native in eastern North America, 2 of which attain tree-size. While 1 (Castanea alnifolia, Nutt.) seldom exceeds : lt. in height and is found in the south Atlantic states. The subjoined key will ail in identilying the two species native to Fennsylvania.

\section{KEY TO THE SPECIES.}

1. Large trees: leares oulong-lanceolate, swcioth and green on both sides; nuts $\mathbf{1 . 5}$, usually 2-3, in a bur: buds 3 of an inch long corered by smooth chestnut-brown

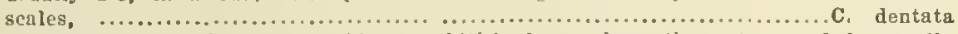

1. Swall trees or shubbs, leaves oblong, whitish downy beneatb; nuts rounded, usually one in a bur; huds $\frac{f}{3}$ of au inch long, covered by seurfy red scales, ........ c. pumila

Page. 


\section{CHESTNUT.}

\section{Castanea dentata, (Marshall) Borkhausen.}

FORM-A large tree usurlls attaining a height of 60-80 $\mathrm{ft}$. with a diameter of $3-4 \mathrm{ft}$. but may reach a beight of vier $100 \mathrm{ft}$. wita a dlameter of 10 feet. A tree with a diameter of $\mathbf{I t}$ ft. bas been recorded from francis Cove, westorn Yorth Curolina. Open grown trees bave short trunks with decp. widespreading crowns. Trees in close stands tall, with little stem taper and few lateral branelues.

BARK-0n old trunks fbrous, deeply fssured; fssures separate somewbat oblinue ridges which are covered wit'l dark brown scales. On young trunka and older branches much smoother. See Fig. 82.

TWIGE-Stout, smooti, greenish to brown, round or angular, strollen at the nodes; corered with numerous smnll, white, ralsed lenticels, Pith star-shaped.

BUDS-Alternate, axillary; terminal bud absent; oroid, to an lucb long, sharp to blunt-pointed; covered by $2-3$ darle clestnut-brown scrles.

LEAVEs-Alternte, simple, oblong-lanccolate, susp-pointed at npex, toothed on margin, smooth on both lowtr and upper sides.

LEEF-SCARS-Semicral in outline; raised from twig; with numerous, rather lnconspicuous, scattered, occasionally clustercd bundle-scars.

FLOWERS-Appear in June or July. Sianingte in erowded elusters along ament; pistillate appear at base of upper aments as globular involueres.

ERUIT-Mntures in September or Oetober. A bur corered with numerous, prickly spines and containing $1-5$, usually $2-3$ nuts.

WOOD-Dlstinctiy riaz-porous; with indistinet uedullary rass; quite strong in joung trees, rather weak in olde? ones: jellowish-brown, vars durable, splits easily, rieh in trunic ncid. Wrighs 28.07 lbs, por cuble foot. Used for railroad ties, telegraph poles, fence yosts, rans, cheap furniture, and tanale acid.

DISTINGUISHING CFARACTERISTICS-The ("Lestout ean readils be distingnished from all other trees except the Chinquapin by its chnracteristic fruit. See "Distinguishing Charncteristics," under Chinquapiu, page 127. For Gezus Iitscription and key to snecies, see page 125.

RANGE-Maine te Michigan, south to Delawre and along the mountains to Alahama, Mississippl, and Arkansti:

DISTRIBUTION IN PENNSYLVANIA-Ters common in the eastern, southern and central parts and localls jn other parts. It is the most common tree of Penasjirania.

HABITAT-Grows almost on ang kind of soil, from bottom lands to mountain tops, but does not lore limestone or extremely wet soil. In the Xorth it is common on glncial drift but in the South it remains close to mountains und reaches its best development in western North Carolina and eastern Tennessee.

IMPORTANCE OF THE SPECIES-This speeies, which reproduces itself hest by sprout, bnt ciso by seed and sceding, is one of the most important commercial species la this State. It has shown itself to be the surest of all our trees to reproduce a stand fully from sprout. It growe fast and is used for many purposes in small as well as large sizes, aud thus can be managed in short rotation, Which insures a certain proft on the inrestment. A Chestnot forest managed for tive purpose of produeing telegraph poles should be run on rotatjons of ehout 55 rears. On puor soil it mas be necessnrs to increase the length of the rotation. Good tendnnce reduces tise length of the rotation while the absence of it will not only increase the length but also result in an inferior grade of mood. The great rariety of uses to which the wcod of this species is put will drain the existing forest to an enormous extent. There is urgent need to reproduce, derelop, and improre our existing stnnds and also to guard against such destructire organic enemies us the Chestaut Bark Disease (Endothia gsrosa rar. parnsitica) commonly known as the Chestunt Blight. 


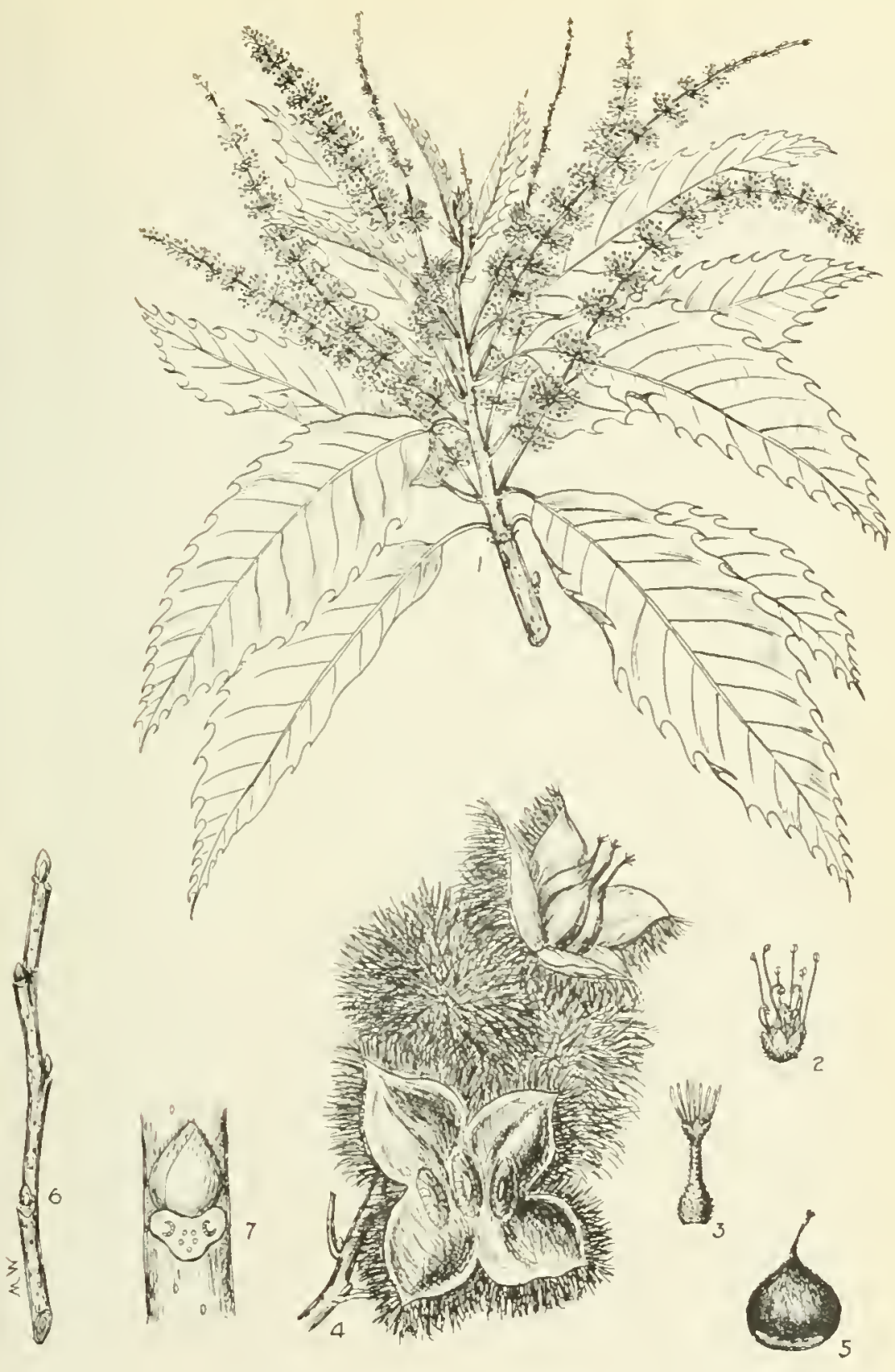

PLATE LIII. CHESTNUT.

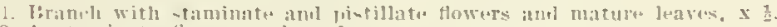

2. A taminate flower. "hlarged

3. A pi-tillat, thower, rilargert.

A liritinth wit

fi. I trintur tiranch, $x$ th

i. A sectinu of winter livanch. wlarged. 

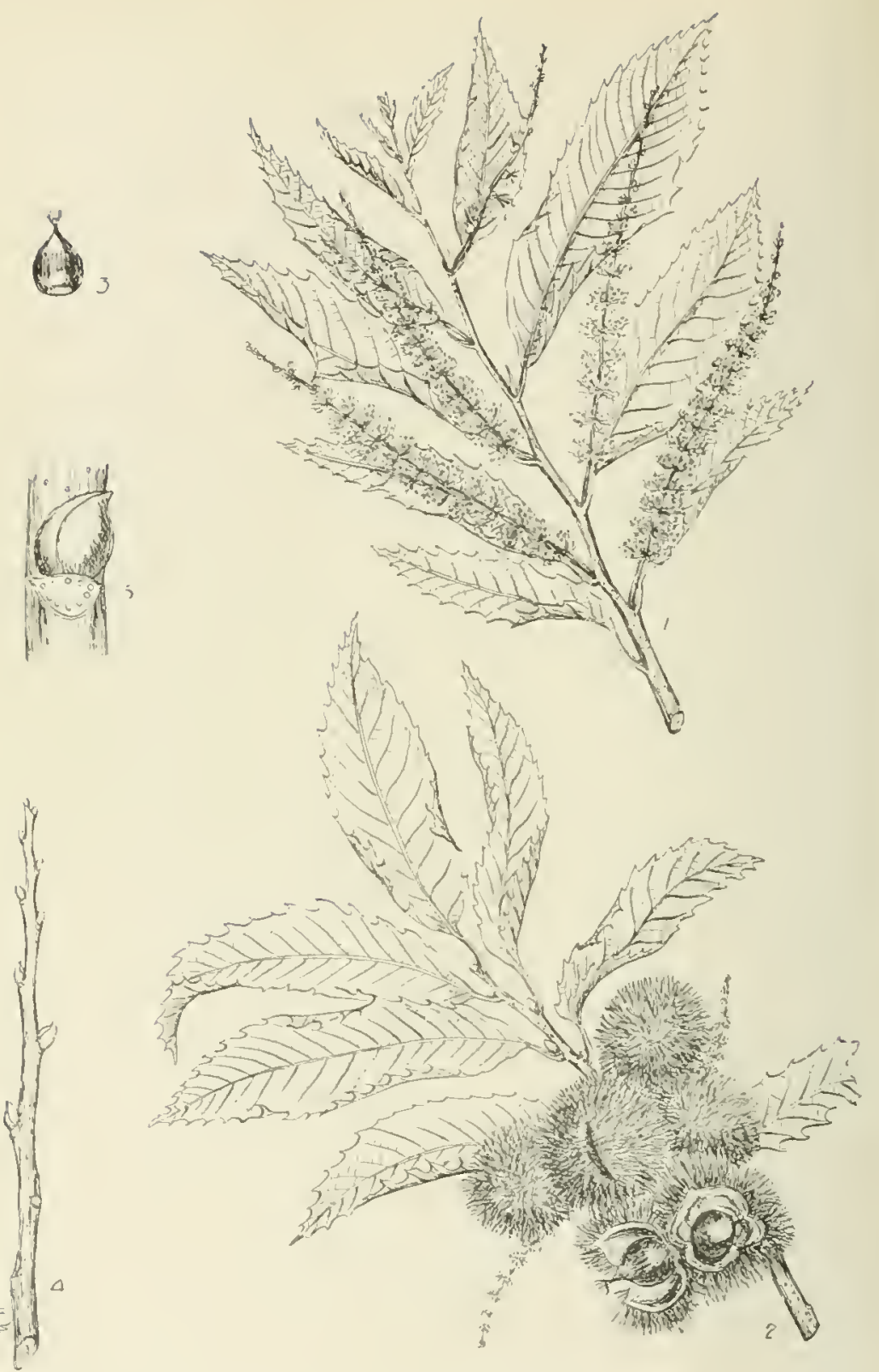

PLATE LIV. CHINQUAPIN.

1. A Howering hram with lesves, $x$ k.

2. A fruitiug manch with matule leases, 、

3. A uut, $x$ w.

5. A section of winter branch, "ulargel. 


\section{CHINQUAPIN. \\ Castanea pumila, (Linnaeus) Miller.}

FORM-I small tree or shrub usualiy attaining a height of 20.30 ft., but may reach a beight of 50 It. with a diameter of 3 feet. In Pennssirania seluutu exceeds 20 (t. in beight and ofter is only $3.5 \mathrm{ft}$. in beight. Thls is the nothern limit of its distribation. Trank usually Ehort and crowd rouldish.

BARK-May attain a thickness of onm inch, usuaily fissured and brotien iuto light reddishhrown loose plate-like scalps. On branches and young trunks rather smooth, dark graylsh-brown.

TWIes-slender, at first pale woolly, later pubescent, finally smoother, reddish-brown to dark brown; corered with nusuerous lenticels.

BUDS-Alterate, axillars; torminal bud absent; ovoid, biunt-polutud, about \& of an inch long: ccrered with scurfy red scales.

LEAVES-Alternat, simple, oblong, thick, firw, straight-reined, sharp-pointed nt apes, sharply toothed on margin, rellowish-green and smooth on upper surface, pale green and whitish-downy beneath.

LEAF-SCARS-Seml-oval, somewhat ralsed; with scrittered, occaslonally clustered, rather inconspicuous bundle-scars.

FLOWERS-Appear in Ming or Junk in more ne lesg spreadiog atoeuts. Staminate occur in crowded clusters along ament: pistilate nt uase of upper aments do orold, prickly inrolncres.

FEUIT-Matures in September or Octaber. A bur corered with numeroua stiff spines and containlag usually i, seldom 2, orold bright brown and sweet unts with a mors or less bairy apex.

WOOD-Ring-norous; with Indistinct ruedullary rass; hard, strong. brown, durnble, rich in tannir acld; splits easily. Welghs nbont as lbs. per cubic foot. Üsed for fence posts, ralls, and railroad ties.

DISTINGUISHING CHARACTERISTICS-The Chinqunpin is a littlc brother of the Chestuat whicl ode mar sce ly comparing their chasacteristic fruit. It can be distioguished from the Chestnut by its smalicr size, its whitish down on lower surface of leal-blades, its smaller scurfy red buds, and smaller burs containing usualiy $I$ out.

RANGE-Sew Jerset and Pensyivnaia to Florlda, Missourd, and Tesas.

DISTRIBUTION IN PENNSYLVANIA-I.ocnily in a few counties in the fouthern part of the State. Known to occor in the counties cl liranklin, dams, Fork, Lancaster, and Cheater.

HABITAT- - 'sualis found on drs. sandy'slopes, pather fertile billsides, and margios of ponds and stregms.

IMFORTANCE OF THE SPECIES-It is of Do commerclal importance in this State on accunt of its small size and $j$ ts linjited distribution. It is rery attractive as an ornamental shrul and sields delicious nats. 


\section{THE OAKS-QUERCUS, (Tourn.) L.}

This geuts, which consists almost entirely of trees, comprises about 300 species in the world. The Oaks are world famous on account of their wide distribution, plysical sturdiness, great strength, and the high commercial ralue of their mood. Ilost of them attain a great age and are aggressive competitors in the constant struggle which is going on in the lorest. They can be reproduced by sprouts or by seed, naturally or altificially. Their modesty reconmends them from a silvicultural point of riew since they will grow in habitats which are most ol diy, strole or fertile, cold, temperate or tropical, at low altitudes or at hiwh altitudes up to the timber line. They prefer the temperate climate.

Economically this genus is onc of the most impoltant among the trees. Its wood is used extensively and is especially adapted for high grade work. The hatk is rich in taunin, while that of a few European species is used for colk. The galls which ale caused by insect stings are also oftern rich in tannin. The nuts are used in some platces as food for man and swinc, and occasionally when roasted form a substitute for coffee.

The leares are altelnate, simple, and nanally shed in ąutum. I dirision of the Oaks known as the Brelogreen or Live Oaks, sheds the leaves at the eud of the secrnil or third season. The flowers, staminate and pistillate. aljeal on difielent parts of the same tree and often on diflerent parts of the same branch. The staminate or male flower's are small and arranged singly on a long sleuder and drouping anent which emerges from the buds on the twigs of the llevious rear's glowth. The pistillate or female flowers are small. inconspicuous. un-like bolles which appear singly or in groujs from the base "if tho dereloping leaves of the season. The flowers are fertilized log the wind and clerelop into a nut-like funit kuown as an acoln. The fiuit is distinetive in having a sealy, often bristly cup separated from the thin-shelled mut which it partly or almost wholly encloses. In autumn the nuts may fall to the ground while the cups per'sist on the tree, or the mut and cup ma! fall together. The acorus may gelminate immediately after falling to the ground, but usually they remain dormant until the following spring. The seed-leaves of the nut remain in the shell and furnish nourishment to the reveloping seedling. I loug tap root is characteristic of an oak seedling. This makes them difficult to transplant in a nursery or to plant in the place where they are to develop into large trees. A large lart of the tirst two seasons growth of many of our Oaks is concentrated mostly in the derelopment of a root system. The 
acorns are heavy and disseminated maiuly by water, mammals, birds, and gravity on slopes. The fruit of some Oaks matures in one season, while others require two seasons. At the end of the first season the latter appear as immature acorns. The mature fruit of the annual fruiting Oals is attached to the growth of the season, while that of the biennial fruiting Oaks is attached to last season's growth. During the winter seasou, immature acorns of the biennial fruiting Oaks are found on the glowth of the previous season. The Oaks of Pennsylrania may be classified in two groups:

A. Acorns mature in one season; leares with rounded lohes, not bristle-pointed; shell of not usualiy smootb iaslde: kernel usually sweet; bark pale often scaly-WHITE OAKS, ANNUAL OAKS. LEPIDOBALANUS.

B. Acoras mnture in two seasons; leaves nt thejr lobes bristle-polnted; shell or nut nsually puhescent Inside: bark dark usually furrowed-BLACK OAKS, BIENNIAL OAKS, ERYTHROBALANUS.

The subjoined list shows the respective groups to which the several Oaks of Pennsylvania belong.

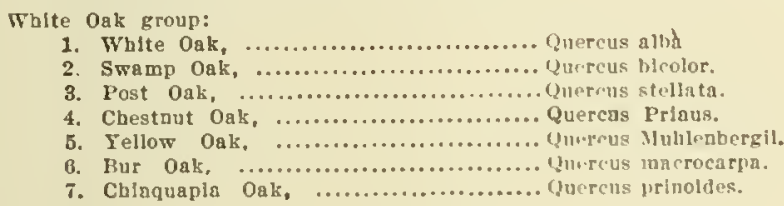

Of the 300 speeies of Oaks which are known, about 55 species are native to North America, and 16 speeies to the State of Pennsylvania. Of the 16 species native to Pennsylvania, 7 belong to the White Oak group and 9 to the Black Oak group. The centre of distribution of this genus is in the mountains of Central America and Mexico. A few species are found in Europe. The subjoined keys will identify the species natire to Pennsylrania. 


\section{KEY TO THE SPECIES BASED PRIMARILY ON FRUIT AND BUDS.}

1. Accrns maturing at ead of second season on last season's growth; immature acorns may be present la winter; sbell of nut hairs inside; scales oo acora-cup usually

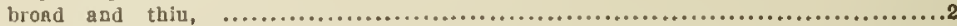

1. Acoros maturing at end of first season on growth of season; immature acorns never preseat in wiater; shell of aut not hairy inside; scales of acora-cup more or less

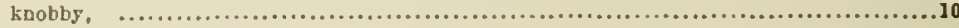

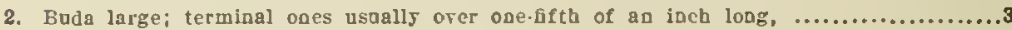

2. Buds smaller; term:ca! ones ode-fifth of a iach or less in length, .................7

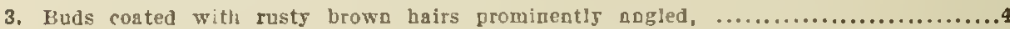

3. Ruts not couted with rmsty browu Lairs; not promiceutls augled, ...............5

4. loner bark gellow; buds 1 th of an inch long; acorn-cup top-shaped to hemispheric.

Q. velutina

4. Jnner bark not fellow; buds f of a inch long or less; acora-cup bemispherlc

Q. marilandice

5. Buds sharp-pointerd,

5. Buds hiot pointed, the widest part, 0 r or Just below midde; evldently woolly above

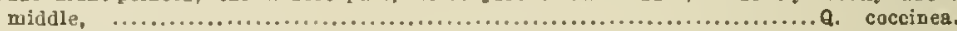

6. Acorn-cups saucer-shaped; buds glabrous except sumetimes slightly hairy ner apex; bark fissured witl intervenlog broad smootb ridges; bradches straight, ....Q. rubra

6. Acorn-cups hemispleric; buds light brown and hairy; bark shallowly fissured, wlth

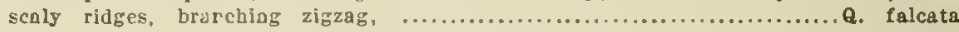

Twigs during first wiater dull, finally hairs; shrubs,

Q. ilicifolia

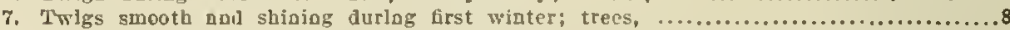

8. Pin-like projectious or lateral branches aumeroos, standing almost at riglit angles to brancb; trunk continuous; acorn-cup snucer-shaped, ...................... palustris

8. Pin-like projectious not present; truak dirided, ............................

9. Accra-cups sauccr-sliaped; buds dark browa; twigs stouter, ................... phellos

9. Acorn-cups bemlspheric; buds light browu aud augular; twigg sleader, ..Q. imbricaria

10. Buds agrrow, conica:, sharp-poiuted, of an isch or more in length, ..............11

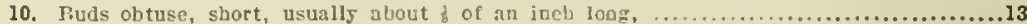

11. Buds pubescent, usually sharp-pointed, lateral buds geuerally appressed; bark on older twigg witl corky ridges; acorn-cuns fringed, .................. macrocarpa

11. Buds smooth, latern: buds divergent; twigs without corks ridges; acorn-cups not

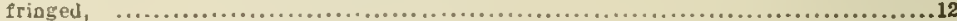

12. Acorns sessile; twigs sleuder and bairs tn smontb. ................. Muhelnbergii

12. Acorns evidentix stalked; twigs stouter aud smooth. ......................... Prinus

13. Bark on brnbchlets peeling into long, dark, layer-like scales; acoros loog atalked,

Q.bicolor

13. Bark on brachlats not peeling off into long, dark, lager-like acales, ................14

14. Twigs usunlly corted with jellowish.browa wool; buds about as long as broad,

14. Twigs smooth,

Q. stellata

15. Twigs slender: shrul or small tree; buds about as loag as broad; acora-cup eacloses

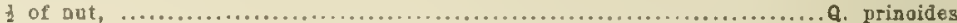

15. Twlgs stout; lnge tree; buds longer tbaa brond; acorn-cup eacloses z of nut, .. $Q$. alba 


\section{KEY TO THE SPECIES BASED PRIMARILY ON LEAVES AND FRUIT.}

1. Leaf-blades or thelr lobns bristle-tinped; acoras maturing at end of the second aeason: suts often pubescegt within, $\ldots \ldots \ldots \ldots \ldots \ldots \ldots \ldots \ldots \ldots \ldots \ldots \ldots \ldots \ldots \ldots \ldots \ldots \ldots \ldots \ldots \ldots . \ldots \ldots$

1. Leaf-bladis or their lobes or teeth without bristle tips: acorns maturing at end of the first seasod; tutg often glabrous within, ...............................

2. Leaf-blades entire; rarely lohwd or toothed except on vigorous conice shoots, ..........3

2. Leaf-blades pinatifid, pluualwly lohed of dilatod at anex, ......................

5. Lower surfaee of leaf-blades glabrous, ............................ p. phellog

3. Lower surface of lat-blades jubescrnt. ........................... imbricaris

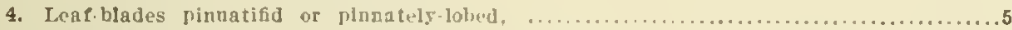

4. Leaf-blades dilated at apex: olavate brown tomeutose on lower surface, Q. marilandica

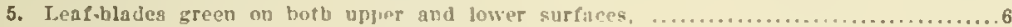

5. Ieaf-bladeg pubescent on lower surfuce, $\ldots \ldots \ldots \ldots \ldots \ldots \ldots \ldots \ldots \ldots \ldots \ldots \ldots \ldots \ldots \ldots \ldots . . . \ldots$

6. Lobes of leaf-bläes about equal tbe widts of tbe midale portloo or body of the

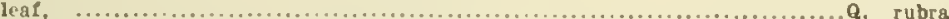

6. Icties of leaf-blatco $2.1 j$ times as loag as the breadtb of the arrowest portlon or

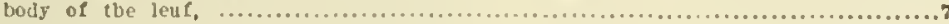

7. Truak contiuuous, covered by stort, slender, often borlzontal lateral brancues; acoracups saucer-shaped. ........................................... palustris

7. I'ruak usaally branclied; covered by ratber long, usually stout and ascending lateral

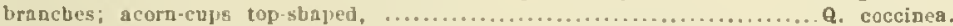

ล. I.enf-blades brown or rusty pubescent on lower surface; inner bark yellow, Q. velutina.

8. Leaf-bladea gray or ;bite pubesceut on Jowir surface; inaer bark not yellow, .......9

9. Labea of leat-blades long aud lanccolate, often scrtbe-ghaped; large trec, .... Q. falcata

c. Lcbes of leaf-blides short and triangular, usually fire in number; small tree or

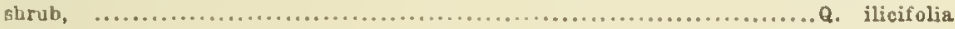

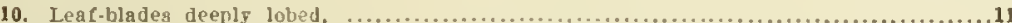

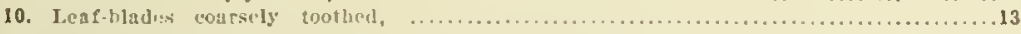

12. Mature leaf-blades glabrous and jale on lower surfice: cuns sballow, ...... Q. alba

i1. Mature leaf-blatles pubescent on lower surfnce; eup enclogea at least one-tuird of

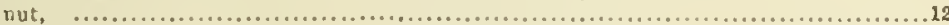

12. Mature leaf-blnder rusty-pubescent below; leares usually 5-lobed; stellate pubeseent above with three terminal large rounded or squarish lobes: upper scales of acoracup not awned, ............................................... stellata

12. Matore leat-blades white towentose bedeath; leaves usually $5-\bar{i}$-Jobed with single large oval and cleonte terminal lobe; uluer scules of acorn.cup awned witb a heavy fribse, ........................................... macrocarpa

13. Leaf-blades broadest at or below tbe middle, oblong to lancrolate, decidedly pointed at

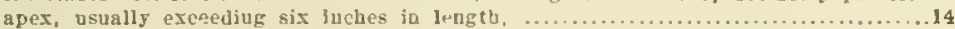

13. Leaf-blades broadest abore the middle, oblong 10 oblong oborate, pointed to roubded at apex, seldom exceeding six iucles In lengtb, .......................15

14. Leaf-blades with acunsinate apex: slender netiole; acoru sesslle, ...... Q. Mublenberzii

14. Leaf-blades with acute arex; stouter petlole; acoro stalked, Q. Prinus.

15. Tall tree; bark on small bruuches often peeling oft in dark fcales: acoras loog-

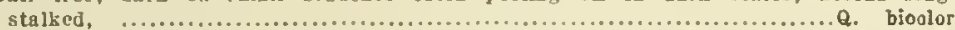

15. Shrub or small trex; bark on small branches suontb; acorn sessile, ..., Q. prinoides

136

137

135 


\section{WHITE OAK. \\ Quercus alba, Linnaeus.}

FGRM-A very large a ad raluable tree, usually attaiaing beight of $70-80 \mathrm{ft}$, bot may reach a maximum height of $140 \mathrm{ft}$. Wilh a diameter of $8 \mathrm{ft}$. whea growa ia a closed stand. When grown la a dease stad (Fig. 11) it bas a clean coatinuous truak often free from lateral branches for $75 \mathrm{ft}$. Whlb a dlacheter of $5 \mathrm{ft}$, and little stem taper. When grown in the opec (Fig. 21) It divides aear the grouod into a great may lateral braaches which are gnarled and twisted formiag a deep, wide, and irregular crowa or occosioally a symmetrical erowu. Open growa trees produce a very small quantlty of timber of commercial Importance.

BARK-0a smaller branches light green to reddish-greea; on matare trunkg up to 2 lacbe日 thick, usually light gray or white, shallowly fissured lato fat, irregular scales often rery loosely attached. Occasionally the bark of truak appears roughls ridged and without acalea. See Fig. 73.

TWIGS-During first summer light greea, tinged with red, coated with loose, pale halre. rirst wiater sleajes, smooth, reddish to gray, corered with oumerous, Iight, mlaute, elevated lenticels. Pith star-sbaped.

BUDS-Alteraate; termiaul buds clustered; broadly orate, obtuse, reddish-browa, of a lach long.

IEAVES-Alteraate, simple, 5-9 laches logg, 2-4 iacbes wide, obovate in oatline, witb 3.9, bat usually 7 ascending lohes; lobes bluat at apex aad separated by deep round-based slauser. Whea full growa thin, brigbt green aad smooth above, and pale, smooth, and occasionally flaucoua below.

LEAF.SCARS-Altcraate, ralsed, coacare to rouad above, rouaded below. A decurrect rldge cftea contlaues from ralsed leaf-scar walch makes the twig 5-angled on account of 5-raned arraggemeat of leaf-acars. Buadle-scars are aumerous, scnttered, laconsplcuous. The leafscars of the osks of this state so closely resemble each other that a deacription of a leafscar of oae specieg will suffice for all.

FLOWERS-Fowers appear in May whon the leaves are ahout developed. Stamlnate fowera are borae in bairy ameats 21.3 jaches loag. Ca.15x is rery bairy a ad rellow. Stameas extead beyond calyx. Anthers are yellow and aotched. Pistillate fowers are borae on short atalks, with bairy involucral seales and red spreading styles.

FRUIT-Aa acora, maturlag during one siason, sesslle or short-stalked. Nut oroid, rouade nt apex, shing, light browa, of a a jach 1005 , inclosed for $\%$ leagth ia cup. Mreat of aut la sweet and edible. Cup bowl-shaped, slightly tomentose on faside, covered with aumerous scaleb whish are thia, short, fat, hliat-jofated wear rlm, tblckeded a ad kaobby aear the bare.

WOOD-Riag-porous; with rery cposplcuous medullars rass; stroag, heary, hard, close-gralned, durable in coatact with soil, light brown with lighter aaprood. The most raluable of all oak wond. Weighs 46.35 Ins per cuble foot. Used ia constructioa, abip bulldag, tight cooperage, furniture, raliroad tles, manufacture of wagoas, agricultural implemeata, interior fiaish of bouses, fences and fuel.

DISTINGUISHING CHARACTERISTICS-1a summer one can distingulsh the White Onk rery lcadily by its loose seal. gragish or white bark from whlch it takes lta common aame, nad by its deeply rouad-lobed leares with a smooth and pale lower surface whea mature. Ia winter it bas some characteristics apparently in commoa with some other Oaks bat can be distiagulsbed from the Red, Black, Scarlet, Cliestaut, and Yellow Oats by its obtuse, ratber small buds; from the Swamp White 0ak by the sleuder reddisb to grayisb twigs and the abseace of dark loose reeling flakes on the branches: from the Post $0 \mathrm{ak}$ by the abseace of greeaish rusty pubeaceace en the twigs; frola the Pia Oak by the abseace of stif lateral pias on the bracbes a ad the more obtuse buds; from the Bur Oak by the abseace of corly wlags on the braches. Ia addition to thesc characteristica the acorna a ad leares wblcb oftea persist will ald coaslderably fo recogaizing the differeat species. A carefal study of the keg to the species will belp ia briaglag out additional äistinguisbiag cbaracteristics.

RANGE-Maiae to Mincesota, south to Florida and Texas.

DISTRIBUTION IN FENNSYLVANIA-Abundant throughout the eastern, ceatral, and wouth. era parts, and rather common at least localis, ia the aortbern and westera parts.

HABITAT-It is toleraat of maay soils, growlag oa saady plaias, grarelly rldges, rich oplanda, and molst bottomlaads. It reaches its best aerelopmeat ia rich molat soll.

IMPORTANCE OF THE SPECIES-The White Oak is the most important hard wood apeclea of Peaasyraaia. It is a slow grower but derelops a exceptionally high grade material. Artifclal regeaeratioa by plantiag is difficalt. Sproatiag canot be depeaded upon. Nataral seed regeneration is the best method ty which thls species can be successfully reproduced. German experlmentation has shown coaclusively that the aatural method is soperior to the artificial, especially with Oak. The great value of its tlmber will jastlfy attempts to grow this opecien in forent otaado of conaiderable extent. 


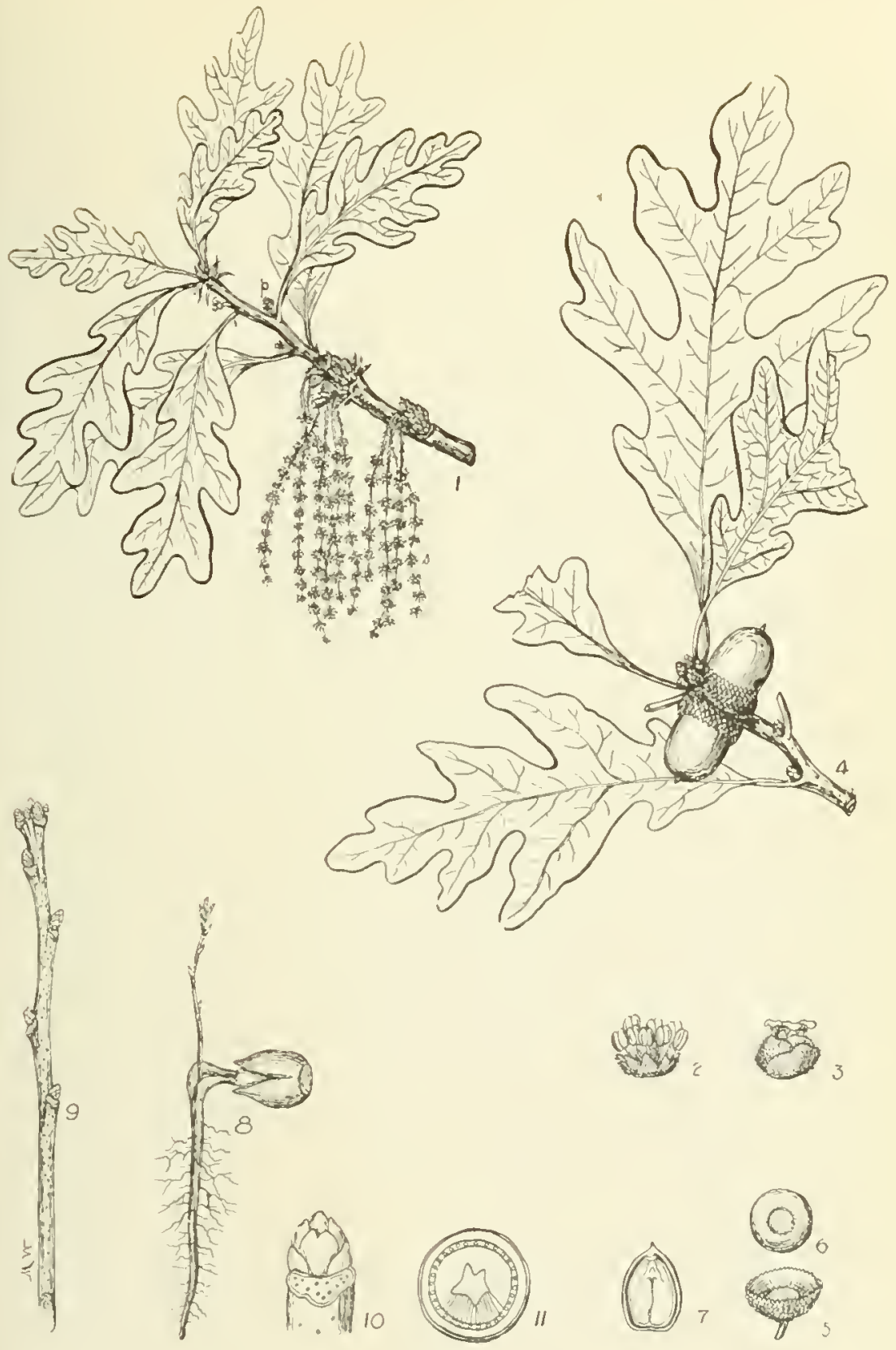

\section{PLATE LV. WHITE OAK.}

1. Flowering branch with immature leaves (s) \&. (iemminating acorn with its young root and stominate blossoms, (P) pistillate blossoms, $x$ is.

2. A staminate Hower, enlarged.

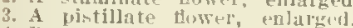

4. Branch with matnr. leaves and mature acorns, $x$ है.

Acorn cup $\bar{x}$.

6. Acorn, basal rierw, $\mathbf{x}$.

7. Longitudinal siction of acoru slowing emshori, $x+$. 9. Wintur liranch, $x$ z.
10. Teruinal section of winter brauch suowing hud witl overlapping seales, a leaf-sear "with lsundle-sears, and lenticels, enlarged.
11. ('uss section of twig showing pentangular filh, wood with conspicnous medullary rays, inner and outer bark, enlarged. 


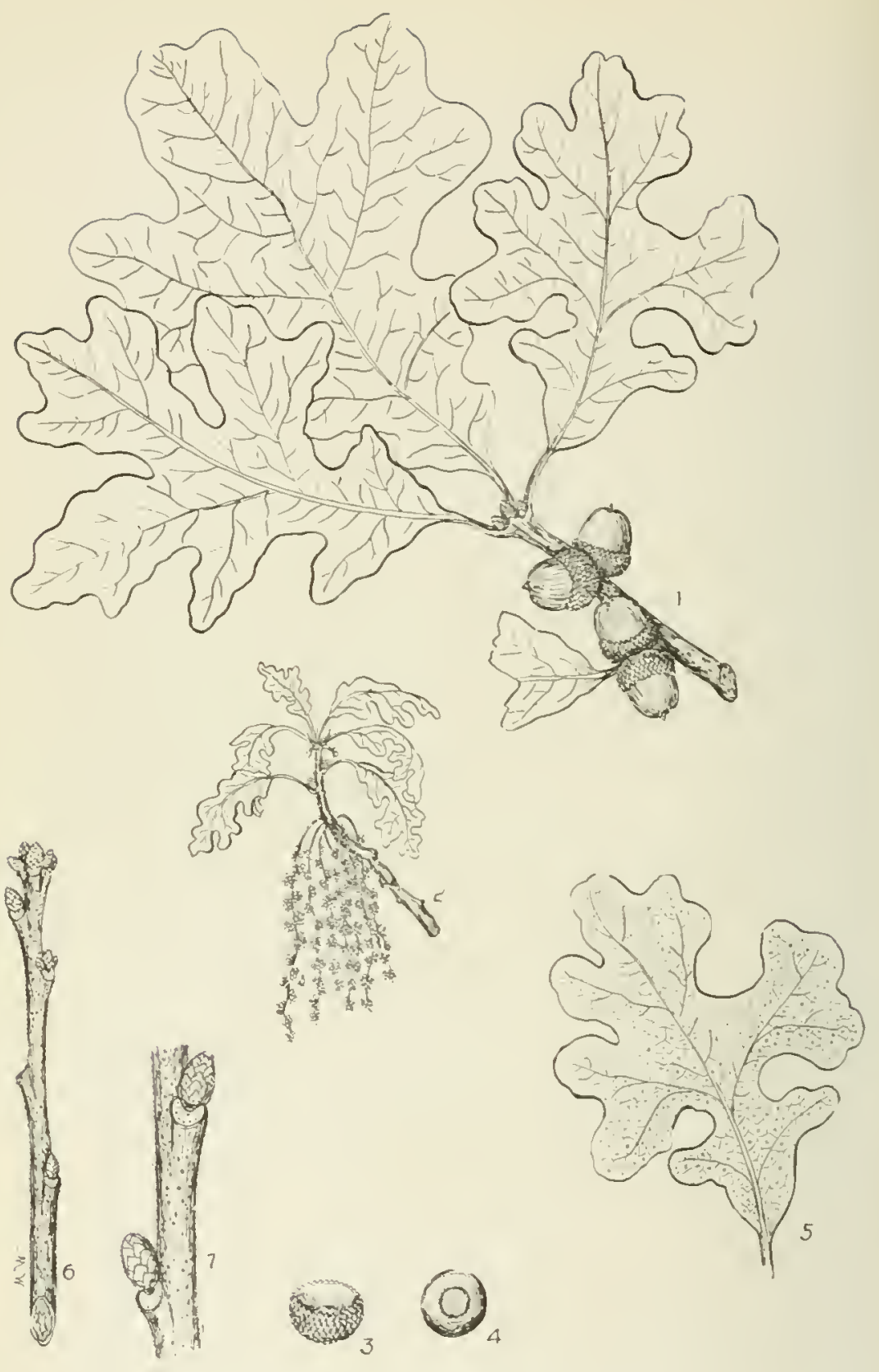

PLATE LVI. POST OAK.

1. lirasels with nature leaves ani matures atotus. $x$.

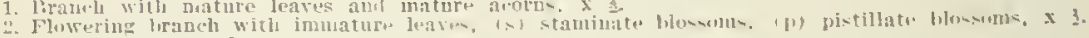

3. In acorn eup, $x$ z.

4. An achri, bakal riew, $x$.

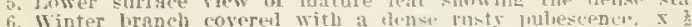

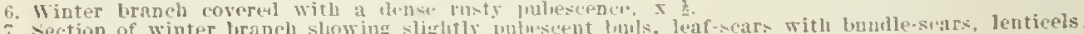

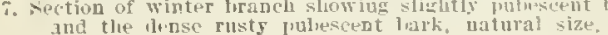




\section{POST OAK.}

\section{Quercus stellata, Vangenheim.}

FORM-A medium-sized tree, usunlly attalning helght of 50-60 ft. bat may reach a maximum belght of $90 \mathrm{ft}$. with a dlameter of 4 feet. In the open It forms a dense, broad, deen, roundtopped crown with stout and spreading hranches. Toward its nortbera limit it is a large shrub.

BARK-On traaka somewhat similar to that of White Oak ooly darker nod often rougber and less scaly. nn young brabches it ig often covered $\pi$ ith loose, dark acalea.

TWIGS-Stont, covered with jellowish rusty pubescence, at first llght orange lo color, Inter dark brown. Senson"a growth stands la strong contrast with later growth on accoust of mach lighter color. Pubescence noon turns dark and foally disappears.

BUDS-Altcrate, hrondly orate, about of an lnch long. sometimes as broad as long, blunt-polnted, covered with numprous ofcrlapjlne, reddlsh-brown, sllghtly pubescent scales.

LEAVJ:S-Alternate, simnle, ohovate in outlinn, $4-7$ inches long, 3.5 inches wlde, thlek, leathery, Eenerally 5-lobed: the mlddle palr of lobes Is the largest and is aeparated by deen alnases: upper surface of leat ts bright green, shiay: lower surface is paler and coated with rusty nabescence.

LEAF-SCARS-See "Ieaf Scars" onder W'btte Oak, page 132.

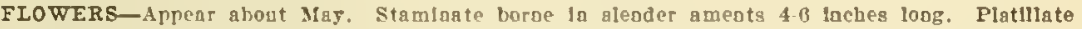
aeaslle or ahort-stalked, woolly; stlgmas bright red.

FRUIT-An acort, maturlag et end of first senson; wsanlly sesglle, occurs golitary, In palrs or claatered. Nut oral. B-g of $\mathrm{Rn}$ lach loag, lalrs at apex, loagltadiaglls striped with darker brown, lnclosed hy cup for $1-\frac{2}{3}$ of its length. Cup thin, bairy withis, and covered with thla, nale, flat woolly sealea.

WOOD-Ring-porous: wth ronsplenous mednllary rays: heavy, bard, clnse-grained, rery durable, Itght to dark brown, with llght sanwood. Welghs 52.14 lhs. ner cuble foot. Used for the same pornoses as White nak. It is fouad on the market alsed witb white Orik.

DIST NNGUTSHING CHARACTERISTICS-In summer the Post Oak, also inown as Iron Oak, may at onee he recognland liv the nemllar form of ita leares, with large rovaded or souarlsb lobes. The tluree terminal lobes are the largest rad the basal lobes taken together are wedge-sbaped In outline. The rigld lenthery leares with thelr shlag green unper surface and rusts pubesceat lower surface. and the rusty pubescent twigs are cbaracterlstic. Ia winter Its short obtuse buds aad stout rusty mihescent twigs are distloctlre. The buda hare also a brighter reddish color than those of the White onk.

RANGE-Massnchusetts, central Penasylvaln, Kansas, sonth to Florlda and Texar.

DISTRIBUTION IN PENNSYIVANIA-Fonnd locally in the eatero aod southern parta, bot not in the western and northern.

HABITAT-Common on dry rocky soll. Foud on grarelly uplaods, Ilmestone bills, aod saody plalas.

JMPORTANCE OF THE SPECIES-The Post Oak closely resembles the White Oak, especlally in the wood, which is sold as White nak. On account of its limited distrlbution in Penosylrania, and the superiority of the White $n \mathrm{nh}$, thls specles eanot be recommended for Porestry purnoseg on an extensive scale. It will, however, grow on poorer soll than the WbIte oak a a mlght be established unon sach areas. It is difficalt to traosplast and growa alowly. 


\section{BUR OAK.}

\section{Quercus macrocarpa, Michaux.}

FORM-Usually attains beight of about T0-80 feet but may reach a maximum beight of 170 feet with a diameter of $6-7$ feet. It attains its greatest beight in Illinois and Indiana. It bas broad spreading branches which form a broad round-topped crows. In the forest the crowa is usually cootracted and covera onls the upper part of the trank. It is a giant among its associates.

BARK-Intermcdiate between flaky bnrk of White Oak and rery roughly ridged bark of Chestnut Oak.

TWIGS-Stout, covered with pale, raised and inconspicuous lenticels, yellowish-bromb, at trat halry, Inter smooth, with corky wings often I inches wide.

BUDS-Alternate, brezdly-orate, nbout $\frac{1}{3}$ an inch long, acute or obtase, reddish-brown, slightly pubcscent. Lateral buds are closely appressed.

LEAVES-Altermate, simple, 6-12 Inches long, 3-6 inches wide, oborate or oblong; 5-7 lobed; sinuses round-based; terminai lobe largert; smooth, sbins, and dark green abore; pnler aod finely bairy benentb.

LEAF-SCARS-See "Leaf-Scars" under Whitc 0at, page 132.

FLOWERS-Mnture about May. Stamioate fowers borne in slender ament $4-6$ inches Iong. Pistillate sessile or short-stalked, with bright red stlgmas and hairs scales.

FRUIT-An acorn, maturing duriog first season; sessile or stalked, asually solitary. Nut orate, 4/5-2 inches long, corered with down. Cup deep, embrncing from 1 to entlre nut, light brown, dowuy on inner side, covered with large imbricated scales forang a distinct fringe near the margin.

WooD-Ring-porous: with conspicuous medullary rays; beary, bard, strong, close-grained, very durable, brownish with light thin sapwood. Weighs 46.45 lbs. per cubic foot. Used for the same purnoses as White Oak from which $1 \mathrm{t}$ is not distinguished on the market.

DISTINGUISHING CHARACTERISTICS-In summer the Bur Oak, also known as Orer-cup or Mnssy-cup Oak, can be distingeished by its mnique leares, which hare deep, rounded sinusea that reach almost to the midrib nud divlde each side of a leaf almost into two parts. The lobes on the front part are rather squarish and those on the basal part triangular. The pubescence on the lower sile of the leares and the corky wingel frojections on the brancbes nre alsn chnracteristic. In winter the corky winged projections on the brapches, the closely anpressed and pubescent buds, the distinctly fringed acorn cups, and the persisteot leares are characteristic.

RANGE-Nora Scotia to Manitnba, soutb to Fenasylvazia, Kansns and Texas.

DISTRIBUTION IN PENNSYLVANIA-Rare or local in the eastern, southern, and western parts of the State. Not reported from ather parts.

HABITAT-Prefers low rỉch bottomlands but can grow upon a variety of solls. It does not thrive on uplands so well as the White Oak, grows much slower than the Red Oak, and ig rather intolerant of shnde.

IMPORTANCE OF THE SPECIES-It is one of the rery largest of American Oaks, has a wide distribution, and occurs in purc and in mixed stands. This specles prodaces raluable wood especially adapted to quarter-snwing on accout of conspicuous medullary rays. It sbould be re. g*nernted especially a the Mississippi basin wlsere it develops at its optimum. This tree is also rery attractire ms nu ornomental or shade tree, since it withstands smoke more than most other Onks, and is relatively free from disease. 


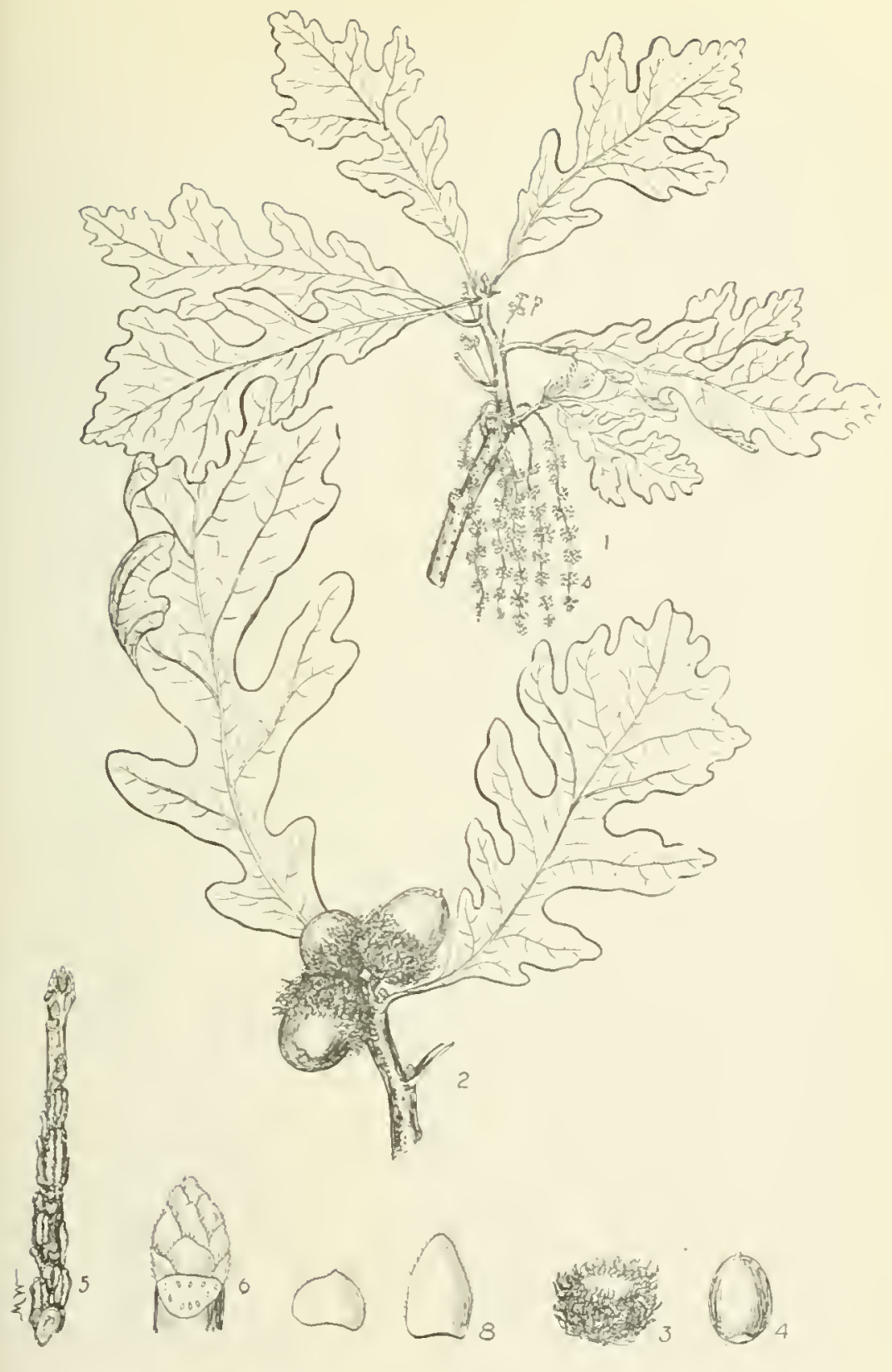

PLATE LVII. BUR OAK.

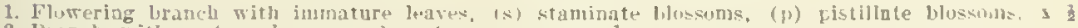

2. Eranch with mature leaves and nature acoras, $x$

3. In acorn cup, $x$ i.

4. An acorn, $\mathrm{x}$ is.

5. A winter hrnnch showing buds, leaf-sears, and rnisud [*olk ridges, s

6. Terminal section of winter branch showing bud with overlapuing solum nul leaf scar witlis onde-scars miarged.

7. Basal bud-scal, with hajre margin, enlarged.

8. Apiral hud-scale with hair serrat." marçis ('nlarmil. 


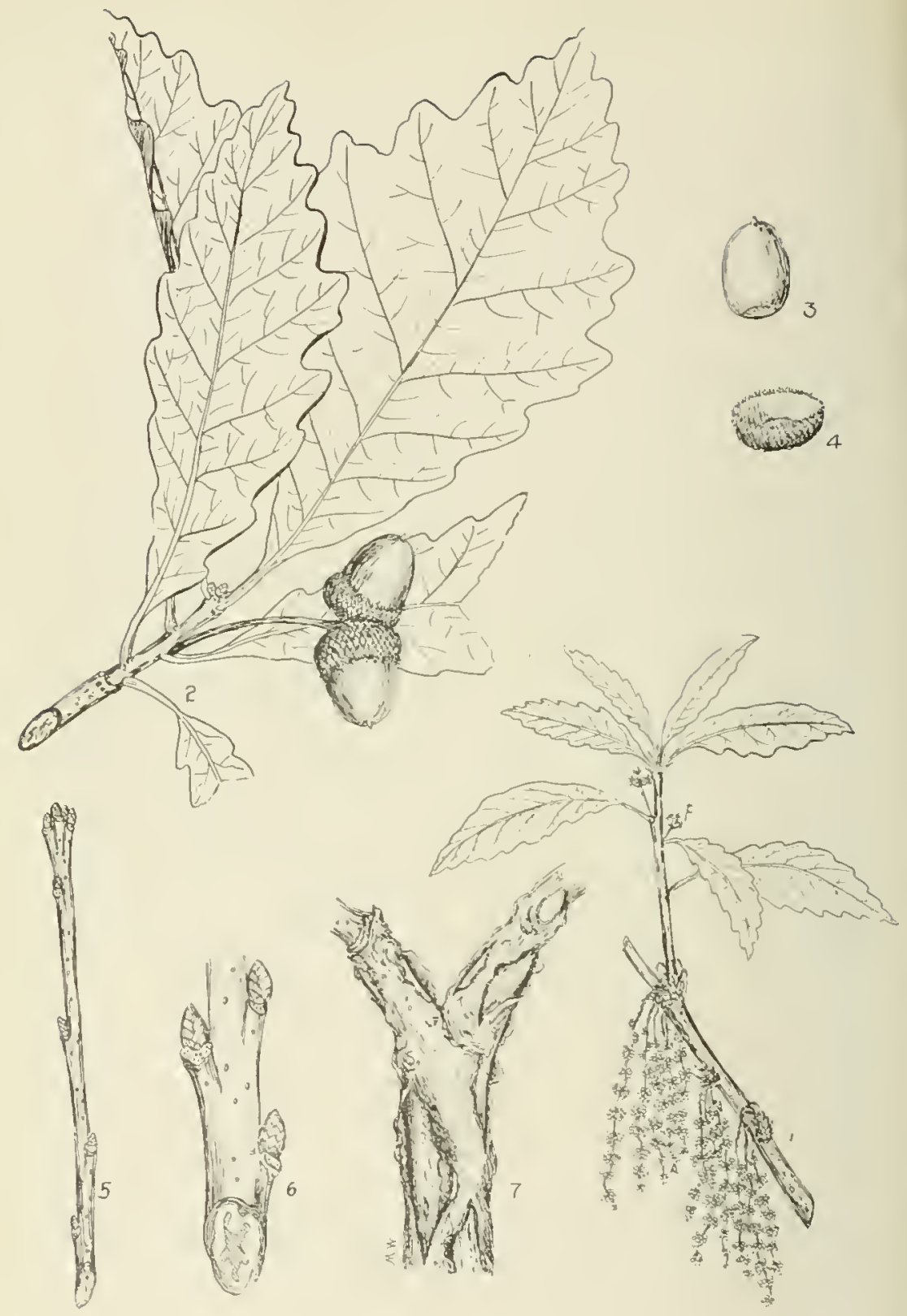

PLATE LVIII. SWAMP WHITE OAK.

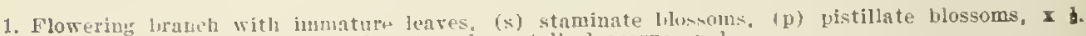
2. Branch with mature lenves aml matule jung-stalked acorns, is.

3. An acorn, $x$.

4. An acorn cup, $x$.

5. A winter twig, $x$.

6. A winter twig with bud, lentices, darli, lirolien, aul seals outer bark, enlarged. 


\section{SWAMP WHITE OAK.}

\section{Quercus bicolor, Willdenow.}

FORM-A a arerage-sized tree asually attahlog a height of $60-70 \mathrm{ft.}$ occasiooally attaloing a belght of $100 \mathrm{ft}$. with a dlameter of $3 \mathrm{feet}$. In the open it derelops a broad, opeo, ronodtopped crowa with the upper branches ascending, the lower ofteo drooping. Scraggy and peeling branches make it rather unattractive. In deose stands the trunk is clear and continuous.

BARK-On soung braches reddisb-browa, swooth, soon becomiog rough nod unkempt by peellog into loog, persisteat, dark scales and exposing llght inoer bsrk. On old truoks thick, graylshbrown, deeply fissured ioto logg, often cootinuous, lat ridges which break ap loto amall gray acales. See Flg. $7 i$.

TWIGS-Stout, yellowish to reddish-browo, usunliy smooth, corered with pale ralsed leuticels; pith star-shaped.

BUDS-Alterate, broadly orate, obtuse, $1-\frac{1}{4}$ of an inch long, corered with light ehestnatbrown scales, often slightly hasty towards the apex.

LEAVFS-Alteroate, simple, asually oborate in outline, 5.6 inches loog. 2-4 iacbes wide, rounded at anrowed apex, coarsely deatate on wargia, with shallow rounded lobes; upper surface shiblag dark gellowish-greeu; lower surface light greeli and flnely halry.

LEAF-SCARS-See "Leaf-šcars" under White Oak, page 132.

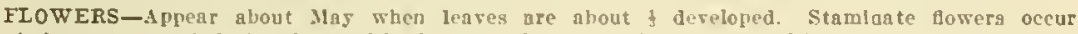
io hairy aments $\$-5$ inchea long. Pistlllate are borwe ou sbort-stalks, elther solitary or few in a cluster.

FRUIT-An acorn, maturing durlng nne segson, solitary or few io a cluster, usually borne oa a loog stalk. Nut oblong, $1-1\}$ foches loog, chestout browa, usually halry at apex. Cup deeply sancer-shaped, thick, eaclosing $\frac{1}{3}$ of nut, bairy inside, curered with pale woolly scales whlch are rather thickened near base, and thin, narrow, often fringed at margin.

WOOD-Diffuse-jorous; with rather conslicuons medullary rass, It possesses the same jubsical characteristics as the White Onk, and is sold oo the market os White 0ak. Weighs 47.i5 Jba. per cuble foot.

DISTINGUISHING CHARACIERISTICS-The Siramp White Onk cao be distioguished from all other Oaks at aoy season of the year by the bark on the gouoger braches which peels off lnto thin large plates as in the Buttonwood tree. In summer this species cna be recogaized by the leaves which have shallow sinuses between the lobes, giving the leaf a broad effect. 10 fall the long-stalked acorus with their cups enclosing atout 3 of nut are characteristic. In winter the rather stout, jellowish to reddish-browa twigs bearing buds with light chestaut-browa scales and the irregular, often drooping, growth of the lower lateral braoches is peculiar to this specles.

RANGE-Maine and Quebec to Michigao, south to Georgla and Arkausas.

DISTRIBUTION IN PENNSYLVANIA-lieported from eight counties in the eastera and southero parts of the State, one io the westera part, and common in the aorthwestero.

HABITAT-Frequents rich soils oo borders of swaups and streams.

IMPORTANCE OF THE SPECIES-The Swamp White Oak is an importnot tree but its propnga. tion should oot be recommended or attempted where the White oak will grow. lts lateral branches have a tendency to persist which results in a laferior grade of lamber. It has no orgamental qualities which especialy recommend it for sucb plaatiag. 


\section{YELLOW OAK.}

\section{Quercus Muhlenbergii, Engelmann.}

FORM-An arerage-sized tree usually attalning a helght of $40.50 \mathrm{ft}$, but oceaslonally may reach a height of If $0 \mathrm{ft}$., witb a diameter of 3-4 feet. Rather stunted in growth In the north. eastern nart of its distribution and attains its maximum development along the Wabash river in Indiana and Illinois. Lateral branches are relatlely small forming a narrow, oftea shallow, round-topped head. Truak often wldely battressed at base.

BARK-Thlek, rongh, close, fissured lato long, frregnlar rldges whlch break np lato graylab to brownish ecalea.

TWIGS-Slender, reddish-brown to grajlsb-brown, at first halry becomlng smooth, longltudinally ridged, curered with pale lenticels; plth star-sbaped.

BUDS-Orold, sharp-polnted, ahont $1 / 6$ of an juch long. corered by numerous orerlapplng, light chestnnt-brown scales which are slightly hairs along margin. The bnds show a general resemblance to those of the Chestrut oak only are smaller.

LEAVES-Resemble those of the Chestnat oak but hare a more acaminate aper; also resemble those of the common Chestout with incurred teeth.

\section{LEAF-SCARS-Sce "Leaf-Sears" under White Onk, page t32.}

FLOWERS-Appear about Mar when leares are about $f$ developed. Staminate flowers acenr in balry ameots, 3.4 incbes long. Pistillate flowers sessile or short-stalked with bright red stigmas.

FRUTT-An acorn, muturing during one sPason, usuallj sessile, occasionallr short-stalked. Nut orold, A.I lnch long, pubescent at apex, llght chestaut-brown. Cup thin, eacloseg about of nut, corerce by pale bromn moolls scales with thlckened bases and thin tips often forming a fringe along the margin.

WOOD-DICuse-gorons; wlth less prorninent medullary rays tha most Oaks; heary, hard, strong. dorable in contact with soll. A distluct difference between spring and sammer mood. Ised for same purposes as White Oak except for tleht cooperuge aud cahinet work, becanse it checks very badly. Welghs 53.63 lbs. per cublc foot.

DISTINGUISHING CHAPACTERISTICS-The Yellow Oak, also known as Chiaquapin 0ak, can be distlnguished from the Chestnut oak by its nsually gessile and smaller acorns, smaller huds, mare acuminate leares, and flaky gray bark. It can also be distingulshed trom the Dwarf Chinquapln oak by litg larger slze, starp-pointed buds, larger and sharper-polnted Jearea, and the abseuce of gray hlotches on the birk of the joung truaks.

RANGE-Vermont to Mianesota, south to Florida and Texas.

DISTRIBUTION IN PENNSYLVANIA-Rare. Found loenlly la the southeastern and sonth. era parts.

HABTTAT-Usually foand on dry rldges, especlally apon llmestone soll.

IMPORTANCE OF THE SPECIES-The wood of thls species is not equal to that of the White Oak and in addition it grows slower. In all localities where both grow the White oak shonld be favored, while in localities where the rinite 0ak la abseat thls Cak might be propagated. It is a beautiful tree and should be planted extensivels la parks and lawns on account of its band. some form and attractive follage. 


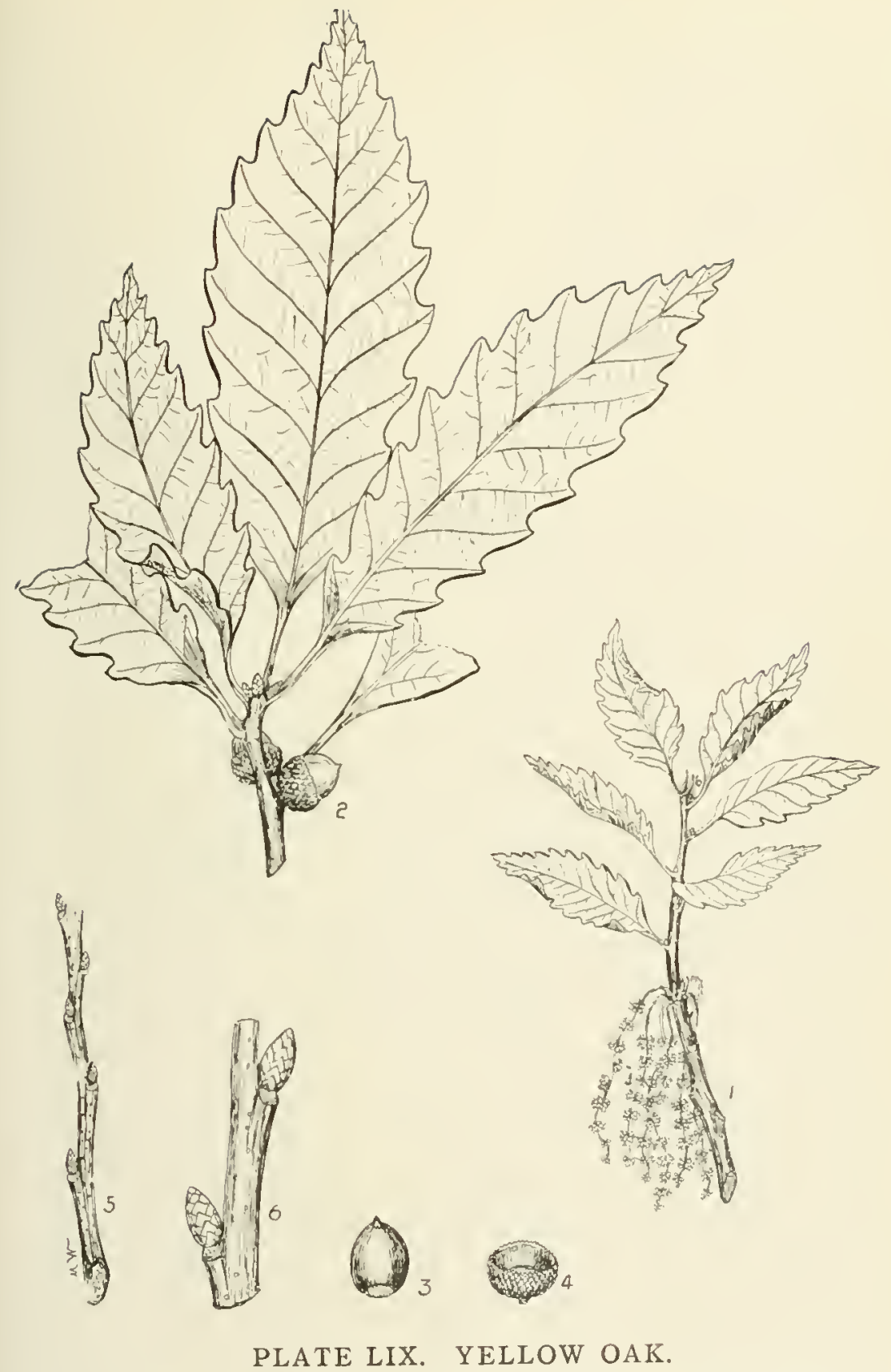

1. Floweriug brauch with inmatur. learts, (s) staminate blossoms, (p) pistillate lilossons, $\mathbb{x}$. 2. Branch with mature lwaves aud luature acoras, $x$ z.

3. An acurn, $x$.

4. $\Delta \mathrm{n}$ acorn cup, $\mathrm{x}$.

5. Terminal section of winter twig. $x^{3}$.

6. Section of winter twig showing buds. Inticels, and lenf-scars with bumdle-scars. enlatged. 


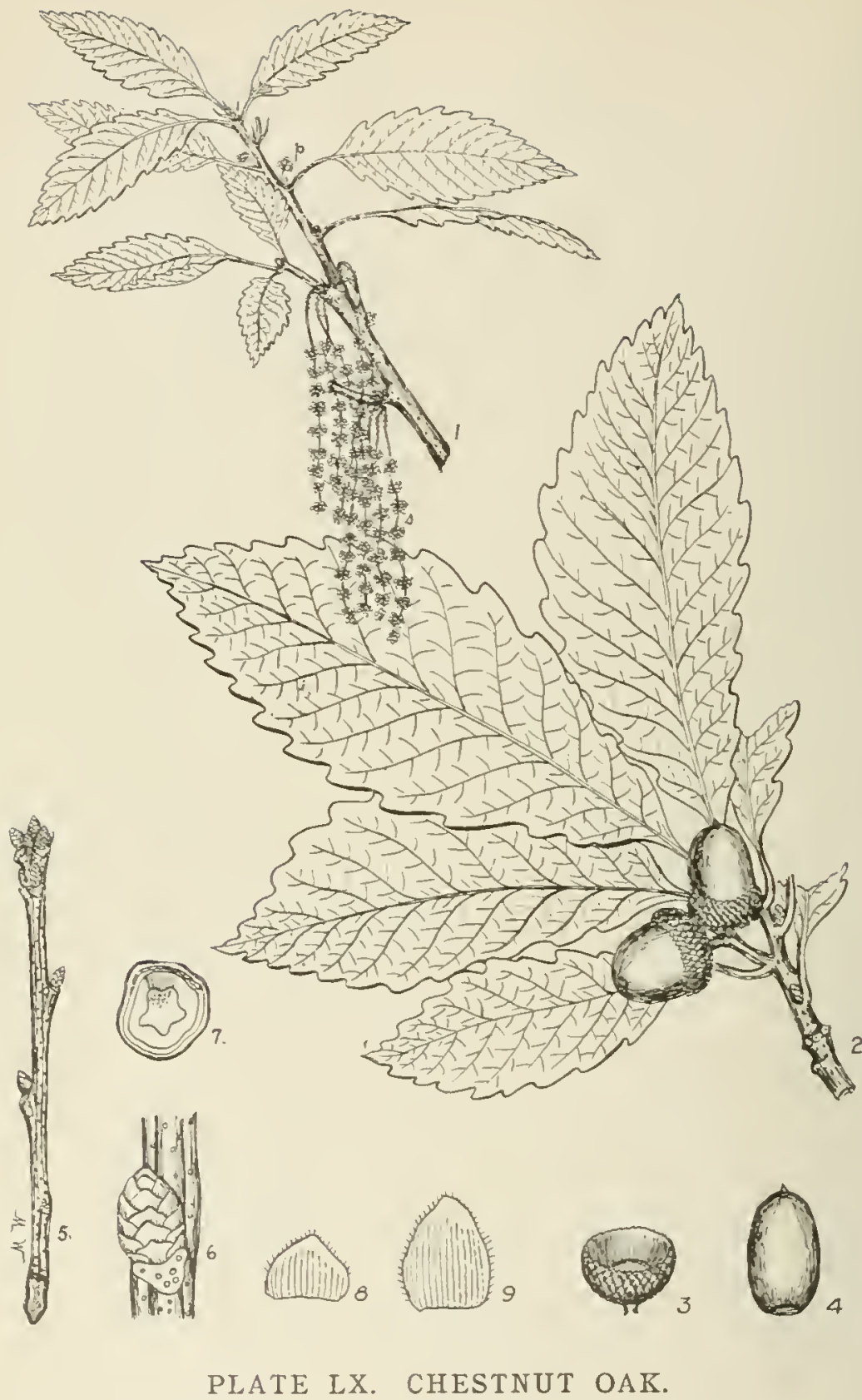

1. Finwerin: laram with immature loaves, (s) staminat. blossons, (p) pistillate blussoms, $\mathbf{x} 1$. 1:iamil with mature leaves and mature acoros. 5 .

3. An acora cup, $x$ z.

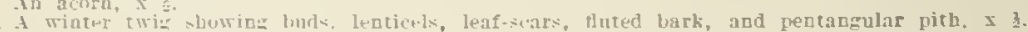
Simeticin of a vinter twio enlarged.

7. Crosu section of a twig showing lentangular nith, wond with conspicuons medullary rays, inner and outer bark, enlarged.

I basal bul-siegle with hairy margin, enlarged.

A: apinal luti-seale with lairy margin, ealarged. 


\section{CHESTNUT OAK. \\ Quercus Prinus, Linnaeus.}

FORM-A medium-8ized tree usually attnining n helght of $60.70 \mathrm{ft}$, occaslonally $100 \mathrm{ft}$, with a dlameter 6.i feet. In dense atands the trunk is stralght aud coutiauous whlle in open stands it 18 low and divided, formlag a rery broad opea crown.

BARK-0n soung stems and smaller branches smooth, thlo, Jellowish-brow. On older hrauches and truak rough, thlck, brown to black, rich in tanoin, dlrided loto long, broad aad contlauous essures. Iidges are rery solld, sbary).nagled, not scaly. Base of the flssures often cluamon-led, especlally ou the larger branches and smaller trunks. See Fig. $\mathbf{7 5}$.

TWIGS-FIrst summer greenlsh-purple; first winter orange or reddish-browa; stout, smooth; bitter; with incoosplcuous leotlcels and star.shaped pith.

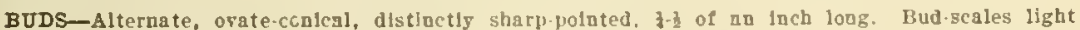
chestaut-browa, imbrleated, slightly hafry towards apex and along margln.

LEAVES-Alterate, olmple, ohorate, thlck, stla, 5.9 Inches logg, $2-4$ juches wlde, usually wedge-shaped at hase, coarsely deatate with rounded teeth on ingrgia; green and smooth ou upper leat-surfuce, pale green and at firet hatry on lower.

\section{LEAF-SCARS-See "Lenf-Scars" under White Onk, pnge 132.}

FLOWERS-Appenr about May when lenves nre bhout $\$$ dereloped. Stamingte flowers are gellow nad borne in bulry nucats 2-3 laches loog. Pistllite dowers have a short disergent, reddah atgle, and occar In small groups upon stout stalks.

FRUIT-Solitary or in palrs; matures in one seasoo on short stalks. Nut $4 / 5.1$ laches long, 2-3 times as loog as hrond, smooth, glossy, oral, chestaut-brown. neute or round-polnted, and contalos a sweet kemel. Cup thin, deep, hemispheric, cosers f of aut, hairs laside. Scales of cun are thin-tipped, reddsh-brown, rather knoliby near the base.

WOOD-Ring-purous; with prominent medullary rays; Leavs, strong, close-gralued, durable in contact with soll, dark brown with lighter snpwood. Wefghs 4i.i3 lbs. ner cubic foot. Used for rallroad tieg, fenclng, fuel and coustructlou. Ranks close to Thiste Oak.

DISTIXgDISHING CHARACTERISTICS-In summer the Chestnut Oak, also known as Rock Onk, cin be distlngulshed by its oblong leaves margined with course rounded teeth and the roughly fissured and nou-scaly hark. In wibter one can readily recognize it bJ lts characteristic bark, its sharp-polnted coalcnl buds and its distinctive fruit. The persistent leares ofter ald in recognizing it in winter, is well as the alseuce of I.year old developing acoras. The sleader, angular, orange-brow twigs terminated by a cluster of light brown sharp-poiated buds with a sligbt aplcal pubescence wlll alwags dctermine this species with certaioty.

RANGE-Malue to Ontarfo, south to Alabrma and Tenaessee.

DISTRIBUTION IN RENNSYLVANIA-Common in the mountafnons reglon of the State. Locally it hecomes a prevalling tree.

HABITAT-Usually found on dry blllsldes and towards the soutb in the mountalng. It reaches Its best developmeat in the mountains of western North Carolion, eastern Tenuessee nad Kentucky upon rich molst soll. It is 11 ght-demanding and unless crowded will develop often into a crooked tree.

IMPORTANCE OF THE SPECIES-The Chestuut Oak belongs to the White Oak group. Ity wood is used practically for the same purnoses as that of the Thite Oak. The wood is valuable and In addition the bark Is rery ralunble because it is richer in tanulu than thut of any other 0ak. Large quatitiog of thls bark are barrested anaually at the present time in the southern Appalacblaus. Thls spectes deserves to be regenerated exteusively, especially by natural geed regenerntlon nethods and admlxed with the nell kwown chestuut. Io case of artillal regenera. tlou it mas be adrisable to sow the seeds rather than plaut seedings alnce this speciea la rather gensitive to transplanting. 


\section{SCRUB CHESTNUT OAK. \\ Quercus prinoides, Willdenow.}

FORM-Usually a low shrub from $2-5$ ft. bigb, but mas attain a height of $18 \mathrm{ft}$. wlth a diameter of 4 inches. Usually occurs in clumps but mas occur solitary.

BARK-'rhin, bitter, light brown, marked with light gray blotches, at first smooth, hut lnter when trunk reaches a diameter of 4 inches $3 t$ becomes rough.

TWIGS-Smooth, slender, at first dark green and rusty-pubescent but later reddish-brown and smooth, marked wlth rather inconspicuons pale lenticels.

BUDS-Alterngte, ovite, rounded nt apex, light brown, coserrd with thin overlapping senles which are sometimes hairy on margln.

IEAVES-Alternate, simple, oborate, $3 \cdot 6$ inches long, $2 \cdot 3$ Inches wlde, corered beneath with pale tomentum. short and stout-petfoled, margined wlth 3-7 rounded teeth on ench margin and terminated with acute or acuminate apex.

LEAF-SCARS-See "Leaf-Scars" under White Oak, puge 132.

FLOWERS-Apnear ahout May when lenres are about dereloped. Staminate aruents I inches long. sellow and somewbat hairy. Plstllate flowers short-atalked and bear bright red plstils.

FRUIT-Ais acorn, mataring at end of first senson: \$. \& of an inch long, sessile or shortstalked, often produced in great abondance, singlg or in pairs. Nut oval, light chestnut-brown; when joung strinted wlth dark longltudinal lineg; blont-polnted, shlng except at apex where it is often corered with pale down. Kernel swcet and edible. Cup tbin, rather deep, covera about 5 of nut, pale woolly outside, downy inslde. Scrles are indistlnct, thlnner towards apex, often knobby or tumid towards base.

WOOD-Ring-porons; with consincuous medullary rnys. Commerclally not Important on account of small size. Locally used for fuel.

DISTINGUISHING CHARACTERISTICS-The Scruh Chestnut Oak, also known as Drarf Chin. quapin Oak, Chis:quapin Onk and Scrub Ouk, cnu readily be distingulahed from most of the Onka of Pennsylvania by Ita dwarf forms. It resembles the Bear Scrub Oak rather closely but can he distinguished from it by its round-lobed leaves, knobbs acorn-scales, scals and often grayhlotched hark on larcer stems, and sweet kernel of the acoros. The foung branches of this species nre pubescent while those of the Scrub Oak nre usually smooth. The huds are small and not so sharp-rolnted as those of the Chestnut Oak and the Yellow Oak.

RANGE-Malne to North Carolina, west to Kansas and Teras.

DISTRIBUTION IN FENNSYLVANIA-Found locally in the costern, southem and central parta of the State, nowhere very common.

HABITAT-Prefers drT roods, rocky slopes or sandy solls. Occasloually found in hillside pastnces and rooist roods.

IMPORTANCE OF THE SPECIES-The Scrub Chestnut Oak is so small in size that it bag practically no commercinl vnlue. It is hardly more thsn a forest weed and should not be planted or protected except where it might be osed as an adrance growth. 


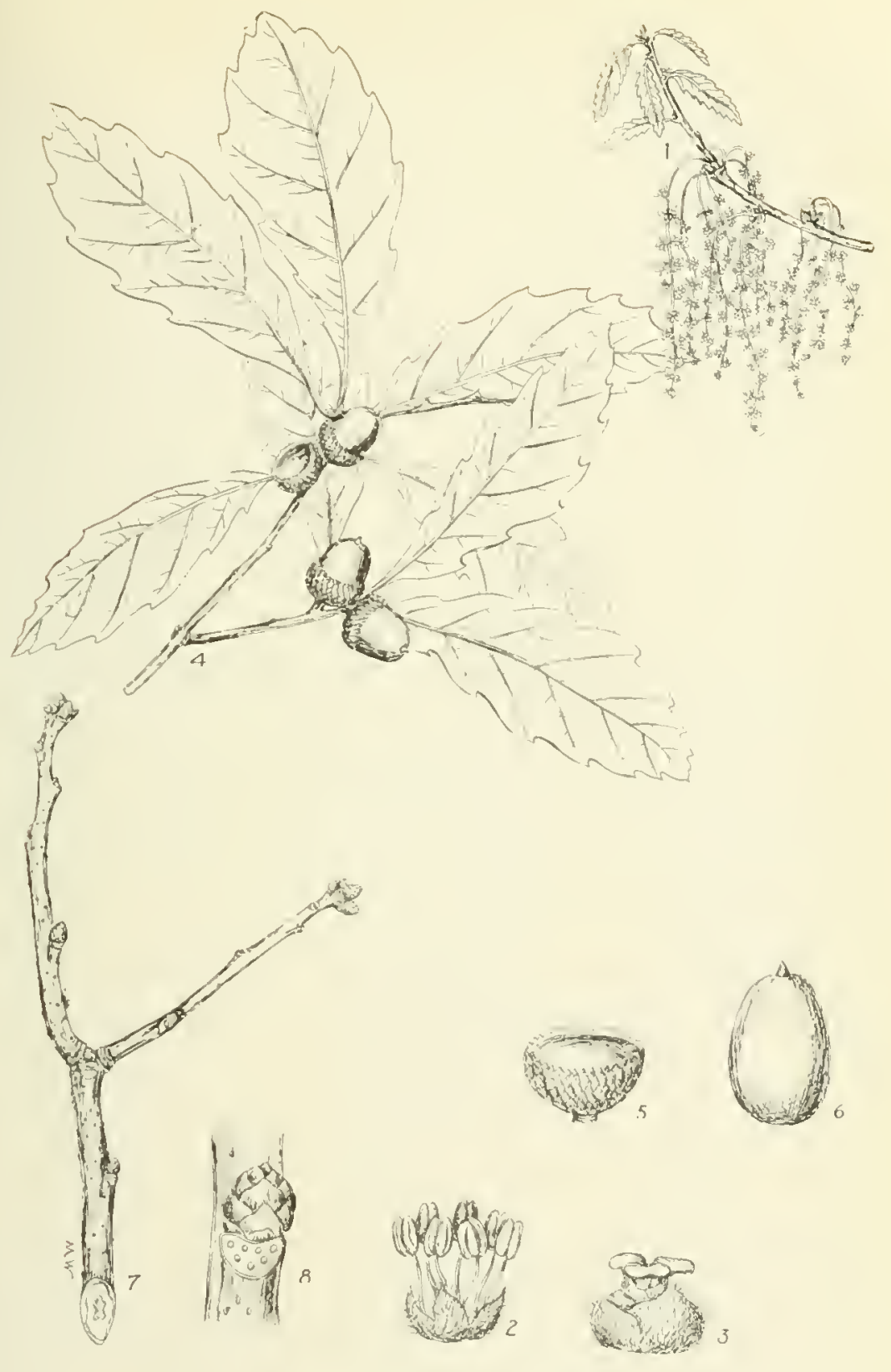

PLATE LXI. SCRUB CHESTNUT OAK.

1. I"lwering hauch with immature leaves, $x$ a.

3. A stamiuate tlower, enlarged.

3. A pistillate tower, enlarged.

4. A fruiting lranch, $x \frac{1}{2}$.

6. An acorth culy, $>\frac{1}{2}$.

7. A winter twig, $x$

$\mathrm{s}$. Section of a winter twig, enlarged. 


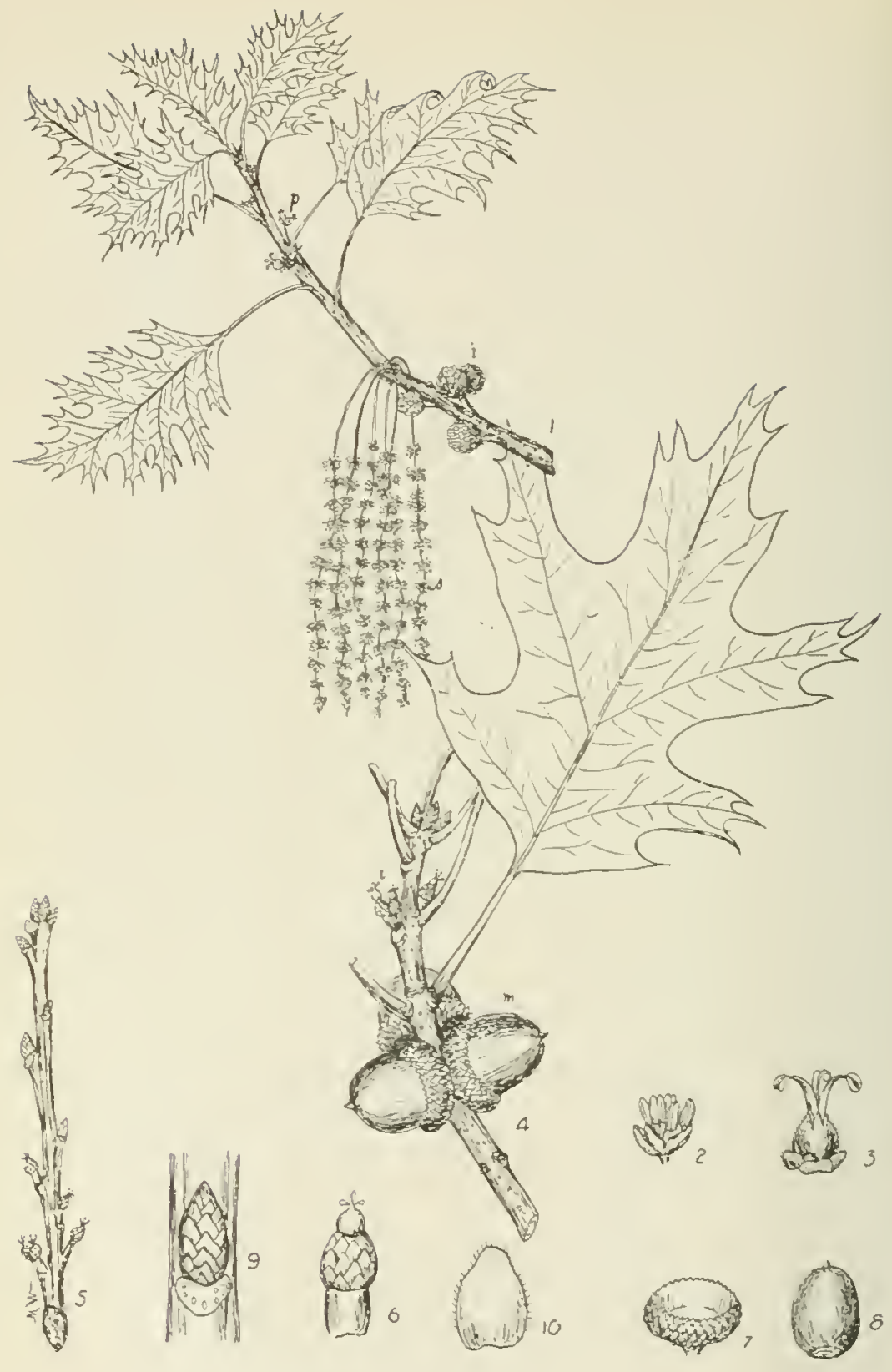

PLATE LXII. RED OAK.

1. Flowering branch with imnature leaves, (s) staminate blomsoms, (p) vistillate lolusmus. 2. A staminate fower, enlarged.

3. A vistillat? fower, enlarged.

4. Rranch with mature leaves. (i) immature acorns, (m) mature aanns, s

5. Winter twig with immature acorus, bulk. and leaf-iants, 3,

6. An immature acorn. enlarged.

7. An acorn cun, $\mathbf{x}$.

S. An aeorn, 3 .

9. Section of a twig, enlarged.

10. A but-scale, enlargeo. 


\section{RED OAK.}

\section{Quercus rubra, Einnaeus.}

FOBM-One of the liggest lorest trees of the Sosthern States, cscally attaining a belgh:

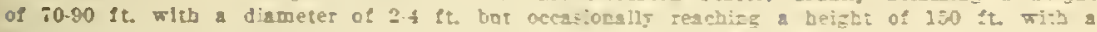
dismeter of 3 feet. When grown in the oper has a sbort trunt and a imad stmmetrical crown: in

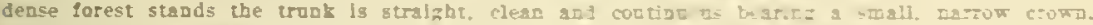
The straigh ascending and dean branches of the comp a:e chara:e-isic.

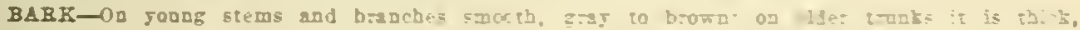

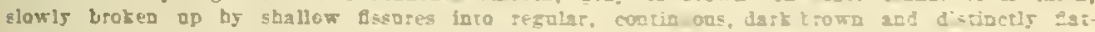

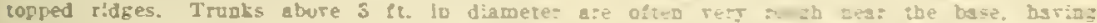

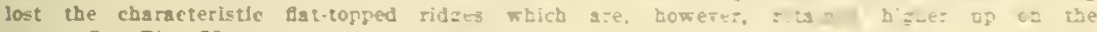
stem. Set Fig. i2.

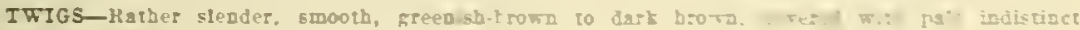
leaticels; pith star-sbaped.

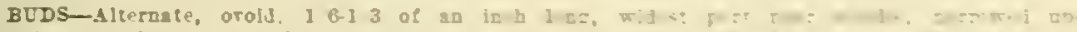

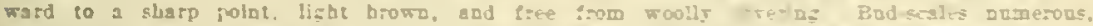

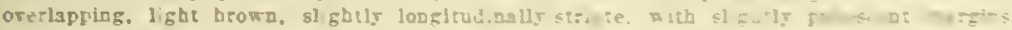

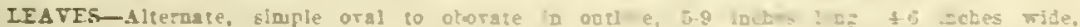

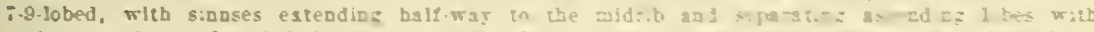

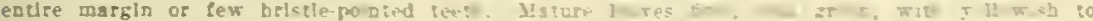

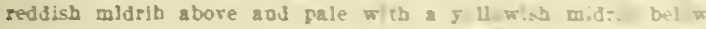

IEAF-SCABS-Fee "Leaf scars" undor White nat, paze 1?

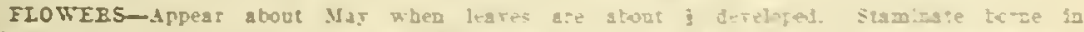

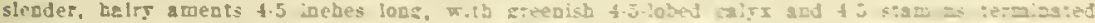

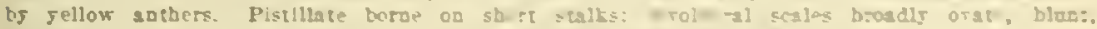

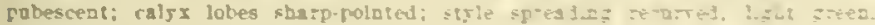

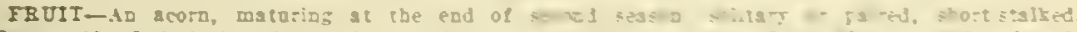

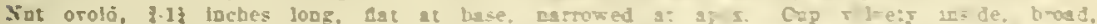

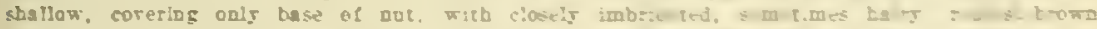

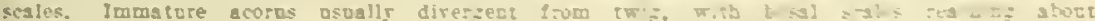

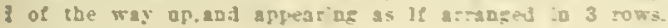

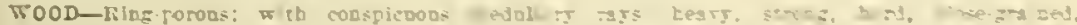

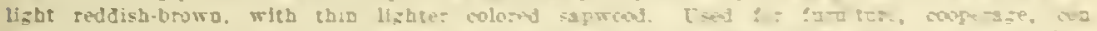

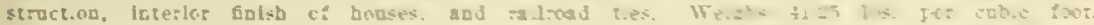

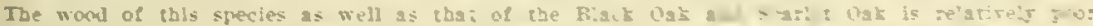

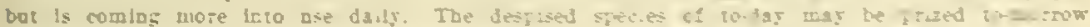

DISTIACUISHISG CRARACTERISIICS-The red dat mas te mozaly 1 by its as ixpred

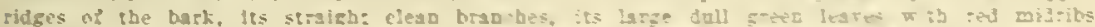

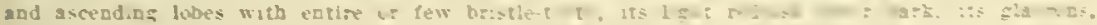

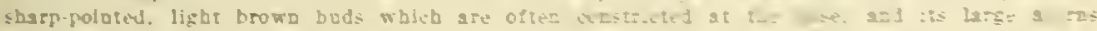
with troad sad shallow ears.

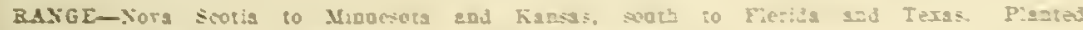
estcosirely in Earope for oramantal and forest: rerposes.

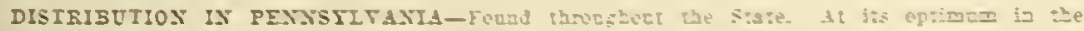

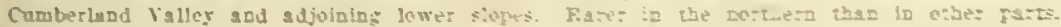

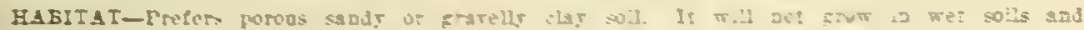
Is also lutelerad of shade. exief wber trons.

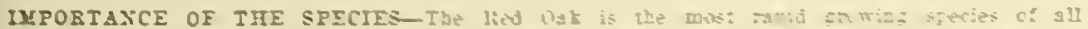
ihe Oats. 10 coe rear it has snwa to the be

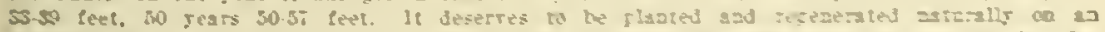

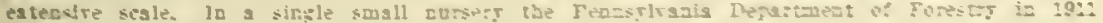

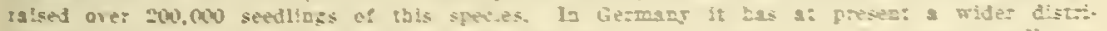

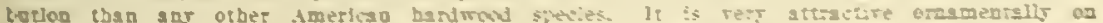

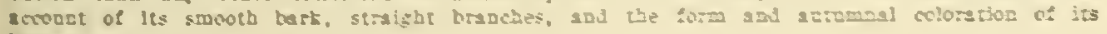
leares. 


\section{PIN OAK. \\ Quercus palustris, Muench.}

FORM-A medium-sized tree usualiy attaining a helght of $50.60 \mathrm{ft}$. with a dlameter of $2 \mathrm{ft}$. but maj reach a maximum he?ght of $120 \mathrm{ft}$. With a dlameter of 3 feet. Trunk atraight, usaally clean, continuous, and hears a symuctrical conic crown. The lower lateral branchea are short and drooping, the middje borizontal, and the apper ascending. The form of the tree is characterlstic. See Fig 38 and 39.

BARK-0n old trunks relatively smooth but slightly roughened by shallow flssurea separatlag low ritiges which are covered by small close seales. On young trunks shlnlag, very smooth, light bromn tu reddish. See Fig. 76.

TWIGS-Slender, tough, lustrous, at first balry, later smooth, dark red to grajlsh-brown, covered with pale and inconsplcuous lenticels.

BUDS-Alternate, amooth, $\frac{1}{8}$ of an inch long. amsil, oroid, sharp-polnted, covered with ligh brown scales whlch mas sometimea be slightly halry on the marglo.

IEAvES-Aiternate, simple, 4-6 inches long, 2.4 incheg wide, orate in outhoe, 5.9-lobed; lobes bristle-pointed, sejarated by broad deep and round-based sinuses. When full grown dark shining green ahore, pale green and smooth below, often with small tufts of haira in the leat axis.

LEAF-SCARS-See "Leal-Scars" under White Oak, page 132.

FLOWERS-Apper ahout May whon leaves are about developed. Staminate flowers in slender and hairy aments from 2.3 inches long. Nistilinte short-staiked and terminated by spreadiog bright red gtyles.

FRUIT-An acorn, maturing at the end of the second season, soiltary or in paira. Nut globose, light brown. ofted striped, ahont of ao Inch long. Cup thin, anacer-shaped, shallow. 1 of an inch neross. encloser only abont $2 / 5$ of nut, covered with thin closely overlapplug scales. Kernel bitter and pale ycllow.

WOOD-Ring-porous; wlth conspicuous medullary rass; hears, strong, hard, close-gralued, check and warps badiy during seasonlng. Welghs 43.24 lbs, per cubic root. Uaed for cheap construction, chenp cooperage, raltroad ties, and occaslonally for foterior falsh.

DISTINGTISHING CHARACTERISTICS-The Pin Oak, also known as the Swamp 0ak and Water Dak, when young and cspecially when open grown, can readily he recognized hy its characteristlc form, Its trunk is continuoug, relatircls smooth, and corered by mang glender and rather short lateral branches which are drooping below, erect above, and horlzontal in the middie. It frequents molst locations and begrs small acoras with ghallow cups. The branchlets are citen beset with short. stiff lateral shoots whlch give it its common name. The buds are smali, smooth, shary-polnted, and light brown in color.

RANGE-From Massachusetts to Michigan ad Missourl, south to Firginla, Teanessee, add Oklahomg.

DISTRIBUTION IN PENNSTLVANIA-Common in the eastern and gouthern parta. Occasional in the mountainous parts. Sparse in the western part.

HABITAT-It occurs in rich molst soil of riser bottomlands, along atreams, on border of awampa, and even thrives la fertile soil oo the slopes and summits of the Allegheny mountalns.

IMPORTANCE OF THE SPECIES-This species does not rank high from a commercial point of riew eren among the Black 0ak group of whlch it ig a member. It is aingularly beautiful for ornanental purposes. It deserves to be planted exfensively as a shade, park, or arenue tree on account of ita rapid growth, ita beantlful form, and antumnal follage, and the ease wlth which it is transplanted. Itg commerclal value, hovever, doeg not recommend it for ertensive planting for forestry purposes. 


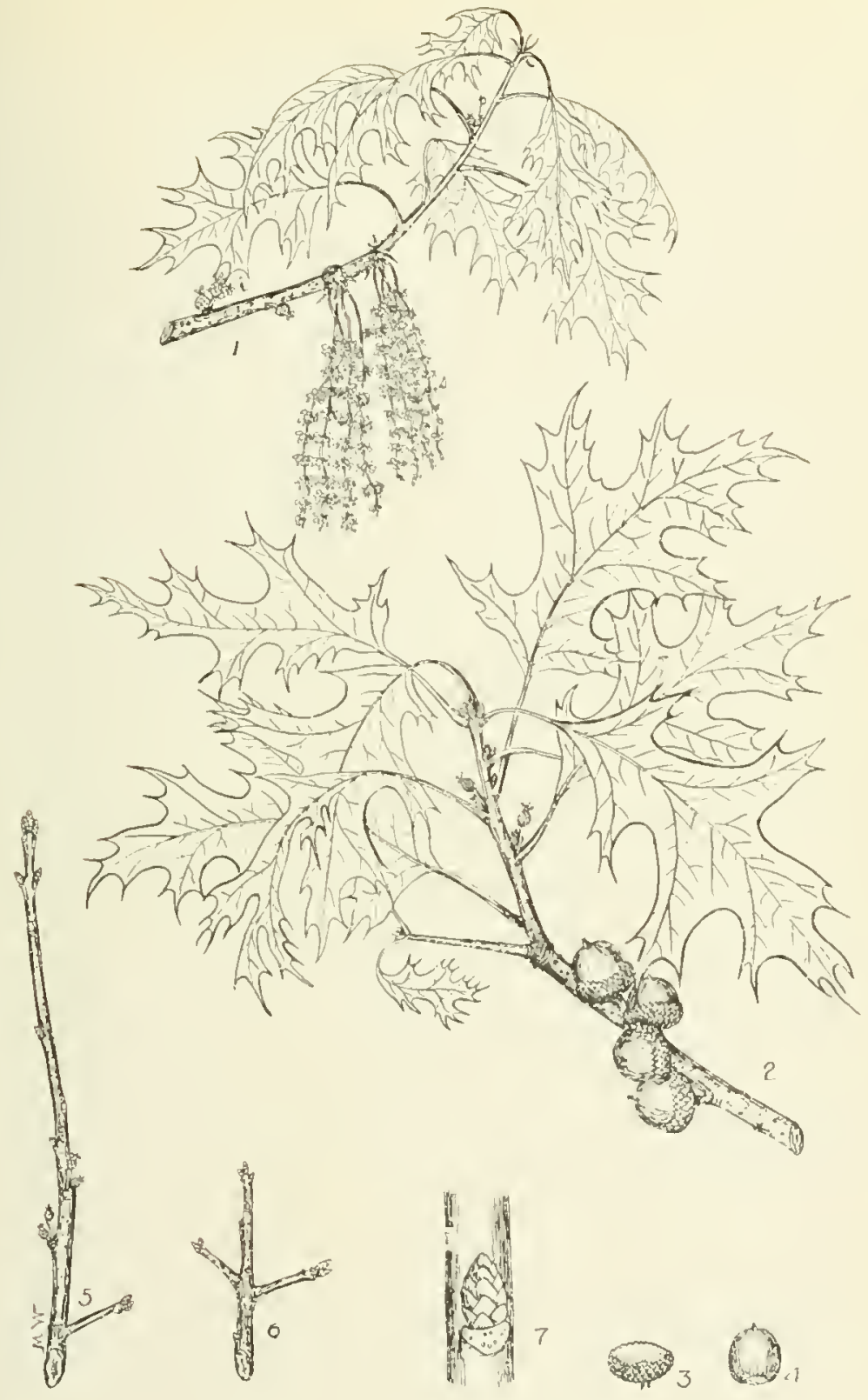

PLATE LXIII. PIN OAK.

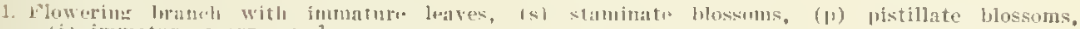
i i immattres acorns, $x \geq 3$.

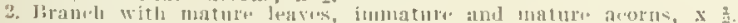

3. An aenrn (a), $x$ in.

4. An acorn, $\mathrm{s}$,

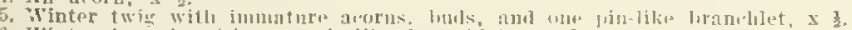

6. Winter hran le with two piu-like hranchlets, $x \geq$.

7. Srintiov of a winter lranch, ealarged. 


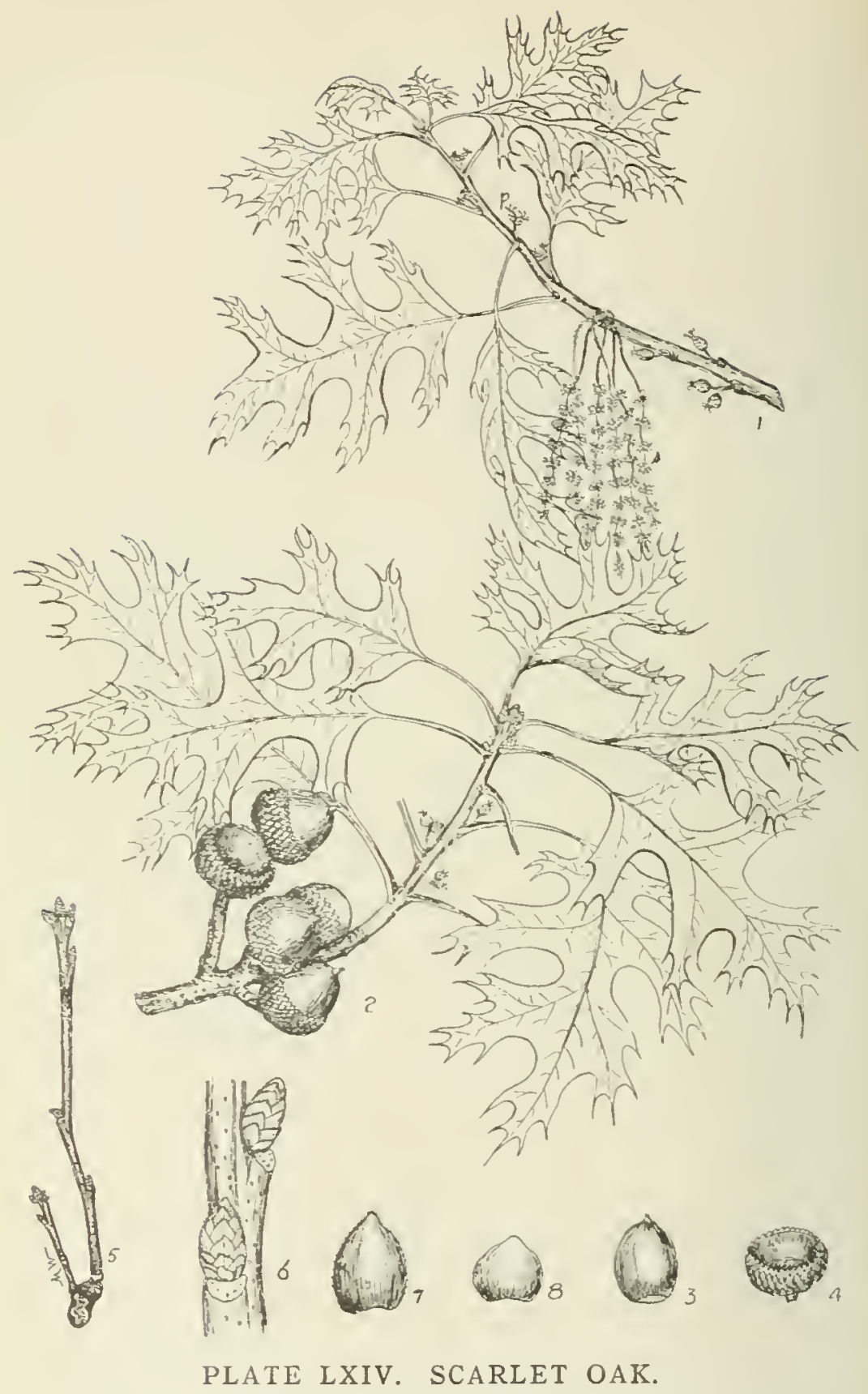

1. Floweriag branth with immature legres, (s) staminate blownms, (p) pistillate blossoms. 2. Branch mith mature least: immature and mature atorns, $x$.

3. An acorn, I is.

4. An acorn cup $x$.

5. Terminal section of a winter twig, $x$ b.

6. Sertion of a winter twig shuming lenticels, leaf-scars with hullescars, and two slights

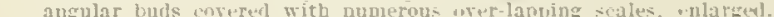

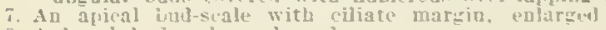

S. A basal bud-scale, eularged 


\section{SCARLET OAK.}

\section{Quercus coccinea, Muench.}

FORK-An aversge-stzed tree vsuslly attaining a belght of $60-80 \mathrm{ft}$, but occasionally reschlug a beight of $150 \mathrm{ft}$. witb \& dismeter of 4 feet. Lateral branebes ascending above, torizontal iu middle, drooping below. Lateral brsnches are slender and lower ones die readily from suading, only persist for magy gears. Trunk very tapering, crown shallow snd narrow.

BARK-OD old trunks Intermediste between the Red Oak and the Blaek Osk, It is broken ap into rough, Irregular, deey fissures which separate ridges not so rough is those of the Blsck Onk sud not so flat-topped as those of the Red Oak. Iuner bsik red to gray. On younger limbs thin, smooth, ligut brown. See Fig. 78.

TWIGS_Slender, smooth, reddisb or grajlsh-brown, corered with numerous, smsll, pale lentlcels; plth star-shaped.

BUDS-Alternate, brodly ovnie, narrowed to a blunt npex, $\frac{1}{b}+\frac{f}{8}$ of inch long, dark reddikb-browa, covered with a psle wool from the middle to the apex.

LEAVES-Alternste, simple, brosdly ovel to oborate, 3.6 luches long, $2 \$-5$ inches wide, 5.9-lobed, lobes bristle-poluted and separated by deep round-based sinuses extending at lesst 3 of the distance to the midrib. In autuma brlliantly senrlet before falling.

LEAF-SCARS—See "I.eal Searg" under White Oak, page 132.

FLOWERS-Appear about May when lcaves are $t$ developed. Staminate flowers sre borne In slender pubescent aments $3-4$ lnches long. Pistllate on sbort pubescent 8talks, reddish In color, with refexed hright red stigmas.

FRUIT-An seorn, maturlng at the end of the secund season, sessile or short-stalked, solltary or paired. Nut oroid, $2 / 5 \cdot 4 / 5$ of un inch long, reddisb-brown, ocensionally strlste, Cup thln, covering about 1 of the nut, narrowed at base, with elosely imbricated, sbarp. polnted, slightly downg sealea ofted forming a fringe at the eup margin whleb is closely appressed to the nut.

wooD-Ring-porous; witl promlncat medullsry rays; strong, beary, coarae in textore. Welgbs 46.15 lbs. per cubic foot. The wood has little commerclal ralue a timber.

DISTINGUISHING CHARACTERISTICS-The Scarlet Oak is one of the commonest of the Black Oak group snd can readily be dlstinguished from the Black Oak by its smoother bark rldges on the trunk, Its pale: lacer bark, Ita deener round-based leaf-ainuses, Its smooth, elose-fiting seales of the acorn-cup, and its stouter, often smaller, less angular tuds which are coverea with pale wool ouly from the middle to the spes whlle the Blsck oak ls distluctly woolly orer the entlre bud. It can be distlngulshed from the Red oak by 1 ts smsller and niore deeply lobed lesves, its less fint-topped rldges of the birk, Ita smaller and deepercupped deoras, sod Its buds which are covered with a pale wool from the middle to the apex whije those of the Red $0 a k$ are tree from wool. The peralstent, stunted, oftea drooping and desd lateral branches are also peculiar to this tree. This characterlatic ls common to trees on the border of bodies of water.

RANGE-Msine to Minnesota, south to North Carolina and Nelirasks.

DISTRIBUTION IN PENNSYLVANIA-Common in the eastern, central, and southern parts. Sparse in westera part. Rse in northern part.

HABITAT-Prefers dry ssudy soll. Frequently met upon light stony or sandy uplands but the best individusls oecur on good soil at the base of the slopes where It is often found bordering bollows flled with water during spring.

IMPORTANCE OF THE SPECIES-The wood of the Searlet Osk ls of little commerclal importance as compared with some of the other osks. The wood la sold on the market as Red Oak bat Is lnferior lo quallty to the latter. Thla species 18 often attacked by fungl whed it has reached medium size, whleh esuses the wood to rot and often results in wind-break in the porest. This apecles on account of its fast growtb, beautiful follsge with its special autumal coloration, is one of the most deslrable trees for street or park. 


\section{BLACK OAK.}

\section{Quercus velutina, Lambert.}

FORM-One of the largest Oaks of Penssylradia usually $60-80$ ft. bigh, bat may attain a maximum beight of $150 \mathrm{ft}$. witb a diameter of 4 le fet. Trupk usually cleas and continooua giving off asceuding brabches abore and borizontal ones below. Branches rather stout and zigzag. Crown deep, irregular, Darrow to wide-spreading, oblong in oatline.

EARK-Ou roung stems smooth and dark brown, lut soon becoming rough and black. On old trunlis rers rough, tbick, broken ioto deep tissures separating thjek ridges which are cross-fisslired. loung trees $\mathbf{2}-4$ joches in diameter often start to derelop rough bark. Inder bark is jellow and bitter, a good distinguishing characteristic. See Fig. 74.

TWIGS-Stout, rusty-pubescent, reddisb-browa, angular, longitudinally ridged from leafscars; taste bitter; covered by rather consplcuova pale lenticels.

BUDS-Mlterdate, ovate, large, $\$ \frac{1}{2}$ of an inch long, stron:ly angled, tapering to obtuse apex, covered with anmerous overlapping lud-scales with a coatiog of yellowish to dirty-white I ubescence.

LEAVES-Alternate, simple, ol oriate to obloug, $4-6$ incbes long, 3.4 inches wide, usually $\%$ loberl terminated by bristle points. Mature leares are dark green and smooth abore and nale to rellowish-greed below witl tufts of rusts baj's in axil of velos at midrib. The leares vary from those of the Red Oak. No otleer onk produces so many differeatly sbaped learea CD the same tree.

LEAF-SCARS-See "Leaf-Scars" under White Oak, page 132.

FLOWERS-Annear abont Iar when leaves are $\frac{1}{d}$ dereloned. Staminate flowers occur lo hairy amedts 4.6 inches long. Pistillate are borne on abort hairy stalks.

FRUIT-AD acorn, maturiug during two seasons, sessile or stalked, solitary or clustered. Nut orate to aval, 3-1 incli long. ligbt redisis-brown, often conted with pabescepce and longitudionlly striate. Cup thin, tajering at Lase, dark reddisl-brown, embracing nut, corered with thin, light brown, slarp-polnted, latry scales tightly overlappiag at base and loosely averlapping at margin so as to form a fringe-like margin to the cup.

WOOD - Ring-porons; witu consnicuous medullars rajs; hard, heavs, strong, Dot tough, durable, checks readily. Heartwood is light brown, with lighter-colored sapwood. Welgh 43.90 llis, ler cuhic foot. Tsed for furniture, interior finisb, cheap cooperage, and ordinary construction. In geperal it fiods the same vses as Red Oak.

DISTINGUISHLNG CHARACTERISTICS-The Black Oak ls also known a Yellow Oak and Quercitron on accoust of its sellow inner bark. The dark colored and rongh outer bark, ered or youne stems, and the yellow inner bark are at all seasons of the year deflalte marks of identification. The leaves, which vary from the shallow lobed onea aimllar to those of the Red nak to the deey lobed onea similar to those of the Scarlet Oak, may also help to identify the species. No otber species of $0 \mathrm{ak}$ has so many rarletiea of learea on the same tree as the Black Oak. In autumn the small acoros with the cap embracing ore-linlf of the nut Das also bely to distinguish it from some species lise the Red oas and the Pin Oak. The large, angular buds covered over the whole aurface with a pale wool are sure characteristics.

RANGE-Maine to Western Ontario, south to Florida and Texas.

DISTRIBUTION IN PENNSYLVANIA-Commor in the eastern, central, and soathern parts. Sparse in western part. Rare iu the Dorthern part.

HABITAT-Usually found on dry uplands, gravelly plaing and ridges, eapecially in the Appalachias foothills. Seldon found in rich bottomlands. In the west aspally found on aterile, sad 5 , or glaciated hills.

IMPORTANCE OF THE SPECIES-The Black Oak should be propagated only where no better trces can be grown. If its reproduction is thought deslrable it sbould be attempted by nutural sced regeneratiou or planting of seeds since planting of yoang aeedlings from the Dursery is expensive and success doubtful. Formerly the jellow inner bark was in demand becruse an extract iv the form of a sellow dre known as "Quercitron." was obtaided from it. The introduction of aniline dyes bas decreased the demand. The Black Oat la not attractire as an ornamental tree. 


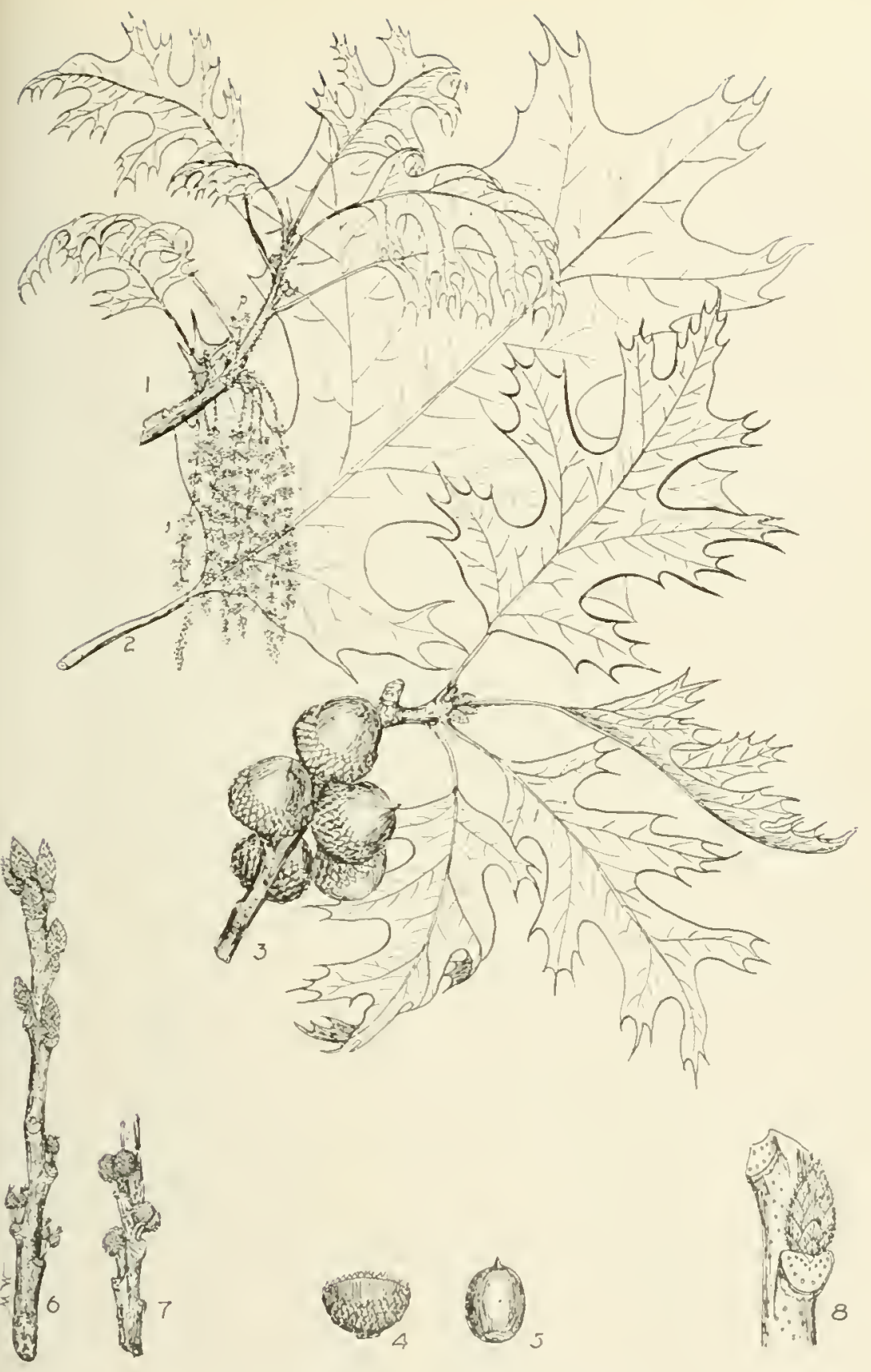

PLATE LXV. BLACK OAK.

1. Flowering iranch with immature leaves, (s) staminate blossoms, (p) pistillate blossoms, $x$. 2. A mature leaf, $x$ i.

3. Pranch with learss and matare fruit, $x$.

4. An acorn $\mathrm{eap}, \mathrm{x}$.

5. An acorn. $x$,

6. Tinter twig with buds, leaf-scars, and Immature acorns, I 1

7. Section of twig with immature acorns, $x$.

8. Section of winter twig showing the large, angular and pubescent bnd and leaf-scars with bnualescars, enlarged. 


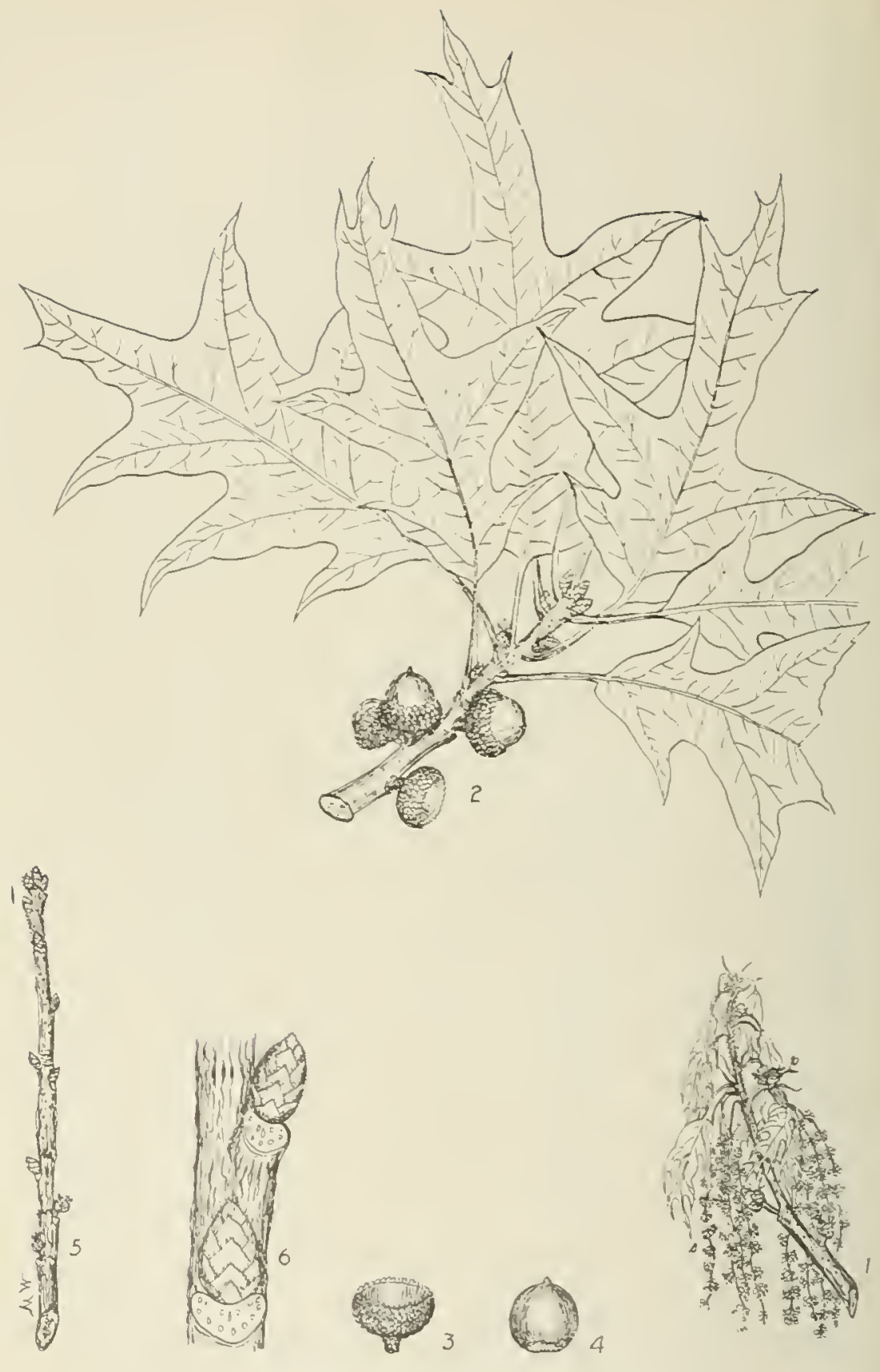

PLATE LXVI. SPANISH OAK.

1. Flumering brauph with imuatmrt loves, (s) staminate blossoms, (p) pistillate blonsums, (i) immature acoras, $x$ t.

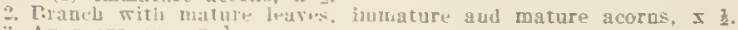

3. An acise cup, $x$ t.

4. An acorn, $x$ in.

5. Winter tric Tith inmatur. akorns, buds, and leaf-scars, s 7

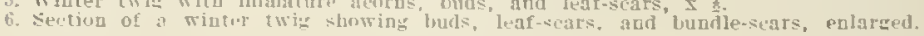




\section{SPANISH OAK.}

\section{Quercus falcata, Michaux.}

FORM-A medium-sized tree usually attolplng a beight of $70.80 \mathrm{ft}$. with a diameter of 2-3 ft. but which may regch a maximum belght of $120 \mathrm{ft}$. with a diameter of $4 \mathrm{l}$ icet. Crowa opeo, broad, round-topped, rather deep.

BARK-On old truoks divfded by shallow fssures which separate low, hrown, acaly ridges. On young parts thln, amooth, dark reddish-browo to gray uud rleh in tapule acid.

TWIGS-Stout, at first covered with rusty Lairs, later almost smooth and reddlsh-brown to ashy-gray.

BUDS-Alternate, orold, sharp-pointed, of ao inch loug, bright chestnut-browa, halry.

LEAVES-Alterante, aimple, 6.7 inches long, 4.5 laches broad, ovate in outline, 3.7 lobed; lobes bristle-pointed and separsted by broad vuriable slousen. They are dark green and abiniog ahore, corered wlth graylsh down bencath. "i'he leaves are very varlable la outline.

LEAF-SCARS-Sce "Leap-Scara" uder White Oak, page 132.

FLOWERS-1'lowers appenr in April or May wileu the leavea are ahout 3 developed. Stami. nate bowers are borve lu slender halry aments about 3.5 laches long. Pistllate on stout halry atalks and terminated by rather short, divergent, dark red styles.

FRUIT-An acorn, maturing at the end of the secood senson; short-stalked. Nut ovold to globose, rouoded at anex, about of an lnch loog, pale orange-brown, enclosed only at bage for f length. Cup bemispheric, th of $\mathrm{na}$ incls across, covered hy thin reddish scalea whlch are lale pubescunt uspecially on the marglog.

WOOD-Ring-norous; whth conspleuous medullary raga; hard, strong, not durable, with light red heartwood, lighter sapwood. It warys ad checka badly. Welgba 43.17 lba. per cublc foot. Largely used for fuel and also used lil cocatruction. Bark is rich in tanoin.

DISTINGUISHING CHARACTERISTICS-The Spanlsh Oak beara leaver which resemble those of the Scrub Oak, only that the lobes of the latter are usually short and triangular while those of the former are mostiy long nod labceolnte. The Scrub Oak attains the helght of a small tree only, while the Snanish Oak maj reach a helght of 100 feet. It can be dlatiogulahed from the other closely related member of the Black Oak group in this State by Ita white or grayish-tomentose coating on the lower leaf surface.

RANGE-New Jersey and southeastern Penosylvania to Missouri, south to Florida and Texas.

DISTRIBUTION IN PENNSYLVANIA-Reported onls from the southeastern and gouthern parta of the State.

HABITAT-It Is usualiy found on dry gravelly or sandy goil. In the South it is common betweco the coastal plain and the Appolachlan mountalns.

IMPORTANCE OF THE SPECIES-Since the atural distribution in this State is limited to a few local places in the southeastern and southern parts and on account of its inferior wood, It cannot be recommended for forestig purposes. Other more valuable apecies ahoulo be propogated in ita stead. It is rather attractive a an ornamental tree and its bark also is rich in tannin. 


\section{SCRUB OAK.}

\section{Quercus ilicifolia, Wangenheim.}

FORM-Shrab or small tree with may crooked latertwined branches; usually $4-8 \mathrm{ft}$. bigh with a diameter of I-3 laches, but occasionally attalalgg a belgbt of $18-20$ feet. See Fig. 4.

BARK-Thin, smooth, becoming scaly ou older stems, gras to dark brown in color.

TWIGS- Then joung slegder, dark green, tinged with red, and tomentose; becoming gray to reddish-browa, finally dark browa and smooth.

BUDS-Alternate, orate, obtuse, of an incb long, chestnot-brown; corered by nameroua small dark-margined closely appressed scales.

IEAVES-Alternate, simple, 25 inches loag, I -3 Inches wide, oborate In outline, with a redge-sbaned base, 37lohed, asoalky 5; witb sballow slauses and acate a ad bristle-tlpped lobes. Mature leares dark green and glossy abore, corered with a dease wbittsb pabescence begeath, thich and leathery in textare, with conspicuous sellow midribs and reins. Petloles roond, tomentose and abont 1 inch long.

LEAF-SCARS-See "Leat-Scars" ouder Whlte 0ak, page I32.

FIOWERS-Appear about Mas wben leares are dereloped. Staminate amenta 45 inchea loog, often clinging to twigs untll late summer. Plstllate forrers borne opon atout tomentose stalks, hare an involucre on red scales, and red stigmas.

FRUIT-Aa acorn, maturing at end of second season, rery abundant, sessile or nearly so, usaally clustered. seldom solitars. Nut broadis oroid, with a flat roouded base, acute or romaded npex, abont half enclosed In the cup, ligbt brown, sbing and often slightly striate, of an lach broad and long. Cap pute and reddish-brown and soft downg mithla, corered on the outside with mans closely set reddish-hrow scales whose free tips form a fringe around the edge of the cop. Kergel brlght sellow.

WOOD-Ring-poroas: with consplenoas medullary raya; pale brown, atrong, hard, toogh, and fine-graiged. Commerclatly not important on accoont of its small size. Iocally psed for tuel.

DISTINGUISHTNG CHARECIERISTICS-Tbe Scrub 0ak, also known as Bear Oak and Ground Oak, can easily be distiaguisted by characteristic bristle-poluced leares sbowa on the oprosite plate, which tura reddisb-brown or browa ia autama, and ofteo persist tbrougbont the winter. It is small in size and forms dense thickets over large areas, especlally recently burned amgs. The smooth nou-scals bark, persistent clusters of froit and the small, brown, blatly corleal buds cerered with sligbt puhesceace are characteristic. In bablt it resemblea the scrub chestnat 0 ak. but the lntter bas a faky bark and ronad-lobed leares and chargeteristic iruit.

RANGE-Maige to Obio south to Forth Carolias and Kentacky.

DISTRIBUTION IN PENNSYIVANIA-COMmon in most of the contles in and east of the Allegbeny Mountains. Found in snme of the coanties in the southrestern portion of the State. Sparse In the gorth-central and northera narts.

FABITAT-Usaally found on tocky bllisldes, sandy plateans, and monntain topa. It is gregarious and nhle to flourish apon barren, dry, Infertlle solls, but canot eudare much shading, beace it seldom occurs in mixture with other species. It has orergrown extenslve areas of burnt-ofer land in this State.

IMPORTANCE OF THE SPECIES-The Scrab 0ak is of no commercial ralue but la economlcally importalic or account of fts abilits to grow apon the most exposed and inhospltable ajtuatlona. This makes it worthy of consideration in protection forests, where it sbeltera the forest-60or, prevents erosion and enriches the soil with accomulations of hamas. In time it is asually displaced bs species of grenter commercial iraportace as Cbestaot. Scarlet Onk, Chestnat Oak. Maple, nnd Aspea. Areas once corered with thickets of this speciea now often have oxly a few single representatives left 

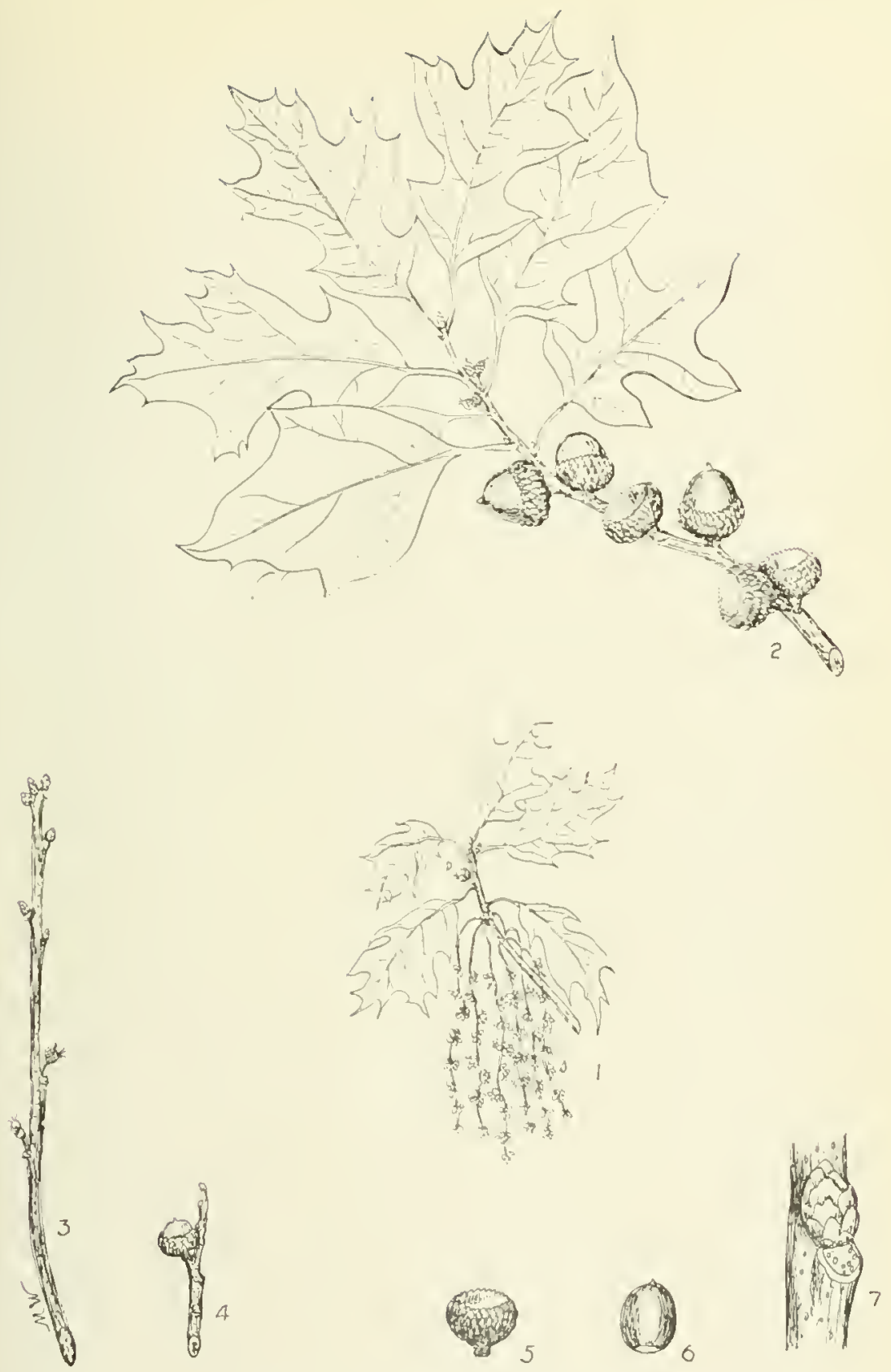

PLATE LXVII. SCRUB OAK.

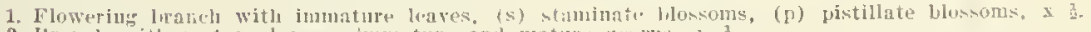

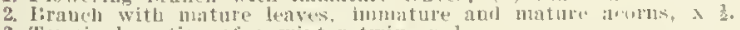

3. Terminal stotion of a s'intel' twig, x

4. Wintir twig with an acorll, $x$,

5. An acortu cuj) $x$ ․․․

6. Au acorn $x$

6. An acorn, $x$.

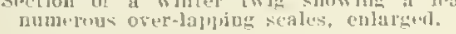



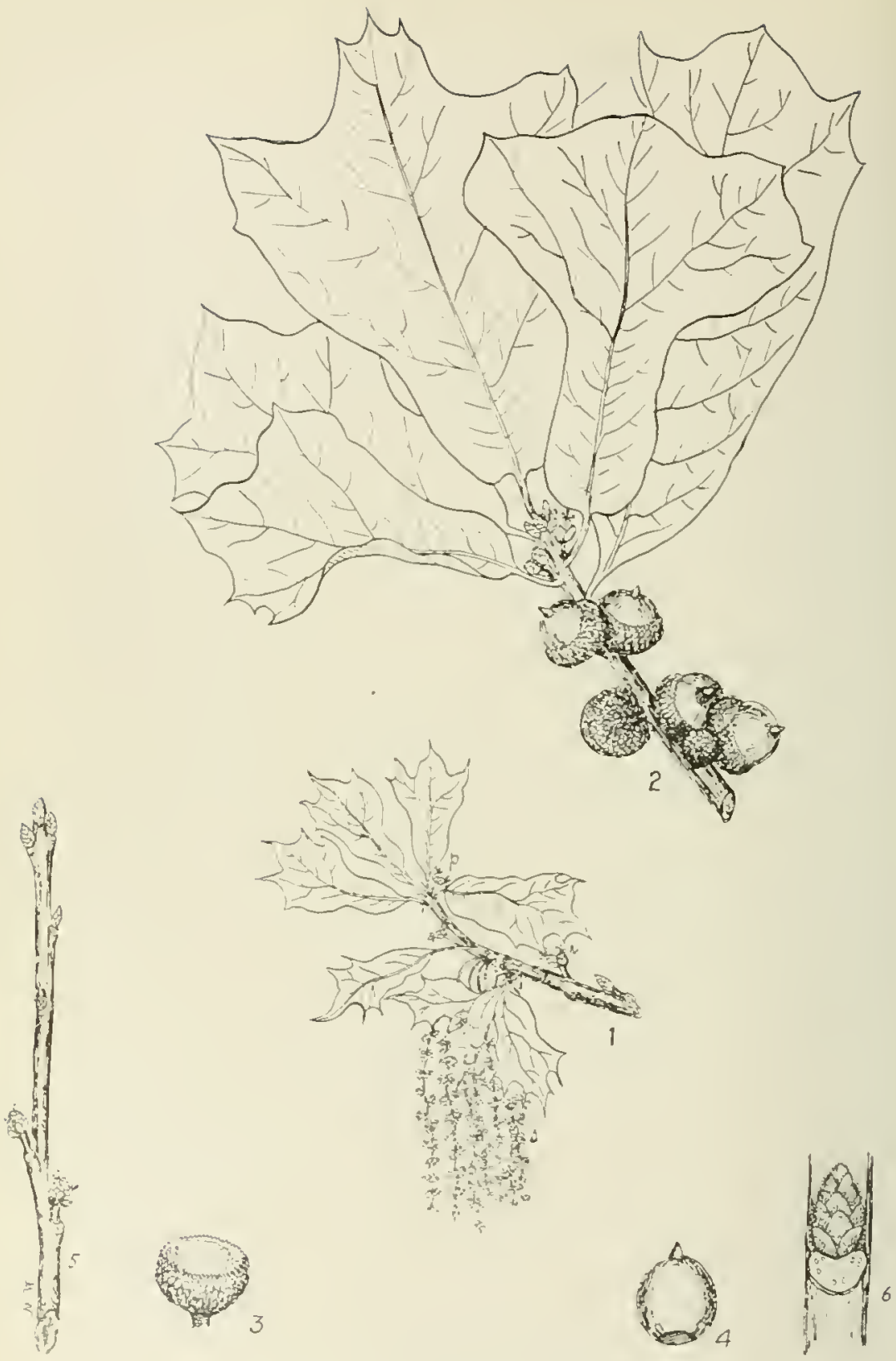

\section{PLATE LXVIII. BLACK JACK OAK.}

1. Flomering liran l, with immature leares, (s) stamisate llossoms, (p) pistillate blossioms, (i) imnature acorus, $\mathbf{x}$.

2. Eranch mith maturt leares. immature and wature acorns, $x$

3. An acorn cup, $x$ t.

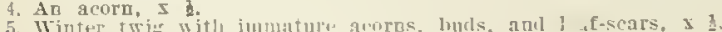

6. sintion of a winter twig, enlarged. 


\section{BLACK JACK OAK. \\ Quercus marilandica, Muench.}

FORM-This tree usually attains a beight of $20-30 \mathrm{ft}$. With a diameter of 18 inches, but may rench a helght of $60 \mathrm{ft}$. with a dlameter of 3 feet. It reaches its masimum size in Texas and Aikansas. Crown usually compact, round-topped, and narrow on accouat of ahort branchea. Upper biunches are ascending, lower ones spreading.

BARK-Thick, roughened by deep blssares which separate brosd angular platea covered with dark brown to nenrly black scales.

TWIGS-Stout, costed at Brst with pale woolis corering of bairs, later becoming fmooth and darli brown to gruy.

BUDS-Aiternate, orate, distinctiy angular, sharp-pointed, of an inch long, reddish-brown and rusty pubescent.

LEAVES-Aiternzte, simple, broady ovate in outiine, 6-7 inclues loug with an almost equn! width, rounded or heart-shnped at the bnse, 3.5-Jobed. Mature learea deep green, thick, :eathery, and smonth above; often rusty brown below.

LEAF-SCARS-See "Lsal-Scarg" auder White Oak, page 132.

FLOWERS-Appear about May when the leares are $j$ developed, Staminate tiowera in slender, oftea persistent aments $2-4$ Inches long. Pistillate towers on short, stout, pubescent stniks.

FRUIT-An acorn, maturing at the end of the second season, solitary or paired, abort stslked. Nut oroid $₹$ of an isch long, neariy snme widb throughout, often fitriate, light brown. Cup hemispherlc, deep, corers one-hall or over of aut, light brown and down on inside, cosered by large reddish-hrown loosely oreriapplng scales. Small benies form a thin rim around the margio.

WOOD-Riag-porous; with conspicuous meduliary rays; dark brown, beary, bard, atrong. Welghs 45.64 lbs, per cable loot. Csed for fuel, charconl, and manufactured into lamber to a limited extent.

DISTINGUISHING CHARACTERISTICS-The Black Jack Oak, also kuown ag Jack Oak and Parren Onk, can be distiagalsbed by the large obornte leaves which are asualiy 3-5.lobed abore the middle, or somctimes eutire and corered with rusty brown pubescence. It is the only Oak of Pennsyivania which has its leares dilated near apex. Its abarp-pointed, distlnctly ancuin and somewhat bairy bud and its hemlspheric acorn cup also aid in distlnguishing it from the other closely related species.

RANGE-New York and Penusylrania west to Nebraska and south to Florlda and Texas.

DISTRIBUTION IN PENNSTLVANIA-Occasional fa the eastern and southera parts of the State and a few local outposts in the westerd part.

HABITAT-Usually found ou poor, dry, sterile, sandy soll, bat in the South it is also foumd on clay. It reachea its best development upon the rlch soll in the sonthern part of Its distribution.

IMPORTANCE OF THE SPECIES-In the North it is a Ebrab only or a small tree of no conile in the South it becomes somewhat larger and is used for fuel, charcoal, and lumber. In Penosylumia it is of no porestal importnnce, but Is a very attractive tree for olnmental purposes on account of its compact and deep crowa. 


\section{LAUREL OAK. Quercus imbricaria, Michaux.}

FORM-A tree usually attaining in height of $50.60 \mathrm{ft}$. but may reach a bejght of $100 \mathrm{ft}$. with a dinmeter of 3 feet. Crown in mature trees rather open, often sballow, while in younger specimens it is pyramidal, ratber closed, and the lateral drooping branches often touch the ground.

BARK-Up to 13 inches in thickness, roughened by sballow fissures which separate ridges corered by close light brown scales. Ou sounger stems thin, often smooth and shing.

TWIGS-Slender, at first dark green and lustrous; later llght brown to dark brown.

BUDS-Alternate, orate, sharp-pointed, sligbtly augular, 1 of an inch long and corered with numerous close-fitting, overlnjping, erose, chestuut-brown scalea with serrate margina.

LEAVES-Alternate, oblong to lanceolate, 4-6 inches long, 1-2 lnches wide, wedge-shaped or round at the base, acute at apex, witu usually entire or undulate margins, Mature leavea are thin, dark and shiny above; pzle green gnd hairy below.

LEAF-SCARS-See "Lea1-Scars" under White Ont, page 132

FLOWERS-Appear about May when leaves are $\frac{f}{d}$ dereloned. Staminate flowera in bairy aments $2-3$ inches long. I'istillate on short stalks uhore staminate.

FRUIT-An acorn, maturing it the ead of the second season, solitary or in palra, stalked. Nut ovold th of an inch long, dark browa. Cup embraces almost th of nut, saucer-suaped, hrown and shining inside, covered bs aumerous, closely orerlappiag, reddish-browa, balry scales.

WOOD-Ring-porous; with conspicuous medullnry rass; hard, coarse-gralned, reddish-brown. It checka easily and couseruently fads a limited use iu construction work. Weighs $\mathbf{4 6 . 9 2}$ lbs. per cubic foot. Used for fuel, charconl, shingles, and manufactured into lumber.

DISTIIGUISHING CHARACTERISTICS-The Laurel Onk, also known as Shingle Oak, Jack Oak, and Water Oak, mag readily be distingulsbed from all the other Oaks of Pennsylvanla except the Willow Onk, by its characteristje lenf. The Willow Oak is smaller, has narrower and sharper-pointed leaves which nre not hairs benenth. The leaves of this specieg are bairy beneath. The acorns are larger and the cups not so flit as those of the Willow Oak. The winter buds of the Laurel ual are light chestnut-brown and somewhat angular, whlle those of the Willow oak are dark chestaut-brown.

R.ANGE-Penusylvania to Michigan and Nehruska, soutb to Georgia and Arkansas.

DISTRIBUTION IN PENNSYLVANIA-Found locully west of the Alleghenies as far north as Indjan counts. Also reported from Lebigb, Huntingdon, and Bedford counties.

HABITAT-It occurs in rich bottomlnnds, often near streams, and also in rather moist fertile uplands.

IMPORTANCE OF THE SPECIES-It reaches dimensions so that it can produce lumber of commercial size aud qunatity. but other superjor species will grow in the same place and consequeutly it camnot be recommended for forestrs purposes. It is, bowerer, one of the most attractice ornacoental oaks and deserves to be plauted exteusirely for sucb purposes. 


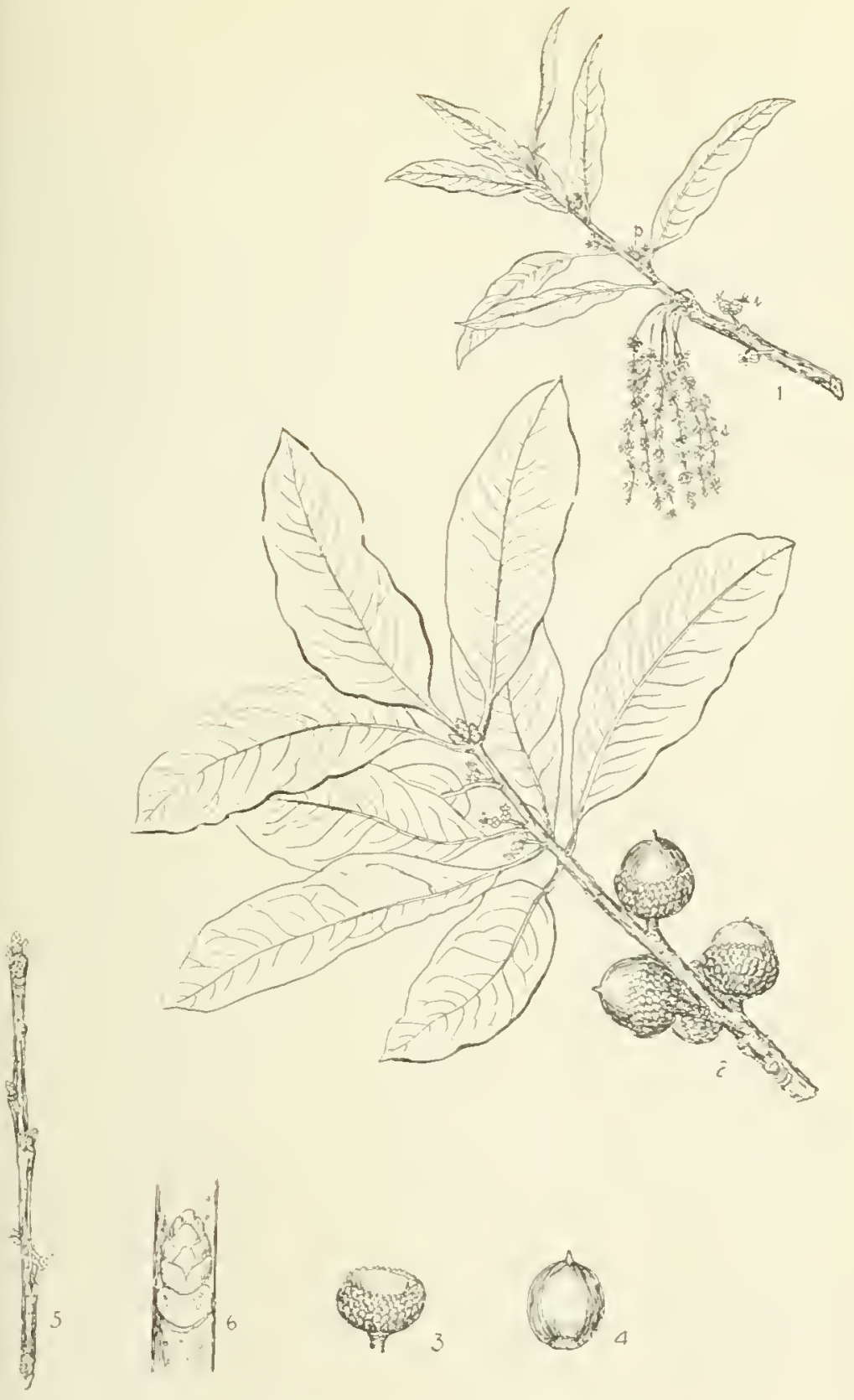

PLATE LXIX. LAUREL OAK.

1. Flowericg brabeh with immature leares, (s) staninate blossous, (p) fistillate l.lonsinus (i) immsture acorus, i to

2. Branch with matup loaves. immsture aul matmce acoras, $\mathbf{x}$ a

3. An avorn cup, $x$ i.

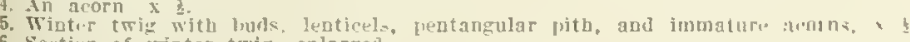
6. Section of winter twig, enlarged. 


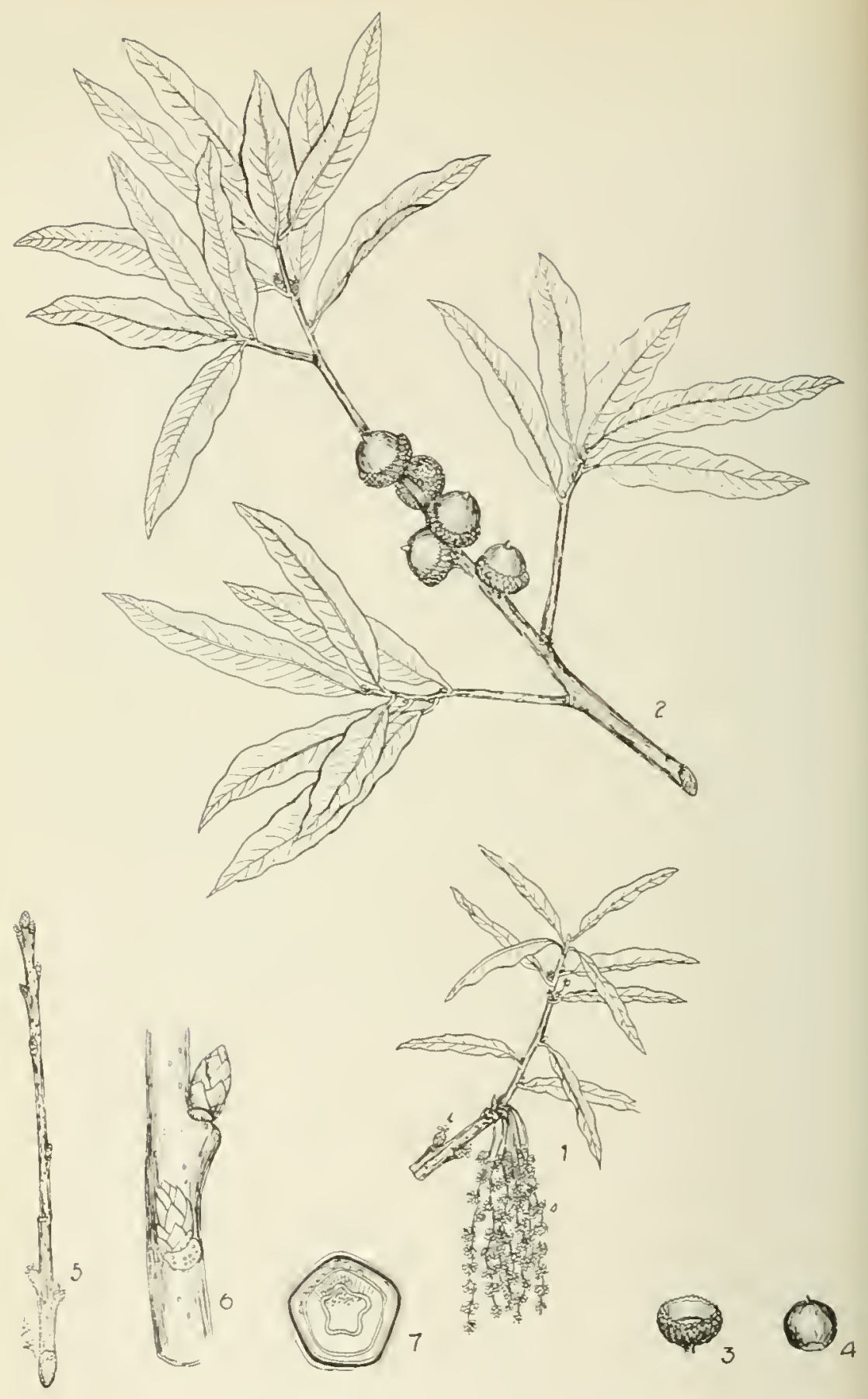

PLATE LXX. WILLOW OAK.

1. Elowering branch with inmature leares, (s) staminate blossums, (p) pistillate blossoms.

2. Branch with nature leaves, immature and mature acorns, $x$.

3. An acorn cup, $x$ i.

4. $\mathbf{A n}$ secorn. $\mathrm{s}$ t.

5. Winter twig with bods, lenticels, and immature acorns, $x$.

6. Section of winter twig, enlarged.

-. Cross section of twig showing pentangular pith, wood with conspicuons medullary rays, and bark, enlargerl. 


\section{WILLOW OAK. Quercus phellos, Linnaeus.}

FORM-Tbis tree usually attaios a beight of 50-60 $\mathrm{ft}$. with a diameter of $1 \mathrm{~d}-2 \mathrm{ft}$, but may reach a helght of so $\mathrm{ft}$. With a diameter of 4 feet. Crown usunlly narrow, rather open, pyramidal and round-topped.

BARK-Reddish-brown, in of an inch thick, sballowly fisured and scaly.

TWIGS-Rather stout, smootb and shining during flrat winter, redaisb-brown to dark brown.

BUDS-Alteroate, orate, about of an inch long, strongly angled, sharp-pointed, corered by loosely orerlapping dark brown scales which are allghtly serrated on the margin.

LEAVES-Alternate, narrowly ellptic, sometimes lanceolate, narrowed at apez and base, 25 Incbes long, $\frac{1}{2}-1$ inch mlde, entire or with slightly ways margins; terminated by a sharp bristle-pointed npex.

IEAF-SCARS-See "Leaf-Scars" under White Ouk, page 132.

FLowERS-Appear nbout May when learea are developed. Staminate flowera slender, t.alrs, yeliowish, 2.3 lacheg Jong. Plstllate flowera borne ou smootb slender stalls.

FRUIT-AD acora, maturing at the end of the second scason, usunlly solitary, sessile or nearly so. Nut hemispheric, Inch in dameter, pale sellow-brown, sometimes striate. Cup saucer. shaped, covera oaly a small portion of the base of the nut nod is covered with close, thio, bairy, reddish-brown scales. Kernel ia very bitter and yellowish in color.

WOOD-Ring-porous; witb consplcuoua medullary rays; strong, conrse-gralned, rnther solt a d light brown. Weighs $\mathbf{4 6 . 5 0}$ lbs, per cuble foot. Used for fuel and to a limited extent for general construction and felloes in wagon whecis.

DISTINGUISHING CHARACTERISTICS-The Tillotw Oak, also known as the Pcach oak, Water Onk. Swamp Oak, nod Pin Oak, mny readily be distinguished from all the other oaks of Pennsylvania except the Laurel onk by its cbracteristlc leaf, which resembles the leaf of a willow rather than the tyjieal oals leaf. The Laurel onk ig the only other onk which bears a leaf that shows nay resemblance, but its lenf is longer and bronder, more obtusepointed, and hairy beneatb. The cuns of the acorns of this species are flatter and the acoras smaller than those of the lanrel Oak. The buds of this species are dark cbestout-brown in color, while those of the Laurel Uak are light brown and oot angular.

RANGE-From Niew Fork to Florlan, westward to Kentucly, Missouri, and Texaa.

DISTRIEUTION IN PENNSYLVANIA-Found only in the southenstern part of the State. Reported fiom Bucks, Chester, Delaware, Lancaster, and Phlladelpbis countles.

HABITAT-Usunlly found on wet sandy soil, and occurs frequently along swamps and streans, but occaslonally is found on bigher areas where it may reach a fair size.

IMPORTANCE OF THE SPECIES-Tbis species is so limited in its natural distribution in this State nad its wood is of so little commercial importance that it cannot be conafdered of forestal value. It should not be planted for forestry purposes but deserves to be planted ornamentully. especially in parks and along nvenues. It hybridizes witb sereral species of other Oaks, especlally the Red Oak, and these hybrids are often very attractive ornamentally. 


\section{THE NETTLE FAMII-URTICACEAE.}

This family contains a great number of representatives, the majority of which are tropical. It contains trees, shrubs, and many other small plant forms. The trees and shrubs alone comprise orer 1,000 species and are found in the temperate and tropical regions of both hemispheres. They grow usually at relatively low altitudes frequenting wet and swampy as well as dry and arid habitats.

Several representatires of this family are important timber trees while others are of less commercial importance. Occasionally they may form pure stands but usually are nixed with other species. This family also contains representatives which are attractive ornamentally and used for hedges.

The leares are simple, alternate, and usually deciduous. The fruit matures in one season, in some species in spring sbortly after the blossoms while in others in fall. The seeds may germinate the same season or lie dormant over winter and germinate the following spring. The fruit of some genera is cdible. It is very variable in form and structure. The subjoined key based primarily on fruit will aid in distinguishing the genera of this family native to Pennsylrania:

\section{KEY TO THE GENERA.}

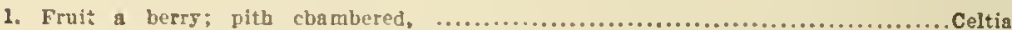

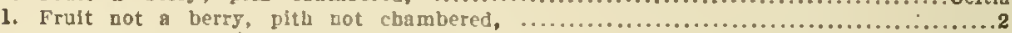

Page.

2. Frult dry, a samara. Winged all around; flowers mostly polygamous, sap not

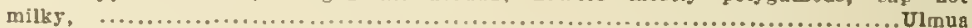

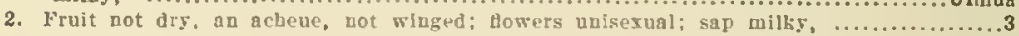

3. Frult elongated, edible; leares dentate 3.nerred; brazebes uuarmed; totb staminate

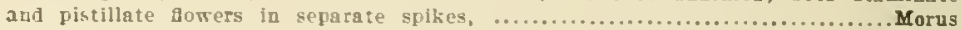

3. Fruit roud, not edible; leares entire; brancbes armed; staminate flowers in racemes.

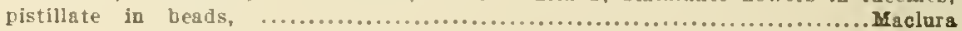




\section{THE ELMS-ULMUS (Tourn.) Tinnaeus.}

The members of this genus are usually trees, rarely shrubs. About 15 species are known of which number 6 species are native to North America and 2 to the State of Pennsylvania.

The leares are simple, alternate, two-ranked, straight-reined, and unequal-based. The flowers may appear before or after the leaves. The 2 species native to this State produce their flowers early in spring before the leaves. The fruit of the native species ripens in spring shortly after the flowers have matured. It consists of a flat seed surrounded by a thin papery wing.

The trees yicld raluable rood and some of them also produce a tough inner bark which is used for food, in medicine, and manufactured into lopes and coarse cloth. The Elms are not only valuable commercially but also attractive ornamentally. The native American Flm and the introduced English Elm (Ulmus campestris L.) are not only beautiful in summer when covered with a dense foliage but also in winter when the little twigs and branches, and the nassive trunk and limbs stand out against the sky. The subjoined key will aid in distinguishing the two native species of Elm and the commonly introduced English Elm:

\section{SUMMER KEY TO THE SPECIES.}

1. Leares amooth abore or nearly so; frult orate or oral, cillate on margin; fowera on slezder drooplag stalks, ...................................... U. americana

1. Learea rery rough abore; frult clrcular, not clllatc; forers nearly sesslle, ..........2

2. Small to medium-sized natire tree; Inner bark mucilaglnour; branchleta and pedicels downy; frult deosely brown-hairy orer seed, ........................... U. fulva

2. Large Introduced tree; Inger bark not mucilaginoas; branchlets and pedicels smooth; frolt smooth throughout, ..................................... campestris

\section{WINTER KEY TO THE SPECIES.} 1. Bud-scales densely browa-halry; Inner bark mucilagloous; twlgs graylah and rough,

1. Bud-scales not densely brown-halry; inner bark not wucilaglnous; twiga not grayish nor rougb,

2. Bada chestaut-brown; bud-scales wlth darker margin; bark ridged; twiga without corky ridges; form of the tree decidedly deliquescent, ................ O.americana

2. Buda smoky-browa to almost black; bud-scales rather unlform in color; bark rather frm, often roughened into oblong blocks; form of tree intermediate with an excurreat teadency, 


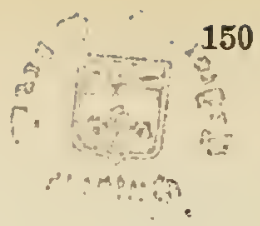

\section{SLIPPERY ELM.}

\section{Ulmus fulva, Michaux.}

FORM-A small to a medium-sized tiee usually attaining a height of $40-60 \mathrm{ft}$. witb a dismete: of $1.23 \mathrm{ft}$. but may reach a maximum height of so 1 . w!th a diameter of 23 feet. Crown broad and flat-topped. Limbs stout and ascendiog.

BARK-Thlck, rough, longitudinally fissured, dark brown, tlnged with red within. Inner bark fragrant, mucilngincus and slippery. whence its common name. See Fig. 66.

TWIGS-Rather stont, difficult to break on account of flexible bark, at first halry and greenisb, later smoother and grayish-browa, roughcned by raised lenticels and raised leap. sсaгs.

BUDS-Alternate; termlaal bud absent; orate, ahout of an Inch long, dark chestaut-brown, corered with about 12 orerlapplng bud-scales conted wlth rusty brown baira. Flower-buds atout and located along side of twig while leaf-buds are relatively slender and located towards end of twig.

LEAVES-Alternate, simple, 5- $\pi$ Inches long, oral to oborate, thick, dark green, rongb on both sides, rounded and oblique at base, acute at apex, doubly toothed on marglo.

LEAF-SCARS-Alternate, nval, raised, lighter than twig, contain usually 3 rather amall and inconspicuous bundle-scars.

FLOWERS-Appear betore the leares from lateral propagative luds. The smaller regetative buds located near the end of the twigs open later. Flowers are perfect and clustered on short stalks.

FRUIT-A short-stalked samara 3.7 of an lncb broad, coaststing of a flat seed surrounded by a wing and maturing in spring a few weeks after the flowers bare matured. The fralt is balry only over the seed.

WOOD-Klag-porous; with rather indistinet medullary rays; pores of the summer wood arranged iu tangentinlly concentric bands; pores of spring wood form a broad band of 3 or more rows. Wood is hears, hard, strong. dark brown to red, conrse-textured, easy to split, very durable In contact with the suil. Welghs 45.35 lbs. per cubic foot. Used for poata, railway ties, slack cooperage, agrlcultural implements.

DISTINGUISHING CHARACTERISTICS-The Sltppery Elm, also known as the Red EIm and Moose Elm, can be distlnguished from the other Elms of Pennsylvanla by its fragrant and mucilaginous jnner bark and its dark chestnut-brown buds corered with rusty brown pubescence. It is a smaller tree than elther the American or the Engllsh Elm. The leaves are rough in both directions while those of the American Elm are rough only in one directlon. The bark Is not so rough nor the buds so dark colored as those of the English Elm. Its lateral branches are rather straight while those of the Amerlcan Elm are drooping.

RANGE-Valley of the St. Lawrence, south to Florida, and west to North Dakota and Texas.

DISTRIEUTION IN PENNSYLVANIA-Scattered locally throughuut the state. Generally absent in the mountainons region. Most common in the ralleys. Does not form pure stands.

HABITAT-It is commonly found on low rich suil, along streams, and on billsides. In the southern part of Pendsylisia common on llmestone outcrops.

IMPORTANCE OF THE SPECIES-This tree does not attaln a large size nor grow io habliats where other more valuable species will not grow, consequently it cannot be recommended for extensire planting for forestry purposes. It may be recommended for limlted planting in wet places, especially on the border of streams and on limestone onterops. 


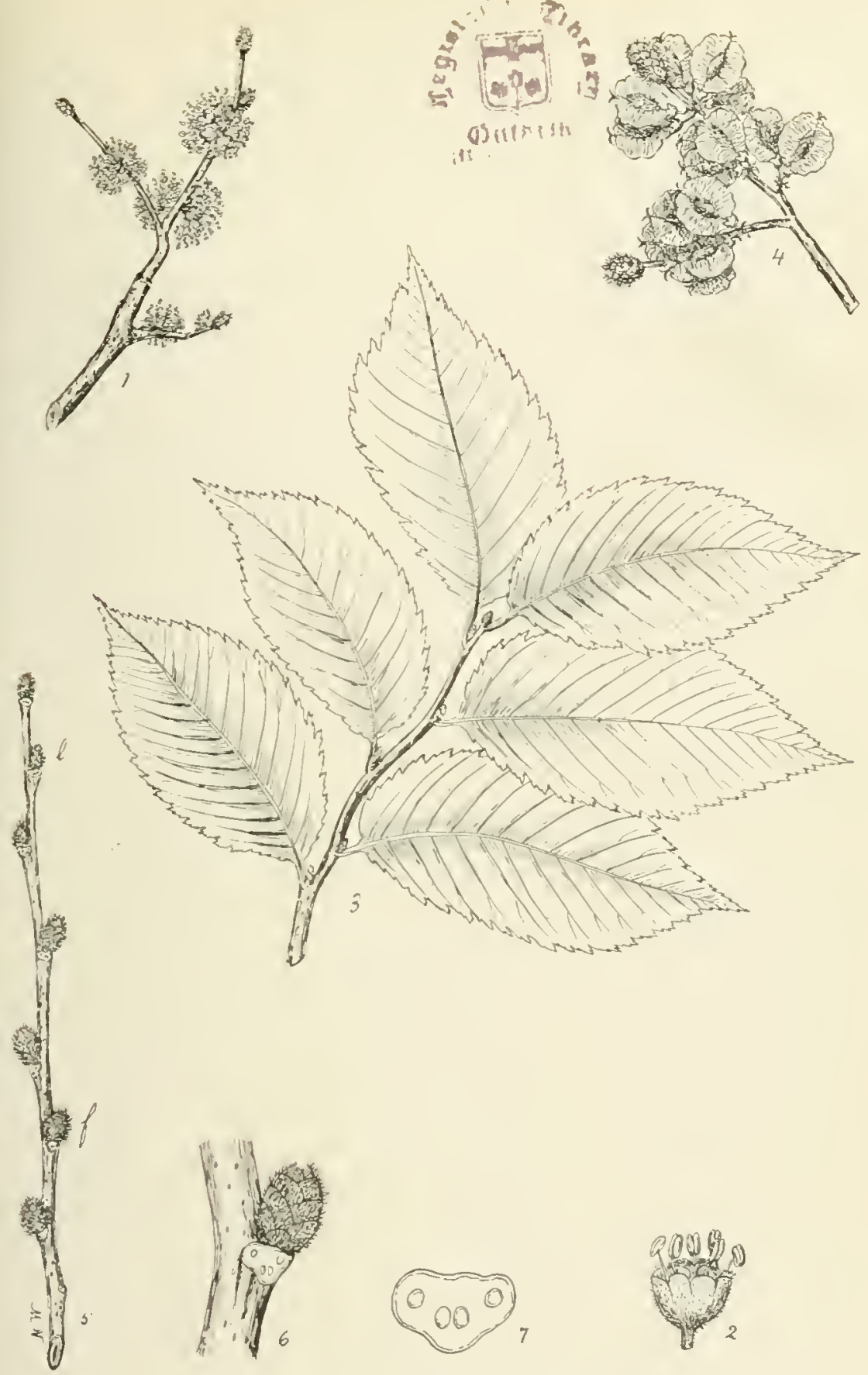

PLATE LXXI. SLIPPERY ELM.

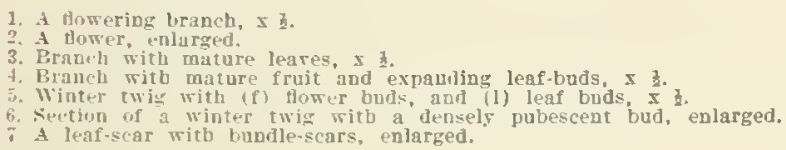

3. Brsnell with mature leares, $x$

4. Branch witb mature fruit and expanding leaf-buds, $x$.

6 . Spetion of a winter twig witb a densely pubescent bud, enlarged.

- A leaf-scar witb bundle-Ecars. enlarged. 

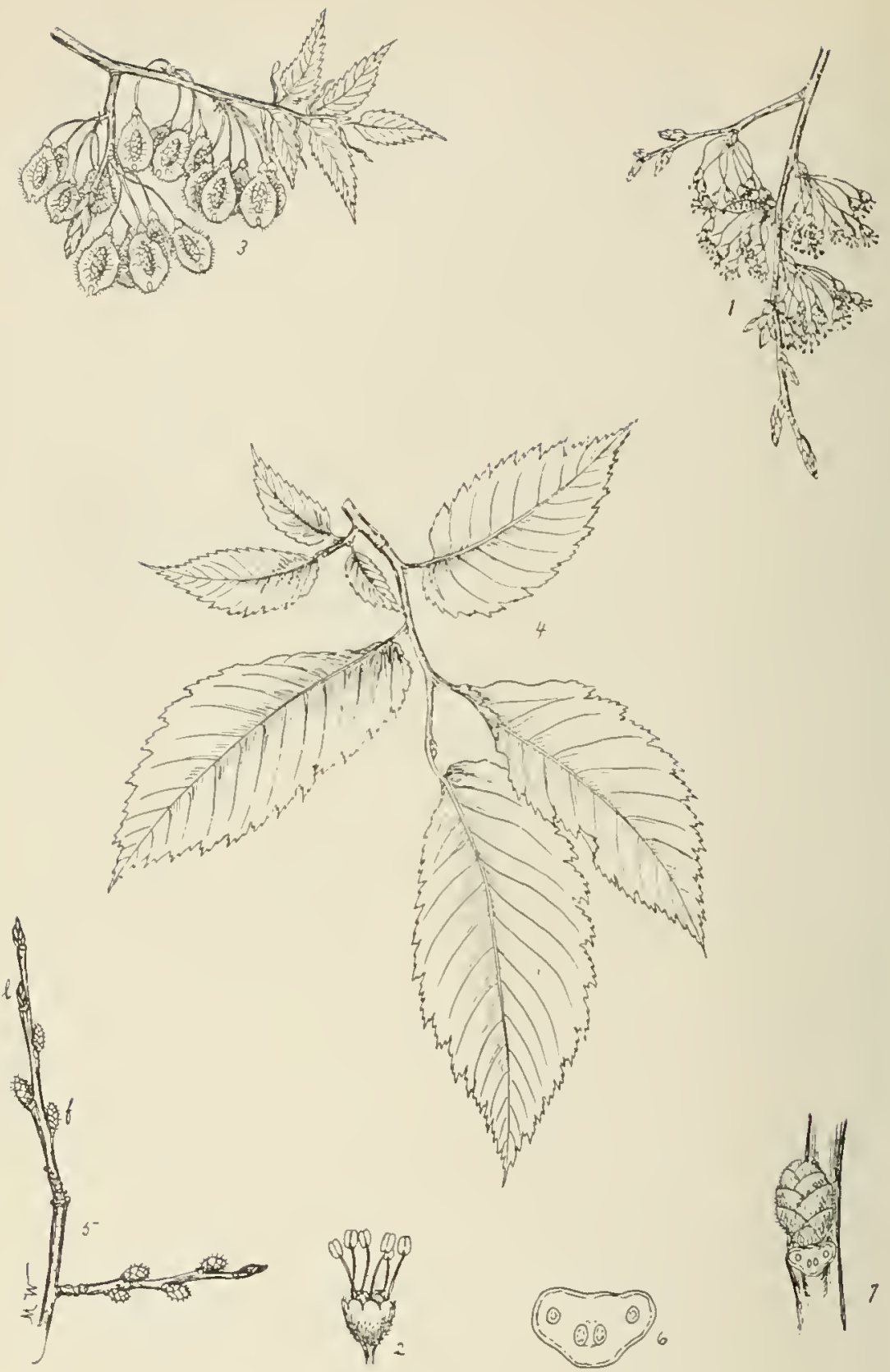

PLATE LXXII. AMERICAN ELM.

1. Whwering branch witls lataf buk, $x \quad 3$.

2. A flutrer, enlarged.

Prauch witl mature fruit, immature leates and an expandiog bud. $x$.

4. Rrancb with mature leaves. $x$ z

5. Winter twig with (f) flower buds, and (1) leaf buds, $s$ is

7. Sertion of a wintur twig with a slightly pubescent bud, enlarged. 


\section{AMERICAN ELM. \\ Ulmus americana, Linnaeus.}

FORM-A large tree asually attalning a helght of $80.100 \mathrm{ft}$. Whth a dlameter of $2-4$ t., unt mas reach a height of $120 \mathrm{ft}$. With a diameter of 8.11 feet. A tree In Jefferson connty. Pennsylvanla, reached a belght of $1.10 \mathrm{ft}$. and bid a crown kpread of if feet. It cnt aimost 9,010 board feet of lumber. The form is very varlable. The most common kinds whleh are recozaized are "Yase Form," "Umbrelin Form," "Oak Form," and "Feathered Form," Some trunks are rall and straight terminnted by a shallow but brond crown composed of rery gracefully drooping lateral branches. In open grown trees, the trunk often difides nent the ground. The form may resemble the spray of a fountain. See Fig. 35.

BARK-Rather thick, graylsh whence its name Gras Elm, rougher by long and 1rregular furrows separatlog ratuer lroad, flat ridges whlch are usually firm but occasionally flaky or corks. Cross-section of bark often shows alternating white and brown layers.

TwIGs-Siender, at Arst greenish and pubescent, lnter smooth and reddish-brown, runghened by leat-acars and pale, Inconsplcuous, scattered lenticels. Base of trigs marked with persistent ring-jike bud-scale sears.

BUDS-Alternate; terminal bod absent; orate, sharn-polnted, sllghtly pattened, reddishbrown, visully smooth, rarely slightly huirg, corered with about 6.10 overlapping reddishbrown scaleg with darker margin. Leap-buds are smalier than the flower-buds and lochted tomard end of twig. Flower-buds are inrger and located along glde of twig. Buds are nsuslly located abore one end of leaf-scar.

LEAVES-Alternate, simple, orate, t-6 Inches long, thlek, rough, unequaily based, acute at aper, doubly-toothed on margin. Frimury velug run atraight from mldrib to polata of the teeth.

LEAF-SCARS-Alternate, 2-ranked, elevated, seml-clreular, with corky surface, marked with three equldistant bundle-scurs which mas be componaded and are usually sunkea.

FLOWERS-Appear before the leares from lateral propagatire buds. Flowers occur in $3-4$ fowered clusters on drooping stalks nbout 1 inch long. Thes are perfect with greenlsb calyx, seddlsh anthers, and light green styles.

FRUIT-An oral samara, nbout th of an lach long, borne on a slender stalk; consists of a fat sced surrounded by a wiog which is terminally deeply notched and elllated on margin. Matures enrly in spring shortly after bowers.

WOOD-Somewhat similar to Slinpery Elm, page 150, bnt difera sligbtly. Weighs 40.54 lbs. per cubic fout, is lighter in color thm slippery Elm, and has itg pores In spring woor In a varrow band of usually less thnn 3 rows. Its wood has a wider range of usefalness.

DISTINGUISHING CHARACTERISTICS-The American Elm, aiso known as White Elm, Gray Elm, aud Water Elra, can readily be recognized by its leaves whlch are smooth on the upper surface, and by the oval fruit with cillate margin. The flowera occur on slender drooping stalks. The buds are only alightis pubescent and covered witb the chestnut-brown scales. The form and method of braochlog are rery distinctle. Also gee "Distingalshing Charactes istleg" nnde: Slipperz Elm.

RANGE-F'ew trees hare so large a range. It extends from Newfoundland acrosa Canada to the Rockg Nountains a distance of almost 3,000 miles and south to Florlda and Texas, a distance of 1,200 miles.

DISTRIBUTION IN PENNSYLVANIA-Found locally thronghout the state. Most commop in the well watered portlons. Less frequent in the mountainous parts.

HABITAT-Prefers rieb moist bottomlands. Ia commoniy found along streams, bordering lakea nd ponds, and in rich allurial soll. Usually mixed with otber hardwoods.

IMPORTANCE OF THE SPECIES-The Americao Elm is the most raluable of all the Elma

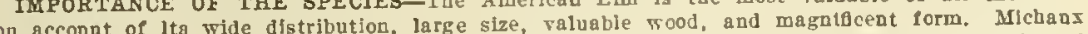
on accont of Ita wide distribution, large size, valuable rood, and " It has not been planted called it "the moat magniflcent regetable of the temperate zone." It has not been planted much for forestry purposes but deserres to be pianted, especially on rieh soll whlch may be too
wet for agricaltare. It must he planted close in order to prereat the derelopment of lateral branches. 


\section{HACKBERRY. \\ Celtis occidentalis, Linnaeus.}

GENUS DESCRIPTION-The genus Celtis comprises sbout 60 specles, of whlch number about 9 are native to North America and 1 to Pennsylrania. Representatives of thls genus are found in temperate and tropical regions of both the eastern and restern hemispheres. Another species knowu as Rough-leared Hackherry (Celtis crasslfolla, Ismarck) is also reported from 3 counties in this State. The leares of the latter are rery rough and the fruit is snbglobose.

FORM-Usually a small tree 20-35 ft. in height, hot single specimeng with a helght of $8 \mathrm{C}$ ft. and a diameter of 30 inches hare been reported for this State. In the Sonth It becomea larfer. Trunk usually short. Crown rather wide-spreading and round-topped. Witches' brooms sre Irequently tound uron it.

BARf-Grasish-brum, sometimes as smooth as Beech bark, others have rery rough bark due to harkh, warty projectlons. Younger branches are dark brown to redalsh-brown in color. Sec Fig. 102.

TWIGS-slender, somewhat shiny, occasionalls slightly downs, brownish, corered by acattered raised and often longitudinalls-elongated lenticels; contaln chambered white pith.

BUDS-Alternate, 2-ranked, small, often malformed and swolled, f of an loch loog, orate, starp-poloted, appressed, corered with $3-4$ risihle and ciosels orerlapplng bud-8calea. Bud. scalea sometlmea longitudipally-striated and dark margined. Swolien buda caused by insects.

IEAVES-Alternate, simple, orate, 2-4 inches long, acute at apex, obliquely rounded at babe, serrate on niargin, entire near base, rough on upjer surface, with prominent prlmary velna. Petlolea slender, slightly bairy and grooved.

LEAF-SCARS-Aiternate, 2-ranked, small, semf-oral, at or alwost at right angles to twig on projecticns of twig, with I.3 bundle-acars,

FLOWERS-Appear about May. Three kinde, staminate, pistllate, and perfect, may be found. Tbey are greenlsh and borne on slender drooping stalks.

FRUIT-A berry-like, dark purple, globular drupe about with peralstent style and borne on s slender stalk. Matures about September and often persists into winter.

WOOD-Rirg-porous; rays rery distfoct; pozes in summer wood arranged in tangentially wary bands: hears, not strong, coarse-gralued, Jellowlsh. Weighs 45.51 lbs. per cubic loot. Used for fencing, crates, boses, slack cooperage, hoe hasdles, agricultural implemeata. Resembles Ash. Yost mills sell it as Asb.

DISTINGUISHING CHARACTERISTICS-The Hackberry, also known as Sugarberry, Nettletree, Hoop Ash, and Hack-tree, can be distingulshed by its chambered plth, herry-1ike iruit, warty or corky bark and disflgured twigs and bude. Abnormally awollen twigs are due to stings of gall insects. Witches' brooms are also common and rery distinctlve. The leares resemble those of the Eims onls are sharper pointed.

RANGE-Its range corers abont 2,000,000 square miles in the Dnited States, ertending over the major part of the United States east of the Rocky Monntains.

DISTRIRUTION IN PENNSYLVANIA-Occasional throughout the State. Nowhere abundant. Sometimes onls a single tree is known in a locality. Large speclmena are fonnd in North. ampton and Montgomery connties.

HABITAT-Prefers rich moist soll, but also grows an grarelly uplands. Doea not form Iure stands, but usualiy occurs solitars.

IMPORTANCE OF THE SPECIES-The Hackbers is of little commercial importadce in this State since it is a rare tree and seldom reaches a large size. Oaly a lew large trees bare been recorded in this state. It cannot be recommended as a timber tree, nelther bas it any specialls attractive oroamental qualities. Its continulty is insured becauae tha birda carry tha geed far and wide. 

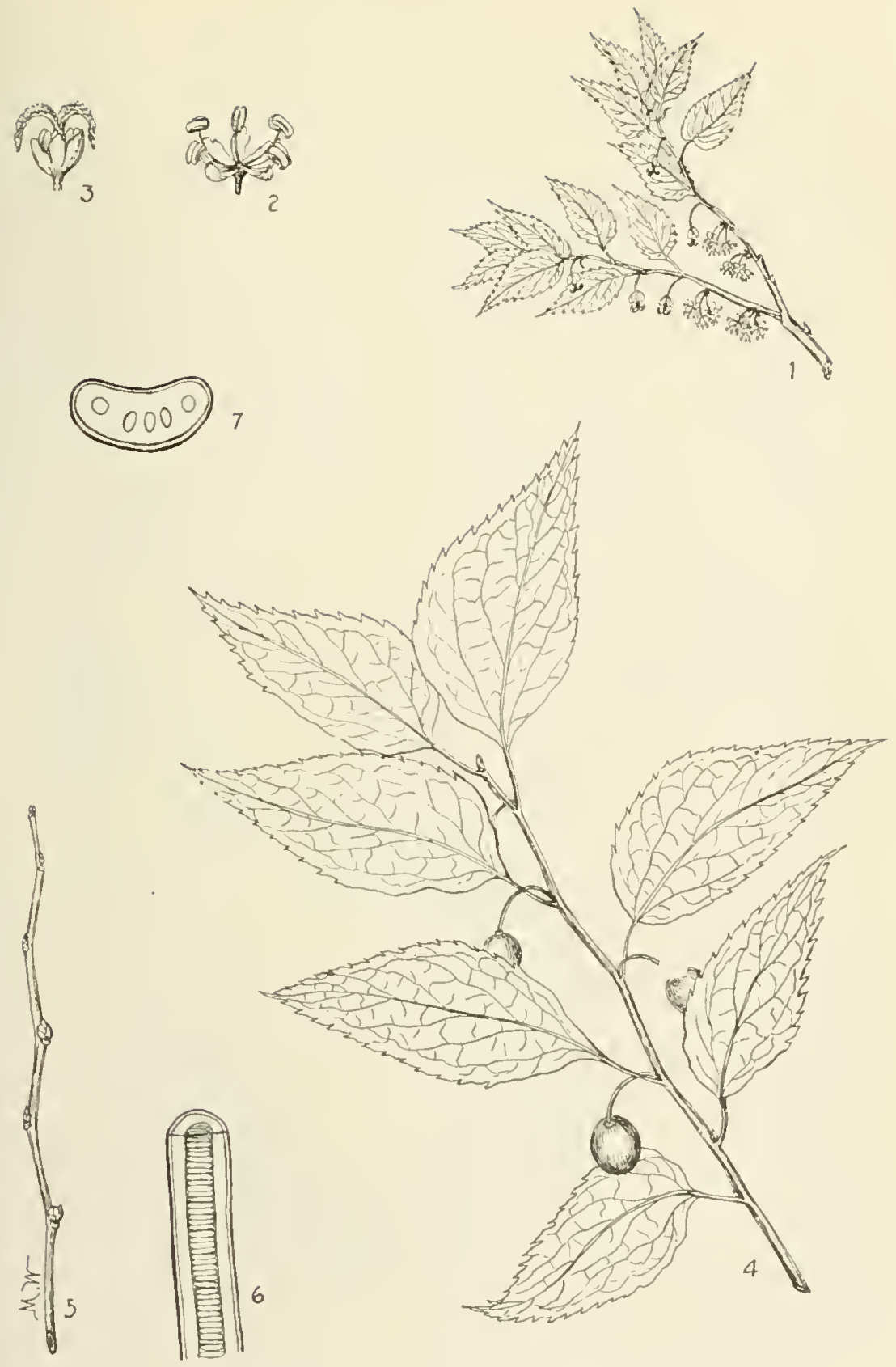

PLATE LXXIII. HACKBERRY.

1. Brunch with immature learus, staminate and pistillate flowers, $\mathbf{z}$.

2. A staminate tower, enlarged.

3. A pistillate flower, enlarged

4. A tranch with mature leaves and mature fruit, $\mathbf{x}$.

5. A winter twig, ${ }^{2}$.

7. A leaf-scar witl bundle-scars, enlarged. 


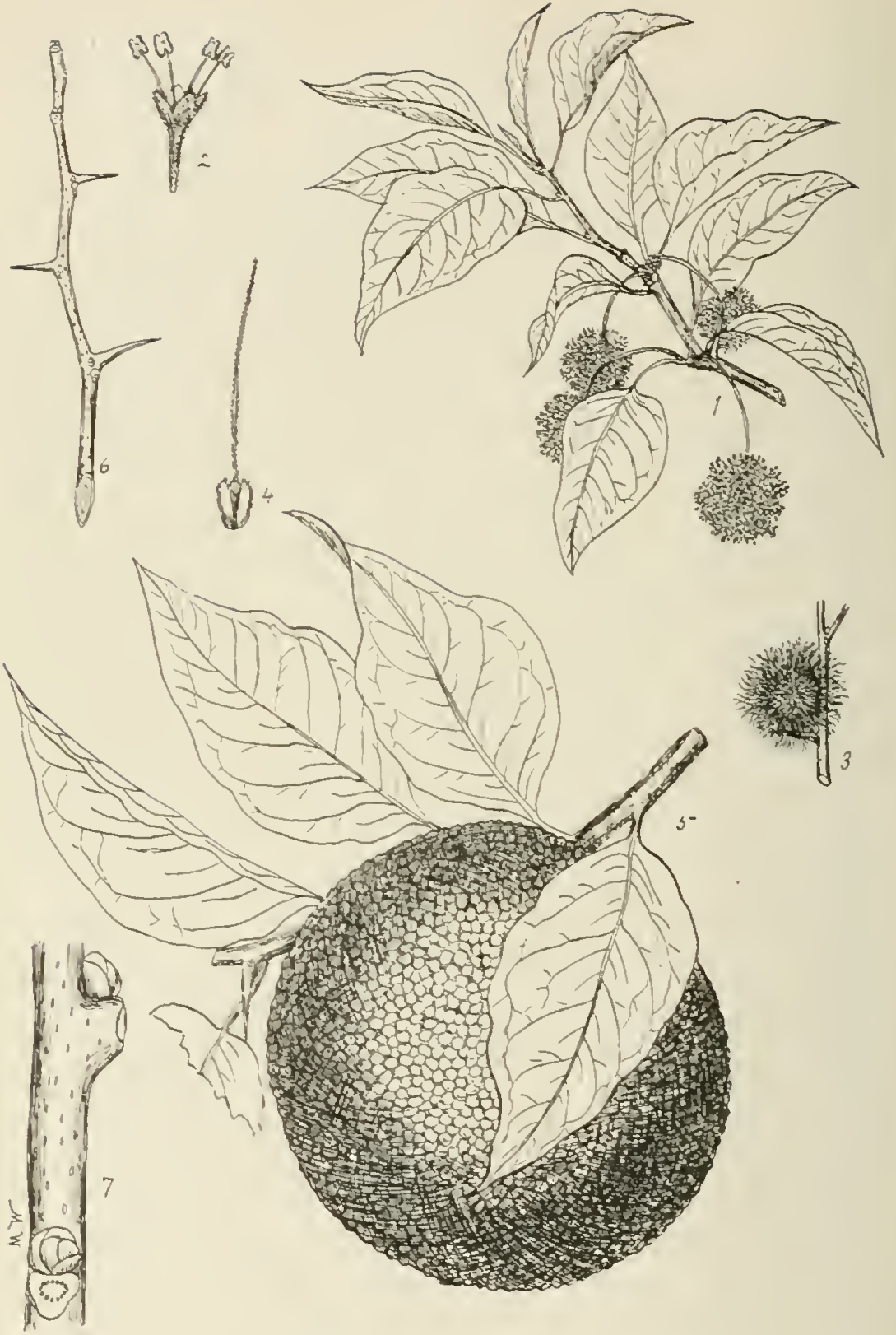

PLATE LXXIV. OSAGE ORANGE.

1. Beandi with immature laves and beats of stamiuate thowers, $x$.

3. A staminate Hower. enlarged.

4. A pistillate motrer. enlarged.

5. Brancla with mature leares and a single mature fruit, $x$ z

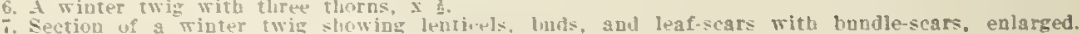




\section{OSAGE ORANGE.}

\section{Maclura pomifera, (Raf.) Schneider.}

GEXUS DESCRIPTIO:-The species cescribed on tbis page is the sole repiesentatire of thls genus.

FORY-A small or mediom.slzed tree usualls attalnloz a belgbt of $20-40$ et. With a diamete: of 12 lncbes but resches a beight of $50-60$ it. Fith a diameter of 2-3 foet. Trunk usualy short, stcut, often corered with deare grawth of Erronts. Crown ronde-topped, rather

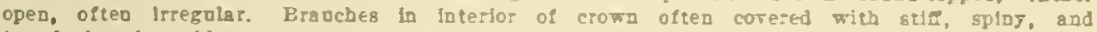
interlaciaz brancblets.

BARK-0n older tranks rough, dask gray, about \$-1 fnch thick, longltudinally and sometimes

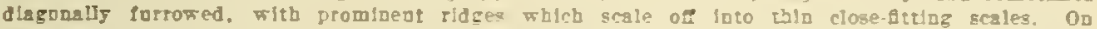
trancbas it is thinger. pale browa tigged with jellow. Branches are ofteo aroned with stralght arllars splaes and contain sellow pitb.

TWIGS-Ajternale, rather stont, at first zieenjab and glightly pabencent, later jellowsh. kroxn, contala jellow plth, marked by pale jellow lentlcels. Younger braches are often armed witb stoot, stralgbe, arllarg spioes aod stout, spor-like, lateral branchlets.

BUDS-Altemate; fermInal bnd absevt; equal-sizad, bromd, circular, with 5-7 gmall chestrat brown scales.

LEAvES-Alteroate, simple, about 4 Inches long and 23 lacbes wedge-shaped at base, acute at apex, entre on magin, dark green abore, pale green below.

IEAF-SCAES-Altermate; located on twis enlarzement at aodes; small to medium-sized, brosdly trlenguis to ellntlcal. contaln pandly 1 o: 3 bundle-sesis, sometimes more.

FLOFERS-Appear abont Jome when leareg are almosi inlly dereloped. Stamlate Lowers arranged is racemeg on long sleader drooplag stalks; plstlllate in dense beads wibh stort stalks. Orang la terboloated hy a long, slender, balrg style.

FRUII-Pale green, orange-like in appearance, 4.5 focheg in diameler, composed of masr small drapes which are closely grown together. When panctured eradeg a miky falce which tarng black npot exposure.

WOOD-Rigg-porous: rays racher inconsplcunas; golden-jellow is color, streaked rertically Wlth red Etulpes; hears, rery bard and stronz. res dorable. Welghs 45.21 lbs. pe: cublc foot. Ceed tos lence rosts, wazon felloes and rlms, bridge piling, insulator ping, pollce clubs, rustlc cbalrs, and tobacco plpes.

DISTIFUISHISG CHABACTERISTICS-The Osage 0razze, also known as Bowwond. Osaze Apple-tree, Iellow-mood, and Hedge-tree, can be distingulabed by lts larze oranze-like greer 1rult. The twigs are armed with stout stralght axills spmes, contaln a milky fulce and tilck orange-colored plth and are corered with a light brown bart sometimes tinged with o:acze. The leares are altemste, aimple, and entle. Tood is rerg bard and orange to brown in colo: with light jellow sapwood.

RAKGE-O\&latoma sooth to Dalles, Texas. Also reported from Albansas. To date it has beeo planted in possibly every State in the Colos.

DISIRIELIIOX IX PESTSIIVAXIA-Introdnced in fractlealig ere.y part of the State as a bedge or ormamevtal tree.

RABITAT-It Is less exacting in soll than most of our trees, but when it has che privilege It chooses the best. In Its natural range it thrires best on the black fercile ists, agd rarely occurs on sandy soll. Occasionally found in skamps. Otfginslly foudd in sIsll pure stands.

IMPORTEXCE OF THE SPECIES-The Osaze Orange is ad oatire to Peorgylrala but bas been plated extenslrely for bedge and ozamentsi parpases. No wocd is mo:e raluble for fence post. We bare otbe: trees whlch are more atractire as a bedge and the thorns whicb the tree bears are also objectionable when it 15 used as 8 bedge. It is difficalt to ellowleate it trom as area wbere it bas established itself. 


\section{RED MULBERRY.}

\section{Morus rubra, Linnaeus.}

GENUS DESCRIPTION-The gean Morus comprises abont 10 speclea of which namber 3 are natire to North America ad 1 to Penasflrania. Its representatires occar as treea or shrubs in eastern North America, Ceatral America, Soutb America, and Earope but are most abuadant in Asia. The White Mulberry (Morus alba L.), a natire of Aaia, baa been planted exteasiraly in thls State.

FORM-Usually attaing a beight of $35-50 \mathrm{ft}$. with a diameter 12.18 incheg bat mas reach a height of $70 \mathrm{ft}$. with a diameter of 3 feet. Largest in Ohio and Mississippl valleys. Trunk asually short, subdiriding near the ground. Crown usually broad, round-topped, and dease.

BARK-Begias to roughed about third sear by splitting longitudinally or diagoaally. 0 n older truoks rather thin, dark grayish-brown, peels off in long oarrow lakes which somewhat resemble the flakes of Catalpa. See Flg. 55 .

TWIGS-Stont, smooth, gloss 5 or occasionally dull, slightly zigzag, greenish-brown tinged with red, enlarged at oodes to bear bads and leares, corered with few scattered loconspicuons lenticels, rougheded at base af season's growth by ring-like bud-scale acars. A wilky jaice is excreted from twigs if they are cut or punctured.

BUDS-A1terate; termiaal bud absent; orate, ronad in cross-section, sharp-nointed, about 2/5 of an inch long, sllghtls dirergent and laterally lnclined, corered by 3-9 exposed bad-scales which are 2-ranked, greenlsh-brown to greenish-red with darker margin. Bads are located on twig enlargements. A bud is ofteg found at ead of twig; it is aot a termianl bud but an axillarg one sometimes called a pseado-terminal bud which meaga a false terminal bad.

LEAVES-Alterate, slmple, orate, 3.5 inches long, often cordate at base, serrate on margln, acute at apex, usualls with 3 primars reias, except in lobed forms where more may be present. Usually not lobed but occasionalls glore-form, 3-1obed or 5-lobed. Leareg are slightly rough on upper surface.

IEAF-SCARS-Alteraate, 2.ranked, ralsed on twig enlargements, bollow or concave, almost circular, w!th ratsed bunde-scars arranged in an ellipse or distrlbuted irregularly orer leat-sca:

FLOWERS-Appear Jay or Juge. Stamlate fowera occar in aarrow splkes about 2 inches long origlnating in axils of prospectife or dereloping leareg on short hairs green stalks. Pistillate flowers occur in dense spikes about I lnch long. Occasionaily the staminate and plstiliste arc slightls mixed or a spike.

FRUIT-Appears about Juls. Componad or ageregate, about 1 Inch long, composed of many small drupes, at first green, later red, foalis dark purple, juics, sweet and edible.

WOOD-Rigg-porous; pares in summer wood small lo groups of 3-6; raya nanally quite distinct; oragge rellcw to rellowish-brown, with thin negrly white sapwood; soft, not strong, durable in costact with soll. Weighs $3 G .75$ iba. per cabic foot. Lsed for fence posts, scythe snatba, cooperage, bcat building.

DISTINGUISHING CHARACTERISTICS-The Red Malberry, also kaown as aimply Malberry and sometimea Black Mulberry, can be distinguisbed by its large alteraste 2-ragked greenish. bnown buds with darker colored bud-scale marging, by its 3-relaed learea wblch hare their veins sunken on apper surface, and are usually rough on the opper sarface. The milky jaice of the twiga and it3 pecaliar flowers and fruit are distinctire. The leares are occaslooally lobed. In winter the elevated and hollowed leat-scara witl bundle-scara arranged in an ellipse are characteristic.

RANGE-MIassacbusetts to Florida, west to Kansas and Nebraska.

DISTRIEUTION IN PENNSYLVANIA-Iocal aDd sparse to the eastern and aouthern parta, occasioosl in the central part and rare in mouatainopa parts.

HABITAT-Prefers rich moist soll. Yost common in ralleys and on foothills. Usaally mixed with othe:" bardwoods.

IMPORTANCE OF THE SPECIES-The Red Sulberry does not produce wood of any special commercial fmportance because it is nowhere abundant and does not reach a large aize. It is used for feace posts becanse it ia darable in contact with the soll. The wood resemblea Black Walnit nheg polished, oaly is somewhat lighter. It produces a pleasing effect when made up Into furalture. It cannot be strougly recommended for forestry porpoaea but it la an excellent ornameatal tree and also furnishea food for birds. 

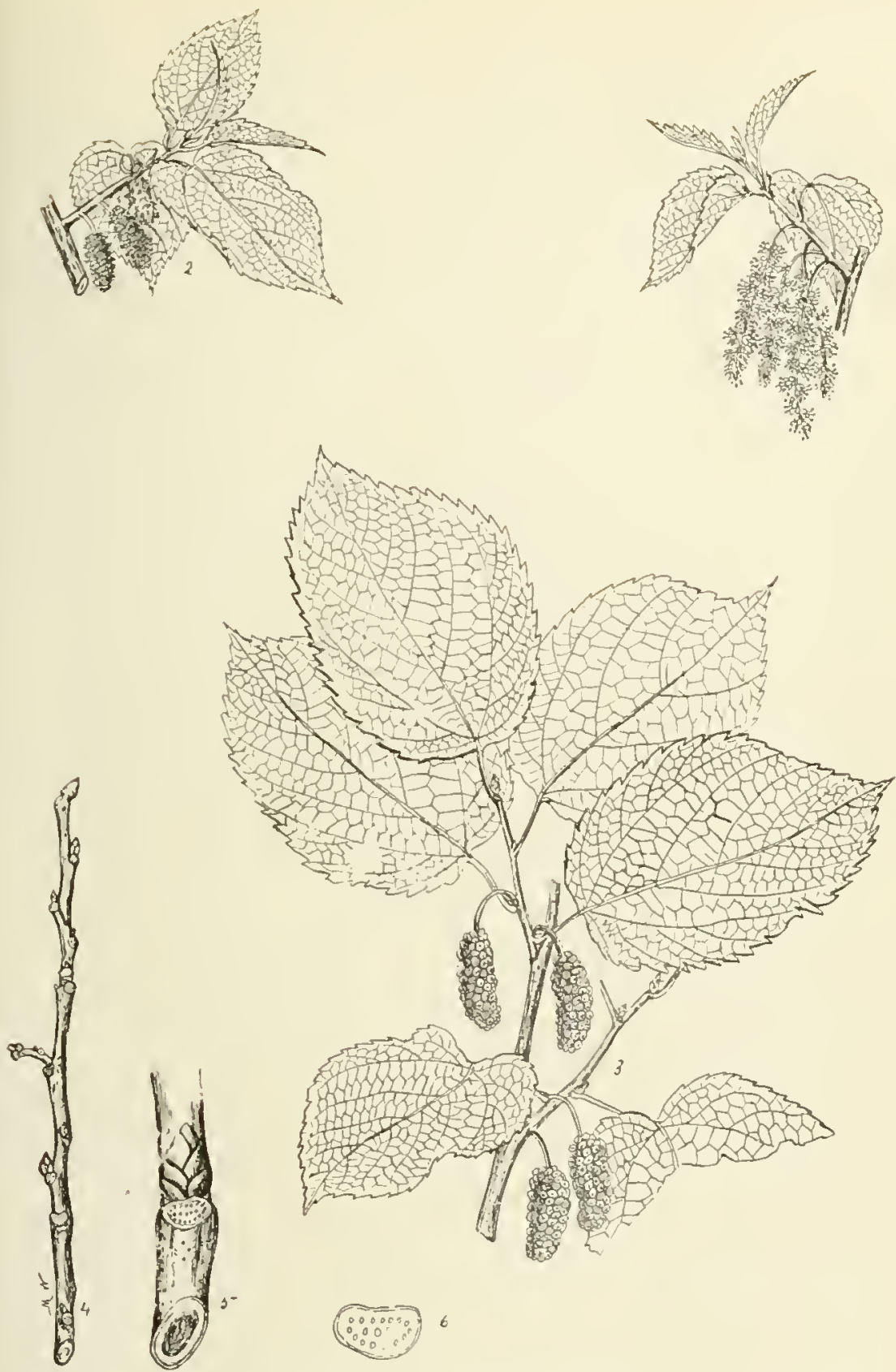

\section{PLATE LXXV. RED MULBERRY.}

1. Branch with immature levers and four staminate fotwer spikes, $x$ t

2. Brancla with immature luses and threw jistillate flower spikes a

3. Branch with mature leares and mature fruit, $x$

4. A winter twig. $x$.

5. Seetion of a winter twig, enlarged.

5. A leaf-scar with bundle-scars, enlarged. 



\section{THE MAGNOLIA FAMILY-MAGNOLIACEAE.}

The Magnolia family comprises about 10 genera with about \$5 species of trees and shrubs, which are widely distributed in temperate and tropical regions. The flora of North America embraces 4 genera, 2 of which comprise only shurbs while the other 2 contain some of our well-known and irmortant timber trees. The 2 arborescent genera, Magnolia and Liriodendron, include about 9 species in North America. Both genera are represented in the flora of Pennsylvania, the former with 3 species and the latter with 1 species.

\section{KEY TO THE GENERA.}

1. Leaves not lobed; truit a cone of teshy cohercnt follicles; buds orate to conlcal, sharp-polnted, hairy at lenst withln; leal-scars luate to oral usually wlth 3 ,

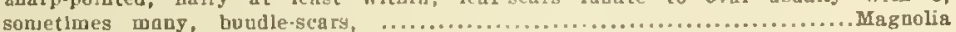

1. Leares 4-lobed or G-lched; frult a spinale-shnped cone of ary enrpels; buds flattened, oblong, blunt-pointed, smootb hoth ou outslde and fnside; leaf-seurs circular or sometimes slightly fluttered at top wlth mang seattered bundlescars, Liriodendron

Page.

\section{THE MAGNOLIAS-MAGNOLIA, Linnaeus.}

The Magnolias are among the most beantiful trees native to the State of Pennsylrania. All the Magnolias have the appearance of tropical trees and in fact most of them do not venture far beyond warm latitudes. Their large, entire-margined, pinnately veined leares and their large, solitary and conspicuous flowers are largely responsible for their tropical alpearance. This genus derived its name from Pierre Magnol, a liench botanist, who was sometime Professor of Botany in Montpellier and died in 1715. It embraces about 25 species of trees aud shrubs 3 of which are native to Penn. sylvania. The members of this genus are uatives of eastern North America, southern Mexico, the West Indies, and easter'n and central Asia.

\section{SUMMER KEY TO THE SPECIES.}

1. Leaves crowded at the end of the flowering branches in a umbrellu-like circle,

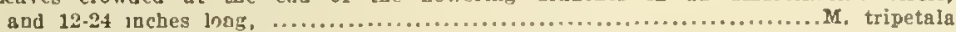

1. Leavez scattered along the hrnnches, and 3.12 Iachea $10 n g, \ldots \ldots \ldots . . . \ldots \ldots \ldots . .2$

Page.

2. Large tree; leares $\mathbf{4 - 1 2}$ inches long aud deciduous; fowers green to fellow; follicles

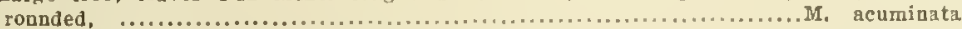

2. Small tree or shrub; leaves 3-6 lnches long, glaucous on under side, often persistent; fowers white; follleles taperlng or tlpped with styles, ............... virginians

\section{WINTER KEY TO THE SPECIES.}

1. Bada 1-2 lucbes long and smooth on outslde; leaf-scars large; twigs stout. M. tripatala

1. Buda less tha 1 lnch long, silky to almost smooth on outside; leat-scara small; twigs aleader,

2. Large tree; leaves decldnona; twigs brown; bark forrowed aad taky; buda blnntpoluted, deasely downy, ............................................. acuminata

2. Small tree or ahrab; leaves maj peralst; twiga greea; bark anooth; buda greea, polnted, balry to amooth. ........................................ virginisna 


\section{LAUREL MAGNOLIA. \\ Magnolia virginiana, Linnaeus.}

FORM-Usually a Bmall tree or shrob seldom exceeding a helght of aj $\mathbf{f t}$. but in the aonth. particulanly in Florida, mas attals a helght of $75 \mathrm{ft}$. With a diameter of 3 feet. In Pennsjlrania rather small. Truak usnally short, often much swollen at the baae.

BARK-On old trunks thin, gray, smooth to sealy; on joung stema light grag to whlte and smooth.

TWIGS-Green, roun, bitter, relatirels slender, downy, later reddish-brown, ronghened by broadly crescent-shaped lea1-вcnra. Pith has a tendency to become chambered.

BUDS-Alternate, bright green, $2 / 5-3 / 5$ of an Inch long, clrcular in croas-sectlon, pointed, decldedly hairs, corered by successlve pairs of stlpules. Each pals of btipulas bcalea entelopes the lenf just ahore it.

LEAVES-Alternate, simple, oval to brondly lanceolate, 3.6 lachea long, obtuse at apex, tapering at base, entiro on margln, glaucous beneath. Fall off in autumn in the North but persist in the South. Persist until spring in Franklin connty, Penusylranla.

LEAF-SCARS-Altern!te, scnttered along twig, narrow, oral to crescent-ahaped, with its hundle-sears arranged In a broad U-shaped line.

FLOWERs-Appear the latter part of May In thls State. Complete, salltary. globnlar, white, calyx nuc corolli of same color, about " inches long, and rery fragrant.

FRUIT-Matures about October. Conelike, derby to drs. scarlet, oral, about 2 inchea long. composed of coherent folllcles. Seeds are red, shing, drube-like and sospended at maturity by a thin long cord.

WOOD-Simliar to that of the Cucumber Tree, page 157, except that Its raya are blgher und more crowded on the cross-section than thase of the Cucamber Tree. Prodncea wood of com. mercial sizt only in the South. Welghs $31.38 \mathrm{lbs}$. per cublc foot.

DISTINGUISHING chaRACTERTSTICS-The Laurel Magnolla, algo known a Small Magnolia, or Sweet Bay, can be distinguished by its leares which nre scattered along the branchea, 3.6 inches loag, oval, ohtuse, and glaucous heneath. The leaves of both the other natire species nre larger. The flowers are globular and whlte while those of the Cucumber Tree are slender-bell-shaped and greenlsh tinged with jellow, and those of the Cmbrella Tree are only slightly sccuted. The leaf-buds are sllky whlle these of the Umbrella Tree are smooth or slightly hairy. Its small elze will also aid in distlngulshing 1t. The "Dlatribution in Fennsylvuin" of the three native specles will also aid in Identifylog them.

RANGE-Eastern Massachusetts, south to Florlda, extending went to Caledonla near Chamhersburg, Penssiranla, central North Carolins and through the Gulf States to Texaa and southern Arkansns.

DISTRIBUTION IN PENNSYLVANIA-Found only in the sontheastern part of the State. Recorded from erers county southenst of a line drawn through Northampton, Iebigh, Lebanon, Cumberland and Franklin countlea. Its westero limit is at Caledonla near Chambersburg in Franklla county.

HABITAT-Prefera swamps and wet places. Found along creeka or in bottomlands adfoining creeks, lakes, or ponds, Often a low shrub uader moisture-aeeklng trees uke Red Japle, Yellow Birch, Black Gum, White Oak, Hemlock, White Pine, and Tulip Tree. Its assoclatea of ten are Rhododendron and Mountaln Laurel.

IMPORTANCE OF SPECIES-Thls species is of no commerclal Importance in Pennsyiranla because of Its small size, limited distribution. slow growth, and inferior rrood. It ia extremely uttractive and may be clnssifed among our most beantiful astire ahruba. It is well adapted for oramental planting, only it growa rather slowly. 


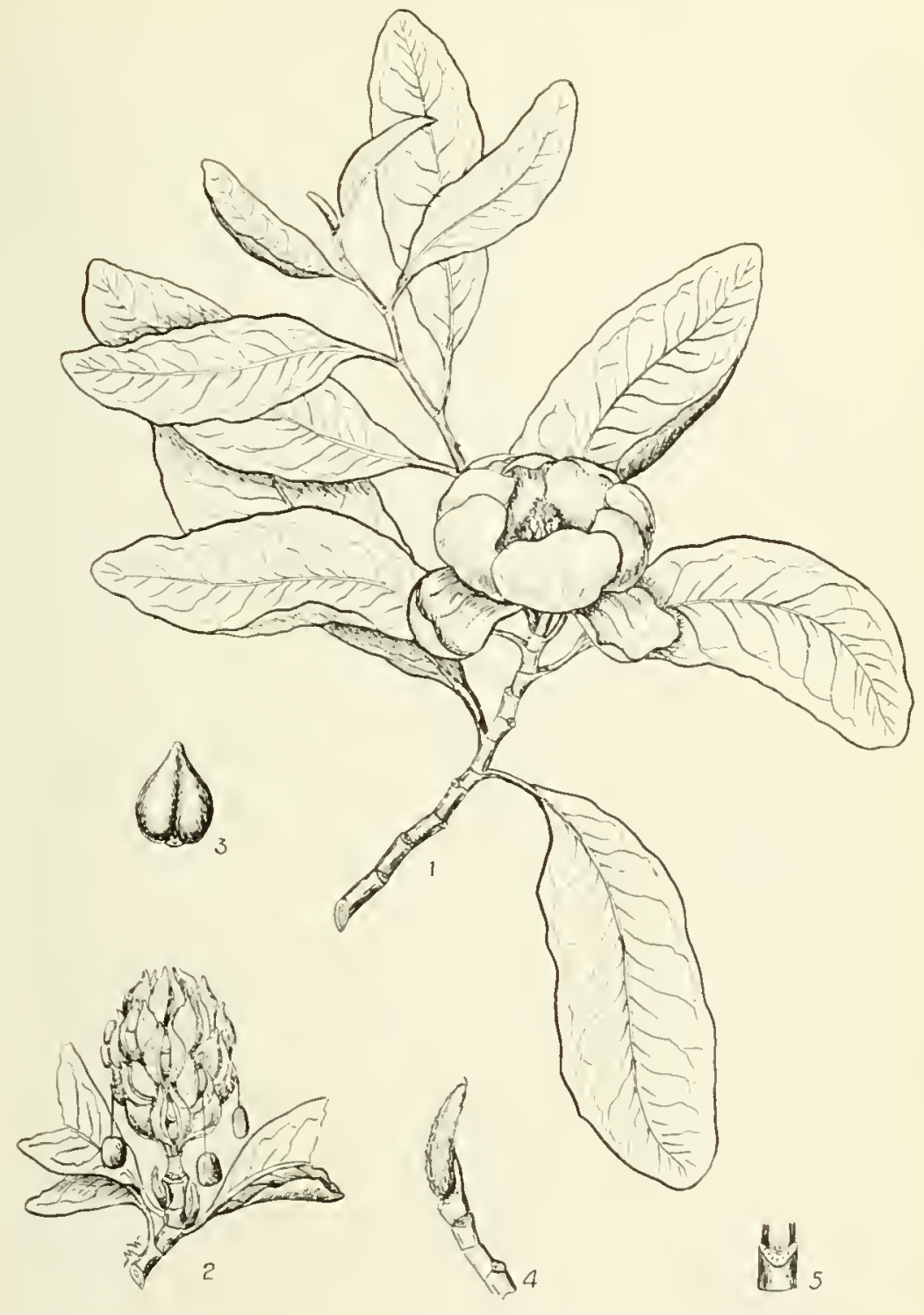

PLATE LXXVI. LAUREL MAGNOLIA.

1. A flowering branch with mature and dereloping leares, $x \frac{z}{3}$.

3. A seed natural size.

4. A winter twig, $x$ i

5. Section of a winter twig sluniug a leaf-sear with bundle-sears, naturnl size. 


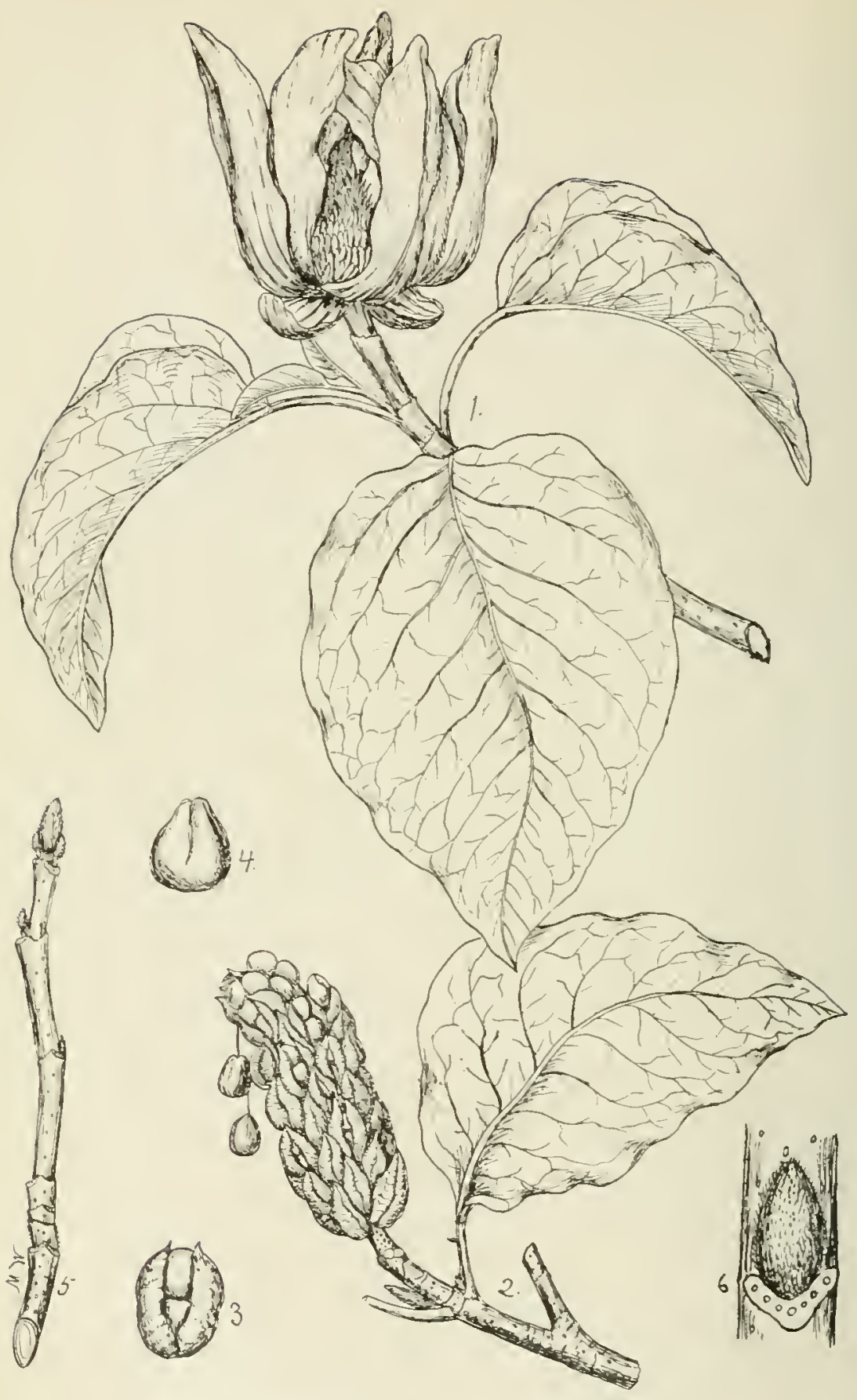

PLATE LXXVII. CUCUMBER TREE.
1. A fumering branc
ing leares, $x \frac{2}{2}$.
2. Branch with a cone-like fruit, seeds banging lar thregds, and g mature lear, r
4. A seed, enlarged.
5. A winter twig. 5 . 5 . 3. A carpel just starting to open, showing two a leaf-scar with bundle-scars, enlarged.

3. A carpel just starting to open, showing two
seeds on the inside, natural size. 


\section{CUCUMBER TREE. \\ Magnolia acuminata, Linnaeus.}

FORM-A lnrge tree, whlch may attain a height of $90 \mathrm{ft}$. With a diameter of 3-4 feet. The form of the forest grown tree is distlnct from the open growD. Open grown speclmeas bave a pyramidal crowa with limbs orlglnatlag all alogg the trunk from dear the base to the Darrow top. Lateral brancheg are wide-spreading and rather borlzontal near the base, ascending and short at the top. Forest grown apeclmens hnve atralght, slightly tapering, rather smooth trunks whlch are free from brasches often for $50 \mathrm{ft}$. from the ground.

BARK-Grayish-biowa to brown, with long furrowa separating loog, rather loose, scaly rldges. See Fig. 85 .

TWIGS-lysully slender, round, asually smooth but sometlmes slightly balrs, sllns, bltter, covered with a few olauge-colored lnconspicuous lenticels, and contaln white pith which may show a teudevey to become chambered.

BUDS-Alternate, elicular In cross-sectlon, densely covered witb thlck, pale, allky balra, terminnl buds about $2 / 5-4 / 5$ of an IDch long nd oblong; laternl buds ef of an inch lopg, bluntpolnted, nearly surrounded by leal-scars. Buds nre corered with valrate scaleg, the outer ones falligg fa sprlug, the Inner oues developing lato atfpulea.

LEAVES-Alternate, simple, ovate to oblong, thin, 4-12 foches long, fointed at apex, tapering or rounded at base, eutire on rargla, green and sligbtly downs bedeath, with prominent midrlb and primary reins on lower aurface. Fnll In respoose to firt heavy frost ln autuma.

IEAF-SCARS-Alternate, acattercd along the twIga, narrow, erescent to broadiy U-sbaped, witb Its bundle-scars arranged Iu a U-ahaped line. Buadle-seara number nbout 6-8.

FLOWERS-Appenr from April to June. They are upriglit, solstary, complete, slender-jellshaped, greedisb tinged with jellow, ahout 3 lncheg long.

FRUIT-Maturea about October. A red, cone-like or cucumber-like, cyllndricnl masa about 2.2l Juches long. composed of numerous coherent follicles. Seeds searlet, diuje-11ke, and auspeuded at maturity by long, sleuder white threads.

WooD-nifuse-porous; rass distinct and rather uniform ln wldth; light, soft, brittle, stralght-grnined, durable, does not warp wheu gensoning. light jellowlsb-brown to redalshbrown; sajwood ls thin and jellowlsh-wbite. Welgba about 20 lbs, per cublc foot. Uaed for interlor finlsh, furnlture, pump stocks, as a substlute for Fellow Poplar, and for the same useg as White Pine. It is not so atrong but more durable than the latter.

DISTINGUISHING CHARACTERISTICS-The Cucumber Tree can be distinguished by its laves which are thln, oblong. joivted nad green bedeath. The lenves are larger than those of the Laurel Mngnolin and smaller than those of the Umbrella Tree. The corolla is greedisb tinged with jellow nud the follicles of the conelike frult are rounded whlle the otber two native specieg bre white flowera nnd tapering follcles. It attains a much larger alze and has sharper-pointed hu:le than the Laurel Magnolia and la considernbly larger than the Umbrella Tree but bas smaller and more downy buds. The bark is thicker and deeper ridged than elther ci the other specles. The twigs are brown whlje those of the Laurel Magnolia are bright green.

RANGE-Western New Fork and southern Ontarlo south through West Virglala to Georgla, west to lllinola and Arkansas.

DISTRIBUTION IN PENNSYLVANLA-Found locally across the State from north to aouth In the mountainous region and on their eastern and westera slopes. Recorded as far east a a Lancaster county and ag far west a Forest and Allegheny counties. Some speclmens pearly $\sigma$ fr. In dameter bare been recorded from the nortbwestern part of the State.

HABITAT-Usually found a rich woods close to streams, also IDhablts slopes. In West Virglnla and is this Stnte it grows well on the soils of the carboniferous formation. It la 11 ght-denianding.

IMPORTANCE OF THE SPECIES-Tbls species is the most important of the Magnolia uatlve to the United States. The wood is similar to that of Yellow Poplar. In nddition to produclng raluable wood it grows rapjdly and is rather free from the attack of destructive agents. The value of the wood alone will justify rengonable efforts in attemptiug to propagate it. It 38 also attractive orpamentally on account of fta large lraves ad aymmetrlcal crown. 


\section{UMBRELLA TREE. Magnolia tripetala, Linnaeus.}

FORM-A small trec sometimes attaining the height of $45 \mathrm{ft}$. With a diameter of 16 inches. Trunk sloort and slender, bearing a beod rond-topped crown. Iateral branches stout and spreading, often turned op towards the end.

BARK-Smooth, thick, light gras, ronghened by small irregularly seattered projectiong.

TWIGS-Stont, smooth, shining, at first greenish, later reddish to greenish-brown; hitter, swollen at the base of each jear's growth, corered with a few conspicons lenticels; contaln large, white, pink-ilotted pith.

BUDS-Alternte; cosered wlth ralrate scales in pairs, each successire pair eacloses a leaf; terminal and lateral buds difer wuch; terminal op to 2 inches in length, narrow, conleal, longrointed, often curvel towards the apex. smootis or glaucous, purple, with small dots; lateral small, often barely visible, conical, divergent.

I.EAVES-Alterase, simple, oborate-lanceolste, 12-24 inches long. thin-pointed at apex. tapering at base, entire Ju margin; smooth when old; petioles 1 -It inches long.

IEAF-SCARS-Alternate, often clostered at swellings along the branch, large, conspicnons, oral, somewhat raised, contain nutneroos Irregulsrly scattered bondle-scars. Stipulate-scars conspicucas, enclrcle twig, and originste from the side of the leaf-scar.

FIOWERS-Aprear abont Mar. Tpright, solitary, completc, surrounded by a spras of leares, white, slightly and unplcasantly odorous, $4-6$ inches long. Sepals fall axag early.

FRUIT-Matures about Octoher. An oblong rose-colored, cone-like mass abont 2-4 inches long composed of mang cohereut follicles which split open and liberate red flattish seeds. The fruit is verg beatiful in autumn.

WOOD-In general resembles that of the Cucumber Tree, page 15i. It is not used for commercial purloses, becanse it is rare, small in size, light, weak, and brittle. Welghs $\mathbf{2 7 . 9 6}$ lbs. per cubic foot.

DISTINGUISHING CHARACTERISTICS-The Crubrells Tree, slso known as Elkwood, Is natire only to a limited portion of the state in the susquehanna River ralles in the counties of look and Iancaster. It bas Inrger lesf scars, stooter twigs, larger iruit, larger and smoothe: buds, and larger leares than the two other native species of Magudia. Ita leares are crowded on the summit of the flowering brauches in $\mathrm{s}$ umbrella-like cluster while those of the wher two species are scattered along the branches. It is larger in size than the Iaurel Mag. rolis but smalle: thas the Cucumber Tree.

RANGE-Southern Fennsrlran:a south to Georgia, west to Kentucks, Arkansas, and northern Mississippi.

DISTRISUTION IN PEXISYIVAXIA-Iiecrded only in tir extreme sonthern part of the state in Lancaster and lork counties along the Susquehang Rirer.

HABITAT-Lisnally found in swamps, along stresms, or ir ravines. It is tolerant of shade and usually occurs solitary; sometimes mised with other hardwoods.

IMPORTANCE OF THE SPECIES-This tree is of no commerclal importance in Pennsslrania on account of its lim.ted distribution. its local and solitary occurrence, and the inferior wood which it produces. It is attractive and, herce, mas be recommended for lawn and park planting. but it cannot be recommended for forestry parposes. 


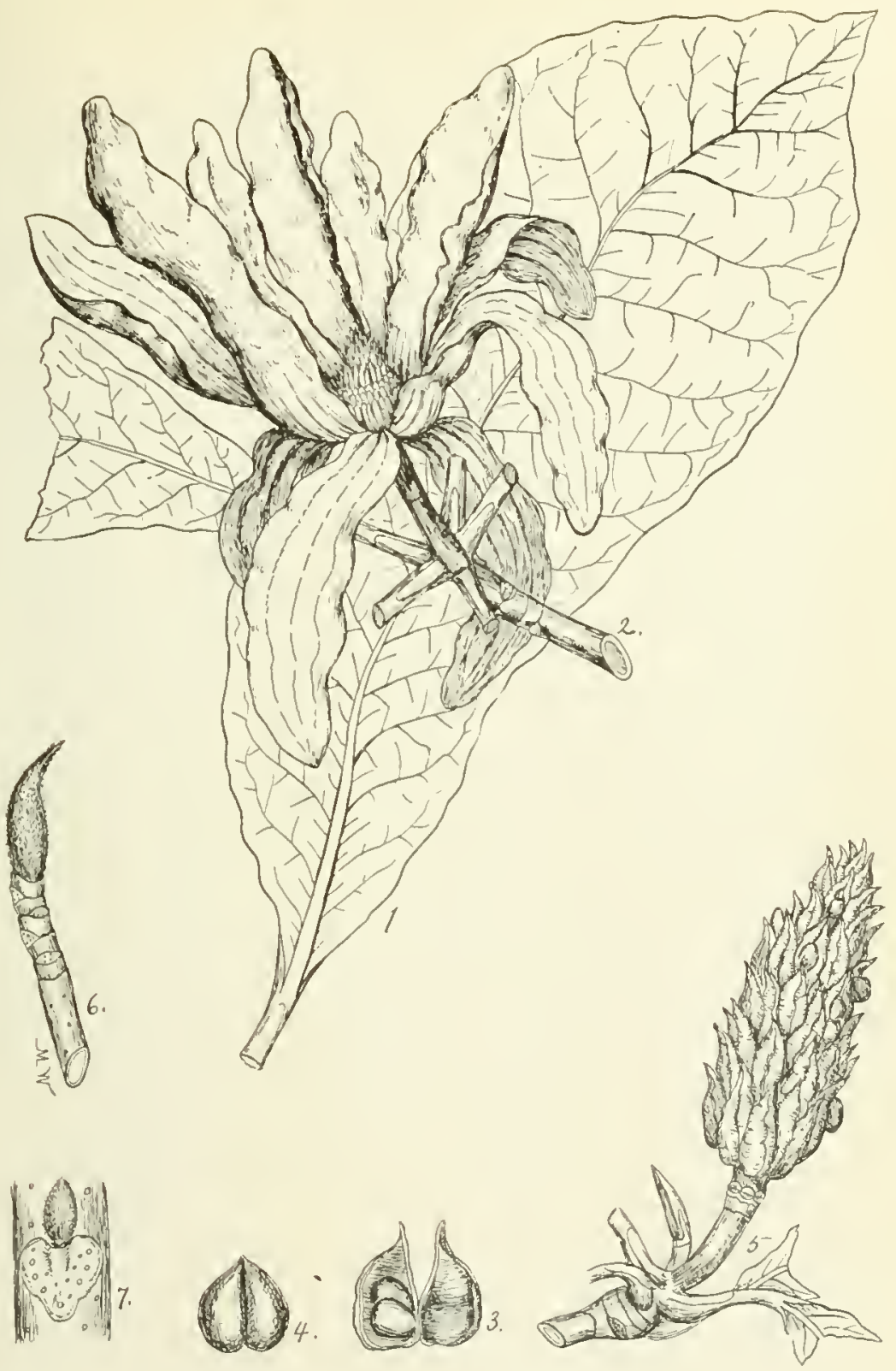

PLATE LXXVIII. UMBRELLA TREE.

1. A mature lear, $x$,

Prancl with a single Hown and the hases of five leaves arranged in an umbrella-like circle, $x$.

3. A earpel split oneo slowiug seeds, natural size.

4. A secd, enlarged

5rabeh with a terminal cone-like fruite $x z$.

6. A wiuter twig, $x$.

7. Section of a winter twig, enlarged. 

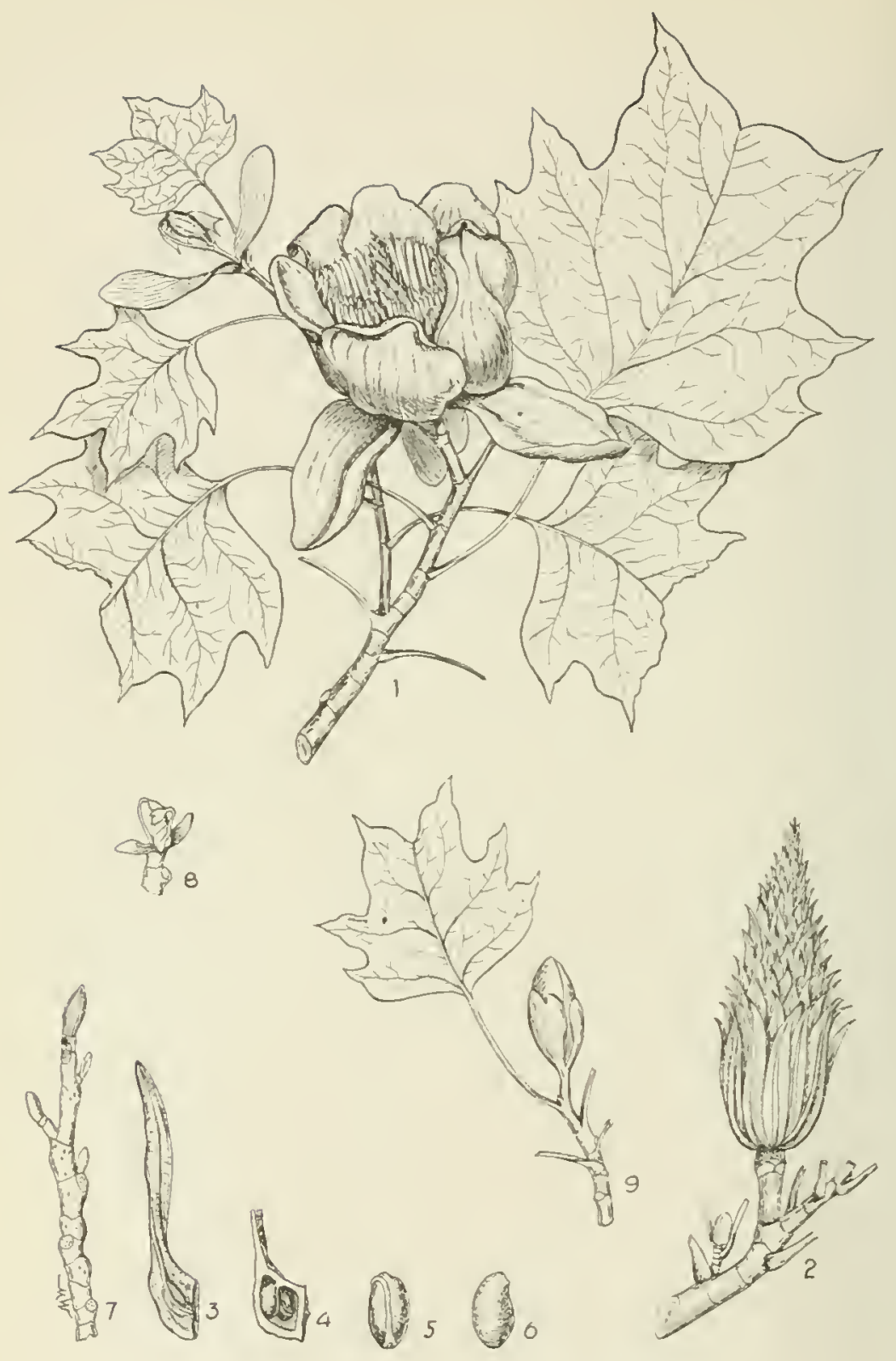

PLATE LXXIX. TULIP TREE.

1. A flowering branch with mature and developing leares, $x$ a.

2. Tranch with a conwlik liust. $\rightarrow$ t.

3. A single calpes intural sice

4 lorting of a carpel showing secols, natural siza.

i. A side riew of a need, enlariend.

A winter twig, $x$ is

s. A termingl huil just upening. $\times 3$.

4. A trig stuwing dereloping leaves, $x$ k 


\section{TULIP TREE.}

\section{Liriodendron Tulipifera, Linnaeus.}

GENUS DESCRIPTION-This geaus has Dumerous fossil represestatives, but only one other liring specles, a native of Chiag (Liriodendroo chineasis, Sarg.) is baowo.

FORM-A large add interestiag tree often attaining a height of 50-70 1t. with a diameter of 2-3 ft. and sometimes reaching a helght of $200 \mathrm{ft}$. with a diameter 01 10-Il feet. Prof. Gasot recorded a tree io Fraocle Cove, westera North Carolioa, koown as the "Gugot or Grang Poplar," whlch has a diameter of $16 \mathrm{ft}$. a ad was free from lateral braaches for more than 10. ft. from the base. Trunk tall, stralght, rery slightly tapering, free from lateral brabches for a considerable distance from the base. Crowa in young trees pyramidal, ia older trees rather shallaw, broad, and spreadiog. Sce Fig. 41.

RARI-When soung smooth, bitter, astg-gray. On trunks brow, thick, distfactly marked with $100 \mathrm{~g}$ and regular furrows and ridges. At a distance it resembles the bark of the White Ash but lacks the churacteristic diamoad-shaped fissures of the latter. See Fig. Sit.

TWIGS-During the first summer green, smooth, rather sledder, often branching, marked with indistiaci lenticels, eacircled by a fralt of stipules at each node. Durlng first winter reddishbrowa, snooth, shing, marked bs conspicoous pale lenticels, elevated leaf-scars and stipolar rings cacircling the twigs which often persist for mang years.

BUDS-Alteroate, large, smooth, flattened, oblong, blunt-poloted, reddisb-brana mottled with white dots ad corered with glaucous hloom. Lateral buds rather dlvergeot, smaller than the termioal. sometimes superposed. Lud.scales smooth, white-dotted, spoon-shaped, valvate in pairs forming a distinct ridge where they nict. Sach pair of stipular scales incloses in successlon a reflesed. Folded, stalked leat with its 2 stipular scales. Stipular scales enlarge when the bud opeps to a length of 2 ioches and widu of 1 lach. Each succeeding leaf is reflesed io the opposite direction of the precedlog ove.

LEAVES-Alterpate, simple, broadly orate in outliae, truocate at upex. with 2 apical ad 2.4 Lasal lobes, bright greeo above, 1aler below. Petioles slender, 5.6 jacbes lodg.

LEAF.SCARS-Alternate, clevated, consjicuous, large, orbicular. Buadle-scars small, oumerous, scattered uniformly over the leaf.scar.

FLowERS-Appear after the legves; large, $11 \%$ inches deep, cup-shaped, greenish-yellow, with 3 reflered sepals and ti converging petals.

FRUIT-Matures la September or Octuler; a light brown, oblong, pointed cone 2$\}$-3 iaches long. 3. of so iuch wide, coasustiug of carjuels 1-1] ibches long in the base of which the seeds are contaiatd.

WOOD-Diffuse-porous; with small Iaconepicuous medullary rays; suft, not stroag, light, oot aurable iu groud, easily worked, ligbt yellowish or browaish beartwood with thin white sapwood. Welghs 26.36 lbs. per cuble $100 t$. Esed in castructioa, foterior foish, furditure especially jo reneering, shinoles, wooden-ware and automobile bodies. Its uses are somewbat similar to Thite Pide.

DISIINGUISHING CHARACTERISTICS-The Tulp Tree also knowo as Yellow Poplar, Whitewood. Iulip toplar add sometumes lopple, cag readily be recogaized in summer by its straight clean fiscuied bole, its characteristic leaves with truncate apex and large stipules. The leaf caanot be confused with that of any uther species since it appears from a distance to bare its apex cut of at right angles to the midrib. la spring the flower is also distioctive. In winter the lacge clean truaks whth their peculiar issures in the bark together with the fruit which often perslsts, are characteris?lc. Af close ragge the buds with the stipule-scars eocircling the twigs will glways eoable ooe to recognize this species without fail. The rather large pith often divided by partilivas of stone cells is pecaliar.

RANGF-Botanical rauge 1rom lihode Island to Michigan and Miseouri, south to Florida and Artianss. Commercial range not sa wide.

DISTRIEUTION IN PENNSYLVANIA-Most common aloag streams or moist locations io the eastero and southero pgrts of the State. Also loobd locally io westera part. It does not appear lo pure stands, but some excelleat stads aimost approaching pure stads are foubd in Franklio, Adams, ad Northemptoa counties.

HABITAT-It prefers deep, rather fich, and moist soil. Common along streams, on islands, upoa semi-swampy areas, and at the base of mountaio slopes. Sometimes found on the tops of mouatains especially where small streams aad spriogs are prevalent. Usually occars as scattered indfiduls mixed with otber bardwoods and sometimes White Piae and Hemlock.

IMPORTANCE OF THE SPECIES-The Tolip Tree is one of the most ralaable and desirahle timber trees of Peansylrania. Its wood belongs to the first rask with White Pine. It is rather difficult to propagate artiflcully oa accoust af the low fertility of the seeds and Its sensitiveness to trabsplantiog. Attempts bave beed made to propagate it by means of cottiogs but without success. Nataral seed regegeration of this specles can be carried on with saccess and should be adrocated and dereloped in preference to the artificial. This species ia also free from insect ad fungal diseases aod most deslrable a a shade, lawa, and areooe tree. 


\section{COMMON PAPAW.}

\section{Asimina triloba, Dunal.}

FAMIIT AND GENUS DESCRIPTION-The Castatd Apple tamlly, Anonacese, comprises abont 46 geners with 600 specles conllned mostly to the tropics. Onls a few species are found in temperste regions. This fsmils produces little thst is of real economic importance. Only 2 genera, Asimina and Anona, are represented by tree species fo the Cnlted States. The genos Asimina does not have representatives outside of liorth Amerlca, where about 8 species sre known to occur. The sole representatise of this family astive to this $\mathrm{State}$ is tha specles described on this page.

FORM-A small tree asually $10.40 \mathrm{ft}$. in height with a diameter ap to 12 inches. Trunk short and slender. Crown rather broad, bigb, and formed by strsight rather spresding latersl branches.

BAFE-Thia, close, sometimes slightly fissared, dark brown, often corered with scattered white blotches.

TWIGS-Round, ollre-brown, enlarged at the nodes, rather sleader, at firat often somewbat hairs towards apex; later smootb, covered with a few fine lenticels wbicb become erldent during second sear; pith small snd white.

EUDS-Alternate, 2-ranked or sometimes 3-ranked, brown, naked, bairy. Terminal, lateral lesf and glower buds difer in size gnd form. Terminal bnd is mach longer thsn the others and eridently lattened. Lateral lest-buda about to of an inch long. closely sppressed to twig and located in notch oa upper surface of leat-scars. Flower-buda sre lateral sloag the twig. sphericsl in outline, about $1 / 6$ of $a n d n c b$ in diameter, rerg bairy snd dark brown; do aot stand quite parallel to twg.

LEAVES-Alternste, imple, pborate-lsnceolste, 4-12 laches loag, th!n, pointed st aper. taperlng st bsse, entire ou msrgiu, when mature dark green sbore and psler below, lo autumn they toru rasty jellow.

IEAF-SCARS-Alternste, located on eulstged projections of the twig, Inclined at abont an sngle of 35 degrees to the twig, brosdly U-shaped, almost surround bud, somewhat lighter than the twig, coutgin usunlly 5 bandie-scars which are often compounded. A ridge extends across the lenf-scar from the bud to the base of the scar.

FLOWERS-Appear about April or May with the leares bat sre nsuslly locsted below them along the twizs. T'hey occur sclitsry and axhlury; are perfect. st first green, later reddisbpurple, 1-13 inches wide, and borne on stont hairy stalks.

FRUIT-Suggests a stubby banana, is crlindrlcal, roonded, or occaslonslis blant-pointed at the ends, 3.5 joches long. at first green, later dark-brown, pulpy, edible, contains msng dsikbrown, sbins, gattened seeds which are scattered througboot the gesh.

WOOD-Ring-porons with a diffuse-porons tendeacy; rags rery numerous and distinct; heartwood bromaish; sapwood seliowish; weak, soft, welghs ahout 25 lbs. per cubic foot. Not nsed commetcialis.

DISTINGUISHING CHARACTERISTICS-The Common Papaw can be recognized best in a. tamn by its unique frut which is rery suggestive of a stubbs banans. In spring the greenish. brown to reddish-ourple flowers which occur solitary along the twigs and messure 1.13 inches across are also chsracteristic. The large, tropical-uke, asteruste leares will also ajd in recognizing it. In winter the long, slender, somewhnt flattened, naked, brownish, termins! bods and the spherical lowerbads along the side of the twigsand the $\mathbf{C}$-shaped leaf-scars which almost surround the buds snd usunlly containg 5 bandle-scars, will easble one to distingaish it. The fact thst it occurs onls in about the southern third of the State msg also belp ln diatinguishing it.

RANGE-Western Sew Fork and west central New Jersey sonth to Florida and west to Michigan, Kansas, and Texss.

DISTRIBUTION IN PENNSYLVANIA-LOcally fond in smail groups in practically erery county of the State south of a line drawn from Pittsburgh throngh Harrisbarg and Reading to Doglestown ia Bucks county. Not common anjwhere but well known on account of Its pecnlis iruit. [suplly found below altitude of 1,000 feet bat in the South Monntains In Adams and Franklin counties fond at 1,200 feet.

HABITAT-Prefera rich moist situstions. Esusliy found in river ralleys near stresma bot oc. casionally pscends low fertile slopes. It may form dense thickets bat in this State asually occurs salitary or in rather open gronps. Occurs with other species in the anderstory of the forest, and is rery tolerunt of shade.

IMPORTANCE OF THE SPECIES-This species is of Do commercial Importance as a forest tree anywhere in its rauge. The fruit which it prodaces is of more ralne than ita wood. It never reaches latge size, and in sddition is local and limited in its distribation. It is, how. erer, a vers attractire tree on Hccount of its somewhat drooplng tropical learea, handsome lowers, and peculiar truit. 


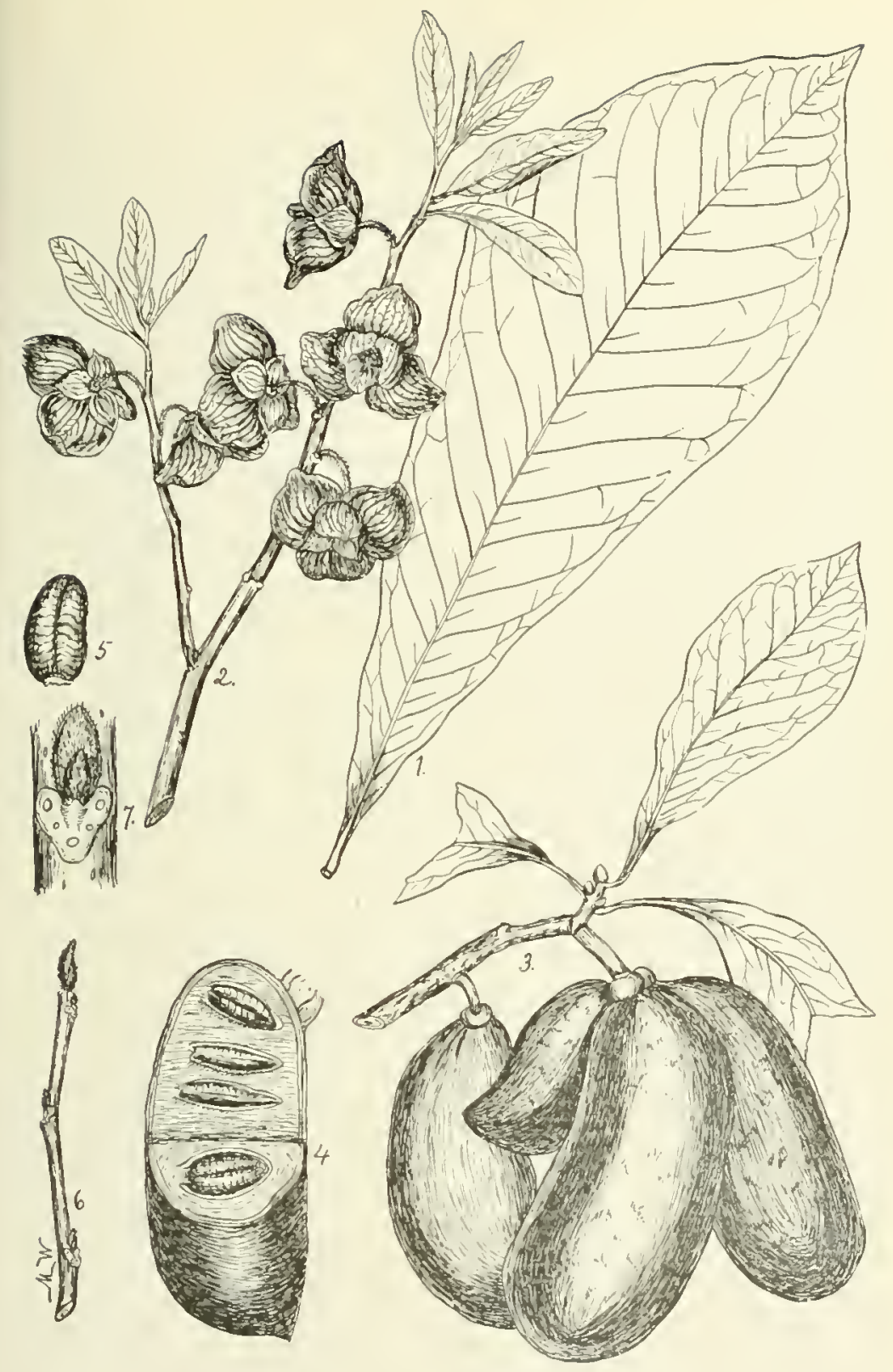

PLATE LXXX. COMMON PAPAW.

1. A mature leaf. $x$ z

2. A Howeriug liranch with immatures leaves, $x$

3. A fruiting branch, $\mathrm{x}$ s.

4. Section of a fruit showing serveds, $x z^{2}$.

5. A seed, natural size.

6. A winter twig. $x$

7. Sectimn of il winter twig, inlarowt. 

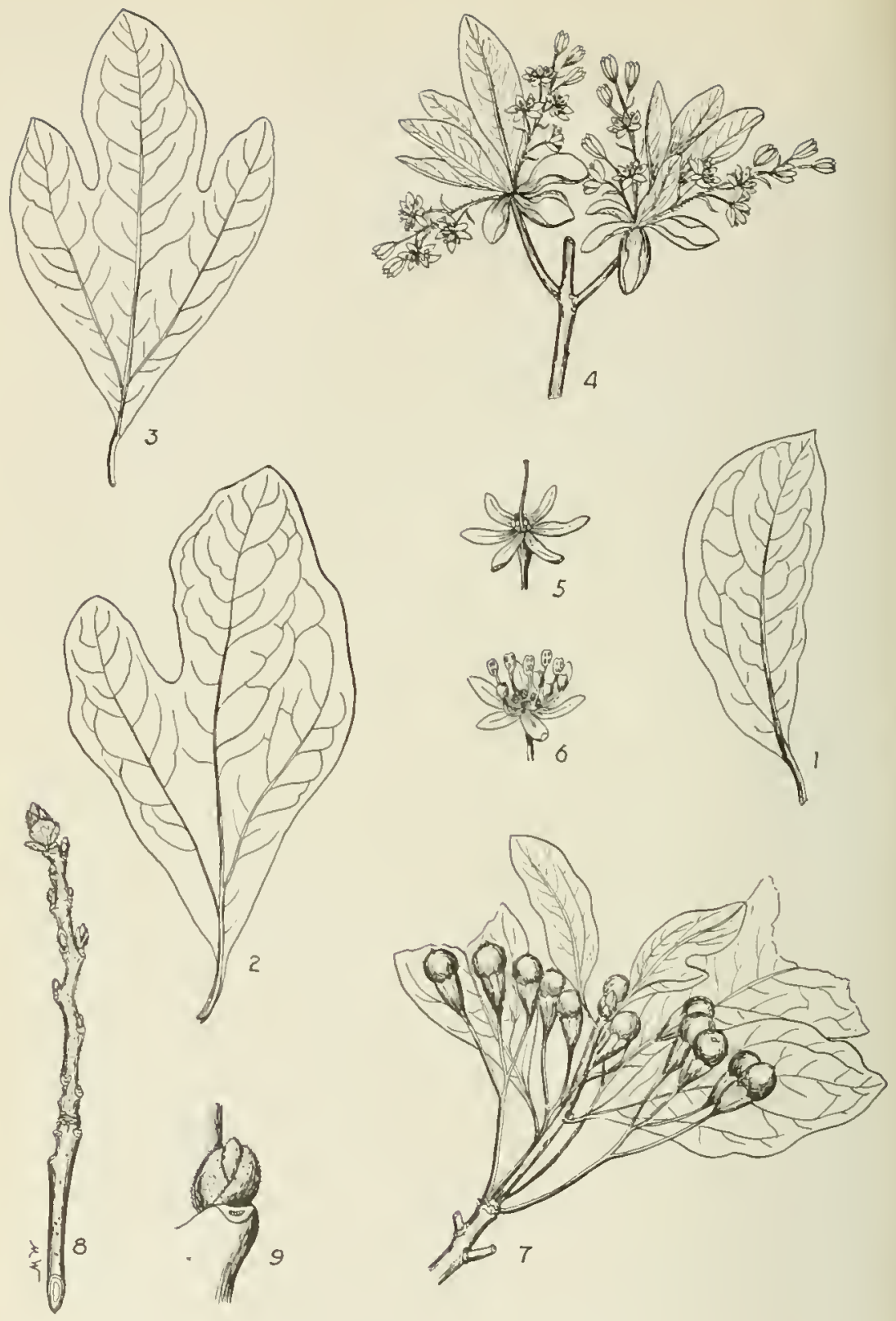

PLATE LXXXI. SASSAFRAS.

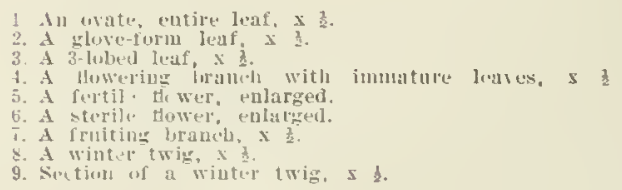




\section{SASSAFRAS.}

\section{Sassafras variifolium, (Salisbury) Kuntze.}

FAMILY AND GENUS DESCRIPTION-The Laurel famlly, Lauraceae, comprises about 40 genera with between 900 and 1,000 species which are confined mostly to the troplcs. Sis genera are found in North Anerica, 4 of which reaeb tree-size. Two genera, Sassalras and Benzeis, are ontive to Pennsylvanla. The species described on this page is the sole representatire in Nicrth Americn of the geuus sassafras, but another species Is recorded from China. The sole rejueseotatives in this state of ine genus Benzoin is the Spice Bush (Benzoln aestirale (J.) Necs.) The spice lissh cao readily be distiuguisbed bs its sman size, its aromatic and splcy twigs, fts simple, entire, alternate leaves, its clusters of jellow flowers wbich appear before the leaves, and its senrlet fruit.

FORM-Usunlly reaches g helght of $40-50 \mathrm{ft}$. With a dinmeter of $1.3 \mathrm{ft}$, but is the South may reach a helght of $100 \mathrm{ft}$. with a dinmeter of 24 feet. Trunk usunlly stout, short, bearing a crown with more or less contorted brapches, Clown usually fat-tompd or rounded, the terminal part rather dense, the lower part very open. Iranches are extremely brlttle. See Fig. 40.

BARK-Roughened with shallow fissures frequeatls as early as the third jear, bence a joung tree uftan appeara old. On older iruaks raddisb-brown, deeply fissured, aod fat ridged. Iidges resemble small blocks, or lis, or is, anil sepnrate Into thin appressed scales. Shallow, horir.ontal. and ring-like tissures sometimes nluus enclrcle trunk. Sce Flg. Gi.

TWIGS-Usully siender excegt in sprouts, rather brittle, yellowisb-green or sometimes reddish, sumewbat bairs. often smootb aud glosss, aromatie, brittle, fall off young, corered with few leaticele, contain large white pith. IDner hark of twigs is rery mucilaglnous upon belng chewed. Sproata branch freely and steölings more sparingly.

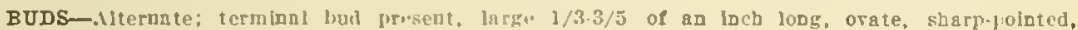
corered with a few rather loose-fiting, slightly hairs green bud-scales with thickeded velus. A lew, usually 3, ratber thick, loose, short, narrow scales sarroubd terminal bud. Lateral bnds are kmnller, gaplng, nd somewhat divergent.

LEAVES-Alternate, sinrle, orate, f-fi inclu's long, azute at apex, wedge-sbaped at base, entire or $\mathbf{2} 5$.lobed, usuelly smouth and dark green abore and paler below. Ètire, 2 lobed, 3-lobed, and 5-lobed ones unay be found on sane branch.

LEAF.SCARS-Alterdste, small, rafsed, semi-clliptical or concare, with a sidgle, confluent, linear buude-scar.

FLOWERS-Aplear about $\mathbf{M a g}$ with the leares. Stmminate and pistillate flowera are separate. They are grcenlsh-geliow find arianged in loose drooplng racemes.

FRUIT-1 dark lufur, shiny drupe borne on a bright red, club-shaped, flesby stem terminated by an enlarged calyx ia? which the drope rests. Falls rnther early, rarely persistent.

WOOD-ling-forous; with indistinct medullary rass; soft, very brittle, durable lo contact with soll, aromatic, dull-orange brown, with thin ligat sajwood. Weighs 31.42 lbs, per cubic 1oot. Used for posts, rails, furbiture, interior finishings, often sold as Asb and Chestnut.

DISTINGUISHING CHARACTERISTICS-The Sassafras, also known as Sarlfras, and Sassafrac. can be distinguished at $a n y$ time of the year by its very smooth glosss bark of the twigs which Is decldedy mucilaginous and aromatic. The leaves wbich mas be entire, or 25 -lobed and the siogle bunde-sen in the lenf-sears are also characteristic. The frult, the rough and distinctively fissured bark, and the brittle lateral branches are peculiar to this specles. once recognized it is hard to confuse It with apother species.

RANGE-Massacbusciin to Floridu and west to Mlchigab, Kansns, and Teras.

DISTRIBUTION IN PENNSYLVANIA-Rather common in the enstern, sonthern, and western parts of the State. Raler lo the central and uorthera or mountainous parts.

HABITAT-Vers common along fence rows, in abandoned fields, and on abandoned cbarcosl hearth. I'refers ricj sandy loam. Rather tolerabt of shade and water.

IMPORTANCE OF THE SPECIES-The Sassufras is of little commercial importadce in this State on account of its limited distribution and the small size which it reaches. It is a rathet picturesque $t r \geqslant e$, espccially in winter. The fruit furnishes a valuable food for birds wblle the wood, bac:, and especialty the roots, gield an aromatic oil extensively used to flavor medicinc and caody, and to perfume soags. 


\section{WITCH-HAZEL. \\ Hamamelis virginiana, Linnaeus.}

FAMILY AND GENUS DESCRIPTION-The witch-hazel famils, Hamamelidaceaf, "ontain, about 16 genera with iu surecies of which number only 2 genera bave tree representatives in Narth America. The 2 gentra are II:1mamelis and Liquidanbar. Eacb genus is represented by

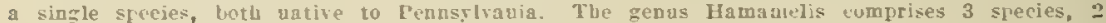
of which are fond 3 eustern Asia and 1 described bere.

FORM-A small tree cr shrub sometimse reacbing a hejeut of $25 \mathrm{ft}$. with a diameter of 14 inches, but ustally smuller. Trank sbork, bears unuerous sprealing. crooked branches whieh form a broad open bead

BARK- About 1/5 of an inch thick, light brown, somewhat motted with light hotely's: wher gaung smuctu, dater scilly. Inner bark reddish-purple in color. tsed for medieine, extract, and anroles.

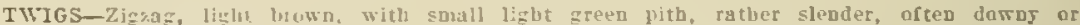
scurfy espurialls near thic eni, sometimes smoutb and shing, covered with a few, seattered, wbite lanticels.

BUDS-Ilterate, 2.rabed, flutuish, vmetimes evrrel ar faleate, covered with senle-like undeveloperl leaves beartus dense brown bairs. Terminal bads usually siekle-sbaped, about 11 of ag inch long. Laleral buds few aud very small.

LEAVES-Alternate, simple, oval, 4-1; inches Ings, rounded or sometimes acute at apex, ablique at base, deatate un margit, dark green abure, palor leneath; midrib and primary veins promineut.

LEAF-SCARS-\$lternate, Fanked, semi-circular in outliue with a raised martin, and contain 3 single or often compound bundle-siars which are liohter in culor than the dark brown surface of the leaf.scar.

FLOWERS- l pear in Octuber and Xurember. Rright pellow, yerfect, occur in small axillary

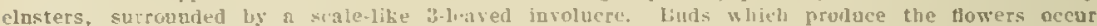
in elusters of 3 on sho.t stillis, are spherical in form, and start to develop about August in the axils of the leaves.

FRUIT-Kunas in Outher and Norember at the same time that the blassoms appear. It results frum blossoms of the previous year, consists of a sellowisb.brawn woody nod with two cells in which shing hack sweds ar. produced. The woody fods burst aven when ripe, and propel the sped for 5 ar more feet.

WOOD-Difuse-Inrous: rass not rery distinct; little difercace between spring and summer

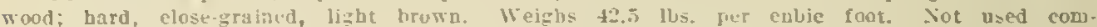
mercialls.

DISTINGUISHING CIARACTERISTICS-The Witch-hazel can he distinguished in winter by its sicklo-sbajed, browe, forminal buds, Its gelluwish-brown fruit in the form of a woody pod with two cells, its Iersisteat remnants of the dowers on stalks and its white blotelued or mottled light brown bark. In late autamn tho flowers with stray-lik jellow petals are characteristic. The altunate oral leares with straicht ve-ins and oblinue bases are also distinetire. It usually frequents maist rocky luertions.

RANGE-Nicra Scotia ad Outario, south to Florida, and west to Minnesata and Texas.

DISTRIBUTION IN PEMNSYIVANIA- io doubt foumd in every caunty of the State. Repnited apd obserred in more thar one-balf of the counties, located in every lat of the State. This is the most cummon anrl widely distribnted small tree or shrub in Pennsyirania.

HABITAT-L"sually funni in moist rocky situations. Coromon along streams, in swamps, and on the borders of pond and lakes. Gceasionaly ascends slopes to rather dry locations. Tolerant of shade, lience often foud in the understory of the forest.

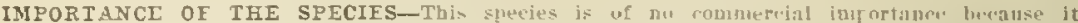
remains ton small and proonces inferior wood. No records are arailable which show that a single boart font has erer been on the market. lt is, howerer, a rers interesting small tree because it lolds a unigue fosition in that it blossoms lase in autumn when mang other trees hare shed their leaves and are prefared for winter. It mas be proteeted in sitnntions where it coes not inturere with the growth or utilization of more valuable speeies. No Epeeial eforts are necessary to insure an abnodant future supply. 


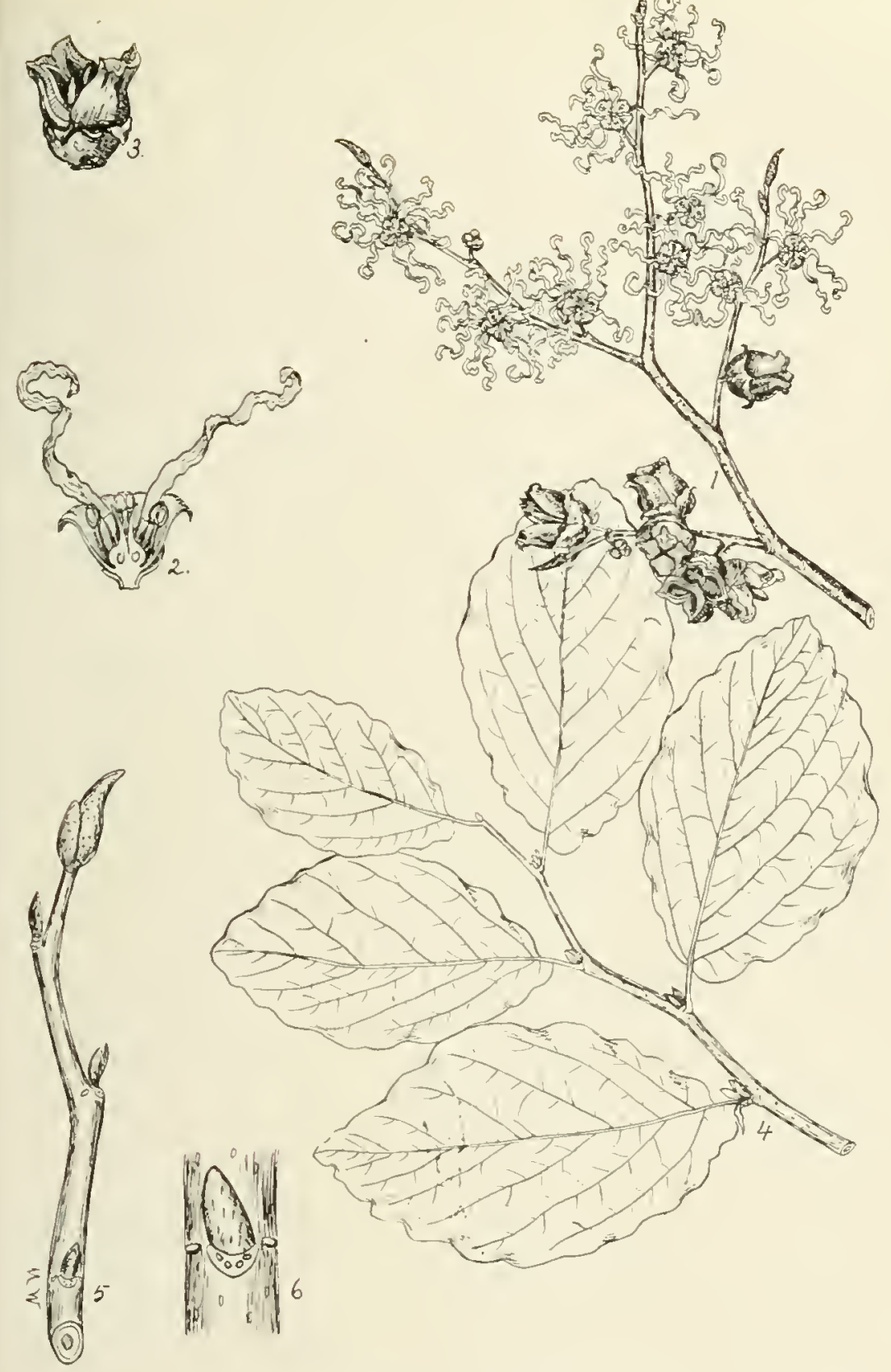

PLATE LXXXII. WITCH-HAZEL。

1. A flowering and fruiting branch, $x$.

4. A branch with mature leaves, $x 13$.

5. A winter twig, natural size.

6. Sectinn of a winter branch. enlarged. 

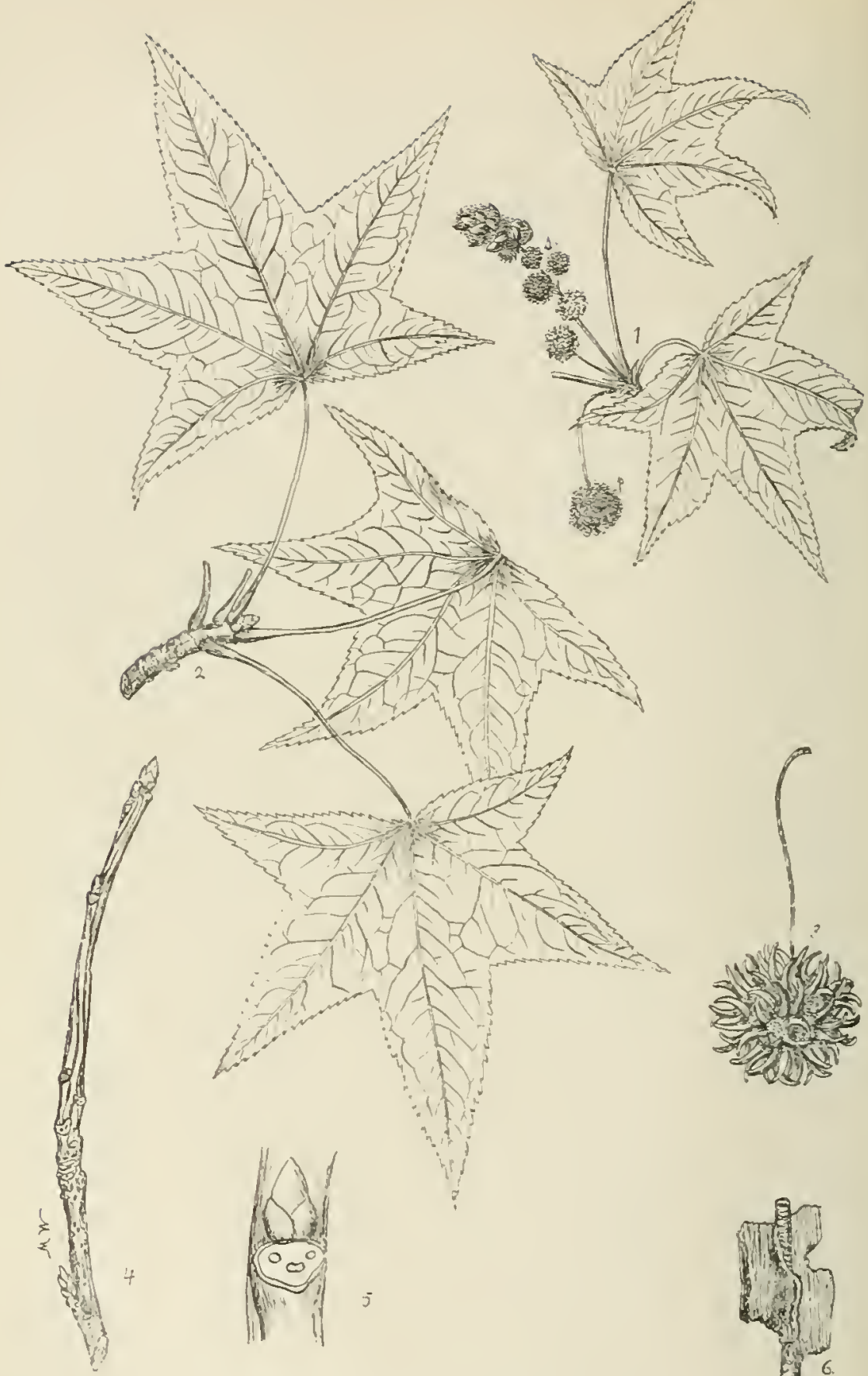

PIATE LXXXIII. SWEET GUM

1. A towering branely sluming immature leares. 4. A winter twig, $\mathbf{x}$. staminate dowers. (p) pistiliate fotrers. I 1 .

A branch with mature leares, $x$, 3. A spherical fruit, $x$ z. 


\section{SWEET GUM.}

\section{Liquidambar Stryaciflua, Linnaeus.}

GENUS DESCRIPTION-Tlis benus comprises 3 species, 2 of whlel are found in Asia and 1 in North Americ:. "fhe latter is uative to a siuall jortion of soutbeastern Peunsyania. A few fussil forms aro alsa known. 'l'he getaerie uauf, linujuabar, is a mougrel, the fore part of which is of Iation origin und means liguid abd the latter part of Arabic origin aud means nmber in allusion to lit frastat juice of the tree.

FORM-A large forest true usually froin ,il in $1 \mathrm{t}$. lighly with a diameter of $2-3$ ft., but may rench a heignt of $150 \mathrm{ft}$. with : Ginuter of 4 ; feet. In tlu. forest the trunk is tall, cleas, slightiy

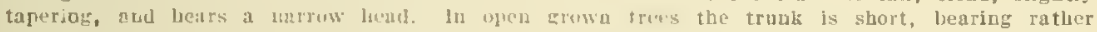
regular sprcading brachis which form :t symuctrival and rather coajeal crown.

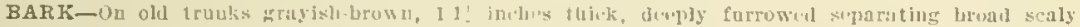
ridges. On Jounger trinks thinner and dirk gray.

TWIGS-liather stout, obseuruly angulur, at first rusty hairs, latel smouth, ligbt brow to

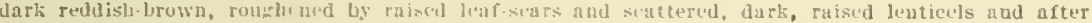
the second sassou oftea by corkg-winged jojections of the hark. Fith rather large, angular, and very light hrown.

BUDS-Alterante, mo:e that 2.rabied, ovate to coujejl, blunt-poiated to slarp-pointed, glossy,

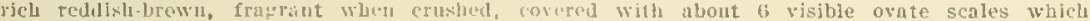
bave a short.jointud ulux, downy margin, and a rounded back. I.ateral buds are sumetimes accessory.

LEAVES-Aiteidate, simple, star-shared, 3 i imelies bong, hrogler thun long; base at right

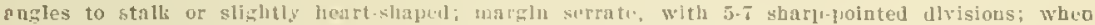
mature brlght green and shiny abovi, jaler below, Leaf stulks long gud round.

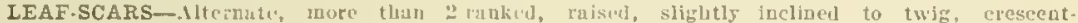
shaped or broadly heart-shajed, with a durk surface, contalujug 3 ejrcular buadle-scars which

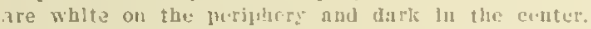

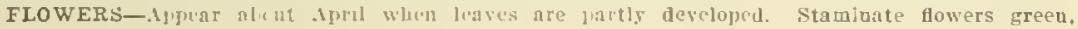
horne in terminal racmos, $2-3$ inches lung, currul with rasty hairs. Fistillate flowers gueen,

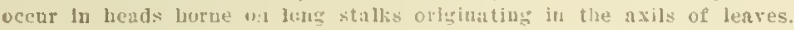

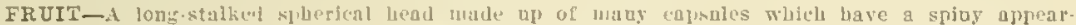
ance, about 1.If Inches in diancter, fursists car intu winter. Individual capsules often buled with sawdust-llke matcrial which consists of aborthe secds.

WOOD-1)fluse-porou.; rass distiuct; rutler bury, bard, with juturlocked graiv, somewlat

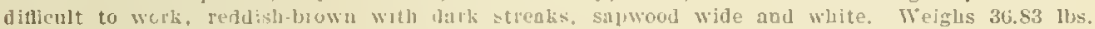

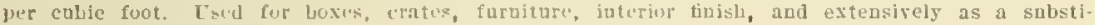
tute for Clrenssian Wakut.

DISTINGUISHING CHARACTERISTICS-Th. Swcet Gum, also kuomus Bilsted, IRed Gum, and Liquiambar. can le renognimed by its fruit which is in the form of a spine-like head suspended on a lon: slevile" stalk. The fruit ofter jersists far iuto wiuter. The corkg-winged

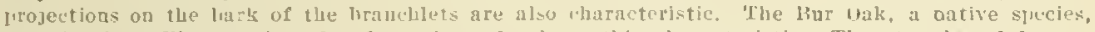
and the Cork Elm, au Intruluecd specics, alsu bast this characteristic. The star-slaped leares, reddishbrown twigs, aud luf scars with their bunde-sears are distinctive. It is aatire oaly to th: extrene soutleasteru jart of th. State, but ratber commoniy planted iu other parts.

RANGE-Southera Cunectieut soutl to Morida and west to Ohio, Missouri, aud Texas, and suntbward to Guatemala.

DISTRIBUTION IN PENNSYLVANIA-Found unly iu the extreme soutbeasteru part of the State. Reported from Bucks, Milallelilia, and Delaware coutius.

HABITAT-It jrefers deep rich soil such as will produce White Oak, Hickory, and Yellow Pollar. Does not tolerate shade, heuce aluost invariably found in the open or in evea-aged stands. On account of its intoleradee ouc seldrin finds it as regeneration on the forest floor.

IMPOFTANCE OF THE SPECIES-This speries nttains a large size aud produces fairly valuable wood but it nsualiy rejuiles soil adajted to agriculture or which will grow more raluable trees such as White Oak, White Ash, Ijukury, aba Lillow Fojlar. It Larlly pays to propagate this species artucially in this State a ad it is tuo Jimitud in its distributiou to regeoerate it by natural meaus. It is a very attractive oraametal tree. 


\section{THE ROSE FAMILY-ROSACEAE.}

This is one of the largest families of plants. It comprises about 100 genera with about 1,500 species, many representatires of which are native to North America. The flora of Pennsylvania comprises about 30 genera with more than 100 species.

The members of this family comprise trees, shmbs, and herbs. Thes have a world-wide distribution. A fow of the trees are important on account of the timber which thes produce while many are important on account of the raluable fruit which they yield. Nost of our common and well-known fruit trees belong to this famils. Many of its shrubs are common and most attractive.

The leares of the representatives of this family are simple or compound and always alternate, never opposite. The flowers are perfect, showr, and open in spring or early summer. Many species hare rery fragrant and attractive fiowers. The fruit matures in one season and is rariable in form and structure. It may be in the form of achenes, follicles, pomes, or drupes. Some species like the Cherries, Plums, and Peaches hare fruits which are edible and well known. Their pulp is usually juicr, swect or bitter, sometimes astringent, and corel's a hard-shelled round or fiat seed. On account of the fralatable nature of most of the fruits they are readily eaten by man, birds, and wild animals. The seeds are not injured by passing through the alimentary canal of animals and hence may be thus midely dispersed. The wood in many species is raluable but in our flora all but one species remain too small to be of any commercial ralue.

Of the large number of genera and species found in Pennsylvania only 9 species belonging to 4 different genera are described below. In addition to these a few other genera have well-known representatives. The Nincbark (Physocarpus opulifolius. (L.) Maxim.), is a comnon shrub throughout the State along rocky banks of streams. It is the onls representative of its genus in Pennstrania. The Strawberrics belonging to the genus Fragaria have a few common 1 epresentatives. The Raspherries. Blackberries, and Dewberries, belonging to the genus Rubus, hare about 20 species native to this State. The Wild Roses, belonging to the genus Rosa, have at least 7 species native to the State. In addition to these there are many herbaceous species.

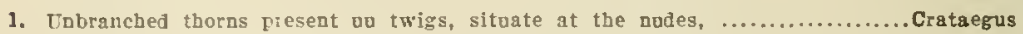

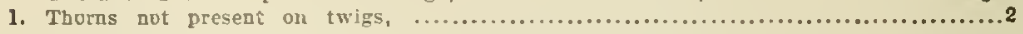

2. Fruit a drupe: pistil one; twig with chargeteristic taste and udor, usually

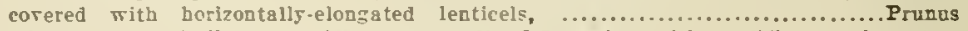

2. Fruit a pame; pistils more than one nsually $3-5$; twigs with a different charaeteristic toste, withuut borizontally-elongated lenticels, .........................

3. Carties of the axary same number as the styles; buds nut narraw-canical and not

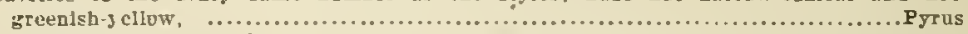

3. Caritiez of the avary becaming twice the number af the styles; buds aarrum-canleal

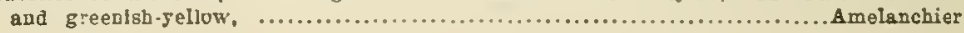


THE PLUMS AND CHERRIES-PRUNUS, (Tourn.) Linnaeus.

This genus comprises about 90 species well distributed over the north temperate zone and locally in the tropics. A large number of the representatires are found in North America. Seren species are natire to Pennsrlvania and 4 foreign species hare been extensirely naturalized. Only 4 of the native species are described on the following pages. The other native species are Porter's Plum (Prunns alleghaniensis), Appalachian Cherry (Prunus cuneata), and the Sand Cherry (Prunus pumila).

Among the introduced species which have been cultivated extensively are the Domestic or Sweet Cherry (Prunus avium), the Sour Cherry (Prunus Cerasus), the Perfumed Cherre (Prunus Mahaleb), and the Peach (Prunus Persica). The latter was introduced from Asia and the others from Europe.

\section{SUMMER IEY TO THE SPECIES.}

1. Flowers la racemes ternibating leafs brnoches, hence appearing after the leaves,...2

1. Flowera in umbels developlng from lateral buds before or with the leares. ..........3

2. Leares thicklsh, chloge or oblong.lanceclate, taper foloted, serrate with short lacurred stout tecth; Jager bark aromatic, ........................... s. serotias

2. Leaves rather thin, oral to oborate, short-polnted, rery shnrply serrnte with somewhat surending slcnifer teeth; Joner bark wlth a raok dlsagreeble odor, P. virginiana

Page.

3. Flowers small; fruit small, borce do elusters; braaches not thoray or armed,.......

P. peoosplvaoica

3. Flowers large; frult large borne siagly; brarches oftea thoray or armed. P. americana

\section{WINTER IEEY TO THE SPECIES.}

1. Terninal buds abscnt, ................................. P. americana

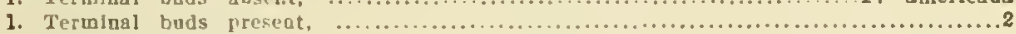

2. Bods clustered at the tips of the twigs; twigs ratler sleoder asually Jess thao $1 / 10$ of an Inch in tlediness. .................................... penasylvanica

2. Buds rurelr clustared and if clustered ools oo stubbs lateral gpurs: trigs relatirely

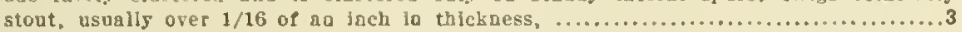

3. Merinm to large tree; bark oo old trunks black ad rough; buds relatirely gmall with uniformly.colored scales sharp.pointed at apex. .................. gerotina

3. Small tree 10 shrub; bark on old trunks browo and rather smooth; buds relatirely large with grayjsh-margined senleg rounded at the apex, ............. virginiana 


\section{WILD BLACK CHERRY.}

\section{Prunus serotina, Ehrhart.}

FORM-Lsualls reaclupe a height of $50.5 \mathrm{ft}$ with a diameter of $2-3 \mathrm{ft}$. bnt mas attain a heighi of $110 \mathrm{ft}$. Wirh a diameter of 5 feet. In forst zrown specimems the trunb is usnally long, clagn, anö with little taper. While in oren grown specimeus it is asually short. Crown rather irregularly-ohlong

BARK-On Joung triths (Fig. nti) rather smooth, gloss, reddish-broma, marked with conspicuols nhite horizontally-elongated linticels; peels nd in thin film-like lasers, and exnoses greenish inner bark. Ou old trunks ( $F *$. 9F) blackish, roughened by thick irrugular plates with projecting edges.

TWIGS-Smoctu, rather slender. reddish-hrowa, marked with wumerous, pale, round lenticels which in time become horizontally-elongated: pith wbite or light hromb. oftep corered with a thin. fim-like, grarish coating whjeb rubs off readils. Iuner bark has a ebaracteristic bitter taste and a rather fleasant odor.

BUDS-AJternate, ahout 1/S-1/6 of au iucb lonz, orate, usualls sbarp-[minted, smooth, gloss. reddish-brown. covered by about 4 risillo nwato bod-siales wbich gre sometimes coater with a

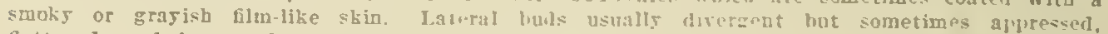
flattened, aud larger thas the terminal.

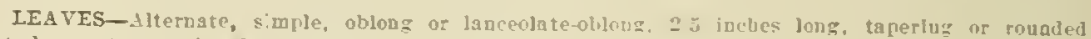
at base, taper fointe1 al apex. serrate on margin will shore inenrved teetb. rather thick aud shing abore. paler heneath.

LEAF-SCARS-Alternate, more tuan a ranked, rajkel on [rnjections of the twig. semielliptical tcudency a outline, with 3 bundle sigs.

FLoWERS- Mppear ib May or June: whto, perfert, ghout 1 of an inch armus, lorne in elongated drconing racemes $3-4$ inches long.

FRUIT-A purplisb black juirs drugle, \&- uf an inch in lianieter, arrangel in rather open drooping clusters: seed stops. Matures in summer.

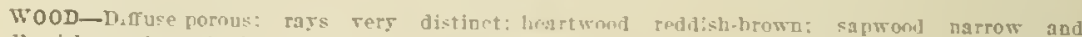

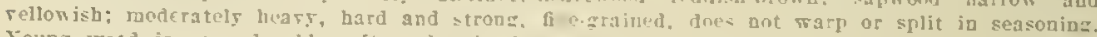
loung wod is very durable. Its ralup is du\% tw woln: an lustre gad not to finure. Weight

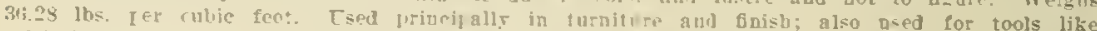
spirjt lesels, implements, patterns, cores, abd for bi: h rlass panels.

DISTINGUISHING ChARACTERISTICS-The Wild lia,k Cherr, also banw as Wild

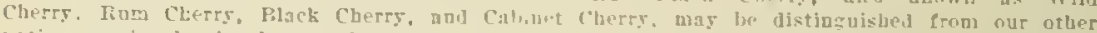
natire species by its larger size and by thw rough. dark, staly latk wbich is cound on the

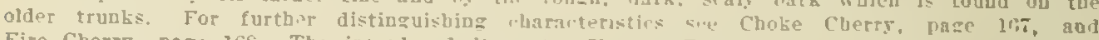

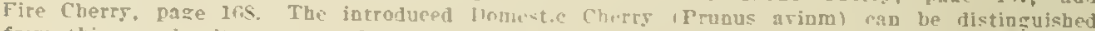

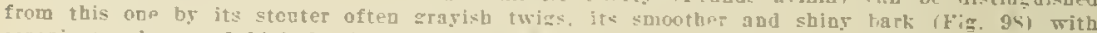
conspicuors loge and high lenticels and its rlistered hadk at the tips of stubby, latecal, spurlike brauches. The eruit of the Immestic cluerry is larzer than that of our natire cherries and the leares bave rocnded teeth often with nlands and are frequently slightly pubescent on the lover side.

RANGE-Nora Fcotia sootb to Flnrida. Westward to South Dakota. Kansas, and Texas.

DISTRIBUTION IN PENXSYLVANIA-Fond throughout the state. Rather common but nowbere rety ahundut. I'sually nccurs solitary in mixrure with other species.

HABITAT-Turires hest on rieb alluvial snil and fertile slopes. It will arow on dry and often rathez sterile slcjes. On acenunt of its long tap-root jt requires loose deep soil.

IMPORTANCE OF THE SPECIES-This is a rers important timber tree. Its wood is ralnable especially for furniture and interior fojsb. Nowbere in its range bas it ever been rery abandant aud on account of its prized rrood it bas been cut extensirely. As a conseguence it is pow becoming rare, ili fact unrrbing towards extinction. It deserres to bp planted estensirely and to be protected earefully where it is lound groming baturally. 


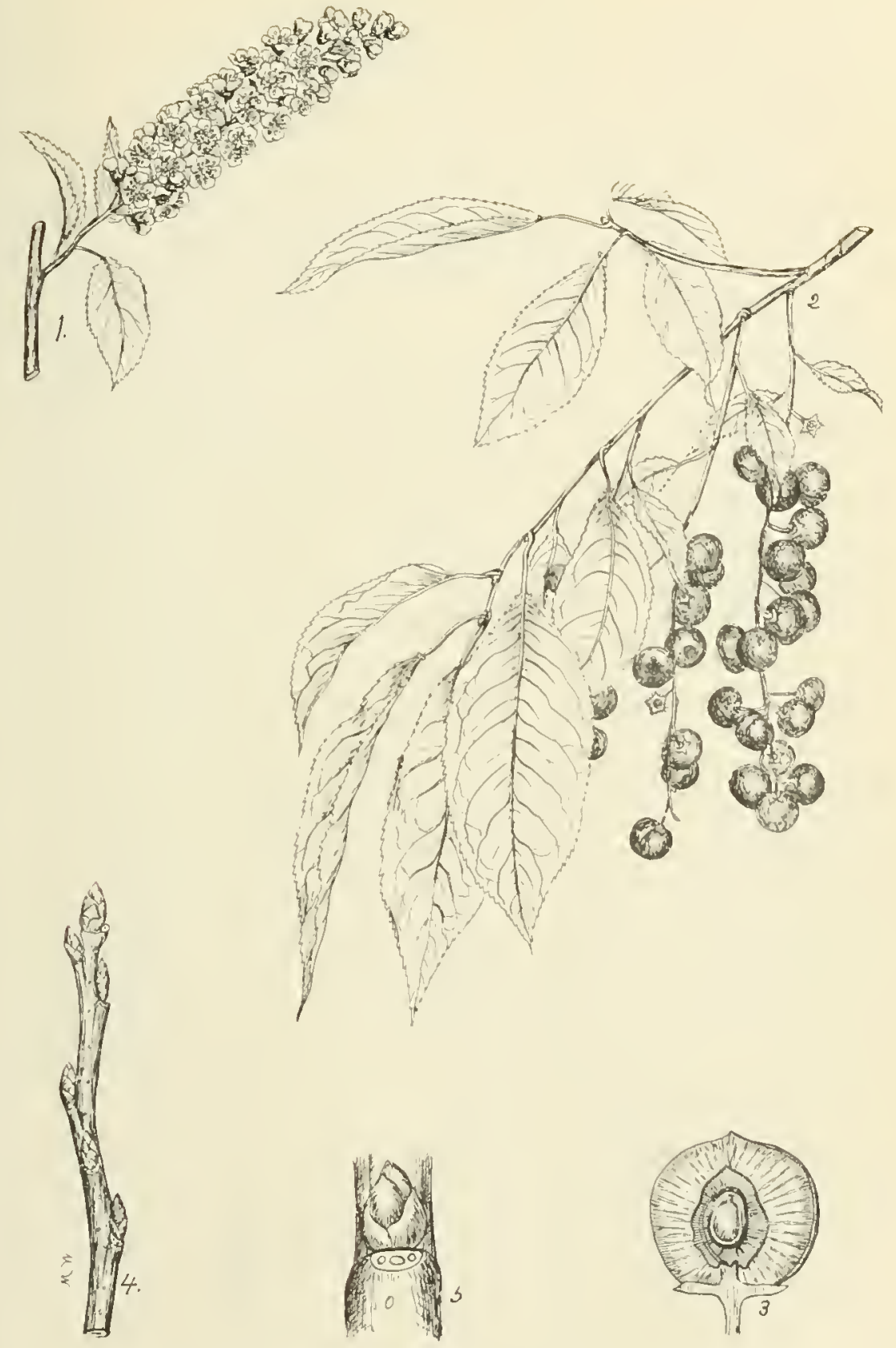

PLATE LYXXIV. WILD BLACK CHERRY.

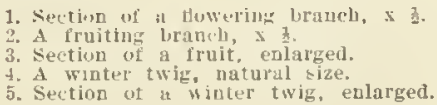




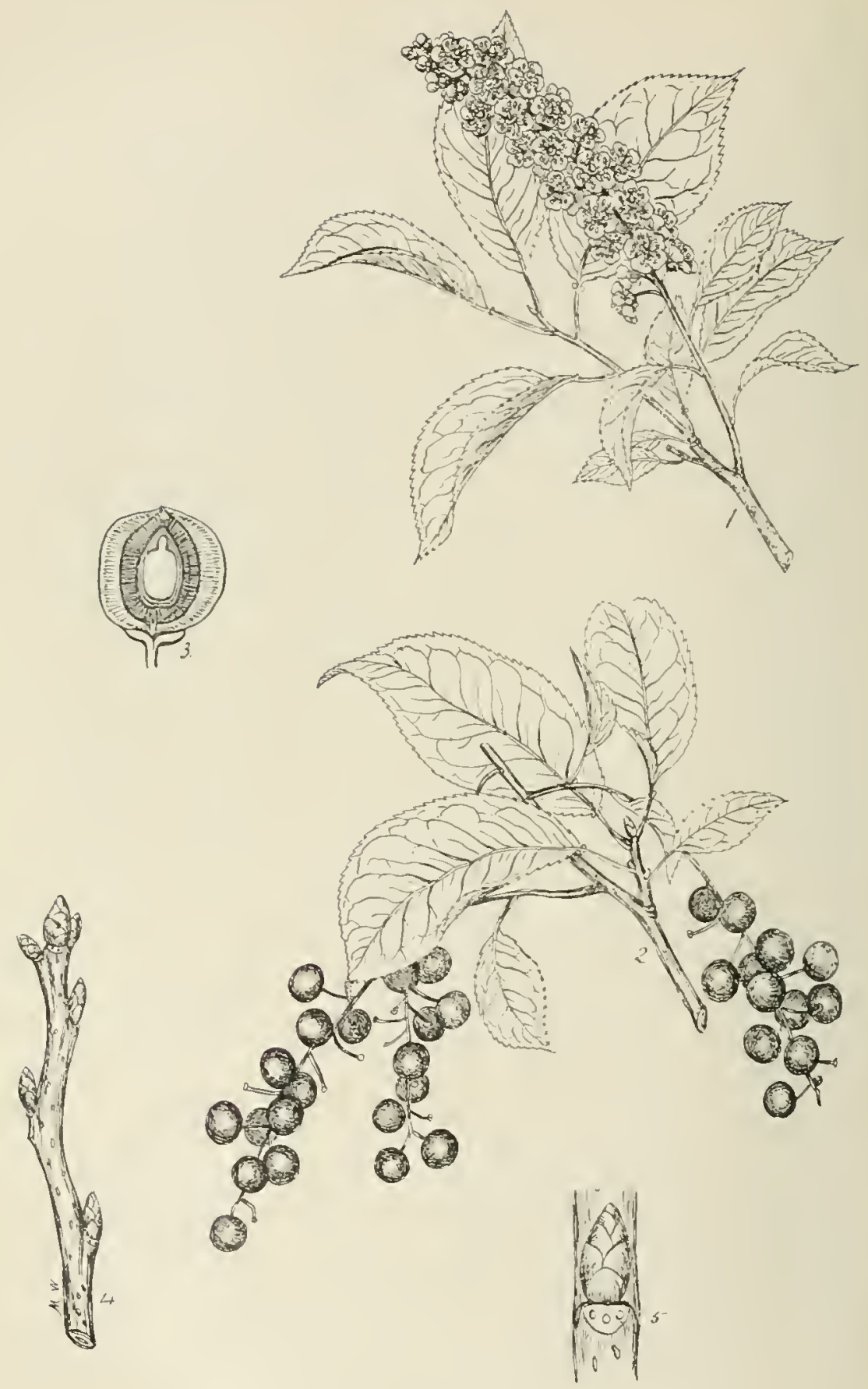

PLATE LXXXV. CHOKE CHERRY.

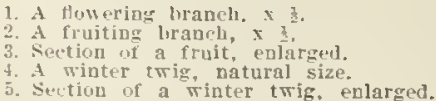




\section{CHOKE CHERRY. \\ Prunus virginiana, Linnaeus.}

FORM-A small tree rarely exceeding $25 \mathrm{ft}$, In helght with a dlameter of $\mathrm{S}$ laches. It reaches its largest size in the southern part of its geographical range.

BARK-On young trunks smooth, shiny, brownish, peels of easlly in thin film-like layers and exroses the green loner bark. On older trunks alout $2 / 5$ of an inch thick, dark grayish. slightly roughened by shnllow fissures. Inner lngers of the hark bare a very disagreeable odor.

TWIGS-Rather stout, "ssully smooth, ligbt brown to readish-brown, corered with numerons. censpleuous, dnll yellawish lenticels which are not erldently horlzontally-elougated; pith white. Brulsed twigs have a disagreeable gior.

BUDS-Alternate, about I// $;$ of an inch long, conleal to ornte, smooth, sharp-polnted, brownish, covered with aheut 6.8 rlsllue and closeiy overlapping scales. Latern] buds are often rather divergent and larger thin the termiusl.

LEAVES-Alternate, simple, oval, oljlong or oborate, 2.1 Inches long, tapering or rounded at hase, ab-optly pointed nt apex, sharply serrate on margin witb slender teeth, rather thln, tright greer above, poler below.

LEAF-SCARS-Alternate, more than 2-ranked, somewhat ralsed on projectlons of twiga with a tendercy to become elliptical in outline. Bundle-scara 3 in number.

FLOWERS-Alpear about May when the leaves are fully dereloped. Thes are perfect, white, $\frac{1}{2}-\frac{1}{3}$ of an inch across, arranged in many-fowered droopling raccmes, 3-6 inches long.

FRUIT-1 reil to lark crimson fulcy drupe, ahout 1 of an inch in diameter, arranged in rather open droopling clusters. Seed smooth and atony. Fruit is harsh and astringent.

WOOD-Sinilar to that of the Wild Black Cherry, only hearier and of no commercial importance. Not fond on the market. Welghs 43.32 lbs, per cubic foot.

DISTMIGUISHING CHARACTERISTICS-The Clike Clerry can be distinguisbed from the Wild Rilack Chersy by its smaller size, smoother and browner outer bark and an fnner bark with a mere disngreeahle odor, ns well as hy its thinner and sharper serrate leares with somewhat spreading slender teeth. The leaves of the wild Black Cherry are thicker and moderately serrate with somewht spreading slender teeth. The buds of the Wild Black Cherry are smaller ant have rathir uniformly-colored senles with a sharp apes whlle the hudg of thls specles hare grajlsh-margined scales with a roumled apex. This tree can be distinguished from the jire Cherry by the abstace of clustered terminal buds, by its stouter twigs, and by Its fowers whirl are borne in a raceme whlle those of the pire cherry are borne in umbels. It can be distingnisbed from both the Wild Black Cherry and the Fire cherry by its buffcolored lecticels which do not elongate borizontally.

RANGE-Newfoundland to Minnitobn, southward to Georgia and Texns.

DISTRIBUTION IN PENNSYLVANIA-Locally throughout the State bat nowhere abnadant. Ilost common in the muntainons and southeastern parts,

HAEITAT-Frequently found in thickets, in opm wonds, along fences, in ahandoned fords, along streams, and on dry situntions.

IMPORTANCE OF THE SPECIES-This tree is of no commercial jmortance. It is rather attractive in its naturnl babitat and when artlficially planted. Even though it bas no commerclal ralue still it need not be regnrded as an objectionahle forest rseed because it interferes little with the growth or other trees or their utilization. 


\title{
FIRE CHERRY. Prunus pennsylvanica, Linnaeus.
}

\begin{abstract}
FORM-A small tree reaching a beigbt of $30 \mathrm{ft}$. With a diameter of about lo incbes. Trunk asually short bearigg rather ascending brancbes wbicb form a narrow ad rather lat-topped crown.
\end{abstract}

BARK-On old trunks somewhat rowgheaed but not fssured. On jonnger truaks about $\frac{1}{5}$ of an Inch thlck, leddish-lirows. rather smooth but rougbeged by large borlzontally-elongated lenticels. The outer bark peels of rendily su thin film-jike lagers and exposes the green inner bark which is bitter.

TWIGS-Slendi.r, smontb, glossy, hright red, sometimes wholly or partly corered with a thin grariah conting which rubs of rery readily, marked with aumerous nale to jellowish and conspicuous lenticels which in time become harizontaliy-elnagated. The twigs bare a characteristic bitter taste and a peculiar odor.

BUDS-Alternate, small, usually less than of an inch long, orate, dull-pointed, amootb or sllgbtly grayich, senly, clustered at the end of twigs and often along the sides; corered with scales which are tard to distinguish. Thes are sometimes clustered on stubby lateral spurs.

LEAVES-Alternate or sometimes paired but not onnosite each other, simple. ohlong-lanceo1ate, 3-5 lnches long, tapering or rounded at base, sharp-nointed at apex, sbarply and finely serrate on margin, ratler sbining, green a ad smooth on both sides.

LEAF.SCARS-Alterate, more tban 2-ranked, somewhat ralsed on projections of twigg. elongated, seml-elliptical in outline. with 3 bundlescars, the central one of which is usually tbe largest.

FLOWERS-Anpear nhout May when leares are partly dereloped. Thes are white, nerfect, about $\frac{1}{2}$ of an inch across, borne on long stalks in $4-5$-flowered umbels.

FRUIT-A globular, julcs, light red drupe ahout 3 of an lacb in diameter, tinped with parts of nersistent styles, corered with thin skin which contala sour lesb and oblong stone. Ripens about July.

WOOD-Sinular to that of the Wild Black Cherry, page 166, only lighter in weigbt and of uo comurelal intpurtance. Not found on the market. Weighs $31.30 \mathrm{lbs}$. per cubic foot.

DISTINGUISHLNG CHARACTERISTICS-Tbe Fire Cherry, also known as Wild Red, Bird and Pin Cherry, ean be distingulsbed from Wild Black Cberry and Choke Cherry by its flawerg which are borne in uubels while those of the other snecies are borne in racemes, and by Its sleader twigg bearing clustered terminni buds while those of the otber species ocenr solitary. The bark cau be distinguished from the Choke cberry by the nresence of amerous erange-colorec horizontaliy-elongated lenticels and from the Wild Black Cherry hy the absence of dark scaig plates with projecting edges.

RANGE-Newfoundiand to Britisb Columbia, soutbward to Georgla, Tennessee, and Colorado.

DISTRIBUTION IN FENNSYLVANIA-COmmon in the mountaluous parts of the state, particularly among the Allegbenies. Rare or abseat southeast of a line drawn from Easton througb Harrisburg to Chambersburg. Also rare in the western part of the State.

HABITAT- Isually found in rocky woods and recent clearings. Very common along fencea nnd roadsides, in abaudcued fields, on lumbered and burntorer areas, on mountain glopeg and
occrsionally found on bottomlands.

IMPORTANCE OF THE: SPECIES-Tbis tree is of go commercial importance. It is rery attractive lut its short life prevents it from being planted extensively for ornameatal par10ses. It is rather aggressive springing up rapidly after ires and lumbering operation, often tuking complete control of the situation. It 1s. howerer, a temporary species acting as a shelter or russe tree to other more raluable species whicb asually follow and form the degired forest stnad. The main value of this tree lies in the sbelter which it gives to othera and the food wbicb it furaisbes for birds and wild animals. 


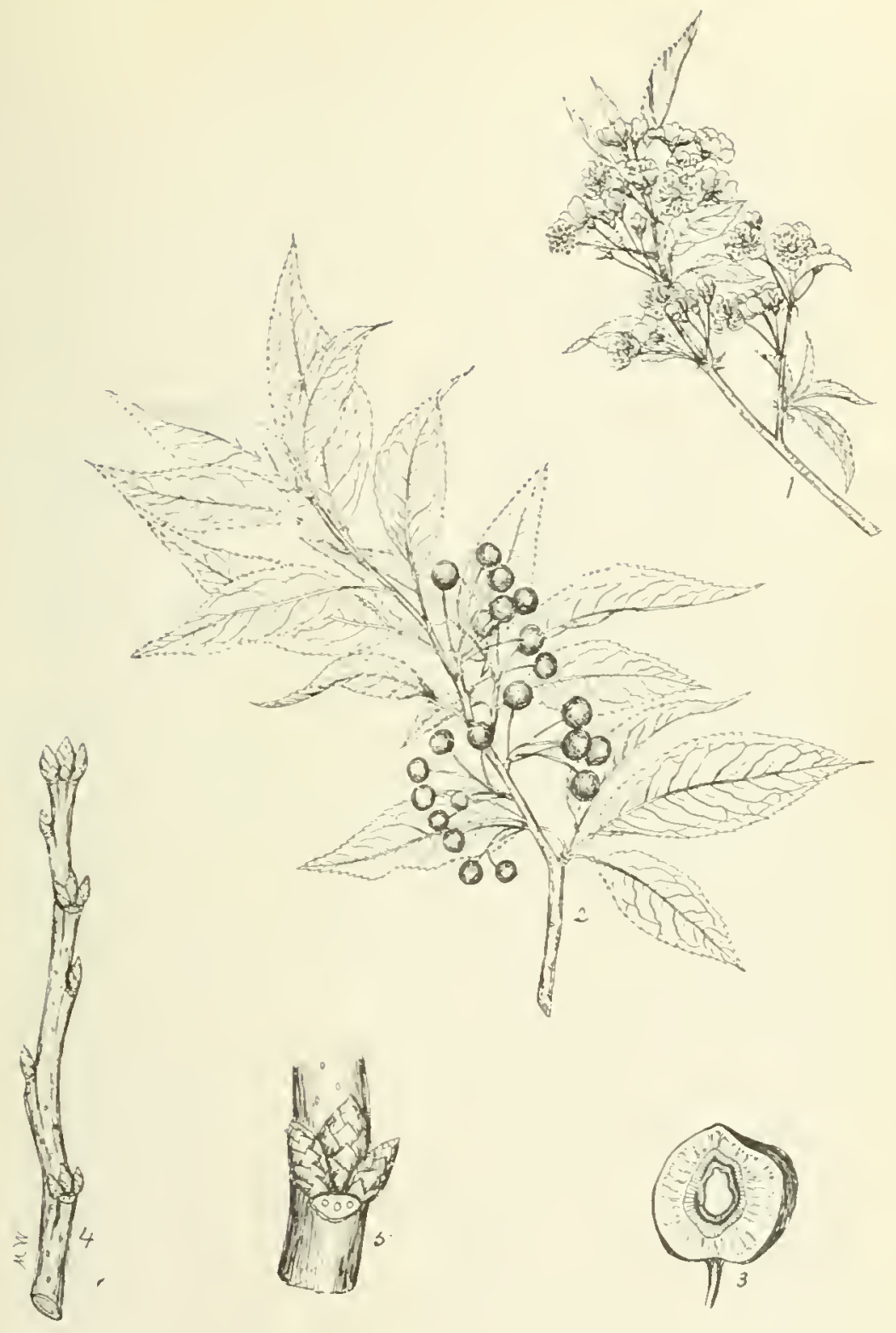

PLATE LXXXVI, FIRE CHERRY.

1. A fowering branch, $x$ s.

3. A fruiting branch with mature

4. $\rightarrow$ winter twig natural size

5. Section of a winter twig, ealarged 


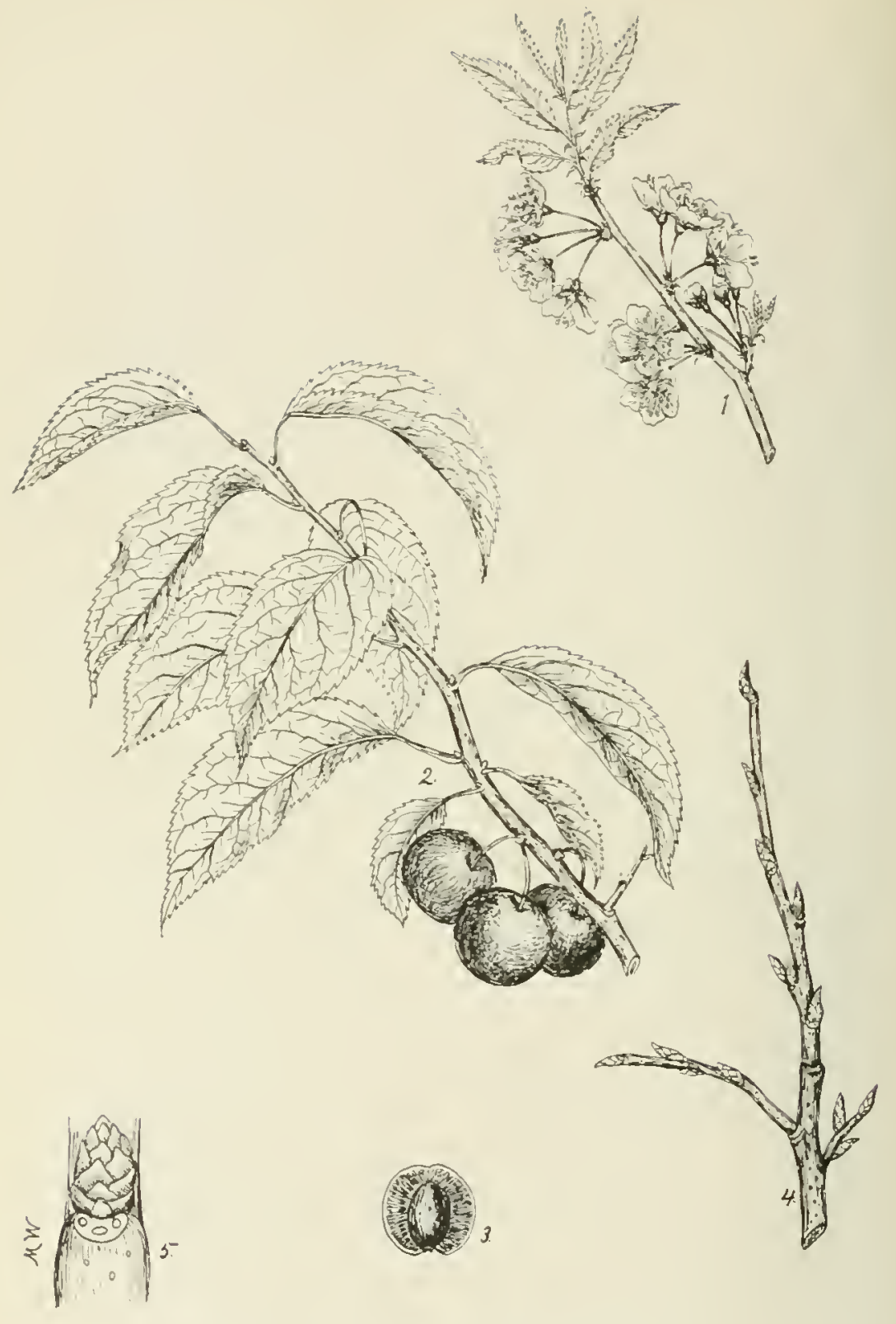

PLATE LXXXVII. WILD PLUM.

1. A Howering liraneh, $x$,

3. Section of atural slze.

4. A winter twig. $x$,

5. Section of a winter twig, enlarged. 


\section{WILD PLUM.}

\section{Prunus americana, Marshall.}

FORM-A amall tree from 9.30 ft. bfgb with a liameter of G-12 ioches. Truak short, beariog many wide-spreading, ofteo drooplog brapches folning a deep and rather broad crowo.

BARK-At first with a smooth grajlsh-brown lark, later becoming rough like the Wld Cherry by breaklog ap foto thilo dark brown plates.

TWIGS-Rather stont, at first hairg and light green, later smooth and reddigh-browa, corered with a few roncdish leuticels. Twigs ofteo bear aomerous spur-Uke apjaea.

BUDS-Alteraste; termionl one abaent; about of an loch loog, broadly cooteal, sharppoloted, brown, corered with oumeroua triaggular scales which are pale aod hairy along the margin.

LEAVES-Alteroate, simple, 1 -4 loches long, aarrowly-oborate, taper-poloted at apex, usually rounded at base, sliapply and doubly serrate oo marglo, firm, dark green, aod rough ahore, paler and halry below.

LEAF-SCARS-Alteroate, more thao 2-raoked, broadis cresceot-shaped, with 3 consplcuoua bundle-scars.

FLOWERS-Appear abont May when the leares are 1 developed. They are perfect, white, 1 lach across, occur oo sleoder bmooth stalks arranged in 2 -5-fowered umbels.

FRUIT-Matures lo late summer or early autumn. It is a subglobose drupe becoming red at full matarity, about 1 loch in diameter. With a thlck tough skin and a fattened oral atoce.

WOOD-Diffuse-poroas; hard, heary, stroog, close-graioed, reddish-brown, shios, with thin sapwood. Welgha about $46 \mathrm{lbs}$. per cubic loot.

DISTINGUISHING CHARACTERISTICS-The Wild Plum also koowa as the Wild Yellow Plum aod Red Plum, can be distioguished trom the other members of thls geous here described by the absence of a telmianl bud. by the characteristic bitter aromatic taste of the twiga and by its red globose frult ahout 1 joch io diameter, corered with a thlek tough bin and and by its red globose frult ahout l foch another species of Plum kaowo as Porter'a Plum or Sioe (Prunus anleghaievgib). Is aatire to this State. It Is distlnguished by its purple frait which is usually rorered with a bloom, rarely over of a inch in diameter aod seldom apiny.

RANGE-New Iork suth to Florlda, westward to Mootaoa, Colorado, aod Texas.

DISTRIBUTION IN PENNSYLVANIA-Foud locally throughont the State. Host common in the southeastern and swothern parts, preseot bot rarer io other parts.

HABITAT-Prefers rather molst rich soll. Common along banks of atreams aod horders of woods.

IMPORTANCE OF THE SPECIES-Th's swall tree is of Do commercfal Importance on account of the timber which it produces, but it forms an excelleot stock opoo whlch to graft the Domestlc Plum. It responds very readily to the attention shich a gardener may give to It. The frult is used for preserres aod jellies. It is attractive ornameatally on accouot of tta foe form, beatifal icllage, aod profusion of attractire flowers, 


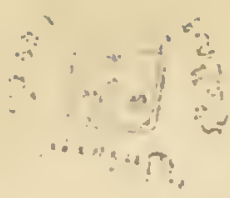

\section{COCKSPUR THORN.}

\section{Crataegus Crus-galli, Linnaeus.}

GENUS DESCRIPTION-The genas Cratnegus has the center of its distribntion in eastern North America. It reaches its best derelonment in the great limestone formationg rather common fo this part of America. Prjor to 1900 fewer than 75 specles were knowa in tbe world of which number aboat 30 were catire to North America. At the preseat time about 700 suecies of trees and strubs belonging to this genus "bare been descrihed. In the State of New lo.k alone 218 speci.z hare been described. Porter in his Flora of Pennsrirania publlshed in 1903 records 16 species as natlre to this state. Onls 2 species are descrihed in this bulletin becanse they are practically of no commerelal Importance and rery dificult to identily.

FORM-1 small tree sometimes resching a beisbt of 25 ft. with a diameter of 10.12 incbe日. Trunk sbort, bearing stout and spreadiag brancbes which form a broad and ratber flat erown.

BARK-Graysh to redish-brown, sometimes rougbened by small scales.

TWIGS-Smootb, rather slender. at flrst greenisb, later ligbt bromn to gray. usually bearing stralght or sllghtly curvel and abranched chestaut-brown thorns abont 3 inches long.

BUDS-Alternate, of an Jach long, often almost spberical, rers blout-pointed; termlnal bud usally present and ghout the sane size as the latergls. 1ateral accessors buds are often found at the usse of a thoro. Bads are corercd with numerone, thick, bluat-polnted, chestautbrown scales.

LEAVES-Alternate. sinple, obovate to elliptical, 1-3 incbes lons, lons-taperlng at base, rounded or short-pointed at ayes, alarjly serrate on margin except townrds base; smootb, thlek, and shing on the upper surface when full grown. Petioles short and brond.

LEAF-SCARS-Alternatc, more than 2-rmaked, small, crescent-shajed, containg 3 bundlesears.

FLowers-Appear about June when leares are fully dereloped. Thes are perfect, wbite, about 3 of an incb across and arranged in smootb corsmbs.

FRUIT-lifens ahout September but persists iuto winter. A globose or pear-jlke pome, about $2 / 5$ of an lnch long. greenisb or dull red, with persistent calps lobes at apes, contalning small nutlets which are rounded 3 t the ends and $2-3$ groored on the back.

WOOD-Difnse-porous: rmss rery Incoosplenous; growth fings rariable tu wldth and wary; beary, uard, reddish-brown, elose-gratned. Weighs ahont 45 lbs. per enbic foot. Used for fence posts and fuel.

DISTINGUISHING CHARACTERISTICS-The fonkspur Thurt, smmitimus alen kanwn - s Newcastle Thorn, Thorn Aprle. Thorn. Hawthorn, and Haw, can best be recozulzed by its long, asually ubianchul chestnat brown thorns, its small nearly spherical buds, its oborate to elliptieal lenrez with short and fatteged retioles, Its fowers wbich are arranged in corynbs. and its bright, scarlet, apple-like fruit which often persists far into wiuter.

RAXGE-Suthern Cangda sonthward though Connecticut and rirginia to northern Georgla, westward to Miebigan, Missourl, and Alauma.

DISTRIBUTION IN PENNSYLVANIA-Common in the eastern and sontbern parts of the State, Local in the other parts.

HABTTAT-Commou on sandy and grarelly soil. Jost frequent on the foothllls.

IMFORTANCE OF THE SPECIES-This specles is of no commercinl importance as a forest tree. It is, however, no attractive small tree which has been plated rather exteosirely for ornamental [n pospes. It is res rarinble in its form. leaves, lowers, and frult. It bas been planted as a hedge and in some cases has prored equal to the general requirements. The thorna were formorly used to elose woolen sackg in carding mllls. 

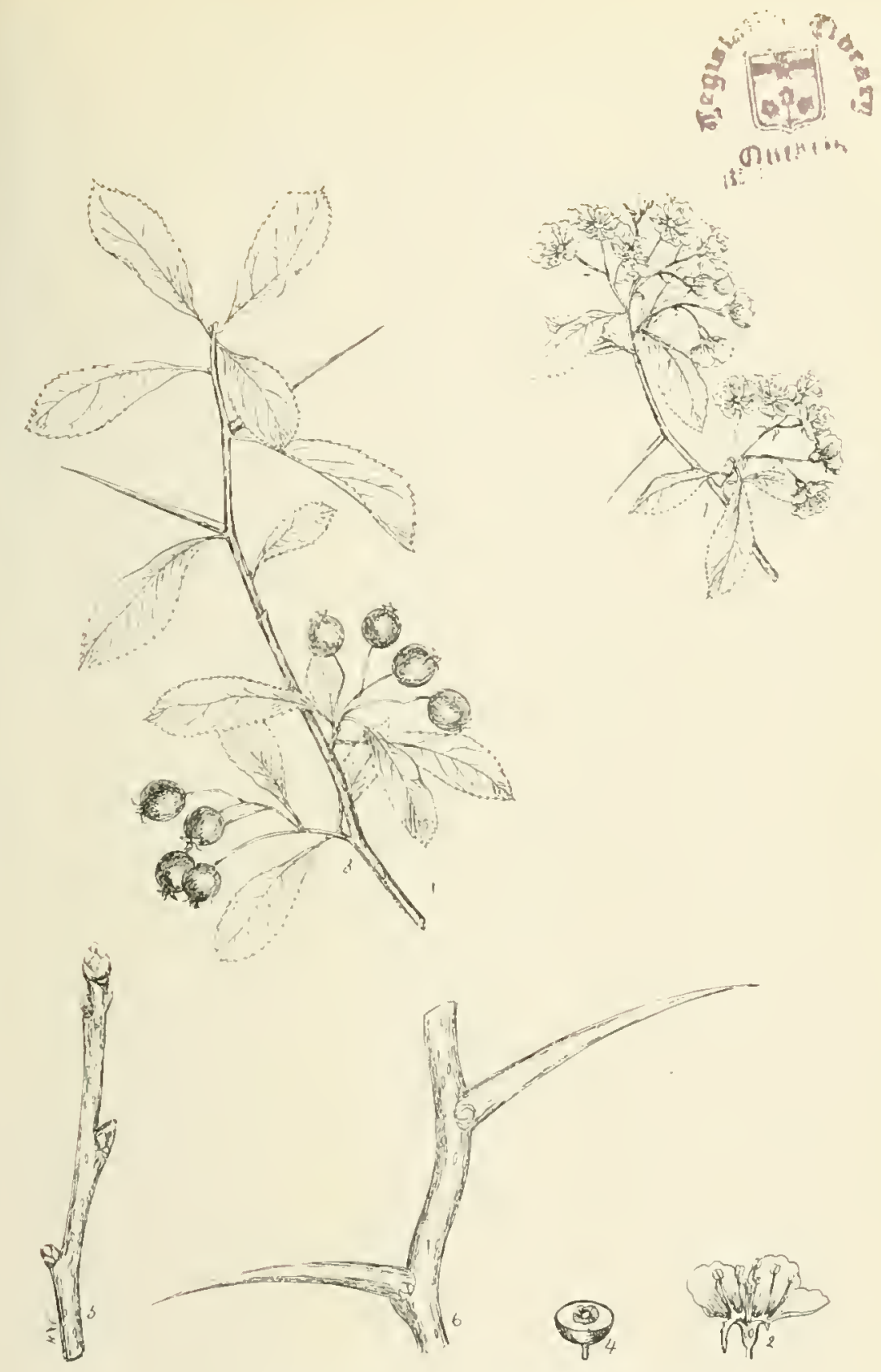

PLATE LXXXVIII. COCKSPUR THORN.

I A Howeting hranche $x$

2. Lonpitudinal switini of a flotrer, natural size.

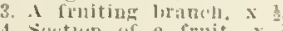

4. Siecturn of a fruit, $x$ z

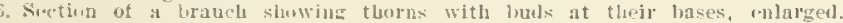




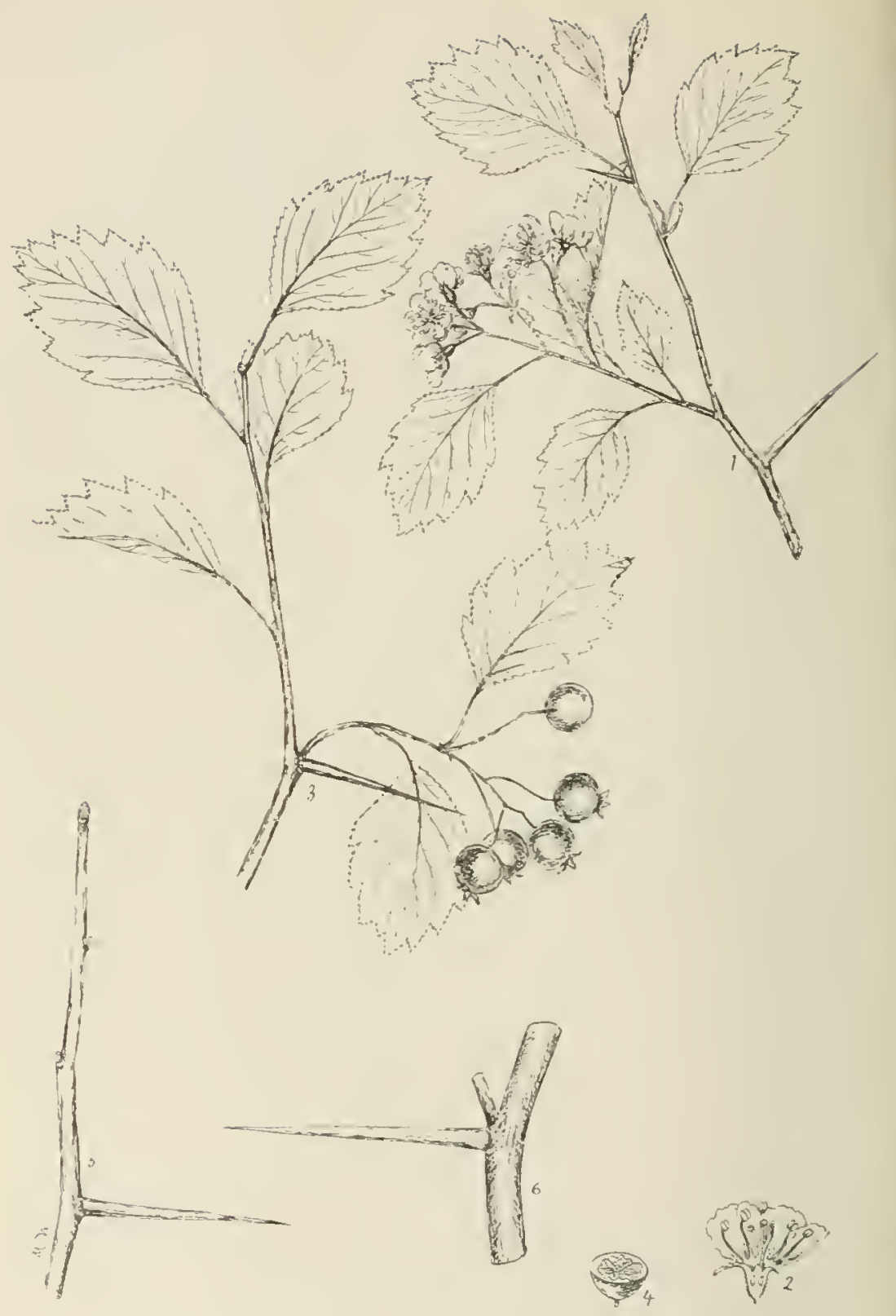

PLATE LXXXIX. SCARLET HAWTHORN.

1. A Huwering branch, st th

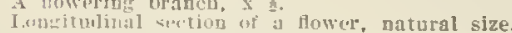

A fruitins branch, $x$.

i. A winter twios with a thorn $\Sigma 3$

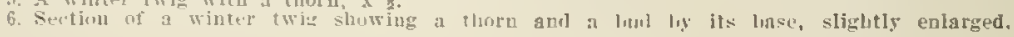




\section{SCARLET HAWTHORN. \\ Crataegus coccinea, Linnaens.}

FORM-A sinall tree rasely exceding a light of 20 ft. with a diancter of 10 inches. Truak short, stout, beneng rather crooked spremling branches which form a uroad a od tat crowa.

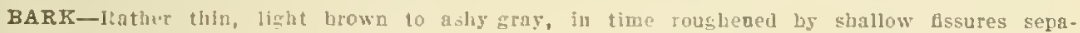
ratiog small sciales.

TWIGS-Stif, roun! In cross-section, at first greenlsh, later reldish, browaish or grayish,

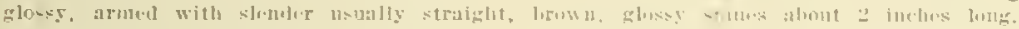

BUDS-Allerante, about \& of an inch louy, ofter almost spberical, very liluat-jointed, corered with aumerous. thick. blunt pointed, chestunt brown seales. Terminal but usually nreseat and about same size as laterals. Lateral aecessory buis nre ofteo foud at the base of a thorn.

LEAVES-Mtornate, simple, uroudly orute, 1 i, inches kng, rough [mbesceat, taperiag, romnal or trmeate $n t$ base, often sliglatly 5-9-lobed or durly cut and finely serrate ou laargin, polnteil at ajes:

LEAF-SCARS-Alternstc, more than "romled, small, cresceut-shaped, contaialas 3 buadleSCQTS.

FLOWERS-Appar about June when luwes are almost fully develoned. Thes are perfect,

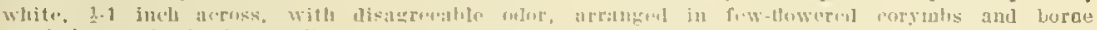
or liajry nnil slender stalks.

FRUIT-Iipris io Siptemher or O.tobre nnil is arranged in small umbels. A sabglobose to ellipsuidal porme, yellowisli-green, lager dark reddish lirown, pubrscent, ahout $2 / 5$ of a iach tbick. crowned with calyx lohes: containing asually $3-1$ nutlets.

WoOD-Similar to that of the Cuckinur Thord, Itige 170, only Leavier and more raluable. Used for canos, naphla risgs, engravint blocks, rulers. The wood is of a bigh quality, takiag a be polish but the trae is small and scarci.

DISTINGUISHING CHATACTERISTICS-Ibe Seurl.t Huwtinm, alio brown as White Thora,

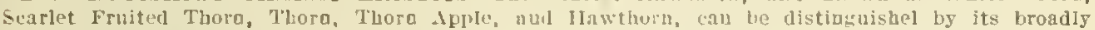
orate leares and rulasli-brown globose frut, both of which are juhescent. The leares are 5-9-lobed or deejly cur and fiaely serrate. The small nearly sjluerieal chestaut-browa buds and the slendir usully straight thoms on abe braches will aid ia distingulshing it from most of our antive species of trees. It is uext to lapossible to distiaguish all the species of the genus Cratacias from ench other.

RANGE-Easteru Massachusetts aad Vermont, soutlward through New Iork aad Peansylraaia to Norta Carolian.

DISTRIBUTION IN PENNSYLVANIA-Fonnd throughout the State. Not so aluundan io the aorthern and soutbwestern parts as isewhere.

HABITAT-L'sually found in rockg wools and old pastures with sandy or grarelly soil. Rather common along feces.

IMPORTANCE OF THE SPECIES-This sncuins is of ao commercial imprtance in the forest. It is, howcrer, attractirc on accouat of its flowers, autumnal color of its folinge, and the color of its persisteat fruit. 


\section{AMERICAN CRAB APPLE.}

\section{Pyrus coronaria, Linnaeus.}

GENUS DESCRIPTION-This genns embraces abont 40 species of small trees and shrubs whicb inbabit the north temperate zone. About 10 species are ngtle to North America and 6 to Pennsylrania. Xis important timber trees are members of this gens but some of our important fruit trees like the Apples and Pears belong bere. Both ant Common Pear and Common Apple hare been introduced from Europe. Some authors make a distinct genus, Malus, for the Apples and anotber one, Sorbus, for the Monntain Ashea, Both are included uoder Pyra: in this publication.

FORM-A small trae whlch may attain a beight of $25 \mathrm{ft}$. with a diameter of 14 Inches. Trunk usually short and bearing rather slender, spreading, and crooked branches whlch form a rather broad round-topped crowa.

BARK-Cy to of no Jach thick, reddish-broms, toughened by longitudinal furrows whlch separate low ridges often corered with scales.

TWIGS-Rather stout, at first white-woolly, fater smootb, reddish-brown, after first year bearlog stubby spurs or sometinjes sharp spines.

BUDS-Alternate, about s-z of an Jach long. Uright red, blunt-pointed or on rigorons terminal shoota sharp-polnted aad corred, corered with $4-8$ rislble scales.

LEAVES-Alternate, simple, orate or ellintical, 3-4 inches long, usnally ronnded at base, shrpp-pointed at apex, sharply scrrate on margin, usually smooth, dark green abore, pale green below. Stipules long, falling early.

LEAF-SCARS-Alternate, raised on projectlon of twlgs, crescent-shaped; with nsually 3 conspicuous bundle-scars.

FLOWERS-Appear in May or Jane when the leares are almost fully dereloped. Perfect, iragrant. rcsy-mbite, about İ-2 inches across, arragged in ambel-1lke cjmes. The flowers as a whole resemule those of the Common Apple.

FRUIT-Ripens abunt october. Pome or apple-like, borne on long slender stalks, depressedglobose, 1-13 lnches in diameter, crowned with persistent calys lobes and flaments, jellowish. creen. fragrant. The nesl: is clear a d hearily charged with bitter malle acld. Seeds chestnotbrown and sulny.

WOOD-Difuse-porsus; rays not distinct; hard, bezry, light reddish-brown. Weighs about $40 \mathrm{lbs}$, per cubic 100:. Tsed for carring, engrariag, tool Landles, and some turned articles.

DISTINGUISHING CHARACTERISTICS-The American Crab Apple closely resembles our cultivated rople only thr leares of the former are smoother. the flowers more brilliant red, and the frult smaller and very bitcer. The fruit often persists far into winter and does not lot readity. Il can he distingujshed from the losely related Narrowleared Crab Apple (Pyrus angustifolia, Ait.) bf its persistent calyx-lobes on the fruit, and by its orate leaf-blades while those of the latter are osually lanceolate.

RANGE-Ontario south thrcugh South Carolina to Alabama, west to Michigan, Missouri, and rorthern Lculsiana.

DISTRIBUTION IN PENNSYLVANIA-Common in the sonthwestern part of the State. Local outnosts reported from the central and western parts of the State. Peter Kalm, a papll of Linnacus, who travele.1 is America in 1753, reported this species "plentiful in Pennsylrania."

HABITAT-Csualis found in thickets and oper woods where rich moist soll Is present. Probably occurs most frecuedtly on little hill-tops near streams and ponds.

IMPORTANCE OF THE SPECIES-This specles is of no commerclal Importance as a forest tree. It rarels crceeds $25 \mathrm{ft}$. in helght. The fruit ls ased for jellies and for clder. It is a most attractire ornamental tiec on account of 1 ts showy and fragrant flowers produced in great Frofosion. 


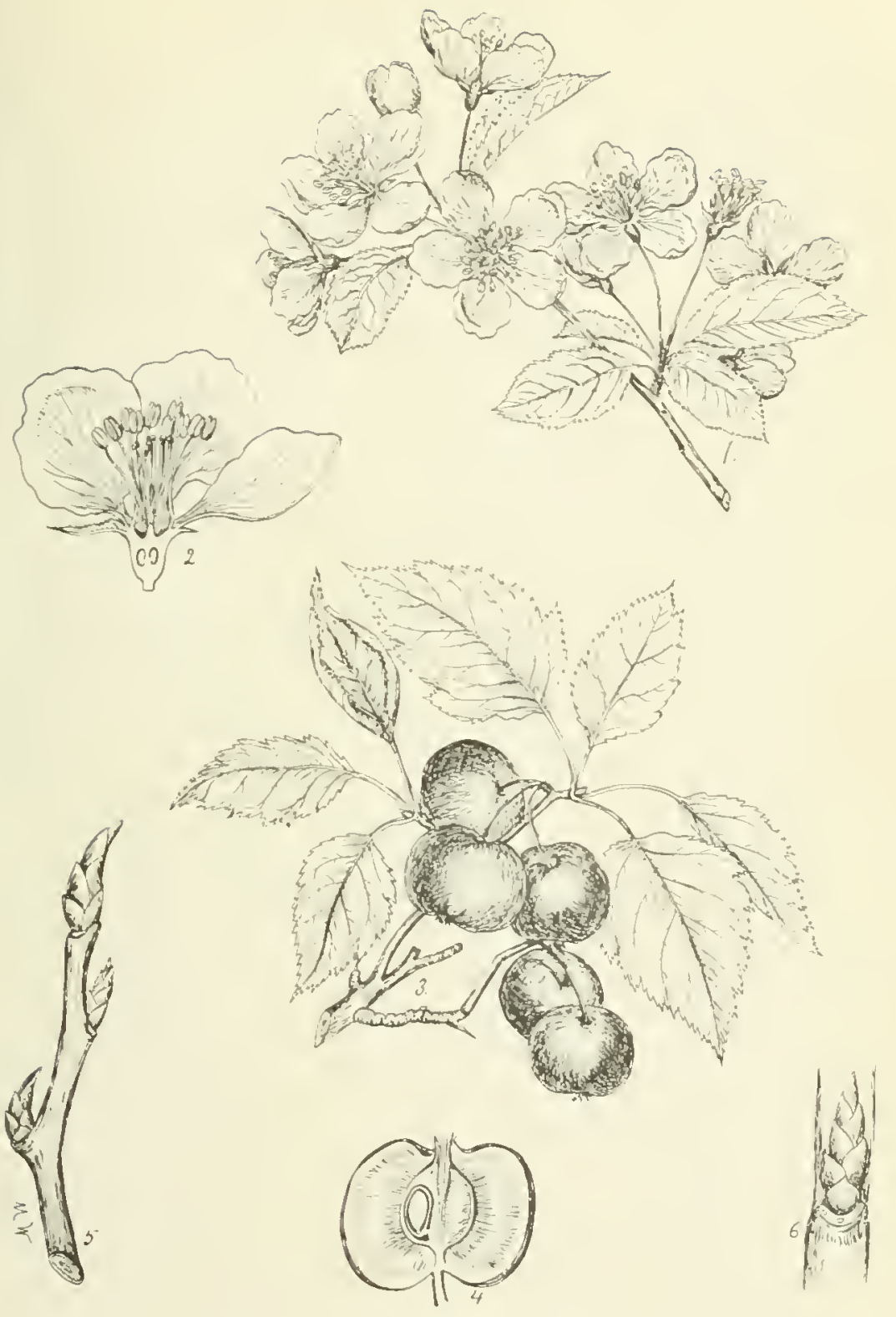

PLATE XC. AMERICAN CRAB APPLE.

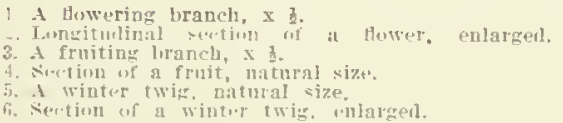




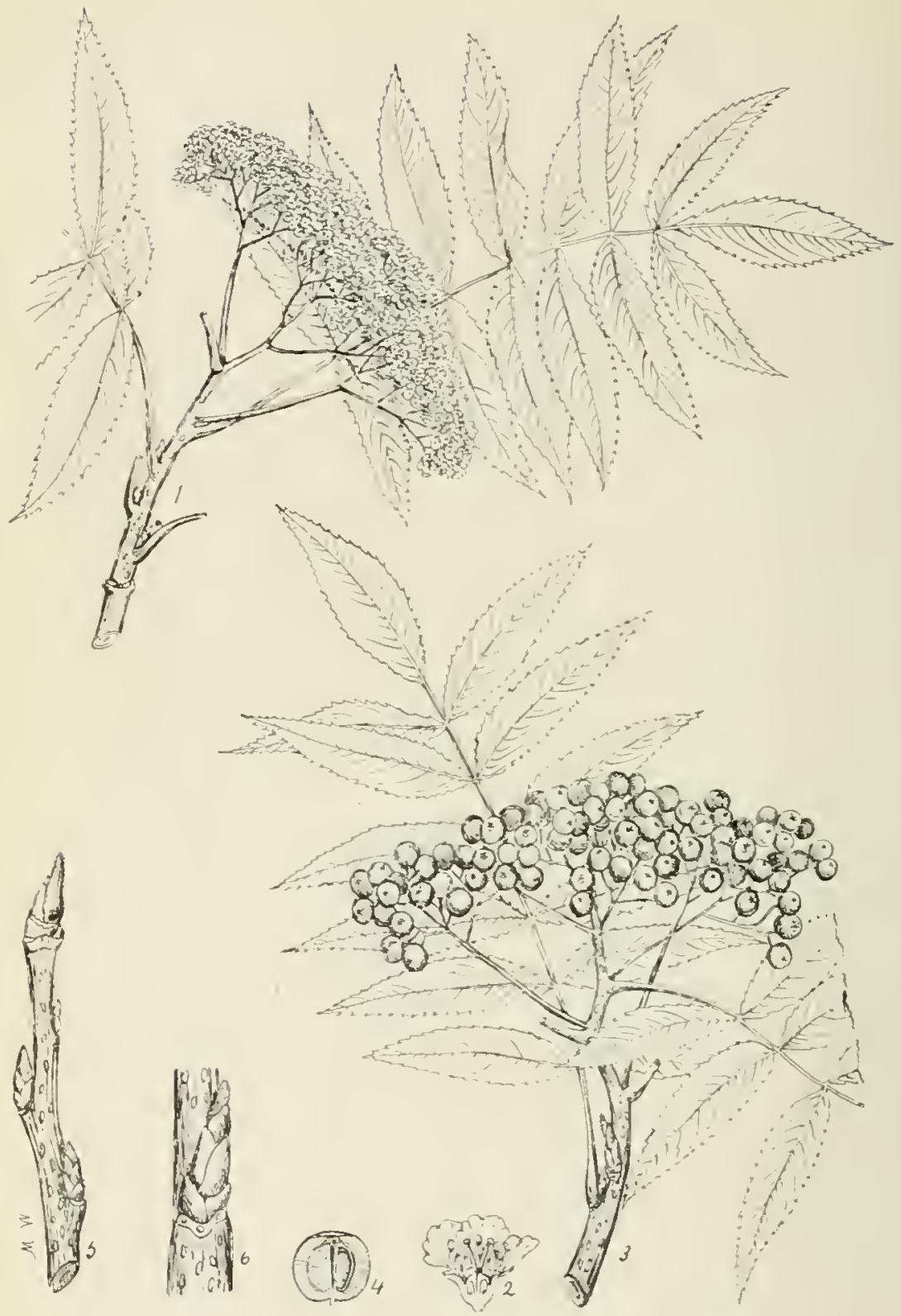

PLATE XCI. AMERICAN MOUNTAIN ASH.

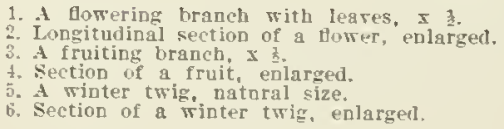




\section{AMERICAN MOUNTAIN ASH. Pyrus americana, (Marshall) De Candolle.}

FORM-A Emall tree rarels exceding $20 \mathrm{ft}$, in height with a dinmeter or 12 laches. A tree 14 Lnebes in diamets is reported rrom Iscoming county. Trunk rather short and the crown narrow and round-toried.

BARK-Thin, smostl or slightly scaly and grazish.

TWIGS-Rather stout, smooth, grayish to reddish-lrown, covered with consplcuous, pale, oblong lenticels, pith lorge, hrowitish.

BUDS-Alternate, lugplish-red, smooth or slightly hairy ro outaide but densely bajry on inside; terminal linds large, ahout $t$ of an lnch long, uroadls conlcal, with $2-3$ risible bud. ecales, sharp-heinted and ofteu curved at ajes; luteral buds about of an inch long. closelg alpressed, somewhat flattened, with 1.2 visible Lud-scales.

LEAYES-Ajtcrate, compound, j-jo lnches lons, with 13-I7 sesalle leaflets. Leafleta in paira except termial one, laceolate, 2-3 incbes long, sharp-ponted at quex, serrate on margin, taperige or rounded at base. Swooth and ancli gellowish.green wheo full grown, turning sellow in autumb.

IEAF-jCARS-Alteruale, rather Inrge, lesated un a projection of the twig, broadly U-shaped, with wars margin, contaiuing 3.5 bundle-scars.

FLOWERS-Appear aliout Mng whun the leares are fulls devcloped. Thej are white, perfect, a hout 3 or an inch acress, arranged lu that cymes $3 \cdot 1$ inches actoss.

FRUIT-Arranged in fint-tonped clusters, persisting far into winter, berry-like, about the cize of a medium-sized cberry, brabt red, round or pear-slaped, in winter wrinkied, its flesb strongly acid.

WOOD-Difuse-porous; rays indistlnct; soft, wenk, browblsh, close-grained. Welghs about 34 lbs. per cable foct. Sot used cormwercjally.

DISTINGUISHING CHARACTERISTICS-The Jmerican Moutain Ash can be distinguished log Its alternate compound leaves with I3-IT sessile leaflets which are conspicuously toothed. The fat-topped cymes of white fowers measuring about 3.4 , Inches across, and the bright red frat alucut the slze of a yea and arranged in flat-topped clusters are characteristic. The stout gajish to reddish. lrown twig with conspicious pale leatlcels and the purylish-red, sharp pointed, somewhit gumbs and usually smouth alteraate buds are also characterlstic.

RANGE-Newfoundand Westward to Manitoba snd Iowa, scuthward in the mountains to Nurth Carclisa.

DISTRIBUTION IN FENNSYLVANIA-Iimited to the mountginous region of the State. A line drawn from the western part of Tioga couty south to Somerset county and thence north. east to Morroe county will include the general distribution of this specles.

HABITAT-Prefers molsi or rocky billsides. Jften found on the border of streams and localls common on rocky hillwides.

IMPORTANCE OF THE SPECIES-This species is of no commercial importance. It rarely crecds beight of so.s $1 \mathrm{t}$. with a diameter $1212-15$ inches. It is rather attractive and deEerves to be planted for ornamental purposes. Its attractive ornamental features are its form, hrond cyme-like elusters of white flowers, and its bright red clusters of fruit which ripen in autumo. 


\section{SHAD BUSH.}

\section{Amelanchier canadensis, (Limnaeus) Mendicus.}

GENUS DESCRIPTION-The genus Amelanehier eomprises abont 30 species of small trees and shrubs foud mainj is the temperate portion of the aorthera hemlsphere. About 23 species are found in North Ameriea, $G$ of which attain tree-size. Four species are natlve to Penasylvanin, only 1 of which attaias tree-size.

FORM-A swall tren usualls 10-25 $\mathrm{ft}$. in heifht with a dismeter of (6-12 juches hut mos reish a beight of $40 \mathrm{ft}$. willt a diameter of 20 iachos. Truak usualls stralght, slender, with little

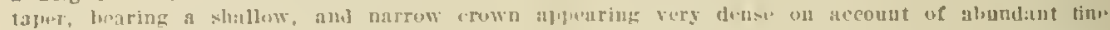
syrays of branchlets.

BARK-Tiather smootla on sounc and old spreeineus. On alder specimeas there la th tendency to ronglea th:ougli slanisow, longitudinal, suuniunes liagonal fssures which are rather dark and separate broad, ligliter, und swooth ridges becomiag scals near the base.

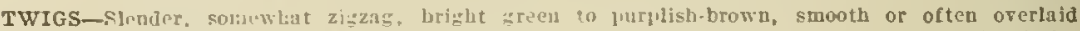
with a gray ish tilm-litie eanting which peels un; coveril with is few, pale, scattered lenticels; pith small, greenish, ahgubr.

BUDS-A]ternate, nsually 2-ranked, sleuder, confenl, 3 of an inch long, $3-4$ times as long as broad, sharb-poisted, greenish-lowa often inged with purple, sometimes smooth oftea balry towards ap.x nat alone bud-seales. Termlual buds lenger tha lateral which are usnally apruessed clost to twic, sometimes romilaing vers small. Bud-seales largest near base, oftea 3-netred, darker aud finely latry along margin.

LEAVES-Alternato, simple, orate to ovate-ablong. $3 \pm$ inches loag sharp-polated at apex, ronud or heart-bhaled at base, finely and sharply serrate on margia, at first fiaels hairy, later smooth, dark greeu above, jaler below.

LEAF-SCARS-Jiterngte, usually 2-rauked, sm:1l, inconspicuous, rather linear with projection at buthle-scars whlch are large and 3 in number.

FLowERS- Ippear alout April wheu leaves are just starting to develop; large, whlte, perfect, stalked, arranged in droojing racemes 3.5 uches loag.

FhUIT-Matnres in Julle or July. I:ery like in racrmes, reddish-purple, with a bloom when fully ripe, ubont of an inch iu diameter, sweet, ad cuntuialag small seeds.

WOOD-Diffuse-porous; rags aumeruns, indlstiant, darle browz often touched with red; hears. bard, strong, checks :ud warps easily, viry susenptible to bigh polish. Weighs 48.85 lbs. per cubic foot. User! to a lusited extent, mainly in suruery.

DISTINGUISHING CHARACTERISTICS-The Shad Bush, also knowa as Serrice Rerry. June Rerrs, aud sarvice, can reidilg be alstiuguished la winter by its smooth grayisb oftea blackstreaked bark and its long, slender, coniral, sharploituted, greenish-hrown to furplish buds which are ofted fincly hilisy towurils the apux and alung the marpiu of the scalis. The huds, is form and to some exteut la size rusenule the beech but the liuds of the Beech are osually larger, elear reddish-hrowa ia eolor aud have from 10.2u scalts arranged in 4 rows. The twigs of the Beech are sbiaing rerlibh-brown while those of the shad Fush are usually bright green to grayish or ynrplish-Jy:owu. [bu stipule scars are abseut ou the shad Rush while they nearly encirele the twig of the licen. The large white flowers nuranged in dropiog rncemes 3.5 inches loag भie alsn eharacteristic. The leares nod the frult will aid in distinguishing it in snmmer.

RANGE-Newfounilland and Ontario, sonthward to lorida, westward to Kansas and Lousiana.

DISTRIBUTION IN PENNSYLVANIA-Fund in every fortion of the State. Most abuadant amoag the momatrin rages.

HABITAT-Ocfurs solitary or oceastonally in elump. Prefers open situations and moist soil, but also grows on sandj rather sterile sol\}. Common aloag the border of forests, banks of streams, forest roads, and eliffs. Small slrecimens connos is thir understory of vur hardwood forests.

IMPORTANCE OF THI SPECIES-This specles is of litt?c commercial importance beeause jts mood is rarels used. It will nlwass be a minor preeit's not ou aceount of the inferiority of its wood bnt on account of its small size and limited and seattered distribution. The mood is actually stronger and stiffer tban Thite oak. Its coaspcuons wbite flowers in earls spring before the leares are nit justify its retention in the forest, espeeially where it does not interfere with the growth cif ether more raluable trees. The berries are excelleat food for birds, beasts, and mas. 


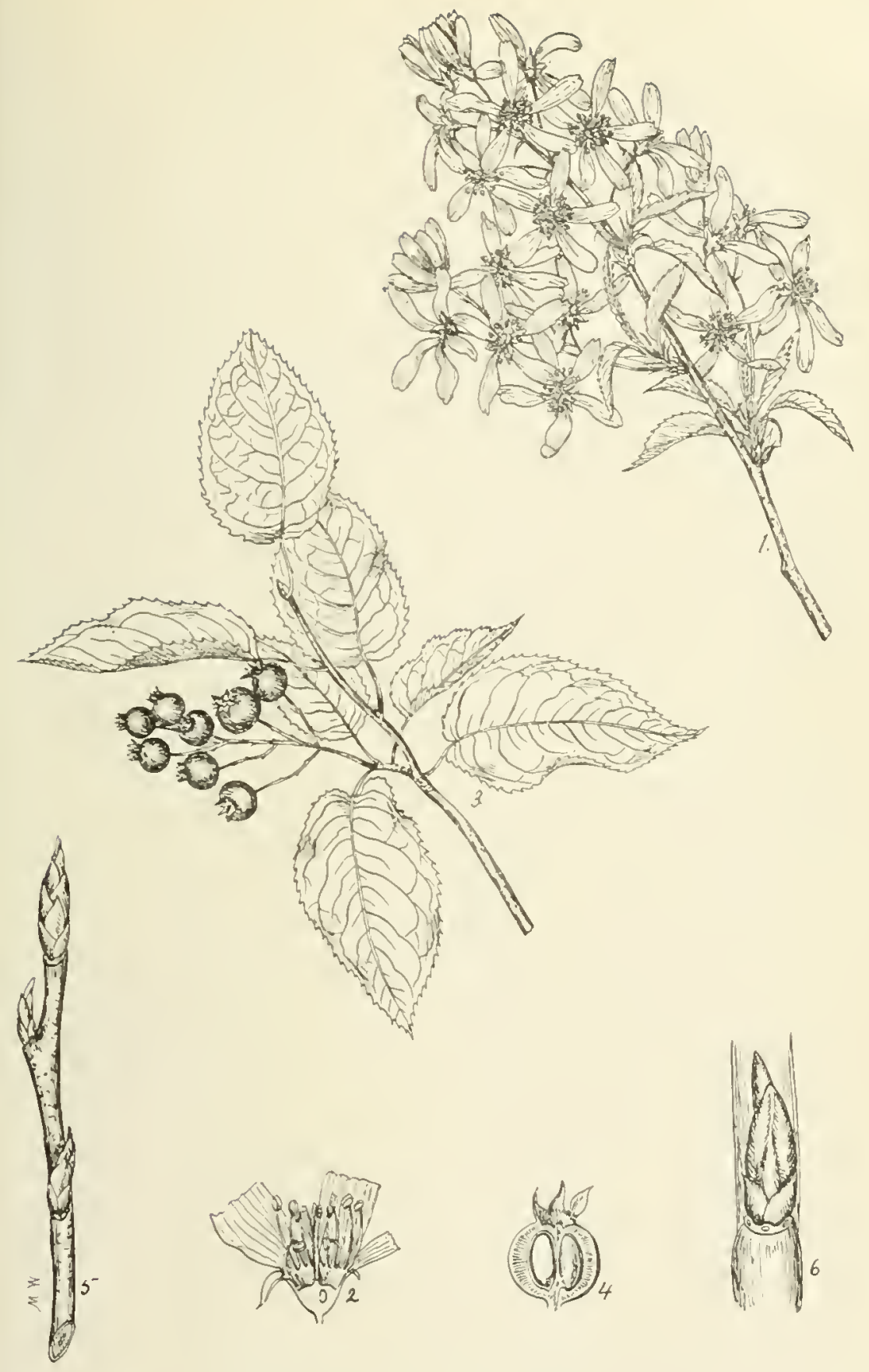

PLATE XCII. SHAD BUSH.

1. A flowering brancb, $x$.

2. Longitudinal section of a flower, enlarged.

3. A fruiting branch with roature leares, $x_{3}$.

4. Section of a fruit, enlarged.

5. A winter twig, natural size.

6 . Section of a rinter twis, enlarged. 


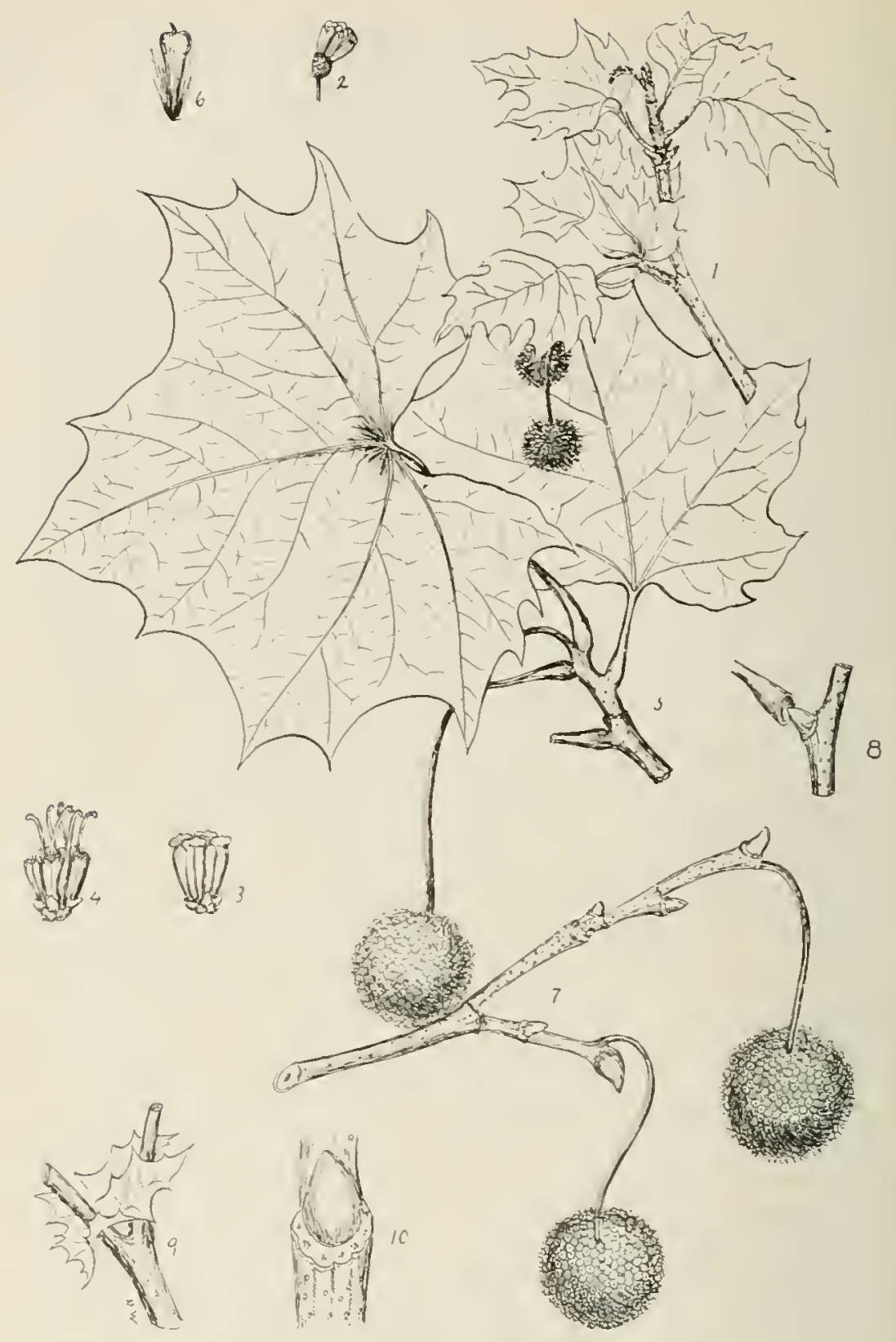

PLATE XCIII. BUTTONWOOD.

1. A flowering branch, $x$.

2. A bead of flowers with most of the flowers removed. I i.

3. A staminate fomer, enlarged.

4. A pistillate flomer. cnlarged.

5. A pistillate flomer. enlarged.

6. An acbene, enlarged

7. A winter twig with twe beads of fruit, $\leq 3$.

8. Section of a twig showing a subpetiolar hud $x$,

9. Section of a twig showing a stipule natural size.

10. Section of a winter trig, enlarged. 


\section{BUTTONWOOD.}

\section{Platanus occidentalis, Linnaens.}

FAMIIY AND GENUS DESCRIPTION-IJ, Flane Tree family, luatancen, comprimes only

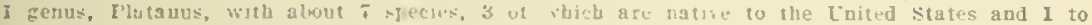

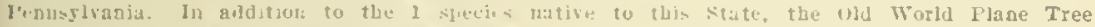
(I'atanus orientals $\mathrm{L}$.) is very comouly la isted as a sbade tree ia the cartera states.

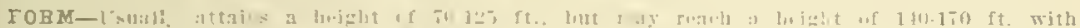

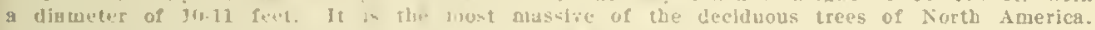
Trunk usualls hrawhes mear the base into bea:s -ub truaks, which sub-divide and form a rery

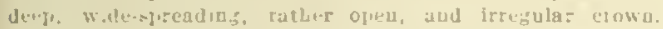

BARK-r a old trunk; rather thick, r.ged, rousitentel lig sl illow fissures segaratiog broad

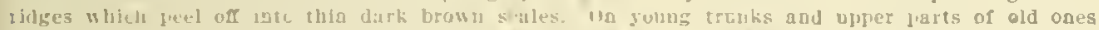

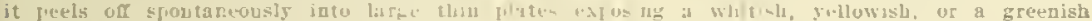

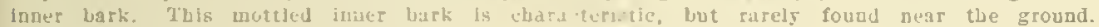
sue Fig. $3 \pi$.

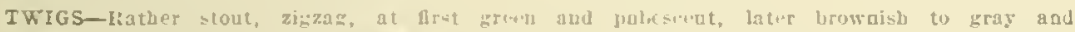

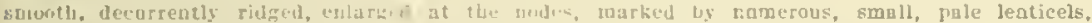

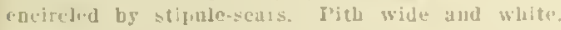

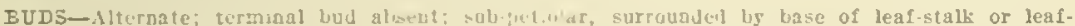

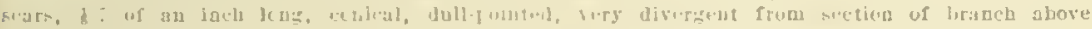
snd slightly fiom section below, covered with 3 sislus, the puter out of which is smooth,

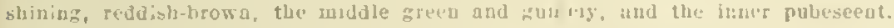

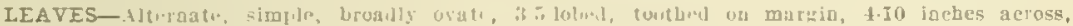

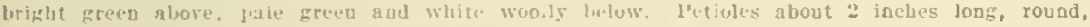
with enlirged bollow lases. StIuth 12 inches lorg, consicuous, eneircling twig.

IEAF-SCARS-Alternate, 2-ragked, un*al in width, bave a wavy cuter margin, aearly

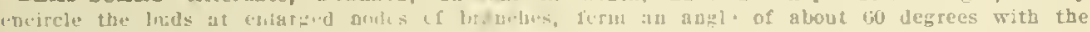

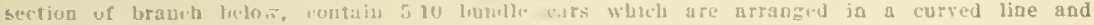
w. ur singly or in g.o:ais.

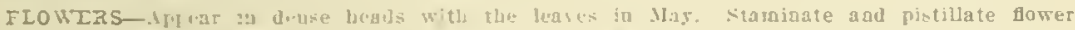
buds our of differet stalks. Stamimutu ate axillury agl dark red; pistillate terminal, greetush aut often ringed with red.

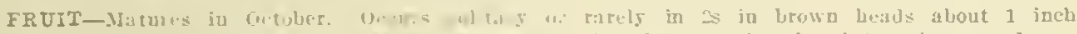

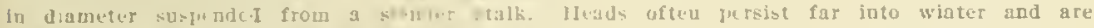

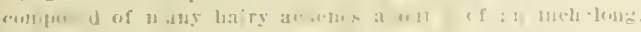

WOOD-mifuse-jorous; rags conspilurusly lrosu; pres minute; Lard, diflicult to fplit,

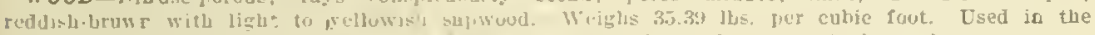

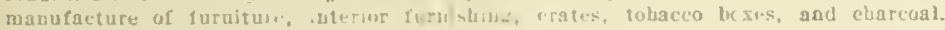

DISTINGUISHING CFARACIERISTICS-lite Iitwaisoud, also knawu as Buttonball, Sycamure, and ['lane. Tree, cau readely be distinguished in tummer by lis mussire form, its

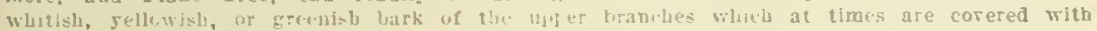
large, thiu, datk looma sralos of wuter bark. Tue large leaseg with their enlarged bollowbased Inticl. and the fluvers in the form of $n$ 'uds, are alos characterastic In wiater the

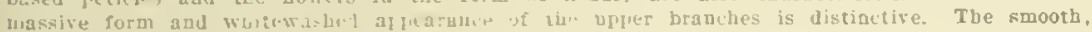

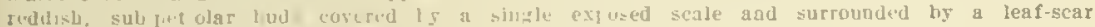
with j-10 bunlle-acars wil present out from confusiag it wita ang other of aur natire species. The jersisteat frue which usully cucurs soliters is Ieadily distingushed from the orieatal

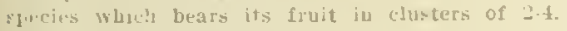

RANGE-Maine and Urtario south to Floriula, vest to Minnerota, Nebrasba ad Tezas.

DISTRIBUTION IN TENNSYIVANIA-Common alung streams, especially in the eastern, southern, ad ecritial iarts of the stute.

HABITAT-I'refers rurıa, f(rtilo sul, but will grow in ratber ary soil. Best derelopment in the moist vallegs of the nlio aul Mississipui sivers.

IMPORTANCE OF TRE SPECIES-The wund of this specits is aanualls becoming of more commercil imicitane ant bence at suold be lanted at least to a limited extent. It may

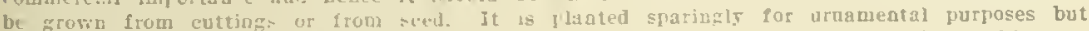
alue oriental sreanure stens to bu preferred suce it is more attractive aud less sabject to fuagous diseases. 


\section{THE PULSE FAMILY-LEGUMINOSAE.}

This is a rery large family and contains many well-known trees, shrubs, and herbaceous plants. It comprises about 460 genera with $\tau, 350$ species of which number more than 100 genera with about 1,400 species are native to North America. The flora of Pennsylrania comprises about 32 genera with approximately 90 species but only 4 species belonging to 4 different genera can be classified as trees. Some authors separate the members of this family into 3 distinct families known as: (1) The Himosa family, Mimosaceae, (2) The Senna family, Caesalpiniaceae, and (3) The Pea family, Fabaceae.

Many domestic and foreign plants which belong to this family are of considerable economic importance. Some of our native trees prodnce very heary, hard, and strong wood. They possess additional merits in that they grow rapidly and are well adapted to artificial propagation. Some of them, in particular the Common Locust, are subject to the attack of destructive insects and fungi. Some of the shrub member's of this family are among the most attractive that one can find for ornamental planting. The herbaceous members comprise some of the commonest and most valuable food and forage plants of the world, such as the peas, beans, clover, and the common peanut. Among the raluable products which some of the foreign members of this family produce one can mention Senna and Log. wood. Senna is prized on account of its laxative properties and is derived from the leares of a few African species of Cassia. Logwood, the most important of regetable dyes, is derived from the lheartwood of the trunk and roots of a tree growing in the West Indies and Central America. Indigo, one of our important and widely used dyes, is also obtained from a member of this family. The well-known Sensitive Plant (Iimosa pudica L.) so common in our greenhouses and a mere weed in the tropics is one of the most widely known and interesting representatives of this family. In addition they comprise a great number of plants which are important on account of the medicinal properties derived from them. Probably one of the greatest values which we can attach to some of the members of this family is the means which they have at their command for restoring nitrogen to barren land. If one examines the roots of clover, alfalfa, soy bean, or the Common Locust he may find little swellings or enlargements upon them known as root tubercles. These swellings are caused by bacteria which possess the power of taking free nitrogen from the air and by means of complicated chemical changes passing it to members of this family. As a result these plants can be grown upon soils rers deficient in nitrates. In addition they will return sufficient nitrogen to the soil so that companion or subsequent crops will thrive which would have barely existed without the nitrogen. The Common Locust often thrires on old abandoned mud-dams found 
about ore mines while other more aggressive species fail even to establish themselres.

The members of this family are distinctly characterized by their fruit which matures in one season and usually resembles ordinary garden beans or peas. The fruit of some of the trees found in the western part of North America raries more or less from the typical bean-like fruit pod. The flowers of our native trees may be irregular in form, i. e. pea-like or bean-like, as in the Common Locust and Redbud, or regular in form as in the Honey Locust aud Kentucky Coffee Tree. The two native tree-species with irregular flower's have also jerfect flowers, i. e. flowers with both the male (pollen producing) and female (seed producing) organs in the same flower while the other two natire tree-species hare regular but imperfect flowers, i. e. flower's with one sex so suppressed that ouly the other sex remains in each flower. Whenever the male and female flowers, also known as staminate and pistillate flowers respectively, occur separately, they may be found on the same branch, or on the same tree, or on ditlerent trees. The leaves of nearly all the tree members of this family are alternate and compound, but a few such as our native Redbud hare simple leares. Some species as our Common Locust are normally ouly once compound, others as the Honey Locust may be once or twice compound, while still others, as the Kentucky Coffee Tree, may be normally twice compound.

\section{SUMMER KEY TO THE GENERA.}

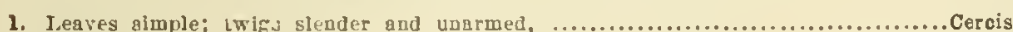

1. Leareg compound: twigs stout or arned with spines or thorns, ....................2

Page. 180

2. Trigs rery stout and clumsy hut not armed with spinea or thorns; frult-pods woody; leares twlce compaund, frasn $1.3 \mathrm{ft}$. long, ......................... Gymoeladus

2. Twigs relatively slevler and armed with spines or thoras; fruit-pods leathery; lenves usualls cnce or sometimes twice compound, rarely over $1 \mathrm{ft}$. long, .................3

3. Flowers greenisb, regulnr or vearly so, imperfect, in asillary spikes; leaves once or twice compound, eren-pinnate; twigs, brancbes, and often trunks with long

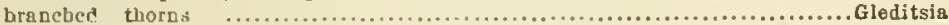

3. Flowers wbitish, irregular, perfect in drooping rncemes; leares usually once compound, odd-pinate; twigg often with two short spines at nodes, ...........Robinia

\section{WINTER IEEY TO THE GENERA.}

1. Twigs, brancbes, and trunks usually armed with spinea or thoras, .................2

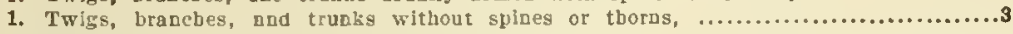

2. Twigs and branches armed with a pair of splnes not exceeding of an inch in length at each node; Pruit-pads 2-4 inches long. If of an inch broad; bark reddiahbrown, eren on roung trunks deeply furrowed, ............................ Robinia

2. Twlgs, brancbes, aud often trunks usually ermed with thoras wbich occur aingly, are often braneitul and usunlly much exseed $b$ of an inch ic length: frult-pods 10-18 inches long, 1.13 luches wlde: bark israylsh-brown to black, not furrowed, often covered wlth ccnspicuous oblong lenticela, ............................. Gleditaia

3. Twiga stont, clumsy, blunt-pointed, with large conspleuous bundle-sears and large pink to brows pith; fruit-pods thick, woody, stubby, cortain leshy pulp and large sceds: buds silkr-puhescent, depressed, uppermost one surrounded by incurved

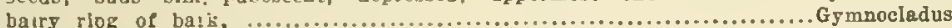

3. Twlgs alcnder, not clumsy nor blunt-poinced, with inconepicuous bundle-acara and pith with reddsh longitudinal streaks; fruit-poda rery thin, leathery, without fleshy palp, an I contaln small seeds; bujs smooth, not depressed, often somewhat

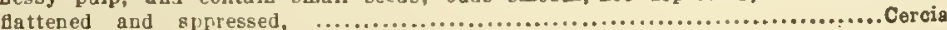




\section{KENTUCKY COFFEE-TREE. Gymnocladus dioica, (Linnaeus) Koch.}

GENUS DESCRIPTION-Tbis geaus comprises only 2 species, one Gymocladus chinensia a native of southern Cbina, and the other describcd here. The generic name Grmnocladus is of Greek origia and means "onked brancb" referring to the stcut clumsy brancheg which are deroid of foliage for about 6 months of the zear.

FORM-A medium-sized tree nsually 40 -so $\mathrm{ft}$. in belght with a dinmeter of $\mathbf{1 . 2} \mathrm{ft}$. bat may ieacb a heigbt of $100 \mathrm{ft}$. With a diameter of 3 feet. Ttuak usually sbort, soon subdiriding into 2 or ? secondary acaris parallel stems. Croma barrow oborate, composed of very stout brapcblet.

BARK-OP medium thickness, dark gras to dark brown, roughened by sballow fissurea separatjog low ridgcs coverel with thin recurred scales.

TWIGs-Yery stout, bluut-poiated, greenish-browa, often coated with a wbitish crusty flm, occasionally corered with tine bairs, and juarked with large conspicuous lenticels usually most numerous on the secogl jear's growth. Pith large, pist to browa ia color.

BUDS-Alteroate; terminal bud abseat; small, dowor, imbedded io twin so that it scarcels projects bejond surface, surrounded bs incurved hairs ring of bark, saperposed. The appermost bud is the largest; the lowest is small and located in the depression at top of leal-gcar.

LEAVES-Alternate, twice compound, 1-3 ft. long, 1 1.2 $\mathrm{ft}$. broad, with 7.13 folinte plonae; I-2 basnl palrs of pingas are reduced to entire leaflets. Piunae hure $3-\mathbf{t}$ pairs of leaflets. Leaffets ovate, 2-23 inches loc $y_{1}$ wedge-shajed to rounded at base, sharp-poiuted at apex, entire to wayy ou margin.

LEAF.SCARS-Alternate, nore than 2-ranked, large, conspicuous, raised on projectlong of twig9, broadly beart-gliapcd, paler jo color tbqa surrounding twig; contain 3-5 large, raised bundle-scars.

FLOWERS-Appear about Jude. Regular, jolygamus, or dioecious by abortiod. Staminate fowers grecuisb-white and arrenged in a raceme-like corymh about 3-4 inches long. Pistillate flowerg greenish-white nad arrauged in terminal racemes $\mathrm{G}-\mathrm{S}$ incheg loog.

FRUIT-A Lroad, flat, tbick, stubbJ, reddisb-brown pod, 4-13 laches long, 1-2 incbea broad, sometimes covered with a grawish bloom. lods often persist far into winter and remain closed. Seeds dark browd, flat, 6.4 to a pod, orer is of a iach across, surrounded by a somewhat sticky sweet pulp.

WOOD-Ring-porous; peres In spring wood large, la late wood small; rass distinct but Dot conspicuous; hears, not hard, strong, coarse-gained, light Lrewa to reddish-brown, durable in coutact witb soll; takes a fine volish. Wieighs about $43 \mathrm{lbs}$. per cubic foot. Used for fence posts, fence ralls, and occaslonally in construction.

DISTINGUISHING CHARACTERISTICS-The Kentucky Coffee-trce, also kuown as Mahogan, Coffee Nut, and Nicker T'ree, can be distinguished bs ita large twice compound leaves, its stout, clumsj, unarmed branches marked wjth large leaf-scara and containing pink to brown pith, and by its thick, stubly, and woody fruit-jods. The superposed, depressed, silky buds, the uppermost of wich is surrounded bs an incurved halry ring of bark, are also character. istic. Io general it resembles the Allantbus "ut it can be distinguisbed from it especlally by its curjous bark, its ciaracteristic fruit, and the narallelism of jts primary brancheg.

RANGE-Central New lork south to Tennessee aud westward to Ninnesota and Indian Territory. It ia absent from mang localities within this range.

DISTRIBUTION IN PENNSYLVANIA-PInated extegsively as an oroamental tree but isually knows under the name cf Malogans. Franklio county is the ouly part of the state where it is reported as a aatjre tree.

HABITAT-Ricb wools gnd bottomlands. Alwass occurs solitary, never in clustera or atands. often ouly a single tree lnown in a localitg. Wheo planted it will grow practically answbere in the state.

IMPORTANCE OF THE SPECIES-This tree is of no commercial importance, especinlly in this State where it is very rare. It is regarded rather attractive as an oromedal tree and 19 planted exteasively in this State. It loses its leares early in autuma and derelopa them late in spring. 


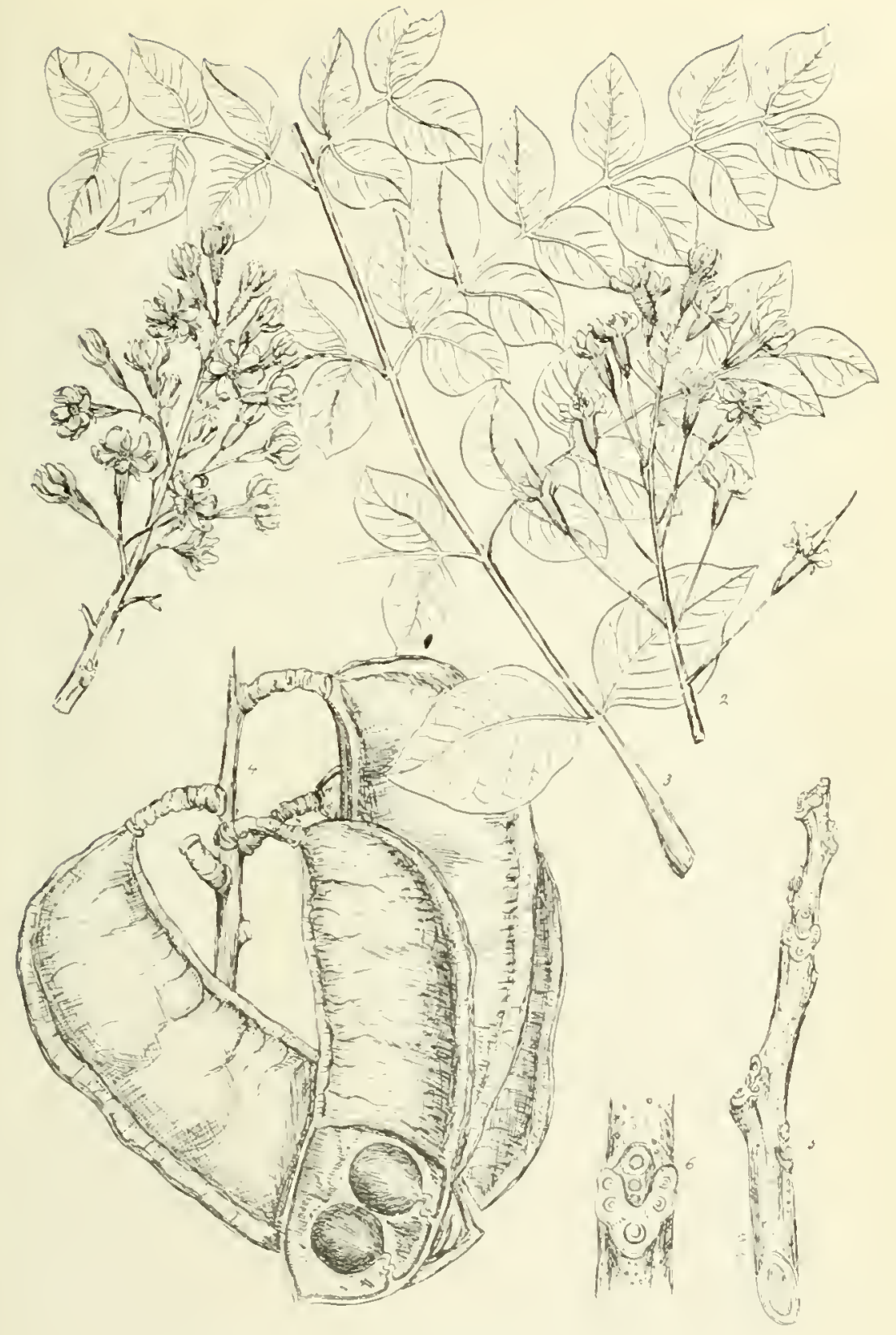

PLATE XCIV. KENTUCKY COFFEE-TREE.

1. Staminate flowers, $x$

2. P'istiliate llowers. $\mathrm{x}$ ?

3. Portion of a doulity mompondud leaf, $x$

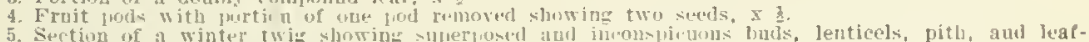

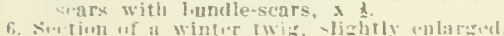




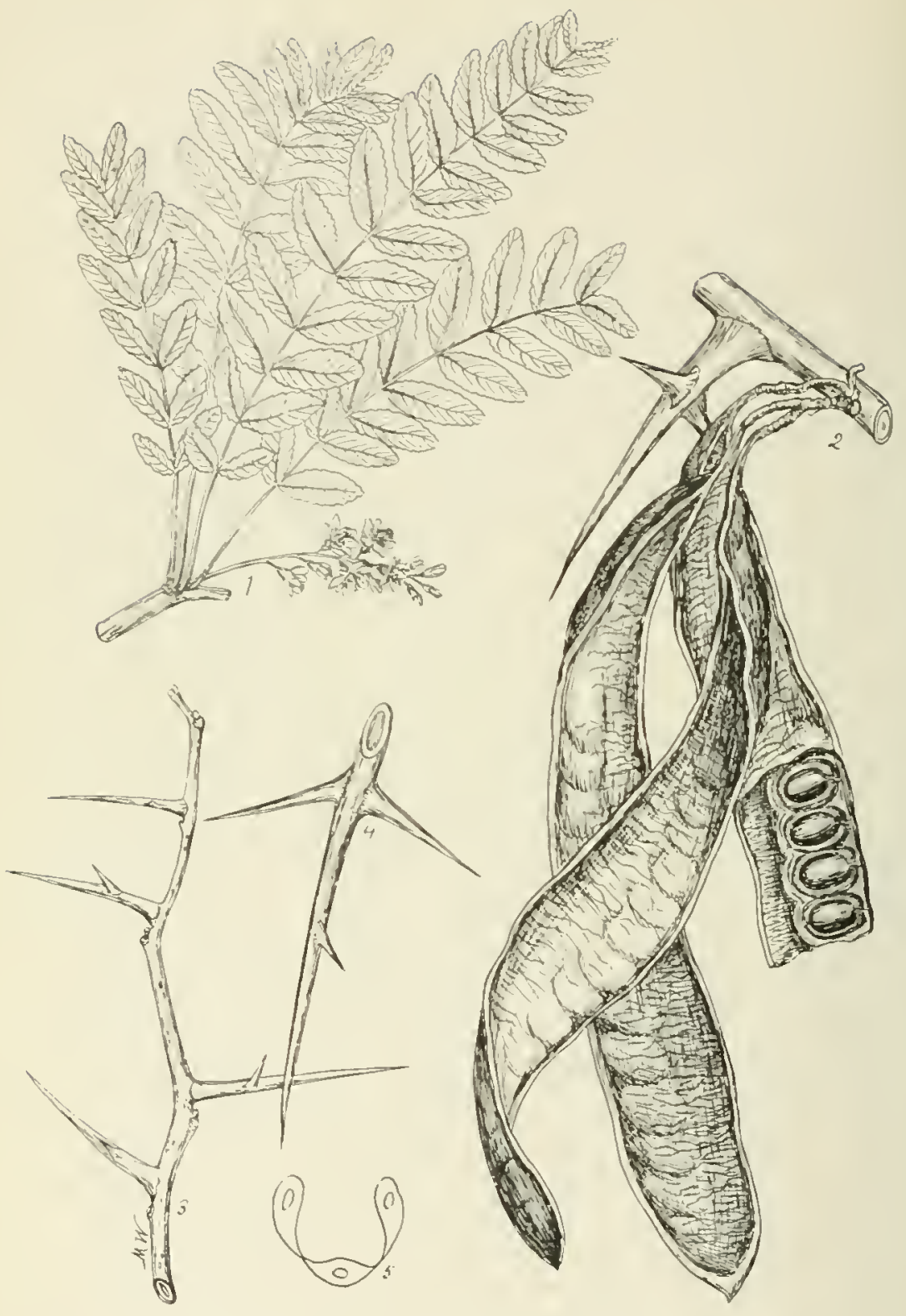

PLATE XCV. HONEY LOCUST.

1. I"lowering luranch with mature leares, $x$. diranched thorn, $x$

section of a liranch with fruitin

3. A winter trig with thorn.
4. A branehed turn. $x$ is.

5 . A leaf-coar, enlarged. 


\section{HONEY LOCUST.}

\section{Gleditsia triacanthos, Linnaeıs.}

GENUS DESCRIPTION-Thls genus comprises about 11 species of trees whlch are nsually armed on the branches and truak with simple or branched tioras. They are distributed fa the temperate part of Asia and eastera North smerica. Fossil refresentativea of thia geaus hare beea reported from Europe. Three specles are antive to eastera North America, oae inhabiting Tesas, one the southen and south-ceutral United States, and oae described bere. The geaeric aame is in conmemoration of the German botanist, Jobn Gottlieb Gteditsch.

FORM-s medium-sized tree usualls from $\$ 0.50 \mathrm{ft}$. bigb with a diameter of $1.2 \mathrm{ft}$. but may reach a hejgbt of 140 . 1 . With a diameter or $4-6$ feet. Truak usually short but when growa la very close stands mog be rather cleu nad long. Crown broad, obovate, round-topped, bigh oa account of lateral droopiag braches.

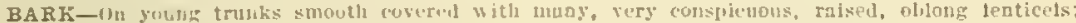
Da old trunks grayish-browa to almost black, sometimes smooth but usualty roughened by a few fissures aud thick, birm, broad ridges whth projecting edges. Bark oa trunks is often covered with mang thuras. See Flgs. 59 and 04.

TWIGS-liather stout, zigzag, smooth, glossy, with ealarged aodes; greeuish-red to brown, covered with few, small, scattered leutieels which become larger la time; pith tulek aad white. Twigs frequertl. bear thorns which are ofted brabched and coutain reddish-browa pith.

BUDS-Alteraate; terminal bud alseat; small, usualty 3-5 at a node, placed one above another; apper oaes scaly add ristle, lowest oat not scals, nor visible except as a dot. Some buds are blow in desclopiag.

LEAVES-Alternate, sirgly or doubly cosupound, 7.5 iaches long. ['etioles tiattened, grooved

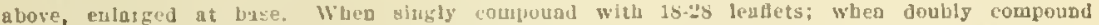
with s.14 placae aud ench with usually is 20 leatlets. Leallets lanceolateoblong, 1z-2 iaches loag. rouaded at the Lise aud aprex, somewhat surrate oa merglos,

IEAF-SCARS-Alternate, 2-ranked or more than 2-rauked, U-shaped; varting in width; brondest nhout the 3 lonade-scars and narrower between.

FLOWERS-Ifuear nlout May or Julue. Folggamus, small, greenlsh. Stamiagte flowers arraged la stort hairs racenjes with stort stalks. Plstillate flowers in few-fowered, ratber eloagated a ad aolitarr rocemes.

FRUIT-A more or less twisted, fat, a ad reddish-brown jod, 10 is jacbes long, containing

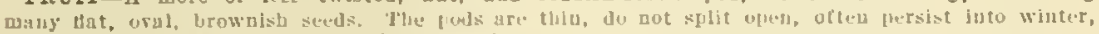
and occasionalls are lirednced in large numbers.

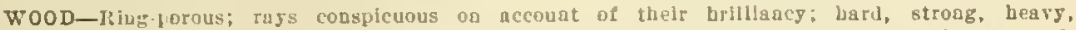
durable in contect with the soil; henrtwoud hright reddisblurowa with thia pale sapwood.

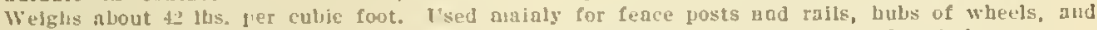
geacal coastruction. Ir time lts use wlll be exteuded and it ay be growa for timber.

DISTINGUISHING CHARACTERISTICS-The Iloaes Locust, also known as the Sweet Locust. Thorn Tree, Three-thoraed Achcia, and Hores stucks, can he distiaguished by its large bragched thorns locatej above atu? lcaf-scars. A thorule.us variety is, bowever, baowa. The oacecomnouad or snmetimes twice-compound evenly-lisante aad alterate leares together with the lenthers frult with conspicuoua obluw leaticels are also chnracteristic. A loagitudiaal sectloa of a twig Just above the origin of n leat or a l1.af sear will usualls show five separated and superposed buds, the upper scaly and extrally risible, the lowest not scals and hiddea beneath the bark.

RANGE-Ontario through Fenasylvapia to Florida, westward to Kaasas and Texas.

DISTRIBUTION IN PENNSYLVANIA-lound as a aative or planted tree ia all parts of the State. Its original distrlbution in this state was limited almost eatirely to the region west of the Allegheas Mountains, except a few leeal ontposts east of them. At present it is common as a planted tree in the eatire enstern fortion of the State and la many places has escaped cultiration.

HABTTAT-it develops best iu ricb soil along moist riser bottoms but will grow in any fertile soil whlch is not too wet. It demads pteaty of light.

IMPORTAICE OF THE SPECIES-This tree is of little commercial importance as a timber tree in Pecusylrauia because it is $1, \mathrm{mited}$ in its distributlon. Most of the existing trees of this State are open grown and aot forest growu, therefore, too knotty to be of any commerclal ralue, if proverls finted it will produce escellent wood. It grows rapldy, is free from iusect and fungal enemies, has a attractire form, and bears graceful foliage. The leares come out late iu sprlag und, heace, it is aot of much valne for shade. 


\section{REDBUD. \\ Cercis canadensis, Linnaeus.}

GENUS DESCRIPTION-Thls genus comprisea $\bar{t}$ specles of small trees and fhruba fonnd in parts of Asia, Europe and North America. Three species are native to North Amerlca, 1 inhablting California, 1 Mexico and Texas, and 1 eastern United Statea. The latter is native to Penosylrania and described here. Thes are prized mainly on account of their ornamental value due to their bright rose-eolored, pea-like flowerg which cover the branches with a profuse and brilliant flame of color ju early spring before the leares come out.

FORM-A small tree usualls about $15.20 \mathrm{ft}$. high with a diameter of 6 inchea but may reach a height of $50 \mathrm{ft}$. With a diameter of 15 lnches. J'runk short bearing rather npright branchea which form a sballow and broad crown.

BARK-Thin, shallowy fissured separating ridges which peel of into nnmerous feales, reddishbrown to vel'g dntk brown. See Fig. 56.

TWIGS-Slender, fmooth, light brown, becoming grayish-brown, corered with aumerous rery small lentlcels, contuining pith which sometlmos bas reddish longitudinal streaks.

BUDS-Alteruate; torminal one absent; small, $\frac{1}{2}$ of an inch long, blunt-pointed, dark purplishred, spherleal or somcriat flattened when appressed. Sometimes superposed with opper one usually the larger, or clustered at the base of a lateral brach, covered with $2 \cdot 3$ vialble acalea with hairg arargin.

LEAVES-Alternate, simple, rounded or heart-shnyed, 3.5 inches long, consplcuouly $\mathbf{5 . 7}$ nerred, cordute at base, pointed at npex, entire on narghn.

LEAF-SCARS-Altermate, 2-roked, inrersely triangular to beurt-shaped, somewhat ralsed, containing 3 conspicucus bundle-scars. Short spreading ridges often origionte at outer margin of the leap-scars and extend down the stem for a short diatance.

FLOWERS-Appear ir Mtarch or April before the leares or sometimes when the leares are just alpearing. Resemhle the sweet pea in form; perfect an brilliant red, barne usually in elusters of 4.8 , oftzu dereloplog from buds locatec at the base of lateral branches as well a from buds loceted nloug the branchea.

FRUIT-A Emall, rosecolored to light brown, short-stalked rod, 2 iz-3 lachea long, abont b of as inch wide, containing ubout 6 broadiy ovte, tattened, light-brown aeeda. Pods may peralat until early winter and are often produced in enormous quantities.

WOOD-Ring-porous; beays, hard, not strong, rich dark reddish-brown with light sapwood. Weighs 39.65 Iba. per cubic foot. Not sound un the market.

DISTINGUISHRNG CIARACTERISTICS-The Redhud, also known as the Judas Tree, can be distinguished by its blmule nlternate and heart-shaped leaves, its aleoder unarmed and light brown twigs with reddish-streaked pith, its small, thin, leathery fruit-porls, and its perfect, pea-like, brilliant red blossoms which occur in clusters of 4-8, appenring in early sprlng hefore the leares : ad dereloping fron a cluster of buds lochted at the base of a lateral branch aa well as from buds located alon the twigs. This is the onls tree native to this state which develops a cluster of perflisb fower buds on a branch just below the origin of a lateral twig.

RANGE-Ontario through New Jersey to Florlda, westward to Mindesota aud Arkansas.

DISTRIBUTIGN IN FENNSYLVANIA-Not known to occur in the northers or easterd parta of the state, Reportel from the southesstern, soutbera, central and western parts. Common In the Schuylinil and Ferklomen Valless and along parts of the Susquebana Rirer Valley, especially acrthwest aud southeast of Harribburg. Common about Gettrsburg, and aouth of Chambersburg in the cumberland Valley. Occurs in a dense pure stand corerlog abont one acre sontbrest of Gettygburg.

HABITAT-Prefers :ieh molst soils. Common in sbandoned flelds, cot-over and open woodlands. Also found a the understory of the forest. Endures shside bat prefers plenty of light.

IMPORTANCE OF THF SPECIES-This tree is of no commeicial Importance ag a forest tree but where a tall shrub or a smail tree is desired tor oranmental planting hardly a more attraetire one could be found. It has a pleasing form at all seasons of the Jear, an exceptionally benutiful and nbundan: bloom in spring betore the leaves coms out, apd in addition, growa rapidy. It ia cultirated extensirely in Europe as an ormamental tree. 

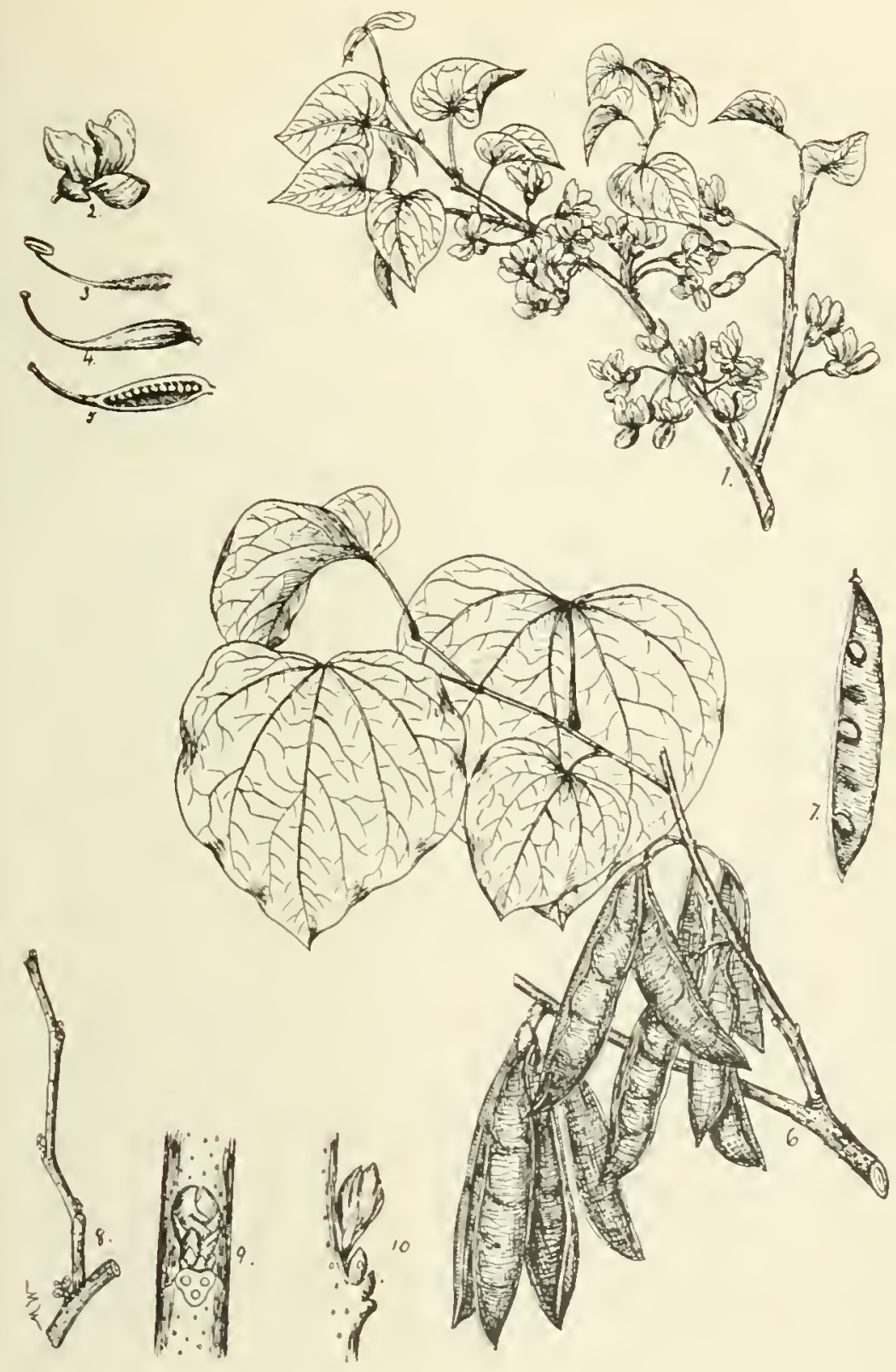

PLATE XCVI. REDBUD.

\footnotetext{
1. A fleswring iraudb, $x$,

$\frac{2}{3}$ A single flomer. $x$ s.

1. A simple ju-til, enlarge-4l.

ctionel an as to show the oruless, enlarioul.

A fruitine branch, $x$

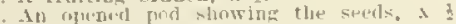

A winter twiar. $x^{3}$

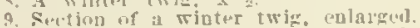

10. jortiens of al winter twic sluwing focation and arraugement of buds, enlarger.
} 


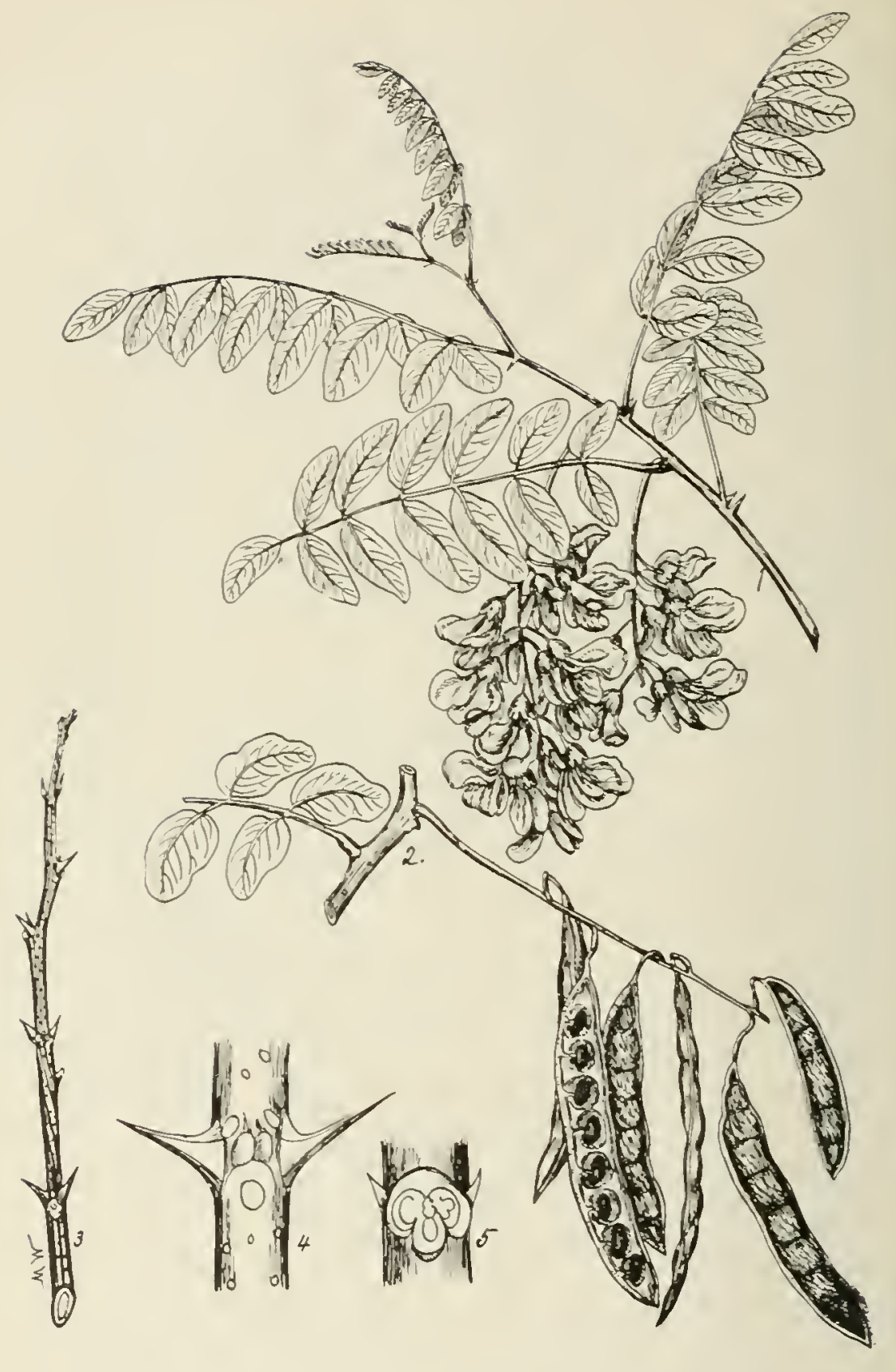

PLATE XCVII. COMMON LOCUST.

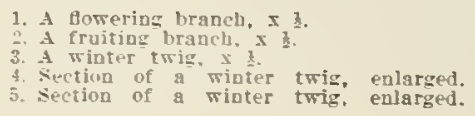




\section{COMMON LOCUST.}

\section{Robinia Pseudo-Acacia, Linnaeus.}

GENUS DEECRIPTION-This genus comprises 7 specles of tiees and sbrubs native only to North Amerfca but some are planted extensively in Europe. Three of the 7 apecfea reach treesize whlle the others remaln shrubs. The gederic name is in commemoration of the French botanlet Jear Kobln and hls soa Tespasiea.

FORN-A medium-sized tree nsually $30.45 \mathrm{ft}$, ligh with a dameter of 1-1 $\mathrm{ft}$. bat mas reach a helgut of $75 \mathrm{ft}$. With a dimeter of $2-21$ feet. Forest grown specimens are often stralght, clean, snil free ficm pradiches for: of height of tree. Open grown specimens usually branch low. Crow口 usurlly Larrow, oblong, and open.

BARK-On both young and old trunks rough, reddish-brown, deeply furrowed, with bigh rather rounded ridges whlch do not peel of a scales; sometlmes 1-1t inches in thickness. See Nig 83 .

TWIGS-Rnther stout, brittle, more or less zigzag, round to angular in cross-section, sometimes rldged, greenlsh to reddish-brown; often bearing two spinea at a node, covered with a few pale leoticels; pitb white and often angular.

BUDS-Alternate; terminal on. ahsent; small, 3.4 superposed, Imbedded ln twig under leap. scar in a rusty somewhat halry cavty. Their position is hardly risible in winter but becomea erldent in spring when growth starts.

LEAVES-Alternate, cempound, S-14 Inches long; petiolea slender, grcored on top, and swollen at the hase. Leaflets odd fo number and stalked, orate to oblong, 7.9 in number, $1-2$ Inches long, nsually ronded at npex and base, entire on margln.

IEAF-SCARS-Alternate, more than 2-ranked, rather large and consplcuous, Irregular in out. line, covertng the buds; often located hetween two prlekles which are dereloped and bardened stipules; contain 3 bundle-scars.

FLOWERS-Appenr about May after the leares or accasionally before the leaves, resemhing

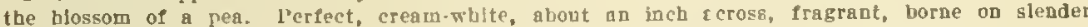
stalka ahout $z$ of an Ineil long, arranged in loose drooplng racemes $4-5$ lnches long.

FRUIT-A small, dark brown, and thin nod, 2.4 fncheg long and of an lach wlde; nsally con talnlng from 4.8 small dark brown mottled sceds. The pods often persist far lato winter.

W0OD-RIng-norous: rays qulte distlact especlally on radfal section; heary, very hard and strong, rery darable in contact with the soll. Jellowish-brown to cherry-red or reddish-brown with thin preenlsh or sellowish sapwood. Weighs about $46 \mathrm{lbs}$, per cuble foot. Used extensirely in former time for ship bullding, and at present for posts, in turnery, for tree nalls, Insnlator pins and fuel.

DISTINGUISHING CHARACTERISTICS-The Common Locust, also known as the Black Locust, Yellow locust. White Locust, Locust, and Acacia, may be distingulshed by Its droopIng racemes of white irre-ular fowers, Its odd-plnase compouad leares, Its twigs with two ahort splnes at a node, Ita 2.4 inches long leathery frust pod and Its deeply farrowed reddish- brown bark. The leaf-scara locnted hetween the two splnes when present and coveriag $3-4$ rosty downy bark. Te loaf of this tree when attacked by the Locnst Lea! Miner and the characteristfe swellng of the branches tree when attacked by body of the Locust Rot (Fomea rimosus) so common in southern Pendsylranla, is a sure means of ldentifying the tree.

RANGE-Mountaing of Pensytranja, south to Georgia, westward to Iowa and Eansaa. Naturalized crer an extensive area In America and widely planted in Enrope.

DISTRIBUTION IN PENNSYLVANIA-Originally it was found only in the central and south. ern portions of the Allegheny Monntalus in this State. At present it is fond all over the State as an ornamental tree or in fence rows nnd in mang places it bas escaped lato the forest and abandoned fields.

HABITAT-Grows vigorously on molst fertile soll, especially on rich bottomlands and along mountafn streams. Also grows on rather rocky and sterile mountain slopes. Frequent on abandoned charcoal bearths and mud-dams found near ore mlnes.

IMPORTANCE OF THE \$PECIES-The real Importance of this tres fa gomewhat in doubt. It produces excellent wood and growg rapldig in some localitleg, especlally where it la iree from enemles. Two Ingects, known a Locnat Borer and Locust Leaf Miner, and a fnngua known a the Locnst Rot (Fomes rimosar), are dolng enormona damage to thla tree locally. In reglona where these enemles are $w a n t h g$ and where autable soll and cllmate are at band it may bo adpiable to plant this tree eapeclally when poste, poles, or tlea are dealred. 1t baa very attractive fowera whlch may appear before, with, or after the leavea 


\section{THE CASHEW FAMIIY-ANACARDIACEAE.}

This family contains a large number of small trees and shrubs and a few woody climbers widely distributed orer the world, but most abundant in the tropics. Many of the representatires of this family are noted for their acrid, resinous, or milks juice which makes them of considerable ralue in medicine, tanning, and the manufacture of varnishes and resins.

About 50 genera with 500 species belong to this family. North America has few representatives. Only 3 genera with tree representatives are embraced in its flora. The genus Rhus is the only one matice to northeastern America. It has representatires in Pennsylrania.

\section{THE SUMACHS-RHUS, Linnaeus.}

The Sumachs comprise a large number of trees and shrubs which are widely distributed. Abont 120 species are known of which number about 16 species are native to North America and 6 to Pennsylvania. Most of the species of this genus are found in South Africa. All hare large pithy twigs and a milky, sometimes poisonous, sticky juice. The leares of all are alternate. One species alone is erergreen and one other has simple leares. All others are deciduous and have compound leaves.

Three of the 6 species native to Pennsrlvania reach tree-size. The others are mere shrubs. The Poison Iry or Poison Oak (Rhus Toxicodendron $\mathrm{I}_{\text {s. }}$ ) is verr abundant along fences and by roadsides. Its stem often trails along the ground and sends up short branchlets which bear the compound leares with 3 leaflets. The leares are poisonous to the touch. The Smooth Sumach (Rhus glabra L.) is a low-growing and spreading shrub sometimes becoming a small tree. It has glabrous branchlets which are more or less glaucous. It has compound leaves with 11-31 leaflets. It is rery common in abandoned fields and seems to thrire on sandy soil. The Fragrant Sumach (Rhus canadensis Marsl.) reaches a height of $2.6 \mathrm{ft}$. It has compound leares with 3 leaflets which are aromatic when crushed. The Smoke-Tree (Rhus Cotinns L.) is one of the commonest plants of our gardens and lawns. It is an introduced species com. ing from Europe and warm-temperate Asia. Locally it has escaped cultiration. 


\section{SUMMER KEY TO THE SPECIES.}

1. Leaf-petloles winged; leaflets with entire margins except near apex, ..R. copallina

1. Leaf-petioles not winged; leaflets either with entle or serrate marglns, ........ 2

2. Leaflets $7-13$, with entire margins,

.R. Vernix

2. Leaflets 11-31, with serrate margins,

R. glabra

3. Ieaflets glaucous beneatb: twigs smonth: shrubs.

R. typhina

3. Leaflets not slaucous benenth; twigs deasely lairs; small trees.

\section{WINTER KEY TO THE SPECIES.}

1. Termlnal bud present; fruit white, smooth, in loose, drooping, grape-like clusters frequents swamps; leal-scars broad, do nt encircle buls; Julce poisonons, ....
$\mathbf{R}$. Vernix

1. Terminal bud abseni; Pruit red, bairy, In :ompact erect clusters; frequents dry soils; leat-scars enclrcle o: almost enclrcle buds; joice not poisonous, ..................2

2. Twlgs stout, with whtery fulce; len 1 -scars broadir crescent-shaped, ..... copallina

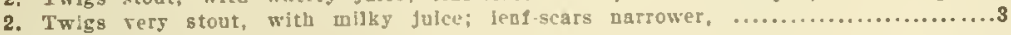

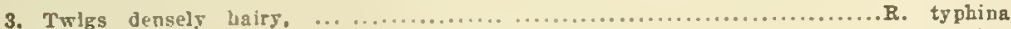

3. Twigs smooth. 


\section{POISON SUMACH.}

\section{Rhus Vernix, Linnaeus.}

FORM-A shrub to small tree, usually 5-10 $\mathrm{ft}$. bigh but maj reach a height of $20 \mathrm{ft}$. With a dismeter of 8 inches. Usually branches neat ground. Crowa wide, deep, and osually rounded.

BARK-Smooth, somewhat streaked, thin, light to dark gras, roughened Fith borizontally. elongrted lenticels.

TWIGS-Stout, orange-krown, later light gray, smooth, often' glos $\$ 5$, corered with numerous ralsed lenticels, contain sellowish-brown pith; if punctored ne cut, exode watery juice whlch turns zellow opon exposure.

BUDS-Alternate; terminal bad present and larger than lateral ones; purplish, conlcal, acote. about $1 / 5 \cdot 3 / 5$ of an lach long, corered with a few acales which are downy on back and margin.

LEAVES-Alternate, compoond, i-It loches long. with wingless petiole, and with $7-13$ leaflets. oborate, 3.4 Incheg long, acute at apes, wedge-shaped at base, entire-morglned, dark green and ahing abore, pale below.

LEAF-SCARS-Alternnte, large, broad, consplcuous, do not cncircle buds, opper margin stralght or nearly so, contain numcrous bundle-scars which are scattered or arranged in a curred line.

FLOWERS-Appear abont June or July. Staminnte and pistillate forers borne on differeat plants. The small yellowish-green flowers are arranged in long, drooping, rather narrow panjelea.

FRUIT-A small, spherical, glossy, trors-white to zellowish-white drape arranged in loose, droopling, grape-like clusters. It is about $1 / 5$ of en inch in diameter, slightly compressed and often persists far into winter. RIpeng about September. Pistlllate trees alone bear fralt.

WOOD-Ring-porous; brlttle, solt, cosrse-grained, light jellow in color. Weighs 27.31 lbs. per cubic toot.

DISTINGUISHING CHARACTFistics-The Polson Snmach, also known as Polson Oak, Poison Dogwood, Polson Elder, and Swamp. Sumach, can be recognized in winter by its alternate bads with the termlnal bud present, its broad leal-scars which do not encircle the bud and itg smooth and rather stout branchlets. Thr white berry-like fruit arranged in drooping clnsters ofteb persists far into winter. The lenres are compond, withont winged petloles and bare from $\mathbf{7 - 1 3}$ shing leaflets with entire margin which turn to a brillant scarlet or orange In aotumn. This specles is usoally found in swamps.

RANGE-0ntario, south to Florida, west to Minnesota and Loolsiaca.

DISTRIBLTION NN PENNSYIVANIA-Occasional and local in the eastero, southern and central parts. Rarer in other parts.

HABITAT-Prefers low grounds and swamps, Occaslonally fond on molst slopes.

IMPORTANCE OF THE SPECIES-This shrab or small tree is one of our most poisonous plants. The wood which it produces is of no commercial importance. Some people are entirely fmmone to its poisonuus principles, while others are affected by it apon handling it while a few need onls to walk by it. It is clalmed all traces of the poison can be remored by washing the parts thoroughly with a saturated alcoholic solution of acetate of lead immediately or a fer hours after the contact. Pore alcobol is also raluable as a wasb if applied shortly after contact. 


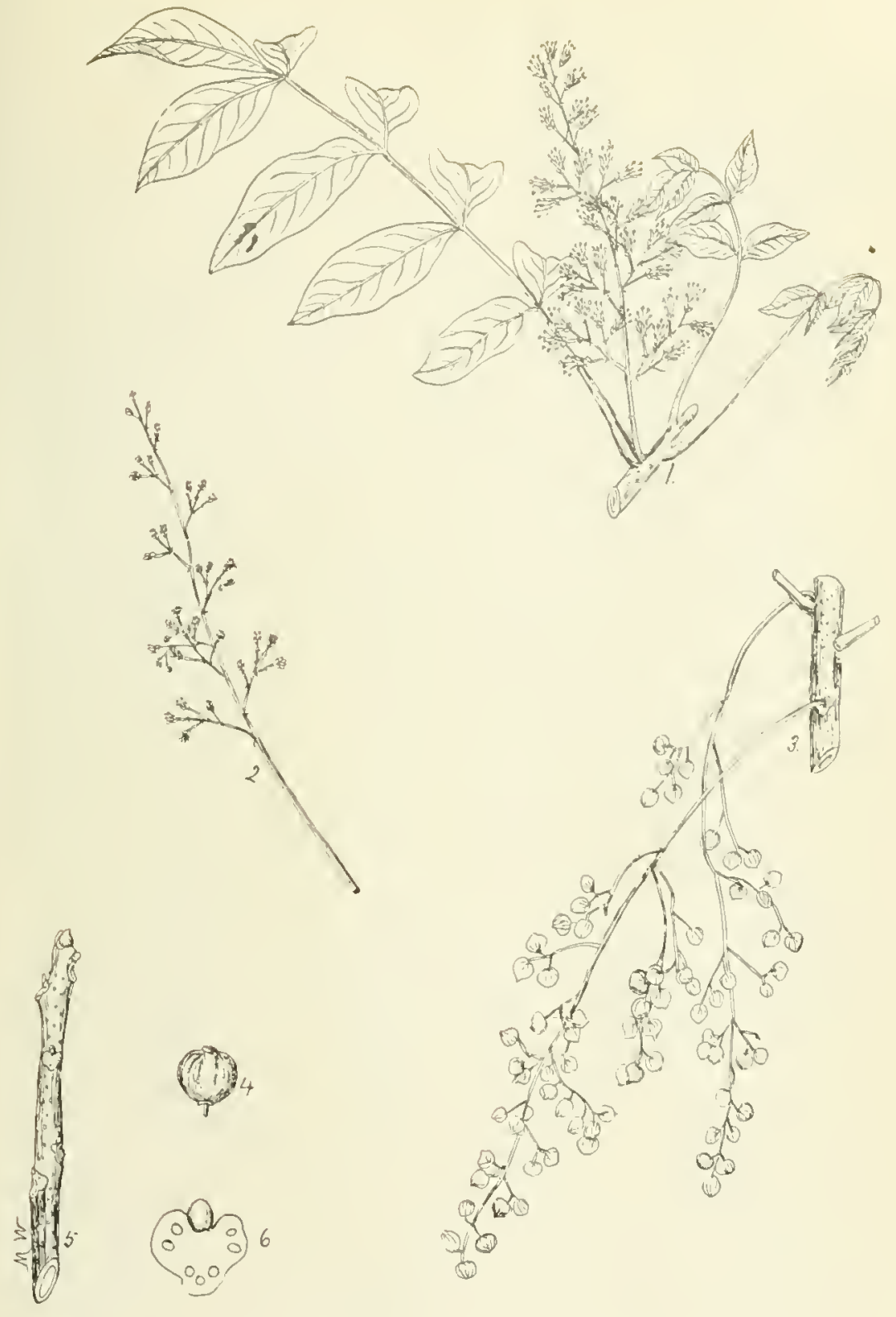

PLATE XCVIII. POISON SUMACH.

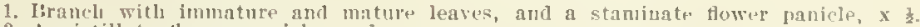

2. A pistillate tlower panicle, $x$.

3. A sectiun of a brancis with two drooping clusters of fruit, $\mathrm{A}$,

4. A single fruit, enlarged.

5. A winter twig. $x$ t.

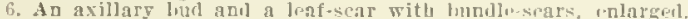




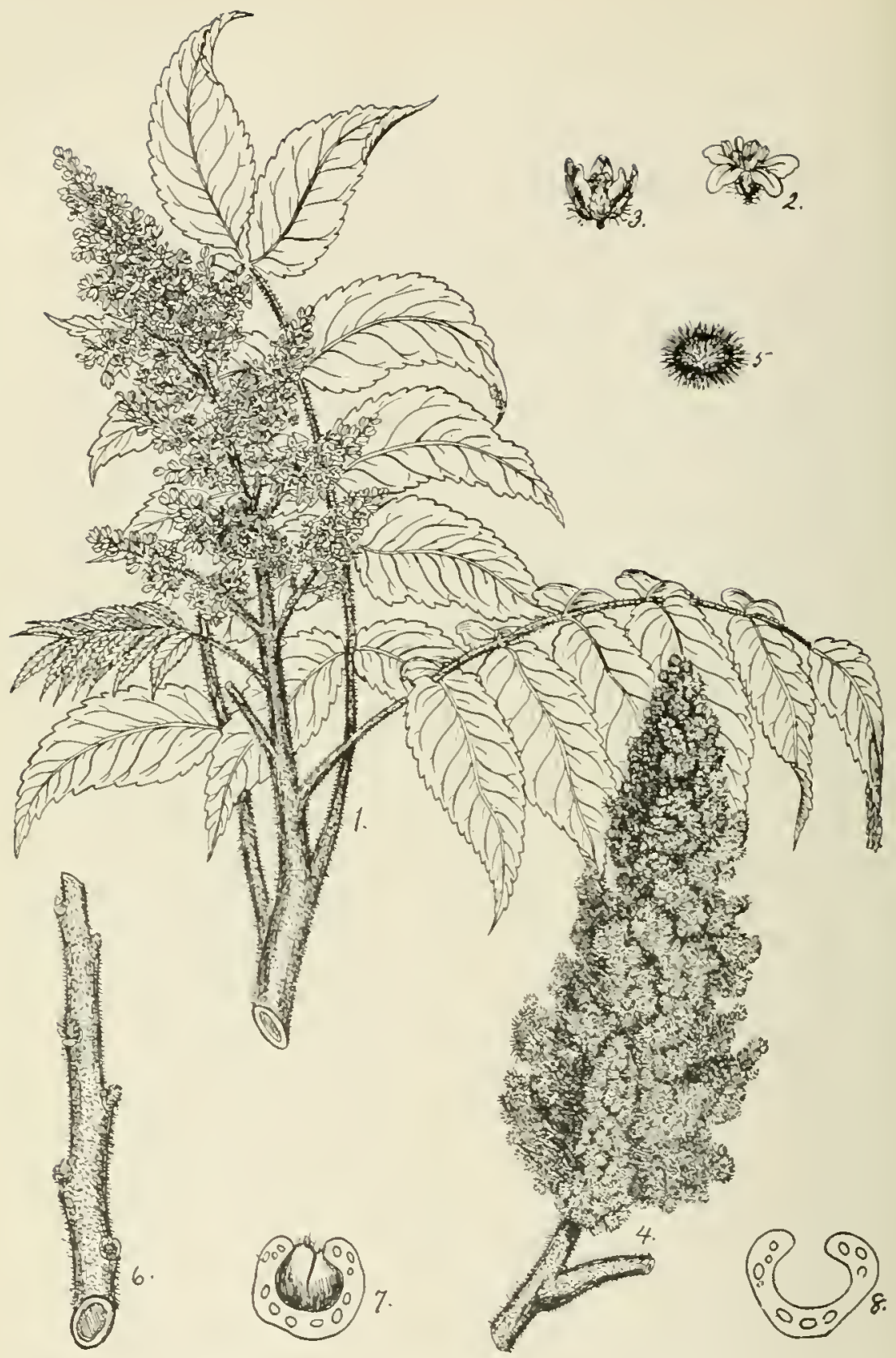

PLATE XCIX. STAGHORN SUMACH.

1. Brancl with a fluwer panicle and mature legres, $\mathbf{x} 3$.

2. A staminat flowe1, enlarged.

3. A pistillate flower, enlarged.

4. An erect cone-like fruit cluster, $x$.

5. A single bitrs fruit, entargen.

A Lairs winter twig. a z.

$s$. A leaf-scar, enlarged. 


\section{STAGHORN SUMACH.}

\section{Rhus typhina, Linnaeus.}

FORM-A shrub or small tree usnally reachlng a belght of $10.20 \mathrm{ft}$, bot mas reacb a helght of $40 \mathrm{ft}$. with a diameter of 15 inches. Trunk usually ghort, bearing a broad fat-topped crown. Lateral branches are decldediy ascending.

BARK-On old trunks rengb, dark brown, sometimea sealy; on youuger tranks and brapchea smooth, thin, somewhat papery, covered with anmerous lenticels whlch later derelop into rong b dots. Rich in taunin.

TWIGS-Corered for 3 rears with brown to black relretr pabescence, later amooth, stoot. clnmsy: if cat or ponctured exude mllky jnice, whlch turn black opon exposure. Twigs are often frozen back ln winter, corered witb consplcuons orange-colored lentlcels, and contain a large gellowish-browa plth.

BUDS-Aiternate; terminal had absent; conlcal, spherical obtuse, corered with degse rusty balra.

LEAVES-Alternate, compond, 16.24 loches long, with atoot wingless petlole and 11-31 leaflets. Leafets oblong, 2.5 inches long, nearly sessile, acute at apex, serrate on margln, rounded or beart-ahaped at base; when mature smooth, dark green abore, and pale beneatb.

LEAF-SCARS-Alternate, nearly encircle bud, large, cousplenons, U-sbaped, contalo acattered Lundle-scars gometimes grouped in $3 s$.

FLOWERS-Appezr in May or Jnne. Occur in dense yellowish.green panjcles. Staminate panicles are ahont 5.12 Inches long and 5-6 laches broad. Pistllate pandeles are only 5-8 inchea long but more compact.

FRUTT-Arrnnged Ix compact, erect, conelike, red clustera which are 5-8 fnches long, 2.3 Inches broad and perslet far into winter. Only plants bearing platlllate flowers prodoce frait. The slngle frult is a spberleal drupe corered with red balrs and contalos a small bard aeed. Snmachs with red frolt are not polsonons.

WOOD-RIng-poroua; brittle, aoft, orange-colored, streaked with green, rather sattng to tonch. Saprood broad ane white. Nelghs $27.1 \%$ bs. per eubic foot. Used for manofacture of apiles, cyps, napkln rlggs, and balls for dara!ng stocklngs.

DISTINGUISHING CHARACTERISTICS-The Staghord Somach, also known a Velvet Snmach, can be distingnished from all on uatlre Sumachs by its relrety pubescent twigs. The Smooth Somach (Rhus glabra L.) is usnally smaller and has Its twig coscred with a bloom, bot not with pnbescence. The Dwarf sumacb (Rhus copallua) has winged petioles and a ratery falce pho sto Somach whlle the Stagborn Snmacb bas do winged leat-pctioles but baa a milks jalce. The Polson somach bads, and frequenta 6 жаmps, whlle the Staghora Sumach bas no terminal bnd, has red and erect frult clastera, serrate leaf-margins, leap-scars which almost enclrcle bods, and frequenta dry aolls.

RANGE-New Brunswick to Minnesota, add sootbward to Georgla and Alabama.

DISTRIBUTION IN PENNSYLVANIA-Locally throoghont the State. Vers common in eastern and sonthern parto. Rarer in northera and western rarts.

HABITAT-Usoally foond on fertile dry ppland soil. Rarer on border of swampa and streams. Frequenta abandoned flelds and fences.

IMPORTANCE OF THE SPECIES-Thls species is of little commerclal importance. The mood is rarely nsed. The bark of the stem and roots, and the leavea are rich in tangla. It is occaslodally planted for orpamental purposes. 


\section{DWARF SUMACH.}

\section{Rhus copallina, Linnaeus.}

FORM-A small shrub rarely more than 6-8 ft. tall, becomes a tree only In Arkansas and Teras.

BARR-Rather thin, light to reddish-brown, often smooth; on older specimens mas peel orf into papers lagers, freuvently roughened by large, elevated, brownish projectiona.

TWIGS-At first hairy, somewhat zigzag and greenish-red; later smooth, reddish-brown, and roughened by prominent leaf-scara and large dnrk-colored lenticels; frequently roughened bs large elerated rugosities.

BUDS-Alternate; terminal bud absent; aslliary, small, spherleal, corered with rusty brown puhescence.

IEAVES-Alternate, cempound, 6-12 inches long, with winged petioles and 9-21 leafiets. Leagets ovate-lanceolate, acute at npex, often unequal and wedge-shaped at base, entire on margin except near apes where a few serrate teeth mas be foud, usualls smooth abore and puhescent below.

IEAF-SCARS-Alternate, broadly crescent-shaped to intersely triangular; partls surroand bada; contaln a few clasters of budile-scars often occorring in 3 s.

FIOWERS-Appear about Juls. Produced lu axillnry of terminal panlcels. Staminate and plstiliate usualfy occur on different plants.

FRUIT-Matures ahout 5-6 weeks after flowers. Csually arranged in dense, stont, pabescent, often persistent, red clusters. The ludividas frait is spherical, about of an inch across, corered with a hairy red coat and contaiss a smonth orange-colored secd.

WOOD-Diffuse-porous: coft, coarse-gralned, light Lrowd, richly striped with yellow and black. Weigbt and uses are abrut the same as the Staghord Sumach.

DISTINGUISHING CHARACTERISTICS-The Dwarf Sumach, also known a Montaln Samacb can be distinguished from oar other oative species of Sumach hy its winged leaf.petioles and Its leaglets mich are entire-margined except near the apex. Its beacheg contain a watery folce while the brapches of the Staghorn and Smootb Sumach contain a mllk julce. Its branches are smooth while those of the Smooth Somach are corered with a bloom and those of the Strgtioro Stmach with a relrety pubescence. It has neither terminal bads nor wbite frult tike the Poison Sumach.

RANGE-Malne to Florlda, west to Nebraska and Texas.

DISTRIBUTION IN PENNSYLVANIA-Local, often common, throughoot the State.

HABITAT-Common on des hillsides and ridges, Occasional on fich bottomlands. Frequents ahandoped fields.

IMPORTANCE OF THE SPECIES-The Dware Snmach is merels a shrub east of the Mis. sissippi and consequeutis of no commercial Importance. It may be atllized In laudacape gardening on account of its dxarf form and attractire autumbal foliage. It reaches tree-size In Arkansas and Texas. 

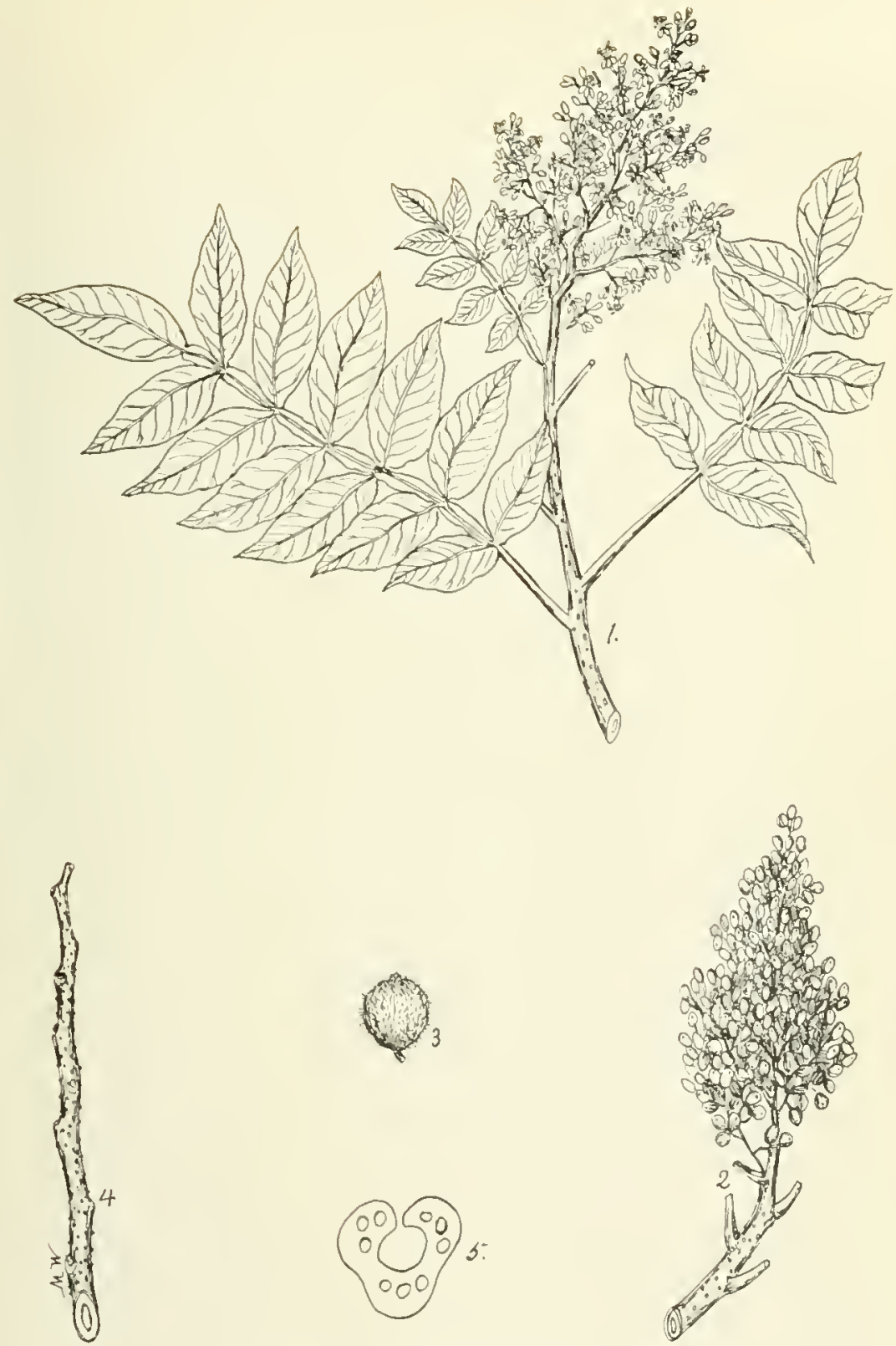

PLATE C. DWARF SUMACH.

1. Brancl with mature leaves with wingul rachises, aud a panicle of fowers. $x \frac{1}{2}$.

2. A branch with an erect cluster of fruit, 3 is.

3. A sipgle hairs fruit, enlarged.

4. A winter twig. $x$

5. A leaf-sear with bundle-scars, enlarged. 


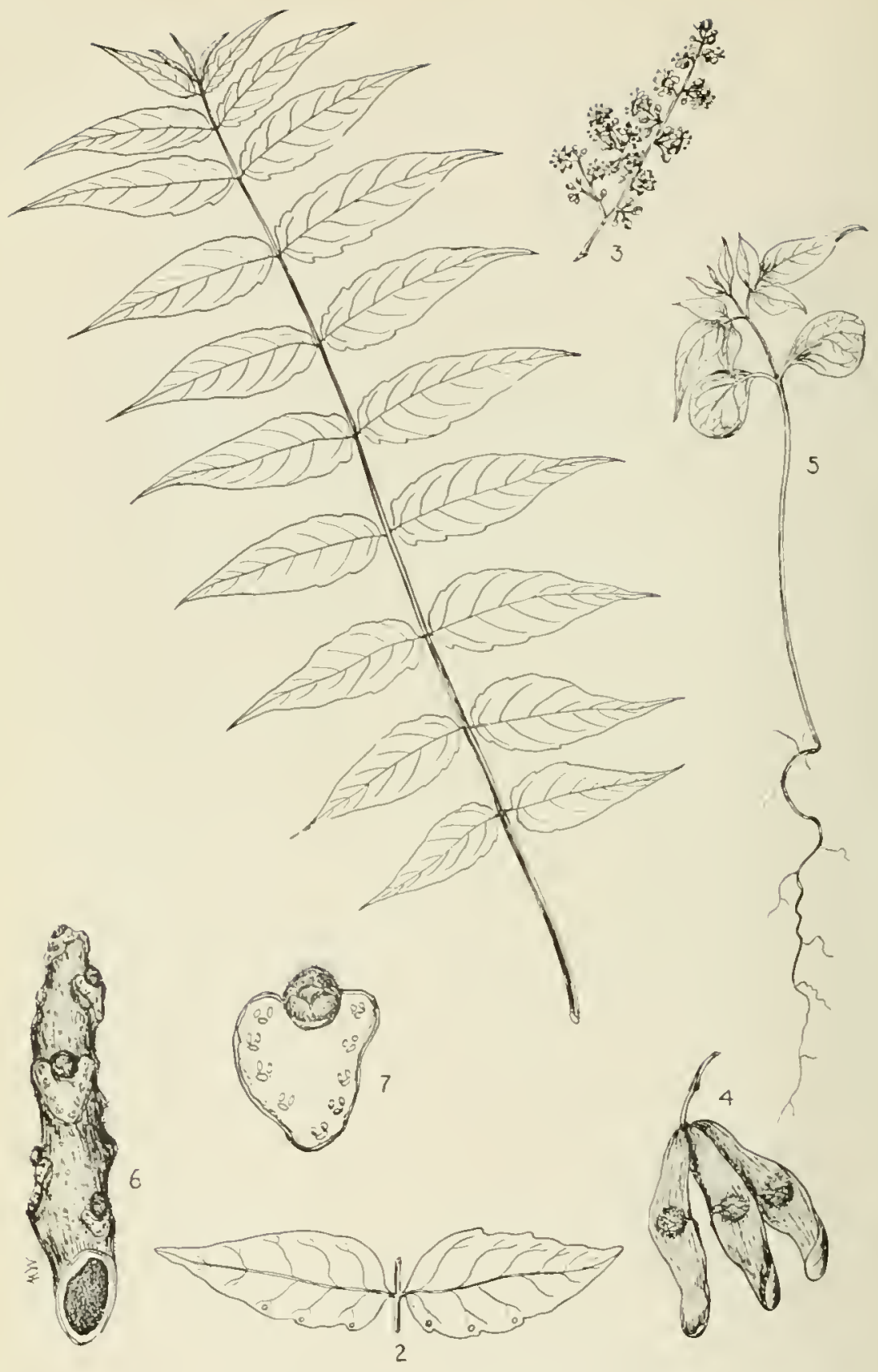

PLATE CI. TREE OF HEAVEN.

1. A mature leaf, $x{ }^{3}$.

3. A panicle of Howers, $x$ z.

4. A small chuster

6. A winter twig, $x$,

i. A bud ind a beaf-sear with bundle-sears, natural size. 


\section{TREE OF HEAVEN.}

\section{Ailanthus glandulosa, Desfontaines.}

FAMIIY AND GENUS DESCRIPTION-The Quassia fimily, Simarubaceae, comprises about 30 gevera with 150 species found mostly in the tropics and the warmer parts of bott the east. ern and western hemispheres. Three genera, each with 1 tree species, are outive to the south. ern part of the ['alted States. A ringle species of a fourth genus has been introduced from China. Thls genns, Ailnnthus, cootalns 7 specles all native to eastern Asla. No member of thla Parally la uative to Pennsylrania.

FORM-May reach a beight of $100 \mathrm{ft}$. with a diameter of \& $\mathrm{ft}$, but usually mucb amaller. Trunk usually short, hut sometimes logg, benriug stout branches with few branchlets, Crown wide, bigh, and fat-topiped.

BARK-0u sounger trunks smooth, thin, Ight gray, somewbat roughened with fissures. Rldges usually dark and strud in strong coutrast with the ligbt fissures. On old trunks thin, close, roughened with dlamond-shaped fissures, dark gray and sometimer black. See Fig. 99.

TWIGS-Stout, elumsy, yellowlsb-grcen to reddish-browo, covered witb a flae relvety dowo and numerous, longltudionlly-clongnted, ochre-*olored, acattered lentlcela. Pith large, ratber bard, light brown. When broken or crushed the twigs give forth a raok smell. Iongltadina! atriations moy appear after outer coverlag of twlgs scales off.

BUDS-Aiternate; terminal bud absent; false termioal bud often present; redafb-brown, downy, about I/8-1/G of a incb long. located in totcb of upper surface of the leaf-scar, covered with scales; the two outer acales do aot quite cover the bud, beace they leave a nnrrow slit running parallel with the twig.

LEAVES-Aiternate, compound, $1 \frac{1-3}{\mathrm{et}}$, long, composed of $11-41$ leafleta. Leafleta ovate. lancrolate, 3.5 inches lone, acumlaste at apex, truacate to heart-sbaped at base, almost entire with a lew coarse teeth towards the base of the leal. Glands may be preseat on the lower side of the leafleta near or on the smull busal lobes.

LEAF-SCARS-Alteroate, iarge, consplcuous, more than 2-ranked, heart-gbaped, ligbter in color than twig. have ralsed marglos and contain abont 8-14 conspicuous buodle-scara arranged in a V-shaned line, Bundle-geara sometimes curred or compouoded.

FLOWERS-Appear ahout Juve wheu legs's are fully dereloped. Strminate and plstlllate Dowers occur on separate treen. Individunl lowers small, green, and arraged in terminal padeles. The staminate dave a rery unpleasaot oåor.

FRUIT-Borne only on ferale or pistlilnte trees io cospievous clustera whlch often peraiat far into winter. Each frult consists of a sulrally twisted wiug ahout 11 inches long and of an jacb wide, in the center of which a small seed ia located.

WOOD-Riog-porous; whth conspicuous rays; white to pale sellow, ligbt, solt, weak, and oped. grained. Used in cabinet work, for wooden ware, aod for charcoal.

DISTINGUISHING CHARACTERISTICS-The Tree of Hearen, also known a Paradse Tree, Allaothus, Havea. Wood and Cblaese Sumach, ean be distiogrisbed in winter by its stout twigs whlch are cover?d with flae down and conspicuous scattered leatlcels, and contala a large ligbt brown pitb; twlgs are roughened by large leart-shaped len?-acara containiog a curved llae of bundle-scars. The small gaping dowoy buds situate in the ootch on the upper surface of the lenf-scars, are also characteristic. In summer the large alterante leares with $11-41$ leaflets whtch often have glands on the lower surface, are distinctire. The bars canoot be confused with that of any native tree.

RANGE-Natire of China. Widely planted in Ontario, Canada and the nortbeatern United States. Frequentl'y it bas escaped cultivatloo and is fouod in aboudoned leids, is forest borders, and a loog fcocea.

DISTRIBUTION IN PENNSYIVANIA-Naturglized extensively in the eastern, sonthern, ceotral aod westerd parts of the State. Escaped cultivation in many placea. Thicketa of it are found in Fraaklin couty. In some places it is not only foudi in the open fields and aloug fence but is migrating into the forest with the bardwoods aod plnes.

HABITAT-Tolerntes almost asy kind of soli and dease shade, Ita rapid growth often enables it to dominate over its associates.

IMPORTANJE OF THE SPEC1ES-1'his tree is of no specinl funportnnce as a forest tree and has serioug demerits as a sbade or park tree. It was introduced foto Eaglaad about 1751 by missionaries and from there it was soon brought to America and frst planted dear Philadelphia. At firat it was a very popular tree, but it soon lost faror. The staminate flowers are very 111 smelling. The wood is loferior in quality. The rapid and free growth of the root sprouts makea it aimost Impossible to eradicate it when once establisbed, 1ta aggressire migration lato flelds and forest la undesirable. 


\section{AMERICAN HOLLY.}

\section{Ilex opaca, Ait.}

FAMILY AND GENUS DESCRIPTION-The Holly family, Aqulfoligeeae, comprises 3 genera with about 290 species of small trees and shrubs distributed in temprate and troplcal regions. Two genera. Ilex and Xemopanthus, are native to Pensslinnla. The former genus la representer by 5 species and the latter by 1 specles. Two of the 5 specles of the genua llex are descrlbed below. The Mountali Holls, Nemopanthas mucrounta, is usually a shrab rarely orer 10 Pt. In height.

FORM-Usaslly a small tree reacblng a helght of $15-30 \mathrm{ft}$, but may attaln a helght of $50 \mathrm{ft}$. with a diameter of 3 feet. It la small in the Nortb, but becomes larger in the South. Trunk short and bears slender, spreading and ascenlling branchea whlch form a conlc crown.

BARK-Close, whlte or grasish or jellowlsi-brown, up to of an inch in thlcknesa, becomlng rough with age.

TWIGS-Rather sleoder tnely rusty halry but soon become smootb and llght brown, corered by a few laconsplcuoua leaticels.

BUDS-Alternate; termlnal one present and rolnted; Interal ones are short, blunt-pointed, and somewhat downy.

LEAVES-Alternate, simple, erergreen, thlek, mostly smooth, flat, oral, with wary margin and sping teeth. Petiolea are short, atout, and often bardy. MIdrlb is rery promlnent on the lower sarface of the leat.

LEAF-SCARS-Alternate, semi-ornl, rather conspicnous, with ralsed margin contalning aolltary bundle-sears.

FLOWERS-Aprear fror April to June. The staminate and plstillate asually occur on different trees. The stamlnnte are $2-9$ on a common alalk whlle the platillate are usually aolltary.

FRUIT-A bright red drope, about the size of a rer, smooth, shining, peralsting far into winter; containlug a light brown nutlct witb assally 4 rlbs.

WOOD-Diruse-norous: with distinct and eolorless medullary rnjs; chalkj.white In color, medium in welgbt, hard, tough, Lot strong, close-grajued. Welghs $36.26 \mathrm{lbs}$. per cublc foot. Cised $j$ turners, cablnet making and laterlor gnishings, and for keys in planos and organa.

DISTINGUISHING CHARACTERISTICS-The Amerlean Holls, also known as Holly or Wbite Folis, can be distingulshed at ang senson of the gear hy its unlqure leares, which are thick, tat, and oral, have wavg margins with bcattered splns tecth nnd persist for 2 or more rears. Branches, bearing these nuique lcaves, are sold extensirely about Chrlstmas in most of our northern markets. The small red fruit, often rersisting far into winter, is also distinctive. Ia eultiration one often tuds the closels related European IIolly (Ilex Aquifollum) whlch baa leares of a deeper grcen and with mare Nary margina whleb bave transincent edges. The berrles of the European specles are deeper red in color.

RANGE-Malne, throogh Penngrlvada to Florida, westward to Indiana, Missourl and Texas.

DISTRIBUTION IN PENNSTLVANIA-Fery rate and local. Found in the followlng counties: Bucks, Dapphin, Delaware, Chester, Franklln, Iancaster and Fork. Only one specimen la known to grow wild in Franklin counts.

HABITAT-Crualls found in molst soil near water. Prefers shelterd and ahaded altuations.

IMPORTANCE OF THE SPECIES-The American Holly loes not produce any wood of com. merclal Importakce in this State, Immeose quantlties of branches, bearing the uninue and attractive leares and brigbt red berries. are used for decoratjre parposea durlng the Christmas seasou. It ls occasionally flanted for ornamental purposes because it is sers beautlful, but one should remember tbat it grows slowly. 

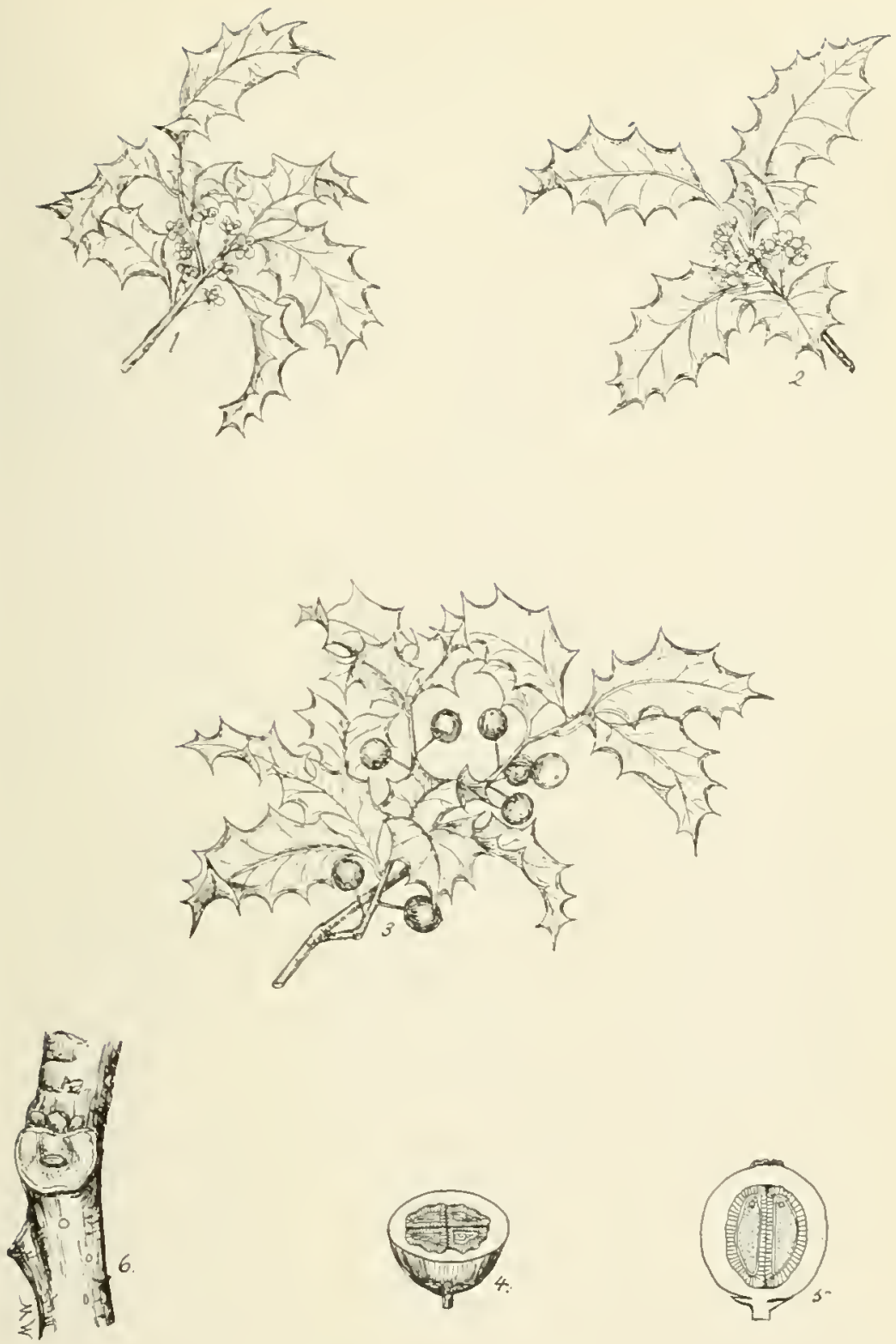

PLATE CII. AMERICAN HOLLY.

1. A pistillatu tomering brancb, $\Sigma$ I.

1. A staminate formering branch, $x$

4. Cross sumtion of a fruit, enlarged.

5. Longitudinal section of a frnit, enlarged.

6. Section of a twig, enlarged. 


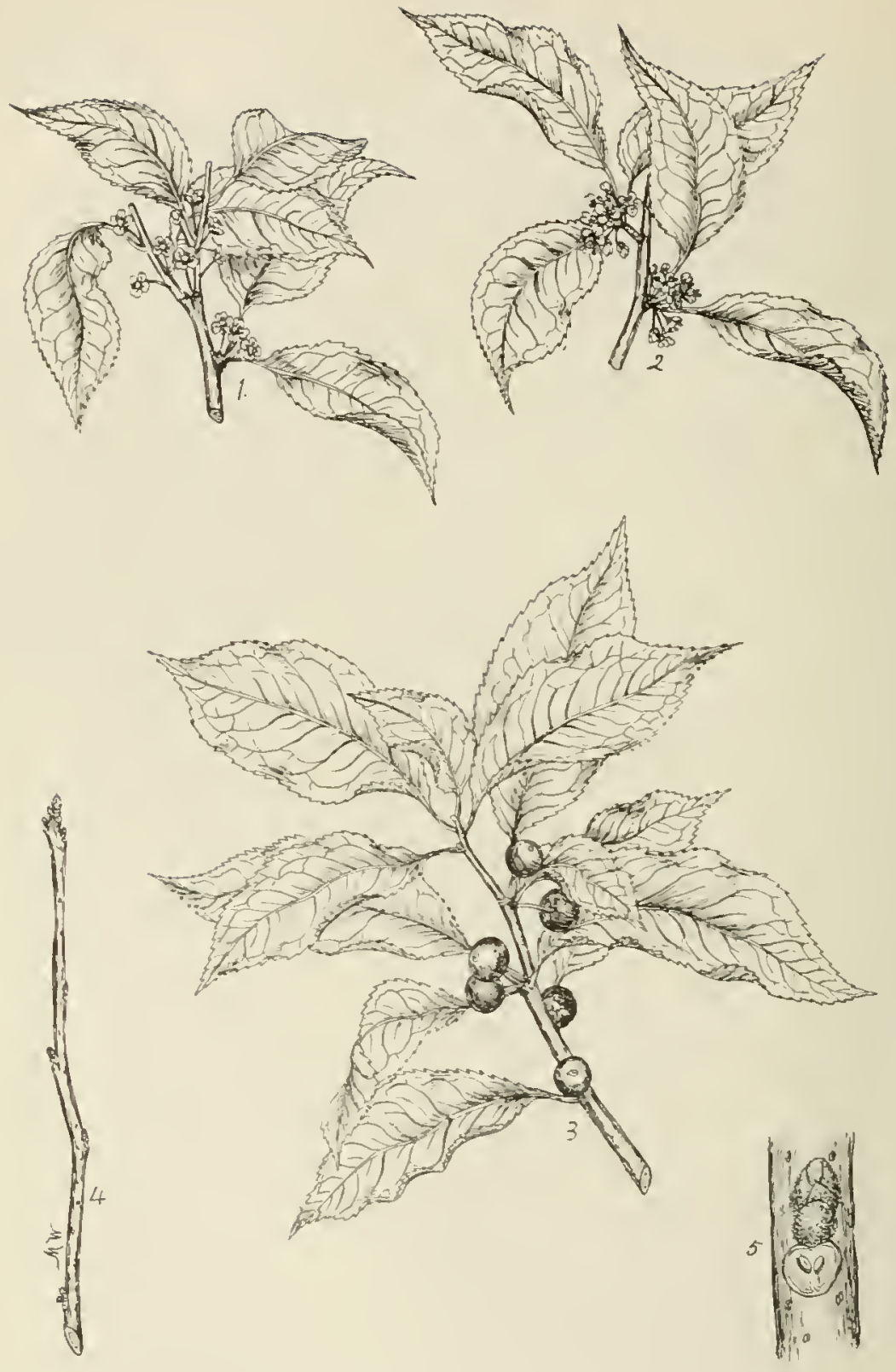

PLATE CIII. LARGE-LEAVED HOLLY.

1. A pistillate forrering branch, $x$.

2. A staminate flowering branch, $x$

3. A fruiting branch, $x$,

4. A winter twig. $x$. 


\section{LARGE-LEAVED HOLLY.}

\section{Ilex monticola, Gray.}

FORM-A shrub or small tree usaalls less thno $20 \mathrm{ft}$. in height but mas reach a helght of 40 1t. with a diameter of 12 lacher. It reaches its largest aize In North and In Sonth Carolina. Trunk sbort, bearlng in rather wide and deep crowa tormed by alender, spreading, ascendlng brancbes.

BARK-Tbin, light brown, rougb, warty, corered with numerous lenticels.

TWIGS-Smooth, reddish-bruwp, becoming jark gras, ealarged at podeg; with decurrent' ridges runnlng down frow leaf-scars: round, marked by maus small lentlcels at first indistinct but later conspicuons. Pith round, narrow, llght sellowlsh-green.

BUDS-Alteragte, terminal bud present; lateral buda often superposed and corered with gaping acnles: brondy ovite to globular, small, about is of an lnch long, sharp.polnted or occasionally blont-polnted. Bud scales ovate, keeled, shnrp-polnted, light brown, finely bairy at apex.

LEAVES-Alternitc, simple, decidunue, 4-5 laches loog, i-2 inches wide, orate or lancenlate-oblong, tnper-pointed at apex, sharply serrate on rasinin, taperiug or rnunded at base, thin, smooth, dark green abore, puler below.

IEAF-SCARS-Alternate, elliptlcal to broadly trlangular, very sinall, inclined to twig. Bundle-scara solitary, lunate to nlmost clrcular.

FLOWERS-Appear ou short Interal stalks about June, whea the leaves are almost developed; white or benrly sn, small, about $\$$ of an inch across, Staminate clustered, borme upon pedicels about $2 / 5$ of an inch long; plstillate solitary or few in $H$ cluster, on rery sbort pedicels.

FRUIT-IIatureg about Septcmber. Brlgbt scarlet, globose, about $2 / 5$ of an ineb fo diameter containlug 4-6 nutlets; putlets narrowed at the erds, strlate, prominentls many-ribbed on the back.

WOOD-DIfuse-porous; bard close-grained, nearly white. In general resembles that of the Amerjenn Holly, page 1SS. Weiglas nhout $41 \mathrm{lbs}$, per cublc font, Not found on the masket.

DISTINGUISHING CHARACTERISTICS-The Mountaln Holly may be distinguisbed by ita smull size, is small clustcred whlte flowers, its bright scarlet globose clustered trult with strlate mnug-rlbbed nutlets, Its avate or lanceslate-oblong, smooth, sharply-serrate, dark green decilunus leaves, 115 small leat-scnrs with a solitary bunde-scar, and ita bitter reddishbrown twigs marked by many stunll lenticels and decurrent rldges below the leal-scnrs. The clasely related Black Alder or Winterberry (Ilex verticllata) bns mang characteristica In comunn with this specles bnt may be distlngulshed by its smooth and eren nutlets, Ita finwers whlch are all sbort-stalked, Its lenves whjch are more dnwny no the lower surface.

RANGE-New Fork to Georgia and Alabama.

DISTRIBUTION IN PEIISSIVANIA-Ratber common in the mnuntainous parta of the State. liare or absent in pther parta.

HABITAT-Usualiy found In mountain woods. Prefers rich, molat, often rocky aituations. Frequently oecurs in shaded places under a Jense canopg of larger trees.

IMPORTANCE OF THE S'sECIES-Thls tree is of little forestal importance. It remaloy small, grows slowly nud occurs scattcred or in small clumps. Ita brigut follage and brilliaot fruit recommend it for ornamental purposes. It reaches tree-size ouly io the South. 


\section{THF MAPLE FAMILY-ACERACEAE.}

The Maple family comprises in addition to the Asiatic genus Dipteronia, with only 1 species, abont 70 species, all of which are included in the genus Acer, and distributed with a few exceptions in the northern hemisphere. This family consists mainly of trees and a few shrubs. The members of this family are used more than those of any other family as oruamental aud shade trees. Further characteristics of the family are inchuded in the description of the sole American genus which follows.

\section{THE MAPLES-ACER, (Tourn.) L.}

This genus comprises approximately 70 species in the world, with 13 species in the United States and 6 species in Pennsylrania. A few exotic species have becu introduced exclusively for ornamental and shade purposes. The commonest exotic species are the Norway Maple (Acer platanoides L.) and the Sycamore Maple (Acer Pseudoplatanus L.). On account of their abundance and wide distribution in this State, a descriptive page, together with an accompanying plate, has been devoted to these two species.

The leares of the Maples are opposite, usually simple or in a few species compound with 3.5 leaflets, and are shed in the autumn. The flowers are regular or polygamous, rarely perfect. and appear before, with or after the leaves. The time at which the flowers appear aids considerably in distinguishing the various species from each other. Some trees bear only staminate flowers, while others bear only pistillate, with the result that one may occasionally find a mature tree which does not produce any fruit. The flowers are pollinated by insects, which are attracted in hordes by the aromatic pollen-bearing blossoms. The fruit is composed of a pair of winged seeds joined together to form the well-known maple key or samara, which matures in early or late summer, depeuding upon the species. The fruit which matures in early summer germinates at once, while that which matures in late summer remains dormant over winter and germinates the following spring. Wind is the chief agent which disseminates the seeds.

The Maples are seyarated into two classes with reference to their commercial value, Hard Maple aud Soft Maple. This classification is based upon the physical characteristics of the wood. The rood of the Maple is diffuse-porous with rather small medullary rays, usually fine-grained, dense, and in some species hard and beautifully curled and figured, which makes it especially prized for interior finish and cabinet work. Most species yield a saccharine sap which may be coucentrated into maple syrup or maple sugar.

Within a family one may often find a wide rariation of plant organs, but the genus Acer possibly presents a wider range or a greater 
rariation in its organs than any other genus of trees found in this State. The leares may be simple or compound, large or small, smooth or hairy. The twigs may be green, brown, or red. The flowers may be in small lateral clusters, in long terminal racemes, or in drooping cluster's; appear before, with, or after the leares. Their color may be green, yellow, or red. The fruit, while similar in all the species so far as type is concerued, raries considerably in size, divergence of the wing, and arrangement. Their habitat also varies, some like the Red Maple, preferring moist locations, while the Mountain Maple frequents rockr situations. In addition to these general differences among the species, il greater difference becomes erident as one studies the detailed description of the species which follow:

\section{SUMAIER KEY TO THE SPECIES.}

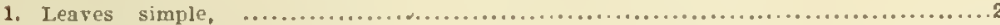

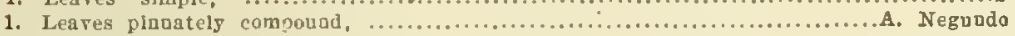

Page.

2. Lea1 pctioles witb ucrid milks sap, ............................... plataroides

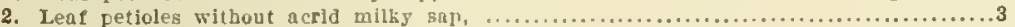

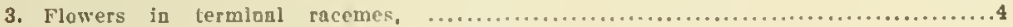

3. Flowera la internl clusters, gpleariug before or with the leares ................6

4. Flowers apper with the leares, .............................. Pseuda-platanus

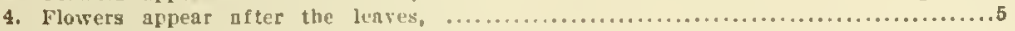

5. Flowers in erect racemes; lcavea conesely strate and usually 3-lobed,...... spicatum

5. Flowers in drooplog racemes; leaves finely serrate, 3 lobed at anex, at first browa

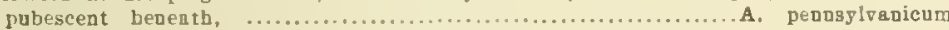

6. Flowers onediog before the leave, the Irooplng fruit rinening in apring or early

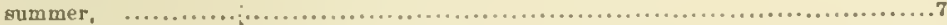

6. Flowers opening with the leaves, drooping fruit pipenlng in summer or early

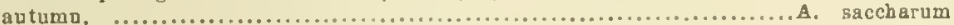

7. Flowera with petals; leases bright green stove, pale greea nearly glabrous beneath

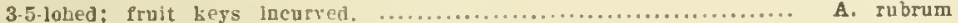

7. Flowers withont petals; leares green ibove whitish or silvery beneath, deeply 5-lobed; frult keys divergeot. .................................. saccharinum

\section{WINTER KEY TO THE SPECIES.}

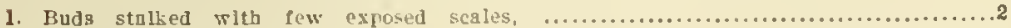

1. Buds sessile or pegrly so, with li or more exposed scales, .......................

2. Buds erideatly-stalked; bark strenled longitudinally with white lines,

A. penasylvanicum

2. Buda short-stalked; bark not streaked longitudiaally with white lines, ...........3

3. Buds small, 1/5 of an inch long including stalk; twigs reddish-brown to dingy

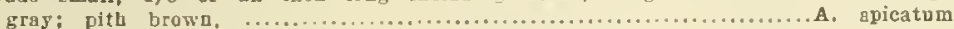

3. Buds large, ovoid, the termingl one acute the lateral obtuse and closely apressed;

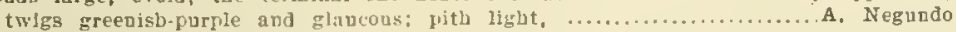

4. Buds with 8-1G exnosed scules, brown, gcute, non-collateral, leaf-scars nearly

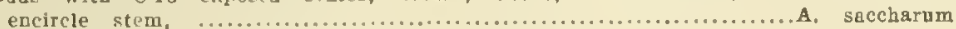

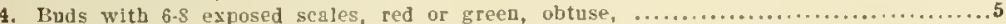

5 Terminal buđs small, generally less than $1 / 5$ of an inch loog; terminal and lateral

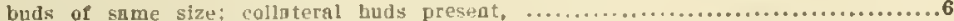

5. Termianl buds large, geverally over $1 / 5$ of an inch long; termingl huds larger

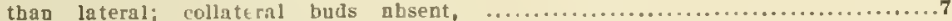

6. Twigs red and lustrous; bark rough but not flaking in large pieces, ........ rubrum

6. Twigs brlght chestuut-brown; bark falling away in thio lnrge flakes. A. saccharinum

7. Bads red; leaf-scars encircle stem; lenticels scattered; Iateral buds appressed; bark black, fissured, not scals, ............................... platanoides

7. Buds green; leaf-scars do aot encircle stem; leoticels aumerous; lateral buds proJecting; bark browndsh and scaly, ....................... Pseuda-platanus 


\section{STRIPED MAPLE. \\ Acer pennsylvanicum, Linnaeus.}

FORM-Usually from 10-25 ft. in height with a diameter of abont 6-12 Inches, but may attain a beight of 40 feet. Trunk usually sbort diriding lnto slender and atraight branchea which form a deep and broad crown.

BARK-ThIn, rather smocth, greenish or reddish-brown, conspicnously marked vith longltudinal white streaks; later becumes rougher, darker, and less streaked. See Fig. 63.

TWIGS-Smooth, stont, at first greenish, Inter red, with rery lew inconsplcuous lenticels, and brown plth. Season'a growth morked by 2 or sometimes 3 dark lines encircling the twig, formed by fnllen onter bud seales. White longitudinal atreaks appear the second season.

BUDS-Opposite, evidently-stalked, large, about $2 / 5$ of an Inch long excluding stalk, taperlng but hlunt-pointed, red, glossy, angular, corered by a slogle pair of red, smooth, ralvate scales eoclosing a lew pairs of smalfer and lightcr scoles, Outer acales are smooth oo surface with clliate malgins whlle the inger scales are bulry a s shown la opposite plate. Terminal buds are barge while lateral buds are smaller and closely appressed.

LEAVES-Opposite, simple, goose-font-like, 3-lobed at apex, floely serrate on margin, rounded at base, rusty-pubescent below. Petioles long, groored, with enlarged bases.

LEAF.SCARS-Opposite, broadly U-shaped, nearly exclrcle atem; adjacent edges form rather blunt teeth which are separnted by a ridge. Bundle-scars usually 3, often sabdivided into 5-8.

FLOWERS-Appear in May or Juue after the leares are full grawn in drooplng terminal racemes. Staminnte aod pletlllate flowers occur on same plant but in different clnsters.

FRUIT-Matures in September in drooping racemes: wings of the keya, thin, rery divergent, about of an fnch long, marked on one side of seen with a depresslon.

WOOD-Diffuse-porous; roft, close-gralned, light brown with wlde zone of apwood. Seldom used commercially. Welghs $33.0 \div$ lbs, per cubic foot.

DISTINGUISHING CHARACTERISTICS-The Striped Maple, also known as Joosewood aod Whistlewond, can be readlly distinguished at all seasons of the sear by the light longitudinal streaks on the branches and trunk. Thes often appear the secood sear and persist for many years on the truak. In winter the large, evidently-stalked, ralrate, and red buds together with the smooth branches and brown pith are cbaracteristic. In aummer the drooplng raceme of fowers and the goose-foot-like leases with their finely serrate margina and rusty pubescedce $c 0$ the lower surface are distinctire.

RANGE-From Nora Scotin west to Minoesota, south especlally along the mountains to Georgla.

DISTRIBUTION IN PENNSYLVANIA-Rather common locally in the mountainons parta of the State especinlly on shaded slopes and in deep ravines. VerJ common in Miftin, Centre, Blair, and Huntingdon connties.

HABITAT-It prefers moist, cool, shaded, often rocky mountain slopes.

IMPORTANCE OF THE SPECIES-The wood is of practleally no commercial ralue. Tha chlef ralue of the tree is its attractire ornameztal qualities bet's a an individual tree and aa a component of the understory of the forest structure. 

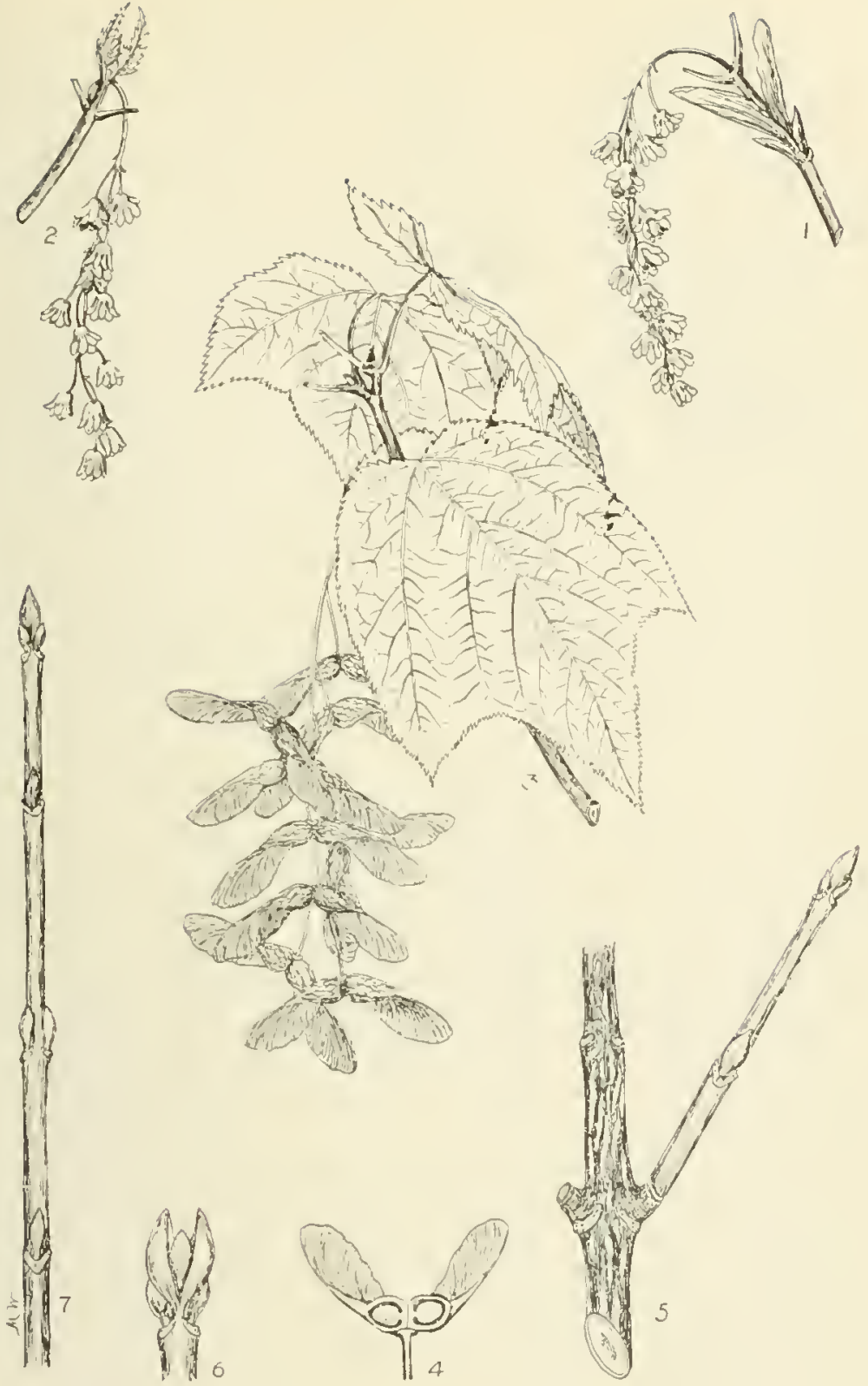

\section{PLATE CIV. STRIPED MAPLE.}

1. Branch witl droplins raceme of staminate flowers, $x$ z

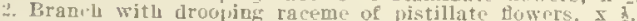

3. Frauch with mature leares and drooping riceme of fruit, $x$

4. A malule king with exprosed secels, $\mathrm{x}$ t.

5. Section of winter luranels slowing strijull lark, buds, and leaf-scars, $x$

6. Trrminal section of winter twig stowing triflently stalked lands with onter pair of bud seales

- scmrated, exposing the poluescent inger seale's patural sim.

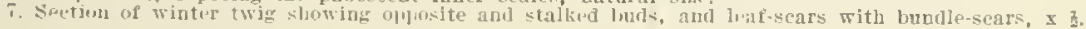




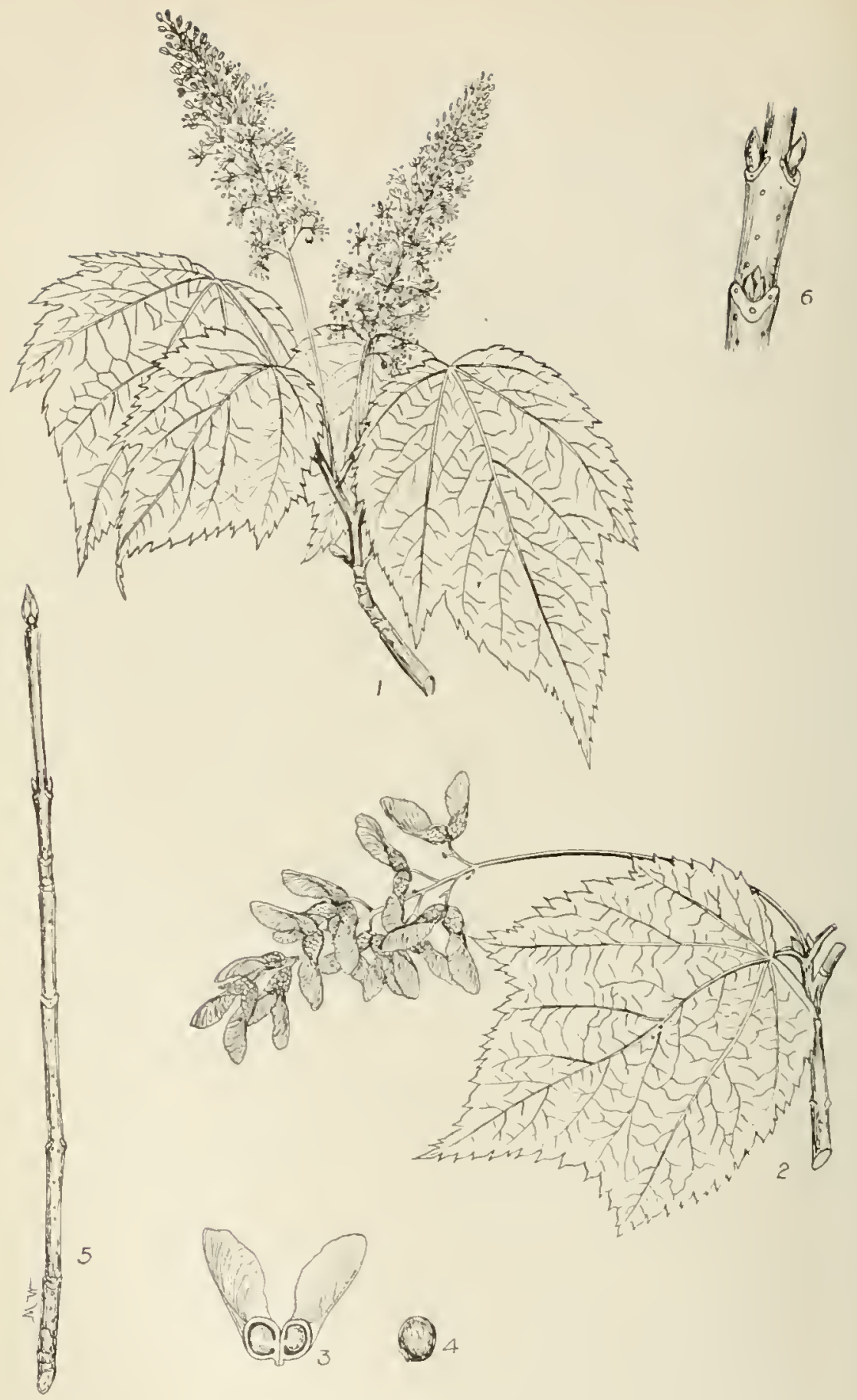

PLATE CV. MOUNTAIN MAPLE.

1. Bunch with mature leares and two erect, 1 . A seed, slightls eularged.

Tinter twig with stalked bulk, lunticels and

2. Eranch with a mature leaf and a raceme of 1 leaf-scars with hudle-scars, $x$.
6. Section of a winter twlg, enlarged.

3. A maple key with exposed seeds, $x$. 


\section{MOUNTAIN MAPLE. \\ Acer spicatum, Lambert.}

FORM-A shrub or small tree sometimes attaining beight of $35 \mathrm{ft}$. With a diameter of 11 inches. L'sually a shub growing in clumps on rocky soil. Trumk usually short and bears rather stralght, slender and upright brancbes.

BARK-Tbin, ratber smooth, browa or grajisb-brown mottled witb diogs-gray bloteles.

TWIGS-Slightly balry, at frst reddish-priple on exposed side and yellowish-green on sbaded slde, Jater bright red and then chnging to grayish-brown, covered with few scattered lentleels; contain brown plth, and are enclrcled by 2 or 3 dark rings formed by the scars of fallen bud-scales.

BUDS-Opposite, short-stulked, rather small, about 3 of an inch long including stalk;

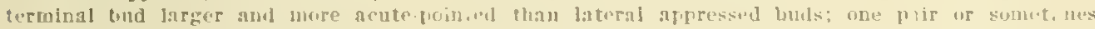
two pairs of nore or less halry, zragisil or gerentsh seales visihle.

LEAVES-Opposite, simple, 3-5-lobed, coursely serrate on margin, cordate at hase, sonewhat hairy on lower surface. Petioles loug, sleuder, nad enlarged at base.

LEAF-SCARS-Opposite, V-shaped, hollow, with 3 buadle-scars, and nearls encircle sten.

FLOWERS-A Apear about June after the legves are full grown, in erect terminal racemes. Staminate fowers occur unually at the top an.l the pistllate at the hase of the raceme.

FRUIT-Matures in Septenber in drooping racemes; wings of the kegs somewhat divergent. nbout 1 of an Inch long, the eed-bearing part strongly striated.

WOOD-Diffuse-porous; saft, close-grajned, light to redlish-brown ritb wide zone of light sapwood. Seldom used commercialls. Weighs 33.22 lls, per cubic foot.

DISTINGUISHING CHARACTERISTICS-The Hountalu Maple is essentialiy a shrubby spe-

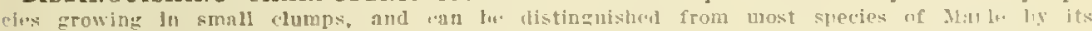
stalked, fow-scaled winter buls, erect raceme of flowers, hairy-purplish to greenish twigs, and simple, 3-5 lobed coarsely serrate leares. It differs from the closely related striped Maple In the absence of light-strined bayk nnd hrown pubescence on the lower sides of the leares, and in the presince of pubcserese on the hranches. and smaller often gaping hads.

RANGE-Newfoundland to Manitoba, soutb to Mlichigan, Pennsyivania, and along the mountains to Georgia.

DISTRIBUTION IN PENNSYLPANIA-Fond locally io all parts of the State. Rather com. mon in the mountainous parts.

HABITAT-It prefers molst rocky billsides. Commonly found bordering ravines. It demands the sbade of other species. Very thrifts on the moist slopes and tops of the fouthern Appalgchian Mountalns.

IMPORTANCE OF THE SPECIES-It is of practienlly no commercial imrortance as a timber tree, but is raluable as a so.l protector on rock slopes where a protection forest is desirable. This species is pleuted vers extusively for ornamental purposes. 


\section{SUGAR MAPLE.}

\section{Acer saccharum, Marshall.}

FORM-A large timber tree attaining a masimum beigbt of $120 \mathrm{ft}$. with a diameter of 5 leet. Open growa trees bare slort trubss beariog stout, ratber ertet branches wbich form a spreading, egg-sbaped, ofter round-topped crown. Trees in closed stands bave long, straight, clea trank bearing shallow, rouad crowas witb large limbs.

BARK-On branches and rouag trunks smooth and ligbt browa; on older truaks brown, deeply chandelled into long irregular plates or flakes wbicb often loosea rertically aloag the side. See Fig. 6 .

TWIGS-Siender, smootb, reddsb-browa to oragge-brown, corered with aumerous pale leatlcels.

BUDS-OInosite, brown, sbarp-polnted, conleal, hairy at apex: terminal hud ahont twice as long as appressed lateral ones; coreted by overianning seales, with irom 8-16 of them exposed.

LEAVES-Opposite, simple, usualls 5-lohed, with a sparsely toothed margin and rouadbased sinuses, cordatc at base, thin in testure, $\hat{5} \mathbf{5}$ incbes long and greater in width. Mature leares are brigbt greed abore and pale green heiow.

LEAF-SCARS-Opnoslte, $r$-sbancd to $\mathcal{C}$-shaped, nearls cncircling stem, l3unlle-scars usually 3 , in a lusate line.

FLOWERS-Appear in April and Jay with the leares, ia droopiag corgmba both from the terminal mlsed bods and the iateral propazatire buds. The stamlate and pistillate accur in differeat clusters.

FRUIT-Mntures about septcmber; clustered, horne on drooping stalka; winga of the kess about 1 -I inch long, parallel, or slightly dirergent.

WOOD-Inifuse-jorous; henry, bard, slose-grained, with fine surface. light brown to rpullish. Csed for interior flnlsh, furniture, shoe lasts, raliroad ties. Abnormal modifications of the structure of the wood known as Curly Vaple and Bird's Ere Yaple are rather common aud especially prized in cabinet makiag. Weighs 12.0S lbs, per cubie foot.

DISTINGUISHING CHARACIERISIICS-The Sigar Maple, also known as Hard Maple and hock Marle, ean be distinguisbed in summer froiu the uther Maples by its large, simple leave whinb are thin in texture and bave their lohes coarsely toothed. Tbe forsers appear with the leares wblie tbose of the Red Maple cac the Silrer Maple appear before, and thase of the Mountain Maple and the Strlped Ilaple after the leares. The frult clusters of the Sngar Maple are nsalls derfloped from t3miagl buds wbile those of the Red Maple and Silrer Maple are developer. Iron lateral buds. The fruit of the Sugar Maple does not mature until September and may often nersist into tic winter wblle the fralt of the Red Maple and Silver Vanle matures in early summer and germinates at once aftor falling upon the ground. In winter the Sugar Maple can be recogoized by its confcal, sbarp-pointed, brown buds with from \$-16 exposed and orerlappiar segles, and by the sleader broma twigs marked with pale lentlcela. The rongb furrowed trank is also characteristic of older trees.

RANGE-Nenfonadland to Masitoba, sooth to Florida and Tesas.

DISTRIBUTION IN PENNSYLVANIA-Common, especially in the northern and eastern parts of the State. It is possibly, next to Cbestant, the commonest tree in this State.

HABITAT-1t flourisbes best on well draiged ricb scil, but will tbrire eren when the soll ig not rich. It is common on low ridges $B$ t the base of mcuntains, and along slopes. It reaches its best development in central New England, NeT York, northern Peansylrania, and the Lake States.

IMPORTANCE OE THE SPECIES-The Sagar Maple is a raluable timber tree. Its Importance is being realized more as its wood finis new uses. The process of timber impregna tion bas raised the raive of the wood of this species. It is not only raluable as a timber tree bot produces ansually a large quantlty or maple sagar and maple syrup, and in addition is one of our most attractive ornamestal irets. 

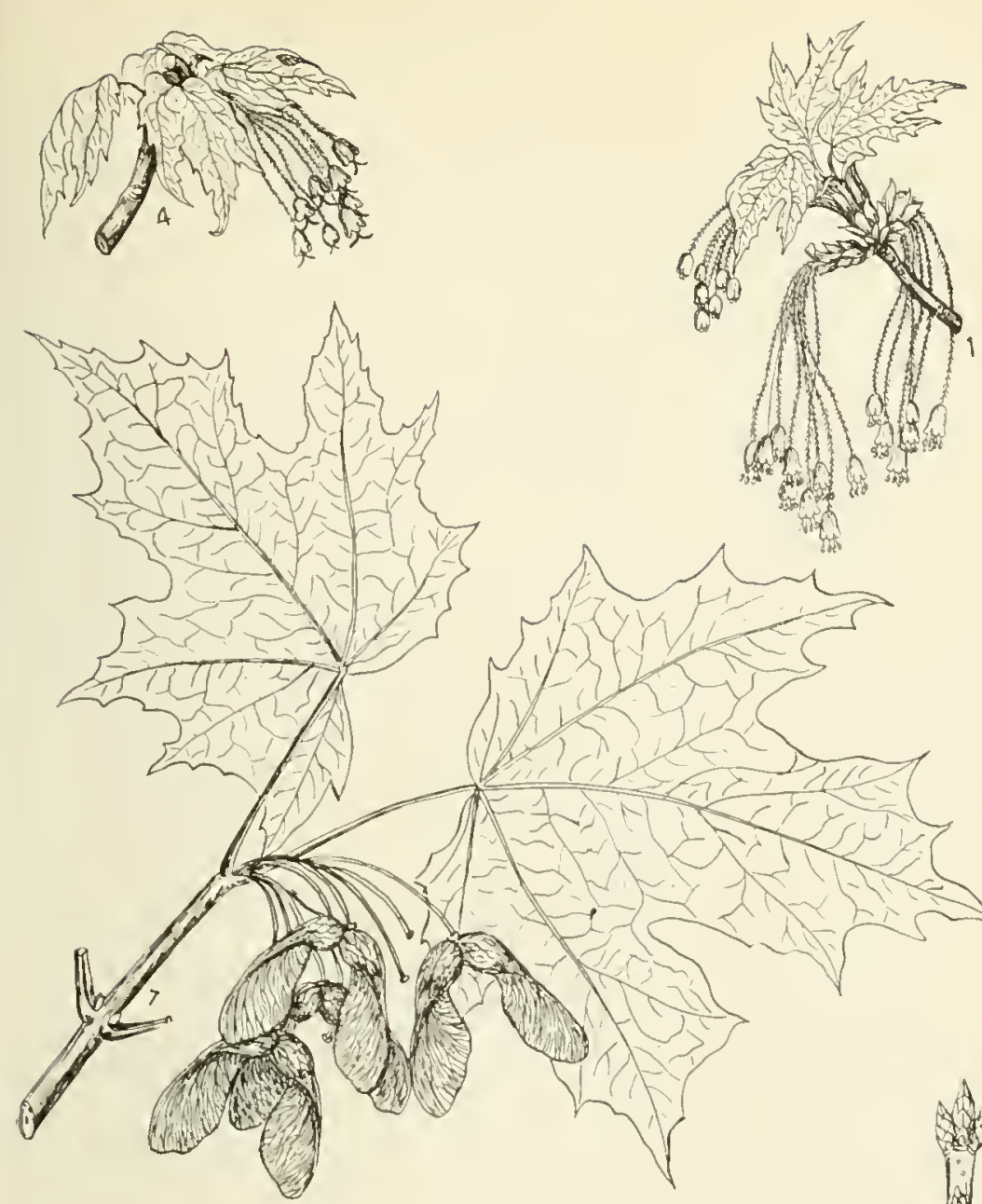


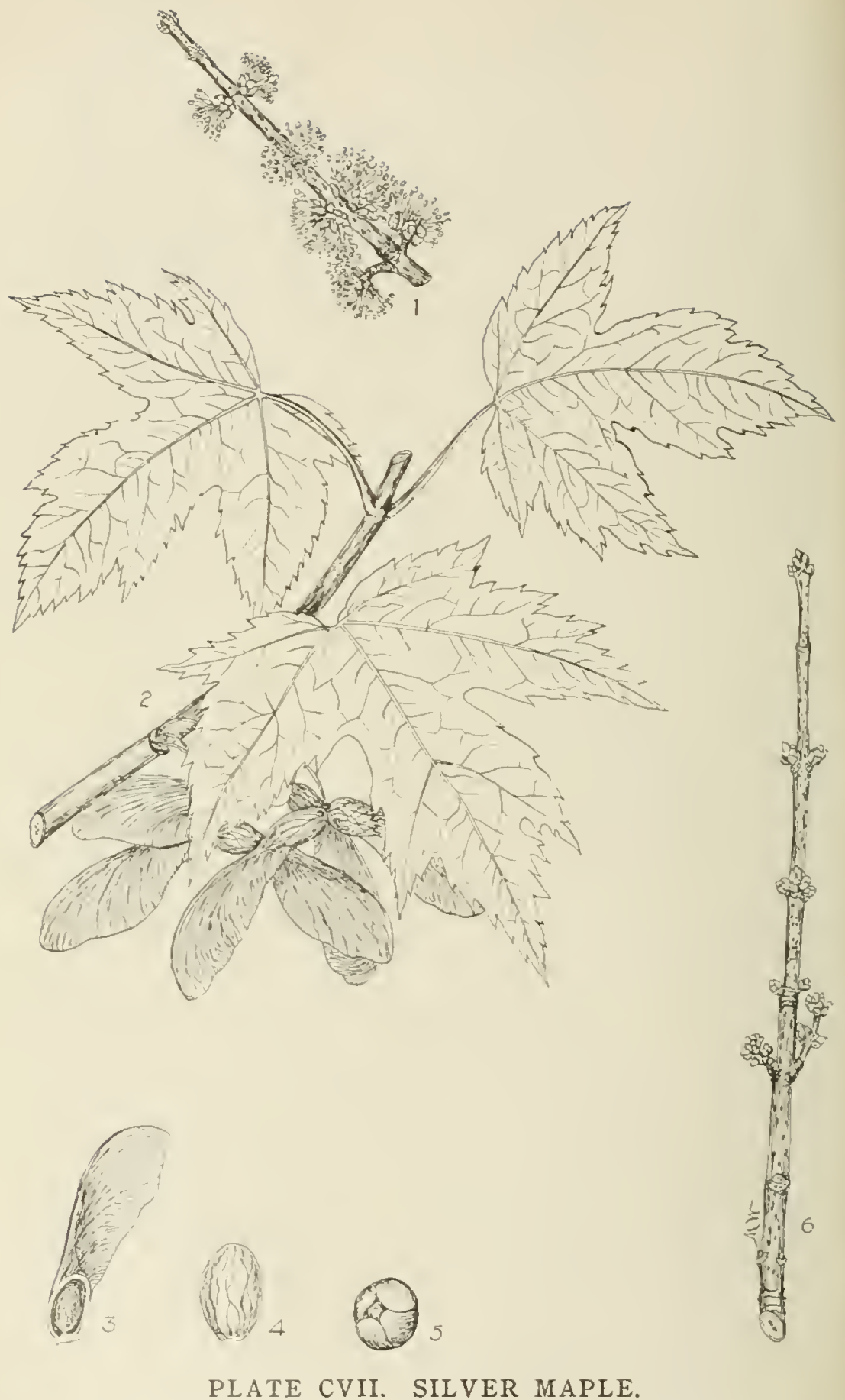

1. Flowering branch, 5 h. 4 , A seed, enlarged.

2. Branch with mature leares and mature fruit, 5. End riew of a seed enlarged,

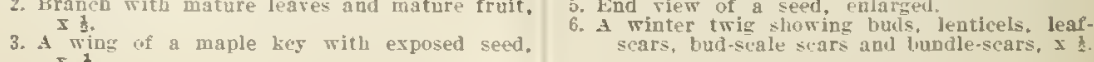


SILVER MAPLE.

\section{Acer saccharinum, Linnaeus.}

FORM-Uraally a tree abolt 50-60 1t. 10 haigbt but may actaia a rasimum height of 120 ft. with a diameter of 41 feet. Trut short and divides into lateral brauches which ngain freely subdivide rad form A broad head. Loteral brasches have proaouaced droop, and distinct opward curve at the ead.

BARK-OZ branches and 5 cuag trunks smooth aud gras; on old traks brown with a some what furrowid sarface sepatntig into thin flukes which are fastened at the ceater and loose at both ends.

TWIGS-Somewhat slender, glossy, nt first green, later hright chestnnt-brown, eorered with vumerons light lenticels.

EUDS-0nposite, rod, obtuse-Tolnted, sessilio or short-stalkrd: flower buds stout, spherical, accessory, covered with overlsping scales, t3 of which was be cxposed. Margin of scalea cillated and oftea lizht in color.

IEAVES-Oprosite, simple, 5-lobed, coarsuly tootbed; bright greea on upper sarface and gilvery-white on lowur; with deep round-based sicuses.

LEAF-SCARS-Opposite, [-gheped to V-shrped, not encireling stem. Jundle-scars 3 , in a lunate live.

FLOWERS-Appear io March or April belore the leaves are out, la dease, sessile, axlinry

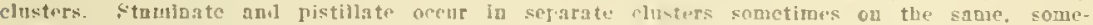
tImes on different trees. Petuls absent.

FRUIT-Matures about Mas; clustered llong brachlets, borve ou sleader drooping stalks: wings of the hesg usually fron, $1-2$ inches lung, divergent, suruetimes stralght, or corred.

WOOD-Difuse-porous: moderately bard, rather brittle, closegraiged, with wide sapwood. Used for flooring, cheap furature, and paper linjp. Weighs 32.84 Ibs, per cabic foot.

DISTINGUSHING CHARACTERISTICS-The Silrer Maple, also known as White Maple, River Minple, and Soft Maple, can he recogaized la summer by its leares with a silrery-whlte lower surface nad decp rourd-based siunses, in winter it closely resembles the Red Maple but may he distinguished from it by the puagent ador of the broken twigs and the brigbt chestaut-hrown twigs. The baric of the Sifper Maple is somewhat furrowed and separates into thin flakes whlch are loose at both ends and fastened in the middle. The lateral branches hare a prononaced droop aod a distinct upward curve at the eads. This mas sometimes be a dis. tibctire character. The Red Maple and the Sirer Maple are distioguished $150 m$ all the other Maples of the State by tlee namerona, round, red, collateral buds.

RANGE-New Branswick to scuthers Ontaria, south to Florida and Indian Territory.

DISTRIBUTICN IN PENNSYLFANIA-Oceacional and local throughout the state, especinly aloug larger streams.

HABITAT-It preferg a noist deep soil sucb as is fond aloog stream bankg. It will exist In drier locatlons bot not actain a latge size.

IMPORTANCE OF THE SPICIES The Silfer Miple is a vers attractive ornamental tree. A lew special ornamental rarictles have beed duloped. The wood is brittle and consequently the branches are apt to be breken off duaing a storm. This defect somewhat checks the planting of this apccles la esposed places. It is a rapid grower. The wood which it prodnces is of no special commerejal importance and coasequeatly it has little to recommend it for forestry purposes, except that it forms an excelledt soil cover id the under-story of the forest. 


\section{RED MAPLE. Acer rubrum, Linnaeus.}

FORM-[sually a tree aboot $50 \mathrm{ft}$, high, but ic n moist balitat sometimes attaids a height of oret $100 \mathrm{ft}$. with a diameter of 4 feet. When grown in the open it branehes Dear the ground and forms a deep, broad, dense crown. Upper lateral branches are rather uprigut whlle lower ones are horizontal ant slighlly turned upwards at the end.

BARK-On branches and rnung trunks smertb and srar: on old trubs dark grayisb, thick, shaggr, and roughend by long ridges which peel off in'leng riates. Spe Figs, lin and ril.

TWiGs-Somewhat slonder, gloss., at fist green, later fer, corered with oumerous light lenticels.

BUDS-Similar to those of the Silver Maple. See page 195.

LEAVES-1)pinsitr. simple. 3\%lohud, enarfelr-toother, ligbt sreed atore, pals green to whitish below, with rather stollow sharp.based siouses.

LEAF-SCARS-0pposite, U-shaped to V-shaped, not encircling stem. Bandle-scars 3 , in a louate line.

FLOWERS-Apnear in Marcb or Aprll before the leares are ont. in dense sessile axillary clusters. Staminate and pistillate oceur in different clasters, on the same or different trees. Petals prescot.

FRUIT-Matures in May or June; clustred and borue on Jromping stens: wings of the kegs nsially less than 1 inch long. red to lrown in color, at first conrergent hut later dirorgent.

WOOD-Diffuse-porous; rather solt, not strong. elose-graived, light hrown with wlde light saprood. [sed for furniture, in turnery. nd naper pulp. Teighs 35.5 lbs, per cohic foot.

DISTINGUISHING CHARACTERISTICS-The Ied Maple, also known as Soft Japle, Swamp Maple, and Whlte Maple, can be recosnized in summer by its sirople, rather small, 3.5-lobed, warsiytonthel leares whicl are rarels silvers white underneath. and have rither shallow shmrp-based sinnses. In winter it closely resanbles the Sidrer Maple, but may he distingushed by its red Instrous twigs antl the absence of $\&$ pungent odor. from broken twigs. In winter these two closely related speries can be distinguished from the sugar Maple by their

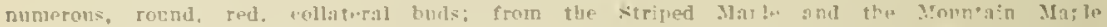
by their larger size and the absence of stalked buds; from the Astleared Maple hy the absence of short-stalked down buds and grecnish twig corered with a whitish bloom. The European species, both Vorway Maple and sycamore Maple, have much larger bnds and stouter 1migs.

RANGE- Tora Scotia to Manitoha, south to Florida and Texas.

DISTRIBUTION IN PENNSYLANIA-Common localls throughont the State, especially in regions traversed by strenna and in wet babitats.

HABTIAT-1t prefers wet soil. often found in swamps but also frequents drier hillsides. Commonly fond along riters, creeks, lakes, in smamps, and as an andergrowtl in the forest orer extensire, and often rather hilly areas.

IMPORTANCE OF THE SPECIES-The 1:ed Marle prodnces a wood which at present is of little commercial importance it mas in time hecome mo:e raluable. The despised species of to-day may be the prized species of to-norrow. It is tolerant of shade and its chief foture ralue in forestry moty be in furnishing scril protection $\varepsilon s$ a member of the under-stors of the forest. It may play the same role on our future fores that Bepeh is playing to-day in the intensirely managed fcrests of Germany, ools that it is of less ralue for foel. 

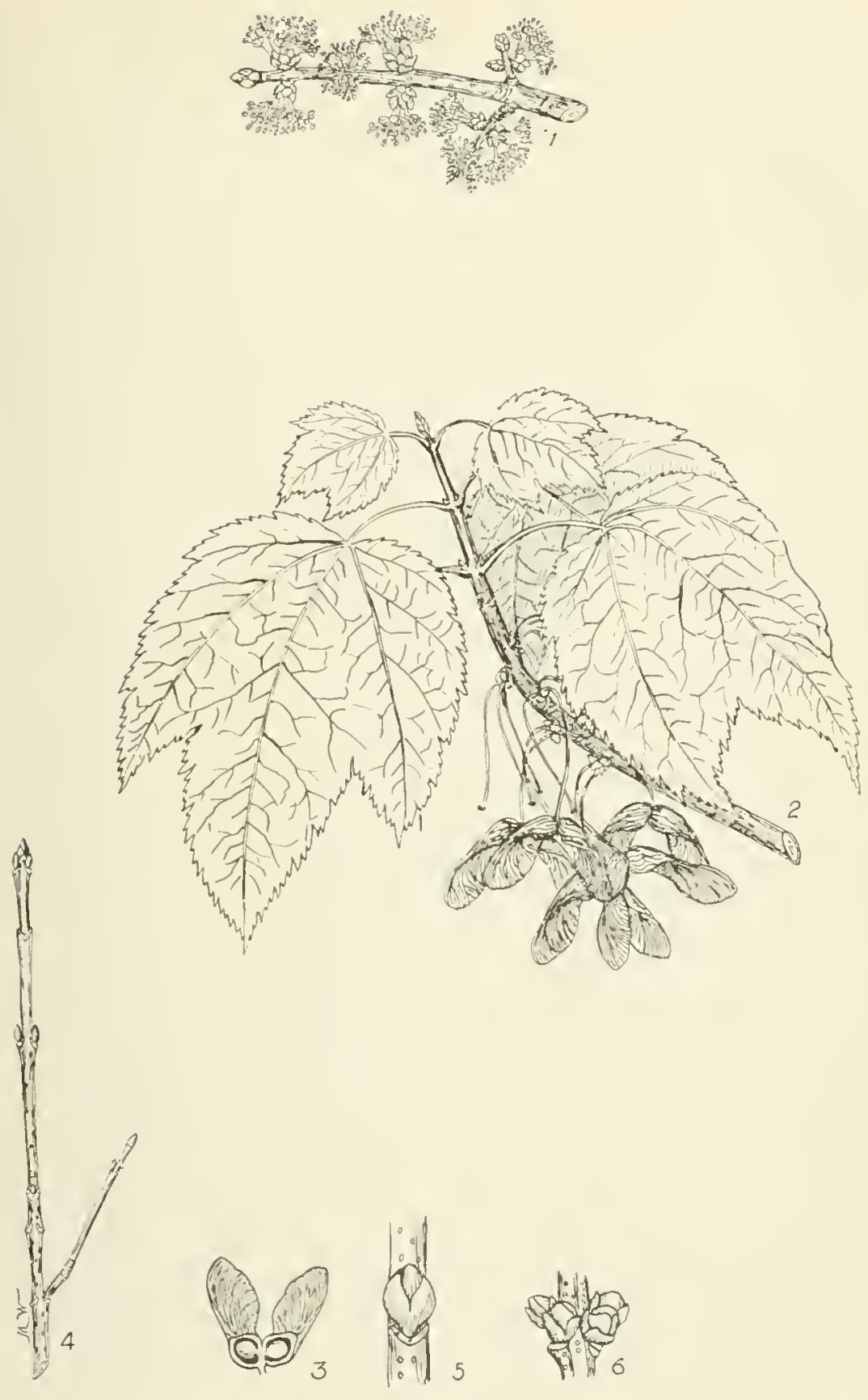

\section{PLATE CVIII. RED MAPLE.}

1. Flowering branch, $x$ z

2. Branch with mature leares and matare fruit,

3. A maple key with exposed seeds, $x$ z.

5. Section of winter twig showing lenticels, a leaf-scar and a gaping lateral bud, natural size.

4. A winter branch, $\mathrm{I}$.

6. Section of twlg showing conspieuous Ienticels and a eluster of accessory buds, natural slze. 

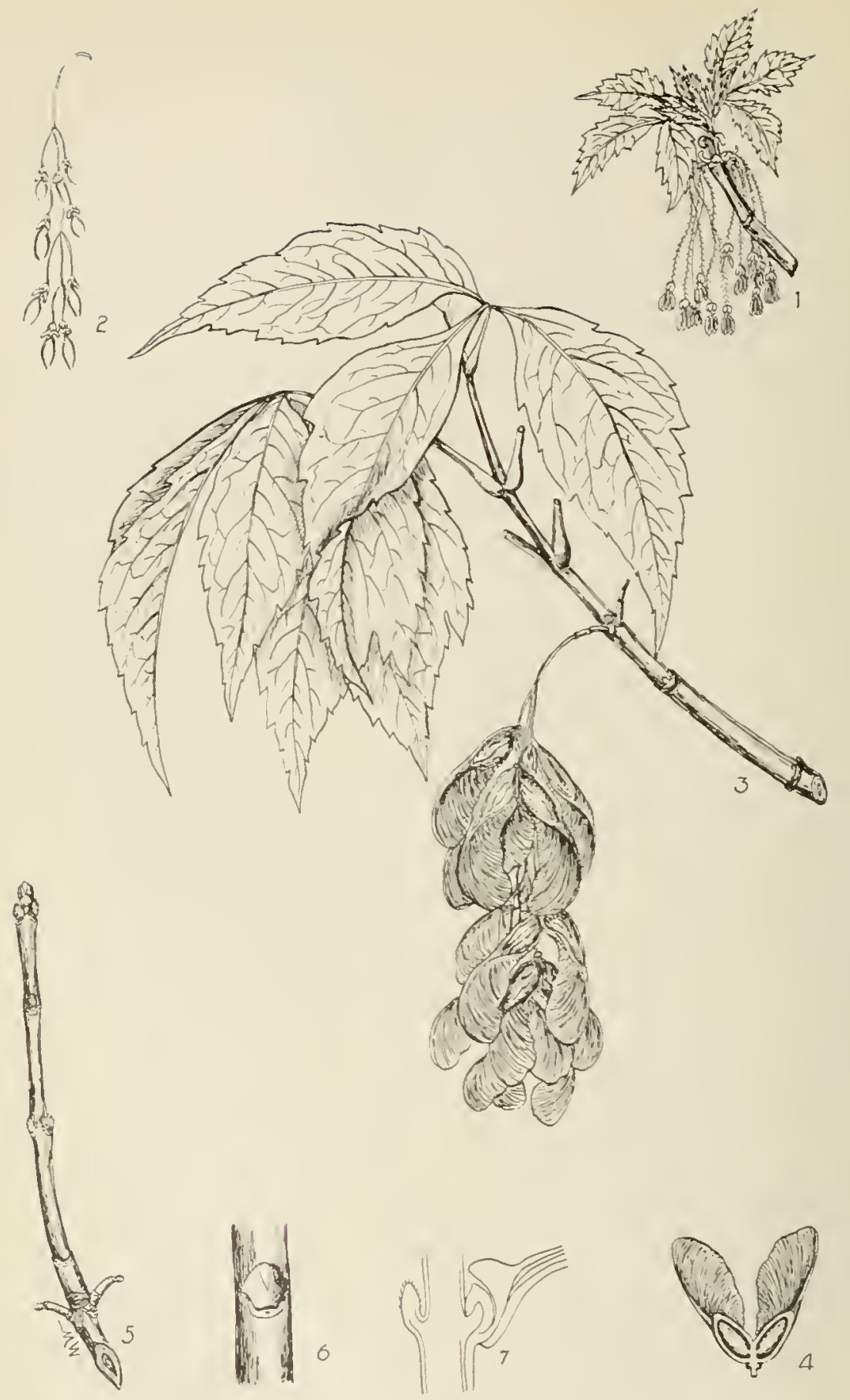

PLATE CIX. ASH-LEAVED MAPLE, or BOX ELDER.

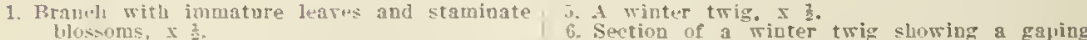

2. A druoping raceme of pistillate blossons, $x$. 3. Branch with mature leares and a raceme of
miature fruit, $x$ ? 4. A liey of frut with expured seeds, $x \underline{x}$. liud and a leaf-scar with budle-sears.

7. Tiagramatic section of a twig with luds and a wrering leaf-base, enlarged. 


\section{ASH-LEAVED MAPLE, or BOX ELDER.}

\section{Acer Negundo, Limaeus.}

FORM-A medium-sized tree oceasionally attninimg a leelght of $50 \mathrm{ft}$. with a diameter of 3 leet. Trumk usually short, diriding into stout, sometiraes drooping branches which form a deep broad crown. Oecrsinally an open zrown tree jossesses a loug clean trunk.

EARK-Oc bradies nné roun: truvks smootl and fraylsb-biowu; that of older ones tather tblck, distluctly Darcow ridged, and seldom scals.

TWIGS-Stout, purpilsh-grceu or green, curnotimes smooth, often corered with a whitish bloom and sentered ralsul lentleels.

BUDS-Opposite, suort-ktnlked, large, oroid; the trralnal acute and the lateral obtuse; white-woolls, roverel by luriscales, the cuter pair usualiy completelf enciosing the inner palr. Collateral ludus are commou and oftea disteal outer scales.

LEAVES-Onposite, compena, witl 3-5 lenflets, Ifeaflets osnte, consely and irregularly serrate, $2-4$ jucbes loug and $2 \cdot 3$ inches broat.

LEAF-SCARS-Opnosite, F-slanel, lordered hy light colored margln, encirclug stem so that adjacent edges of opposite scars ment at a very sbarp augle. Bundle-scars usually 3 , seldom divlded, erranged in a lumate line.

FLOWERS-Appear in Apul! bofore or with the leares ou the past season's growth. Stanimate and pistillate accur on different trees, toe former on bairy drooplng pedleels, the latter lo Darrow droping racenes.

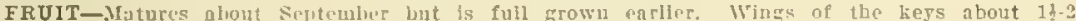
inches loog, parallel or incuryed, borde in drooplog racemes. Fruit-stalks rersist far into winter.

WoOD-Diffuse-porous; light, solt, creamy-shite, close-gralned, not durahle. Csed in the manencture of woodenware, coonerage. Tood nuli, and sometimes in cluegp Purniture. Telghs $\mathbf{2 6 . 9 7}$ lbs, per cuble foot.

DISTINGUISHING CHARACTERISTICS-The Ash-lenved Maple, also kDown as Box Elder, is rendily distinguishnd in snmmer by Its opnosite. compound Jenves with 3 to 5 lenflets aud jts greeo branchlets corerel with a whitish bloodn. The uaple liess arranged in drooplng racemes are also characteristlc. In winto the green branchlets atc distinctive together with the large, oroid. often colleteral and downy buds. The lfaf-scars eacircle the stem and their adjacent edges form a very shary angle.

RANGE-Termont westwart to Ontario, south to Florlda, Texas, and Mexico.

DISTRIBUTION IN PENNSYLVANIA-Fare ELd local. MoEt abundant in the easterD and southern parts of the State witl a few outposts reported in Westinoreland and Allegheng countles.

HABITAT-Thrlves best in moist soil, but also tolerant of drier situntions. Commonly found along streams, border of lakns or swamps. Often planted for ornameatal purposes on dry locations.

IMPORTANCE OF THE SPECIES-It is of Iftle commercinl imprtance as a timber tree It yields a sap from which sone malle sugar is made locally. This tree is rery attractive as an ornamentnl tree and is planted extensively as a shade, lawn, road-side and park tree. It grows rapidy and bas an nttrnctive form in winter and a deuse green follage in summer. 


\section{SYCAMORE MAPLE.}

\section{Acer Pseudo-platanus, Linnaeus.}

The Sycamore Maple is a Europen specles. It is natire to central Enrope where it attains a height of $120 \mathrm{ft}$. and derelops a large spreading bead. The trunk is aometimes furrowed and the hark fakes ofi in thin scales.

This tree is cousidered the mest attractire of the Maples for ornamental planting. It is ratber intolerant of soll couditions and consequently not planted so extenairels as the Norway Maple.

The Sycamore Maple is readily distingulshed by its firm, 3-5-lobed leareg with abarply serrate margins, acute-based sinusef, and pubescent lower leaf-snrfaces. In winter the large, obtuse, greeu buds are characteristic together with the leat-scars which do not quite encircle the stem. The lenticels are alsc more numerous and the lateral buds stand ont from the twig more than on the Normas Maple. The frult kess are also smaller and the wings less dirergent than those of the Norway Meple.

\section{NORWAY MAPLE. Acer platanoides, Linnaeus.}

The Norway Inple is a European specles extending from Norway to Switzerland. It attaius a beight of $100 \mathrm{ft}$. Iud develops a round head. The trunk of the tree is closely fissured but not scaly.

Thls tree is one of our mest aftractire ornamental trees and is planted extensirely along the streets in cities aud in lamos and parks. It is especlnlis adapted for city planting because it is more tolerant of optororable city conditiuus than our natire Maplea. It is also rather free from the nttreks of insucts and fongl, and retaing the leareg longer in fall than our Dative species. The wood is of no commercial importance in America, bat is used for tojnor purposes in Europe.

The Norway Maple can rendily be distingulshed in summer by its large leares whlch resemble those of onr Sugar Maple, hut are dewer in color and firmer in texture. The largetoothed and almost entire-margined leareg are readily recognized from the smaller 3-5-lobed leares of the Sycamore Maple with sharply serrate leaf-mangins. A certain test for identifying the Norwar Maple is the prosence of milky sap in the lest-petiole which readily exudes upon twisting. In winter the Nornay Maple can be recognized by the large, obtuse, glossy. red huds which may be more or less olire-green at the base and by the lateral closely appressed buds. The leat-scars whirh enctrcle the stern are filso charactertstic. The rery dirergent wings of the large maple keys and the closely lissured, but not sealy bark will also aid in recog. ing it. 

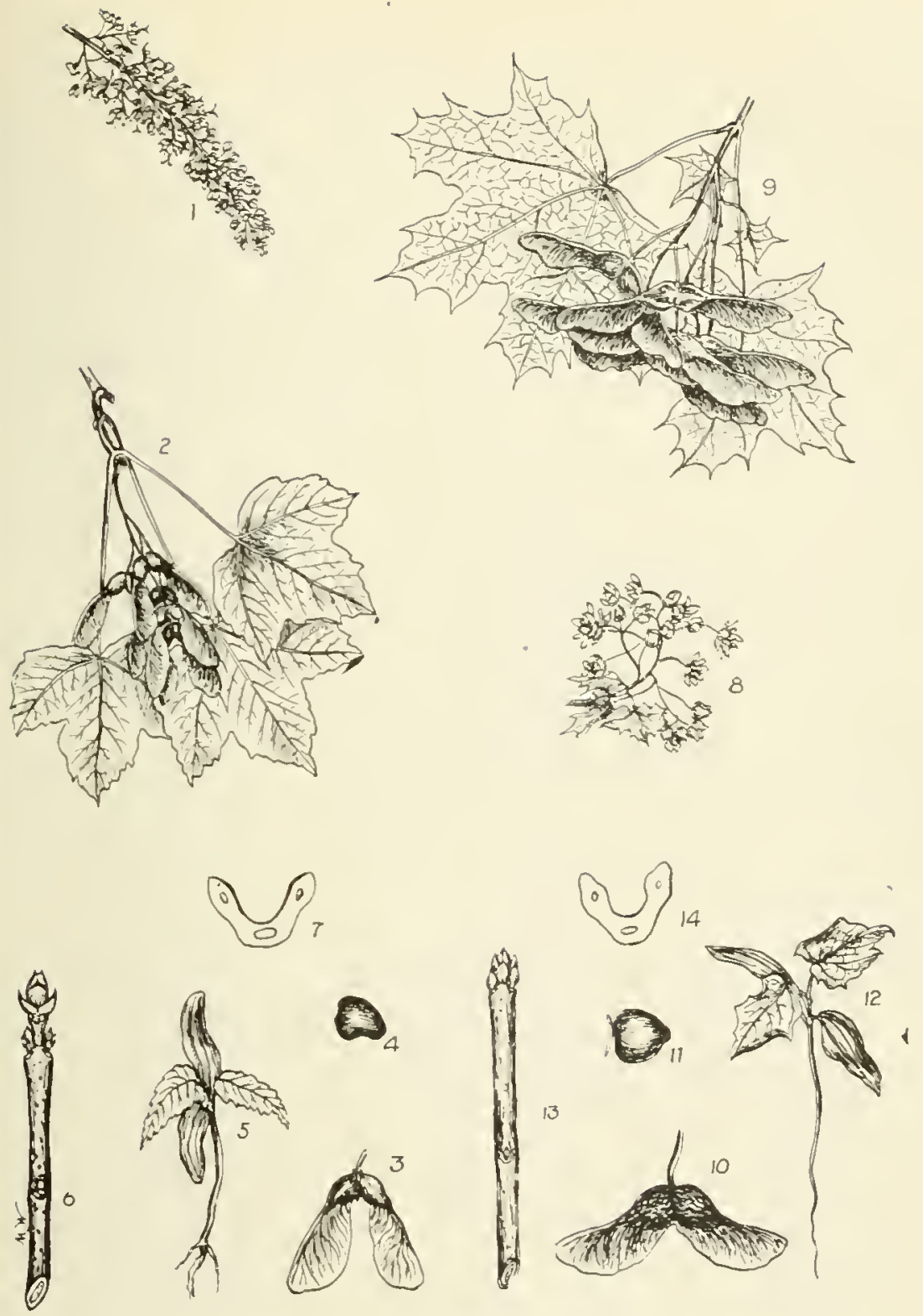

PLATE CX. EUROPEAN MAPLES.

SYCAMORE MAPLE.

1. A spike of flowers, I

2. Aranch witl leaves and fruit, s z.

3. A key of fruit, I 1 .

4. A seed, datural size.

5. A seedling. $\mathrm{x}$ रे.

6. A wioter twis, $x$ s.
7. A leaf-scar, enlarged.

\section{NORWAY MAPLE.}

5. A vuster of fowers. $x 3$.

9 . Branch with leares and fruit, $\leq$

10. A key of fruit. $\leq 1$.

11. A seed Datural size.

12. A seediling. 5 \&

13. A wiuter twig. 5 .

14. A leaf-cear, enlarged. 


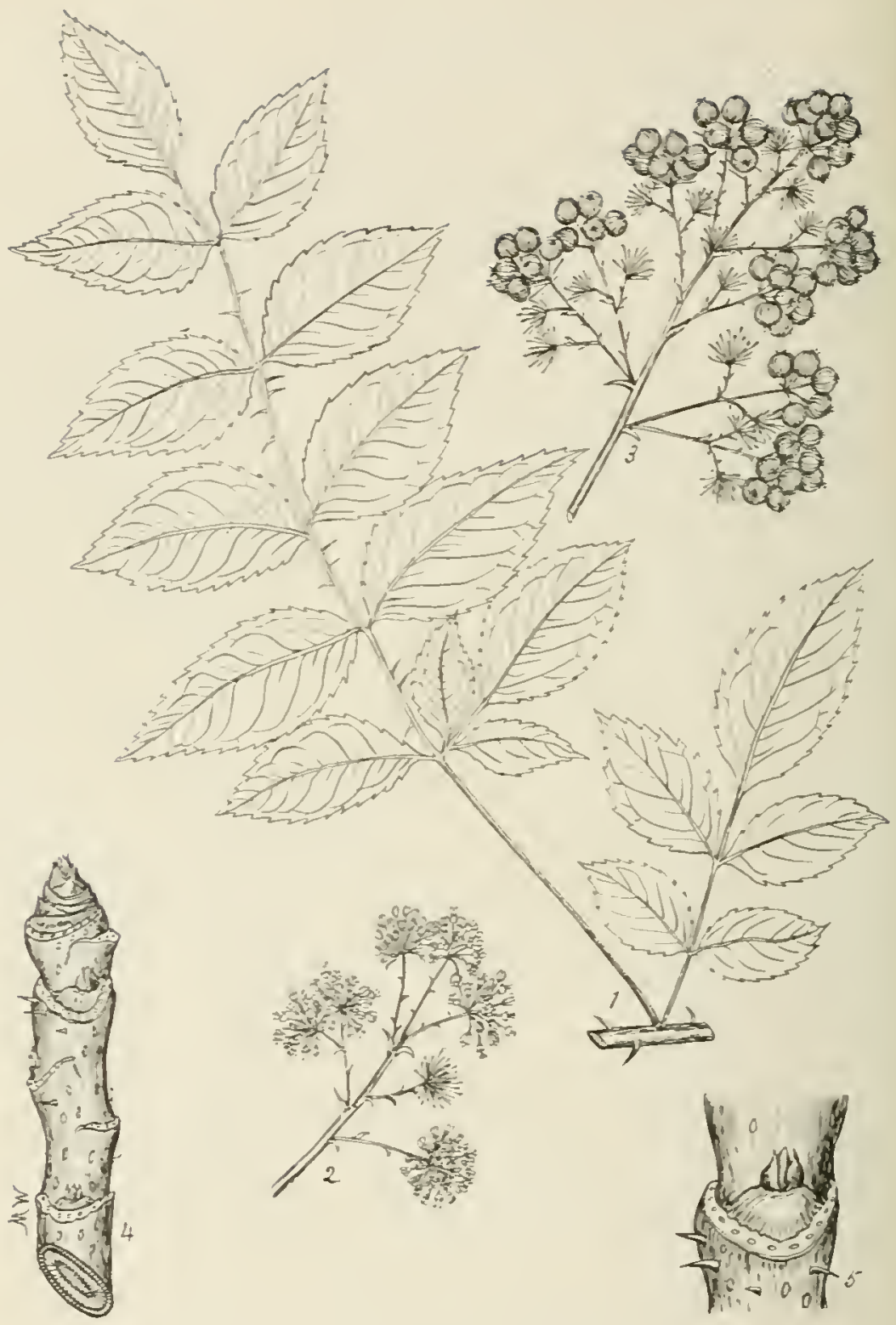

PLATE CXI. HERCULES' CLUB.

1. Section of a bratch with compond leaves. I 1 .

2. A panicle of Dowes. $x$ 3.

3. A panicle of fuit, I

4. Section of a winter trig, natral size. 


\section{EERCLIES' CIUB.}

\section{Aralia spinosa, Limaets.}

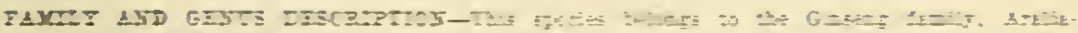

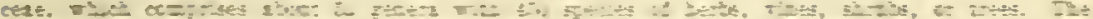

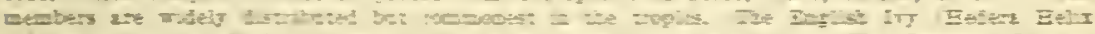

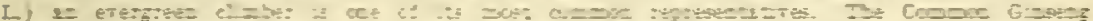

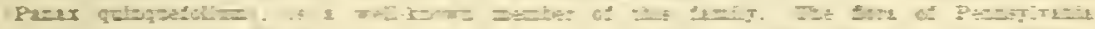

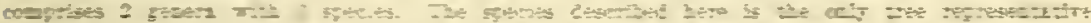

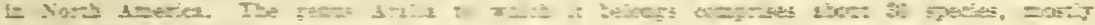

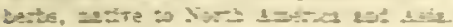

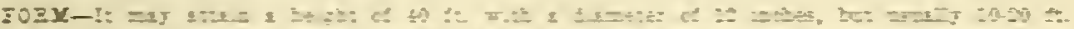

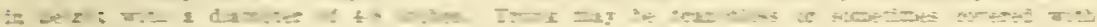

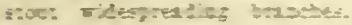

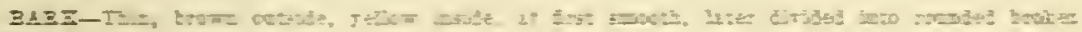
Fises.

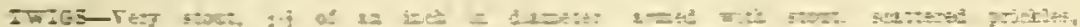

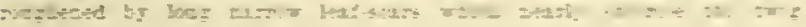

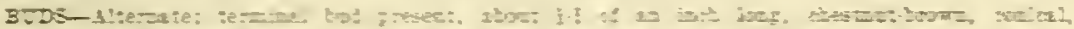

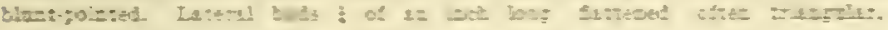

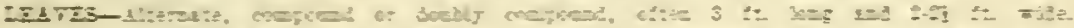

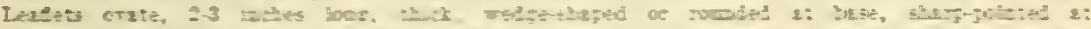

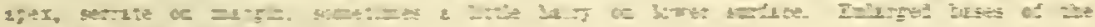

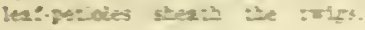

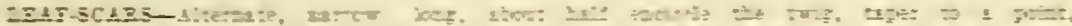

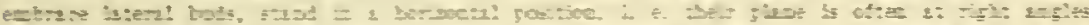

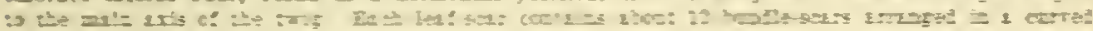
lise

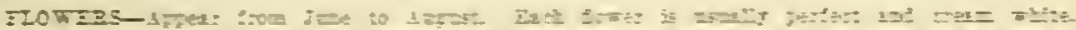

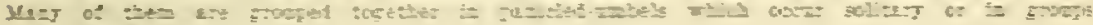
e:-es $3 \pm \therefore$ kec:

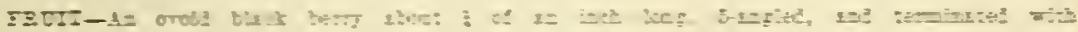

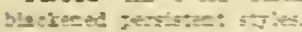

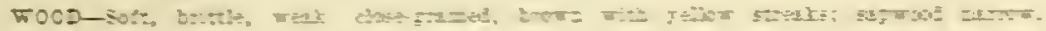

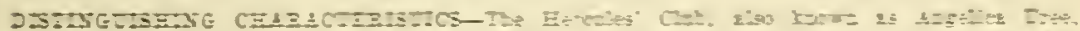

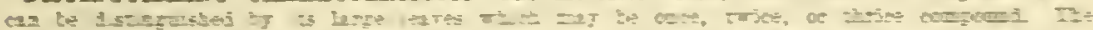

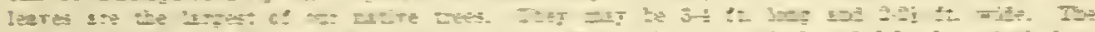

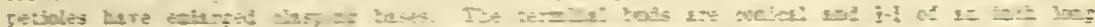

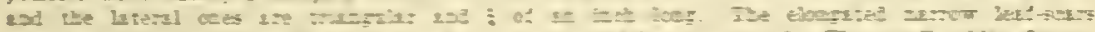

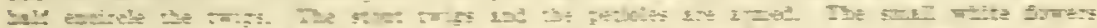

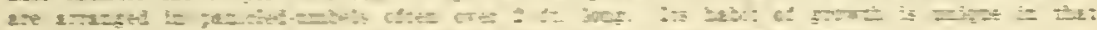

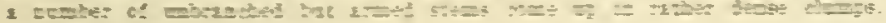

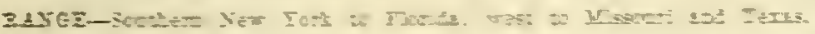

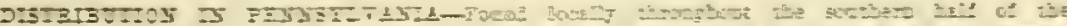

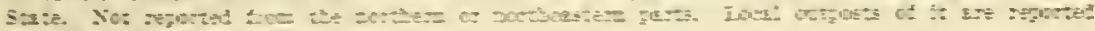

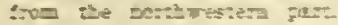

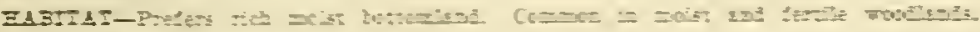

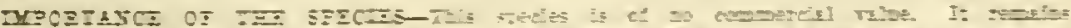

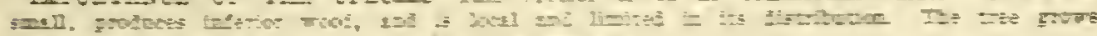

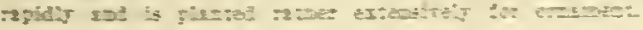




\section{FETID BUCKEYE.}

\section{Aesculus glabra, Willdenow.}

FAMILY AND GENUS DESCRIPTION-The SOapherry family, Sapindaceae, comprises about 100 genera with more thap 1.000 species. Ther are widely distributed, but commodest in the tropical regions of the old World. The flura of North America comprises 6 genera of trees with alorat 13 species. Tho getws Aesulus ulote bas representatives in Penusylvania. It comprises 14 species, 10 of which are Dative to America and 2 to Pennsylvania. In addition to the pative species, the Horse-ehestbut IAtscolus Hippocustanom) is widely introdaced in this State.

FORM- Csually a small tree not gver $40 \mathrm{ft}$. In beight with a dlameter of 12 inches, bot mag reach a height of $90 \mathrm{ft}$. with a diametur of 24 ldehes. Trunk short and slender. Crowd brosd, deep, round-topped.

BARK-Gray, thick, eridently-furrowed, breaking up into flates.

TWIGS-Stout, at first dewoy and browd, later swooth, reddish-brown to asby-gray; 111smelling if bruised. Pitb large, light greed, circular ju outline.

BUDS-ODiosite; terminal buds normally present but occasionalls absent; about ; of an inch Iong, sharp-fointed, resinous, covered by rearly triangular keeled seales, outer budseales reddish-brown, Dnely hary on margin, covered with n thin bloom; inner bod-scales sellowlsh-green, edagging in spriag to 12 lnches and persisting until leaves are balf dereloped.

IEAVES-Omposite, compoun: with 5, rarely 7 , teaflets. Ifaflets orate to oral, 3-6 tnches long, rnther long pointed gt afiex, narrowed at bose, lrrerularly and finely toothed on margin: when roung rather hairs, dater smoutb, yeliowlsh.green above, paler beneath. Leal-stalks 46 incbes long, stout, laairy when 5oung, enlu:zed at base. Voliage ill-smelling If bruised.

LEAF-SCARS-0pposite, large, heart-shaped to inversely triagular. Bubdle-scars large, in more than 3s, usually 3\%, often arraoged in 3 groops.

FLOWERS-Appeat about April or May aitor the leares re developed. Small, jellowish or greenisb, with four upright petals; borne in more or less downg terminal panicles about 5-6 inches long and $2 \cdot 3$ inche $=$ tronl. Pedicols 4-6-flowered. stamens project beyond zellow corolla.

FRUIT-Matures about Octcler. A thick, rouod or pear-shaped, prickly eapsule about 1

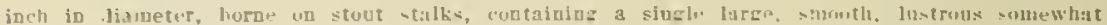
flattened brown nut. The falling fruit leares a large scar on the twigs.

WOOD-Diffuse-porous; rats rers fine, IDdistinct; pores rerr small, invisible to unaided eze, evenly distributed, mostly solitars; wood elements not in ther-like arrangement. Wood is weak, soft, whitish or sometimes pale jellow, lustrous. Weighs 3.31 lbs. ler enbie fout. Csed for paper-pulp, woodenware, artifial limbs, chip hats.

DISTINGUISHING CFARACTERISTICS-The l'etid Buekere, also known as obio Buckere, Stinking Buckere, a Ad American Horse-chestnut, ean be distinglished by its leathery, dehiscedt fruit containing one to three shining seeds. The fruit of this species is corered with spines while thrt of the sweet Buckeye is smooth. The leaves are opposite nud digitately com Iound with usually 5 or oceasionally - leafzts. The buds ar free from a resinous coating; the terminat one is often licking. The flowers are shows, $5 \mathrm{cltowisb}$ or greenish lo color and arrunged in large panieles borne at the ends of branches. The stamens project bejond the corolla while those of the Sweet Buckese are just as long or shorter than the corolla. It is natire only in the western part of the state.

RANGE-Western Pennsylahia, south to Alabama, west to llinols, Iowa, and Oklahoma.

DISTRIBUTION IN PENASYLVANIA-Found only in the extreme western part of the State. Reported from Allegheny, Fagette. I-awrence, Mercer, and Westmoreland counties.

HABITAT-Ľsually found grcwing in moist soil. Prefers banks of streams, ravipes, or similor situntions.

IMPORTANCE OF THE SPECIES-This tree is of Do commercial importadee in Pennsylrania. It is vers linited in its distribution and usualls remains small. It is occasionally planted as un ordamental tree, but is less popular than the Horse-chestmut. 


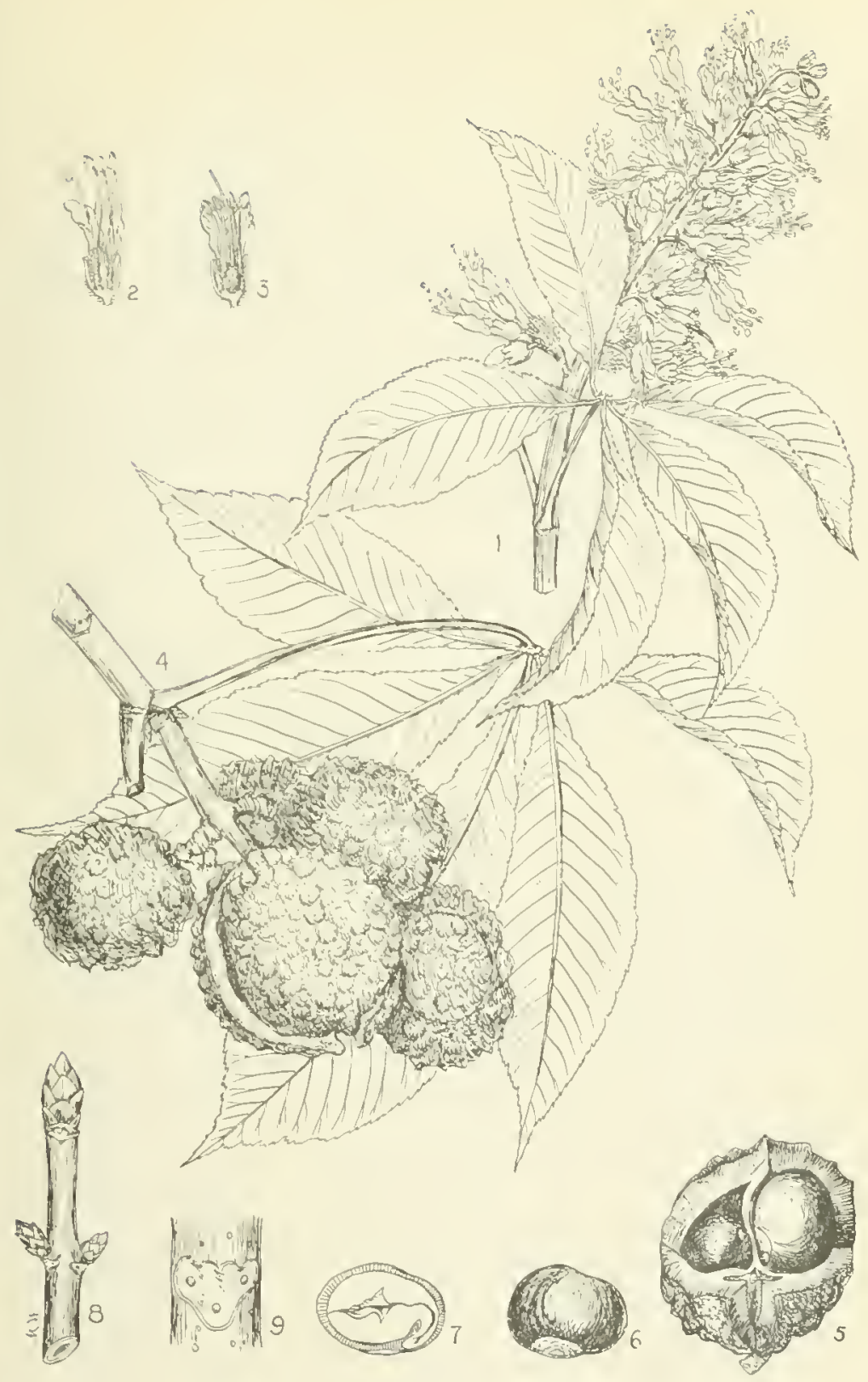

PLATE CXII, FETID BUCKEYE.

1. A flowering brancli, $x$ s

it flower with stimna lielow anthers, natural size.

3. A tlower wath stizmat illove autlurs, natural size.

4. A fruiting lirauch, of

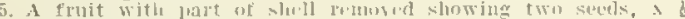

6. A seed. $x$ a

i. Irrmititudinal sertion of a secd, $x z$

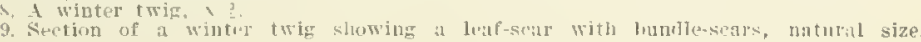




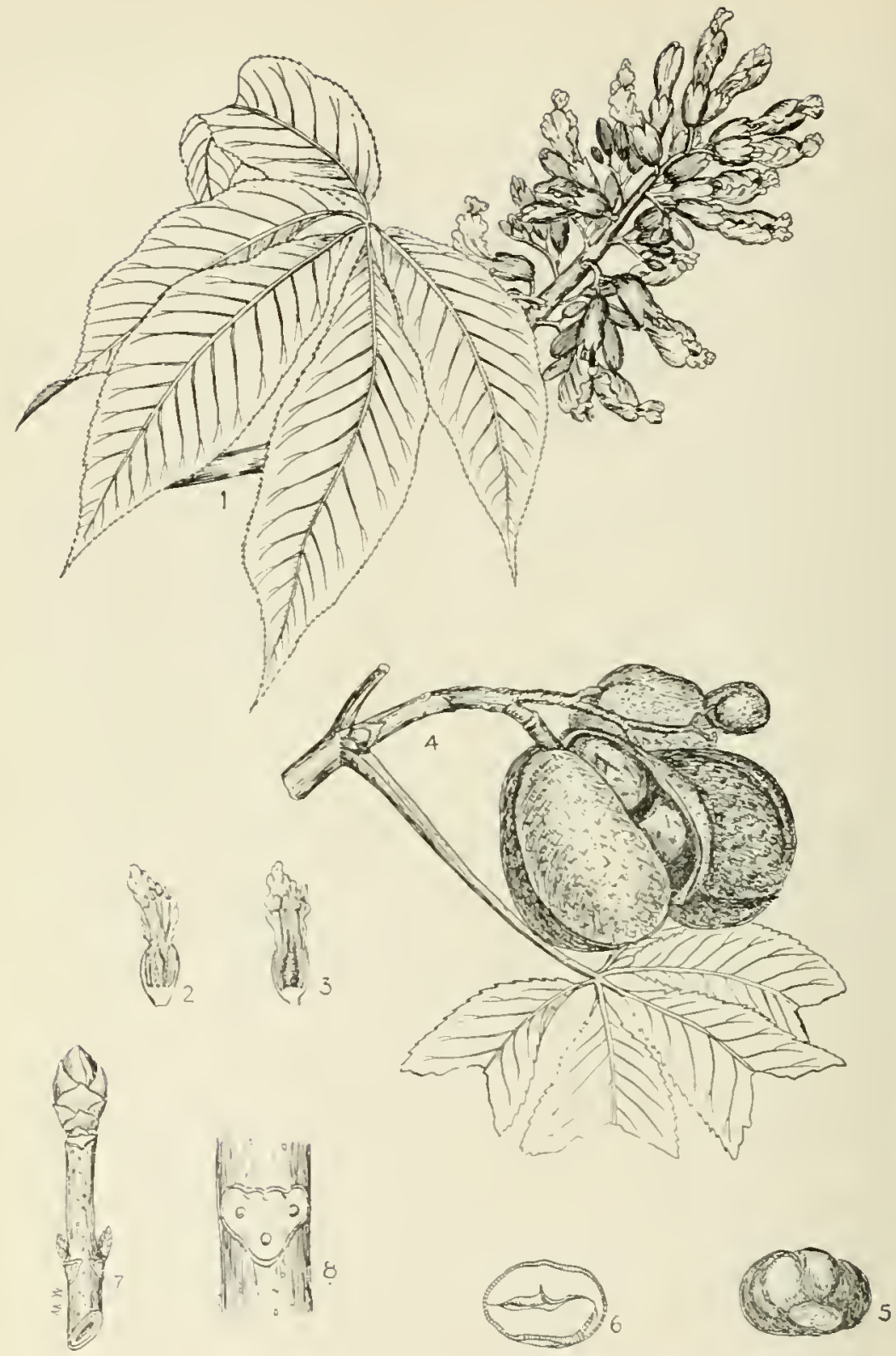

PLATE CXIII. SWEET BUCKEYE.

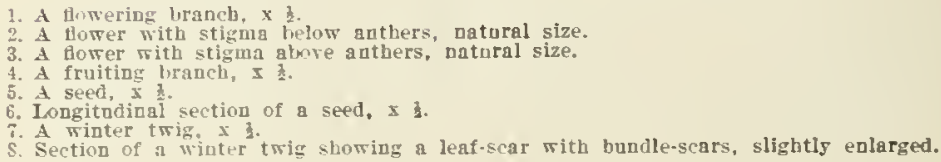




\section{SWEET BUCKEYE.}

\section{Aesculus octandra, Marshall.}

FORM-The largest Americap species of the genus. Csnall a small tree less tban $60 \mathrm{ft}$. In beight with a diameter of 18 laches, but may reach a beight of $110 \mathrm{ft}$. with a diameter of orer 3 feet. At 1 ts aptimum in western North Carolina and eastern Tennessee. Reported a mere shrub in western Tevas.

BARK-Light Drown to erayish-brown, cridectly-fissured, brenking up into mant thln Irregular scales. See Fig. 5 .

TWIGS-Stont, at first finely bairy, becomizy smooth, reddish-brown to asby-gray, slightly ill-smelling when bruised. Pitli large, light gicen, circular in outline.

BUDS-Opnosite; terminal bud present and about 4/5.2 incbes lang; non-resinous, somewhat

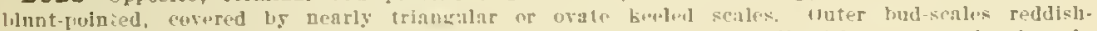
brown, covered with a thin lifuisb bloon; fuzer bud-scales yellowish-green, enlarging in sirring to 1.2 incbes.

IEAVES-Opiosite, compound, with 5 , sonetines $\bar{i}$ short-stalked or stalkless leaflets. Leaflets oral to abovate, t-10 Inches long, finely toothed on margin, long-pointed at aper, narrowed

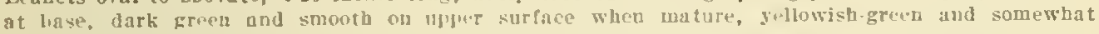
bairy on under surface.

IEAF-SCARS-0pposite, lare, heart-sluped io inversely-tunugular. Bunde-sears large, in more than $3 \mathrm{~s}$, usually $3-9$, often arranged in 3 aroups.

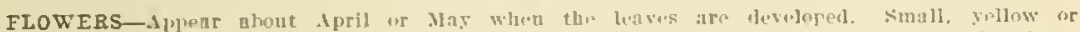
purplisb, with 4 conniving petnls; borne in fluely hairs terminal panicles about 4 -12 inches long. Stamens are included in gellow corolla.

FRUIT-MItures about Oetcher. A smootb choroid cafsulp, about 1-2 inches thick. Seeds aeveral, large, smooth, reldisli brown, lustrous, In inches bread, somewbat flattened. Valves of capsule thiu, pale brown, not splny or warty. The fruit is nolsonous to stock, but seldom proves latal.

WooD-Similar to that of the Fetid Buckeye, page 200, but it is somewhat lighter in welgbt and bas the wood elcments in n tiel-libe arrangement. Used for lumber, reneer, sluck cooperage, paper-pulp, candy boxes, dishes, bowls, aud artificial limbs.

DISTINGUISHING CHARACTERISTICS-The Sweet Buckeys, nlso known as Iellow Buck. eye and Big Buckeye, is natirc only to the extrme western part of the State. The leares are oprosite, digitntely compound witb usually 5 n: sometimes ? lenflets. The flowers are showy, yellowish in color, an 1 arranged in large pavicles borne at the ends of brancbes. The stamens are usually included in the corolla while those of the retid Buckege project beyond it. The ralves of the fro:t cancule are smoah. The twigs are stout, contain a large pith and are rougbened by ln:g': cospricuous huullescars. The buds nre large aud non-resinons, The twigs when bruised fre less ill-smelling tlan those of the Fetid Puekeye. It is the largest American species of the genus.

RANGE- Testern Peunsylranim to Illinois, Iowa, nnd obluhoma, south to Georgia and Texas.

DISTRIBUTION IN PENNSTLVANIA-Found only in the extreme western part of the State. Reported from Allegheny county.

HABITAT-Usually grows in mixtare with hardwoods in rich soll. Prefers rich bottom. lands and rullegs. Common along or near streans.

IMPORTANCE OF THE SPECIES-This tree is of no commerclal iroportance in Pennsylvania. It is very limited in its distribution in the state. The wood whicb it produces and the small size which it attains ic tle northern pa!t of its range do not justify its planting for forestry purposes. It is, bowerer, the largest American representative of the genns. It grows rapidly and mas be planied for ornamental purposes. 


\section{BASSWOOD.}

\section{Tilia americana, Linnaeus.}

FAMIIY AND GENUS DESCRIPTION-The Linden, family, Tilaceae, comprisea about 35 gesera with prohably $3 i 5$ species fond in temperate and troplcal regions. The members consist of trees, shrubs, and a fets herbs. One genas. Tilis, alone has tree representatires in North America. This serus comprises about 20 species, $S$ of which are natlre to North America and 3 to Pennsylrania. Tro species are described here. The third species, known as Vichaux's Basswood (Tilia Michanxii Nitt.) is rerg rare in thls State. Its leaves which are densely pabescent and graslsh.green bezeath and its floral bracts usoally rounded at the base are distinctire. The bark of the branches is asnally smoother and lighter than that of the 2 other astire species.

FORM-A large tree usaally attaining a height of $60.70 \mathrm{ft}$. bat mas reach helght of $120 \mathrm{ft}$. with a diameter of 43 fect. Trunk straight, clezs, with littie taper. Crows dense, broad, rather deen, oroid or rounded.

BARK-On old trunks firm but easily rut, thick, longltudinally-10rtowed lnto flat scaly ridges. Ridges often dirlded by transverse seccadary forrows. On soung stems dark gras and smooth. See Fig. 79.

TWIGS-Smooth or rery finely hairy, shinirg, bright red; second year olfre, olire-red, or coverf with a gras skin: usuallr zigzag, inogh, macilaginons if chewed, corered with scattered, dark, oblong lecticels. In cross-section, characteristie blunt confeal masseg wlth interrening lighter colored areas are present.

BUDS-Alternate: temisal bud absmt: oroid, 2ranked, stout, often sompwat flattened, dirergent, usually deep red, occastonally zreedish, muclaglnous, swooth or sometimes slightly hairy towards apes: Bud-senles glabrous, thlek, rounded st back, asoally 3 rislble; ooe large scale makes bud unsmmetrical.

LEAVES-Alternate, simple, orate to orblcular, f-7 laches long, firm in texture, longpointed at apes, deeply tocthed on margin with sharp tmeth, anegually heart-shaped to truncate st base, dark green and shining on upper surface, freen and smooth on lower except for a few rusty halrs, Leaf-stalks slender, t langth of blade. The aide of the leaf nearest the branch is the largest.

IEAF.SCABS-Alternate, large, conspicuons, ralsed, 2-ranked, containing few to mans bundle-scars artauged in a ring or a single curved llne, or scattered. Stipnle-scars distlnct, one usrrow, the wher hroad: often show bunde-sers.

FLowers-Aprear about June. Perfect, regalar, 8weet, fragrant, Jellow!sh.white, 5.20 in droofing crmose clusters. The long pedancle which bears the flowers is united for abont half its length with a consficturs green brect.

FRUIT-A woody, spherital, not-like drume about the size of a pea. Occars singly or lo small elusters with a common stalk attached to a leafy bract and often persisting far into winter.

WOOD-Diffuse-porous; rays distinct, but colorlcss; light, soft, compact, moderately strong. light brown to nearls white, tine in texture; little difference between spring wood and sammer wood. Weighs 25.20 lbs. jer cnbic foot. Lsed in the manofactare of paper-palp, woodenware, cheap furniture, panels for carriages, legs, palls, barrel headings, berry bozes.

DISTINGUISHING CHARACTERISTICS-The Bassmood, also known as Linden. Lime-tree, Whitewood, Beetree, Whistle.wood, and L5na, may be distingussbed br its large, frm unequally bused leaves with green and smooth lower surfaces, by its smooth bright red twigs, br its alternate. demp red. Lngynmetrical buds with 23 risitle scalfs, by its white flower: arranged in drooping clusters attached to a freen bract, and by Its woods spherlcal nut.like drupe about the size of a pea attacbed to winged hrscts. The dark funnel-shaped areas in the inner bark glternating with lighter areas as spen in a cross-section of a twig are cbaracteristic. The emooth dark gras bark of younger stema and the thick longitudinally-fortowed bark on older tranks are distinguishlog features.

RANGE-New Brunswick to Manitoba, southward to Georgia and eastern Texas.

DISTBIBUTION IN PENNSYLVANIA-COmmun in the eastern and sontheastern parto of the state. Rare in the mountainous parts except in rlch rallegs. Iocalls abundant in the mestera part.

HABITAT-Rarely grows in pore stands, bot astally mised with other hardwooda. Prefera rich soils in bottomlands. It can endure consiaerable shade. It saffers little from windfall bot Dccasionally from windbreak ipon exposed situatlons.

IMPORTANCE OF THE SPLCIES-This tree is one of oar important timber trees on accont of the raluable wood and the bark which it produces. Seeds or aeedlings may be planted. If seedlings are used, they should be planted early in spring before growth starts. The tree sproats from stump very freely (Fig. 79). It growa rapldly, prodaces benotlfal sweet smelling flowers, and is rarels attacked by fungl. It is one of our moat attrectire ornamental tree. 

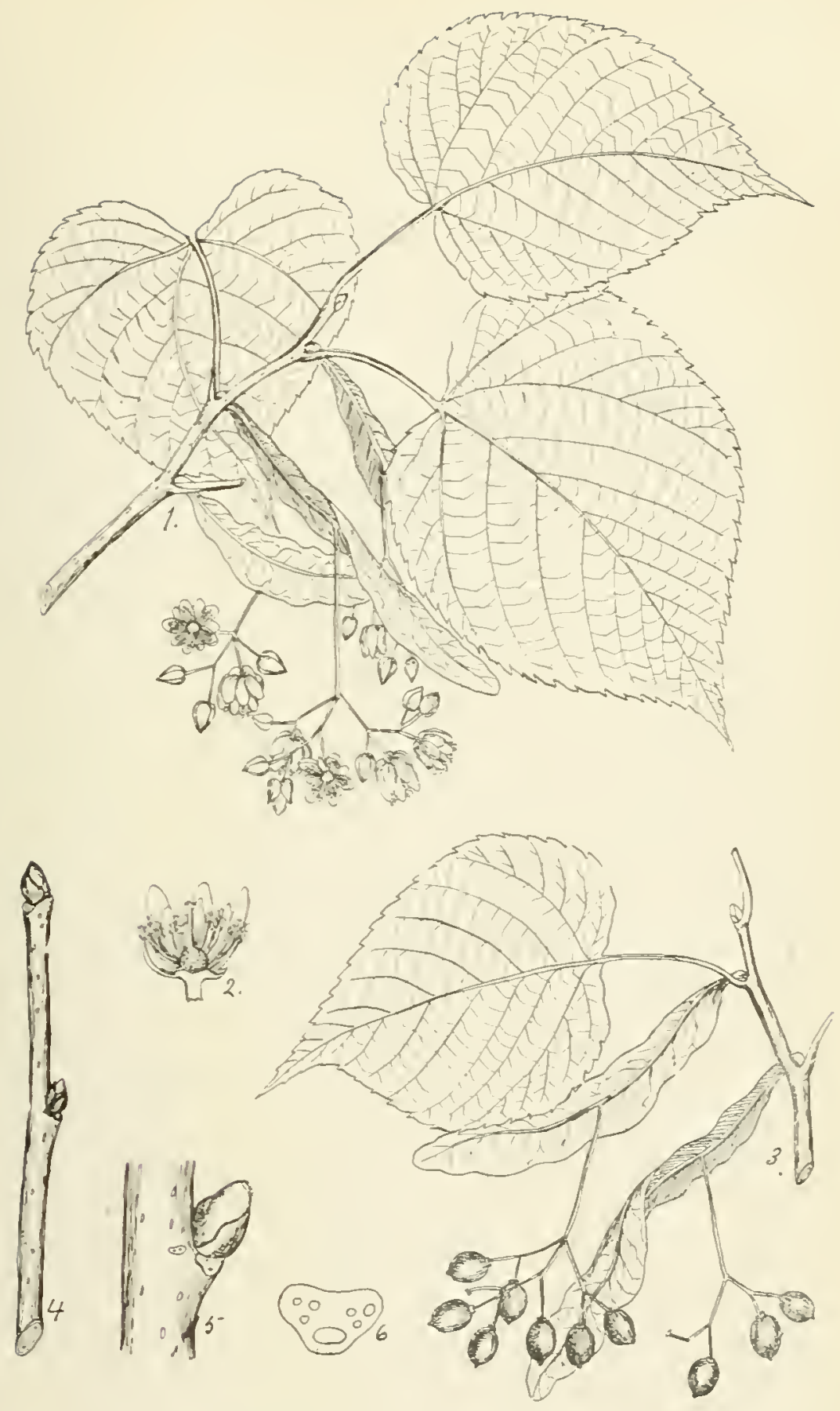

PLATE CXIV. BASSWOOD.

1. A fowering branch with mature leares, $x \frac{1}{2}$.
2. Iongitadinal section of a flower, slightis en-
5. Section of a winter twig. enlarged.

2. Longitudiaal section of a flower, slighty en-
larged.

3. A fruiting branch, I 


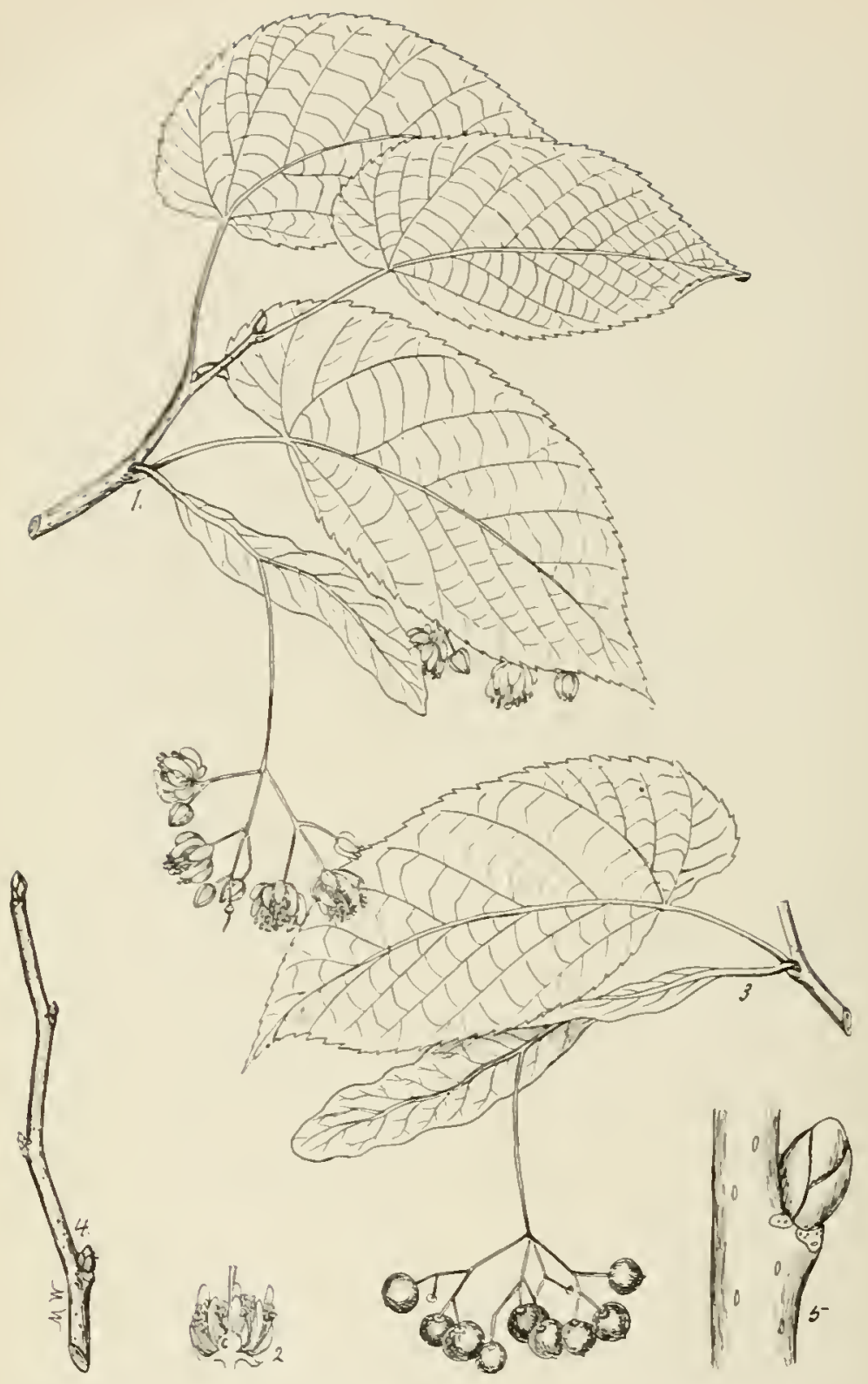

PLATE CXV. WHITE BASSWOOD.

1. A flowering branch with ingture leares, $x$ s.

3. A fruiting branch, $x$.

4. A winter twig a

5 . Section of a winter twig. enlarged. 


\section{WHITE BASSWOOD.}

\section{Tilia heterophylla, V'entenat.}

FORM-Usunlly 50-60 $\mathrm{ft}$. blgls but nias rencls is height of $90 \mathrm{ft}$. with a dlameter of 4 is feet. It becomes as thlck but not so bish as the lBasswood. Trunk straight, clean, stightly tapering. Crowa dease, broud, rather rounded.

BARK-Similar to that of the Basswood, page 202.

TWIGS-Simllar to those of the Rasswood, page 202.

BUDS-SImilar to those of the Rasswood, page 202.

LEAVES-Alteraste, simple, iurfaile in outline, oblong-ovate to orbleular-ovate, 5-8 inehes long, firm in textute, short taper-pointed at apes, deeply toothed on margio with sharp teeth, vaequally heart-shapre to trubcate at base; uper surface dnrk green asd smootb, lower surface sllvery-whlte all fincly bairy. Leaf atalk aleoder, $\frac{1}{2}$ length of blade. The side of the leaf neacest the branch is the largest.

LEAF-SCARS-Similar to those of the linsswood, page 202.

FLowERS-Appear about Juae or July. Perfect, regular, sweet, fragrnat, sellowish-white, 5-15 in drooping eguose clueters. The long preduacle which bears the flowers is uaited for ubout balf its leagth with a conspicuous greeu bract.

FRUIT-A roods, spberical, nut-like drupe nleut the size of a pea. Oeeurs siogly or in small clusters rith a common stall attached to $n$ leafy bract and ofteu persists far into winter.

WOOD-Similar to that of the Busswood, page 202, only about 2 pouads lighter.

DISTINGUISHING CHARACTERISTICS-The White Basswood, also knowo as White Linden, has the general characteristles of the Basswoud, page 20\%. It can be distinguished from the latter in its leaves whlch are slightly larger, sllvery-white and finely hairy on the lower

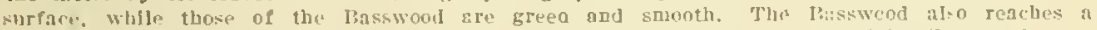
somewhat larger size and has a wher distribution in this state than the White Basswood.

RANGE-New Fork to Florlda, westward to Illinois, Teanessee, nud Alabama.

DISTRIBUTION IN PENNSYLVANIA-Lowally in the northeastero, eastern, and southern I'arts. Sparse in the mountsincus pists. Not laow to occur in the western part.

HABITAT-Lsually found in rich woods in mountajoous regions. Tolerates dense shade. but thrires in full light, a wirs in mixture with othor hardwoods. C'ommon wn limestone souI.

IMPORTANCE OF THE SPECIES-Thls tree is of little commercial importnnce in this State oo account of lis limited distribution. Fartber sooth it is more abuadant. being the prevail. ing lasswood of West Virginia. 11 is une of our most attractive omatmental trees. 


\section{FLOWERING DOGWOOD.}

\section{Cornus florida, Linnaeus.}

FAMILI AND GENUS DESCRIPTION-The Dogwood family, Cornacene, camprises about 15 genera found mostly in temperate regians. Only 2 genera are native to North America, beth of which have representatires in this state. "lheg are the Dogwoods, Cornus, and the Gums, Nyssa. The genus cornus is widely cistributed in temperate regions and comprisea about 40 species of which number 15 are native to North Amerlea and 8 to Pennsylvania. A few species reach tree-size and yield a rery hard and valunble wood.

FORM-A small tree usuallg from $15-35 \mathrm{ft}$. high but may reach a height of 40 feet with a diameter of 1 s inches. 'Trunh with little taper up to the first branches and then practically disappears entirely in the branches. Crown low, broad, high, and rather dense.

BARK-Oa younger stems aLd branches light broms to reddish-gray aud rather smaoth. On older stems reddlsh-brown to black, broken uj into quadrngular scaly blocks. Bark rather bitter and ill-smelling. See Fig. 103.

TWIGS-Csually red, sometimes tiuged with green, smooth, glossy, aften cavered wlth a glaucous bloom; lenticels few and small; pith whlte and gritt.

BUDS-Opposite; terminal bad present. Flewer-buds terminal, spherical, $1 / 5-2 / 5$ of an inch broad, corered by two opposite pairs of bud-scalas, Lateral buds small often covered by persistent bases of leaf-stalks. Terminal lenf-buds reddisl, slightly downy, corered by 2 gaping bud-scales.

LEAVES-0pposite, aimple, clustercd towards end of branches, orate, 3-5 inches long, 2-3 inches wide, gcute at apex, wedge-shaped at hase, entire to wary on uargiu, bricht dark green above, pale below. Mírib aad primary heins promineat.

LEAF-SCARS-Opposite, may or may not encircle stem; bunde-scars 3 and accasionally

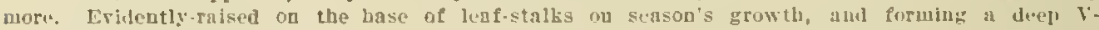
shaped notch between them.

FLowERS-Appear about April. Perfect, grecnish, arranged in dense heads, and surraunded by a large white iaveluere which is often izistiken far tbe carolla.

FRUIT-Ripens about October. A scarlet oroid drune about $3 / 5$ of an inch long. containing a grooved stoue, borae solitary or la clusters of 2.5 on a stalk. Uadereloped plstillate Bowers often persist about base of iruit.

WOOD_Diffuse-porous; medullary rays distiuct; ligbt red or pink in color. Wood rery heary, hard, strong, tough, pale reddish-brawn to pinklsh, with lighter colorcd sapwood. Weighs 50.81 lbs. per cabic foot. Uscd for sbuttles, golf stick heads, brusb blocks, wedges, engraver's blacks, tool bandles, and many kinds of turuery.

DISTINGUISHING CHARACTERISTICS-The Ilowering Dogwod, also known as Borwood, Dog. wood and Flowerlag Corael, can be distiaguisbed by its opposite brauching, bright red or nccasionally greenish twigs, small lateral buds covered by the persistent buses of the leaf-stalks, large spherleal flower-buds, terminal lezf-buds with a slagle pair of bud-scales, and by itg alligator bark. Ia autumn the fruit, and in spring the flowers, also aid in distinguishing it.

RANGE-Massachusetts west through Ontario to Michigan and Missouri and south to Florida and Texas.

DISTRIBUTION IN PENNSYLVANIA-Locally througbaut the state; most common in the eastern and southera parts.

HABITAT-Prefers well draiked sail bat will grow on mos: of our solls. Generally prevaleat but mast ccmmon and thrires best in low, rasist, and rucher fertile situations. Usually fouad in the understory of the forest.

IMPORTANCE OF THE SPECIES-The Fluwering Dogwood is raluable for ornamental pnr. hoses and for its wood. Few trees surpass it in heauty when in lihom and when frujting. In this state it does not reach a sufficieut size to be of commercial importance. It should be maintained ia our forest on acceunt of its bealty and its ralne as a soil improver, since lt is rery tolerant and $w 11 \mathrm{l}$ grow readlly in the understory of the forest. 

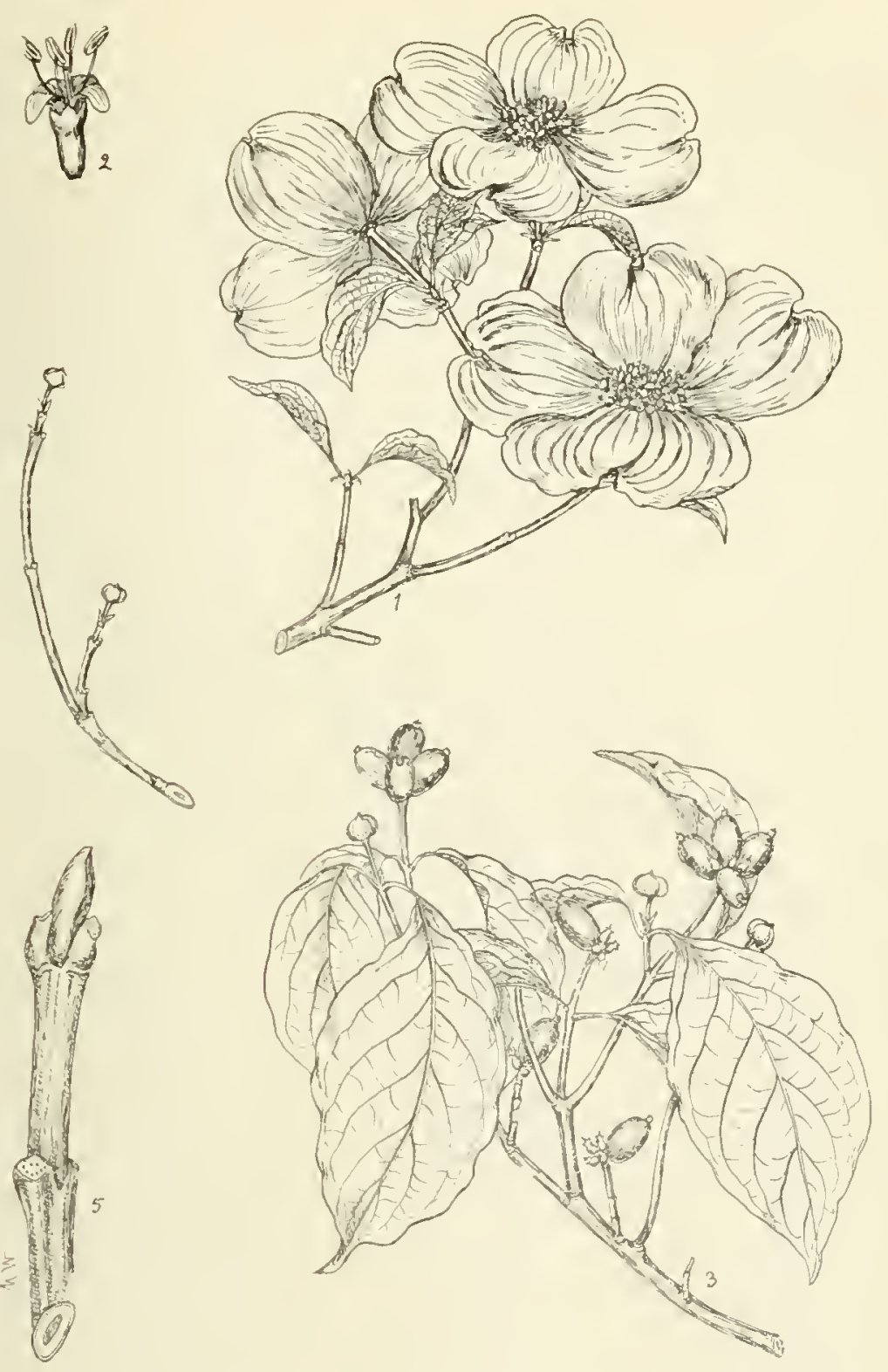

PLATE CXVI. FLOWERING DOGWOOD.

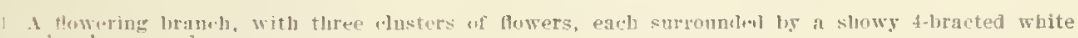
involucte. $x$ is.

A singl. thwer, enlared.

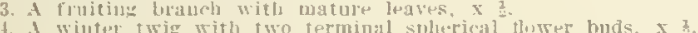

4. A wilfer twig with two terminal splerical thiser huds. $x$ h. 

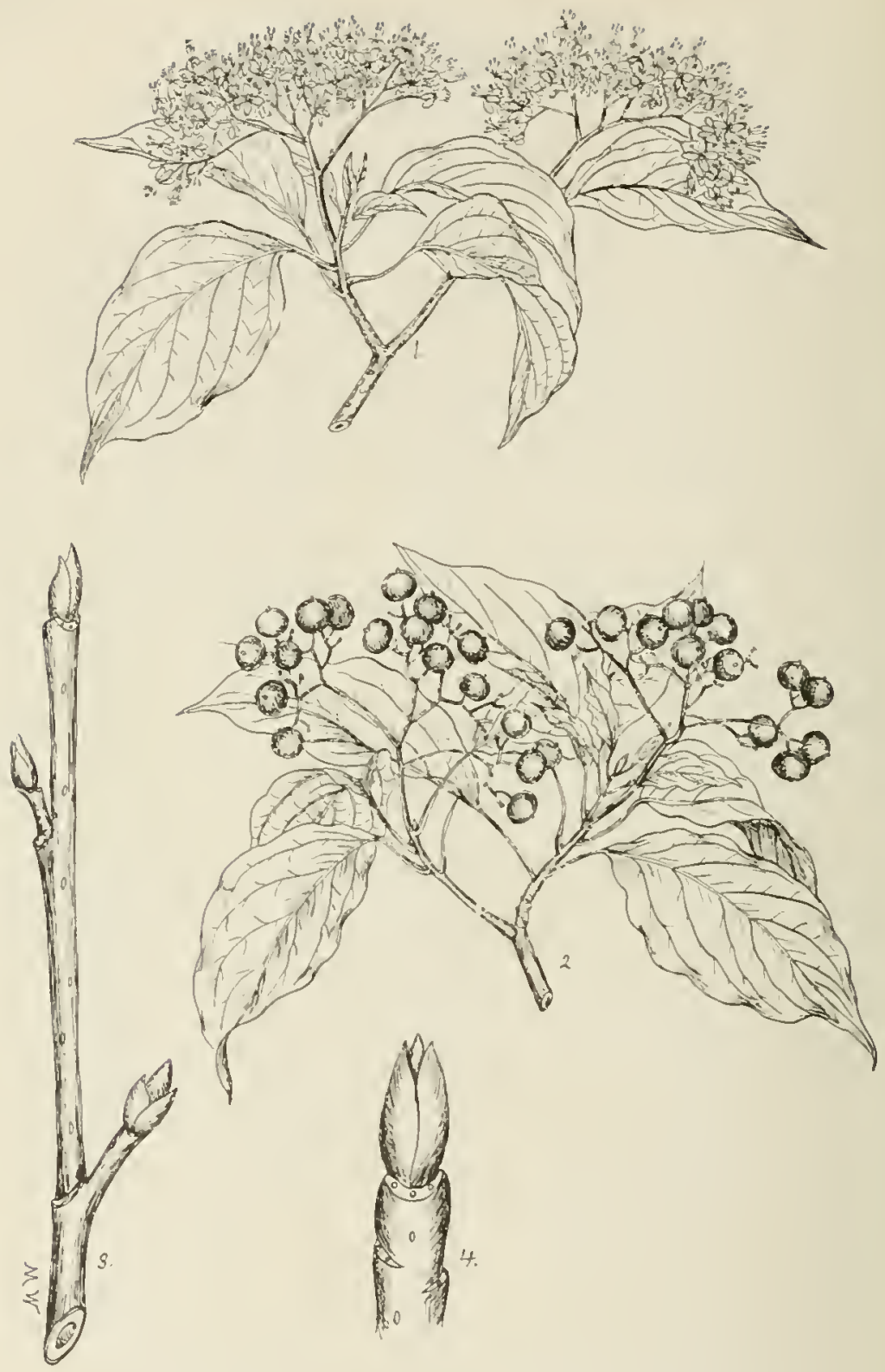

PLATE CXVII. ALTERNATE-LEAVED DOGWOOD.

1. A tlowering branch, $x$ ?

2. A fruiting branch, $x$.

3. A winter twig, natural size. 


\section{ALTERNATE-LEAVED DOGWOOD. Cornus alternifolia, Linnaeus.}

FORM-A small tree usualiy about $10-20 \mathrm{ft}$. high but mny rcach a weight of $30 \mathrm{ft}$. with a diancter of 8 lncbes. Truak is short. Crown hrond, deep, lut-tonped, and dense.

BARK-Rather thin; on younger stems zreenish streabed with white, and smooth; on older stems reddish-brown and rouglacined by shullow longitudinal fissures which are sometimes joineu transrersely.

TWIGS-Alternate, rather sicuder and fexible, smooth, often glossy, at frst reddishgreen, later dark green and of tru striped with white; bitter to the taste and emitting an offensive smell if punctured; marked with lunte leaf-sears und scattered lenticels.

BUDS-Alternate, rarely opposite, oval, sbarp-polnted, corered with a few, usunlly 2-3, cliestnut-brown scales. Outer scales are often separated towards apex.

LEAVES-Alternate, sometimes opnosite, imple, frequently clustered at end of branches, $\mathbf{3}-5$ inches long. $2-3$ inches wide, ovate, neuminate $2 t$ apex, wedge-shaped at base, eatire or wary on margin, bright green abore, usually ulnost wbite dowzy below*

LEAF-SCARs-Alteruate, scusetimes opposite, situnte on exteosions of the twigs, with their surfaces often at right angles to twigs; iu outline resemble the moon in first quarter and containing 3 bondle-scars.

FLOWERS-Appear abont April. Cream-colored, perfect, borne in many-fowered terminal crmes.

FRUIT-A dark blue spberleal drupe, $\$$ of an lech in diameter, tipped with remants of the style, horne in cymes. Ripens in October.

WOOD-Ahout the sume as the dowering dogwcod, but no uses of it are repurted.

DISTINGUISHING CHARACTERISTICS-The Alternate-lenred Dogwood, also known as Blue Dogwood, Purple Dorwoorl, Green Osler, and Pigeon-herr. may be dlstinguished by ity alternate branchlag, reddisb-green to dark greeg twigs, cream-colored fowers and dark blue fruit arranged in cymes. It does not have the alligator burk of the Florering Dogwood and usally frequents moister babitats.

RANGE-Nora Scotia to Alabria, and westrard to Minnesota.

DISTRIBUTION IN PENNSYLVANIA-Throughont the State, Commoo in the portions which are well watered.

HABITAT-Prefers moist well drained soll. Most common along streams and other bodies of water and border of woodlands. Verg tolerznt of slade.

IMPORTANCE OF THE SFECIES-The Alternate-leared Dogwood is of little commercial importance, It is rerg pretty and mas be of vnlae as a soil-conserver and improver. 


\section{BLACK GUM. \\ Nyssa sylvatica, Marshall.}

GENUS DESCRIPTION-The genus Nisssa is rother limited in its distribution being conflned to the eastern [uited States and southern Asia. It comprises 7 species in the world 5 of which are native to Yorth Americo and I to Penasslvanis. Alt the representatires prodoce wood which Is vers tough on account of its twisted and : miltorted grain.

FORM-Csually a medium-sised tree with a Leight of $15-40 \mathrm{ft}$. but may reach a height of $100 \mathrm{ft}$. with a diameter of 5 feet. Truik straight and rather contiuuons. Maoy lateral Lrabches are hormontal: some of the lower are drooping and the apper ascending. Old trees oftel hare a low fiat crown but bave their middle and lower truok corered with smalt horizontal branches.

BARK-Grayish, smooth to scaly on young trunks; reldish-brown to grayish-blsck, rery rough and scaly on older trunks. Forms what is known as alligator bark on rerg old trunks charscterized by quadrangular gad bexagonal blocks. See Fig. 100.

TWIGS-Smooth, with iew lentjcels, grajlab to reddisb-bicwa; pith rather large, whlte, separated by layers of stone culls which onay be seen with raggaifing glass.

BUDS-Alternate, orgte, reluish brown, \& of gu inch long, asually amootb, corered by $3-5$ risible, ovate, closels orerlapwing scules, Jatural buds sometlmes superposed, smaller than terminal one. Buds griginate close to leaf-scar and occosionally protrude into it.

LEAVES-Alterugte, simple, oral, $2-5$ joches long. acute at apex, redge-shaped at base, entlre and slightly thickicnel on margin, dark gretu and shing above, often hairy below, turning to a gorgeops red ill falt.

IEAF-SCARS-Alteruate, conspicuons, rarber large, broadly crescent-shaped, with tbree single or 3 groups of bundle senrs, which are eeuspicuous on accont of size; browalsb in color, contrasting with ligliter surface of the leat-bcar.

FLOWERS-Appear in Ilay or June. Borne on long sleuder somewhit doway stalks. Staminate and pistillate flowers separate. siambate occur in dense many-fowered beads; plstllate in oyen few thowered clusters.

FRUIT-A small, dark blue. Dabhy berry or drupe, orold, 3 of au inch long, $1-3$ in a cluster, often with a few renuants of uoleviloped pistillate lowers at base. Borne on long stalks. IRipens in Octoluci.

WooD-D1fnse-porous; rays indistinct; yrowtli-riogs usualls indistinct; pores pomerous. small. uniform in size and distrbutivin; wool cross-grained, tough to split, difficalt to work, not hard, moderately stroug ant st. $x$, not thraule, light jellow. Weighs 36.91 lbs. per cuble foot. Used for hubs of whets, buxes, irouing loards, rollinis pins, chopping bowls, excelsior. broom bandles, baskets, and berry crates.

DISTINGUISHING CHARACIERISTICS-The Llack Gun, also knowo ns Sour Gum, Tnpelo,

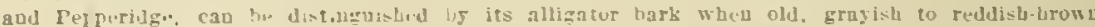
swooth char twigs when roun: whlch are marked with cousludus leat sears with three bundle-scars. The tuds diverge rery moch frou the Iwigs and way the sumerjosed. Lateral branches on ycung tres-s oitun take y horizuntal pusition. The sefaration of the pith 1.5 stone cells, the Ecrgcous red color of the autumal foliage and the blulsb Irerries also aid in recognizing it.

RAYGE-Maine to Tampa Bay, Florida; west to southero Ontario and Michigan, southward to Texas.

DISTRIEUTION IN PENNSYLVANIA-TETy commu in the eastern, central, and sonthern parts, local in western part, rarer in northirn part. Reaches large size in swamps of Adams nad Franklin counties.

HABITAT-Found in rariable babitats. Very common on butatorer areas, on dry mountain slopes, abandoned felds, Bbaudoned charcosl henrths; but reaches its best derelopment along stregms and in low wet situstions. While it lias preferences it is not a chooser of habitats.

IMPORTANCE OF THE SPECIES-The Black Gum las been despised since the early farmers tried to split it for ferce rails. It is slowly galning faror, bnt is not of snthlent importance to be recommended for forest planting. Its autumnal foliage is beantiful and in winter the form of jcung trees is rers attractive. 

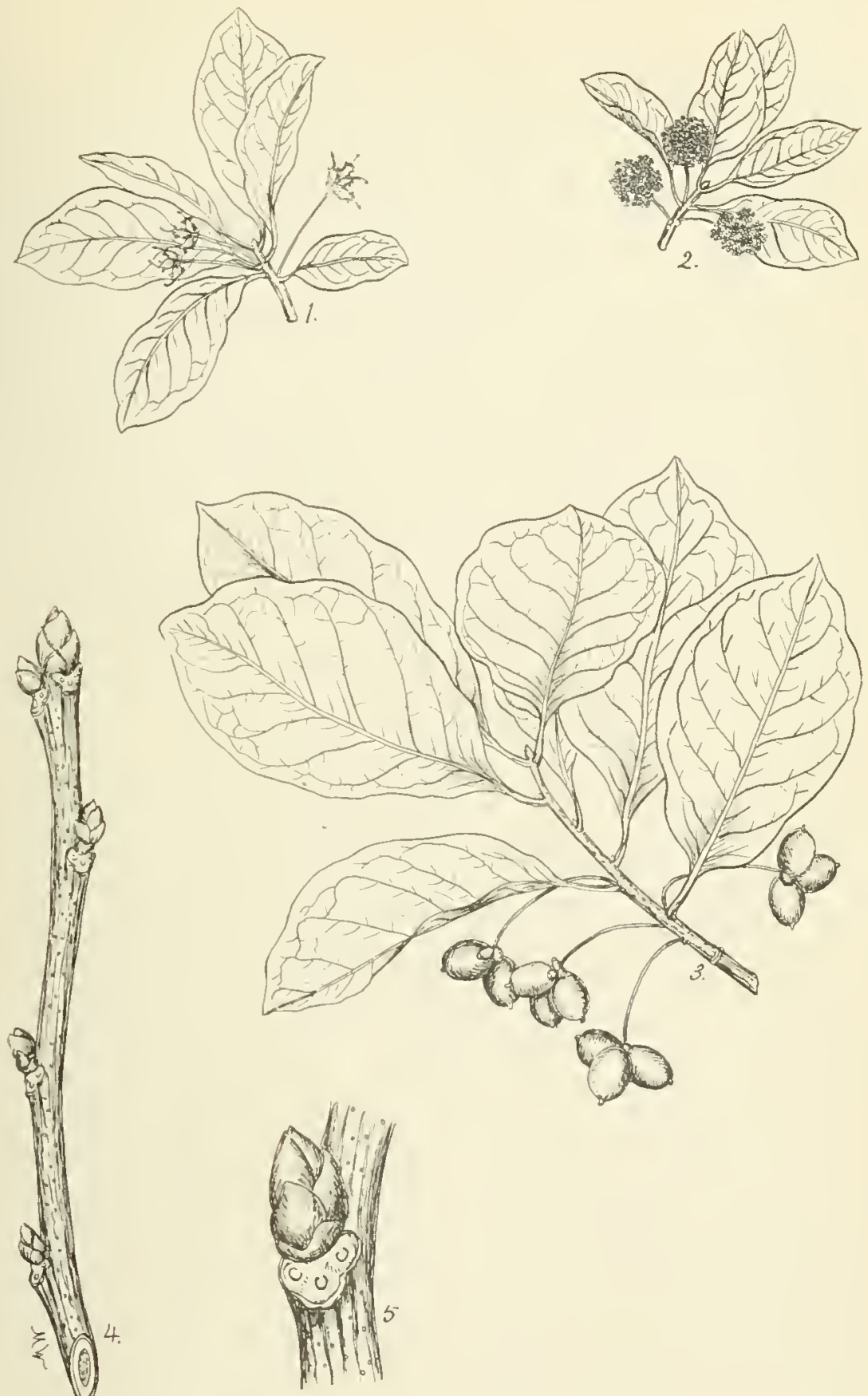

PLATE CXVIII. BLACK GUM.

1. A pistillate flowering branch, $x$ ㅊ.

2. A staminate Howering branch, $x$ z.

3. A fruiting liranch with matur

4. A winter twig, natural size. 

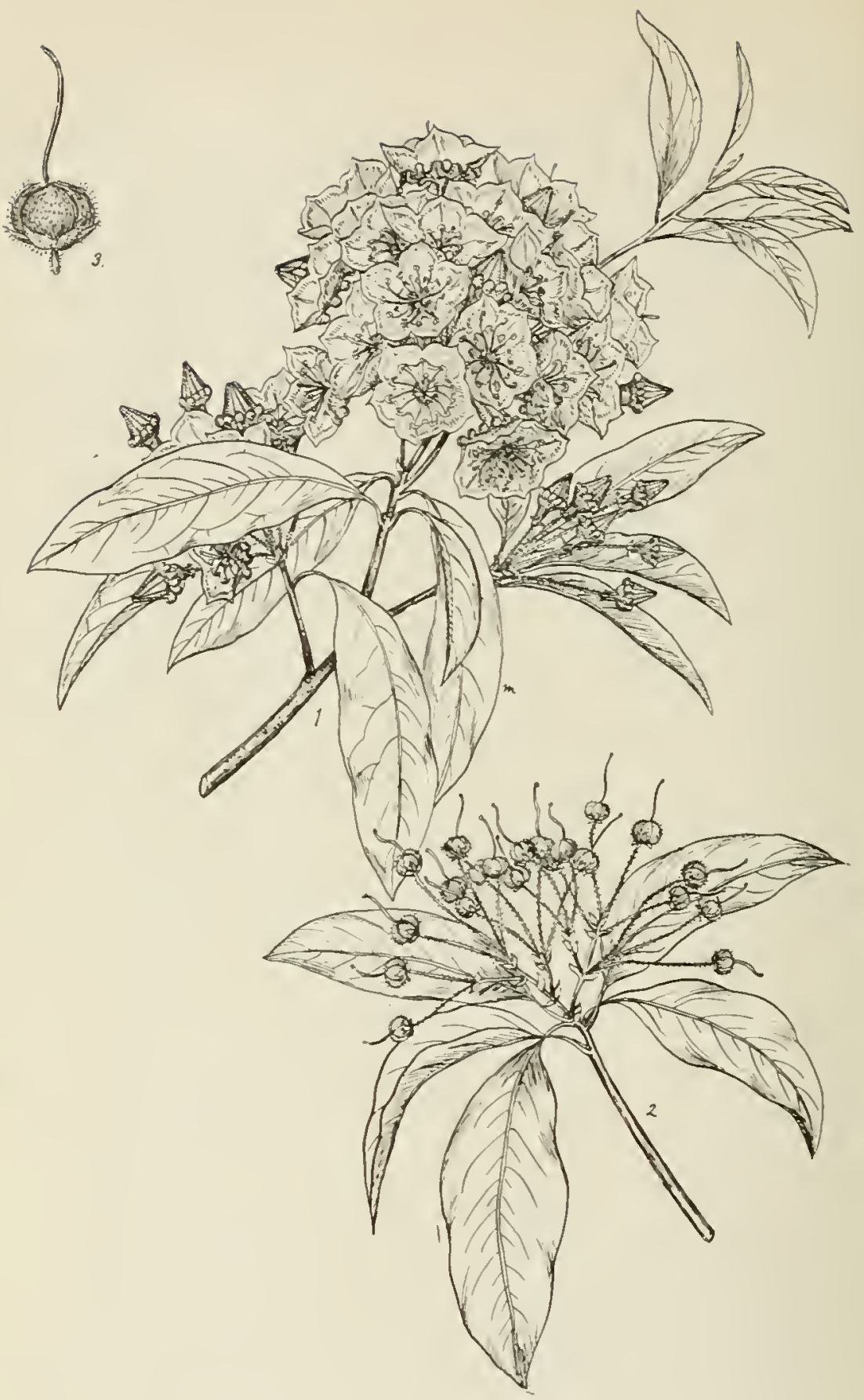

PLATE CXIX. MOUNTAIN LAUREL.

1. Flowering branch with (i) immature leaves, (m) mature leares, and with open and elosed 


\section{MOUNTAIN LAUREL. \\ Kalmia latifolia, Linnaeus.}

FAMRY AND GENUS DESCRIPTION-The II-ath famil5, Erleaceae, embraces species which are awongst our hest knowo and most popnlar shrubs. The Huckle-berries, Blueberries, Cranberries, Azaleas, Kalmlas, and Rhododendrons are some of the commonest representatires. Very few representatires are of any special feonomie value on account of the wood whleh they produce. Some are important on accoun of their aesthetic value, while otbers yield raluable lood or are used to medicine. This famils comprises about 90 gedera with zore thas 1,400 species, of whlch nomber about 40 gipera are found in the United States, 7 of whlch have tree replesentatives. The dora of l'ensylrania comprises 27 gentera with about 45 species. Since most of them are slirubs only 3 species itpreseating 3 gedera are described here. The gesera here described are Kalmia, Khododendron, and oxsdeadrum.

The genus lialmia comprises 5 or 6 specles in North $\mathrm{Am}+\mathrm{rica}$ and Cuba. The species described on this puge is the only one which reabes tree-size. Fwo other strub species, sbeep Lourel (Kalmia angustifolli, L.) ad $\$ w$ imp Laurel (Kalmia polifolia Wang.), are also Dative to this State. The genus is named after Peter Kalm, a Swedish naturalist, who trareled in North America during the middle of the 1sth ceptary.

FORM-ID Pennsylranis usually a strub 5.10 ft. 10 height with a stout stem which is usualis forked, often incliped and bearing ilirerged brancies which form a round compact head. In the Soath it reaches a height of $3010 \mathrm{ft}$. vith a dianeter of 20 idoches.

BARK-Fery this, reddisthrown, furrowed, yeels off into long, Darrow, thin scales exposing clonamon-red loder bark.

TWIGS-At first leddisb-green eovered with siscid bairs, later becoming decidedly green, and finally brown. liather suowh except whete roughened b5 leaf-scass and bud-scale scars.

BUDS-Alterdate, orate, sbarp-polnted, greenish in color. Leaf-buds are formed early and appear below the clustcred fower-huds. Flower-buds are corered by aumeroos, dow and orerlapplog green scales which arc coatred with slandolar bairs and enlarge witb the dereloping shoot in spring.

LEAVES-Alternate, sometimes paired, simple, obloug, wedge-saged at base, edtiremargined, acute at apex sometlmeg tipped with bristle point, 3-4 Inebes long, about 1 of an ineh wide. Mature leareg are thick, leathery, dark green, glossy above, yellowish-green below, and persibt for two seasons.

LEAF.SCABS-Large, imbedled in twig, wizin a cluster of bundle-scars.

FLOWERS-Euerge from fower buds whieb begin to expaad in early spring and oped about May or Jube. Flowers are horne on red or green scurfy stalks and arranged in dense mapyauwered corymbs which hav a diameter of about 4 ibehes. Calsx is divided into fire parts. Corolla is white to rose-colored and riseid pubescent.

FRUIT-Matures about Seftmber, It is a nany-seeded moods capsule. roundish in outline but slightly fire-lobed and covered with riscid tairs. Both style and caljx persist. Each capsule produces mas seeds.

WOOD-Difuseporous; heary, bard, strong, rather brittle. Heartwood reddish-hromb, sapwood lightיr colored. Wrigis 44.62 lbs. per cubic foot. Whete it grows to a fair size it is an cxcellent wood for fuel. It is also used in wanfacture of tool handles, penholders, buetet handles, turners, and tobacco pipes. About $\$ 5,000$ lbs. of this rood are produced auunally is North Carolida lol pipes.

DISTINGUISHING CHARACTERISTICS-The Jountain Laurel, also kDown as Ealmia ad Calico-Bush, is ode of our few broadleared cpecies whose leaves persist orer Tister. It can be distinguished from all other specles Dative to this State by its thich leathery leares which are $\mathbf{3 4}$ inches long, rerslstcot, decidedly glossy on upper surface and yellowish-green on lower surface. The Great Laurel or Rhododediron is also erergreen but its leares and buds are much larger than those of the Mountaln Laurel. The leaves of the Monatain Laurel are shorter, narower, and sharpes-pointed than those of the Rhododendron.

RANGE-Tew Bruuswick south gederally :long the mountains to Florida, west to Arkansas.

DISTRIBUTION IN PENNSYIVANIA-Thioughot the State. Most commod in the montainoos parts, where it often forms almost jumpenetrable tbickets.

HABITAT-Common along blargins of swamps and as an understory in deciduous fforests. Alsa fond on hillsides and billtops. Vers ronmon on rocks and round hilltops.

IMPORTANCE OF THE SPECIES-The Mourain Laurel remains too small id this State to be of commercial importadee on accoud of the wood which it produces. Next to Rhododediron, it is the most attractive aatire shrub fund in our flora. It is a farotite with lovers of the woods who admire not only its blossons, bet also its leareg add ita babit of growth. 


\section{GREAT LAUREL. \\ Rhododendron maximum, Linnaeus.}

GENUS DESCRIPTION-The natne Ibododeulron is of Greck origin and ments Rose tree. It comprises ahout Inn species of shruls and a few small trees in the unrthern bemisphere. About 10 species are native to Vorth America and 1 to Pennsylvana.

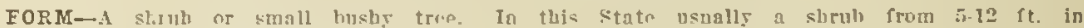
leight, but in the mountnins of the Sonth it mes reach a height of 35 feet. Stems often twisted, bearing contorted branebes which fom no irregular rouad head.

BARK-Thin, reddish-brown, zt first close, later peeling of into thin scales.

TWIGS-At first green and conted with rusty puluesence lut hecome smooth duriug first winter, and gradually turn to brigbt red-brown.

BUDS-Alternate: leaf-buds and fower-bods distinct. l-eal-bads nsually axillary sometimes termial, dark freen, cone-shaped, form in nidsummer. Flower-bnds asually terminal, coneshrje. 1.12 Inches long, corered bj bamerous, orerlapping, greeu bracts.

LEAVES-Alternate, simple, persistent, sustered nt apex of branches, orate to oblong, ncute at apex, rounded to wedge-shaped at base, entire on warglu, 4-11 inches long, 13-2? Inches wide, thick, leathers, smooth and dark greeo on upper surfaee, whitish on lower surfuce.

LEAF.SCARS-Alteruate, sligbtiy raised, coaspicnous, ronnded at hnse, slightly dejressed at tor. with serernl hucdic-scars arrazged in a $\mathrm{L}$-shaped line.

FLOWERS-Ampar Ahout June after the now inges are fully devolnged. are arranged in

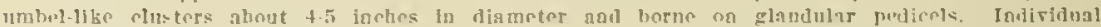
fowers are nerfect, pale rose to white in color; apper putals marked hy sellowish-green dots.

FRUIT-.1 dark reddish-hrown capsule about 3 of an lach loag. which persists antil the following season. Capsules split open ingabwive lihernting oblnog fattened seeds. Surronnded at the hase by nersistent calyx and terminated hy persistent linear style.

WOOD-nifuse-porous: bard, strong, brittle, light brown witl lighter sapwood, Weighs 3..2 las. jer cubic feot. of little commercial use but occasionally manufaetured into tool handles and engraviar blocks. Exrellent for fuel where it reaches a fair size.

DISTINGUISHING CHARACTERISTICS-The frent Taurnl. also known as Ithodolendron and Rose Bay, can be distinguished from all other species of trees butive to Penasylranin by its

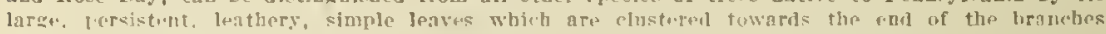
and alternate ir their arrangenmet. Its suruliby form and its proforine for maist habitats alsa aid in distinguishing lt. The coolcal fowertuds, which are nsually terminnl and often over a inch loug, are also cbaracteristic. 'The twigs are eridentls marked by the bud-scale scars.

RANGE-Nora Scotia anc. Lake Erie on the Dorth, south along the monntains to northern Georgia.

DISTRIBUTION IN PENNSYLVANIA-Foud throughout the State. Fare in the southeastera pnet. Abundant througlout the mountainoas purts.

HABITAT-In the North frevivents a cold swannF situation. In the Sonth it asceads the mountains to 3,000 feet but remains along the banks of streams. Tolerates most soils excent limestone.

IMPORTANCE OF THF. SFECIES-The Rboilodendron does not reach a large enongh size In Peansylranin to produca rood of commercial importance. In the Sonth it often becomes a tree. It is the tuost attractive slurbi in obr flora. and will thrive ln a variety of situations hut prefers moist lorations and fues from soils which contain lime. 


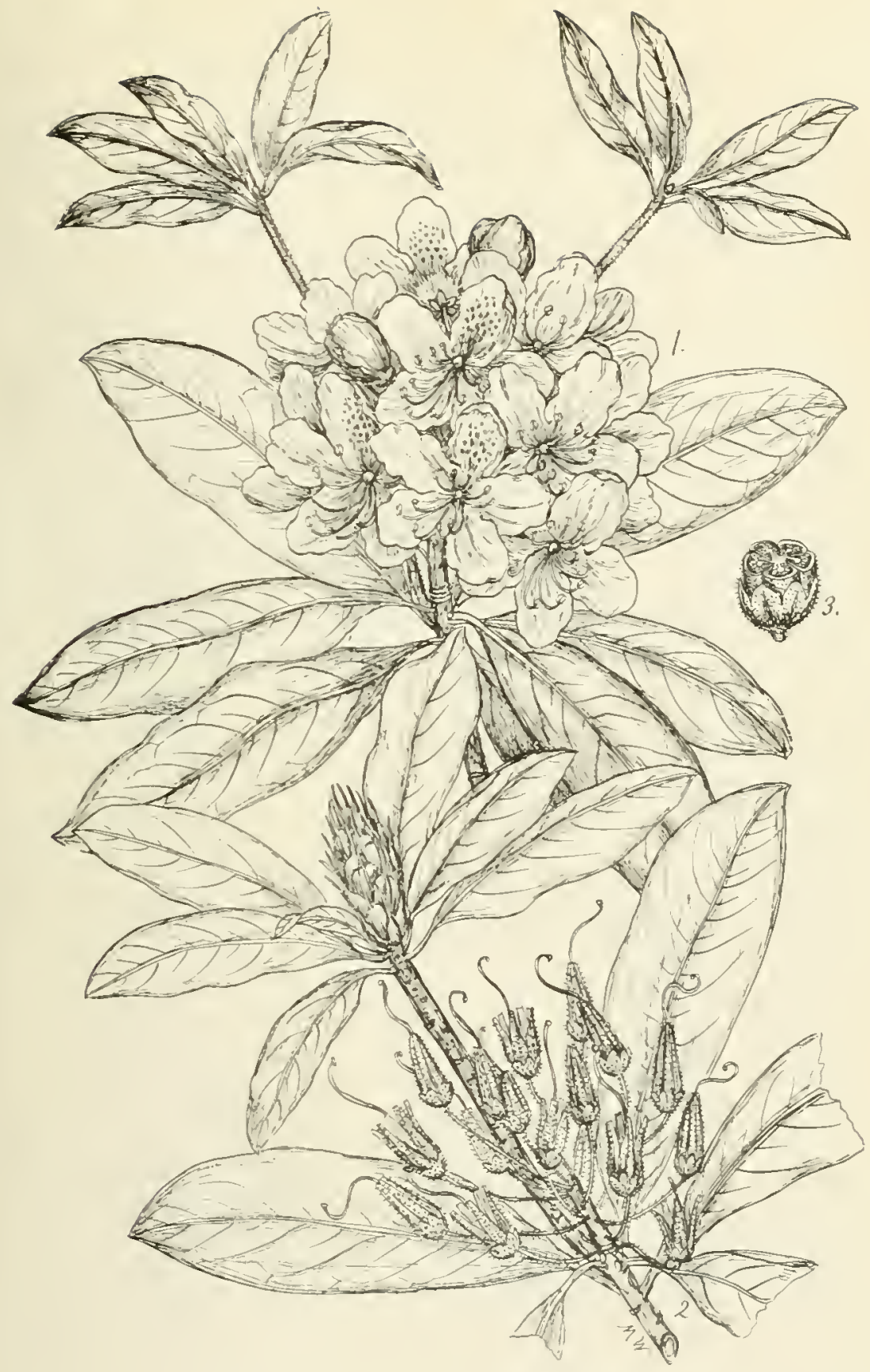

PLATE CXX. GREAT LAUREL.

1. Branch wirh mature and immature leaves, and a cluster of ofin flowers, $\bar{\Sigma} \frac{1}{2}$.

2. A fruiting liranch with a large terminal bud, $x$.
3. Cross-section of a fruit capsule showing fire cells, natural size. 

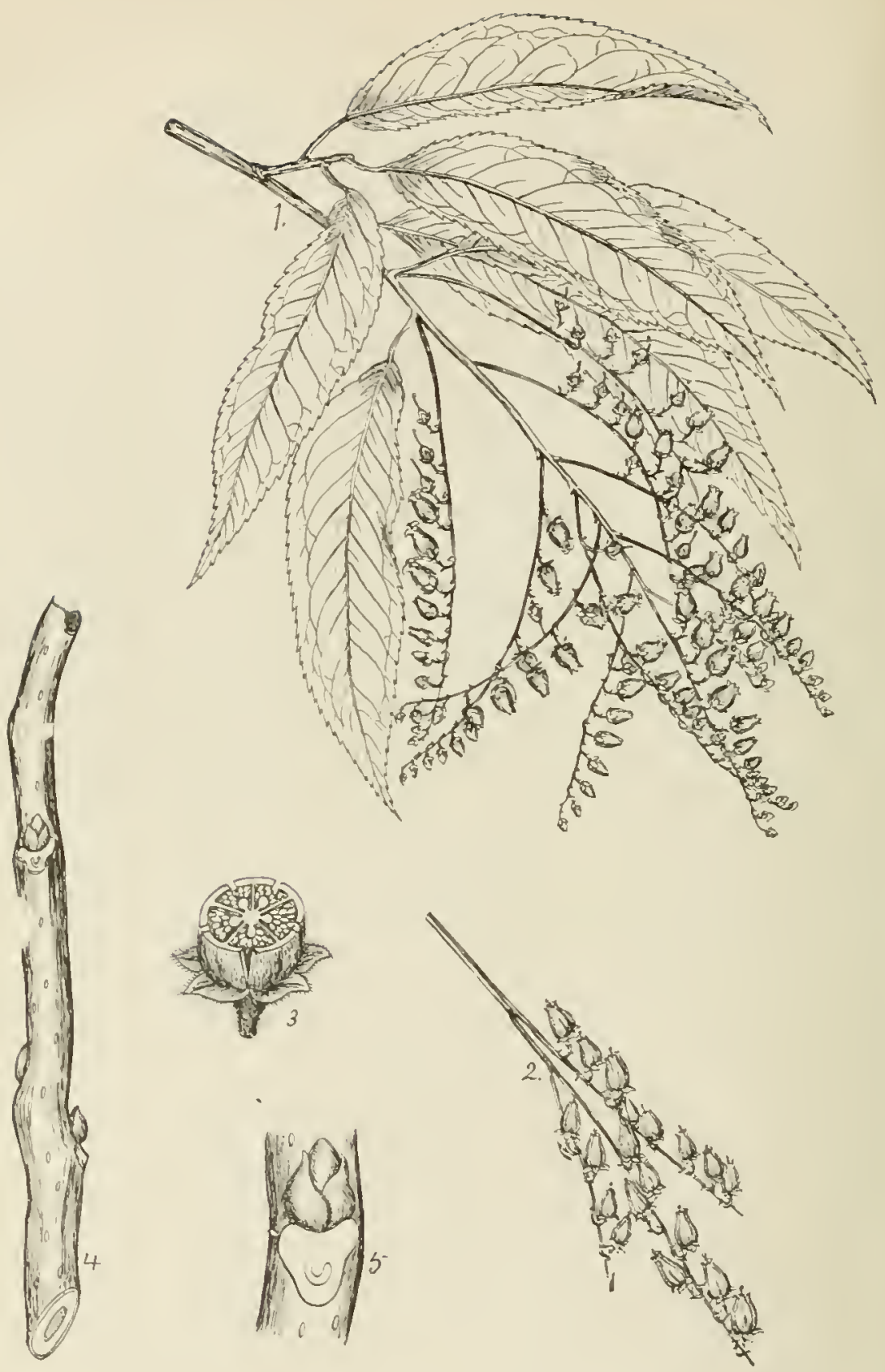

PLATE CXXI. SOUR-WOOD.

1. A fluwering branch with long one-sided racemes of flowers clustered in an open banicle, $\mathbf{x}$. 3. Cross-section of a causule shoming five alls filled with seeds, slightig enlarged. 4. vinter trig enlarged.

5. Secting of a winter trig, enlargerel. 


\section{SOUR-WOOD.}

\section{Oxydendrum arboreum, (Linnaeus) De Candolle.}

GENUS DESCRIPTION-The Sont-mod is the Eole representative of the genus oxydendrum.

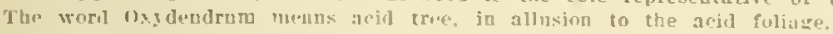

FORM-A medinm-aizca trep which mas reab a heigbt of $50-60 \mathrm{ft}$. with a diameter af 30 inches, but usunily is nbout $\mathrm{i}$ ft. In lielght with a dismeter of $\mathrm{S}$ inches. Trunk usually strajght, tall, slender, and hears a narrow ronod-topped crown.

BARK-lRather thick. rourhered by fissures which separate rouded ridges corered with thick scales, On olu trunha grajish often ringed with red; an young branches redish-browa.

TWIGS-Rather slender, at first sellowish-greeu, luter ozange-colored and redish-brown. Marked with nameruus, cblong, elerated lenticels.

BUDS-Alternate, axillary; teiminnl buds absat; suall, partly imbedded in the bark, acute at alex, corered with sareral opjosite dark red scales.

LEAVES-Iiternate, slmile, oblong, stalked, acutc at apex, Wedge-shaped nt hase, serrate on nuargin, rery smooth, $5-7$ inches long. $I \frac{1}{2} \cdot 2 \frac{1}{7}$ inches wlde.

LEAF-SCARS-Alternate, elevated, nearly trjagular, with a single compounded bundle-sear.

FLOWERS-inper about July. White, perfect, with cjlindrical corolla, and borne in racemes often $6-\$$ laches loug.

FRUIT-A 5-slded, walred capsale terminated by a persistent style. Mlaturcs in september mly a montls of six werks nfter the flowers. Cunules often persist in clnsters.

WOOD-Difnse-porous; hard, hears, compact, reddish-hrowa with Ighter sapwood. Medulary rass are numerous but nerrow. Weighs $46.4 \mathrm{~S}$ lhs. per cubic foot. Used locally far runners of the Apralachlan tanbark sleds, and for tool handes.

DISTINGUISHING CHARACTERISTICS-The Sour-wood, also known as Sorrel-tree and Sonr Gum. can be distinzuisbed in summer by its white bell-shaped flowers which are arranged in racemos resembling lic $11 y$ at the-ralley. The alternate bitter leares which resemble the peach leat are also characteristic. The bark on older trees resembles that of the Plack Gum. The wlnte: bnds, which alt dark red, alternate, vers small, often partly inbedded by bark, are also characteristic.

RANGE-Penosylraia and Indiana south to Florida and western Lauisian.

DISTRIRUTION IN PENNSYLVANIA-Foud only sparsely in the southeastern part of the State.

HABITAT-Csually trentrents mell-drained soils, Commonly foond on Lillsides, seldom along streams.

IMPORTANCE OF THE SPECIES-The Snup-wood is native only to a rery small portion of southeru Pennstranla. Its small size and limited distribution in this state prerent jt from being recommended far forestry purposes. It is. bowerer, an attractise ornamental tree on account of its form, iate fowering, beautiful and attractise a atumal foliage. 


\section{COMMON PERSIMMON.}

\section{Diospyros virginiana, Linnaeus.}

FAMILY AND GENUS DESCRIPIION-The Ebong fnmils, Ebenaceae, is widely dlstributed iu the tropics, and Jnly a few representatives are found in the temperate regions. It comprises about 6 gellera with mure than 250 species. The most important genus is Diospyros which has 2 representutives in the florg of the Luited states and 1 in Pennsylvania. Thls genus comprises ahout 160 suecies found mostly in the trolics. Members of this genus produce some of the cbong of commence, and raluable foods in Chim and Japan. The species described below is the sole representative of this genus in enstern North America. One other species is found in the southern and western parts of Texas.

FORM-A small tree esually from 25 to $50 \mathrm{ft}$. in height with a diameter of less than 19 inches, but maj rench a beight of 100 it. With a dinmeter of 2 feet. Truak usunlly short and slender. Crown high and brond-topped. It often spreads by roots migrating under the ground, forming dense thickets.

BARK-On old trunks thick, bard, dark gray to dark brown or black, clnnnmon-red at the bottom of the fissures; smparotes into thlek squarish blocks which peel off lnto thin scalea. See Fig. 101.

TWIGS-SIender, bittar, astringent, grayisi to reddish-brown becoming darker in second year, usually pale pubescent, covered with i few scnttered orange-colored lenticels, and contain Inrge pith or pitb chamber.

BUDS-Alternate, broadly orate, closely pressed against twig, t of an loch long, abarppointed, corered by 2 dark brown glossy scales; terminal bud absent.

LEAVES-Alternate, simple, oral, acute at apex, entire on margla, redge-shoped to heartshrped nt base, 4-6 inches long, thick, dark green and shing above, often hairg below. Leafstalks are $2-1$ inch long, and contain 1 flbro-vascular hundle.

LEAF-SCARS-Alteronte, elerated, fattened, contain I prominent bundle-scar which ig trangrersuly-elongated, or sereral becoming confluent.

FLowERS-White, appearing about Maj or June. Staminate and plstilinte flowers occur separate. Staminate arranged in $2-3$. fowered cymes. Pistillnte solitary, and borne on short stalks.

FRUIT-A fuics, spherical, orange-colored, often red-cbeeked berry with rempanta of atyle persisting and seated in enlarged greun calyx. Often rery astringent. Sometimea edible berore frost appents. Contains from 1-8 sceds, usually $4-6$.

Woon-Diffuse-porous: henrs, bard, compact, susceptible to a bigh polish, strong; heartwood is brown to black but usunily forms late; sanwod is wide, jellowish and often atreaked with black. Weighs about 49 Ls, jer cuble foot. Used for shutties, gold heads, blllard eues, mallets, parquet flooring, brusb hacks, reneer.

DISTINGUISHING CHARACTERISTICS-The Persimmon, also knowo as Date-plum and Possum.wood, can be distinguisbed in sumner by its alternate, simple, entire-margined, deep green lesres with onls 1 hbro-rascular bunde in the leaf-stalk and the rough bark which is often broken up into quadrangular blocks and is evidently cinpamon-red at the base of the flssures. In autumn the fruit is characteristic. In winter the rough bark with cinnemon-red color at the bottom of the tissure, the semi-orblcular leaf-scnrs with only 1 bundle-scar, the broadly orate buds with 2 dark brown scales, the reddish-brown sligbtly pubescent twigs with relntirelg large pith or pith carity, and the persistent remants of flowers are distinctire.

RANGE-Connecticut to Florida, westward to lowa aod Texas.

DISTRIBUTION IN PENNSYLVANIA-Common in the erstern and southern parts of the State. Abundant on Gettysburg battlefield. Local in southwestern part of the State. Absent in the higher mountainous parts.

HABITAT-Prefers a light, somewhat sandy well-drained soil. Tolerates rich bottomlnads especially in the South.

IMPORTANCE OF THE SPECIES-The Persimmon is too small in size and too limited in diatribution in this state to he of commercial importance from the point of view of wood production. It is essentinlly a southeru trce. The tree has an attractive form, beautiful clean foliage, and nn exceptionally attractive bark. It rarels exceeds 40 feet in helght with a diameter of 12 inches in this State. 


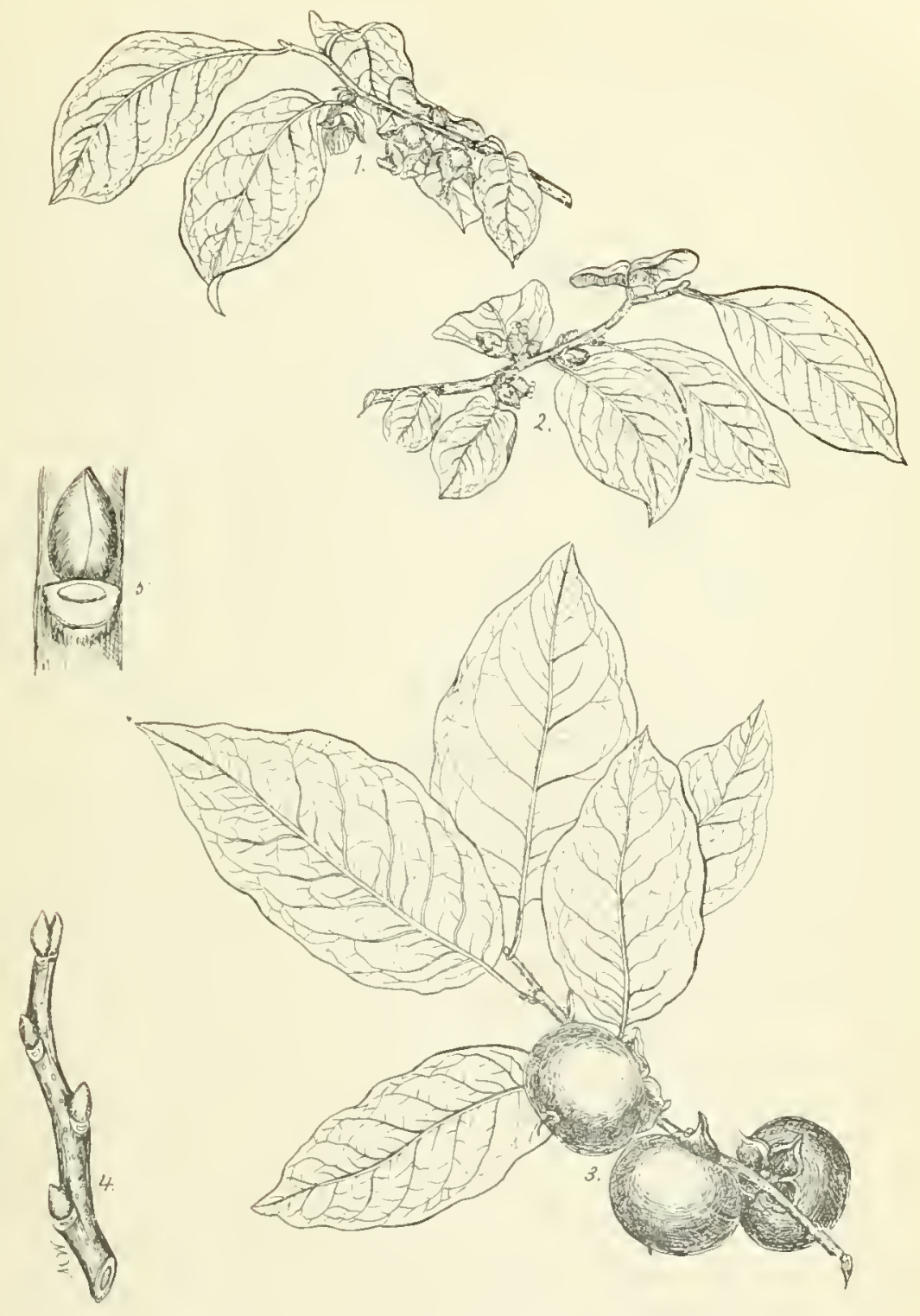

PLATE CXXII. COMMON PERSIMMON.

1. A branch with pistillate flowers, x $\frac{1}{3}$.

2. A branch with staminate flow+rs, $x$ h.

3. A rrutter twiv nataral size.

5. Section of a winter twig, enlarged. 


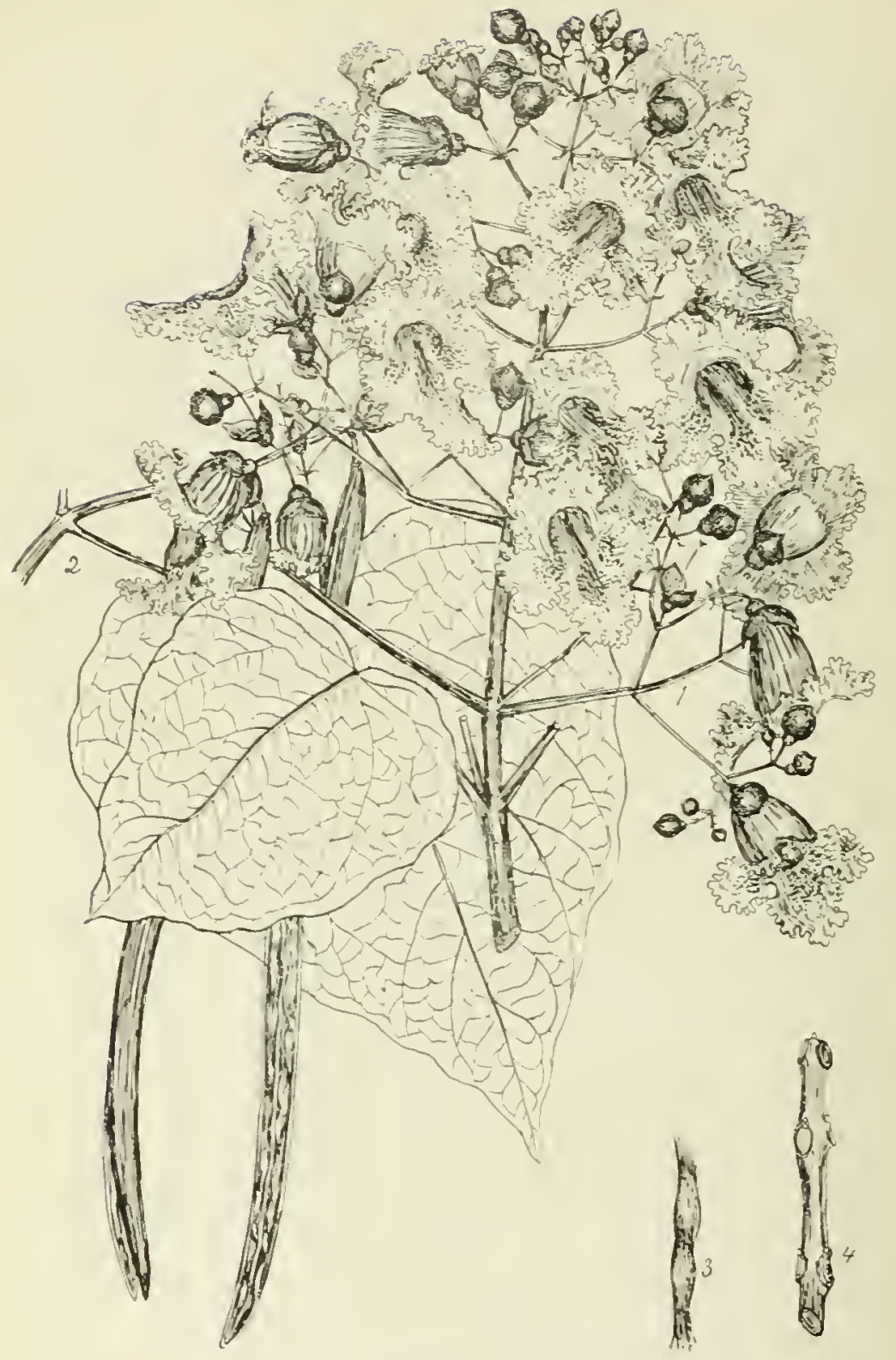

PLATE CXXIII. CATALPA.

1. A prri, le th Humers, 5 t. 3. A winged seed. I 1 . Stre Mate II. 


\section{CATALPA. \\ Catalpa bignonioides, Walter.}

FAMII AND GENUS DESCRIPTION-Tbis tree beloogs to the Bignonia family, Bignonjaceae, which comprises about lvo genera with 1,500 species. Most of the representatives of this family occur in the tropics; only a few are found in the temperate zone. They occur as trees, shrubs, woody climbers, or rarely herbs. North America bas only 6 genera witl 8 species in its fora and Pennsylraia 3 genera with 3 species. The geaus Catalpa is the only one which has tree representatires occuring rather frequently in this State. This genus comprises about 7 species in the world, of which number 2 are aative to North America. No representative of thia geaus is natire to Peansylrania hut 1 species bas beea anturalized so extensirely in every part of the State, that a description of it ia thla publication was considered desirable.

FORM-Usually $25-40 \mathrm{ft}$. high unt may reacls a helght of $60 \mathrm{ft.}$, with a diameter of 3 feet. Truok usually short, crooked, often angular, ad unattractlve. Crown high, broad, and rather symmetrical in appearance in summer, due to the dense folinge.

BARK-Light browa, rather thin, shallowly-ridged, sealy, bitter.

TWIGS-Stout, smooth, or slightly dowos, Jellowish-browu, usually frozen back, corered with numerous large lenticels, roughened by lealscarg. Pith large, white gometimes chambered at the nodes. See Plate II, 2.

BUDS-Terminal bud usually nbsent. Lateral buds small, almost inhedded in bark, usually less than \& of an inch long, corered with $5-6$ visible, small, browa bud-acales.

LEAVES-Opposite or wholled $\mathrm{i}$. e., nore than two at a node, simple, 6-10 fucheg long, 4-5 inches broad, orgte, heart-glaped at base, acute at apex, entire or way on margia. Fall simultaneously after firat heary frost.

LEAF-SCARS-Opposite or 3 at a node, Inrge, conspicuous, wlth projecting margin, elliptical in outline, with consplenous bundle-scars usually arranged in an ellipse.

FLOWERS-Appear io June or July. Perfect, arranged in many-fowered crowded panicles from \$-10 inches long. Corolla is conspicuously spotted on inner surface.

FRUIT-A long, cjlindrical, bean-like capsule which often persistg far into wiuter and contains mang flattened winged seeds. Wings surround seeds and are fringed at eads. Tree ia sometimea called Indian Beac on account of fruit.

WOOD-Ring-porous; distinct demarcation between heartwood and sapwood; odor somewhat like kerosene; light, soft, coarse-grained; durable in contact with soil, light browa, and has a sating surface. Weighs about 26 lbs, per cubic foot. Used mainls for cross-tiea, posta and polea.

DISTINGUISHING CHARACTERISTICS-The Eastern Catalpa, also known as Catalpa, Indian Beav, and Cigas Tree, can be distioguished in summer by its leases whlch are oppasite or whorled and ita large panlcles of fluwers. The cigar-like or bean-like fruit is chalacteristic in nutumb and wiater. In winter it can be distinguisbed by its large elliptical leaf-scars which are opposite or whorled and hare their buadle-scars arraged in an ellipse. The pith is sometimea chamberel at the nodes. The Eastern Catalpa closely resembles the Western Catalpa but has glendeser and thinder walled fruit, larger flower-clusters, more distinct markiugs on inner surface of corolla, aud more blunt-pointed leares. The Western Catalpa la more frost hardy than the Eastern Catalpa.

RANGE-Original range was Jimited to parts of Georgia, Alabama, Misaisappi and Florida. At present found in all parts of the country east of the Rocky Mountaina and as far North as New England.

DISTRIBUTION IN PENNSYIVANIA-Planted for ornamental purposes in mang parts of the State and has escaped cultivation in practically every part of the State. Individual specimeos or small groups of trees are common io the forest aear settlemeata.

HABITAT-Prefers moist and fertile situation, is most common along streams and river banks, but also found in drier plices. Prefers shaded to oped situations.

IMPORTANCE OF THE SPECIES-Two species of Catalpa are commonly recognized, the Eastera Catalpa and the Western or Hardy Catalpa. Both have been widely adrertised. The Western species is hardjer against frost and produces a straighter and cleaner trunk. Neltber of the 2 species should be planted for forestry lurposes in this State. Both apeciea produce beautiful fowera and foliage and attractive irnit. 


\section{THE OLIVE FAILI-OLEACEAE.}

The Olive family comprises representatives which are widely disIributed in temperate and tropical regions, lut are commonest in the northern portion of both hemispheres. A great rariety of trees and shrubs is embracel by this family, some of which are raluable timler trees. while other's are valuable for ornamental purposes or tor the food which they rield. The most important is the Olive Tree (O)lea liuropaea, L.), whose fruit and the oil derired from it are nsed almost mirersally as food. The Olive Tree was cultivated in ancient times in Syria and Palestine; later it was introduced into the Mediterranean region. where one can find large orchards of it at the present time; and within the past few lecades it las been introduced on a large scale into the southwestern part of the United States. A few specimens are ilso growing at the present time near Mont Alto, Pennsylrania. The Ashes which are among our most valuable timber trees, the Forsthias and Lilaes which are among our most attractire and popular shrnls, and the. Privets, which are used so extensively as hedge plants, are also members of this family.

The Olive family comprises about 21 genera with 500 species of trees, shrubs, and a few herbs. The flor: of Yorth America contains 5 genera with about 20 species. while that of Pennsylvania contains 4 genera with 9 species. Only 2 of the 4 genera native to Pennsylrania liare tree representatives.

KEY TO THE GENERA.

1. Lenwes com;ound: Iruit a dry samara: fowers wituout a corolla; winter bnds with

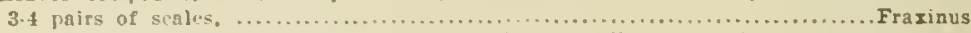

1. Leares simple; fruit a fleshy herrs: flowers with a corolla; winter buds with more than 4 palrs of sealt's.

Page. 213 217

THE ASHES-FRAXINUS, (Tourn.) L.

The Ashes with one or two exceptions are trees, which occupy a variety of situations but prefer rich, moist soil. Some species may also be found occasionally iu swamps or along streams, while others frequent drs ant pool ullands. The trees are usually straight, have little stem taper, and often attain large dimensions. Ther are, locally, rather abundant and yield wood which is straight-grained, strong. and elastic. The wond of all the easteru species except that of the Black 1 sh, is sold as White Asla. This classification is legitimate since there is little difference for practical purposes. They are also valuable as shade trees. Our native species and the introluced Enropean species (Fraxinus excelsior, L.) are planted rather exteusively in parks and lamns. The trunk and leares of Fraxinus ornus. I.. a species of southern Enrope and Asia Mrinor, rield the. manna of commerce.

The Ashes may be regenerated by natural and artificial methods. The natural regeneration mar he accomplished by means of regulated 
cutting of the mature trees accompanied by the establishment of a roung growth from the seed scattered by the seed trees which remain, or by means of coppicing. Coppicing is a practical method of regen. eration especially on rich, moist soils and where very large sizes are not required. The artificial regeneration may be accomplished by sowing seeds, or what is still better, by collecting the seeds, rlanting them in the nursery, and after a rear's growth in the nursers, lifting them and planting them out upon the alea where they are to remain and produce a timber crop.

The leaves of the Islues are opposite and compound. The leaflets oceur in $2 \mathrm{~s}$ oljumite each other along the principal leaf-stalk with a single leaflet at the end, lence the total number of leaflets is always ord. The twigs are stout and occur in pairs opposite each "ther along the main axis. The branchlets are usually flattened at the nodes. The flowers are produced in dense clusters and usually aplear in spring before the leaves have made their appearance. The frnit, known as a samara. matures in fall and occurs in clusters. The individual soed is winged at one md. This wing aids in the dispersal of the seed by the wind, which is the most important dispersing agent; but water mas also scatter a large quantity of the seeds, esprocially of such species which are mmmonest near streams or where flood waters occur.

The Ashes are distributel thronghont the north temperate zone and comprise about 40 known speries, of which number 16 oceur in North America and 4 in T'ennsrlvania. Three specics are common in this State, while anotler speries known as the Biltmore Ish (Fraxinus Biltmoreana, Beadle), is found locally only orer a limited region in the sonthern part of the State. A variety of the Red Asl linown as the Green Ash (Flaxinus pennsylvanica var. lanceolata) is also found locally in the sonthern part of the State.

\section{SUMMER KEY TO THE SPECIES.}

1. Leaves with sessile leaflets: seud surrounded ly wing: bark scaly, not furrowed witb

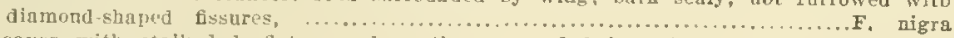

1. Leaves with stallied leatets seed pirtly surrounded by wigg; bark furrowed with

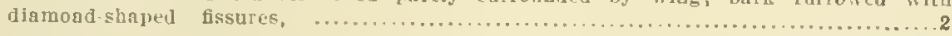

2. Leares and twigs smooth or aearly so; seed usually wiaged only at apex,

2. Leares and twigs relvety pubescent; seed wiaged usually at americana

\section{WINTER KEY TO THE SPECIES.}

1. Buds usually black and acute at apex; bark scaly, not furrowed with diamond-

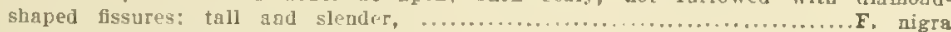

1. l3uds rusts to lark browa, usualls obtuse at apex; bark furrowed with diamoad.

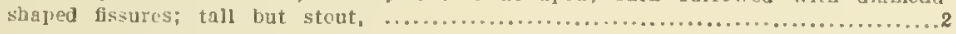

2. 'Fwigs smooth or nearly so; leap-scars evideatly indented on unper margin,

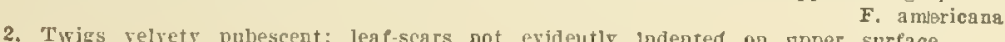

Page. 


\section{WHITE ASH.}

\section{Fraxinus americana, Linnaeus.}

FORM-Usually reaches a height of $70 \mathrm{s0} \mathrm{ft}$. With a diameter of $2-3 \mathrm{ft}$, but may attain a belght of $120 \mathrm{ft}$. with a diameter of $5 \mathrm{f} \mathrm{ft}$. Trunk usually tall, massire, clear from branches for a considerable distance from the ground when grown in the forest, bearing a narrow, somewhat pyramidal crown. When open grown the crown is decidedly round-topped and often extends almost to the ground. In forest grom trees trunk often continuous and dividing into a number of spreading branches.

BARK-Grayish-brown, rather thick unon older trunks, decidedly divided by diamond-shnjed fissures into rather flattened ridges which are covcred by thin, close-fiting senles. Iongltudinal ridges often transversely-fissured so that the primary fissures are connected. See Flg. 86.

TWIGS-Opposite, stout, usunlly smooth, sometimes corered with a slight bloom, decidedly fiattened nt the nodes. Durlng the first whter graylsh-brown in color, and decidedly lustrous; covered by scattered, large, pale lenticels.

BUDS-0pposite, orate, blunt-jolnted, usuelly dark brown, occasionally almost black. Term. inal bud larger than laterais, covered hy 23 jairs of risible scales which occur onposite each other. Scales on the terminal buds mas be somewhit sharp-pointed, whlle those on the lateral buds are usuaily obtuse. Toro lateral buds are usually found at base of terminal bud cnusing a terminal enlargement of twig.

LEAVES-Opposite, compound, about 10 jnches lone with 5-1 lenfets. Leaffets $3-5$ inches long. nbout 13 inches broal, evidently-stalked, slightly serrate on nargin, acute nt apex. wedgc-shnped to rounded at hase. When full grown usunlly smooth nad dark green abore and nale helow. A few halrs are sometimes found along the relns on the lower surface.

LEAF-SCARS-Opnosite, seml-cireulnr in outilne, notched on the upper margin, raised, conspicuous; bundle-scars small, numerous, arrunged in a eurred line.

FLOWERS-Appent about May before the lenves. The stuminate and pistllnte on different trees. Stamingte occur in dense reddish-purple clusters: pistllite in rather open panicles.

FRUIT-A samara horne in dense drooplng pnnicles about 7 inches long. Panicles often persist far into winter. Individunl samarn 1-2 Inches long, consists of a seed bearlog portlon and a winged portlon. Seed frortion round in rross-sertion, terninated by the wlag which aids in the dispersal of the seed. Since some trees bear staminate flowers onl 5 , seeds are never found upon them. Trees bearing pistillate flowers alone iroduce seeds.

WOOD-Ring porous; very heary and strong, odorless add tasteless, tough, clastlc, and brown, witb thick and much lighter colored sapwood. Pores in spring wood large, usually $3 \cdot 10$ row日 wide. Pores in summer wood isolated or in groups of $2-3$, and usually joined by wood paren chyma. Weighs $40.75 \mathrm{lbs}$. per cubic foot. Used in the manulacture of agricultnral implements, wagon buildng, furniture, interior finishing of houses, and for tool handes.

DISTINGUISHING CHARACTER1STICS-The White Asl, nlso known as the Canadian Ash, can be distinguished from the Black Ash by Its leaves, which bare stalked leaficts, whlle the leaflets of the Blnck Ash arc sessile. The buds of the White Ash are usually obtuse and brown in color, while those of the Black Ash are usually Heute and black in color. The bark of the White Ash is usually furrowed aud has diamond-shaped fissures between the ridges, while the bark of the Black Ash is scaly, often corky and not furrowed. It can be distinguished from the Red Ash by its smooth leares and twigs. Those of the Red Ash are usually relrety-pubescent. The leaf-scars of the White Ash nre usually evidently-Indented in the upper margin, while those of the Iied Ash nre not. The seeds of the White AsL bave wings which are tastened only to the npex of the seed, while in the Red Ash they are castened to the apex and often extend down along the sides, nad in the Black Ash the wing usually surronds the seed.

RANGE-Nora Scotia to Mlinnesota and southward to Florida and Texas.

DISTRIBUTION IN PENNSYLVANIA-Generally distributed throughont the State. Common in the eastern, southern, and western parts. Sparse in the mountainoua parts, except in moist ralless and rich bottomlands.

HABITAT-Prefers fertile, moist soils; rery common in rich, moist woods and along streams, lakes, and other bodies of water. Occasionally found on rather drs hillsides.

IMPORTANCE OF THE SPECIES-The White Ash is one of the most important timber trces of Pennsylranin on account of the large size which it attains, its general distrlbution throughout the State, Its rapid growth, as well as its immunity from the attack of fungous diseases and insects. Nature did not produce it in pure stands, bence in developing our future forests we should aim to follow nnture and plant White ish in mixture with some other desirable species. Wbite Ash and White Pine will undoubtedly prove to be a raluable mlsture. 


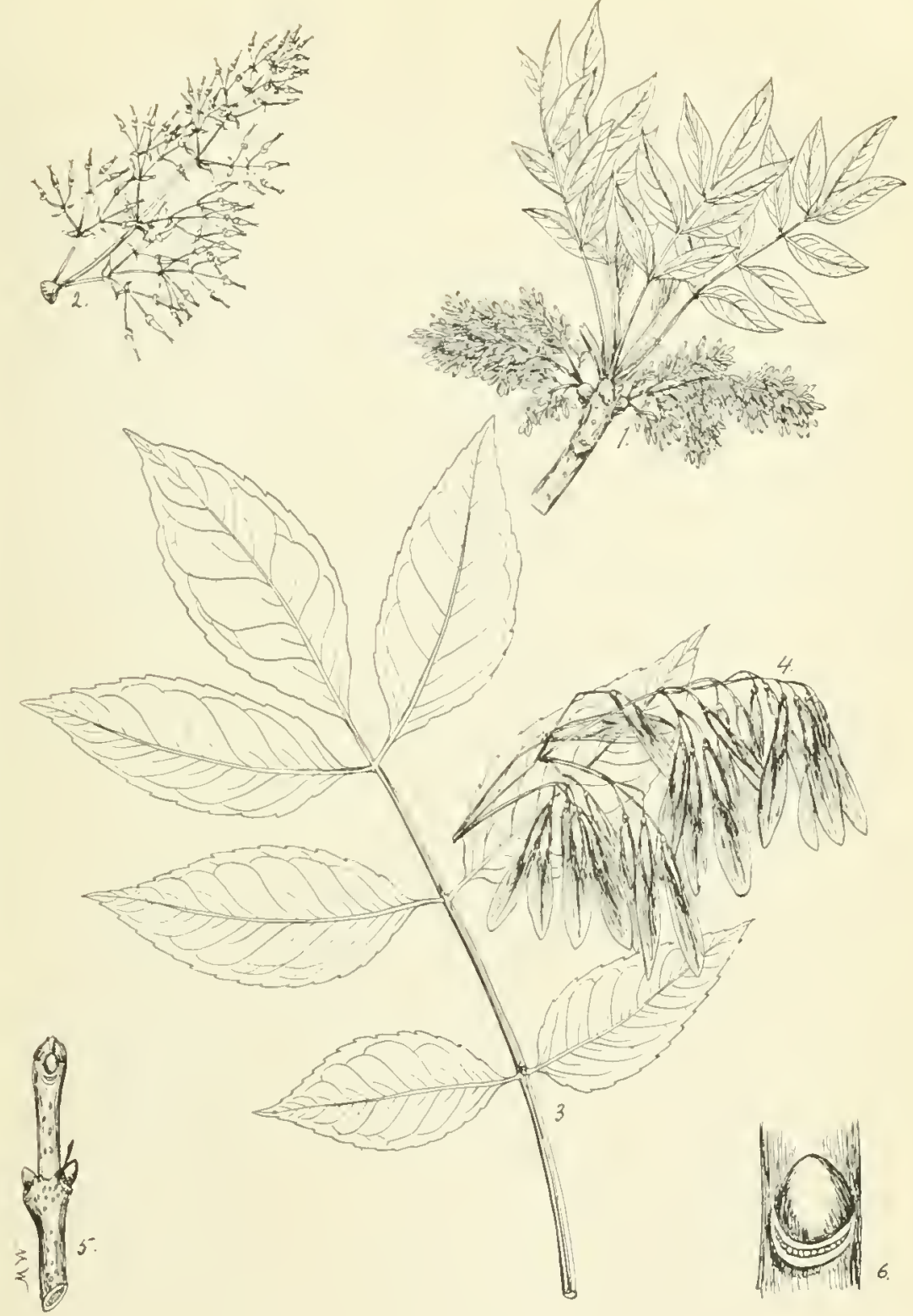

\section{PLATE CXXIV. WHITE ASH.}

1. A brancl witl a cluster of staminate duwers and immature leates, $\Sigma$ 表.

2. A panicle of pistillate flowers, $x$.

3. A mature compuund leaf, $\mathrm{s}$ k.

4. A cluster of fruit, $x$.

5 , A winter twis. $x$ ?

6. Section of a winter twig, enlarged 


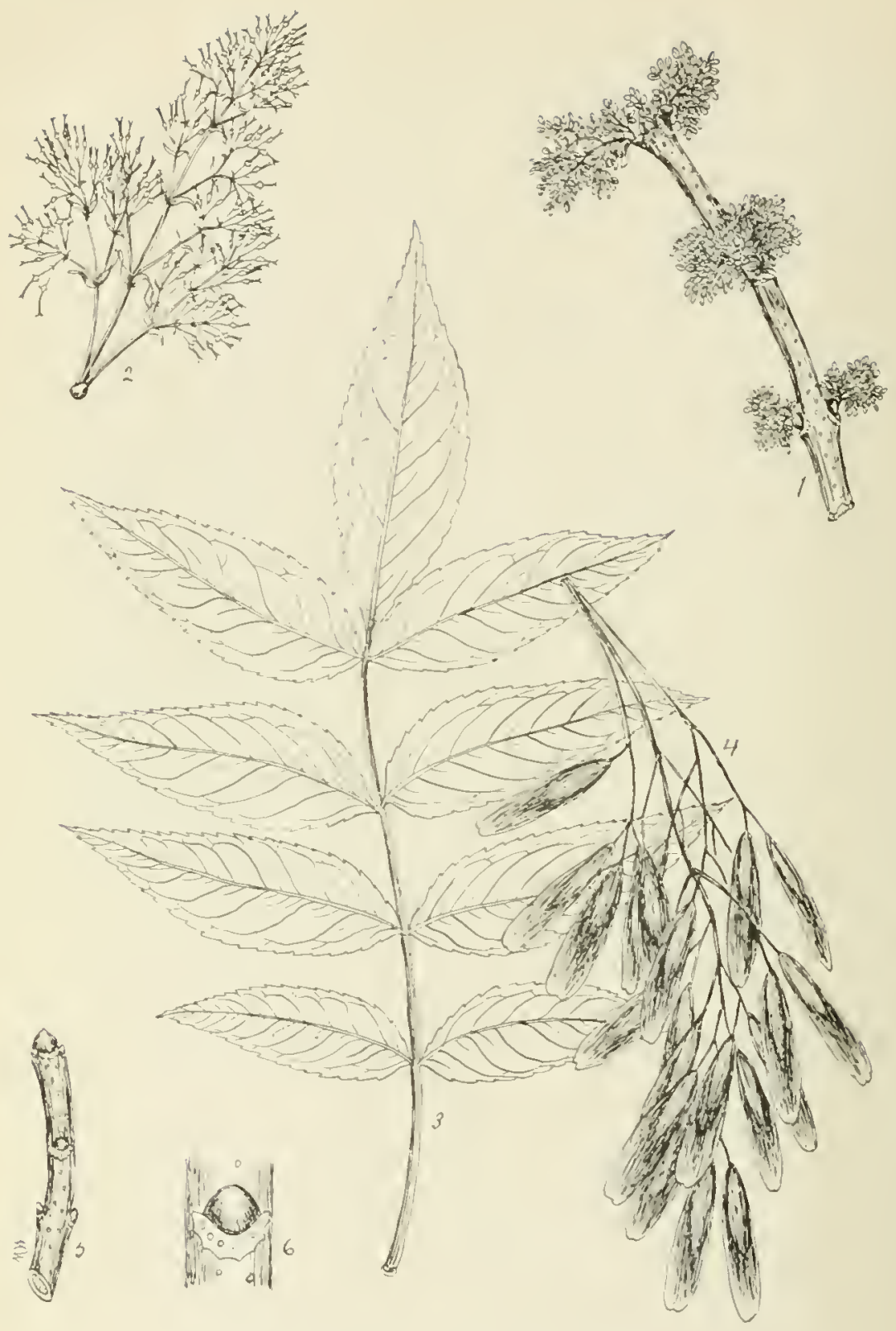

PLATE CXXV. BLACK ASH.

1. Branch with staminate fiowers. \&

2. A maicle of pistillate towers, a

3. A matnre comprounil leaf, $x$ t.

4. A cluster of fruit, $x$.

b. Section of a winter twig. onlar:ot. 


\section{BLACK ASH.}

\section{Fraxinus nigra, Marshall.}

FORM-A medium-sized tree which usually attalns n height of $60.80 \mathrm{ft}$, with a diameter of 1-2 $\mathrm{ft}$, but may reach a beight of $100 \mathrm{ft}$. with a diameter of $\mathbf{2}$ feet. It usually bas a rather tall. slender trunk oftea free from brancheg for a considerable distance from the ground bearing a Darrow and shallow crown formed by numerous rather upright branches. Usually found in the forest, where the slender form prevalls, but accasionally may be found la the open, where its form resembles that of the White Ash.

BARK-Thin, grasisb, shallowly and irregularly fissured; ridges betwee the fissures decidedly scaly and somenhat corky. By rabbiag the bark it breaks up into a very fine powder. See Fig. 57.

TWIGS-Rather stont, at first somewhat bairy, but soon becoming quite smonth. Resemble those of the White Asb but lighter in color, and not so smooth and glossy.

BUDS-Olposite; termiual bul present, orate, sharp-poiated, binck, corered with 1.2 pairs of risible bud-scales, usually at some distance from nearest lateral buds; lateral buds usually almost as brond as long, oftea obtase at apts, closely oppressed to twigs.

IEAVES-Oprosite, compouod, about 14 loches logg, with $i-11$ sessile leaflets. Ierflets are all sessile excent the termial one, 3.5 iacbes loog, abont 13 inches wide, acute at the apex, serrate on the margin, wedge-shaned at the base, dark greea aad smooth abore, palor below.

LEAF.SCARS-Opposite, large, conspicuous, crescent-shaped, upper margin usually straight or coorex; hundle-scars numerous arranged in a curred line, sometimes joined so as to form a compound scar.

FLOWERS-Appear about May before the leares. Staminate and pistillate borne on the same or different trees; the stnminate in dense, dark purplish clusters; the pistillate in rather onen Iranjeles.

FRUIT-A samara which resembles the fruit of the White and Red Ashes, but differs io that the wing is broader, decidedly notched at the apex, and completely surmounds the somutrat flatteoed seed buring portion.

WOOD-Ring porous; beary, smooth, soft, not strong, rather coarse grained, somewhat dur able. Heartwood dark brown with white sapwood; marked difference between snriog and summer wool; annul layers of the wood easily separated. Pores ia snring wood in a broad zone often comprisiag one-half of the ring. Pores in summer wood large, fer, scattered. Weighs 3:).37 $1 \mathrm{bs}$. per cuhic foot. ['sed in the manulacture of baskets, boons, chair bottoms, aad the interfor floishing of boases.

DISTINGUISHING CHARACTERISTICS-The Black Ash, also koowa as lloon, Swamp, Basket, and Browe Ash, call readily be distinguisbed from all the otber species of Ash in Pennsylvauia In summer by its opposite and compound leares with sessile leaflets. The leaflets of all other species of Ashes are evideotly-stalked. In wioter it cao be recogoized by its black and acute huds, its scaly, aoo-6issared bark, aod its tall and slender form. In autumn by its fruit with a flattist body which passes insensibly into the wing.

RANGE-Newfoundlaed to Maditoba, soutb to Virginia and Arkansas.

DISTRIBUTION IN PENNSYLVANIA-Generally distributed orer the State. Common fa the eastern, southero, central and westero parts. Rare jo moutaioous portion except fo moist ralleys.

HABITAT-Prefers swamn habitats, in this respect differing very much from the other species of Asb uative to the State. Flourishes best in the cooler portioas of its rage. Seldom thrires na dry groond.

IMPORTANCE OF THE SPECIES-This species bas probably neter beea groma for forestry mrposes. It mas be so recommeoded $\pi$ bere natural reproduction may be depended upon and io sach locations where other more raluable trees will oot grow. Few better species grow is its chosen bome and consequently it may be one which we will plant in the futare in extremely wet locations together with others such as Spruce, Fir, and Larch. 


\section{RED ASH. \\ Fraxinus pennsylvanica, Marshall.}

FORM-Tree of middle or large size, vsuully attaioiog a height of $30-80 \mathrm{ft}$. with a diameter of $1.3 \mathrm{ft}$. but may reach a height of $70 \mathrm{ft}$. with $n$ diameter of 5 feet: Truok similar to that of White Ash. lvt smaller and beaflog numerous upright brnoches which form a ratber irregular aod compact crown.

BARK-Grajish-brown, ronghened by namerons fissures splarating promlneot ridges which in time become sealy. Fissures usnally dinmoad-shajed. Ridges ofteo sub-divided by transrerse secoodary fissures.

TWIGS-Simina to those of the White Ash but oot so stout nod corered with a dense relrety pubeseence, or sometimes almost smooth. See "Twigs" under White Ish, page 214.

BUDS-Opposite; termlnal hud nresent; orate, brown, corercd hy brownish scales, 2 pairs of which are usually risible. Scales of the lateral buds usunlig hare an obtuse apex while those of the terminal buds bure a more acute apex. See "IBuds" usder White Ash, page 214.

LEAVES- Oprosite, compound, ahout 11 inches long, with 59 stalked lrabets. I.eaflets from 3-5 Inches long, 1-11 incles wide, arate, acute nt npex, slightly tonthed on mnrgin, wedgeshaped at base. At first coated on the lower surfnce with wibte toolentum, later becoming reliowish-green above, nad decldeâly rilsety-pubescent beneatb.

LEAF-SCARS-Opposite; seni-elrcular in outline. conplewous, slightly notched on the upper margio; bunde-sears numprous, usunlly sonll. nnd arrauged in a carved line. Sometimes a number of budle-scars unite to form a compound huadle-scar.

FLOWERS-Appear about Mas before or with the leaves. Stamiate nnd pistllate are usunlly borde on diferent trecs. Staminate accur in dense pnrplish-red clusters; pistlllate fo opeo greenish-red panicles.

FRUIT-A samara, borne io open janicles which often persist far into winter. The indiridual sumara raries io leugh from 1-2 Inches, nnd consists of a seed benring portion nod a winged portion. Fruit resenbles that of the White $A$ sh, but has the winged nortion attached not oaly to the gres of the secul hut also along the sides, whlle the White Ash has the wing attachol nt the anex only.

WOOD-Ring-porous; henys, hard, rather strong, light brown, with rather wide nod light coloren sapwool. Pores in the sprlog and summer wood are similar to those of the White Ask, lut the lines of pores in the sminmer wand are loager than in the White Ash. Felghs 44.35 lbs, per cubie foot. [und for the same parposes us the White Ash, hat is somewhit luferior to it from a commercial noint of rlew.

DISTINGUISHING CHARACTERISTICS-The lied Ash enn be distligulibed at nngr sprson of the Jear from the nther snecies of Ash nntive to Penusylvanla by Its relvety-pubescent twigs and retloles. In addition it cuu be distingulshed from the White Asb by its fruit, the wings of which are attached to the npex nad the sidns of the speds. while those of the WhIte Ash are at. tached at the afex noly. The leatlets of the linl ish are decidedly stalked while those of the Black Ash are sessile. The buis of the Thed ish are browo jo color a d asirally obtuse, while those of the Rlyck Ash are black in color and usually acnte. The bark of the Red Ash is prominently-dssured while that of the mack Ash is not flssured but decidedy scris and presents somewhat of a corks anjearance.

RANGE-Yermont West to Minoesota and soutunra to Floridn aod Texas.

DISTRIBUTION IN PENNSYIVANIA-Found in the eastern and southero parts of the state. Not koowa to occur in other parts.

HABITAT-Prefers rich soil la valless; also found lo swamplowlands and along the marglos of streams, lakes, nod poods; oeczstoonlly found unoo rather drs hillsides.

IMPORTANCE OF THE SPECIES-The Red Ash in manj respects resemhles the W"hite Ash, but it is of less economic importance sioce it does jot attrin so large a size ns the White Ash, "its wood is oot quite so ralnable, and it requires a somewbat moister soil. The White Ash will grom in all places where the Red Ash thrires, nod consequently the White Ash should be favored. It is sometimes nlanted for oroameotal parposes but the Thite Ash is geoerally regarded more attractire and $j n s t$ as free from the attacks of insects and fungi. The only Ince where the Red Ash could be recommended for plantiug for forestry purposes would be io such situations where it is too wet for the White Ash to thrire. 


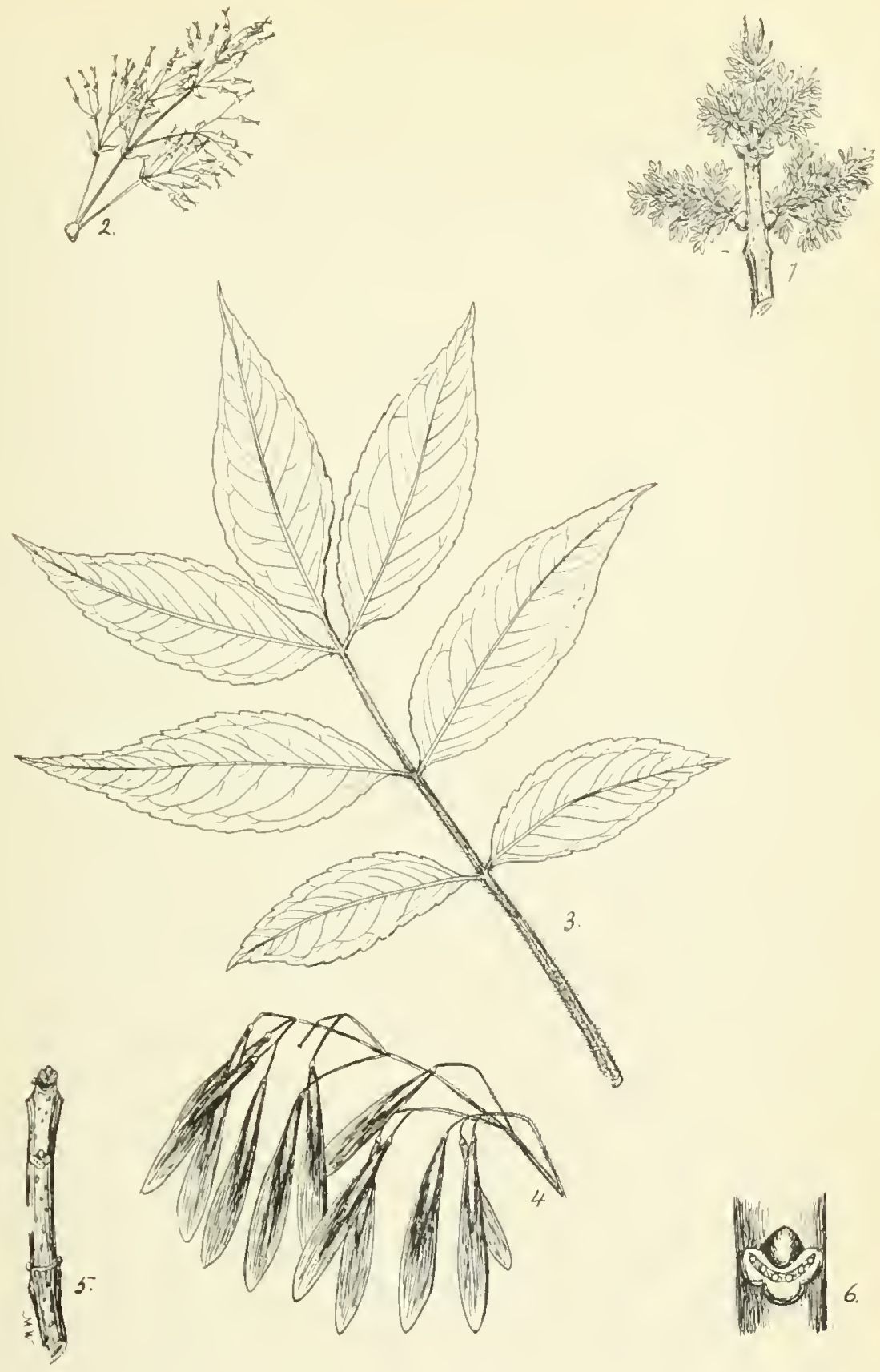

PLATE CXXVI. RED ASH.

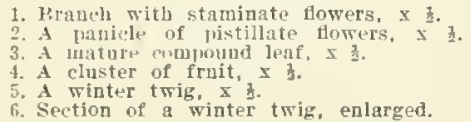




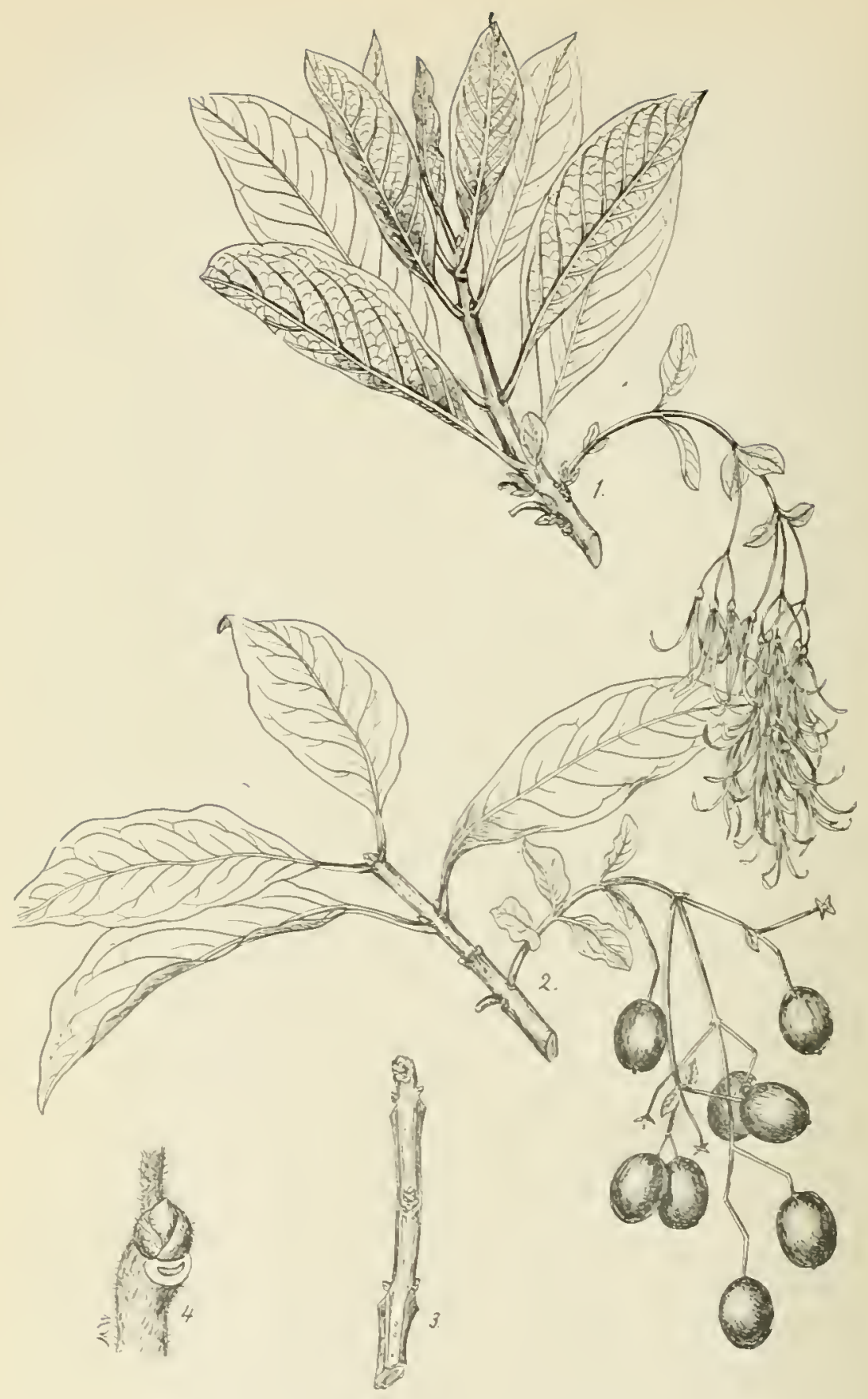

PLATE CXXVII. FRINGE-TREE.

1. A flowering branch with immature leares, $x$

2. A fruiting brancb witb mature loaves, $x$.

3. I winter twig. $x$.

4. Seetion of a winter twig, nutural size. 


\section{FRINGE-TREE.}

\section{Chionanthus virginica, Linnaeus.}

GENUS DESCRIPTION-The genus to which the Fringe-tree belongs has only one otber representatire. Both species are cultivated primsrily for ornamental purposes. The generic name of these trees, Cbiomunthus, refers to the white flowers which resemble snow.

FORM-A sleuder, small-sized tree usually attuiniog a belght of $20 \mathrm{ft}$. with a diameter of $6 \mathrm{~s}$ inches, but may reach a beight of $\$ 0 \mathrm{ft}$. With a dinmeter of 12 inches. Trunk usunily short, bearlog numezous, stout, and ascenling branches which form a ratber deep, unrow crowu

BARK-0. main trunk rather thin, scals, reddsh-brown; on branches light brown to orange, and stoooth.

TWIGS-Rather stuut, light hrown tinged with green, somewhet nngled, slightly bairy. Marked log lerge, couspicuous and eleroted leaf-senrs and dark colored lenticels,

BUDS-Opposite, ovold, sharp-rointed, abont $\frac{1}{8}$ of inch lang, corered with about 5 pairs of scales whlch fincrease fo length frow the outer surface and clliated on the margin.

LEAVES-Simple, opjosite, thickish, ornte, 4.8 inches long, 1.4 incbes $\pi$ lde, wedge-sbaped at buse, entire on margin, ucute at apex, dark green abore, pale and smooth below excent along the reins,

LEAF-SCARS-Opposite, ruised, semi-circular in outliue, upper side of margin rartly surrounds bud; bundle-senrs solltars. large, located on custrions,

FLOWERS-Appear In Mag or June when leaves nre Just dereloping. IRorne in drooping panicles about $f$ in inches long; perfect, wbite, nnd sligbtly iragrant. The appearadce of the snow white flowers resembles fringe, lsence the common name Frlage-tree.

FRUIT-1 berry, lorne in loose clnsters, Dark blue in color, about 1 f of an inch long, and surroulled at the hase hy a jerslstent calyx. Stalks beardag the fruit may bear leallike bracts. Skln of fruit usually thick and stones usually thin.

WOOD-light brown in color, with rather wide and lighter colored supwood; bearg, bard, close-graloed. Weighs ubout 40 lbs. ner cubic foot. It is put to no special commercial uses.

DISTINGUISHING CHARACTERISTICS-Tbe Fringe-tree, also known as old Man's Beard, White Fringe, American Fringe, Flowerlng $\mathbf{A}$ sh, and Snow Flower tree, is sative to only it few counties in the soutbern nart of the State. This jimited distribution, togetber with its small size and its simflr, opposite, entlre-margined and thick leares will enable one to dis. tinguish it quite really during the summer. The white fringe-like panicles of fowers will also ussist during a limited portion of early summer. In winter, the opposite, Iather stout branches bearing sbarp-polnted, opjoslte huds covered with more than 4 pairs of scales, are also characterlstic. The kerry like frult combined with the opposite branching will dlstinguish this tree from practically all otbers foud in the state.

RANGE-Southern New Jersey and southeastern Pennsplvania to Florida and Texas. It fs essentially a southern specles.

DISTRIBUTION IN PENNSYLVANIA-This tree Is found lockliy in about 6 counties in the southeastern part of the State. It is nowbere abundant, nor does it attain any large dimensinns.

HABITAT-Usually found in rlch, moist soil; also frequents banks of streams, lakes and sTamps.

IMPORTANCE OF THE SPECIES-Tbe Frlnge-tree is planted extensirely for ornamcntul purloses ns far north as Massachusetts. Its beantifn] Howers and its attractire form recommend it for planting in lawns and parks. The main abjectionable feature is the fact that it retains its foliage for a relatively short period during the summer, since the leares are late to appear and earls to disapuenr. The noor quality und small size of the wood which it produces, together with its limited distribution and selectire situations, do not recommend it for forestrs jorposes. It can readily be grafted uion our common species of Ashes. This enables one to derelop it uyon situatious somewhat ury for the tree itself. 


\section{SWEET VIBURNUM.}

\section{Viburnum Lentago, Linnaeus.}

FAMII AND GENUS DESCRIPTION-The Honeysuckle family, Caprifoliaceae, is rather widely distributed in temperate regions. It comprises abont 10 genera with $2 \overline{5}$ species of shrubs, trees, vioes, and a few perennial berbs. Abont 8 genera are natire to Jorth Imerica and 7 to Pennsylranis. The 7 genera native to this State comprise about 31 species, most of which are shrubs. The prlncipal native genera are: The Elderherries (Sambrcus), the Tiburnoms (Vihurnnm), the Bnsh Honeysuckles (Dlerrilla), the Honersnckles (Lonicera) and the Snowberries (Symphoricarnos). Since most of the representatives of these genera are shrubs only a few bave been discassed in this prblication. A description of the otherg may be found in Gray's New Mannal of Botany, or Porter's Flora of Pennsylrania. The Elders, belonging to the genus Sambncns, are among our best bnown shrubs. The Common Elderberry (Sambucus canadensis L.) ig probably the best known. The fowers are conspicuons and sometimes nsed in making wine. The fruit is eaten and also made into wine, pies, and jellies. The Honessuckles (Lonicera) nre rery common in our gardens and parks as ornancatai shrubs and rines. Thes comprjse about 100 species of which number at least 10 species are natire to Pensslrania. The Tiburnums (Viburnum) also conjprise about 100 specles of which number about 20 species are natire to North Americg and 11 to Pennstrauia. Alt of our species are usually shrubs, rarely small trees. The two species described on the following pages are occasionally fonnd as small trees.

FORM-A sbrub or small tree usually attainine a helght of 10-15 ft., but mas reach a helght of $30 \mathrm{ft}$. with a diameter of 10 inchess. Trunk usually short, bcaring a round-topped crowa formed by slender asd usually urooping brasches.

BARK-Disagreenble in ocor, reddisb, roughened in older specluens by diriston and subdirlsion into thick plates which are scaly on the sartace.

TWIGS-At first greenish and corered with rasty balrs, later reddish to orange and rather smooth.

BUDS-Opposite, long, slender, scurfy, reddisb-brown, covered by two rather rongh scales. Interal buds are usually leafhuds and closely anpressed to twigs. Terminal buds are often flower buds with a marked swclling at the basc, and about of an inch long.

LEAVES-Opposite, simple, orate, about 23 inches long, sharb-nointed, aarrowed or rounded at base, closely and rery sharply serrate on margin, bright green, smooth on both upper and lower surfaccs. Velns consplenously connected by reinlets. Petioles often winged and groored.

LEAF-SCARS-Oplosite, wide, broadly ${ }^{2}$-shaped, not encircling twigs, and nsually with 3 bondle-scars.

FLOWERS-small, perfect, white, appearing in May or Jnae la dense, many-flowered, sessile, terminal cymes which are wsalls 3-5 inches broad.

ERUIT-A black or dark blue fleshy. swcet. rather jnicy drupe, containiog a fat oral stone, and grouped iato small clusters borne on slender, reddsb, and ofter drooping stalks.

WOOD-Dlffuse-porous; heary, bard, dense, sellowish-brown, with rery disagreeable and per sistent odor. Weighs 45.51 lbs. per cubic foot. Tot important commercially.

DISTINGUISHING CHARACTERISTICS-The Sweet Vibrrmm, also known as Sheepberry, Nannyher, and Wrld Raisin. resembles the Black Haw more closely than any other of onr native Vihnmums. It can be distinguished from the latter by its leaf-blades with acuminate apexes, its loog-nointed bnds, and its winged petioles. The Black Haw has leaf-blades with obtuse or merely acute ajexes, short-pointed huds, and no winged leaf-petioles. The small lateral branches of the Blget Haw are often stiff and stand ont almost at right angles to the main axis. while those of the Sweet Viburaum are flexible and more erect.

RANGE-Quebec to Janitoba, sonth to Georgia, Indiana and Missonrl.

DISTRIBUTION IN PENNSYLVANIA-Common in the eastern, sonthern, and central parts of the State; local in the westera part, and less frequent in the northern part.

HABITAT-Csnally fond along or near banks of streams and borders of lakes located in or near wooded areas.

IMPORTANCE OF THE SPECIES-The Sweet Tibnroum bas no commercial ralne, so far as wood production is concerned. Its form, flowers, fruit, and follage make it one of the most attractive of our small ornamental trees. 


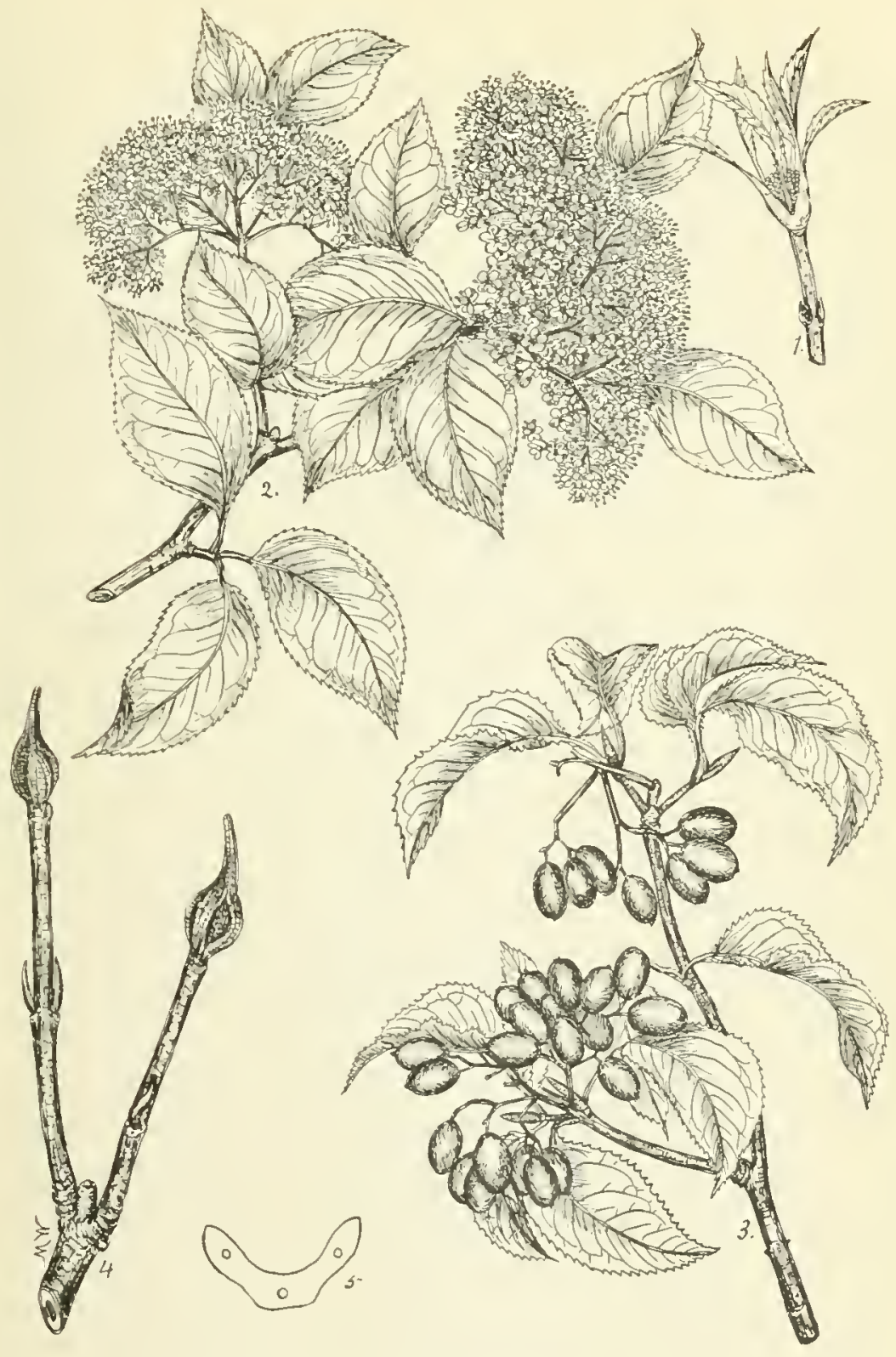

PLATE CXXVIII. SWEET VIBURNUM.

1. A twin showing the opening of a terminal bud, $x$ t.

2. A branthlet with leaves and two crmes of dowets, $x$ z

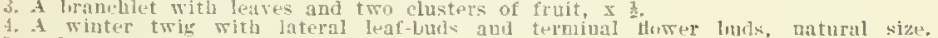

5. A leaf-scar witu three londle-sears, enlarged. 

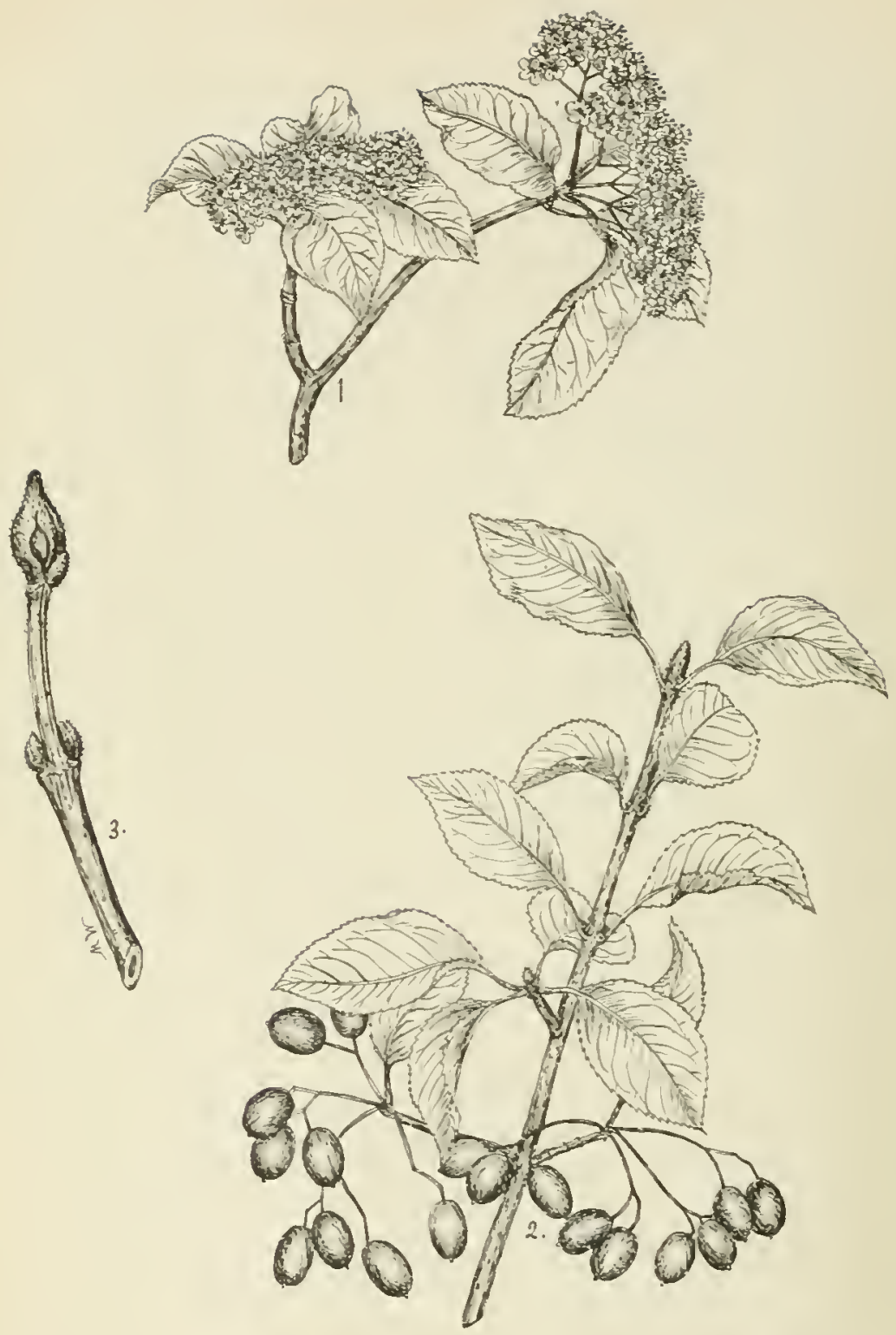

PLATE CXXIX. BLACK HAW.

1. A branchlet with leaves and two crmes of fluwers, $\mathbf{x} x$

2. A trabchlet with leares and two clusters of fruit, 3 is. pusite, and located ahout thr michlly of tho twig. While the third is at the base aud to the riwht of the terminal tower lud, natural size. 


\section{BLACK HAW. \\ Viburnum prunifolium, Linnaeus.}

FORM-A shrub or small tree usually attainiag a bejobt of $1 ; \mathrm{ft}$, but mag reach a beight of $3 \overline{5} \mathrm{ft}$. with a dianeter of 10.12 laches. Trunk short, often clookted berang a ruther broad and round-topped crowa folmed bs stifi lateral brabches.

BARK-About $2 / 5$ of nu lnch thick, reddish-brown, rough, broken lnto thick plate-like senles.

TWIGS-At frst reddish and suoutb, then greed, nul luter, duriag birst wiater, spine-like, gray linged with red, anol often covered with thin tilm-1ke bloou. Lsually marked with orange-colured lenticels.

BUDS-Opnosite, at of nn foch long, corered with 2 rusty pubercent seales which eularge lato lenf-like hodies in spriug when growth begins. Axillary hads के an and long, flattened, closely migressed to twig. lilower buds swgllen near base.

LEAVES-Ojposite, simple, oval, 1-3 inches loog, outuse or slightly pointed at apex, usually wealge-shnped at base, fuely sermte on margin, sonetlunes leatlery when old, dark greed above and frale greea below; jetioles usually rousd, barely wiaged.

IEAF-SCARS-See "Len $\ell$-scars" uader Sweet Tiburaum.

FLowERS-Small, jerfect, whitc, appenring about May in dense, mang-Howered, sessile, aud terraianl ejmes which are 34 trches broad.

FRUIT-Fleshy, dork blue drupe which is rersisteat, sweel and rather Juieg; contajos a flut oral stone; grouped in few.fruited clusters horae on reddish stallis.

WOOD-See "Tood" under Swet Vihuraum.

DISTINGUISFING CHARACTERISTICS-The Plack Haw, also linown as sweet Haw, Sbeenberry, Stag-bush, aud $\mathrm{X}$ miny-lwrry, elosely resembles the Swet Vilurum. See "Distinguishing Conracteristics" under sweet Vilurnum. The Black IIaw and the sweet viburnum may further he distinguisbed from the Minle-leaved Viburaum (Viburnuas aeerifolium) by the palmate vena tion of the leaf-blade and the small gapiag buds of the latter, and from the Arrowwood (Viburnum deatatum) br the cuarsely deatate leaves, the small gaping buds, and the evidently. stalked fiower clusters of the latter.

RANGE-Conjecticut, south to Georgia, and west to Arkausas.

DISTRIBUTION IN PENNSYLVANIA-Common in the cnstern nad southern parts of the State, and local to sparse ia the other parts.

HABITAT-Pueters dr5 rockJ hillsides. Sumetimes found in rather moist lacations. Fre. quent along fences and roalsidis where seeds may have been dropped bj birds. often forms almost impenetrable thickets along feaces, expecially when conpiced.

IMPORTANCE OF THE SPECIES-It is of ao commereinl importance as a woor-producing tree, but for ornamental purnoses deserves to be planted extensively. The bark of the roots is rnluable medicinally. 


\section{GLOSSARY.}

Abortion. Imperfect derelopment or aon-derelopment of a organ.

Abrticc. That which is hrovght forth prematorely: eming to naught before it is completed. Achenc. A small, hard, drs, l-celled. I-seeded fruit which does aot open by valres.

derid. Sharp or biting to the taste.

Acuminote. Decidedly taperiog at the end.

iculc. Tapering at the cod.

Aesthrtic. Pertaining to the beatiful.

Afforcating. Turaing grouni: jato forest after heias without a furest for a coasiderable length of time.

Alluriol. Relating to the dermsits of saad, clas, or grarel made br river action.

Alternatr. Sot opnosite to each otber, hut scattered siogls along tbe axis.

Ament. A peculiar. scals, raisexual spike.

Anther. The ealarged terruinal part of a stamen which hears the pmllen.

Aper. The tip or end of a bud or leaf. i. c. the part oppisite the base.

Apicnl. Pertaining to the tip. ead, or apex.

Appresard. Lriog tisht or cloke agaiast.

Arborsccnt. Tree-like io apnearance, size, and growth.

Aromatic. Frasrant: With a pleasing odor.

Astringent. Coatracting: iraming together: biadiag.

Axil. The upper angle formed hy a lonf or brgach with the stem.

dxillory. Situate in a axil.

Axis. The central libe of an organ: a stom.

Bork. The nuter covering of a truak or hranch.

Bosal. Pertaining to or situated at base.

Brry. A fruit which is hishy or ralpy throughout.

Biscrual. Having both stameas and pistils, 1. e. male and female organs.

Bloom. A powdery or somewhat wary suhstance easily rahbed off.

Bolf. The linds or stem nf a tree.

Borenl, lortainiag to the anrtb.

Bract. A madified lenf subtending a Anwer or hulnnging to a inflorescence.

Bud-scalcx, Jloditied legves errering a hur.

Bundle-scors. Srars on the surface of a leaf-scar. Severed ends of the filora-raseular bundlu which coanented the twigs with the lenves.

Calyx. The outer portion of a flower, usually green in color.

rambinl. Pertaining to the crimbium.

Combium. A thia-wolled fornulive tiscue lwitrent the lark and woul.

Copeule. A drs fruit composed of more than ono manel nal splitting onen at naturity.

Carpel. A simple plstil or one member of a compound pistil.

Catkin. An ament or snike of naisexnal flowers.

Chamberer. Said of the pith whon interrupted lig hollow spaces nt rnther regular inturvals.

riliatc. Fringed with halra on the margia.

rohrrent. Sticking together: coanected.

Collniral. Iccessors huds at the sides of axillary buds.

Completc, Said of fowers whet all parts ars prosint.

Compound. Composed of two or more similar parts unltid in a whole.

concentric. Ssid of growth rings when the griswth erenter coiacides with the geometrienl eenter

ronfuent. Flowigg tugether: uniting. Said of the tunulle-sears whra the separate ones tinw together and amber as one.

Conirol. Cone-shaped.

Conifers. A gronp of treas whicb asually proluve th.ir fruit in tbe form of a cone.

Coniferous. Cone-bearing.

Conniting. Brought close together.

contertch. Twisted togethor or hack apou itself.

Contcrgent. Teading to oae poiat.

Cordate. Heart-shaped.

Corollo. The ianer portion of perianth, composed of petals. The loright colnred part of most flowers.

rorymb. A that-tonped or conrex flower cluster, hlonaing first at the edces.

Corrugated. Shajed into grooves, folds, or wrinkles.

Croicn. "The upper mass of urancbes, also knowa as bead.

Cyne. A fower luster hloming frou ares or middle first, asually somembat lat.

Cymasc. In a cyme; cyme-like.

Dccidunu. Falling off, vsually at the close of the season.

Dcourent. Exteadiag down the stem beluw the insertion.

Defoliation. Remoral of foliage.

Drhiscrnt. Splittios open.

Deliquesernt, Said of the form of a tree with a broad spreading habit. The braaches subdiride until they appareatly disappear.

Deltoil. Delta-like, triangulaí.

Dentnte. Toothed, Dsually with the tefth directed outwards.

Diffuse-pormus. Equal-pored. Said of sood whea pores ia a growth ring are equal in size. 
bigitotcly-compound. With the members arising at the same juint at the cnd or top of the sulpurt.

vioccious, Lnisexual. With the two binds of flowers un differeut plants.

Lisacminated. Suattered; thruwn broadeast.

vitcryent. Ivinting awas; exteudiag out. said or buds which point awas from the twigs,

Doacny. Corertal with tine buirs.

urupt. A fleshy fruit witl a pit or stune.

Licentric. Nut cireular. Sajd of growth rings when growth conter dues nut coincide witb geouetrical center.

Elongoted. Long drawn out.

Eimbryo. a youog plant in भ seed.

Entirc-margincd. Margio smoull, not cur or roughened.

Epidcrmis, 'The outer layer or coveriug or plants.

Eifnidistant. Equal distauces ayart.

Eicn-pinnatc. With all the leurlets occurring in pairs.

Excurrcnt. Said of a tree with a cuntinuous trunk and erect habit pf growth.

Exroliation. Splitting or cleaving off of outer lajers of bark.

Errotic. Of foreign origin.

Erudotion. Oozing out of sap, resin, or uills.

Frasciclc. A cluster, usually cense.

Fertilizution. The process by wlich pollen stimulates the ovule to produce a sced.

Fetud. Ill-smelling.

Fioro-vorculor bundles. The condurting strnuds which eonnect the leares with the stem.

Fibrolls. Cousisting of filers: woven in texture.

Filunint. The stalk bearing the anther.

Fissurcs. liruoves, furrows, or ebnnucls as in the bark.

Flura. The complete system of plauts fonud in a giren aren.

flutcd. Grooved, corrugater. chnnneled.

rolliclcs. A dry fruit of one carpel, splitting on one side onIy.

Forcstry. Tue rational trentulent of woodlands for their products.

Fruit. A develupiag or ripcned ovnes. It may also include the axis coutaining the real fruit.

Fingus. A plant devoid of green colur such ns mushrooms and rots.

Gaping. With an open slit at the eud or apex.

Ginus. A group of rehted species, as the jines or the onks.

Glauroils. Smooth, without liairs.

filondular. Hearing glands or glaud-like.

Gloucous. Corered with a bluish or whitisb waxs coating; a bloom.

Globosc. Hall-like or nearly so.

Globuior. Ball-like.

Mabilat. The home of a plant.

Hcad. A fense cluster of seszile flowers or the crown of a tree.

Hcartwood. The dead, centrnl, usually highly colored portion of the trunk.

licruaceous. Herb-like, soft.

IIctrogcncous. Composed of dissimilar elements, as the wood of the bardwoods.

Honogcncous. Composed of closely resenlling elements, as the wood of the conifers.

Imbricated. Orerlapping like the slate on a roof.

Incomplote. Said of flowers in whicb one of the outer parts is wanting.

Incremont. Growth; increase.

Indehiscent. Apjlied to fruits that do not split oyed to let out the seeds.

Inilgenous. Applied to plnnts that are native to a certain locality.

Infloriscence. The flowering part of a plant, and especially its arrangement.

Intolerant. Not sbade enfuring. Kequiring sunlight.

intolucre. A circle of bracts surrounding a flower or cluster of flowers.

Irregulor. Said of flowers showing ineguality in the size, form, or union of similar parts.

heclct. With a central ridge, like the keel of a boat.

Lamina. The blade or llattened portion of a leaf.

Lanccolote. Shaped like a lance; sereral times longer than wide.

Lateral. Situated on the side, as the buds along the side of the twig.

l,coficts. One of the small blades or divisions of a compound leat.

leaf-scars, The sear left by thr falling of a leat.

Lenticcls. A corky growth on young or sometimes older bark whicb admits air to the interior of the twig or brancl.

Lincor, Line-like, long and varrow, witb parallel edges.

Lobcd. Said of leares that have the margins more or less cut or divided.

Lunatc. Of the shape of a half-moon or crescent.

Monna. A sweetisl secretion used in medicine as a mild laxative.

sfedullory. Pertaining to the pith or medulia.

Meduliory Roy. Radial lines of tissues erossing the growth rings at right angles and extending into the bark.

Alidib. The central or main rib or rein of a leaf.

Mongrl. Composed of two elements of entirels different origin.

Monoccious. Bearing stamens and pistils in separate flowers on the same plant.

Iforphological. Pertaining to the form and structure of plants.

Mucilaginous. Shiny, or gummy when cbewed.

Sokcd. Said of luds witbout smales and seeds witbout a covering.

ratol Storcs. Refers to tar, turpentine, resin, etc. 
Nerve. One of the lioes or veins running through a lear.

Node. A place on a twig where one or more leaves criginate.

Non-porous. Withont pores.

Nut. A dry, l-seeted, indehiscedt fruit with $n$ hard corering.

Nutlet. \& small put.

$O b$. A prefis meaning interted or reversed.

Oblique. Slanting, uneren.

Oblong. Abunt twice as long as wide, the sides nearly parallel.

obovatc. Herersed tEg-shaped.

obtuse. Blunt.

odd-pinmote. With so odd or uppaired leaflet at the tip of the compund leaf.

oppositc. Said of leares and buds, directly across from ench other.

orbiculor. Circular.

Orary. The pint of the pistil producing the seed.

Ovate. Egg-shaped.

Ovoid. Lgg-shaped or mearly so.

Orule. The bods wbieh aftar fertilization becones the seed.

Polmote. Hand-shaped; radiatels dirided.

Ponicle. I compound tower claster, the lower branches of which are longest and hloom first.

Porasite. Growing opon and ohtaining its oourishtment from some other plant.

parenchymo. A class of plaot tissue found in the sreen lasers of the hark, in rood and pith.

Pedicel. 'l'he stalk of a single flower.

Pedunclc. The stalk of a flower cluster or of a solitary flower.

Penduluss. Hanging.

Percnnial. Last for more than one jear.

Perfcct. A tlower with both stameas nad nistils.

Perianth. A term applied to the calsx and corolla taken togetber.

Persistent. Remainine nfter blooning, frolting, or maturing.

Petals. The part of a curolla, asually colored.

Petiolc. The stalk of a leaf..

Pinno. A division, part, or leaflet of a plnnate lear.

Pinnotc. With leatlets on botls sides of a stalk.

Pistil. The ceutral unrt of the flower containing the prospectire seed.

Pistillotc. Beariog pistils but no stamens.

Pith. The solt central part of a thig.

Pod. Any dry and deliscent fruit.

Pollen. The dust-like substance found in the anthers of a fower.

Pollinotion. The process of tribsing the fwllen of the male flower in contact with the atigma of the female flower.

Polygamous. With both perfect and imperfect, staminate or pistillate, fowers.

Pome. A fieshy frait with 1 core, such as the apple.

Prickle. A sharp-pointed, needle-like outgrowth.

Profigote. Wasteful, extravagant.

Propogafire. Said of buds containing reproductire organs.

Pseudo-. A prebix menning inlse, not true.

Pubcscent. Hnirs.

Pungent. Endiog in a sliarp priot; acrid.

Pyromidol. Shaped lik a pramid with the broadest part near the base.

Roccme. A simple inforescedce of flowers borne on pedicels of equal length and arranged on a crimmon, elongated asis.

Roy. See Mcdullary ray.

Reflexcd. Abruptly turned hachward or downward.

Reforcstation. The process of patting a forest growth upo an area which had its forest growth remored receritly.

Regular. Said of flowers which are uniform in shape or structure.

Resin-ducls. A passage for the conduction of resiu foud b the leares and wood of the Pines.

Ring-porous. Snid of mood which bis mres of unequal size, the larger ones belng found in the spring wood and the smaller in the summer wood.

Rugoss. Wrinkled.

Rugositics. Projections, wrinkles, knobs.

Sacchorinc. Pertaioing to or having the qualities of sugar.

Eanara. AD iedehiscent winged fruit.

Sapicood. The recentls formco, nsually light rood, iging ontside of the heartwnod.

Scolcs. The small. modified leares which nrotects the groming-point of a bad or the part of a cone which hears the seeds. The small flakes into which the outer bark of a tree divides.

Scurfy. Corered with small brao-like scales.

Sppol. One of the parts of the calss.

Scrrate. Haviog shorp teeth pointlog forward.

Sessile. Sented: without a stalk.

Sheoth. A tubular envelope or corering.

shrub. A low moods growth which usualls bradches near the base.

Silky. 'Corered with soft, straight, fine halrs.

Simple. Consisting of ode part, not compond.

Sinus. The cleft or opening betweed two lobes.

Spccies. A group of like Individuals as Red Oak, White Oak, etc.

Spike. An enlongated arls besing sesslle fowers. 
Spile. A small peg or wooden pin. Sometimes sjoonymous with pile.

Spine. A sharp moody outgrowtb.

stamen. The part of a flower wbich bears the polled.

Staminate. Snid of dowers which lear only stamens. Sometimes spoked of as male.

Stcrigmato. The plojections from twigs hearing leaves.

Stcrile. Barren: unproductive.

Stigma. The end of a pistil tlurough which pollination takes place.

Stipule. A leaf-appendage at the base of the leat-stalk.

Stipulc-scor. The sear left by the fall of the stipule.

Stoma. An openiog in the epidermis of a leaf communieating with the iuternal air cavities.

Striot6. Marked with tine elongated ridges or lines.

Striations. Lring parrow lioes or ridges.

Strobile. A fruit marked by orerlappior scales as in the Pine, Birches, etc.

Style. The pin-like portion of the pistil bearing the stigma.

sub-. A prefs meaning under or Dearly.

Sucher. A sboot arising frum an undergrouod bud.

Supcrposcd. Said of buds when they are nrrangel one ahove the other.

Symmetrical. Regular as to the number of parts. Huring the same number of parts in ench circle.

Tcrminal. Pertaining to buds located at the end of twigs.

Thorn. A stif, woody, shalp-pointed projection.

Toleront. Applied to trees whick eadure certain factors, particularly sluade.

Tomoritum. A deose lajer of hairs.

Tomcritose. Densely pubesceat; hairy.

Truncote. Eading abruntly, as if cut of at the exd.

Tuberele. A small tuber or tuber-Iike body.

Tuftcd. Growing in clusters.

Cmbel. A flower-cluster with all the nedicels arising from the same polot.

Criscanal. Consisting of one sex only, either stamiozte or pistillate.

Valvate. Snid of buls in which the senles merely meet without orerlapplng.

Fegetative. Said of buds which do not contain reproductive organs.

Teins. Threads of filro-rascular tissue in leares or otber organs.

Tersotile. Used for maor purposes.

Iiseid. Glutinous; sticky.

Whorl. A groop of three or more similar organs, as leares or buds, arranged ahout the same place of attachment.

Whorled. Borne in a whorl.

Iylology. The science which treats of the form and structure of mood. 


\section{\%}




\section{INDEX.}

\begin{tabular}{|c|c|c|}
\hline & & Page. \\
\hline nea,$\ldots \ldots \ldots \ldots \ldots \ldots$ & 81 & Red, .. \\
\hline Abies Fraseri, ................... & 84 & White,$\ldots \ldots \ldots \ldots \ldots \ldots \ldots$ \\
\hline 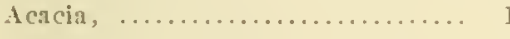 & 181 & Asb-leaped Maple, ............... \\
\hline Three-thornerl. ............. & 179 & Asimina triloba, $\ldots .$. \\
\hline 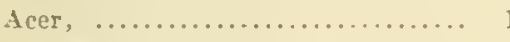 & 190 & 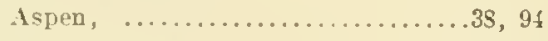 \\
\hline Negundo,....$\ldots \ldots \ldots \ldots \ldots$ & 197 & American,$\ldots \ldots \ldots \ldots \ldots \ldots$ \\
\hline penusylvanirum, ............ & 192 & Large-toothed, $\ldots \ldots \ldots \ldots \ldots$ \\
\hline 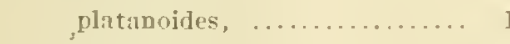 & 199 & Quaking,...$\ldots \ldots \ldots \ldots \ldots$ \\
\hline Pseudo-platanus. ........... & 198 & small-toothed,$\ldots \ldots \ldots \ldots \ldots$ \\
\hline rubrum. $\ldots \ldots \ldots \ldots \ldots \ldots, 5,56,1$ & & Trembling, $\ldots \ldots \ldots \ldots \ldots \ldots$ \\
\hline saccharinum, $\ldots \ldots \ldots \ldots \ldots$ & 19.5 & Balm of Gilead, ................ \\
\hline snccharum. $\ldots \ldots \ldots \ldots \ldots 661,1$ & 191 & Palsam, $\ldots \ldots \ldots \ldots \ldots \ldots \ldots \ldots \ldots$ st $\quad s_{1}$ \\
\hline spicatum, $\ldots \ldots \ldots \ldots \ldots \ldots$ & 193 & liasswood, $\ldots \ldots \ldots \ldots .35,38,44,48,202$ \\
\hline . 1сегасеае, ................... & 190 & White, $\ldots \ldots \ldots \ldots \ldots \ldots \ldots \ldots$ \\
\hline Nesculus: & & Beaked 1lizelnut, .............. \\
\hline glabra,$\ldots \ldots \ldots \ldots \ldots \ldots$ & 200 & 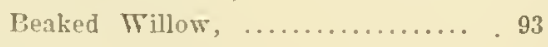 \\
\hline octandra,,$\ldots \ldots \ldots \ldots$. & 201 & Bear Oak, ....................... \\
\hline Hippocastanum, .......... & 200 & Bebb's Willow, .............. 93 \\
\hline Ailanthus, ................... & 157 & Beech, $\ldots \ldots \ldots 30,35,39,45,49,123,125$ \\
\hline glandulos:a,$\ldots \ldots \ldots \ldots \ldots \ldots$ & 197 & Americau, $\ldots \ldots \ldots \ldots \ldots \ldots$. 124 \\
\hline 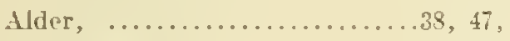 & 48 & Blur,,$\ldots \ldots \ldots \ldots \ldots \ldots \ldots$ \\
\hline Black, ..................39, & 121 & European, ................ \\
\hline Smooth,$\ldots \ldots \ldots \ldots \ldots \ldots \ldots$ & 121 & Water, ..................... \\
\hline 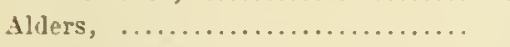 & 45 & Prech family, $\ldots \ldots \ldots \ldots \ldots \ldots \ldots$ \\
\hline Alnus rugosa,$\ldots \ldots \ldots \ldots \ldots \ldots$. & 121 & Bee-tree, $\quad \ldots \ldots \ldots \ldots \ldots \ldots \ldots \ldots \ldots \ldots$. \\
\hline Alternate-leared Dogwood, ........ & 205 & lienzoin aestirale. ............... \\
\hline Amelanchier canadensis, ......... & $17 \pm$ & Betula, $\ldots . . . \ldots \ldots \ldots \ldots \ldots \ldots$. \\
\hline cardiaccae,............... & 152 & alba rar. paprrifera, , ....... \\
\hline ngclica Tree, ................ & 199 & lenta, $\ldots \ldots \ldots \ldots \ldots \ldots \ldots$ \\
\hline Anonaceae, $. . . \ldots \ldots \ldots \ldots \ldots \ldots . . . . .$. & 160 & 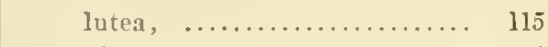 \\
\hline Apple, American Crab, .......... & 172 & nigra, $\quad \ldots . . . \ldots \ldots \ldots \ldots . . . .$. \\
\hline Aralia spinosa, ................ & 199 & populifolia,$\ldots \ldots \ldots \ldots \ldots$ \\
\hline Arbor Vitae, ....................tl, & , 86 & Big Tree of Tule, ...... \\
\hline Arrow-wood, $\ldots \ldots \ldots \ldots \ldots \ldots \ldots$ & 219 & Big Trees, $\ldots \ldots \ldots$ \\
\hline Ash, $\ldots \ldots \ldots \ldots \ldots \ldots \ldots 22,23,4$. & 212 & Bignoniaceae, $\ldots . \ldots \ldots \ldots \ldots \ldots \ldots$ \\
\hline Basket, $\ldots . .$. & 215 & Bignonia famìy, $\ldots \ldots \ldots \ldots \ldots \ldots$ \\
\hline Biltmore, .... & 213 & Bilsted, $\ldots \ldots \ldots \ldots \ldots \ldots \ldots \ldots . . . .$. \\
\hline,$\ldots \ldots \ldots$ & 215 & Birch: \\
\hline Brown, $\quad . . . \ldots$ & 215 & Black, ... \\
\hline Canadian, .... & 214 & Canoe, $\ldots \ldots \ldots \ldots \ldots \ldots \ldots \ldots \ldots$ \\
\hline Green, $\ldots . . .$. & 213 & Cherry, ................. 115 \\
\hline Hoop, $\ldots \ldots .$. & 215 & Gras, ...............115, 117 \\
\hline Mountain, ..............48, & & Oldfield, ................. 117 \\
\hline
\end{tabular}




\begin{tabular}{|c|c|}
\hline Page. & Page \\
\hline Paper, ...............36, 57, 114 & Celtis: \\
\hline Poplar, $\quad \ldots \ldots \ldots \ldots \ldots \ldots \ldots . \quad 117$ & crassifolia , \\
\hline Porerty, ..................... & occidentalis, \\
\hline Red, $\ldots . . . \ldots \ldots \ldots \ldots \ldots \ldots, \quad 116$ & ( rreis canadensis, ...... \\
\hline River, $\ldots \ldots \ldots \ldots \ldots \ldots \ldots \ldots \ldots, 116$ & C"linnaecyparis thyoudus, .... \\
\hline Silrer, .................... 115 & Cherrs: \\
\hline Sweet,$\quad \ldots \ldots \ldots \ldots \ldots \ldots \ldots$ & Appalachian, \\
\hline Yellow, ...................... & Bird, $\ldots \ldots \ldots \ldots$ \\
\hline family, $\ldots \ldots \ldots \ldots \ldots \ldots \ldots, 111$ & Black, .......... \\
\hline $\mathrm{es}, \quad \ldots \ldots \ldots \ldots 30,31,38,44,45,47,48,112$ & Cabinet, $\ldots \ldots \ldots$ \\
\hline er Nut, $\ldots \ldots \ldots \ldots \ldots \ldots \ldots$. 49 & Choke, ... \\
\hline wood, $\ldots \ldots \ldots \ldots \ldots \ldots \ldots \ldots$ & Domestic, \\
\hline Elder, $\quad \ldots \ldots \ldots \ldots \ldots \ldots \ldots$ & Fire, $\quad \ldots \ldots \ldots \ldots \ldots \ldots \ldots \ldots$ \\
\hline ood, $\quad \ldots \ldots \ldots \ldots \ldots \ldots \ldots \ldots$ & Perfumed, ................. \\
\hline ere: & pin,,$\ldots \ldots \ldots \ldots \ldots \ldots \ldots \ldots$ \\
\hline $1 \mathrm{ig}, \quad \ldots \ldots \ldots \ldots \ldots \ldots \ldots \ldots, \quad 201$ & Rum,,$\ldots \ldots \ldots \ldots \ldots \ldots$ \\
\hline Fetid, $\ldots \ldots \ldots \ldots \ldots \ldots \ldots . . .5 i, 200$ & Sand, $\ldots \ldots \ldots \ldots \ldots \ldots \ldots$ \\
\hline Ohio, ..................... 200 & Sour. ................... \\
\hline Stinking, $\ldots \ldots \ldots \ldots \ldots \ldots . \quad 200$ & sweet, $\quad \ldots \ldots \ldots \ldots \ldots \ldots$. \\
\hline Sweet, .................5 & Wild, $\ldots \ldots \ldots \ldots \ldots \ldots \ldots$, \\
\hline Xellow, .................. 201 & Trild Plack, . . . . . . . . 45, \\
\hline & Wild Red, .................. \\
\hline
\end{tabular}

Buckeyes,...$\ldots \ldots \ldots \ldots \ldots \ldots \ldots$. 41

Butternut, $\ldots \ldots \ldots \ldots \ldots \ldots \ldots \ldots . \ldots \ldots, 102$

Buttonball, .................. 175

Buttonwood, ...........31,34,35,39,47,175

Calico-bush, ................. 207

Canoe Birch,

Caprifoliaceae,

Carolina Poplar, ..................

Cirpinus caroliniana, .............

Carya,

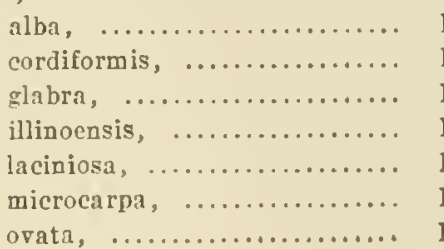

Cashew family, .............. 182

Castanea, .................... 125

alnifolia, ................. 125

dentata, ................... 126

pumila, ................. 127

Catalpa, ......................38, 211

bignonioides, …........., 211

Gastern, ..................! 211

Western, ................. 211

Cedar:

Coast White, ............. 85

Red, ...............20,57, 87

White, $\ldots \ldots \ldots \ldots \ldots \ldots 36,57,85$
Cliestnut, $\ldots \ldots \ldots 20,23,27,30,31,33,38,40$,

$45,46,47,57,125,126$

Chiuquapin, .................... 127

Chionanthus virginica, ......... 217

rigar Tree, .................. 211

18 Coffee Nut, ................. 178

99 Coffee-tree, Kentucky, .......... 178

120 Colorado Rlue Spruce, .......... 79

104 iornaceae, '..................... 204

108 ('oruel, Flowering, ............ 201

10 r'ornus:

109 alternifolia, ............. 205

105 florida, ................. 204

Corylus:

americann, .............. 122

rostrata, ..............., 122

Cotton Tree, ................ 99

Cottonwood, $\ldots \ldots \ldots \ldots \ldots \ldots \ldots . . .94,99$

Black, ................... 98

River, ................. 98

Swamp, ................ 98

Crab Apple, American, .......... 172

Crack Willow, ................. $\$ 9$

Crataegus:

coccinea, ........4i.:s:18114! 171

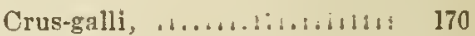

Cucumber Tree, .................. 157

Custard Apple famils, .......... 160

Cypress, Bald, ............... 30 
Date-plum.

Deerwood,

Diosprros virkiniana,

Dogwood,

Alternate-leared.

Blue,

Flowering,

Purple,

Ebenaceae,

Fbong family,

Flder,

Eiderberry, Commun,

Flkwood,

Elm,

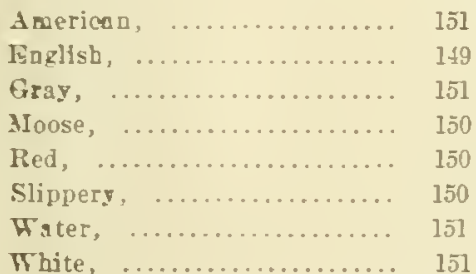

Elms, ................46,47, 149

Lricacese, ................... 207

Erergieen (1sks. .............. 12

Fagacease, ................... 121

Fagus:

grandifolis,

123

gylratica, ................ 125

Filbert,

122

Fir, Balsam, ............... 45

Fire CDerry. ................. 168

Firs, ..................... $\bar{x} 5$

Fraxinus, ................ 212

smericans, .............55, 214

Biltmoresna, ............. 213

excelsior, .............. 212

nigra, ................. 215

ornns, ................. 212

pennsylranica гar. lanceolata, 213

pennsrlranica. ............ 216

Fringe Tree, ............... 217

Gleditsis triacanthos, .......... 179

Great Laurel, ................ 208

Gum:

Blıck, $\ldots \ldots \ldots \ldots \ldots \ldots .33,36,38,206$
Red, $\ldots \ldots \ldots \ldots \ldots \ldots \ldots \ldots . . \quad 163$
Sour, $\ldots \ldots \ldots \ldots \ldots \ldots \ldots .206,209$
Sweet. $\ldots \ldots \ldots \ldots \ldots \ldots \ldots .35,163$

rymnocladus divica, ............ 178

Hackberry , ................ 35, 4 i, 152

Hackmatrek, ................ 77

Hack-tree,
Hamamelidaceae. ............ 162

Hamamelis rirginiana, ......... 162

Haren-mood, ................ 187

$\mathrm{H}_{a w}, \ldots \ldots \ldots \ldots \ldots \ldots \ldots \ldots \ldots . \ldots \ldots$

Black, .................. 219

Sweet, .................. 219

Hawtborn, .................170, 171

Scarlet, .............. 171

Hazelnut, .................. 15

American, ............. 122

Tieaked, .............. 122

Common, ............. 47

Heath famil., ............. 207

Hedge-tree, ................. 15

Hemlock, .......31,33,35,36,50,51,5i, \$3

Carolias, ............... \$3

Ground, ................ 67

Spruce, ............... \$3

Hercules' Club, .............. 199

Hickors:

Big Burd, .............. 108

Big Shell-bark, .......... 107

Bitter, ............... 110

Bitter Nur, ............. 110

Brootm, ............... 109

Mocker Nut, ............. 108

Pecan, ................. 105

Pigaut, ................. 109

Shag-bark, ..........36, 106, 107

Skell-bark, ............. 106

Small-truited, ........... 105

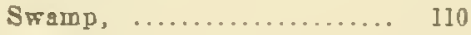

White-beart, .......... 10 s Holly:

American, ................ Iss

Deciduous, .............. 31

European, ............... 188

Carge-leaved, ........... IS3

Mountain, ............. 189

White, ................. Iss

Honey Locust, ................ . 179

Hones Sbucks, ................ 179

Honessuckle famils, ........... 215

Hop Hornbesm, American, ...11, $45,49,119$

Hornbeam, American, .......... 120

Horse-chestnut, .............. 200

Ilex:

aquifolium, .............. Iss

monticola, .............. 199

ораса, .................. 158

rerticillata. ............. 189

Indian Benn. ............... 211

152 Ironwood, ................119, 120 


\begin{tabular}{|c|c|}
\hline & : \\
\hline 180 & tripetala, $\ldots .$. \\
\hline 101 & giniana, $\ldots$ \\
\hline 102 & Magnoli \\
\hline 103 & lia family, .... \\
\hline 101 & $y, \ldots \ldots \ldots$ \\
\hline 100 & Ilaple: \\
\hline ane Berry, & Ash-leaved, ... \\
\hline niper: & \\
\hline$\ldots \ldots+1,87$ & Mountain, ...... \\
\hline$\cdots \quad 87$ & way, $\ldots . . .$. \\
\hline Red,...$\ldots$ & .......... \\
\hline uniperus: & River, ........ \\
\hline 87 & Rock, $\ldots \ldots \ldots$. \\
\hline 87 & $r, \ldots \ldots \ldots$ \\
\hline 1, $\ldots \ldots \ldots \ldots \ldots \ldots, 207$ & , $\quad \cdots \ldots \ldots$ \\
\hline$\ldots 38,41,173$ & ed, $\ldots \ldots \ldots \ldots \ldots$ \\
\hline$\ldots .30,50,55$ & ir,$\quad \ldots \ldots \ldots \ldots \ldots$ \\
\hline$\cdots \ldots 60,7 \pi$ & $p, \ldots \ldots$ \\
\hline …..... 77 & nore, $\ldots .$. \\
\hline European, & $\ldots \ldots \ldots 195,1$ \\
\hline arix: & $y, \ldots \ldots \ldots \ldots \ldots \ldots$ \\
\hline Inricina, $\quad \ldots \ldots \ldots \ldots \ldots \ldots$ & $\mathrm{d}, \ldots \ldots \ldots \ldots \ldots$ \\
\hline idua,,$\ldots . . . . . . . . . . .$. & ........ \\
\hline eae, $\quad \ldots \ldots \ldots \ldots \ldots \ldots \ldots$ & Mor \\
\hline & alba, \\
\hline$\ldots \ldots . \quad 208$ & \\
\hline$, \ldots \ldots \ldots \ldots \ldots \ldots \ldots \ldots, 207$ & Ifulberry \\
\hline , $\ldots \ldots \ldots \ldots \ldots \ldots \ldots, 161$ & k,$\quad \ldots \ldots \ldots \ldots \ldots \ldots \ldots \ldots$ \\
\hline $1, \ldots \ldots \ldots \ldots 31,57,156$ & Red,$\quad \ldots \ldots \ldots \ldots \ldots \ldots \ldots$ \\
\hline ............ 176 & White,.....$\ldots \ldots \ldots \ldots \ldots$. 15 \\
\hline$\ldots \ldots \ldots \ldots \ldots \ldots \ldots \ldots$ & $\ldots \ldots 218,21$ \\
\hline ee, $\ldots \ldots \ldots \ldots \ldots \ldots \ldots \ldots$ & $y, \ldots \ldots \ldots \ldots \ldots, 47,14$ \\
\hline 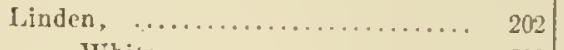 & ............... 15 \\
\hline 203 & e, $\quad \ldots \ldots \ldots \ldots \ldots \ldots \ldots$ \\
\hline $1 y, \quad \ldots \ldots \ldots \ldots \ldots \ldots$ & .......... \\
\hline , $\ldots \ldots \ldots+\ldots, \ldots$ & Nyssa sylratiea,$\ldots \ldots \ldots \ldots \ldots \ldots$ \\
\hline$n, \quad \ldots \ldots \ldots \ldots \ldots$ & Oak: \\
\hline Liriodendron Tulipifera, . ........ & Barrer \\
\hline we Oalss, $\ldots \ldots \ldots \ldots \ldots \ldots \ldots$. & , $\ldots \ldots \ldots \ldots \ldots \ldots \ldots \ldots, 14$ \\
\hline & , $\quad \ldots \ldots \ldots \ldots \ldots \ldots \ldots \ldots \ldots, 11$ \\
\hline$\ldots \ldots \ldots \quad 181$ & Black Jack, ............. It \\
\hline$, 42,45,48,181$ & , $\quad \ldots \ldots \ldots \ldots \ldots \ldots \ldots \ldots$ \\
\hline$\ldots \ldots .38,179$ &,$\quad \ldots \ldots \ldots \ldots \ldots \ldots \ldots$ \\
\hline $\begin{array}{cc}\ldots \ldots \ldots \ldots \ldots & 179\end{array}$ & $\ldots \ldots \ldots \ldots 136,13$ \\
\hline$\ldots \ldots \ldots \ldots \ldots \quad 181$ & Cbiequa\}in,$\ldots \ldots \ldots$ 13 \\
\hline$\ldots \quad 181$ & Ground, $\ldots \ldots \ldots \ldots \ldots \ldots$ \\
\hline$\ldots .33,94$ & , $\ldots \ldots \ldots \ldots \ldots \ldots \ldots \ldots \ldots \ldots$ \\
\hline … 202 & , $\ldots \ldots \ldots \ldots \ldots \ldots \ldots \ldots \ldots \ldots, 145,14$ \\
\hline$\ldots \quad 153$ & $1, \ldots \ldots \ldots \ldots \ldots \ldots, 1+6$ \\
\hline $1,41,57,155$ & Mossy-eup, $\ldots \ldots \ldots \ldots \ldots \ldots$ \\
\hline & Over-cup,$\ldots \ldots \ldots \ldots \ldots \ldots$ \\
\hline $.31,57,156$ & Peach,.............. \\
\hline Small, $\ldots \ldots \ldots \ldots \ldots \ldots \ldots, \quad 156$ & \\
\hline
\end{tabular}




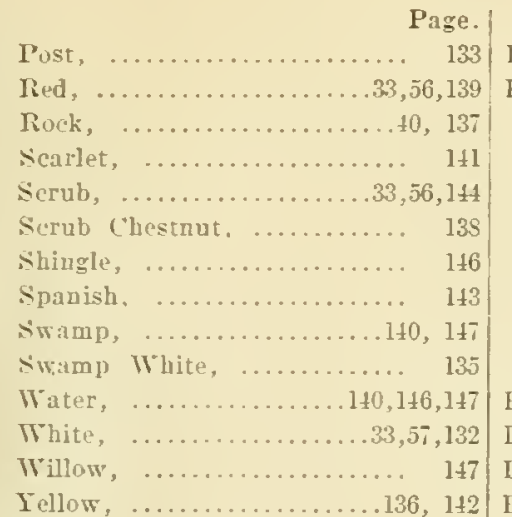

Oilnut,

Fellow

$136,1+2$

Old Man's Beard. ............... 217

Olea Europaca", ................ .212

Oleaceae, ................... 212

Olive family, ................ 212

Olive Tree, ................. 212

Usage Apple-trec, $\ldots . . . \ldots \ldots \ldots .153$

Osage Orange, ................ $\overline{7}, 153$

Osier, Green, ............... 205

Ostrya virminianat, ............. 119

Oxydendrum arborcum, ......... 209

Papaw, ...............3 $, 41,45,47,160$

Paradise Tree, ................ 187

Peach, .. ................... 165

Fejperidge, $\ldots \ldots \ldots \ldots \ldots \ldots \ldots .206$

Persimmon, ..................50, 210

Physocarpus opulifolius, ......... 161

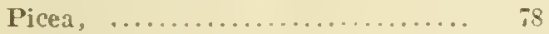

Abies, .................79, 82

mariana, $\ldots \ldots \ldots \ldots \ldots \ldots . . .61$

pungens, ................. 79

rubra, ................... 80

Pigeon-berry, ................ 205

Pinaceae, ....................55, 67

Pine:

Austrian, $\ldots \ldots \ldots \ldots \ldots \ldots . . .6 .68$

Jack, ..................

Jersey or sicrub. .........33,57,75

Nigger, ................

Xorway, ................ $i_{2}$

Pitch, $\ldots \ldots \ldots \ldots \ldots \ldots \ldots .20, \overline{5} 5,71$

Porerty, ................ 73

Red, ...............22,55,57,72

scotch, .................65, 76

Pine:

Short-leaf, $\ldots \ldots \ldots \ldots \ldots \ldots$ it

Table IIountain, ..........5i, 73

White, .....20,22,31,32.33.48,55,70

Yellow, ................ $57,7 \pm$

Pine family, ...............5 67

Pinus:

echinata,$\ldots \ldots \ldots \ldots \ldots \ldots$ it

laricio var. austriaca, ...... 65

pungens,...$\ldots \ldots \ldots \ldots \ldots$. 73

resinosa, ................5 氵2 $^{2}$

rigida, .................

Strobus, ..............

srlvestris, $\ldots \ldots \ldots \ldots \ldots \ldots 6,76$

virginiana, $\ldots \ldots \ldots \ldots \ldots \ldots \ldots . \ldots \ldots$

Plane Tree, ................... 175

Plane Tree family, ............. 175

Platanaceac, .................. 175

Platanus:

occidentalis, ................ 175

orientalis, ............... 175

Plum :

Porter's, ................165, 169

Red, .................. 169

Wild, ................................ 169

Wild Yellow, .............. 169

Puison:

Dogmood, $\ldots \ldots \ldots \ldots \ldots \ldots \ldots$. 181

Elder, .................. 1st

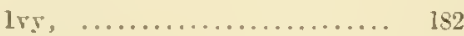

(1ak, $\ldots \ldots \ldots \ldots \ldots \ldots \ldots \ldots \ldots \ldots+182,194$

Sumach, ................. 184

Poplar, ...................24,96,97

Balsam, ............... 94

Birch, .................. 117

Carolina, ................ 99

Downs, ................. 98

Lombards, ................33, 94

silver-leaf, $\ldots \ldots \ldots \ldots \ldots \ldots$. 94

Swamp, ............... 99

White, ................. 94

Fellow, ................. 159

Popple, ................ $96,9 \overrightarrow{7}, 159$

Populus, ........................ 9t

alba, $\ldots \ldots \ldots \ldots \ldots \ldots \ldots . . .69$

balsamifera, ............... $9 t$

candicans, ................. 94

deltoides, ............... 99

grandidentata, ............ 97

heterophyllia, ............. gs

nigra rar. italica, ......... 94

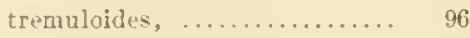

Frunus, ...................... 165

alleghaniensis, $\ldots \ldots \ldots \ldots \ldots$. 165

americana, ............... 169

avium, $\ldots \ldots \ldots \ldots \ldots \ldots \ldots . \ldots \ldots \ldots$

Cerasus, $\ldots \ldots \ldots \ldots \ldots \ldots \ldots$. $16 \overline{5}$

crneata, ................ 165 


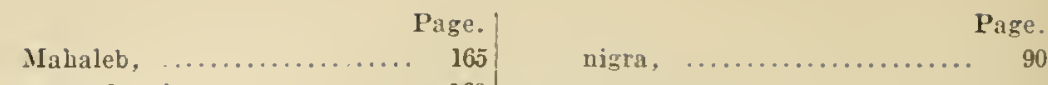

pennsylvanical. ........... $163 \quad$ rostrata, ............... 93

Persica, ............... 165 Sambucus canadensis, .......... 218

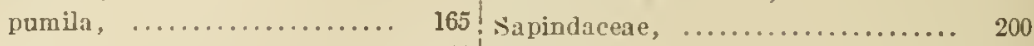

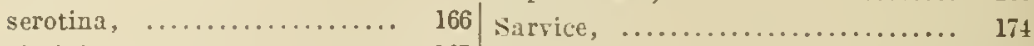

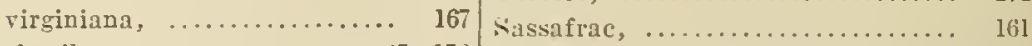

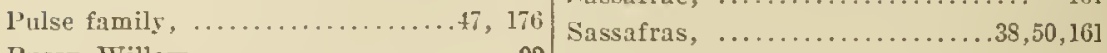

Pussy Willow, ............... $92 \begin{array}{r}\text { varifolium, } \ldots \ldots \ldots \ldots \ldots . . \ldots 1 \\ 161\end{array}$

Pyrus:

americana,

coronaria,

Quaking Aspen,

Quassia family,

Quercus,

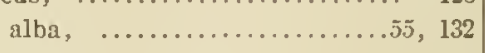

bicolor, ................. 135

coccinea, ................ 141

falcata, ................. 143

ilicifolia, ..................56, 144

imbricaria , ................ 146

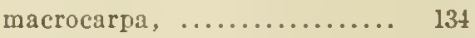

marylandica, ............. 145

Muhlenbergii, ............ 136

nana, ................. 56

palustris, .............. 140

phellos, ................. 147

prinoides, ............... 138

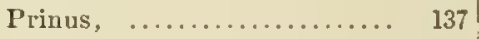

pumila, .................. 56

rubra, ................56, 139

stellata, ................ 133

relutina, ............... 142

Redbud, ..................... 180

Rhododendrou, ................31, 208

maximum, ............... 208

Rhus:

canadensis, $\ldots \ldots \ldots \ldots \ldots \ldots . \quad 182$

copallina, .............. 186

Cotinus, ................ 182

glabra, ................. 182

Toxicodendron, ............ 152

typhina, ................. 185

Vernix,$\ldots \ldots \ldots \ldots \ldots \ldots .184$

Robinia Pseudo-Acacia, ......... 181

Rosaceae, .................. 164

Rose Bay, .................. 208

Rose family, ................ 161

Salicaceae, .................. 88

Salix,

babylonica, ................

discolor,

fragilis,

lucida,

3

Savin, $\ldots \ldots \ldots \ldots \ldots \ldots \ldots \ldots \ldots$ st

saxifrax, .................. 161

Siequoia , ........................ 32,33

Service Berry, ............... 174

shad Bush, ................. $38,48,174$

Sheepberry, ................218,219

Simarubaceae, ................ 187

slippery Elm, ................ 150

Smoke Tree, ................ 182

Soapberry family, ............. 200

Sorrel Tree, ................. 209

Sinur Gum, ...............206,209

Sour-wood, .................. 209

spauish Oak, ................ 143

spice Bush, ................. 161

Spruce, $\ldots \ldots \ldots \ldots \ldots \ldots . \ldots \ldots 1,36,50,55,78$

Black, .................. 81

Colorado Blue, ............ 79

European, ................ 82

Norway, $\ldots \ldots \ldots \ldots \ldots \ldots 22,79,82$

l'ine, ...................80, 83

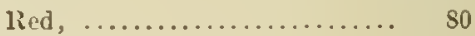

stag-bush, .................... 219

sugarberry, ................. 152

sumach, ........................ is

Dwarf, ................. 186

Fragrant, $\ldots \ldots \ldots \ldots \ldots \ldots . \quad 182$

Molutain, ............... 186

Poison, $\ldots \ldots \ldots \ldots \ldots \ldots \ldots, \quad 184$

Smooth, ...............182,185

Staghorn, ................ 185

Swamp, ............... 184

Velvet, ................. 185

sycamore, $\ldots \ldots \ldots \ldots \ldots \ldots \ldots . .6 . \ldots$

Tamarack, .................. 77

Taxaceae, ................... 67

Taxus canadensis. ............. 67

Thorn Apple, ................ 170

Newerstle, $\ldots . \ldots \ldots \ldots \ldots .6 .6170$

Scarlet, ................ 171

Tree, ................. 179

91 Thuja occidentalis, ............ 86 
Tilia:

americana

heterophylla ,

Iichauxii,

Tiliacene,

Tree of Heaven,

Tsuga:

canadensis, caroliniana

Tulip Poplar,

Tulip Tree,

Tupelo,

Ulmus,

americana,

campestris,

fulva,

Urobrella Tree,

Urticaceae.

Viburaum

dentatum.

I.entago,

Maple-leaved,

prunifolium,

sweet,
Page.

Walnut, $22,38,44,45,101,103$

Black, ................3S,43,103

Euglish, .............. 101

White, $\ldots \ldots \ldots \ldots \ldots \ldots \ldots . .6102$

Waluut family, .............. 100

Whistle-wond, .............. 192

Whitewood, ...................159,202

83 Willow, ............... $31,45,46,47,89$

83 Benked, .............. 93

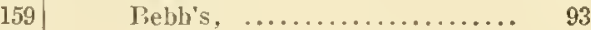

Plack, ................. 90

Crack, ............... 89

Glacous, ................ 92

Flossy, .................. 91

Oak. .................. 147

Pussy, .................. 92

Shining, $\ldots \ldots \ldots \ldots \ldots \ldots \ldots$. 91

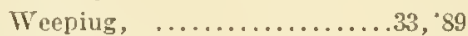

Willow family, ............... 88

219 Winterberry, .............. 189

218 Witch-hizel, .............45,48,162

219 Y Jllow-wood, ............. 153

219 Y 218 


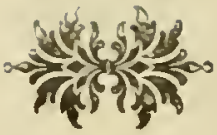





\section{PLEASE DO NOT REMOVE CARDS OR SLIPS FROM THIS POCKET}

\section{UNIVERSITY OF TORONTO LIBRARY}

CK

484

P4I5

cop.?

Biolved.
Il1ick, Joseph Simon

Pennsylvania trees 
